
Digitized by the Internet Archive in 2007 with funding from Microsoft Corporation 
$A$ HISTORY of PRINTING in COLONIAL MARYLAND

1686-1776

\& 

A H I S T O R Y of P R I N T I N G I N

C O L O N I A L

$M A R T L A N D$ I $686-1776$

By LAWRENCE C. WROTH, First Assistant Librarian of the Enoch Pratt Free Library BALTISTORE

Published by the TYPOTHETAE of BALTIMORE MCM XXII 


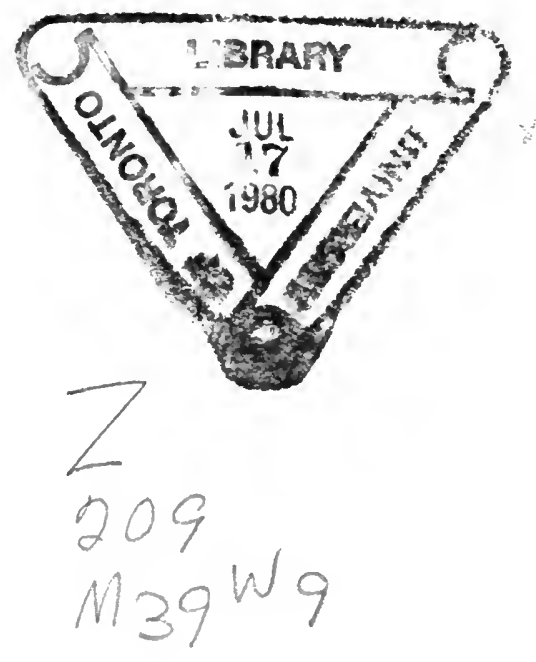

\section{Publication Committee}

Nathan Billstein, of The Lord Baltimore Press, Chairman Edward B. Passano, of The Williams \& Wilkins Company George K. Horn, of The Maryland Color Printing Company 


$$
\begin{gathered}
\text { To His } \\
\text { Father and } \text { Yrother } \\
\text { Its Earliest and Kindest Patrons } \\
\text { this Book is Dedicated by } \\
\text { the Author }
\end{gathered}
$$




\section{.}




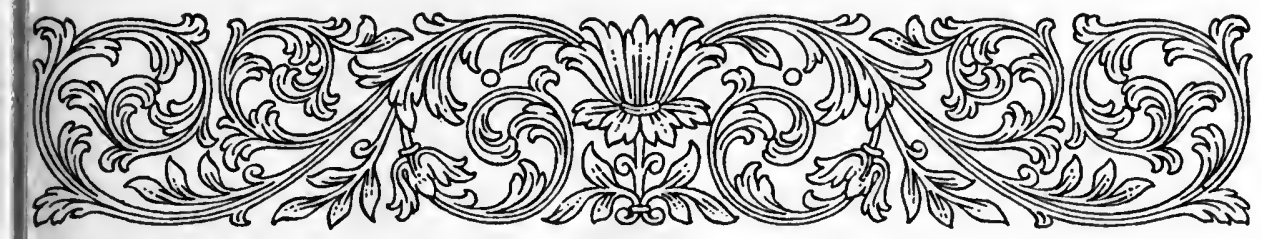

\section{INTRODUCTION}

(ख्) $T$ is only by infrequent contributions that there is being (C) formed abodyof writing on that phase of American literI 1 ary history which has to do with the history of printing I I In the original colonies. Forgenerations in England and at(a) have taken a particular delight, but although Isaiah Thomas wrote his "History of Printing in America" more than a hundred years ago, and although in general American bibliography, Sabin and Charles Evans have compiled notable works which should have given impetus to this study in the United States, yet it remains true that intensive investigations of the printing history of the individual colonies, or of the issue of their presses, have been undertaken with noticeable reluctance. When there have been mentioned the works of Hildeburn for Pennsylvania and New York, of Roden and Little field for early Massachusetts, of Weeks for North Carolina, of Clayton-Torrence for Virginia, and of The Fohn Carter Brown Library for Rhode Island, the tale has been completed.'

The typographical history of Maryland, the fourth of the English colonies in which the art was established, had never been made the subject of an especial study until the present work was undertaken. One whose interest lay in that subject had for authority only the general history of Isaiah Thomas, which, in its section devoted to Maryland, added inaccuracy of statement to an inevitable poverty of detail. Writing before the provincial

${ }^{1}$ Hildeburn, C. S. R., $A$ Century of Printing, The Issues of the Press in Pennsylvania, 1685-r784. 2 v. Phila. 1885. Sketches of Printers and Printing in Colonial New York. N.Y. 1895.

Roden, R. F., The Cambridge Printers, 1638-1692. N.Y. 1905.

Littlefield, G. E., The Early Massachusetts Press, $1638-17$ Ir. 2 v. Boston, 1907.

Weeks, S. B., The Press of North Carolina in the r8th Century. Brooklyn, 1893 .

Clayton-Torrence, William, $A$ Trial Bibliography of Colonial Virginia, 1607-1776. (Published in two sections as parts of the "Report of the Librarian of the Virginia State Library," for 1908 and Ig09.)

Rhode Island Imprints, 1727-1800. Compiled by [Miss Rebecca P. Steere] the John Carter Brown Library. Providence, 1915.

[v] 
records of Maryland had been collected and published, Mr. Thomas asserted that printing in Lord Baltimore's province began with the press which William Parks set up in Annapolis in the year I726, and succeeding writers have repeated his error and continue still to repeat it in spite of the accessibility to them of records unknown to the pioneer historian. Occasionally, it is true, a writer has discovered traces of an earlier group of Maryland printers than that which Mr. Thomas had knowledge of, but as a general thing these discoveries have not been made the matter of permanent record, so that for all practical purposes the current knowledge of Maryland printing origins remains today in the state in which Thomas left it, ${ }^{1}$ and this is true in spite of the efforts at correction made by the editors of his second edition in the year 1874. On the other hand, if in the accepted chronology of American printing, the date of the Maryland origins is set a generation later than is correct, the traditional date of its beginning, a tradition fabricated less than half a century ago by 7 . Thomas Scharf, ${ }^{2}$ has been placed at least two generations earlier than is warranted by the evidence.

It is proposed by the writer of the present work, dismissing as indefensible Scharf's unsupported assertions, to demonstrate that printing began in Maryland probably forty years before Parks set up his press in Annapolis, and that three printers operated in the Province and two others were licensed to operate there before the year which is usually accepted as marking the inauguration of the typographic art on the shores of the Chesapeake. The history of the later presses also will be set forth with some minuteness, and in an appendix to the narrative will be placed a list of all Maryland imprints between the years 1689 and 1776 , in so far as these could be collected either at first hand, from printed bibliographies, or by title from records presumptive of their publication.

If it seem at times in this narrative that undue attention has beengiven

1 In the face of this generalization, one must call attention to the fact that various Maryland writers, particularly William Hand Browne and Bernard C. Steiner, editors of the Archives of Maryland, have consistently pointed to evidence of the existence of earlier printers than were known to Thomas. Hugh A. Morrison cited evidence of the operations of the first Maryland printer in a note, pp. 62 and 63 , in his Catalogue of the Books, Manuscripts and Maps Relating Principally to America, Collected by the late Levi Z. Leiter. Washington, 1907; and an anonymous writer in the Baltimore $\mathcal{S} u n$, June 2, 1907, adduced similar evidence from the Provincial records.

${ }^{2}$ Scharf, J. T., History of Maryland. 3 v. Baltimore, 1879, 1: 190; for a discussion of Scharf's story, see appendix of this narrative. 
INTRODUCTIOX

to the bibliography of Maryland laws and to the legislation underlying their publication, it must be remembered that it was the printing of laws and the public business generally which brought printers to the early American cities. In the seventeenth century, in such capitals as Annapolis and Williamsburg, the private patronage of the press would not have provided a living for the least ambitious of its votaries. Public printing was the living of the printer in colonial Maryland until after the middle of the eighteenth century; the publication of the laws was his reason for being in the Province. The eye of authority looked with uneasiness on such issues of his press as did not initiate in a government office, and its hand was continually raised in the gesture of plucking away the license by favor of which he gained his bread. The literary activity of the Province came late into being, and the religious life was of a sort that rarely sought expression in print. In these pages a few sermons will be taken account of, and a political document or two will be noticed, but it is preeminently the printing of the Maryland laws that forms the framework for the early part of the narrative which here ensues.

It is obvious that to have carried through a work of this character with- out assistance from many persons would have been a supremely tedious task, but fortunately the author has not been compelled to encounter his difficulties alone. In the course of his adventure he has found a helping hand reached out to him in whatever direction he has turned, and for the assistance which has been freely given by everyone to whom he has applied, he here acknowledges himself most grateful. As usual in such cases, however, there are certain individuals whose aid has been of such a character as to give him an especial pleasure in its acknowledgment. Foremost among these must be mentioned Mr. Wilberforce Eames of the New York $P$ ublic Library, that kindly book-lover and scholarwho by making himself the servant of all American bibliographers has become their master. It is with an added sense of obligation, too, that the author recalls the interest displayed in the work at every step in its progress by his chief in the Enoch Pratt Free Library, Dr. Bernard C. Steiner, whose knowledge of even this bypath of colonial history has proved to be an unfailing source which could be drawn upon without restraint, as its richness was yielded always with-

[vii] 
out stint. Mr. Leonard L. Mackall, of Baltimore and Savannah, erudite bibliophile and citizen of the world, has given to the author guidance as to sources of information, and has inspired him with something of his own zest in literary research. Mr.L.H.Dielman, of the Peabody Institute, Baltimore, not only has given freely of his bibliographical and historical knowledge, but as well has displayed throughout that peculiarly sympathetic quality of interest and encouragement which is his choice possession. Mr. George Watson Cole, the Henry E. Huntington librarian, in a specific matter has made easy a part of the task which the author's ignorance of certain bibliographical practices was rendering laborious. For assistance in other specific points thanks are due to Mr. Edward Ingle and $\mathcal{F}$. Hall Pleasants, M.D. of Baltimore; the Rev. Thomas Hughes and the late Rev. E.I. Devitt, both of the Society of Fesus; Messrs. Hugh A. Morrison and 7. C. Fitzpatrick of the Library of Congress; Mr.Victor Hugo Paltsits of the New York Public Library and Mr.Earl G. Swem of the William and Mary College Library. A particular acknowledgment should be made to Mr. Robert A. Hayes and Mr. Charles Fickus of the Maryland Historical Society staff for cheerful and patient acceptance of almost daily demands on their attention. For courtesies extended both by correspondence and in person thanks are owing to the librarians and staffs of the Library of Congress; the Peabody Library, the Enoch Pratt Free Library and the Maryland Diocesan Library, of Baltimore; the Maryland State Library and the Land Office, of Annapolis; the Historical Society of Pennsylvania, the Ridgway Branch of the Philadelphia Library Company, the University of Pennsylvania Library and the American Philosophical Society; the New York Public Library, the New York Historical Society and the New York Bar Association Library; the Boston Atheneum, Harvard College Library, and the Massachusetts Historical Society; the American Antiquarian Society; the Fohn Carter Brown Library and the Rhode Island Historical Society.

An acknowledgment of indebtedness would be incomplete which failed to comment on the spirit in which a difficult piece of typographical work has been handled by Mr. Norman T. A. Munder and his associates, the printers of the book. Each person in that establishment concerned in the 


\section{INTRODUCTIOX}

publication has seemed to the author to be animated by the finest pride of craftsmanship, and more than this it would be difficult to say in praise of practitioners of their exacting art. It is a matter of no little interest in the record of present-day American presses that the completion of this book coincides almost to a day with the conclusion by Mr. Munder and two of his associates of thirty-five years in which they have worked together in the production of works distinguished alike for beauty and typographical excellence.

If it is certain that the book could not have been written without assistance from those persons and institutions which have been named, it is equally certain that alone the author could not have hoped to publish the results of his researches in a suitable form. Owing to the interest of $M r$. Nathan Billstein, however, this responsibility was taken from him by the Typothetae of Baltimore, an association of master printers, the members of which by this action proclaim their pride in the printing art and their interest in its traditions in the State where they practice it. It is the author's hope that their confidence in his work will be justified by its usefulness to the book-loving world.

The Enoch Pratt Free Library,

Lawrence C. Wroth.

Baltimore, May IO, 1922.

[ix ] 


\section{$C O N \mathcal{T} E N \mathcal{T} S$}

Chapter

Page

INTRODUCTION . . . . . . . . . . . $\mathbf{v}$

I The Nuthead Press of Jamestown, St. Mary's and ANNAPOLIS . . . . . . . . . . . . . I I

i William Bladen, Publisher, and His Printer, Thomas Reading . . . . . . . . . 17

iil Thomas Reading, Public Printer . . . . . 27

iv Evan Jones, Bookseller, and Editions of Laws Printed in Philadelphia and London . . . 39

v John Peter Zenger, Public Printer of Mary-

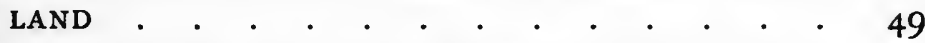

vi William Parks, Printer, of Maryland and VirGINIA . . . . . . . . . . . . . . 59

vil Jonas and Anne Catharine Green, Printers to the Province . . . . . . . . . . . . 75

vili Bacon's "Laws of Maryland" . . . . . . 95

ix The Beginning of Printing in Baltimore . . Ii

x William and Mary Katherine Goddard . . . I I9

Appendix: The Fabled Jesuit Press-Documents Relating to Parks and Green . . . . . I 47

Maryland Imprints of the Colonial Period, I689-1776 . . . . . . . . . . . . . 155

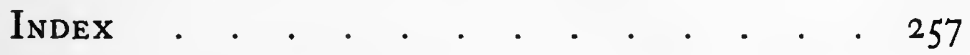





\title{
DESCRIPTION OF THE PLATES
}

\author{
Plate I, page 6
}

Reproduced from the only recorded copy, that in the Public Record Office, London. This is the earliest example of the Maryland press known to be in existence. (See No.I of Bibliographical Appendix.)

\section{Plate II, page 20}

The Brinley copy, reproduced by permission of the Maryland Historical Society, its present owner. In the reproduction, the upper left-hand corner, including part of the letter " $N$ " has been restored by the engraver. This is the earliest example of the Maryland press known to be in America. (See No. 5 of Bibliographical Appendix.)

\section{Plate III, page 32}

Page 113 of the collection of Maryland laws of 1707 . Reproduced by permission of its present owner, a descendant of its original owner, Robert Goldsborough, Esq., of "Ashby," Talbot County, Maryland. The volume has been deposited temporarily in the Peabody Library of Baltimore. (See No.17 of Bibliographical Appendix.)

\section{Plate IV, page 64}

Reproduced from a photostat copy of the title-page taken from the copy in the Library of Congress. (See No.43 of Bibliographical Appendix.)

\section{Plate V, page 66}

Reproduced from the only known copy, that in the British Museum. (See No.70 Bibliographical Appendix.)

$$
\text { Plate Va, page } 69
$$

See this title in Bibliographical Appendix for the years 1727-1732, 1734. Reproduced by permission from copy in the Maryland Historical Society.

$$
\text { Plate VI, page } 78
$$

Reproduced by permission from the copy in the Maryland Diocesan Library, Baltimore. Its first owner, as the autograph and date indicate, was the Rev. Samuel Keene, rector of St. Anne's Parish, Annapolis, I761-1767. The word "Propriety" in the title has been restored for the purposes of this reproduction. (See No.255 of Bibliographical Appendix.)

\section{Plate VII, page 86}

Reproduced by permission from the copy in the Maryland Diocesan Library, Baltimore. Formerly owned by the Rt. Rev. Thomas John Claggett, first bishop of Maryland. (See No.243 of Bibliographical Appendix.)

\section{Plate VIII, page 92}

Reproduced by permission from the copy in the Maryland Historical Society. (See No.29I of Bibliographical Appendix.)

[xiii] 


\section{Plate IX, page Io 8}

Reproduced from the author's copy of the large paper edition. Its original owner, Walter Dulany, Esq., of Annapolis, one of the underwriters of the publication, presented this copy to Messrs. Capel \& Osgood Hanbury, London merchants in the Maryland trade. (See No.254 of Bibliographical Appendix.)

\section{Plates $\mathrm{X} a$ and $\mathrm{X} b$, page 218}

These headings of the second Maryland Gazette are reproduced to supplement the verbal descriptions given under this title for the years $1762-1776$. Reproduced by permission from copies in the Maryland Historical Society. The typical heading of the earlier issues, beginning with I745, is shown facing page 24, vol. 2, of J. Thomas Scharf's History of Maryland, in the form of a reproduction of the first issue of this newspaper.

\section{Plates XI $a$ and XI $b$, page 240}

Headings of Goddard's Maryland Fournal, begun 1773, and Dunlap's Maryland Gazette, begun 1775 . Reproduced by permission from copies in the Maryland Historical Society. 
$A$ HISTORY of PRINTING in COLONIAL MARYLAND

I686-1776

8 



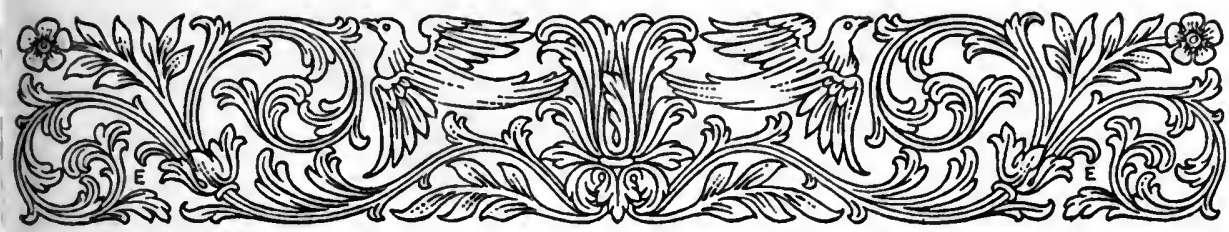

CHAPTER ONE

\section{The Nuthead Press of Famestown, St. Orary's and Annapolis- William Nuthead, the Inaugurator of Printing in Virginia and SCaryland-Dinah Nuthead, his Successor}

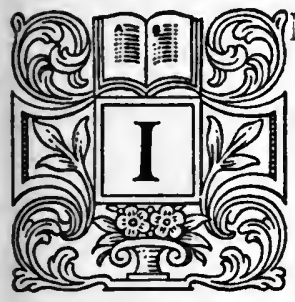

THE year I67I, the Lords Commissioners of Foreign Plantations addressed to Sir William Berkeley, the royal governor of Virginia, a series of questions relating to the state of his government. In his reply to that one of the questions which had to do with religious education in the colony, Sir William, a choleric old gentleman, who had headed honesty of conich whe bu and actions. "I thank God," he wrote, "there are no free schools nor printing and I hope we shall not have these hundred years; for learning has brought disobedience, and heresy and sects into the world, and printing has divulged them, ... God keep us from both!"'

It is plainly to be perceived from this declaration that there existed small chance for the establishment of a press in Virginia under the Berkeley régime, but Sir William's long governorship came to an end eventually, and in the year 1682, during the administration of Lord Culpeper, Mr. John Buckner, a merchant of Gloucester County, brought in a press and a printer and set up at Jamestown the second printing establishment of English America. Begun auspiciously enough, what seems to have been the first venture of this partnership met with such ill favor from the authorities as to discourage further attempts at printing in Virginia for many years. The action of the Virginia Council on hearing that Buckner's press was preparing to issue certain session laws is told in the following record: ${ }^{3}$

Att a Councell held att James Citty February 21: 1682/3. . . .

Mr. John Buckner being by his Excellency Thomas Lord Culpeper ordered to appear

${ }^{1}$ Hening, W. W., Statutes at Large ... of Virginia, $2: 517$.

2 John Buckner, Gent., the ancestor of a numerous family in the United States, patented 1,000 acres of land in Gloucester County in 1669 , and became a merchant with wide connections in Maryland and Virginia. Virginia Magazine of History and Biography, I: 406, and William and Mary College 2uarterly, 7:9, 10 and 11.

${ }^{3}$ Public Record Office: C. O. 5. vol. 51, No.42, 1683, Jan.-May. See Cal. State Papers, Col. Ser. A. E W. I., $1681-1685$, p. 390 , No. 961 .

[ I ] 


\section{A History of Printing in Colonial Saryland}

this day before him \& the Councel to answer for his presumption, in printing the acts of Assembly made in James Citty in November 1682, and several other papers, without lycence, acquainted this board, that he had several times commanded the Printer not to let any thing whatever passe his presse, before he had obtained his Excellencies lycence, and that noe acts of assembly are yet printed, only two sheetes, wch were designed to be presented to his Excellency for his approbation of the print: This board having seriously considered, what the said Mr. John Buckner has said, in his defence, are well satisfied therewith, but for prevention of all troubles and inconveniences, that may be occasioned thorow the liberty of a presse, doe hereby order that Mr. John Buckner and William Nulhead (sic) the Printer enter into bond of one hundred pounds sterling with good security, that from and after the date hereof, nothing be printed by either of them, or any others for them, of what nature soever, in the aforesaid presse or any other in this Colony, untill the signification of his Maj'ties pleasure shall be known therein, which his Excellency hath promised to acquaint his Majesty with.

Nicho: Spencer, Secr'ty.

Several months later, on September 29, I683, this order of the Virginia Council was read before the Lords of Trade in England, and it was by them decided that the new governor, Lord Francis Howard of Effingham, should pursue a policy of absolute prohibition in regard to printing in his government. On December 14, 1683, they approved the King's letters of instruction to Howard, in which his Majesty had written,

"And whereas We have taken notice of the inconvenience that may arise by the Liberty of Printing in that Our Colony, you are to provide by all necessary orders and Directions that no person be permitted to use any press for printing upon any occasion whatsoever.'I

Seven years later this restriction was modified to accord with the usual form of conditional prohibition under which the press operated in other colonies. In his instructions of October 9, I690, Howard was told that "No printer's press is to be used without the Governor's leave first obtained,"2 but even then, after it had been put on the same footing of sufferance as it stood upon in the northern colonies, the press in Virginia did not revive as might have been expected. ${ }^{3}$ It was not until the coming of William Parks to Williamsburg in the year 1730 that printing became an established feature of life in the oldest of the American colonies, al though as has been shown, it had been practised there for a short period nearly half a century before this time. ${ }^{4}$

${ }^{1}$ Cal. State Papers, Col. Series, A. $E$ W. I., $1681-1685$, Nos. 1426 and 1428 ; new number in P. R. O. is C. O. 389/8, pp. 267-272. Colonial Entry Book. Plantations General, 1679-1684.

${ }^{2}$ Cal. State Papers, 1689-1692, No. 1099.

${ }^{8}$ The lethargy of Virginia in regard to printing during the ensuing forty years is not easily accounted for. In Maryland, during the same period, as the narrative will bring out, various presses existed and were patronized by the government, and in Pennsylvania in spite of the disapproval of William Penn (Minutes of Provincial Council of Pennsyloania. Philadelphia, 1852, 1: 278), the press throve from its first establishment.

"A single Williamsburg imprint of the year 1702, with printer's name given as "Fr. Maggot," has been recorded. It is generally supposed that this imprint is false. As far as the author knows, it has never been made the subject of an extended investigation. Evans No. 1057. 
The foregoing incidents in the history of the neighboring colony are related here for the reason that they have a direct bearing upon the story of the press in Maryland, and in particular upon the life of the first Maryland printer. It seems clear that the orders which Howard brought with him to Virginia effectually put an end to the venture of John Buckner and William Nuthead. To Buckner, the merchant and planter, the failure of the press meant only disappointment and vexation; to Nuthead, the printer, it meant ruin. Under circumstances so distressing as this, it has been the immemorial custom for the Virginian to move to Maryland, and Nuthead, not long after his press had been stopped, packed his equipment and betook himself to the traditional place of refuge. In Lord Baltimore's province, he lived and worked at his vocation from 1686 , or earlier, until his death in the year $1695 .^{1}$

\section{"William Nuthead of St. Marys Citty Printer"}

The decade from 1685 to 1695 is less well known than almost any other period of Maryland history, for the reason that the documentary record for these years contains many lamentable gaps. During the Protestant Revolution of 1689 , and for two years thereafter, the records were kept either badly or not at all, and in the removal of the capital from St. Mary's to Annapolis in the year I694 many of the precious documents of earlier years were damaged, while of those which remained intact a number of important volumes were consumed by the fire which destroyed the State House in the year 1704. On account of these several losses, it is not possible to tell the story even of the principal events of the period in satisfactory detail, much less to relate consecutively the history of an individual citizen of the Province in those troublous years. In the documents which have survived accident and neglect, however, there remain a sufficient number of references to one William Nuthead of St. Mary's to enable the investigator to delineate in outline his life in Maryland, and to claim for him the distinction of having established and operated the first Maryland press. The existence of his or of any other printing office in seventeenth-century Maryland has been questioned, but it is believed that the evidence which will now be adduced establishes beyond doubt the fact that the press of William Nuthead was in more or less regular operation at St. Mary's during the years from 1686 to 1695 .

The first recorded evidence of the presence of a printer in Maryland occurs in an act of Assembly for October 1686, in which provision was

I For a brief statement of Nuthead's venture in Virginia, see Bruce, P. A., Institutional History of Virginia in the I7th Century. 2 v. N. Y., 1910, I: 402 and 403.

[3] 


\section{A History of Printing in Colonial SCaryland}

made for the "Payment and Assessmt of the Publiqe Charge of this Province." Therein, among many others, is found this item, "To Wm. Nutthead Printer five Thousand five Hundred and fifty pounds of Tobaccoe." In view of his earlier history in Virginia, and of his later history in Maryland, the simple and natural assumption in reading the item which has been quoted is that when the Province paid William Nuthead for services rendered, and designated his trade in the act of payment, those services had been performed in the practise of the trade therein specified.

In the following month, November I686,"William Nuthead of St. Marys Citty Printer" took up three hundred acres of land, known thereafter as "Nutheads Choice,"lying in Talbot County and "to beholden of the Mannor of Baltemore." The annual quit rent for the property was named as twelve shillings sterling, but the conditions under which the warrant had been granted were not specified in the certificate of survey. A short six months after the date of his warrant, on April 4, I687, for a sufficient sum, the amount of which was not disclosed, "William Nuthead of St. Marys Citty Printer" sold or made perpetual assignment of his plantation in Talbot to one Edward Fisher, and with its sale "Nutheads Choice," together with its new owner, becomes of no further interest in this narrative. ${ }^{2}$

\section{The First Recorded Issue of the Maryland Press, The "Protestant Declaration" of i689}

William Nuthead's earliest printing activities have not been kept in remembrance. In spite of the fact that he was a resident of St. Mary's City and in the pay of the Provincial government certainly as early as I686, it is necessary to pass over the ensuing three years to the riotous days of the "Protestant Revolution" before there is found an issue of his press which has been recorded by name. The circumstances out of which arose the publication in question give it a singular interest in Maryland political history. After overturning the Proprietary government in July I689, Colonel John Coode and seven others of the leaders of the Revolution drew up a manifesto entitled "The Declaration of the Reasons and Motives for the Present Appearing in Arms of their Majesties Protestant Subjects in the Province of

\footnotetext{
1 Archives of Maryland, I3: 131. The assumption will be permitted that William $N$ ulhead, a printer, compelled to forego his trade in Virginia in the year 1683 , and William Nushead, a printer in the pay of the Maryland government in 1686 , were one and the same individual. Whether the assumption be allowed, however, is of comparatively small importance in the ensuing relation of the activities of William Nuthead, the first Maryland printer. It should be said too, that although he is variously known as Nulhead, Nuthead, Nutthead and Nothead, his name certainly was not "Roughead" as it is given in the number of the Virginia Magazine of History and Biography previously referred to.

2 Land Records, Liber 22, folio 295, ms. in Land Office, Annapolis, Md. The parcel of land described lay in what is now Caroline County, then a part of Talbot.
} 


\section{The Nuthead Press . William and Dinah Nuthead}

Maryland,"' signed it as of July 25, I689, and transmitted the original or a manuscript copy of it to London for the information of the King in whose name and interest their subversion of the government had been undertaken. A perusal of the document makes clear the fact that it was intended not only as a justification of their proceedings in the eyes of King and Council, but even more as a means of explaining their usurpation and gaining support for it from the people of Maryland.

To make effective their purpose of gaining adherents it is evident that a wide local distribution of the "Declaration" would have been regarded as desirable by the Associators, and nothing could have been more natural than that they should have turned to the printer who was established in the village where they had ensconced themselves and demanded his services in the interests of their propaganda. This much is assumption. No copy remains of the "Declaration" as printed by William Nuthead of St. Mary's City to demonstrate that the Associators pursued the course which has been suggested, but that such an edition of it was actually published is rendered almost certain by the circumstance that later in the year I689, one Randal Taylor, a London publisher, issued an edition of the Maryland "Declaration" 2 which bore as its colophon the following succinct statement: "Maryland, Printed by William Nuthead at the City of St. Maries. Re-printed in London, and sold by Randal Taylor near Stationers Hall, 1689." While it is true that frequently through the ages books have been issued bearing false or misleading imprints, there has never been adduced a reason for believing that the London edition of the Maryland "Declaration" belongs in that category. William Nuthead was an actual person living in St. Mary's City in the year I689, and in the same year a London publisher declared in a work licensed by an authorized official that this William Nuthead had printed the original edition of the work in question. It is axiomatic that the statement of an imprint is to be accepted as true unless reasons can be urged for believing it to be false; otherwise imprints would possess no significance, and long ago would have fallen into disuse.

Formerly the claim that Maryland printing began in the year 1689 was not allowed because no Maryland printed copy of the "Protestant Declaration" could be produced as evidence in support of it, and although even

\footnotetext{
${ }^{1}$ Original signed document in Public Record Office, London. See Cal. State Papers, A. E W. I., I689-1692, No. 290. Copy of original published in Archives of Maryland, 8: 101 .

2 The full title of the "Protestant Declaration," as printed by Randolph Taylor in London is as follows: The Declaration of the Reasons and Motives for the Present Appearing in Arms of their Majesties Protestant Subjects in the Province of Maryland. Licens'd, November 28, 1689. J. F. [Colophon:] Maryland, Printed by William Nuthead at the City of St. Maries. Re-printed in London, and sold by Randal Taylor near Stationers Hall, 1689. For additional facts concerning it, see under the above title in the bibliographical appendix.
} 


\section{TH E \\ A D D R E S S}

\section{Of the Reprefentatives of their Majeftyes Fratefont Subient, in the Provinnce of Mary-Land Affembled.}

To tle Kings mojt Excellent Mai /ty.

W hereas we are I with all humilizy I fully affured that the bene. fit of your Mareftycs glorious underiakeings and bleffed luce cefs, for the Proceltane Religion, and civil rights and libertyes of your Subicet, was gracioully incrided to be Extenfroe, as well to this remore pare, as 10 all others of your Majellyes Territories and Countries; and heing: theicby infiuenc'd tu exprels our utmoft zeal and endeapousis for your Maieltyes fervice, the Proteftant Religion, here of late notori. cully ofpol'd, and your Maieftyes Soveraigne Right and Domivion, to rhis your Maieftyes Province of Mary.land, Invaded and undcrmined, by our late Pupith Governours their dgents and Conplices.

Wee yenr A_cieftyes molt duryful and loyal Subicas of this Province, being Alicmbled, as tlic Reprefentacive body of the lanse, doe humbly pray your Maieltyes gracions confideration, of the great Grevances and Upprelfions, wec have long la ien under, lately reprefented to your $M_{2}$ icfty, and direCled ro your Ma ieftyes principal Secretaryes of Stace, ina cerraine Declaration from the Comanders, Ofticers and Ctnlemen lately in Armes for your Maieltyes Sesvice and ele Detence of the Proteltane Religion.

And that your Maic fty would be gracioully pleafd in fuch wayes and mert ods as to your Princely wifdom hall feeme meer, to appoint fuch $a$ deliverance to your Suftering People, whereby for the future our Renggion Kingis and Liberrjes may be securd, under a Proteftant Govemment. by your Maielly es gracious direction Elpecially ro be appointed... We will wayte withall becon,eing Dury and Loyalry your Maieltyes Plea. flire herein; And wiil in the mean time, to the halard of our lives and Fortunes Perfeverr, and continue to vindicate and defend your Maieftyes Kight and Soveraigme Dominion over this Province, the Proreftant Religion, and the civil rights and libertyes of your Muieftyes Subiects here, againt all manter of attempes and oppoficion whatloever. Hereby unanimoully declateing. thas as wee have a full (ence of the blefing of Fieavcaven upon your Maieftyes Generous undertakeings, fos will endeo. vour to exprels our due gratitude for the $f_{2 m e}$, as becomes profeffors of the beft of Religions, and Subients to the beft of Princes.

Maryland printed by order of the A flembly at the Citty of St. Maryes Auguit: 26th. 1689.

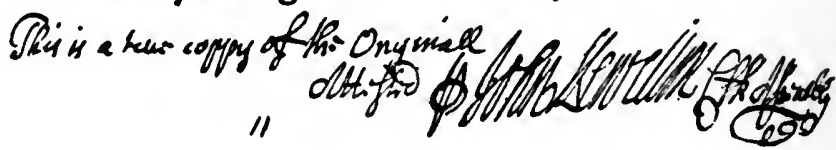

Plate I. See page xiii. 


\section{The Nuthead Press . William and Dinah Nuthead}

yet no such copy has been discovered, the necessity for evidence of this character is now less imperative because of the greater existing knowledge of the life and activity of William Nuthead, and because through the discovery of a broadside printed in Maryland a few weeks after the presumed publication of the "Declaration" at St. Mary's City, the burden of the claim has been shifted to a more firmly established base. In the following section of the narrative the broadside which is here referred to will be described and discussed.

\section{The First Extant Issue of the Maryland Press, THE AsSEMbly "AdDress" of I689}

The services of William Nuthead to the Associators were not concluded by the printing of their "Declaration." Soon after the publication of that document, addresses from various sources began to be drawn up for presentation to the King, some of them by the Protestant supporters of the Revolution, others by Protestants who had remained loyal to the Proprietary and his government. In the class first described was an "Address" from the Assembly, which, in the official manuscript copy transmitted to his Majesty, was dated "September 4, 1689." This copy, as it turned out, was received by the Lords of Trade on December 3I, I689, ${ }^{1}$ but fearing with good cause that it had been captured by the French, ${ }^{2}$ Coode wrote to the Privy Council on December I 7 th and stated in the letter that he was sending enclosed additional copies of the "Declaration" and of the "Address" of the Assembly. ${ }^{3}$ On February 7, I689/90, Lord Shrewsbury turned over

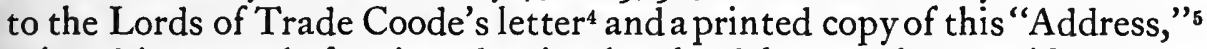
printed it seems before its adoption by the delegates, but certified as an authentic copy in the following words written across its bottom margin by the Clerk of the Assembly: "This is a true coppy of the Original. Attested per John Llewellin Clk Assembly."

The title and description of this broadside, preserved in the Public Record Office, London, ${ }^{6}$ is as follows:

The |Address | of the Representatives of their Majestyes Protestant|Subjects, in the Provinnce (sic) of Mary-Land Assembled.|

1 Archives of Maryland, 13:239 and 240, where it is reprinted with the Lords of Trade indorsements.

2 Archives of Maryland, 8: 167 .

Archives of Maryland, 8: 151 and 152.

-Archives of Maryland, 8: 152 . Lord Shrewsbury was one of his Majesty's principal secretaries of state. For an account of him see "Talbot, Charles, 12 th Earl and only Duke of Shrewsbury" in the Dictionary of National Biography.

Archives of Maryland, 13: 231 and 232, where it is reprinted with the Lords of Trade indorsements.

- Old reference for this paper in P. R. O. was America and West Indies. No. 556, B. D., p. 6. Noted in the ms. calendar of Maryland papers in P. R. O. compiled by Henry Stevens, now in the Maryland Historical Society, as B. T. Maryland, vol. I. B. D., p. 6. Its present number is C. O. $5 / 718$. 


\section{A History of Printing in Colonial SCaryland}

It contains a concise statement of the causes of the Revolution and an expression of loyalty to their Majesties, presented in terms appreciably more moderate than had been employed in the "Declaration," and what is of the greatest importance in this story of the Maryland press, it bears at the bottom of the sheet the following colophon:

Maryland printed by order of the Assembly at the Citty / of St. Maryes August: 26th. 1689.1

Coode's assertion in his letter of December 17 th that he was sending a copy of the Assembly's "Address," the fact that Coode's letter and a printed, attested copy of that "Address" were received by the Lords of 'Trade from Lord Shrewsbury on the same day, and the colophon of the "Address" itself combine to furnish a reasonably clear pedigree for the printed broadside in the Public Record Office which, in the absence of a copy of the Maryland edition of the "Declaration," must be claimed as the earliest extant issue of the Maryland press, and the chief bibliographical evidence for the seventeenth-century origin of typography in Lord Baltimore's Province.

\section{Later Activities of Maryland's First Printer}

When we find Nuthead figuring once more in public affairs, the Province, now under a royal governor, has resumed that aspect of peacefulness into which the turbulency of the Protestant Associators had entered brusquely some four years before. On October I 4, 1693, there was read in the Council a deposition made by William Nuthead in regard to a printing "job" which Colonel Darnall, agent of the dispossessed Lord Baltimore, had demanded that he put through as a "rush order." The transaction is of importance in this narrative inasmuch as in the entry which records it, one is enabled to catch a glimpse of the first Maryland printer in the actual prosecution of his business, and to observe the straight course which a public printer must needs hold to in that day of restricted liberty of the press. At the meeting of the Council on the day named above, there was

"Produced at this Board Coppy of a blanck Warrant which was Given by Coll Darnall \& Mr. Smith as a president (sic, precedent) to William Nuthead the Printer in order to print a certain Number of the same, for their Use, the Tenor whereof followed in these words, Vizt.... [Here follows in the original a blank land warrant running in the Proprietary's name].

On the back of the abovesd Warrant was taken the following Deposition, Vizt.

Octbr 14 th 1693 .

The Deposition of William Nuthead of St. Maries City Printer Aged Thirty Nine years or thereabouts. This Depont saith that Coll Darnall \& Mr. Richard Smith comeing to this Deponts house on the 6th of this instant month would have had him to have printed the within written blank Warrant to the Number of ffive hundred, to be done imediately out 
of hand, and that this Deponent did promiss to finish the same by Twelve of the Clock the next day if in case this Depont had the assistance of a Joyner, which said Joyner did the Wooden Worke and was paid for the same in Money; afterwards the said Coll Darnall \& Mr. Richard Smith came again to this Deponts house and Required him to perform his promiss, to which this Depont made Answer that the Press \& Letters were none of his and therefore could not complye therewith without Order, and that the said Coll Darnall \& Mr. Smith were pressing \& Urgent for this Deponts printing the said Warrants, but this Deponent did not print the same and further saith not. . . .

Whereupon it was Ordered by advice in Councill, that the Printer hereafter presume to print noething but blank bills \& Bonds, without leave from his Exncy or the further Order of this Board."'1

It is not perfectly clear what Nuthead meant by his disclaimer of ownership of the "press and letters," unless it be that he intended to convey to his importunate clients the idea that his equipment was theoretically the property of the government as long as he continued to use it under a government license. Later it will be brought out that, unlike many of the colonial pioneers of typography, he was the actual owner of his press, and that at his death it passed as personal property into the possession of his widow. The importance of his deposition, however, lies not in any question of the ownership of the press, but in the testimony which it bears to the fact that there was in Maryland in 1693 a printing press in such customary use that demands might be made upon it for work "to be done immediately out of hand," and that such service under normal circumstances might be rendered.

In April of this year I693, William Nuthead and two others were named in a warrant which directed them to search the lodging room and closet of Sir Thomas Lawrence for certain papers which they were ordered to seize, seal in a bag and bring straightway to the Governor for perusal. In so far as the record indicates, the issue involved had nothing to do with the story of Nuthead's life as a printer; it is likely that he was named for this duty simply because of a probable familiarity with the papers which the Governor wished to examine. Doubtless our printer man was thankful that he was not the person designated to make the search of the baronet's pockets which was ordered at the same time. ${ }^{2}$ In October of the year I694, William Nuthead was one of the signers of the petition addressed to the Governor by the citizens of St. Mary's, protesting against the removal of the capital from its ancient site to the settlement on the Severn which later was to be known as Annapolis. ${ }^{3}$ In the act of the September session of 1694 for paying

I Council Proceedings, October 14, I693, Archives of Maryland, 20: 33 and 34 .

${ }^{2}$ Council Proceedings, April 8, 1693, Archives of Maryland, 8: 501.

${ }^{8}$ U. H. J., October 13, 1694, Archives of Maryland, 19: 75.

[9] 
the public charge of the Province, Nuthead, in seven separate payments, was allowed, all told, six thousand eight hundred and twenty pounds of tobacco. ${ }^{1}$ In this session also the Rev. Peregrine Coney had been desired by the Council to have printed the fast-day sermon which he had preached on September 26 th. ${ }^{2}$ It is evident that not only did Nuthead, as the French say, "exist," but as well that he occupied a position of some importance in the life of the colony.

\section{Nuthead's Death and the Inventory of his Estate}

William Nuthead died in his forty-first year, a few months after he had set his name to the St. Mary's "remonstrance." The exact date of his death has not been discovered, but on the seventh of February 1694/95, Dinah Nuthead appeared before the Prerogative Court, stated that her husband had died intestate and requested that she be appointed administratrix of his estate. ${ }^{3}$ One of her sureties in the bond of two hundred pounds sterling which she was required to give was John Coode, the leader of the Protestant Revolution, a personage whom we must regard, in spite of the evil name which he left behind him, as one of the first patrons of the press in Maryland.

The inventory of Nuthead's business and personal property, dated April 2, I695, makes sad reading. ${ }^{4}$ The value of his personalty was only six pounds and nineteen shillings, a small amount even in that day of primitive living. On his books, however, there stood accounts in the names of some sixty persons who owed him various sums ranging from thirty pounds to three thousand pounds of tobacco, so that the total amount due the estate was nearly twenty-four thousand pounds of the current medium. ${ }^{5}$ Of the amount named, about nine thousand pounds of tobacco was secured by bills and bonds from ten persons who were then connected with the government, or who a year or two earlier had been employed in some one of the several capacities of county sheriff, member of Assembly, justice of a county court or government clerk. In this inventory Nuthead was described as "of the Citty of St. Maryes;" it was reserved for Dinah Nuthead, his widow, and a competent woman of business, to transport the printing establishment to the new center of provincial life on the Severn.

\footnotetext{
${ }^{1}$ Acts, Sept.-Oct. 1694, Archives of Maryland, $38: 33$.

2 Council Proceedings, September 27, 1694, Archives of Maryland, 19: 40. No copy of this sermon has been recorded. See bibliographical appendix.

${ }^{3}$ Testamentary Proceedings, $1692-94$, I 5 : 171 , ms. in Land Office, Annapolis.

"Inventories and Accounts, 13A: 263, ms. in Land Office, Annapolis.

Tobacco at this time was worth about a penny a pound. Twenty-four thousand pounds of tobacco would have been valued at one hundred pounds sterling. The rapid rise of prices in the last few years makes it difficult to calculate the equivalent of this sum in modern money.
} 


\section{The Nuthead Press . William and Dinah Nuthead}

There are several items in the Nuthead inventory which are of interest in this narrative. If the "printed papers" which were discovered among his effects had been listed in good bibliographical form, the activities of the first Maryland printer doubtless would have been clearly outlined for us, but having little idea that Nuthead's work in St. Mary's would ever be of interest to posterity, the appraisers contented themselves with only the briefest description of his office file. They were equally terse in recording that they found "In the Printeing house a printing press, Letters \& a parcell of old Lumber," and as cautious as they were terse when they set upon thisitem the modest valuation of five pounds. An en try of somewhat pathetic interest in this short and simple catalogue of a poor man's goods was "one old sorrell horse hardly able to stand valued at . . 5 5 shillings." It is not improbable that the beast had been brought to this pass through long journeys undertaken by his owner in the hope of collecting those outstanding debts.

The fact is significant that Nuthead had on his books at the time of his death sixty or more accounts with individuals of his own county, and of Kent, Cecil and Talbot, for there is no reason to believe that he was at any time engaged in a trade other than that of printing for which these accounts might have been opened; he had no tools, no merchandise, no farm stock; the printing press was the only implement listed among his effects by means of which he might have gained a livelihood, and the general employment of his press in that pioneer country, as indicated by the number and geographical distribution of its patrons, is cause for astonishment. It may be that an explanation of its apparent popularity is to be found in a petition which Thomas Reading, the third Maryland printer, presented to the Assembly in the year 1706, in the course of which the petitioner prayed that

". . . whereas there hath been a former Ordinance of this House to Mr. W. Bladen and others that had printing Presses in the Province obliging all Clerks, Commissarys, Sheriffs, and other officers to make use of printed Blanks [that ordinance] may be renewed and settled on your Petitioner."1

It is likely that Nuthead, in no less degree than his successors in Maryland, carried on a lively business in printing the legal and mercantile forms in daily use in the Province. In this day he would be considered the veriest "job printer," but such as he was, he deserves commemoration as having been the pioneer of printing in Virginia and Maryland, the first individual to practise the art of typography in any colony south of Massachusetts.

1L. H. J., April 8, 1706, Archives of Maryland, 26: 577. As Bladen and Reading began printing in Annapolis in the year 1700, the phrase "others that had printing Presses in the Province" must refer either to William and 


\section{A History of Printing in Colonial SCaryland}

\section{A New Chronology of American Printing}

If one might assume that the payment to Nuthead of five thousand five hundred and fifty pounds of tobacco in October 1686 had been made for services rendered by him throughout the previous twelve months, it would be possible to set the year 1685 as marking the inaugural of printing in Maryland, in which case the typographic beginnings of that province would be coeval with those of Pennsylvania. Indeed it is likely that, finding his press under the gubernatorial interdiction in Virginia in the year I683, Nuthead had come immediately to Maryland, so that although the first occurrence of his name in the records of Lord Baltimore's colony was in the Act of 1686, yet it is possible that in the future there may be found documents to show that his art had an even earlier origin there than the year in which its initiator was first mentioned.

If the facts relating to the operations of the Nuthead press in Virginia and Maryland be accepted at the value which has been attached to them here, it appears at once that the received chronology of American printing has suffered alteration. In that case the order in which presses were established in the several English colonies would read, as to the first five of them, as follows: Massachusetts, I $638 ;^{1}$ Virginia, I $682 ;^{2}$ Pennsylvania, I685; Maryland, I686; $;^{4}$ New York, I693. ${ }^{5}$

The order of priority as suggested in this chronology gives to Virginia the position which Isaiah Thomas conceded to it in the appendix to his first edition, and it claims for Maryland the place to which it seems to beentitled by the testimony of $i$ ts records.

\section{Dinah Nuthead and the First Annapolis Press}

Dinah Nuthead, the widow of William, was a woman of admirable courage. A few months after the death of her husband, she removed from St. Mary's to Anne Arundel County, whither, some months before, the government had preceded her. It is nowhere expressly stated that she carried with her the printing press which had come to her at William Nuthead's death, but it seems unreasonable to believe otherwise in the light of certain events which are now about to be related. Entirely without education, not

\footnotetext{
Dinah Nuthead, or to some other printers working in the Province before that year. There is not, however, the slightest trace remaining of any other Maryland printers of this period except the Nutheads.

${ }^{1}$ Roden, R. F., The Cambridge Printers, $1638-1692$. N. Y., 1905, p. 11 .

${ }^{2}$ Ante. Thomas, rst ed., 2: 544; also Thomas 2 d ed., $1: 331$ and $33^{2}$.

${ }^{3}$ Hildeburn, C. S. R., A Century of Printing, The Issues of the Press in Pennsylvania, 1685-r784. 2 v. Phila. 1885 .

"Ante. Even if the year 1689 with its printed "Address" be taken as Maryland's inaugural year, the relative order of this list is not disturbed.

${ }^{5}$ Hildeburn, C. S. R., Sketches of Printers and Printing in Colonial New York. N. Y., 1895.
} 
well provided with money, she yet made plans to carry on a business in which some knowledge of letters and a certain amount of capital is usually regarded as indispensable. She was shrewd enough to realize, however, that if she were successful in finding a journeyman printer to conduct her establishment, the possession of that rare article, a printing press, would surely provide a decent main tenance for herself and her two children. Boldly she made the venture.

On May 5, 1696, more than a year after her husband's death, "Dinah Nuthead's Petition for License to Print was read and referred to the House that if they have nothing to Object her Paper might be Granted provided she give Security for the same." 1 Eight days later her petition was read to the delegates, and the House expressed its willingness that she should have leave to print if his Excellency pleased. ${ }^{2}$ Evidently the Governor offered no objection, for on the next day the persons described as "Dinah Nuthead of Ann Arundell County Widow, Robert Carvile and William Taylard of St. Maries County Gentn" gave bond to the Governor to the amount of one hundred pounds lawful money of England for the good behavior of Dinah Nuthead in the operation of her press. Theinstrument continues as follows:

"Now the Condition of this Obligation is such that if the said Dinah Nuthead shall exercise and Imploy her printing press and letters to noe other use than for the printing of blank bills bonds writts warrants of Attorney Letters of Admrcon and other like blanks as abovesd nor Suffer any other person to make use thereof any otherwise than aforesd Unless by a particular Lycense from his Exncy the Governor first had and obtained And further shall save harmless and indempnifye his sd Exncy the Governor from any Damage that may hereafter Ensue by the said Dinah Nuthead misapplying or Suffering to be misapplyed the aforesd Printing press or letters otherwise than to the true intent $\&$ meaning before expressed, Then this Obligation to be Voyd or else to Remain in full force and Virtue."

This fearsome instrument for the protection of the Province against the evils of indiscriminate printing was signed by certain witnesses, by the two bondsmen and by the principal, who, as one observes, was compelled to make her mark instead of signing her name to the document, a disability under which she labored to the end of her days. Clearly Dinah Nuthead herself could not have intended to act as the compositor in the establishment which she had brought up from St. Mary's to the new seat of government at Annapolis.

For how long a period Dinah operated her "press and letters" in Annapolis, it has been impossible to determine. No imprints bearing her name have been recorded, but it is quite possible that in addition to the blank forms

${ }^{1}$ U. H. J., May 5, 1696, Archives of Maryland, 19: 306.

${ }^{2}$ L. H. J., May 13, 1696, Archives of Maryland, 19: 370 .

${ }^{8}$ Council Proceedings, May 14, 1696, Archives of Maryland, 20: 449.

[13] 


\section{$A$ History of Printing in Colonial STaryland}

which comprised a large part of the printing output of the day and place, there issued from her press a sermon by the Reverend Peregrine Coney, a clergyman whose discourses seem to have met with the approval of the delegates on the several occasions of their delivery. It has been seen that during the life of William Nuthead, this reverend gentleman had been requested to have printed a fast-day sermon, delivered by him before the Assembly. Again on May 13, 1695, in the interval between William's death and the re-establishment of the press by Dinah, Mr. Coney was returned thanks by the House for his fast-day sermon, ${ }^{1}$ but doubtless for the reason that there was no press in operation in Maryland at that time, he was not asked to have his discourse printed. One year later, however, three days after Dinah had petitioned for leave to print, the Upper House ordered that "Mr. Couey (sic) be desired to Print his Sermon preached yesterday,"2 an action which was concurred in by the delegates on the following day. The discovery of a copy of this sermon or of any other imprint from Dinah Nuthead's press would be an event of importance in American typographical history, inasmuch as it would constitute the first known American imprint from a press conducted by a woman.

No further references to Dinah Nuthead's activities are to be found in the Assembly proceedings, a circumstance from which one must conclude that the Nuthead press of Annapolis had ceased operations or even had been removed from the Province. It may be that Dinah had employed her press for other purposes than those described in the bond, with the result that she had been prohibited its use; or it may be that, illiterate herself, she had been unable to procure for the conduct of her establishment that rare bird in the colonies, a journeyman printer, and in consequence had been compelled to give over entirely her venture into a difficult and uncertain business. The probability that it was just at this time, however, that she married a second husband must not be overlooked in seeking for the cause of her withdrawal from the business of printing.

The date of Dinah Nuthead's second marriage is uncertain, but sometime before the month of December 1700, she married one Manus Devoran of Anne Arundel County, who dying in this month left his personalty to his daughter Catherine, and to his children-in-law, that is his step-children, William and Susan Nuthead. ${ }^{3} \mathrm{His}$ wife and executrix submitted her account

${ }^{1}$ L. H. J., May 13, 1695, Archives of Maryland, 19: 178, where date is incorrectly given as 18th.

${ }^{2}$ U. H. J., May 8, 1696, Archives of Maryland, 19: 313,316 and 362. This sermon also is recorded in Ethan Allen's Ms. List of Works by Maryland Clergymen, in the Maryland Diocesan Library, but Dr. Allen had seen no copy.

${ }^{3}$ Maryland Calendar of Wills, 2: 2 ro. 
under the name of Dinah Devoran. ${ }^{1}$ In later years Dinah married again. Her third husband was "Sebastian Oley of Annarund'l County a German born," as he was described in an act of naturalization of 1702 .

In spite of the fact that this woman whom we knew first as Dinah Nuthead was unable to sign her name, she seems to have made her way to a position of respect in the community. William Taylard, a man of some prominence in the Province, had sufficient confidence in her character and ability to act as bondsman for her behavior and later to accept the guardianship of her children; ${ }^{2}$ but as even more striking evidence of her worth is to be remembered the fact that in a day when women were few in public life, she had been able to secure from the Governor and Assembly of Maryland permission to operate a printing press in the service of the Province. As far as is known she was the first woman in English America to conduct or to attempt to conduct a printing establishment, the forerunner in this trade of Anne Catharine Green, Sarah Updike, Clementina Rind and Mary Goddard, who nearly a century later in Maryland and elsewhere carried on such establishments with notable success. It is a matter for regret that no more was heard of Dinah Nuthead's printing activities after the recording of her bond for good behavior in the conduct of her press.

\section{A Summary of the Evidence for a Seventeenth-Century Press in Maryland}

In the foregoing pages of this chapter there has been set forth evidence, in such amount as it has been possible to collect, with the object of demonstrating the seventeenth-century origin of printing in Maryland. An examination shows that the following facts have been brought out by this evidence; namely, that from 1686 to 1695 there lived in St. Mary's City, the old capital of the Province, one William Nuthead, who was several times designated as "Printer" in contemporary documents; that as early as I686, "William Nutthead, Printer," was in the pay of the government; that after his death, a printing press and a font of letters were listed in the inventory of this Nuthead's personalty; that in the colophon of an important Maryland political pamphlet, printed in London in I689, William Nuthead of St. Mary's was specifically named as its original printer; that there exists

1 Inventories and Accounts, 21 : 190. March, 1701. Ms. in Land Office, Annapolis.

${ }^{2}$ Deeds, Anne Arundel County, Liber W. T. No. 2, p. 684. Ms. in Court House, Annapolis. Indenture between Dinah Oely (sic) of Anne Arundel County, Widow, and William Taylard, Gentleman, trustee of William Nuthead, Susannah Nuthead and Sebastian Oely, children of the "sd Dinah Oely lately called Dinah Devoran." Sebastian Oley, the elder, died in 1707 (Maryland Calendar of Wills, 3: 85), leaving in addition to his wife and executrix, this son Sebastian and a daughter Margaret, who as she is not mentioned in the above indenture may have been Oley's child by a former wife 


\section{$A$ History of Printing in Colonial Scaryland}

a printed broadside, attested officially as a true copy of an Address of the Maryland Assembly, which, its colophon asserts, was printed in Maryland during the period when William Nuthead was resident in its capital; that a Maryland Council minute has been preserved which records a discussion of the propriety of Nuthead's action in printing or promising to print certain warrants, and in which the future limits of his printing activity were prescribed by the councillors; that in his deposition read before this body, Nuthead confessed to having promised to print five hundred warrants by noon of the day following the receipt of the order; and, finally, that after his death in I695, Nuthead's widow asked and received permission to operate a printing press in the Province, presumably that press which a few months before had been listed in her late husband's inventory. In view of these facts, it seems permissible to affirm that the generally accepted chronology of American printing should be corrected by placing the beginning of Maryland typographical activity in the year 1686 when Nuthead first was entered on the public pay roll rather than with the coming of William Parks to Annapolis in 1726 . That the forty years by which this change in chronology extends the printing annals of Lord Baltimore's province were not barren of interest for the student of American typographical history, the pages which follow will make clear. 


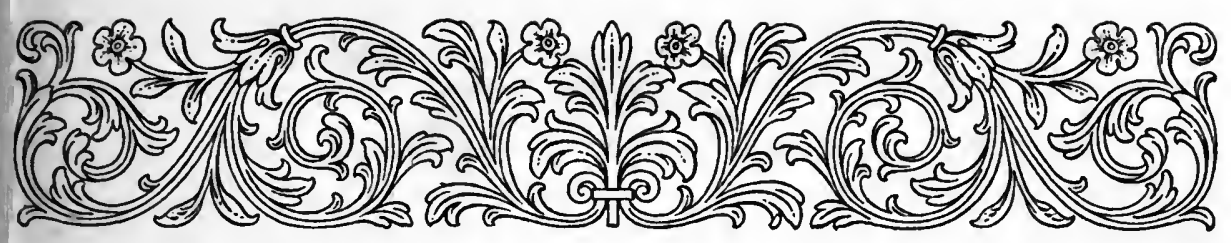

\section{CHAPTER TWO}

\section{William Bladen, Publisher, and his Printer, Thomas Reading-}

\section{The Bray Sermon of Annapolis, I700- \\ The Body of Lares of 1700}

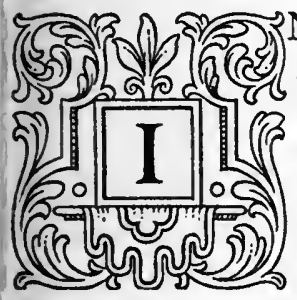

$\mathrm{N} \mathrm{SUCH}$ of the northern colonies as had printing presses available during the closing years of the seventeenth century, there were printed with fair regularity the annual session laws of the assemblies, and, occasionally, bodies of compiled laws. Nothing of this sort, however, seems even to have been contemplated in Maryland until the year 1695 , when, doubtless on the initiative of the new governor, Francis Nicholson, zealous always in intellectual and educational matters, the Upper House proposed to the delegates,

"That when the house have compiled such a Body of Laws as they think may be the Standing body of Laws of the Province that they then imploy Some able Lawyer in England to digest them and put them into better Language, and So have them returned in again for perusall and approbation of the whole Assembly $\&$ afterwards to Send them back in Ordr to procure the Royall Assent to the Same and have them printed."'

At this time in the colony the only form in which the body of law existed was in the several collections of manuscript session laws in the possession of the counties and the government. The disadvantages to court and people of this arrangement were perfectly understood by everyone, but for some reason no action was taken by the Lower House on the remedial suggestion proposed by the upper chamber, and again, in May 1697, their Honors returned to the matter with a recommendation "That a former proposall about haveing the lawes digested into better Language by some able Lawyer in England be considered anew and is again recommended from the board.",2 This time the Lower House took formal action by referring the matter to a standing committee, ${ }^{3}$ but as nothing was heard of it afterwards, it may be assumed that the committee buried the proposal deep beneath its accumulation of business.

${ }^{1}$ U. H. J., October 15, 1695, Archives of Maryland, 19: 23 I.

${ }^{2}$ U. H. J., May 28, 1697, Archives of Maryland, 19: 51 I.

${ }^{3}$ U. H. J., May 31, 1697, Archives of Maryland, 19: 517 .

[17] 


\section{A History of Printing in Colonial SCaryland}

\section{Mr. William Bladen Proposes to Establish a Press}

In the period intervening between the two recommendations, however, William Bladen, then clerk of the Lower House, had made a proposal which was to result eventually in the printing of the compiled laws, and in the establishment of the typographic art upon a stable basis in the Province. On October I, I696, the burgesses made the following representation to the Upper House:

"Upon proposall of William Bladen Clerk of this House that a printing press would be of Great Advantage to this province for printing the Laws made every Sessions \&c and that he the said Bladen at his own proper cost and charges would send for such press with the Appurtenances provided his Excellency the Governor would give him Leave to make use of the same this House are of opinion that the same will be of Great advantage to this Province \& humbly desire his Excellency will be pleased to Give leave to the said Bladen to make use thereof when arrived according to his proposal." 1

Immediately the recommendation of the Lower House as expressed in this message was approved, provided the petitioner should give "security according to his Majesty's Royal Instructions to his Excellency." 2

From the phrasing of Bladen's proposal to the Assembly one acquires the impression that he intended tosend outside of the Province for his printing equipment, a necessity which would have existed only if Dinah Nuthead had sold her press, or if it had become too old and worn for use. Whatever the case may have been with regard to Dinah's equipment, however, the sense of Bladen's words makes it manifest that her printing office had closed its doors within five months of its establishment. Lacking the opportunity to purchase her plant for any reason, almost certainly Bladen would have been forced to send to England for his press and letters, and even there, he would have experienced difficulty in procuring decent fonts of type. The event will show that from whatever source he obtained his plant, he was compelled in the end to satisfy himself with a second-hand equipment whereof the types and furniture were notably worn and broken.

At the time of his proposal to the Assembly, William Bladen was a youth of three and twenty years of age, but he was then the same industrious and versatile man that he continued to be throughout his life in the Province. Born in 1673 of a well-known Yorkshire family, he came to Maryland some-

${ }^{1}$ U. H. J., October 2, 1696, Archives of Maryland, 19: 466.

${ }^{2}$ These instructions to Nicholson, dated March 8, 1694 (Archices of Maryland, 23: 549), were composed in the usual terms in which instructions regarding printing were transmitted to colonial governors at this time. See ante, instructions to Lord Howard of Effingham in 1690, and Copley's instructions of August 26, 1691 (Archives of Maryland, 8: 279): "And forasmuch as great inconveniences may arise by the Liberty of Printing within our Province of Maryland, you are to provide by all necessary Orders that no person use any Press for printing upon any occasion whatsoever, without your speciall License first obtained." 


\section{William Bladen Publisher and his Printer Thomas Reading}

time before 1692 , in which year he was employed by the Lower House in making a transcript of the laws and in other clerical work of the session. In the year I 694 he signed the remonstrance of the citizens of St. Mary's against the removal of the capital. He assumed prominence in public affairs in 1695 as Clerk of the Lower House, a position which he held until he became Clerk of the Upper House in 1697, in which capacity he served the Province until four years before his death in 1718 . He was Collector of the Port and District of Annapolis in 1697, Clerk of the Prerogative Court in I699, Secretary of Maryland in 1701, Attorney-General of Maryland in 1707, Architect of the State House, $\mathrm{I}_{70}$ to 1708 , and Commissary-General of the Province in 1714. He held office also as an alderman of Annapolis in 1708, and several times served as vestryman of St. Anne's Parish. In the year I696, he married Anne, daughter of Garrett Van Swearingen, by whom he had two children. One of these was Anne, who married the Hon. Benjamin Tasker of Annapolis, and the other was that Thomas Bladen who lived prominently not only in Maryland, of which he was Governor from 1742 to 1747 , but as well in England, where at a later period he sat in the House of Commons as member for the Borough of Old Sarum. ${ }^{1}$

It was characteristic of Bladen's enterprise that he should have perceived the advantage both to himself and to the Province in the importation of a press which should be capable of larger undertakings than those which formerly had been entrusted to the Nutheads. From the beginning he proposed to perform ambitious tasks, although in the first notice that we have of the press after its establishment in the colony, the character of the work suggested for it differed in no particular from that which Dinah Nuthead had been licensed to undertake four years earlier. It should be understood that Bladen was not a printer; he was the entrepreneur only, and he brought in with his press a practical printer, who was without doubt that Thomas Reading of whom we shall hear a great deal as this relation proceeds. An entry in the copy of the Lower House Journal which was transmitted to the Board of Trade, omitted in the Maryland original, informs us that on September 30, I696, it was resolved that if Mr. Bladen were successful in obtaining a printer and a press, he should have the sole benefit of their operations, and the Council was asked to concur in that resolution for the encouragement of his designs. ${ }^{2}$ During the first years of the venture, although the name of Thomas Reading appeared alone on the imprints,

1 "The Bladen Family," by Christopher Johnston, Maryland Historical Magazine, 5: 297; Archives of Maryland, passim; Vestry Proceedings, St. Anne's Parish, in Maryland Historical Magazine, vols. 6-10; article "Maryland Gleanings; Sidelights on Maryland History," by Hester Dorsey Richardson, in the Baltimore Sun, May $29,1904$.

${ }^{2}$ Cal. State Papers, A. \& W. I., 1696, No. 268, p. 155.

[19] 


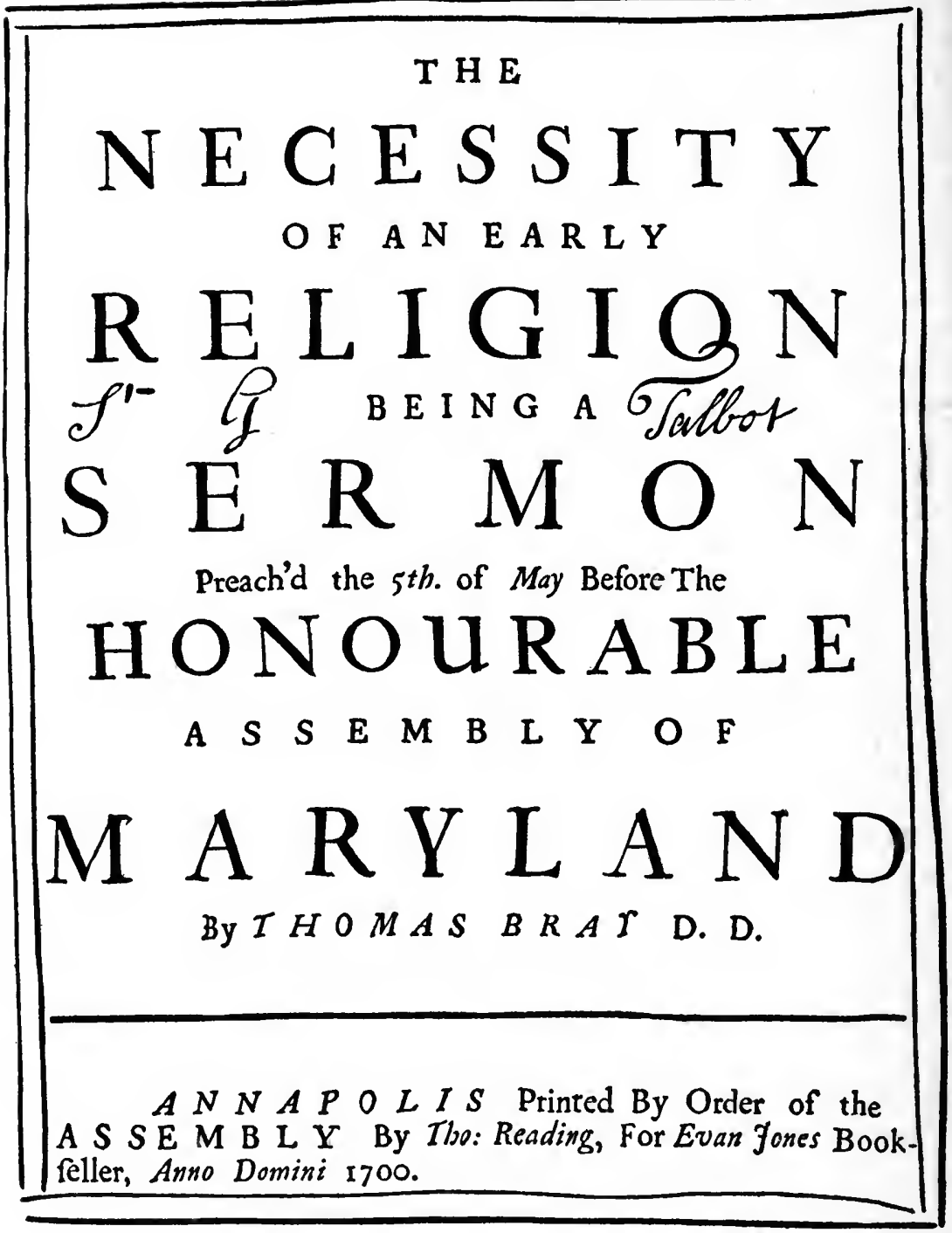

Plate II. See page $x i i i$. 
Bladen accepted the responsibility of the press, and also, doubtless, whatever profits accrued to its operation above a salary or royalty paid to the printer. Exactly what were the relations, however, between Bladen and Reading is not known, but whatever may have been the arrangement under which they worked, it seems to have been altered as early as the year 1704, for then and afterwards Reading was spoken of as public printer and Bladen was mentioned no longer in connection with the business of the establishment. It will be seen later, that although in partnership and alone Reading used for thirteen years the press which Bladen had set up in Annapolis, yet the ownership of it remained with Bladen throughout the entire period.

It was nearly four years after Bladen had been given permission to bring in a printing press that, in the month of May I 700 , he announced himself to the Assembly as ready for business. On May 4 th, the Council sent down to the Lower House the following recommendation:

"The peticon of Wm. Bladen haveing been here read and considered this Board findeing that the Petr has been at great charge and trouble in procureing the Press, Letters, Papers, Ink and Printer Etc. wee doe recommend the same to the house for their consideration and encouragement and that for Promotion thereof an Ordinance pass that after the Ioth day of September next noe other writts be made use of but such as shalbe printed (Save only Speciall Writts wherein are varyous recitalls) and All Bayle bonds, Letters Testamenry, Letters of Admistracon Citacons summonses \& $\mathrm{ca}$ be printed and none other made use of they being allways to be had vizt

The Writts Citations and Summons's at one penny or one li Tobo per peece

And the Lres Testamenry Admon Bayle bonds \&ca at Two pence or two pounds of tobbo per peece." 1

This recommendation of the Council was assented to by the House, and it was

“. . . ordered accordingly provided the Petr give sufficient Caution to his Excy not to printe any other matter or thing but what Shalbe first lycensed by his Excy the Govr or some other p'son that shalbe by him appointed."2

\section{Bray's "Necessity of an Early Religion" Annapolis, i700}

That it was not the intention of the Assembly to permit the usefulness of Bladen's press to be limited to such humble service as the printing of blank forms and legal papers appears from further reference to it during the remaining days of the session. On May 5 th, the Rev. Thomas Bray, D.D., the Bishop of London's commissary for Maryland, preached before the Assembly a sermon which so pleased the delegates that a few days later it was ordered in theHouse "that Doctor Bray bereturned thanks from this

${ }^{1}$ L. H. J., May 6, 1700, Archives of Maryland, 24: 60.

${ }^{2}$ L. H. J., May 6, 1700, Archives of Maryland, $24: 60$.

[2I] 


\section{A History of Printing in Colonial Scaryland}

house for his exct Sermon of that text Remember thy Creator in the days of thy Youth and Acquainte him that this house desires the same may be printed." 1 In the possession of the Maryland Historical Society there is preserved an unique copy of a publication which, as far as has been recorded, is the earliest Maryland imprint of which a copy remains in America. Its title-page reads as follows:

The $\mid$ Necessity | of an Early | Religion | being a | Sermon | Preach'd the 5th. of May Before the | Honourable | Assembly of | Maryland | By Thomas Bray D. D. | Annapolis Printed by Order of the | Assembly By Tho: Reading, For Evan Jones Book-| seller, Anno Domini $1700 .\left.\right|^{2}$

A photographic reproduction of the title-page of this first recorded issue of the Bladen-Reading press is shown on page 20 . The evidence which it presents of the general inferiority of the press which Bladen had set up with great pains and expense is supplemented by the occurrence throughout the text of broken letters, and of repeated indications of the employment of worn and irregular chases. These defects in equipment and a most notable carelessness in proof reading characterize so much of the work of this press as to constitute an aid in the identification of its issues.

The First Edition of the Maryland Laws, AnNAPOLIS, 1700

Although the Bray sermon is the first specimen of the Bladen-Reading press of which a copy remains, it is probable that it was not the first important issue of the new establishment, for in this same session of 1700 , two days before the delegates had taken action in regard to Dr. Bray's discourse, when the bill for religion had been read the third time and assented to, it was "Resolved that the same Act be forthwith printed and that one of them be ordered for every parish in the pvince." ${ }_{3}$ In the absence of a copy of this act bearing the Annapolis imprint it is impossible to assert that the resolution of the House was complied with, but the fact that the delegates had begun immediately to requisition the services of the new press indicates that they appreciated fully its value in the conduct of public business.

Two days after the printing of the Act of Establishment had been ordered Bladen proposed a publication transcending it in interest when he suggested to the delegates:

"That if the house are desirous the body of Laws should be printed soe that every person

${ }^{1}$ L. H. J., May 9, 1700 , Archives of Maryland, $24: 82$.

${ }^{2}$ On the verso of the title-page occurs substantially the same order of Assembly as that which has been quoted, signed "Tho: Smithson Speaker."

${ }^{3}$ L. H. J., May 7, 1700, Archices of Maryland, 24:67. 
might easily have them in their houses without being troubled to goe to the County Court house to have recourse thereto-That the house made (sic) an Order for the printeing thereof and that every County be Obliged to take one faire Coppy endorsed and Titled to be bound up handsomly and that for the encouragement of the undertaker each County pay him therefore $2000 \mathrm{lbs}$ of Tobo upon delivery the said booke of Laws."I

In the same document Bladen proposed to build a prison for the Province, and in conclusion added piously, "All which will be readily undertaken and with the blessing of God Carefully accomplished by yor most humble Servant to command W. Bladen." Planter, clerk, architect and publisherthis W. Bladen was a valuable citizen in a community such as Maryland was at this time.

Bladen's proposal to print the body of laws was timely. In the year 1699 the Assembly had passed an "Act Ascertaining the Laws of this Province," by the terms of which were repealed all laws which had been made theretofore except those of that session, and selected ones of other sessions mentioned in an annexed schedule. This Act had been disallowed by the King for specific reasons, and because in general the advisers of his Majesty had disapproved of legislation whereby, as it was explained later, "the vallidity of all the Laws of the Province, are ... made to depend upon this one Single act, whereas Each of them ought to have been Enacted Separately."2 Accordingly, in the following year, the Assembly changed a specifically named law in the schedule to which his Majesty had objected, that is, the Act for Religion, but in framing a new ascertaining act, disregarded the general ground of his veto, and proceeded on May 9, I 700, to pass an "Act for $\mathrm{Re}$ pealing certaine Laws in this Province and Confirmeing others," 3 a piece of legislation which differed only in small details from its predecessor of I699, to which, as a matter of legislative method, his Majesty had taken exception. It was on the day that this law was sent to the Governor for signature that Bladen had proposed to the House that he be given permission to print the body of law of the Province, and the delegates believing that body of law to have been determined finally by their recent enactment, granted his petition and ordered that

"Mr. Bladen according to his proposall have liberty to printe the body of the Law of this Province if so his Excy shall seem meet And it is likewise unanimously resolved by this house that upon Mr. Bladen's delivery of one Printed body of the said Laws to each respective County Court within this province for his encouragement Shall have allowd him Two Thousand pounds of tobo in each respective County as aforesaid."4

IL. H. J., May 9, 1700, Archives of Maryland, 24: 83 .

${ }^{2}$ L. H. J., April 27, 1704, Archives of Maryland, 24: $37 \mathrm{I}$.

${ }^{3}$ L. H. J., May 9, 1700 , also "Acts" of 1700, Archives of Maryland, $24: 78$ and 104.

"L. H. J., May 9, 1700, Archives of Maryland, 24: 84, where the phrase "his encouragement" reads "this encouragement."

[23] 
The project was now carried out with diligence. The book was set, printed and distributed among the counties within one year following its authorization, for in May 1701, we find a reference to it which leaves us in no doubt as to these facts and as to certain of its features. On May 17th Bladen was summoned to the Lower House and told by the Speaker "of the many Erata's Comitted in printing the body of Laws." Whereupon, the record continues, "it was required by the house tht he cause the Erata's to be fourthwith printed and sent into the severall Countys. To which he readyly concurred and promised to gett the same forthwith printed and sent out ..."1

\section{The Unique Copy of the "Laws" of i700 in the Library of Congress}

There has been preserved in the Library of Congress a volume which the bibliographers of that institution have identified as the collection of laws which has been described here as having been printed on the Bladen-Reading press of Annapolis in the year I700. Unfortunately the title-page of this unique copy has disappeared, so that one is compelled to turn to the evidence of circumstance to verify the attribution. Briefly summarizing the preceding pages, the circumstances related in them are found to be these:

In the year I 700 William Bladen established a press and a printer in Annapolis for the purpose of printing laws and other governmental matters.

In the session of May 1700, in answer to his petition, William Bladen was given permission by the Assembly to print a body of Maryland laws.

In the session of May I 70I William Bladen was ordered by the Assembly to have printed and distributed throughout the counties a list of errata committed "in printing the body of laws."

Keeping these facts in mind one takes up a volume of Maryland laws in the Library of Congress and finds that it contains a dedication "to my Honoured and Ingenious Friend Mr. William Bladen at the [Port] of Annapolis," and this personage is complimented by the unknown editor for his cleverness in having devised so excellent a scheme for the benefit of the Province and of himself as the printing and publication of a body of laws at a price sufficiently cheap to enable all persons to purchase a copy of the volume containing it; ${ }^{2}$ and further that the laws which make up the collection comprise the body of Maryland laws confirmed by the Assembly on the same day that Bladen was given permission to print the laws of the Province, together with the additional laws passed in that session; and fi-

${ }^{1}$ L. H. J., May 17, 1701, Archives of Maryland, 24: 198.

${ }^{2}$ Archives of Maryland, $38: 427$, gives as much of the "Dedication" as remains decipherable in the Library of Congress copy. 
nally that a comparison of the typographical features of this volume with those of certain other known issues of the Annapolis press brings out an identity in the type faces and a similarity in style, chiefly in faults of presswork and imposition, which indicate with some degree of certainty that the same printer, working with the same poor press and appurtenances was responsible for all of them. ${ }^{1}$

So skittish a jade is Fame that this important collection of Maryland laws, having served its three or four years of usefulness, passed into such a degree of oblivion that in Bacon's day, sixty odd years after its publication, the very memory of it had been lost. In the enumeration of collections of Maryland laws which occurs in the Preface to Bacon's Laws of Maryland, this edition of the year 1700 is not mentioned, and a later collection of 1707 is referred to by the learned compiler as the first printed edition of the laws of the Province. ${ }^{2}$ For once, however, Bacon is found nodding at his task; the edition of 1700 , as will now be shown, was well known in the earlier decades of the century. ${ }^{3}$

In the year 1704 there was published in London An Abridgement of the Laws in Force and Use in Her Majesty's Plantations, ${ }^{4}$ a work which has for us in this connection a definite bibliographical interest, for in its section devoted to Maryland the abridgements of the various laws of that province are accompanied by references to an unnamed collection of Maryland laws whereof the page numbers are identical with those of the Library of Congress volume which has been described.

The work was known and used also by Nicholas Trott in the compilation of his "Laws of the Plantations," London ${ }^{17} 721,{ }^{5}$ for in calling attention to the connection herenoticed between the "Abridgement" of I704 and

${ }^{1}$ A description of the Library of Congress volume is given in the bibliographical appendix attached to this narrative, under the year 1700 . It should be said that in affirming a positive result to a typographical comparison of this volume with other issues of Reading's press, the author is giving his own opinion only. He has not been able to bring the various examples of this press together for the examination of an expert. It is to be hoped that the Library of Congress authorities will some day replace the preservative paper with which the leaves of the volume are covered by the material now used in that institution for preservative purposes. A more satisfactory examination will then be possible.

${ }^{2}$ Laws of Maryland at Large, by Thomas Bacon. Annapolis, 1765.

${ }^{3}$ A single reference has been found in the Assembly journal which seems to point to the use by the House and other departments of the government of this edition of compiled laws of 1700 . At the session of September 18 , 1704 , "Mr. John Taylor orderd to goe up to some of the offices for a printed body of laws. He returns and says that there is none perfect but what belongs to the County Court office and that Mr. Bordley the Clk refused to send it." (Whereupon Mr. Bordley was brought to the bar of the House and promptly adjudged guilty of contempt. He made his submission and it was) "Ordered he bring downe the body of law belonging to the County. Which he did and delivered it to Mr. Speaker and upon his Submission he was discharged." (Archives of Maryland, 26: 156 ).

4 Title and description given in bibliographical appendix under year 1704.

${ }^{5}$ Title and description given in bibliographical appendix under year 1721 .

[25] 


\section{A History of Printing in Colonial SCaryland}

an earlier edition of Maryland laws, that ingenious codifier makes the following assertion: "As to the Laws of Maryland," wrote Mr. Trott,

"I have by me three editions in print: The first was that edition out of which that Abridgement of the Laws of Maryland was made which is in the Abridgement of the Laws of the Plantations, printed at London in 1704."

That Mr. Justice Trott was speaking literally "by the book" is rendered certain when one discovers that his own references by act and page to this work, which he described as the first edition of the Laws of Maryland, likewise correspond to the pages of the volume in the Library of Congress, designated here the Bladen-Reading collection of Maryland laws, published at Annapolis, by authority, in the year 1700 .

\section{William Bladen Retires from the Publishing Business}

A brief remark will be permitted as to the amount of the subsidy which Bladen received from the Province for his publication of the laws. If the terms of the House resolution were complied with as intended, he was paid twenty-two thousand pounds of tobacco by the eleven counties, a sum which, rating tobacco at a penny a pound, would have been the equivalent of about ninety-one pounds sterling. In an address of the Assembly to the Governor in the year 1702,1 it was stated that with one year and another, the average wage of the laboring man in the Province was two thousand pounds of tobacco, so that when one adds to the amount of Bladen's subsidy for the work the money which he must have received from its sale to individuals, it seems at first thought that his proprietorship of the press must have been a profitable undertaking in comparison with current wages and salaries, but when the expense of its establishment, the cost of paper and the wages or shares which he paid Reading are deducted, one feels that his enterprise must have turned out after all to be more for the public benefit than for his own profit.

It is probable that Bladen himself reasoned the case in this fashion, for we hear no more of him as a publisher after that day in May, I 70I, when he agreed to have printed and sent out a list of the typographical errors committed in the body of laws of 1700 . The printing activities of our pioneer American publisher seem to have ceased entirely with almost his earliest venture, and it is to his journeyman or partner, Thomas Reading, that we turn now in the continuance of our study of the press in Maryland.

\footnotetext{
${ }^{1}$ U. H. J., March 24, 1701/1702. Archives of Maryland, 24: 22\%. It is very difficult at this time to render these sums into modern equivalents. The cash equivalent of Bladen's payment would probably be represented by a sum at least five times as large as it was in the year 1700.
} 


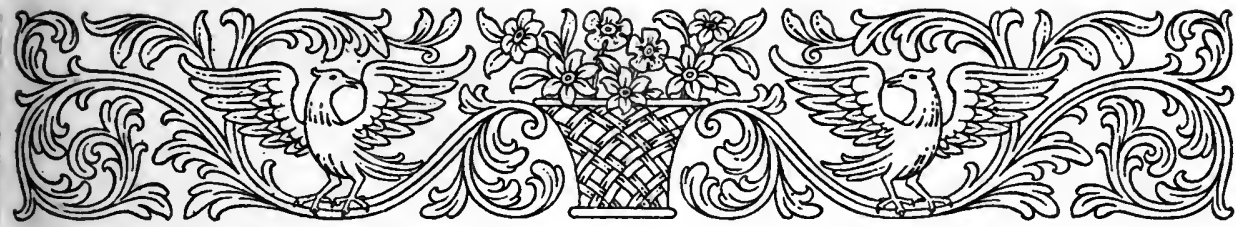

CHAPTER THREE

\section{Thomas Reading, Public Printer-The Keith Sermon, Annapolis, I703-The Collected Laws of I 707-The Begin- nings of the Annual Session Laws}

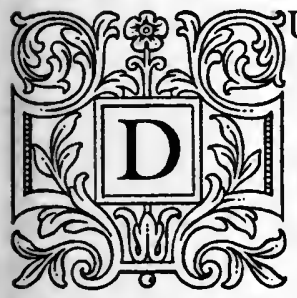

URING the years which followed the publication of that collection of laws which has been described in the foregoing chapter of this narrative as the Bladen-Reading edition of 1700 , it is probable that the press which Thomas Reading was operating at Annapolis continued, whether with or without Bladen's participation is not known, to casionally even to issue a pamphlet of a political or religious character. Only one Annapolis imprint, however, has been recorded between the years I 700 and I704. The title of this work was The Power of the Gospel, in the Conversion of Sinners. In a sermon preached at Annapolis, in Maryland, By George Keith . . . Fuly the $4^{\text {th }}$. Its imprint read, "Printed and are to be sold by Thomas Reading, at the Sign of the George. Anno Domini MDCCIII."

The place of publication of this sermon is not given in the imprint, but there remains evidence of a conclusive and interesting character to testify to its Annapolis origin. In Keith's Fournal, ${ }^{1}$ under the date of July 4, I703, the preacher himself writes these words:

"I preached at Annapolis, on I. Thess. I. 5. and had a large Auditory well affected; my Sermon at the request of a worthy Person who heard it, was printed at Annapolis, mostly at his Charge; and Copies of it sent by him, to many parts of the Country. It is Bound up with other Printed Sermons and Tracts, in the Book abovementioned, which I presented to the Honourable Society, soon after my arrival into England."

The author of these words and of the sermon which they refer to was that George Keith who has been remembered as a factious participant in the religious controversies of the colonies at this period. Formerly a Quaker schoolmaster of Philadelphia, at this time a clergyman of the Church of England, he had been the instigator and center, a decade before, of a con-

${ }^{1}$ Keith, George, A Fournal of Travels from New-Hampshire to Caratuck, on the Continent of North America. London, 1706; p. 66. See p. 39 in reprint in Collections of Protestant Episcopal Historical Society, New York, 1851.

[27] 
troversy which well-nigh had shattered the foundation of the Pennsylvania hierarchy. Since that time he had kept the various colonial presses hot with the issue of his pamphlets. Because of his advocacy of Keith, William Bradford, the first Philadelphia printer, had been compelled to remove his press to New York, where he had continued occasionally to issue pamphlets by or in support of his former friend. In controverting Keith's attacks on the Puritans, Cotton Mather and others had made free use of the presses of the New England colonies. The Maryland press alone had not been called upon either by Keith or by his enemies, but at this time, having secured ordination in England and returned hither with John Talbot as the representative of the Society for the Propagation of the Gospel in Foreign Parts, it befell that he became a patron of the only press in the colonies hitherto not requisitioned in the service of his controversial zeal.

\section{Thomas Reading Becomes Public Printer and Takes a Wife}

In the year 1704 we come again into touch with Thomas Reading in the pages of the Provincial records. In the September session of that year, it was moved in the Lower House that Reading print the Governor's speech, delivered at the opening of the session, and in response, it was

“. . . resolved he be lycensd so to doe likewise proposd that he may be constituted publiq printer to print all laws and other publiq matters Which being debated this house Resolves he be constituted printer first Giving bond with Securety to behave himselfe in that Office." 1

The next recorded action by Reading is his marriage on December II, 1705, to the "Widdow Gittins." 2 Evidently the journeyman printer whom Bladen had brought to the Province was sufficiently well satisfied with his prospects there to wish to settle himself comfortably in its capital.

\section{The Body of Laws of Annapolis, i707}

In April of the year I 706, there was read in the Lower House "The humble Petition of Thomas Reading constituted Printer of the Province of Maryland," in which that personage prayed that their Honors would

". . . order the Laws of this Province to be printed and this House would give him Encouragement for the speedy finishing the same; and That your Honours would please to settle some Annual Salary for his Support and Encouragement for which he will be obliged

${ }^{1}$ L. H. J., September 12, 1704, Archives of Maryland, 26: 129. In this same session (cf. U. H. J., September 25 and October 2, $17 \mathrm{O}_{4}$ ) the sermons preached at the opening of the new St. Anne's church, in the morning and afternoon respectively, by the Rev. Messrs. Wooten and Cockshute, were ordered printed, both Houses concurring. No copies of these sermons have been recorded. See bibliographical appendix.

2 "Births, Marriages and Deaths" in "Parish Register," St. Anne's Parish, Anne Arundel County. Copy in the Maryland Historical Society. 
to print all publick Matters as Speeches, Answers, Votes \& Proclamations \&c as your Honours please to direct.

And further whereas there hath been a former Ordinance of this House to Mr. W. Bladen and others that had printing Presses in the Province obliging all Clerks, Commissarys, Sheriffs, and other Officers to make use of printed Blanks [that ordinance] may be renewed and settled on your Petitioner.

And that there is a small House upon Wapping Wharf built by the Public, but at present of no use, therefore prays that the same be granted him . . .".1

A discussion took place on the reading of this petition from the printer as to "what encouragement might be sufficient to give him for his expeditious Printing the Body of the Laws of this Province," and it was determined finally to allow the petitioner twenty shillings a copy from each county for the proposed body of laws, and to give him permission to offer copies for sale at a rate not to exceed twelve shillings each. Furthermore, he was to be allowed "for what other Acts shall be passed in any future Assemblys ... the same in Proportion to the present Body of the Laws." ${ }^{2}$ Reading agreed to these terms at the time, but a few days later he returned and asked a more generous allowance for the body of laws, receiving in response to his appeal an additional ten shillings from each county and from the "country." 3 The delegates also proposed to him an annual rental of twelve pence, payable each Lady Day, for the unused house on Wapping Wharf, and made a further agreement with him whereby he was to copy the body of laws for the press for the sum of two thousand pounds of tobacco. ${ }^{4}$

The necessity for a new edition of the laws had arisen at this time because in the year I703 Queen Anne had ordered that "all Laws now in force be revised and considered" for the reason that the entire Provincial code depended upon the single "ascertaining act" of the year $1699 .{ }^{5}$ At various times since the confirming act of 1700 the Province had felt some uneasiness as to the validity of its statutes, and in the year I7OI the Governor had asked committees of the two Houses to meet together for the purpose of considering the question of revision. The conferees had gone carefully into the history of the existing body, and after consideration had declared that it would be "soone enugh to alter the present Estabmt when his Matys dis-

${ }^{1}$ L. H. J., A pril 8, 1706, Archives of Maryland, 26: 576-577.

${ }^{2}$ L. H. J., April 8, 1706, Archives of Maryland, 26: 577 .

${ }^{3}$ L. H. J., April 17, 1706, Archives of Maryland, 26: 605. See also p. 585, where Mr. Thomas Bordley was named "to examine \& correct the Press in Printing the Laws," and allowed 3,000 lbs. of tobacco for the service.

${ }^{4}$ L. H. J., A pril 8, 1706, Archives of Maryland, 26: 577.

${ }^{5} \mathrm{~L}$. H. J., April 27, 1704, Archives of Maryland, 24:371. The instructions of the Board of Trade appended to this entry refer to the ascertaining act of 1699 , but L. H. J., May 9, 1701, shows clearly that the Province was using the code adopted by the confirming act of May 1700 . In all essentials the two were the same, save for the difference remarked on in the preceding chapter. 


\section{A History of Printing in Colonial Maryland}

like is knowne and not before." 1 Three years passed after this event, during which the Province was administered under the code of 1700 , but in the year 1704 the royal mandate arrived and in September the Assembly was called for the purpose of revising and reënacting the entire body of law, a task which it straightway accomplished to the royal satisfaction.

Nearly two years passed after the revision had been completed before Reading proposed, as has been related, that he be allowed to print the revised statutes, and his proposals having been accepted, another year came and went before he began to carry them out. In the March session of 1707 he appeared in the House and in response to the demand of the delegates as to why the body of laws had not been printed in accordance with his contract, he declared that he "was and is always ready to do the same when this House will advise what Laws shall be in the Body and so withdrew."2 Whereupon it was resolved, "That all the publick Laws and Reviving Acts be printed at large and all Persons who have Interest in any private Laws be at the Charge of printing them otherwise the Title of such private Acts is sufficient to be printed." ${ }^{3}$ The book as planned on this occasion, containing the entire existing body of Maryland laws, was set and printed immediately, and that it appeared in this same year, we have the word of $\mathrm{Mr}$. Justice Trott, who as will be seen, made use of it in his compilation of the "Laws of the Plantations."

It is the collection which has been described in the foregoing paragraphs that Bacon referred to incorrectly in his Preface as the first printed Maryland collection of laws. "The first edition," he wrote, "contains the Laws from 1704 to 1707, both inclusive, to which are added several Acts of Assembly formerly made, declared to be in force, ... The Copy in my Possession (the Only One I have ever seen) has lost its Title Page, so that I cannot ascertain when or where it was Printed." We are indebted again to Mr. Justice Trott, who it will be remembered, wrote more than forty years before Bacon published his work, for a more definite reference to this collection of the Maryland laws. "So the Laws of Maryland being again enacted," he wrote in the Preface to his own compilation, "were collected into one volume, under the Title of All the Laws of Maryland now in force: And by order of the General Assembly were printed at Annapolis in Maryland in the year 1707."4 This reference is particularly happy in that Mr. Trott has

\footnotetext{
${ }^{1}$ L. H. J., May 9, 1701, Archives of Maryland, 24: 163.

${ }^{2}$ L. H. J., April I4, 1707, Archices of Maryland, 27: 125.

${ }^{3}$ L. H. J., April I4, 1707, Archives of Maryland, 27: 125.

${ }^{4}$ Trott, N., Laws of the British Plantations. London, 1721. The collection of Maryland laws here described is not recorded in Evans or in Sabin, nor does it appear in Lee, J. W. M., Hand-list of Maryland Laws. Baltimore,
} 


\section{Thomas Reading and the Issues of his Press}

given us what seems to be a transcript of the title-page of a volume which he asserted that he had by him at the time of writing.

As in the case of the body of Maryland law printed by Reading in the year 1700, there remains, as far as is known, only one copy of this edition which he printed in 1707 . This copy, as did also that which Bacon had in his possession, lacks its title-page, ${ }^{1}$ but its contents and a note by the printer at the foot of its last page of text enable one to establish its identity with the work described in the foregoing paragraphs and given by Trott the title and imprint of All the Laws of Maryland Now in Force, Annapolis, I 707. The volume contains, under separate session headings, the acts of the session of April 1704, the revised body of September 1704, and the acts of December I704, May I 705, April I706 and March 1707, as well as "Several Acts of Assembly formerly made declared to be in force." In this feature it answers the description given by Bacon and Trott, and the following note, on page I I 3 of the compilation, completes the information necessary to its identification as an Annapolis imprint of Thomas Reading:

"The Reader is hereby desired to take Notice that in the Assembly made Auno (sic) - 1706 the Pages are Folio'd I $23 \& \mathrm{c}$. by reason the Laws made that Sessions were ordered to be first Printed so that they could not be truly ascertained, and instead thereof add 80 8I 82 \&c. otherwise the Index will be false.

These are to give Notice to all Gentlemen \&c. that are any ways interested in private 'Acts of Assembly, that they may have them printed at lnrge (sic, for 'large'): And may likewise be furnished with blank Bills, Bonds, Writts Bills of Exchange, Bills of Lading, Administration Bonds, Testamentary Bonds, Letters of Administration, Letters Testamentary, Warrants for Appraisers \& c. with any other Matters printed at reasonable Rates by Thomas Reading living in the Town and Port of Annapolis."

In spite of the absence of a title-page, there seems no reason, bibliographical or historical, why the copy of laws which has been referred to

1878 , although the title has been added in Mr. Lee's handwriting to the manuscript of his work preserved in the Maryland Historical Society. Mr. Lee had not seen a copy, however, nor any record of one beyond that contained in Trott's preface.

${ }^{1}$ The copy of All the Laws of Maryland Now in Force, referred to in these pages, is believed to be unique. It belonged originally to Robert Goldsborough, Esq. of "Ashby," Talbot County, a practising attorney and a member of the Lower House at the time of its publication, whose notes are preserved on the margins. It has remained in the possession of his descendants ever since, and has now been deposited for safe keeping in the Peabody Library of Baltimore. As long ago as 1765 Bacon spoke of the copy in his possession as being the only one he had met with, and since his reference to it no one has recorded having seen a copy of this edition. About ten years ago a descendant of Robert Goldsborough showed the "Ashby" copy to certain students of Maryland history, but no note was made of its contents, nor of its ownership, so that it had disappeared entirely from general knowledge when it was offered to the author for examination and description. During the years that he was employed on the period of Maryland legislation covered by this collection, Bacon was living at Dover in Talbot County not many miles from "Ashby" where, it is likely, he was a frequent visitor. It is not improbable that the "Ashby" copy, which "has lost its title-page" also, was that which he refers to as being in his possession and the only copy known to him, but if this be true it is difficult to understand his ignorance of its place of publication, a fact which he might easily have learned from the printer's note at the foot of page I I3, present in the "Ashby" copy.

[3I] 


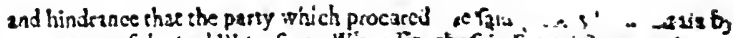

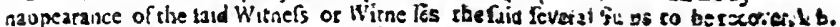

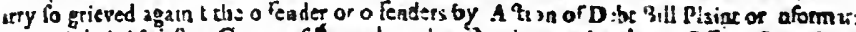
any of rheir Majeftys Courts of Lccord in thes itovince, wherein no EuToya Prorectson iweer of Lew to be allowed.

An Act for the Out Lawing of Ricliard Clark of Ann-Arundel Conniy.

W HE REAS' isappears to this Geseral Aftembly upon Oath thas thers bas heen a wety wicked and Treafonable Confpiracy began \& carryd on by Racibard Cerk of An-Arknde: County and his Arromplices, to ferze upon the Magazine, and his Exeelkn $y$ the Governour, $20 J$ overturn hes Majeitys Government and to bring the Hearben Indians to. gether with the Confpir rors to cus off and exrupate he inhabitants of chis Province; and foeafmuch as the faid $C$ kark fles trom Juftice and dares noc venture hinfel upon a Gir Tryal.

Be it therefore Enacted by rlie Quceas moit Excellent Majefty by and wrth rhe Advicf.and" Confeat of her Majeftys Governour Couneil and Afembly of this Province a ad the thuthority of the fame, that un'ers the Ead Racbard Clark do wirhin twenty Days after the End of this pre fene Seffion of A Temdly furrender himfelf to his Excellency the Governour, or to any one of her Majeltys honourabie Cos nell in order to be tryed for his Treafon aforefaid, that thea the faid Recbard Clark by Force and Vertue of this Ast thall be Ourlawed, and thall forkeit his Gonds and Chatrels Lands and Tenemerts as an Outlawed Pedon, any wans of Procefs es: 2 ny other legal Pruccedings in any wafe nocwathrondug.

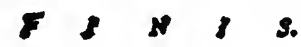

The Reader is hereby defired to take Notice that in the Afembly made Aune, $170 x$ the Pages are Folio'd 123 Éc. hy ceafan the Laws made thut Se lions wers oedered to be firit Printed fo that they could not be wuly afcertaned, and inftead shereof add 808182 Éc. 0 . therwife the Index will be falfe.

Thefe are to give Notice to all Genelemen $G_{5}$. that are any weys incerefted in private Aas of Affembly, that they may have them prinred at Inrge : And may likewife be furai'hed with blank Bills, Bonds, Writts Bi's of Exchange, Bills of Lading. Adminiftration Bonds, Teftametitary Bonds. Leteers of Adminiftration. Letters Teftamencary, Wartants for A ppraifers 6c. with any other Matters printed at seafonable Rates by 1 bomas Reading living un tha Town and Yort of Armapalis:

Plate III. See page xiii. 


\section{Thomas Reading and the Issues of his Press}

;hould not be ascribed to the Annapolis press of Thomas Reading, an issue of the year 1707, and it will be so entered with a full description in the bibiographical appendix to this narrative.

\section{The Beginning of the Printed Session Laws}

Throughout the years that followed Reading's appointment to the office of public printer in 1704 , there are to be found in the journals of the Lower House several significant references to his printing activities. It has been said generally, even by persons familiar with Maryland historical bibliogaphy, that the printing of the session laws of the Province began with Parks in the year 1726, but to indicate the incompleteness of the current znowledge on this subject, one need point only to the copies of Maryland session laws for the year 17 1 $9,{ }^{1}$ printed by Andrew Bradford of Philadelphia, which are preserved in the Library of Congress and in the Peabody Library of Baltimore. The truth is, indeed, that the printing of session laws began in Maryland more than a decade before even thisisolated number of the series issued from the Pennsylvania press.

- It has been shown earlier in this chapter that in the resolution by which the House had recognized Reading as public printer, specific mention had been made of his obligation "to print all laws and other publiq matters." That this was not a form of words, that in accordance with the intention of the Assembly, Reading began at this session to print the laws then enacted, is believed to be indicated by the several entries which are now to be cited from the Lower House journal, and by the bibliographical testimony which will be adduced as a complement to that evidence.

In the year 1706, when Reading petitioned for permission to print the body of laws and asked for the settlement of an annual salary upon him for the printing of "all publick Matters as Speeches, Answers, Votes \& Proclamations \&c.," the House resolved upon a rate of payment to be made him "for what other Acts" should be "passed in any future Assemblys," and ordered that he be "allowed for the same in Proportion to the present Body of the Laws." 3 In the following year, April 15 , I707, it was "Resolved That all the Laws Enacted this Session be printed pursuant to a former Order of the House. And the Printer to be allowed for the same according as before contracted for." 4 Finally in the petition which Reading presented to the Assembly in the year 1709, and in the action taken upon it by the

I See following chapter and bibliographical appendix.

${ }^{2}$ L. H. J., September 12, 1704, Archives of Maryland, 26: 129.

'L. H. J., April 8, 1706, Archives of Maryland, 26: 577 .

4L. H. J., April i 5, 1707, Archives of Maryland, 27: 128 (improperly headed April 13).

[33] 
delegates, there seems to be evidence that printed session laws had been the rule since the appointment of a public printer in 1704 , and further, that the Assembly intended the continuance of this good custom.

In the following paragraphs, Reading's petition of 1709 and the action taken upon it by the House are given in full:

"To the Honble Robert Bradley and the other Gentl. Delegates now sitting in the House of Assembly. The Humble Petition of Thomas Reading

Humbly sheweth to your Honours; That inasmuch as the Assembly in the Year of our Lord I $7 \mathrm{O}_{4}$ thought meet to constitute your Petitioner Printer as may to your Honours appear upon the then Journal, and at the same Time ordered that your Petitioner should be yearly considered by the several Counties for the Annual Laws of every Assembly the which are all ready to be produced to your Honours: ${ }^{1}$ Now may it please your Honours your Petrs Allowance is so small, together with the Inconveniencies that attend the same (as has already been demonstrated to yr Honrs) render yr Petrs Employment insignificant and not sufficient to maintain him.

Therefore your Petitioner most humbly prays yr Honrs will be pleased to take his Case into yr Honrs Consideration and make him what further Allowance your Honours shall think fit and likewise that your Honours will be pleased to make especial Order that the Secretary permit your Petitioner to have the Laws Enacted this Session so convenient to copy in Order for the Press, as to your Honours most wise Judgment may seem most methodical. And your Petitioner as in Duty bound shall ever pray \& ata

Which being read and fully debated, Ordered the same be thus indorsed Vizt

By the House of Delegates Novem'r I I th I 709

Upon reading the within Petition it is Resolved by the House that Mr Secretary permit and allow Thomas Reading the Petitioner immediately after this Session to take a Copy of the Laws now Enacted in Order that for Conveniency of the Province he by all convenient Speed print the same and that the said Reading get the great Seal affixed to each Body at the several Counties Charge and transmit a particular Body to each County for which he is to be allowed and paid by each County for the same and every other Session for the future $500 \mathrm{lb}$ Tobo a Body and that he prepare and deliver to the Clerk of the House one printed Copy for the Use of the Assembly and another for the Provincial Court to be paid for by the Public. Which is ordered to be done by all convenient Speed."2

From the documentary indications which have been presented here, one is able to construct a hypothetical series of printed Maryland session laws from I 704 to I 708 inclusive, and there the matter might rest in unsatisfactory state were it not that the actual sheets of one number of this series remain to render more nearly certain the supposition that the whole of it once existed. In the collection of Maryland laws printed in Annapolis by Thomas Reading in the year 1707, described in this narrative as All the Laws of Maryland Now in Force, the following pagination and signature sequence are to be observed: $\mathrm{B}-\mathrm{U},{ }^{2} \mathrm{X},{ }^{1}$ pp. I-78; B-C, ${ }^{2} \mathrm{D},{ }^{1} \mathrm{pp}$. I-IO; Aa-

\footnotetext{
${ }^{1}$ These italics do not appear in the original, but the phrase is deemed to possess such importance as to render this method of emphasizing it desirable.

${ }^{2}$ L. H. J., November 11, 1709, Archives of Maryland, 27: 461 and 462.
} 


\section{Thomas Reading and the Issues of his Press}

Ee, ${ }^{2}$ pp. 95-1 14 . The gatherings standing isolated in the volume, indicated here by the symbols, B-C, ${ }^{2}$ D, ${ }^{1} \mathrm{Pp}$. I-IO, and bearing at the foot of page Io the word "Finis," its only occurrence in the volume save when it was used at the conclusion, contain the laws for the April session of I 706. It will be recalled that in a note on the last page of the compiled laws of 1707 , Reading desired his readers to take notice that the laws of I706 were "folio'd I 23 \&c. by reason the Laws made that Sessions were ordered to be first printed so that they [i.e. the page numbers] could not be truly ascertained." The explanation of this erratic paging is to be found in the printer's desire to save time and the labor of composition. It has been shown here that in April 1706 he had contracted with the Assembly for an edition of collected laws and for editions of session laws for all future assemblies. Directed, it seems, to proceed with the printing and publication of the laws of that session before setting the collected laws, he had determined to run off from the forms which he proceeded to make up for this current issue, a number of extra sheets to be laid aside and held for inclusion in the larger work in contemplation. As his alternative to this course, he had the prospect of resetting later the matter of the entire session, for with the small fonts which the colonial printer owned, he could not have kept this matter in type until it was needed. Accordingly he ran off his extra sheets of the laws of 1706 , stored them, and a year later, bound them in the "collection" exactly as they had been printed originally for the separate edition of the session laws, retaining their paging, I-IO, their signatures, B-D, and the word "Finis" on their last page, leaving out only their original signature "A," which was doubtless the title-page and preliminary matter of the separate edition. If this reasoning is correct, it seems that the testimony of the documents as to the existence of a series of printed Maryland session laws earlier than heretofore has been known is well supported by the bibliographical evidence which the discovery of the volume of collected laws of 1707 has made it possible to adduce. ${ }^{1}$

There exists further evidence that Reading fulfilled the contract which he made with the Assembly when in 1704 he was appointed by that body "to print all laws and other publiq matters." Almost as this narrative goes to press there have appeared in the auction room two broadside sheets, ${ }^{2}$ printed by Thomas Reading of Annapolis in the year 1708, containing the Governor's "Speech" and the "Answer" of the November Assembly of that

${ }^{1}$ For a further discussion of this item, see bibliographical appendix under 1706 and 1707.

${ }^{2}$ See bibliographical appendix for a description of these two broadsides, unrecorded until they appeared as item No. 452 in catalogue No. 1546 of the Anderson Galleries, New York. They were sold January 11, 1921, to Dr. A. S. W. Rosenbach for $\$ 1260$. 
year. When one learns that Thomas Reading was printing minor legislative documents in 1708 , one assumes fairly that he was not neglecting the more important work for which his services had been engaged; that is, the printing of the acts passed at each session of Assembly.

Reference to the petition which William Bladen presented when in 1696 he asked permission of the Assembly to establish a press in the Province reminds us that it was his intention to make use of that press in printing the "laws made every Session," and al though neither copy of session laws as printed by him nor reference to such a copy remains, yet it is quite possible that the series of Maryland printed session laws began with that which we have called the Bladen-Reading press at the time of its establishment in the year I700. It is not intended, however, to assume upon these conjectural grounds that the printing of the annual session laws began in that year, but it is believed that the evidence which has been brought forward here indicates their beginning in and continuance for several years after I 704, the year in which Reading was constituted public printer and in which it was ordered "that he should be yearly considered by the several counties for the Annual Laws of every Assembly." In consideration of the facts here presented; namely, that there have been discovered the sheets of the session laws of I706, which Reading printed at the behest of that year's Assembly, and that the House journals give strong presumptive evidence that all of the laws from $\mathrm{I}_{704}$ to $\mathrm{I} 708$ were printed, and that there exist actual copies of the Governor's "Speech" and the Assembly's "Answer" for November I 708, one concludes that Reading was stating a plain truth when in speaking to the delegates of the "Annual Laws of every Assembly" he used the words "the which are all ready to be produced to your Honours." It would be difficult to construe his words as meaning anything except that he had printed the annual session laws from September 1704 to November I 708. The sheets of April I 706 having been discovered, there remain to be unearthed and recorded copies of the separate editions of September and December 1704, May I 705, March 1707, September and November 1708, and without doubt of all later sessions to the year of Reading's death in I7I3.

\section{Reading's Death and a Summary of his Services to the Province}

The next that we hear of Reading in the Assembly records is that he is dead. ${ }^{1}$ We are able to credit him with having printed two collections of com-

\footnotetext{
${ }^{1}$ U. H. J., November 14, 1713, Archives of Maryland, 29: 252. A discussion in the Upper House as to the best means to be employed in publishing the laws for the counties, whether on poor parchment or good paper, begins
} 


\section{Thomas Reading and the Issues of his Press}

piled laws, the session laws for at least five years, and a number of smaller works of a legislative and religious character. In the light of these performances he is seen as no small figure in the literary history of a province in which he labored at important tasks from the year I700 until his death thirteen years later. If one were to judge the quality of his handiwork from the Bray and Keith sermons and from the Body of Laws of 1700 , the verdict would form a severe reflection on his skill as a printer, but, fortunately, at least one example of his later work, the collected laws of 1707 , was of a sharacter sufficiently impressive and dignified to demand commendation of his craftsmanship from the most critical observer. This is true in spite of the fact that his proof reading and spelling, things not connected with the mechanics of his trade, remained poor to the end.

The property which Thomas Reading left at his death was not large. The evaluation of his goods and chattels amounted to seventeen pounds and a few odd pence, and although the appraisers listed among his effects several horses, two wigs, ten pairs of "eastern Shore Shoes," and a partly built house, they made no mention of a press or of any other appliances of the printing trade. ${ }^{1}$ Five years later, however, when William Bladen's estate was settled, there was listed among its many items and valued at six pounds, "an old Printing Press \& Some Letters." 2 The presence of these articles among Bladen's effects accounts for their absence from Reading's poor store of possessions. The fact that the printing press was included in the inventory of property which Bladen held in Anne Arundel County, as distinguished from his St. Mary's and Kent Island holdings, has a significance which will be referred to in a later chapter.

If one may judge from the inventories of their personal estates, the first printers of Maryland seem not to have prospered notably in their trade. Nuthead died possessed of little save a press, some promissory notes and a broken-kneed horse; Reading left behind him several horses and some old clothes, but neither printing press nor other tool of his vocation.

with the preamble "Whereas the Printer is dead." The "Register" of St. Anne's Parish (copy in the Maryland Historical Society) records the burial of one "Thomas Redding," doubtless our printer, on May 9, 1713. Reading's inventory is dated August 18,1713 .

Inventories and Accounts, 36B: 176, August 18, 1713. Ms. in Land Office, Annapolis.

${ }^{2}$ Inventories, $1: 324$, November 27, 1718 . Ms. in Land Office, Annapolis. 



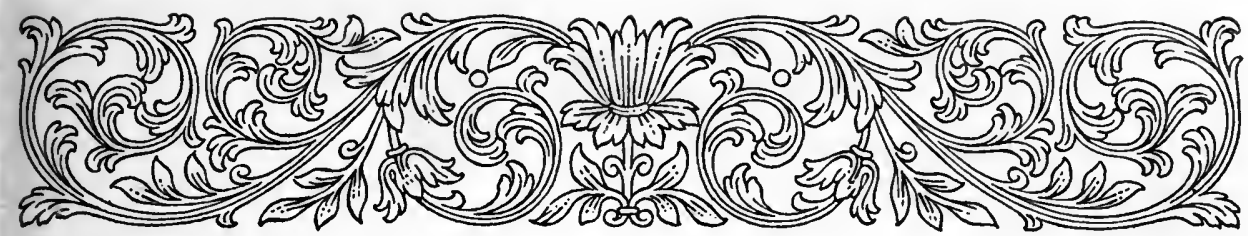

CHAPTER FOUR

Evan Fones, Bookseller-The Fones-Bradford Laws of I7I8The London Edition of SCaryland Laws of I723-

\section{Trott's Lawes of the Plantations}

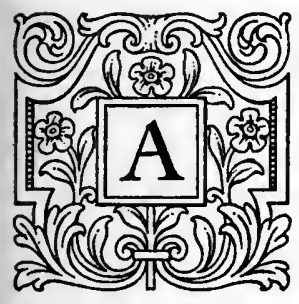

LITERARY history of colonial Maryland would have to deal with a community peculiarly sterile in the production of original works of literature. The reasons for this condition are so many that it would be unwise to institute a general discussion of them here. It is well to recall, however, that in Pennsylvania and in the northern colonies the conflict of religious sects and of sects within sects kept the presses busy with the publication of controversial matter, while in Maryland the firm establishment of the Church of England discouraged not only the publication of works of controversy but controversy itself. Until the years immediately preceding the American Revolution, religious speculation was static in Maryland, a circumstance, we may believe, which did not make for unhappiness among the people. Politics was always a matter of interest to the Marylanders, but except in connection with certain important contentions which will be noticed later, discussion of affairs of state rarely took the form of the printed word. There remained, in general, as matter for the employment of the press only the publication of the laws and legislative proceedings, and upon these, as the framework of Maryland printing history, attention is mainly centered throughout the early part of the period under discussion. Because of this close relationship between the printing of Maryland laws and the history of Maryland printing, the present chapter has importance in our narrative in spite of the fact that it has nothing to do directly with the story of any Maryland press.

The death of Thomas Reading in the summer of 17 I 3 left the Province without a printer. In these early years of the century, printers in search of employment were infrequen tly met with in the colonies. New York had only one establishment at this time, and Pennsylvania, after the passage of several years in which it had been without the services of a printer, had lately induced Andrew Bradford to set up his press in the city where his father

[39] 


\section{$A$ History of Printing in Colonial SCaryland}

had been the first practitioner of typography. It was because of this scarcity of trained printers in the colonies that, during the five years which followed Reading's death, the Maryland laws were transcribed upon parchment or good paper and distributed among the counties, where they were published by the primitive method of voice proclamation. In the year I 7 I8, however, a way was found out of the position of embarrassment in which the colony had been placed by the cessation of Reading's press. In this year Evan Jones of Annapolis, a Welshman and the Provincial man-of-all-work, made proposals to the Assembly in regard to the printing of its laws which resulted in the publication of a work of great importance in Maryland legal history.

The reference to Evan Jones on the title-page of the Bray "Sermon" of Annapolis, I700, where he is described as "bookseller," contains the earliest knowledge that we have of the existence of this individual. There also, for the last time, he was described specifically as "bookseller," but in the years to come he took part frequently in the Provincial business in capacities not essentially different from that of his first description. He seems to have been a ready and cheerful factotum in the public life of Maryland, and the journals of the Assembly evidence the extent of his participation in its affairs. In the year $\mathrm{I}_{704}$ his Excellency in his address to the Assembly asserted that he had never seen "any publick Buildings left solely to Providence but in Maryland," and straightway "Mr. Evan Jones of this Towne a Sober Person" was engaged at ten pounds a year to look after such of the offices as had been spared by the fire which, earlier in that year, had destroyed the State House. In I 708 Jones acted as Clerk of the Upper House for an entire session, and in the November session of 1713 he held the position of "clerk assistant" of the Lower House. In the year I 713 he was spoken of as Deputy Collector of the Port of Annapolis, and three years later he was promoted to the office of Deputy Collector of the District of thePatuxent with jurisdiction of the Port of Annapolis. In June I 7 I 7 the committee of the Lower House for the repair of public records employed him to be the chief undertaker for examining and transcribing the records at the rate of four pounds of tobacco a "side," a unit of measurement which was to be considered as containing fifteen lines of seven words each. For his faithful performance of this task, Major John Bradford, his brother-in-law, ${ }^{1}$ gave bond to the amount of one thousand pounds sterling, a sum of such mag-

\footnotetext{
${ }^{1}$ The will of John Bradford of Prince George's County, probated May I I, 1726, left certain lands to his sister, Mary Jones, with reversion to her two sons, Evan and John Jones. See Maryland Calendar of Wills, 5: 217. This John Jones seems to have been the second child of Evan and Mary Jones who was given the name "John." In removing the debris after the burning of St. Anne's church in 1858 , a tombstone bearing the following inscription was discovered: "Here lyeth the body of John the eldest son of Evan Jones and Mary his wife who dyed the $2 d$
} 
nitude in that day and place as to convince one that the colonial Marylanders regarded the correct transcription of their records as an undertaking of importance. In the year 1718 Jones petitioned, unsuccessfully it seems, for the privilege of carrying the mails, and except for the very important service to the colony which is now to be described, little is heard of this busy and intelligent public servant until his death in the month of June $1722 .{ }^{1}$

\section{The Jones-Bradford Edition of the Laws, Philadelphia, i7 18}

It was doubtless while Jones was engaged in the tedious employment of transcribing the records of the Province that there occurred to him the idea of the project which it is now time to take account of. On May 9, I718, he proposed to the Upper House that he be allowed to print the body of provincial law, and their Honours approved the petition and sent it down to the delegates with the following endorsement:

"The within proposall is recommended to the Lower House of Assembly as reasonable in the Charge and usefull in the Work \& to oblige the said Evan Jones to print them upon good Paper and with a fair Letter."2

When this endorsement was read in the Lower House, Thomas Bordley and John Beale immediately offered

“. . . to make a Compleat Colleccon of all the Laws . . . in force in an entire Body and to make a perfect Index and proper Marginall Notes throughout the whole for Fifty Pounds."3

Further than this the journal is silent. Thomas Bordley was a leader of the House in the contention as to the force of the English statutes in the American colonies, and as the struggle between the delegates and the Proprietary interests was now becoming close after years of relative peace on this subject, Bordley was allowing to pass few chances to annoy the gentlemen of the Upper Chamber. As Evan Jones held with the Lower House in this contention, one is baffled to determine whether in the present instance Bordley's action was a part of his general strategy, or whether he had in view merely the editorial preparation of the copy for Jones's publication. Whatever may be the true interpretation of the incident, however, it forms

of 7 tber Ano dm 1716 aged two years. (Five lines of Welsh)." See Riley, E. S., Ancient City, p. 76. Evan Jones was a vestryman of St. Anne's Parish from 1709 to 1716 . See The Endowment Guild of St. Anne's Parish, by John Wirt Randall, Annapolis, 1909, and Allen, Ethan, Historical Notices of St. Ann's Parish. Baltimore, 1857.

I "Births, Marriages and Deaths," in "Parish Register," St. Anne's Parish, Anne Arundel County. Copy in Maryland Historical Society. The foregoing facts relating to Evan Jones's connection with the Provincial government are to be found in the Lower House journals for the years named.

${ }^{2}$ L. H. J., May 9, 1718, Archives of Maryland, 33: 271. It is possible that this petition had been introduced originally in the Lower House and passed upon there and that this entry indicates simply the concurrence of the Upper House. Neither clerk seems to have made a complete entry of the transaction.

${ }^{3}$ L. H. J., May 9, 1718, Archives of Maryland, 33: 272.

[4I] 


\section{$A$ History of Printing in Colonial GCaryland}

the last reference to Jones's proposal which was entered in the journal of either house. It does not appear from the obviously incomplete record which has been quoted that Jones was given authority to proceed with his publication, but the event shows that he proceeded none the less, and on the title-page of his book, he declared that the compilation had been made by order of the Governor and both Houses of Assembly.

In one sense, the compilation of laws which Jones now presented to the public is the most important collection of the statutes of colonial Maryland. As one of the last acts of her reign Queen Anne had commanded a second revision of the whole body of Maryland law. On April 29, 171 $5,^{1}$ Governor Hart had communicated to the delegates the royal instructions, and on the seventh of the following month the House had proceeded with the required. revision. ${ }^{2}$ The body of law determined by the Assembly on this occasion, as McMahon, the historian of the Maryland constitution, wrote many years later, "formed the substratum of thestatute law of the Province, even down to the Revolution; and the subsequent legislation of the colony effected no very material alterations in the system of general law then established." It was this "system of general law then established" which caused the supersession of the collection of laws published by Reading in 1707 and rendered necessary the new compilation which Jones proposed and carried into effect in the year 1718 .

In this book, which was published through the Philadelphia press of Andrew Bradford in the year 1718,4 the editor, Evan Jones, found himself in the position of a man who thinks to please all parties, but who in the outcome contrives probably to give universal offence. In his Preface he attributed to Governor Hart all the virtues of a paragon among governors; he spoke well of the Proprietary, recently come again into his own, and voiced the most loyal sentiments in regard to Church and King. Moreover, in his opening paragraph, he expressed the mind of the Lower House when he wrote that the Maryland acts "are not expected to speak, but where the General Statutes of England are silent." He continued with the information that until the publication of this book the statutes had existed only in

${ }^{1}$ L. H. J., April 29, 1715, Archives of Maryland, $30: 105$.

${ }^{2}$ L. H. J., May 7, 171 5, Archives of Maryland, 30: 129 . In Chapter Five of this narrative reference is made to the part played in John Peter Zenger's trial by the celebrated colonial lawyer, Andrew Hamilton, at one time a resident of Kent County, Maryland. He represented that county in the Maryland Assembly of 1715 , and as a member of its committee on laws doubtless contributed to the success of the notable revision of that year. See Steiner, Bernard C., in Pennsyloania Magazine of History, v. 20.

${ }^{3}$ McMahon, J. V. L., An Historical View of the Government of Maryland. Baltimore, 1831, p. 282.

${ }^{4}$ Description in bibliographical appendix under year 1718 .

${ }^{5}$ Reprinted, Archives of Maryland, 38: 429. 


\section{Faryland Laws Printed in Philadelphia and London}

ill-written manuscripts without indexes, so that "The Laws of the Province lay so obscure, that they were scarcely known to those that were immediately concerned in the Judging of or Pleading by them." He asserted further that the work had been encouraged by the Assembly, and in the face of his two distinct declarations of this fact, one must conclude that Bacon was mistaken when in later years he said that this edition of the Maryland laws had been published without authority.

Because of the difficulty, experienced often throughout their history, of securing the Proprietary or Royal assent tolegislative enactments, the people of Maryland until this time had preferred temporary laws, expiring by their own limitation, so that their legislation, McMahon says, had "assumed the character of a system of expedients." The body of laws adopted in 1715, and now published by Jones in I7 8 with all legislation of the intervening years, was the earliest body of permanent general law established in the Province. The service which Jones rendered to the people of Maryland in editing and publishing their first "code" was of such a degree of importance as to entitle him to remembrance. Whether the country party was pleased by his prefatorial reference to those of the Court, and whether the sop which he threw to the former in his remark on the force of the English statutes in Maryland was to the taste of the latter did not, after all, affect the practical value of the printed body of general law which he published for the benefit of all parties in the Province.

\section{The Session Laws of I7I9}

Following his venture as the publisher of the compiled laws of the Province in the year I 71 8, Jones made application at the next session of Assembly for permission to continue his activity in the publication of its legislative enactments. On June 5, I7 I9, leave was given him by the Lower House "to print the laws made this Sessions-As also the Governours Speech Answer and the Severall addresses of this Sessions." 1 Jones again carried his "copy" to Philadelphia, ${ }^{2}$ and the session laws for I7I9, and the speeches and addresses for that year soon issued from the Bradford press. ${ }^{3}$ From the cir-

1 L. H. J., June 5, 1719, Archives of Maryland, 33: 444 and 445.

${ }^{2}$ It is regretted that the limits of this work do not permit an extended account of Andrew Bradford, the Philadelphia printer who at various times during the ensuing years acted in the capacity, unofficially of course, of public printer of Maryland. A prolific printer and a useful citizen, he is shown in an unfavorable light in the Autobiography of Franklin, who seems in this case to have acted with ingratitude toward one who had befriended him at a time of great need. Isaiah Thomas has a good account of the Bradfords, and other later writers have defended Andrew against the aspersions of Franklin and set him before the world in a more favorable light as man and printer.

${ }^{3}$ See bibliographical appendix. 


\section{A History of Printing in Colonial Maryland}

cumstance that the pagination of these session laws is consecutive with that of the edition of the compiled laws of the previous year, it seems that Jones had in mind the continuance of a series of annual Acts of Assembly to be bound with the body of laws and used as one collection until the passage of years should render necessary another revision and compilation of the whole. That Bradford's work was fairly well done, the copies remaining attest, but that it was not without vexatious errors may be inferred from a passage in the Upper House journal of two years later, when, after discovering that they had been bickering with the delegates over a point in one of the acts the sense of which, it eventuated, had been beclouded by a misprint, their Honours in an ungracious note to the Lower House declared, "We should be Glad you would Provide agt such Grosse mistakes in the Printing for the future."1

During the three sessions which followed this of May 1719 for which, with Evan Jones as intermediary, Andrew Bradford had printed the laws and addresses, these important state papers, almost certainly, were printed by John Peter Zenger, a resident printer to whose Maryland venture a later section of this narrative is devoted. On the departure of thisindividual from Maryland late in the year I 72I, the Province was again without a printer. Once more and for the last time before his death a few months afterwards, the worthy Evan Jones stepped forward to act as the agent for its printing. On February 28, I 721 / 22, the Lower House journal records that "Mr. Evan Jones has the liberty of printing the Tobacco laws." No provision was made for the printing of the session laws, but as only one public law was passed at this session and as this was a tobacco law, the neglect explains itself. Despite the fact that no copy of this law remains, it is probable that it was printed by Bradford at Evan Jones's behest, for other documents of this session found their way into print through the Philadelphia office. One of the reasons given by Governor Calvert for calling this session had been his desire to explain to the Houses his dismissal of Thomas Bordley from his Council. The several addresses to and from the Governor on this and routine matters before the session, Bordley's defense and other pertinent documents were collected and printed under the title of The Speech of his Excellency Coll. Charles Calvert, Governour of the Province of Maryland, to both Houses of Assembly, Feb. 20, I72I.

Unfortunately there remains of this printed collection a single mutilated copy containing only three pages, ${ }^{2}$ and as none of these is title-page or colo-

${ }^{1}$ U. H. J., August 5, 1721, Archives of Maryland, 34: 186.

${ }^{2}$ See bibliographical appendix. 
phon it is not possible to assert positively that it was from Bradford's press. The type and typographical ornaments, however, aid in making an attribution which one would suspect to be correct from the fact that Evan Jones, who always carried his work to Philadelphia, had been authorized to act as the Provincial printing agent in this session of Assembly. It is likely that the single tobacco law of the session was printed at the same time and by the same printer.

Five years after the publication of the Jones-Bradford collection of 1718 , the Maryland Assembly was called on to consider "The Petition of Andrew Bradford printer praying an Allowance for printing the great Body of Laws which he was Employd to do by Evan Jones Gent deced." 1 After a reading, the petition was immediately "rejected for that this House never Employed the petitioner or Ordered any other person to Employ him." Thus we learn that Jones is dead, and that Bradford either had not been paid at all for his work on the laws, or that he considered himself to have been underpaid. The delegates, on their part, clearly considered Mr. Bradford impertinent, but that the Philadelphia printer bore no malice is evidenced by his willingness to undertake Maryland work at other times in the not distant future.

\section{The Board of Trade Edition of Maryland Laws, London, 1723}

In connection with the edition of Maryland laws which Bradford printed for Jones in 1718 , it is proper to mention now rather than in its chronological order a compilation of Maryland statutes which appeared in London in the year 1723 , for this later compilation, in spite of its date, contains no acts subsequent to the body of law established in 1715 , the same revision of Maryland legislation which had made necessary the Jones-Bradford edition. When the Queen had ordered a revision of Maryland laws in 17 15 , she had directed at the same time that the body of law when completed should be engrossed and a copy sent to the Lords Commissioners of Trade. In a footnote to his Preface, Bacon wrote in 1765 ,

"I have seen (some Time before I left England in the Year 1745) an Edition printed at London, at Lord Baltimore's expence, as I have been informed, for the Use of the Board of Trade, with the Latin Charter prefixed: But could never meet with a copy of it in this Province, nor can I recollect the Date it bears."

In this note Bacon referred doubtless to the edition of $\mathrm{I} 723$ which is now being discussed, a work well known to students of American bibliography and available in several libraries in this country, however vainly he may have sought it in his day. In spite of his supposition that the compilation

${ }^{1}$ L. H. J., September 30, 1723, Archives of Maryland, 34:617.

[45] 


\section{A History of Printing in Colonial SCaryland}

had been printed at Lord Baltimore's expense, there seems no reason for believing this to be true. The collection bears the royal arms, was printed by the King's printer, and has neitherdedication nor preface. There is nothing about the book to suggest that Baltimore had been ordered to publish it, and as it contains none of the laws made since the Province had been restored to his government, it is more probably the case that the collection had been issued by the Lords of Trade from the engrossed copy sent to them in I7I 5 as one of that series of colonial laws which they published customarily for the benefit of those in England who were associated in colonial business enterprises. Similar publications were printed by Baskett, some of them "by order of the Lords Commissioners of Trade and Plantations," for Bermuda and New York in 1719, the Barbadoes in 1721, Massachusetts in 1724 and Virginia in 1727 , to name only the most important collections of the series.

This London edition of the laws is a handsome book, well printed on a thick, crisp, white paper. It was printed by John Baskett, who six years before its publication had acquired unpleasant notoriety as the printer of an edition of Holy Writ which has been known ever since as the Vinegar Bible, by reason of the occurrence in its pages of a misprint in one of the gospels which caused the laborers in the vineyard to be alluded to as the laborers in the "vinegar." Because of this and other blunders which it contained, it was known to a mocking generation as a "Basket-full of printer's errors," but in spite of its textual imperfections, Dibdin described it as "the most magnificent of the Oxford Bibles." Until Jonas Green had printed Bacon's edition of the laws, Baskett's edition was certainly the most magnificent of the Maryland books of statutory law. That it had little use in the colonies is easily explained by the nature of its contents and by its date of publication, for a work published in 1723 containing no laws passed since I 7 I 5 could not be expected to prove useful when even the easily available Jones-Bradford compilation, containing the code of 1715 and subsequent legislation for the three years I7I6-I7 8 , so rapidly became out-of-date that the Assembly in I 722 attempted to have printed a second volume containing the compiled laws of the intervening years. ${ }^{1}$

\section{“Trott's Laws of the Plantations," London, i72I}

Several times in the course of this narrative grateful reference has been made to a special compilation of colonial laws known familiarly as "Trott's Laws of the Plantations." The Laws of the British Plantations-relating to

\footnotetext{
${ }^{1}$ See next chapter under the section devoted to Michael Piper and his attempt to establish a press in Maryland.
} 


\section{Graryland Laws Printed in Philadelphia and London}

the Church and the Clergy, Religion and Learning, published in London in I72I, has served a useful purpose to the historians of two centuries as a dependable and direct guide to the matters of which it treats. It contains thirty-one acts at large which were in force in Maryland at the time of its publication. For the greater part, Nicholas Trott, its editor, ${ }^{1}$ used the JonesBradford edition in compiling his section of Maryland religious enactments, giving in addition, however, marginal references to the Reading editions of I 700 and 1707 . Useful to the church historian of today, his collection, at the time of its publication, must have been of particular value in England, as well as in those American colonies where the Church of England had been by law established.

As has been said, the foregoing notices of works of Maryland law, printed beyond the limits of the Province, have no direct bearing on the story of the Maryland press, but as these works occupy an important position in the legal bibliography of the colony it is believed that a description of the circumstances of their publication should find place in this narrative.

${ }^{1}$ Nicholas Trott was one of the most interesting figures in the colonial panorama. Emigrating to South Carolina in 1698 , he became chief justice in 1702 and held that office until the anti-proprietary revolution of 1719 , a revolution precipitated largely by his own injustice and tyranny. It has been said that "However unscrupulous as a politician, corrupt and tyrannical as a judge, Trott was a profound lawyer, a scholar of great learning, and a most laborious and indefatigable worker." It might be added that he was a devout Churchman and deeply read in theology and the Holy Scriptures. In 1736 he published a codification of the laws of South Carolina which has place as one of the most remarkable legal productions of colonial America, and which, printed by Lewis Timothy of Charieston, vies with any work of the first half of the century in typographical excellence. At the time of Trott's death in 1740, he was engaged upon an "Explication of the Hebrew Text of the Old Testament." One of his most unpleasant habits was that of further distressing those whom he had condemned to death by addressing to them religious homilies. His remarks to the pirate, Captain Stede Bonnet, remain as the record of his remarkable personality and as the fitting conclusion of one of the most dramatic criminal trials of the colonial era. For a good account of Judge Trott, see McCrady, Edward, The History of South Carolina under the Proprietary Government, I670-1719. N. Y. 1897, passim. 


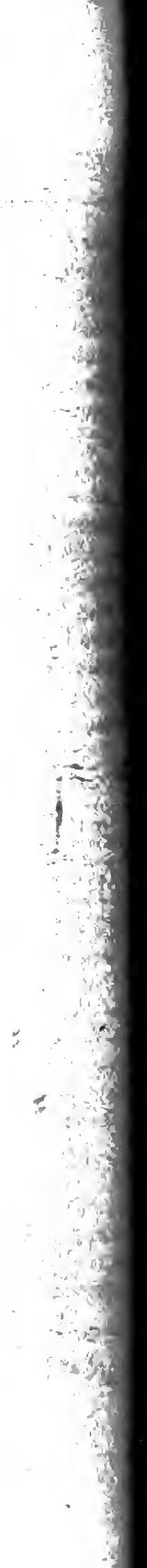




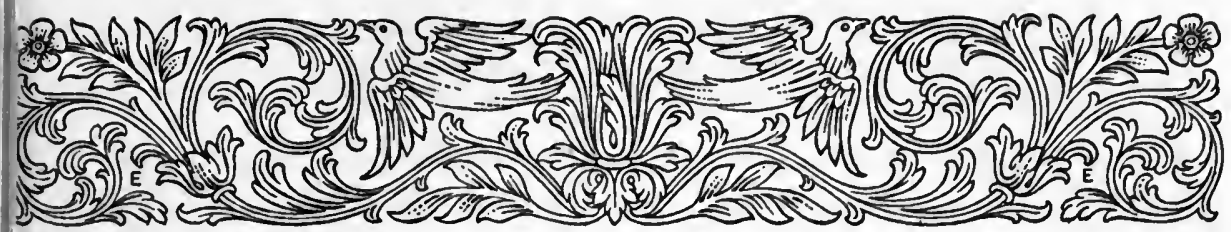

CHAPTER FIVE

Fohn Peter Zenger, Public Printer of SCaryland-SCichael Piper and his Abortive Press-The Beginnings of the

"Votes and Proceedings" Series

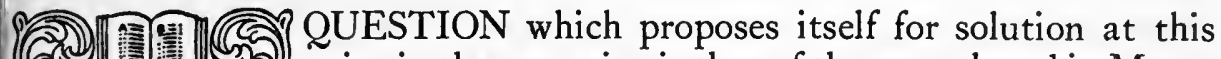
point in the narrative is that of the part played in MaryA land printing activity by John Peter Zenger, the New A 23 York printer, whose trial for seditious libel in the year I734 established in the American colonies the principle of the freedom of the press. It is a matter of record that

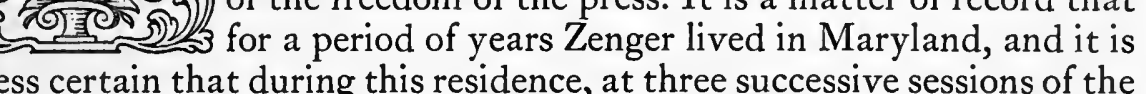
no less certain that during this residence, at three successive sessions of the Assembly he was employed to print the laws of the Province. From the evidence of circumstance one infers that on two of these occasions, certainly, he actually printed the session laws, but immediately the question arises as to where in Maryland was his press and where are concealed specimens of its production or contemporary references to them other than the orders to print which appear in the journals of Assembly. Beyond presenting a statement of the evidence, the following discussion does little for the solution of the problem.

John Peter Zenger, "borne in the uper Palatinate on the Rhine,"1 was brought to this country by his mother in the year I710, among those refugees from the Palatinate whom Queen Anne had removed from a scene of persecution and transported to her American colonies. About thirteen years of age at the time of his arrival in New York, Zenger was soon afterwards apprenticed by his mother to William Bradford, the printer, who in later years was to become his relentless political adversary. Nothing is recorded of him during the customary years of apprenticeship, but at their conclusion it seems that he lost little time in seeking a community in which he might set up for himself as a master printer. Old William Bradford would have known that in the absence of a resident printer in Maryland, his son Andrew of Philadelphia had been doing the work of that Province for five

${ }^{1}$ Act of Naturalization, Archives of Maryland, 38: 277.

[49] 


\section{A History of Printing in Colonial SCaryland}

years. Possessing this knowledge, it was doubtless he who suggested to Zenger that he take his chances at a living in the southern Province. At any rate, Zenger appeared in Maryland, asking for employment, very soon after the expiration of his articles of apprenticeship. In the April session of Assembly of the year I 720 ,

"The Petition of John Peter Zenger praying that he may have the Liberty of Printing the Laws for the Severall Countys the Provinciall Court and Upper and Lower house of Assembly was read and

Resolved that the Petitioner have the Liberty of Printing the Laws for the Severall Countys Provinciall Court and a Body for the upper House and another for the Lower House of Assembly and that he bind the severall Bodies for which the Severall Counties and Publick shall pay Seven hundred pounds of Tobacco per Body."1

In transmitting this resolution to the Upper House for its approval, the Clerk of the House of Delegates added a significant sentence, when he wrote the words, "with which we desire your Concurrence Especially Considering it will be a means to promote the Carrying on so necessary a work amongst us." The resolution of the Lower House was concurred in by the Upper Chamber on the same day, and that the delegates had no doubt of the printer's ability to carry out his contract is learned from a later entry in their journal. On April 22d, the last day of the session, to the question of the Upper House as to how much should be paid the Chancellor for transcribing the laws, they returned the reply that

"Both Houses of Assembly haveing agreed that John Peter Zenger should print the Laws of Each Sessions for the Severall Countys and Provinciall Courts \&c we Apprehend it would be too great a burthen to the Country to pay both the Chancellor and Printer for them."

Well satisfied with his prospects in Maryland, Zenger applied for citizenship in the Province at the next session of Assembly, that of October 1720, when, in response to his petition there was passed "An Act for the naturalization of John Peter Zenger of Kent County Printer \& his Children."3 In the title of this act is contained the only reference that exists to Zenger's place of residence in Maryland, and on the evidence of this description, it has been assumed that at his first coming to the colony he had set up his press in Kent County near Chestertown. The county court records and the records of the Provincial Land Office contain no indication that Zenger took up land in Kent County or elsewhere, and unless he intended to carry on farming in addition to printing, it seems unreasonable that he should have

${ }^{1}$ L. H. J., April I2, 1720, Archives of Maryland, 33: 588, 501-502

${ }^{2}$ L. H. J., April 22, 1720, Archives of Maryland, 33: 639.

${ }^{3}$ Bacon's Lawes of Maryland, 1720, ch. 18. See also L. H. J., October 20, 1720, Archives of Maryland, 34: 56. The complete text of the act was printed in Archives of Maryland, 38: 277. 
established himself across the Chesapeake many miles distant from Annapolis, in which town of course was the source of the greater part of the printing business of Maryland. Chestertown was a village at this time, and a small village at that. Surrounding it was an agricultural neighborhood. If Zenger set up his pressin this community, he must deliberately have chosen a position of isolation, but the description of him as of Kent County in his act of naturalization is at least a positive piece of evidence that he made such a choice; there is no evidence of any nature whatsoever that hesettled in Annapolis, where one would have expected to find him.

It is to be presumed that in the months which had intervened between Zenger's order to print the session laws in April 1720 , and the day of his naturalization in October of that year, he had carried out his contract with the Assembly as to the printing and binding of the April acts, for on October 27 th, it was resolved by the delegates,

“. . . that the Printer be Allowed five hundred pounds of tobacco for the Printing the Laws for the Counties \&ca . . . as last Sessions, ${ }^{\text {a }}$ and that Mr. Tasker make Coppys of all the Publick Laws and the heads of all the Private Laws ... . And the said Copys to be Delivered to the Printer the latter End of the next week."'

If Zenger had failed to print the laws of April I720, it is not likely that in employing him to print those of October 1720 , the delegates would have used the phrase "as last Sessions;" nor in the session of August I 721 would they have resolved,

“. . . that John Peter Zenger print the Body of Laws this Sessions as usual ${ }^{3}$ and be Allowed five hundred pounds of Tobo per Body. And that John Gould Transcribe a Body of the said Laws from the Originals to be by him Sent to the said Printer; . . ."4

The phrases "as last Sessions" and "as usual" employed in these quotations must refer to a series of performances rather than to a series of failures to perform.

In the absence of later references in the Maryland records to Zenger and his work for the Province, it is impossible to assert that he carried out the task imposed upon him by the delegates in August I72I. It is probable, however, that he accepted the contract and completed it as his last important work in Maryland before his return to New York late in I72I or early in the year I 722, after a Maryland residence of some months less than two years. In the preceding chapter it was pointed out that in the session of February I 721/22, Evan Jones had been given permission to print the only

\footnotetext{
1 The omission before these words, italicized by the author, occurs in the original.

${ }^{2}$ L. H. J., October 27, 1720, Archives of Maryland, 34: 111 .

Italics by author.

'L. H. J., August 5, 1721, Archioes of Maryland, 34: 255.
}

[5I] 
public law passed by that Assembly, a sufficient indication that Zenger was no longer a resident of the Province. It is known, moreover, that he married his second wife, Anna Catherina Maul, in New York on August 24, I 722, and that he was made a freeman of the city in the year following his marriage. He formed a partnership about this time with his old master, William Bradford, with whom he printed a book in the Dutch language in the year 1725 . In I726, his name appeared unaccompanied by any other on the imprint of another Dutch book, and from thenceforward, he printed alone in the Dutch, German and English languages. One of his nieces, Elizabeth Becker, married Richard Curson or Curzon, the founder of the American family of Curzon, so that through her Zenger is associated by ties of blood with a family of importance in Maryland and New York. At his death in 1746 , his widow, Anna Catherina Zenger, carried on his press for some years. It was afterwards taken over and continued by John Zenger, his son by his first wife. With the removal of Zenger from Maryland to New York, he passes from the field of activity with which this narrative is concerned. To discuss here the later and more important period of his life would be to extend unduly the length of this relation by the inclusion of matter which has been presented in detail in books and articles which are available to all readers. ${ }^{1}$

It is evident that the final word remains to be said on the subject of the work of Zenger as a printer in Maryland. The silence of the Kent County records and of the records in the Maryland Land Office together with the absence of a single Maryland imprint bearing his name leave the question of the location of his press as much of a riddle as ever it was. When he applied to the Assembly in April 1720 for permission to print its laws, he was newly come to Maryland as a journeyman not long free of his apprentice-

\footnotetext{
${ }^{1}$ For further biographical details of Zenger and his family see Pleasants, J. Hall, The Curzon Family of Nerv York and Balimore and Their English Descent. Baltimore, 1919. For a comprehensive treatment of his imprisonment and trial, of the events which led up to this consummation and of its triumphant conclusion for American journalism, read Rutherford, Livingston, Fohn Peter Zenger, Second New York Printer, his Press, his Trial. New York, 1904; Hildeburn, C. R., Sketches of Printers and Printing in Colonial New York. New York, 1895; and the article devoted to him by Isaiah Thomas in his History of Printing in America. He was defended in his trial by Andrew Hamilton of Philadelphia, who had lived in Kent County, Maryland, shortly before Zenger's residence there. For an interesting discussion of the extent to which this fact influenced Zenger in choosing Hamilton to defend him, see Steiner, Bernard C., "Andrew Hamilton and John Peter Zenger," in vol. 20 of the Pennsyloania Magazine of History. Isaiah Thomas wrote of Zenger that he "was a good workman, and a scholar, but not a correct printer of English." Some of his later biographers, however, are not willing to follow Thomas in his assertion that Zenger was a scholar, and it is generally believed that he had been used as a catspaw in the political dispute which resulted in his imprisonment and trial. Thomas relates that during the dispute Zenger gave such offence to a gentleman of the Council by an article in his newspaper, The New York Weekly fournal, that the irate colonel threatened to lay his stick over the printer. Thereafter Zenger went about his affairs armed with a sword, and the spectacle of a printer so accoutred gave Bradford the opportunity for the exercise of his powers of ridicule. The "crafty old sophister," as Franklin named Bradford, took a little more than full advantage of his opportunity.
} 
ship. It is not certain that he made his home in Kent County on his first coming in to the Province, although he was, it seems, a resident of that county a very few months later. If at this time he had possessed no press of his own, and this would not have been strange in the case of so young a printer, it would have been the natural thing for him to have made his headquarters at Annapolis, where originated the important printing business of the Province, and where as well there was to be found until the year I 723 a printing press andits necessary equipment, doubtless the same outfit which two years before his coming had been listed in the inventory of property held in Anne Arundel County by William Bladen. One would have said that here was a hand-made opportunity for a young journeyman beginning business on his own account, but the supposition that he took advantage of the opportunity is rendered doubtful by his description as "of Kent County" and by the wording of the Assembly order of August 172I, in which it was directed that after transcription the laws were promptly "to be ... Sent to the said printer." Would the word "sent" have been used when the transaction involved was simply the turning over of a manuscript to a fellow villager whom the copyist must have seen every day? It is true that in the October session of 1720 , under like circumstances, the word "delivered" had been employed in the order, but wherever his shop may have been, it is probable that in this month Zenger was in Annapolis in person, attending to the passage through the Assembly of his act of naturalization.

It is upon such evidence as has been adduced that the question of the location of Zenger's press must be argued, and admittedly it is so intangible in character that no decision may be based upon it. The question probably will never be settled until someone discovers a Maryland imprint bearing the name of John Peter Zenger, and it is to be hoped that the discovery will be made by a person in need of the money which a specimen of Zenger's Maryland press would bring at auction.

\section{Mr. Michael Piper, Schoolmaster, and his Printing Proposals}

With Zenger removed from Maryland, and with Evan Jones four months dead, the Province found itself in difficulties in regard to its printing at the session of Assembly of October 1722. There was not lacking, it is true, an aspirant for the vacant office, but with the best intentions he succeeded but poorly in carrying out his proposals to continue the publication of the laws. This individual was no other than Mr. Michael Piper, master of the Free School of Annapolis, that establishment founded by Governor Nicholson in 
1696, known for generations as King William's School, and finally merged with the newly established St. John's College in the year 1786. Nothing of the life of Mr. Piper is of concern in this narrative except the fact that in October 1722, he petitioned the Assembly that he be allowed to print the laws of that session and those to be made thereafter. ${ }^{1} \mathrm{~A}$ few days later his petition was granted, ${ }^{2}$ and it was resolved "that he be printer to this House and that this House will give him all reasonable encouragement from time to time so far as may be consistent with the Justice thereof." Two days later it was provided that Mr. Piper be allowed five pounds currency as his encouragement for collecting, annotating and indexing the laws made since 1718 , in order, as the journal says, "that they may be printed as a $2 \mathrm{~d}$ Volume of the Laws of this Province." 3 These projects seem never to have been carried out. A year later the following resolution was passed in the House:

"On a Motion made as to the further Consideration of Michaell Pipers petition last Assembly relateing to the printing the Laws and Mr. Piper Appearing at the Barr and Alledgeing that the press is now at Philadelphia and that he can't print them here at present, It is Resolved that the Chancellor Transcribe the Laws . . . as usuall and that the like Encouragement proposed to Mr. Piper Last Sessions be given to the first person that will Erect a printing press at the City of Annapolis."4

The extracts which have been quoted here indicate little except that the Maryland authorities were not apathetic in the matter of printing. One assumes, however, from Mr. Piper's case that the old Bladen press must still have been in Annapolis in October 1722, when the schoolmaster proposed to undertake the printing of the provincial laws, and that it was probably sent to Philadelphia ${ }^{5}$ some time between that date and September 1723 . Although Mr. Piper clearly did not print the session laws as he had proposed, yet he may have printed on this old press a few smaller and less ambitious things, such as, for example, the "printed case" of Samuel Gover which was referred to in the Assembly on September 23, 1723. He did not

${ }^{1}$ L. H. J., October 27, 1722, Archives of Maryland, 34: 445.

${ }^{2}$ L. H. J., October 30, 1722, Archives of Maryland, 34: 450 and 454.

${ }^{3}$ L. H. J., November I, 1722, Archives of Maryland, 34: 455.

'L. H. J., September 28, 1723, Archives of Maryland, 34:613.

'In Franklin's Autobiography, Everyman ed. p. 33, occurs this description of the printing equipment of Samuel Keimer, a printer just arrived in Philadelphia. Franklin writes, "Keimer's printing-house, I found, consisted of an old shatter'd press, and one small, worn-out font of English, ... I endeavor'd to put his press (which he had not yet us'd, and of which he understood nothing) into order fit to be worked with." This was in October 1723. It was on September 28, 1723, that Mr. Piper said to the Maryland delegates, "the press is now at Philadelphia." Keimer had lately set up in Philadelphia, and Franklin says that in October 1723 he had not yet used his "old shattered press." From this description of the press, and from the correspondence of dates and circumstances, one hazards the guess, admittedly per saltum, that Keimer had bought the old Bladen-Reading press from the estate of the late William Bladen. 


\section{Zenger's SCaryland Venture. The Earliest Assembly Proceedings}

print Ephraim Hermann's Copies of some Records $\mathcal{E}$ Depositions Relating to Great Bohemia Mannor lying on Bohemia River in Maryland, which issued from Bradford's press in this year, ${ }^{1}$ but that means nothing; Bohemia Manor naturally transacted its business with Philadelphia by reason of its geographical position.

Since Reading's death in I7I3, the Province had been compelled to rely entirely on Andrew Bradford of Philadelphia for its printing, except for the two years during which Zenger had acted in the capacity of provincial printer. Disappointed now by Piper, they offered inducements to all and any, but even so they were destined to wait for three years before their offer should be taken up by William Parks, one of the great figures in the story of American colonial typography.

\section{The Beginnings of the "Votes and Proceedings" Series}

In a former chapter mention was made of the fact that in the year I706 Thomas Reading had proposed that a part of his duty to the Province be the printing of "all publick Matters as Speeches, Answers, Votes \& c" in addition to the regular publication of the session laws. In this proposal is to be found the first mention of that series of Assembly proceedings which was known to generations of Marylanders as the Votes and Proceedings of the Lower House of the Assembly, and which is published today under the title of Fournal of the Proceedings of the House of Delegates of Maryland. Whether Reading was permitted to carry out his plans in regard to the proceedings of the Assembly is not recorded, and there seem to have been printed no publications of exactly this character until the year 1727 , when William Parks began their regular issue. In the year 1723 or 1724 , and again in 1725 , however, there were printed certain of the debates and proceedings of the Assembly which have a peculiarinterest for the students of American history, inasmuch as their publication was associated with one of the most important constitutional issues of the colonial period, an issue which was fought over not only in Maryland but as well in several others of the English colonies of America.

In the sessions of Assembly from 1722 to 1725 there occurred the climax of a struggle, then half a century old in Maryland, in which the Lower House had been striving to secure recognition of the claim that the Englishmen of America came by right of heritage within the jurisdiction of the English statute law, upholding the passionately held belief that in emigrating to a colonial possession of England their fathers had not forfeited for themselves

${ }^{1}$ Hughes, T. A., History of the Society of Fesus in North America. Documents, v. I, pt. I, p. 284. 


\section{$A$ History of Printing in Colonial SCaryland}

and for their children the rights of Englishmen. In the sessions of 1724 and I 725, anxious to put themselves on record before their constituents in this matter, and at the same time to expose the obduracy of the Proprietary and the Upper House, the burgesses determined upon the printing of such of their recent proceedings as related to the contention which had been engaging their interest. The resulting collection was the earliest printed record of which copies have remained of the proceedings and procedure of the Maryland Assembly, but before passing to a consideration of this pamphlet, it is necessary to take account of an earlier publication of the same character which has never engaged the attention of bibliographers.

On October 13, 1724, the following entry was made on the journal of the Lower House:

"Several printed Copys of the Address and the Resolves of the Lower House in October Assembly 1722 being produced to this house are well approved of in the manner as they are now printed."I

No copy of this initial issue of the Maryland Assembly proceedings has ever been recorded. Its printing had not been ordered by the Assembly of I 722, in which year it might conceivably have been printed by Michael Piper. No mention was made of it in the Assembly of I723, and from the expression used in 1724 , "the manner as they are now printed," one acquires the impression that the publication had newly issued from the press. Bladen's old press, presumably, having been sent to Philadelphia, there was no printing press in Annapolis in 1724, so that in seeking the place of origin of the first printed proceedings of the Maryland Assembly, one turns naturally to the office of that busy Philadelphia printer, Andrew Bradford, whose relations with the Province had continued to beclose. It is not listed, however, with the issues of his press, nor is it recorded elsewhere in American bibliographies.

One passes with relief from this ghost book, the "Address and Resolves of the Lower House of Assembly of Maryland in the Session of October 1722," to the well known but rare work of a similar character which Bradford printed for Thomas Bordley, Esq., in the year 1725 . In the October session of 1724 , three days before the occurrence which has been spoken of in the foregoing sentences, the delegates in the resolution cited below had provided for the publication of such of their proceedings as had to do with the English statutes in Maryland and related constitutional matters. "It being proposed," the journal records,

"that for the more effectually publishing the Resolves and the Address relating to the

${ }^{1}$ L. H. J., October 13, 1724, Archives of Maryland, 35: 102. 


\section{Zenger's STaryland Venture.The Earliest Assembly Proceedings}

Zonstitution of Maryland, the same may be printed, Resolved that any person have the iberty of printing them that will undertake the same."1

In spite of the invitation thus cordially extended, no one seems to have volunteered to assume the risk of the publication, so that as the session drew near to its close the delegates found themselves compelled to request one of their own number, Thomas Bordley, a leader in their struggle, to edit and to have printed a collection containing the Charter and "such of the Debates \& proceedings of the three Sessions of this Assembly as relate to the Government or Judicature of this Province,"2 a request "which the said Thomas Bordley Esqr being present promised his Endeavour to perform." A year later the journal records that Mr. Bordley brought into the House several printed copies of the "proceedings of the Lower House in the years $1722 / 1723$ : 1724 relating to the Government and Judicature of this province...," and in receiving them, it was entered on the book that

“. . . this House ... unanimously return their thanks to the said Thomas Bordley Esqr for his Extraordinary Care and pains in making a Collection of the said proceedings and Composing the preface thereto and getting them printed for the publick Service . . ."3

This collection of debates printed by Andrew Bradford of Philadelphia is a vital document in the constitutional history of the Province. Furthermore the series of $V$ otes and Proceedings, the publication of which began a year later to be regularly provided for by the Lower House, and which has continued without serious interruption until the present time, traces its origin to this compilation of legislative debates on the "Government and Judicature" of Maryland.

${ }^{1}$ L. H. J., October 10, 1724, Archives of Maryland, 35:99. The author has assumed, as the narrative indicates at this point, that this resolution of October 10,1724 , was carried into effect when the delegates requested Thomas Bordley to edit and have printed his well known compilation containing the Charter and such of the debates and proceedings of $1722-1724$ as related to the government and judicature of the Province. With equal force, however, this resolution may be said to refer to the "printed Copys of the Address and the Resolves of the Lower House in October Assembly 1722" which were produced in the House on October I3, 1724, and "well approved of in the manner as they are now printed." Before accepting the second interpretation of the documents, however, it is well to recall that as far as is known there was no printing press in Maryland in October 1724 , and that it would have been almost impossible to have sent copy to Philadelphia and received in Annapolis a printed paper of several pages in the interval between October Ioth and October $13^{\text {th }}$. The alternative interpretation is that some person acting without authority had printed the "Address and Resolves," and that becoming aware of this the delegates had confirmed his action by an ex post facto resolution; that is the resolution of October Ioth, thus making it possible for the publication to be presented for approval on October $13^{\text {th. }}$

${ }^{2}$ L. H. J., October 29, 1724 , Archives of Maryland, 35: 149.

${ }^{3}$ L. H. J., October 7, 1725, Archives of Maryland, 35:303. For a valuable discussion of the contention over the English Statutes, the reader is referred to Sioussat, St. G. L., The English Statutes in Maryland (Johns Hopkins Studies in Historical and Political Science, Series XXI, Nos. I I and I2, Baltimore, I903). Mr. Sioussat's suggestion that probably the preface to the collection described above was the work of Daniel Dulany, the Elder, does not seem to be borne out by the extract from the House Journal in which its composition is specifically attributed to Bordley. 


\section{$A$ History of Printing in Colonial SCaryland}

The End of the First Period of Maryland Printing History

The publication in $\mathbf{1} 725$ of the "proceedings of the Lower House" under Bordley's editorship brings to a close the first period of Maryland printing history. Except for unrelated and unsustained researches by various persons, these four decades hitherto have been neglected by American typographical annalists. Even in this day when the evidence of the provincial documents is accessible to every investigator, it is frequently affirmed that printing was not carried on in Maryland during the years in which William Nuthead, Thomas Reading and John Peter Zenger were active there in the prosecution of their trade. It is believed that the foregoing statement of the operations of these men removes the reality of their printing activity from the field of debate. In the next chapter, almost the central point of the narrative, will be assumed the pleasant task of recording the work of William Parks, a notable printer with whose coming to Annapolis in I726, Isaiah Thomas commenced his sketch of Maryland printing. 


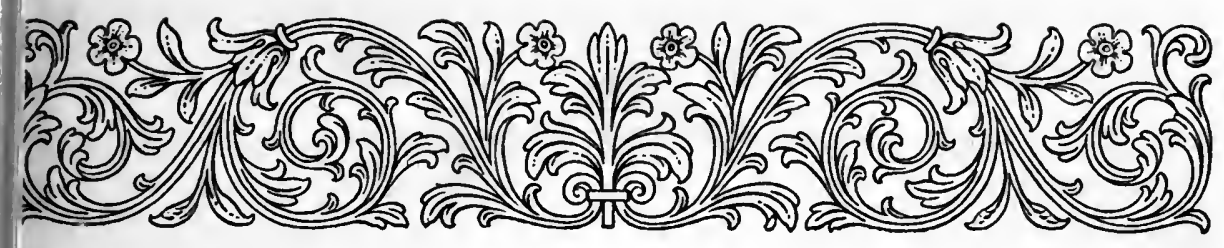

CHAPTER SIX

\section{William Parks Becomes Printer to His Lordship and the Province-} The Collected Laws of I727-The First MCaryland Newspaper-The Early Belles Lettres of STaryland

(ne expression of gratitude by the Assembly for his edi(5) S) al the 57) T 12 volume of "Debates and Proceedings," did not close the 1 account between Thomas Bordley and the Province, for very soon after he had been publicly thanked for this service, he put the people of Maryland under an even greater obligation by his initiative and diligence in procuring for them a permanent resident printer. One month after the incident which has been referred to, the delegates, begging concurrence in their expressed approval of his action, ${ }^{1}$ informed the Upper House that Mr. Bordley had sent for a printer on the encouragement given by the resolutions of 1722 and 1723 . The Upper House sent down its note of agreement immediately, and one assumes that Bordley now gave the word to his printer to transport himself and his equipment to the Province. In the next session of the Assembly there appeared before the delegates Mr. William Parks, an English printer whose intelligence and enterprise gave impetus to the literary progress which occurred in the colonies of Maryland and Virginia during the ensuing decade.

Isaiah Thomas is authority for the statement that William Parks was born in England and bred to the composing stick before leaving his native land. ${ }^{2}$ Where was his initial employment in America, whether he worked first in Pennsylvania or in one of the northern colonies, or whether he came directly to Maryland are questions concerning him which have not been answered. It is possible that he was a journeyman in the shop of Andrew Bradford, where Bordley may well have become acquainted with him during the printing in that establishment of the "Debates and Proceedings" of 1725 , but in truth this conjecture is based upon no real evidence. Indeed,

${ }^{1}$ U. H. J., November 6, 1725, Archives of Maryland, 35: 289.

${ }^{2}$ Thomas, Ist ed., 2: 143 . See also note 2, on page 73 of this narrative.

[59] 


\section{$A$ History of Printing in Colonial SCaryland}

there is, in general, a paucity of personal details in our knowledge of this outstanding figure in American typographical history. The surname of Eleanor, his wife, is conjectural, and there is uncertainty also in regard to his descendants. He left at his death a daughter, Eleanor, who married John Shelton of Hanover County, Virginia, and became the mother of Sarah Shelton, who was presumably the first wife of Patrick Henry. At Parks's death his estate was found to be almost valueless. In the accounts filed in connection with its settlement mention was made of a sum paid Mr. Macnemara of Maryland for his services in connection with docking the entail of a tract in that Province known as "Park Hall," and of a lot in the city of Annapolis. This bare outline and the circumstances of his death comprise practically all that is known of importance in the personal life of William Parks. ${ }^{2}$

\section{Maryland Public Printing Assumes a New Dignity With the Coming of Parks}

Soon after the establishment of the Parks press in Annapolis, the office of public printer of Maryland assumed a dignity which formerly it had not possessed. Until this time the work and remuneration of the several resident printers had been determined at successive meetings of the Assembly by ordinance and resolution, but in the session of October I 727, the status of Parks as provincial printer, his duties in and salary for the performance of that office were fixed by statutory enactment, as always thereafter were the status, duties and salary of his successors. Two years were to pass, however, before the passage of this, the first law for printing in Maryland, but from the very beginning of his residence, the relations between printer and Assembly took on a more businesslike character than had pertained to them in earlier days. In the March Assembly of $1725 / 26$, Parks made definite proposals as to the terms under which he would operate his press in the service of the Province. In briefer form than in the original, these "proposals ${ }^{3}$ humbly offer'd by William Parks" were as follows:

I. He would print the session laws of each Assembly for the sum of two thousand pounds of tobacco from each county, one copy to be delivered to

\footnotetext{
${ }^{1}$ This tract, in what was then Prince George's County, was surveyed for William Parks on April 9, I73r. It contained 1,550 acres. 't is not to be confused with another "Park Hall" surveyed for James Carroll on November 24,1727 , lying in what is now Carroll County, the earliest survey of land made in that county. Mr. William B. Marye of Baltimore, has kindly transmitted the foregoing facts to the author. See also The Old Indian Road, by William B. Marye, Part 1, Maryland Historical Magazine, June r 920.

${ }^{2}$ See note on p. 73 of this narrative. See also references in Thomas, both editions; and in the William and Mary College 2uarterly, 7: Ir. Parks's will and the inventory and accounts of his estate are preserved in the Court House at Yorktown, Va. Copies are in the Maryland Historical Society.

${ }^{3}$ L. H. J., March 21, 1725/26, Archives of Maryland, 35: 475-476.
} 


\section{William Parks, Public Printer of SCaryland and Virginia}

each of the members of the Assembly, the Commissioners of the Peace and the justices of the County Court.

2. He would print journals, votes, speeches, etc., at a price per sheet later to be fixed.

3. If the first two proposals were accepted, and if he were given fair assurance of a permanent establishment in Maryland, he would print a whole body of the laws hitherto made in the Province and ease the public of the charge of it and himself run the hazard of its publication by subscription.

Upon receipt of these proposals, the two Houses appointed a joint committee to treat with Parks on their separate articles or on "whatever else should be thought necessary for his encouragement in the Service of the Country." There was dissension among the conferees as to the acceptance of the second article of the proposals, and reaching a deadlock in the discussion of its terms they agreed finally to refer it back to the consideration of both Houses. The first article of the proposals, with its very much greater rate of payment than previously had been considered necessary, they approved with thequalification that the two thousand pounds of tobacco from each county were to be paid by the year and not by the session as the printer had proposed. In regard to the third article, they recommended that the body of laws should be published at the public charge, and that the printer should be paid for them at the rate of twenty-four shillings a copy, the distribution of the copies to be the same as that prescribed for the session laws. ${ }^{1}$ The conferees of the Lower House reported to the delegates that they had proposed in committee, under the second article, an allowance to the printer of twenty shillings a sheet for their journals and proceedings, and upon receiving this report, the House approved it and

"Resolved that the said Parks be allowed after the Rate menconed ... for printing any the publick proceedings of the last Sessions, And that he be Appointed and have the Character of publick printer to the province."

Although they concurred with the delegates on the first and third articles of the proposals, the Upper House objected to the printing of the journals and proceedings as "an unnecessary charge to the publick," and in regard to the title which the printer should bear, their Honors informed the delegates sharply that the Governor had already licensed Parks "to print the Laws as Printer to his Lordship," and that title, their message said, they conceived "to be a sufficient distinguishing Character."3

${ }^{1}$ U. H. J., March 23, 1725/26, Archives of Maryland, 35: 451 and 452.

2 L. H. J., March 21, 1725/26, Archives of Maryland, $35: 476$ and 477.

${ }^{3}$ U. H. J., March 23, $1725 / 26$, Archives of Maryland, 35: 455 . In his first issue of the "Proceedings," later to be described, Parks "played safe" by adopting for himself two titles; in the imprint he described himself as "Printer to the Right Honourable the Lord Proprietor, and the Province." 


\section{A History of Printing in Colonial SCaryland}

In objecting to the printing of the Lower House journals, the Upper House had in mind not so much economy, as was asserted in its message, as a dislike of publicity in connection with the Assembly's action on the English statutes. Long customary in others of the colonies, however, the regular publication of Assembly proceedings could not be postponed much longer in Maryland. On receiving the adverse report from the Upper House, disapproving their suggestion that the Lower House journals be printed each session, the delegates acted with the assertiveness customary to them in the face of opposition to their plans. The clerk recorded their defiance in these words:

"Notwithstanding which Message, It is Resolved that such of the debates and proceedings of the last Session of Assembly as relate to the Government or Judicature of this Province or other materiall publick Affairs thereof be printed at the Charge of the Publick And thereupon John Beale and Vachel Denton Esqrs. are appointed to Make a Collection of the Laws now in force to be reduced into one Volumn fit for the press with Marginall notes and also of the proceedings above menconed and that the printers observe their directions therein." 1

It is clear from what follows that the new printer was in danger of being torn asunder by the jealousies and antagonisms of the parties. In the next session of the Assembly, he was brought to the bar of the Lower House to explain why he had failed to print the proceedings of the last two sessions in accordance with the terms of the Lower Houseresolution. In his defence, he answered that "his Honr the Governour ordered him not (to) print them until the Bodies of Laws were first finished." ${ }^{2}$ His Honor the Governor this year chanced to be Charles Calvert, a relative of the Proprietary, a personage who would have been sure to support with all his power of negative action the policy of a family which was beginning to regard the people of Maryland as a perverse and ungrateful race. In this instance, one observes with satisfaction that the determination of the delegates to print their constitutional proceedings was equal to the ingenuity of the Governor in postponing the publication of them, for in the year 1727 , after the body of laws had been published and Charles Calvert had been superseded in his governorship by Benedict Leonard Calvert, Parks issued the proceedings ${ }^{3}$ of the three sessions of October and March I 725 and July 1726, collected and edited by Messrs. Beale and Denton, as had been provided for in the original resolution of March 1725/26. The victory was with the delegates; never afterwards did the Upper House gainsay their "liberty to print."

\footnotetext{
'L. H. J., March 23, 1725/26, Archives of Maryland, 35:484 and 485.

${ }^{2}$ L. H. J., July 14, 1726, Archives of Maryland, 35: 536 .

${ }^{3}$ Copy in the Maryiand Historical Society probably unique. See bibliographical appendix.
} 


\section{William Parks, Public Printer of SCaryland and Virginia}

\section{The Compiled Laws of 1727}

In spite of the lack of harmony between the Houses in regard to his work, Parks went quietly forward with the execution of the tasks allotted to him by their resolutions. The laws of the March Assembly of $1725 / 26$ made their appearance in course, ${ }^{1}$ and on their last page was an advertisement in which was announced as forthcoming from Parks's press an edition of the whole Body of Laws from the beginning of the Province down to the year I726, of which the price to subscribers was to be twenty shillings a copy. The edition of the collected laws which he proceeded to publish, probably in the autumn of 1727 , was that which was known in Bacon's day as the "old Body of Laws," and which until the appearance of Bacon's great work in 1765 , remained as the most ambitious production of the Maryland press. ${ }^{2}$ In comparing it with his own larger and more scholarly edition of the laws, Bacon was not especially complimentary to the earlier collection. "The Superiority of the present Edition," he wrote in his Preface,

"will best appear from a Comparison of it with the last mentioned; which, tho' Published (as set forth in the Title Page) by Authority, is in Fact very imperfect, and replete with Errors: The Printer having used no other Copy of the Laws, made before the Year 1719, than that of Bradford's Edition, which was published without any Authority; and consequently hath adopted, as may appear in several Instances, the Blunders of that Edition: Which, together with its own Mistakes, make up a considerable Number."

It may have been that the considerable number of mistakes which he found in "the old Body of Laws" taught Bacon the desirability of making transcripts for his collection from the original acts, so that through the blunders of Parks and Evan Jones he attained a height of editorial grace not reached, or even striven for perhaps, by his predecessors.

\section{The Beginnings of a Literary Tradition in Maryland}

William Parks became almost immediately an important member of the provincial society. To give opportunity for discussion of public affairs, to attempt to form public opinion, are not functions belonging only to the modern newspaper and publishing house. In the Maryland Gazette, which he began in 1727 , Parks plunged to the heart of the economic problems facing the Province, and among the early issues of his press was a pamphlet in which the absorbing question of American politics, the question of the

\footnotetext{
I Copy of this edition of the session laws in the Maryland Diocesan Library, Baltimore, is the only one known.

${ }^{2}$ In his Maryland Gazette for December, 17, 1728, Parks advertises that he has left a few copies of the Body of Laws at the regular price of a pistole each. He vents his vexation against those pluralists in office who have hurt his sales of the book by selling their own duplicates. In the course of the notice, he says that the work was advertised for publication more than a year ago, which means that it had been published probably in the autumn of 1727 .
} 

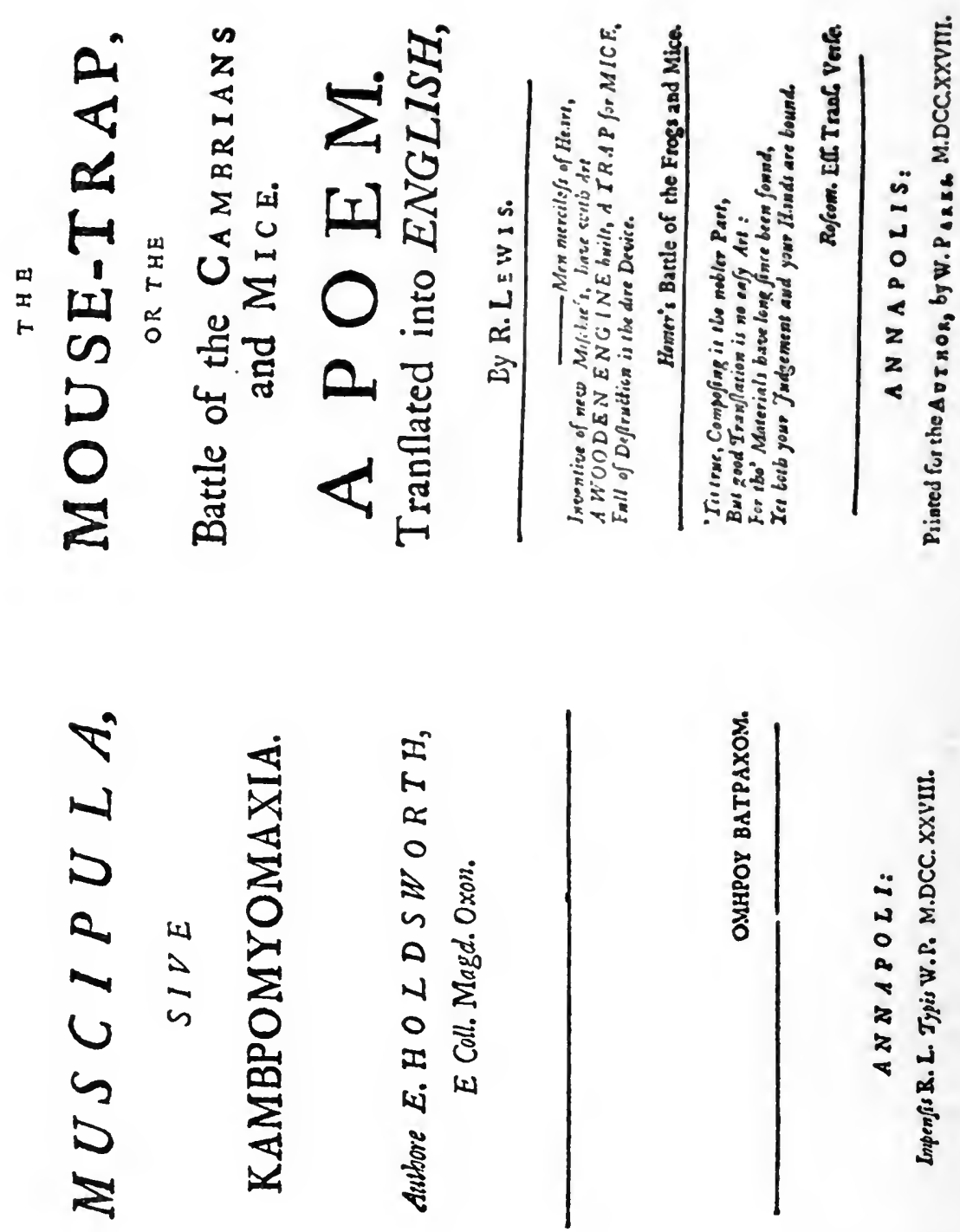

: 


\section{William Parks, Public Printer of SCaryland and Virginia}

extension of the English statutes, was treated in a notable plea by Daniel Dulany the Elder.' Although he was able to keep on good terms with its representatives, Parks was not subservient to the government of the Proprietary. He considered himself to be the servant of the Lower House of Assembly in its constitutional struggles, and all that he did was doneboldly and apparently without regard for the Proprietary influence. The author of the Sotweed Redivivus, published in Annapolis in 1730, commented on the activity and zeal of the Parks establishment in the lines,

". . . the Press with Schemes does swell,

To make us Thrive at home the better,"

and for once the rough-tongued satirist was guiltless of exaggeration. The bibliography attached to this narrative, containing, it is believed, by no means all of the publications issued by Parks during his twelve years of residence in Maryland, indicates none the less the scope of his service to the Province. His newspaper, his almanacs, his issues of works of politics, economics and religion, of satiric verse and vers de societé bespeak him a man of public spirit, and a printer in whom literary appreciation was joined to business enterprise.

The beginnings of the Maryland literary tradition, fostered by the press of the new printer, rest upon the work of Richard Lewis and Ebenezer Cooke, two writers whose names are almost unknown in other connections. On March 18 th of the year I $728 / 29$, Governor Benedict Leonard Calvert wrote in these words to his friend Thomas Hearne, the antiquary, who was somewhat disgruntled, it may be observed incidentally, at having to pay $3 \mathrm{s.} 6 \mathrm{~d}$. postage on the letter and the parcel which accompanied it:

"Wee have had here of late a Printing house set up, which I have encouraged with as much Countenance from the Government as possible. Wee have printed our Body of Laws, and $I$ herewith send you one of our first issue of the press, a translation of the Muscipula by one Lewis, a schoolmaster here who formerly belonged to Eaton, a man realy of Ingenuity, and to My Judgment well versed in poetry." 3

The work here referred to was a satire on the Welsh people, written in Latin in the mock-heroic style by Edward Holdsworth. Its translation by Richard Lewis, ${ }^{3}$ probably a successor of Michael Piper in King William's

1 The Right of the Inhabitants of Maryland to the Beneft of the English Laws. Annapolis, 1728. See bibliographical appendix.

2 See appendix for title and description. This reference to it is found in Hearne's Collections, 10: 109, from which it is quoted in the Maryland Historical Magazine, $11: 282$.

${ }^{3}$ Richard Lewis, who according to Gov. Calvert, was an old Etonian, was in Maryland as early as October 1725 . He remained there certainly until October 27,1732 , at which time he wrote a letter to England describing various natural wonders of Maryland. (See Philosophical Transactions of the Royal Society, 37: 69 and $3^{8:}$ I 19). He was a frequent contributor to the Maryland Gazette, from the columns of which several of his pieces were reprinted. See Maryland Historical Society Fund Pub. No. 36 and Maryland Historical Magazine, $5: 71$. 


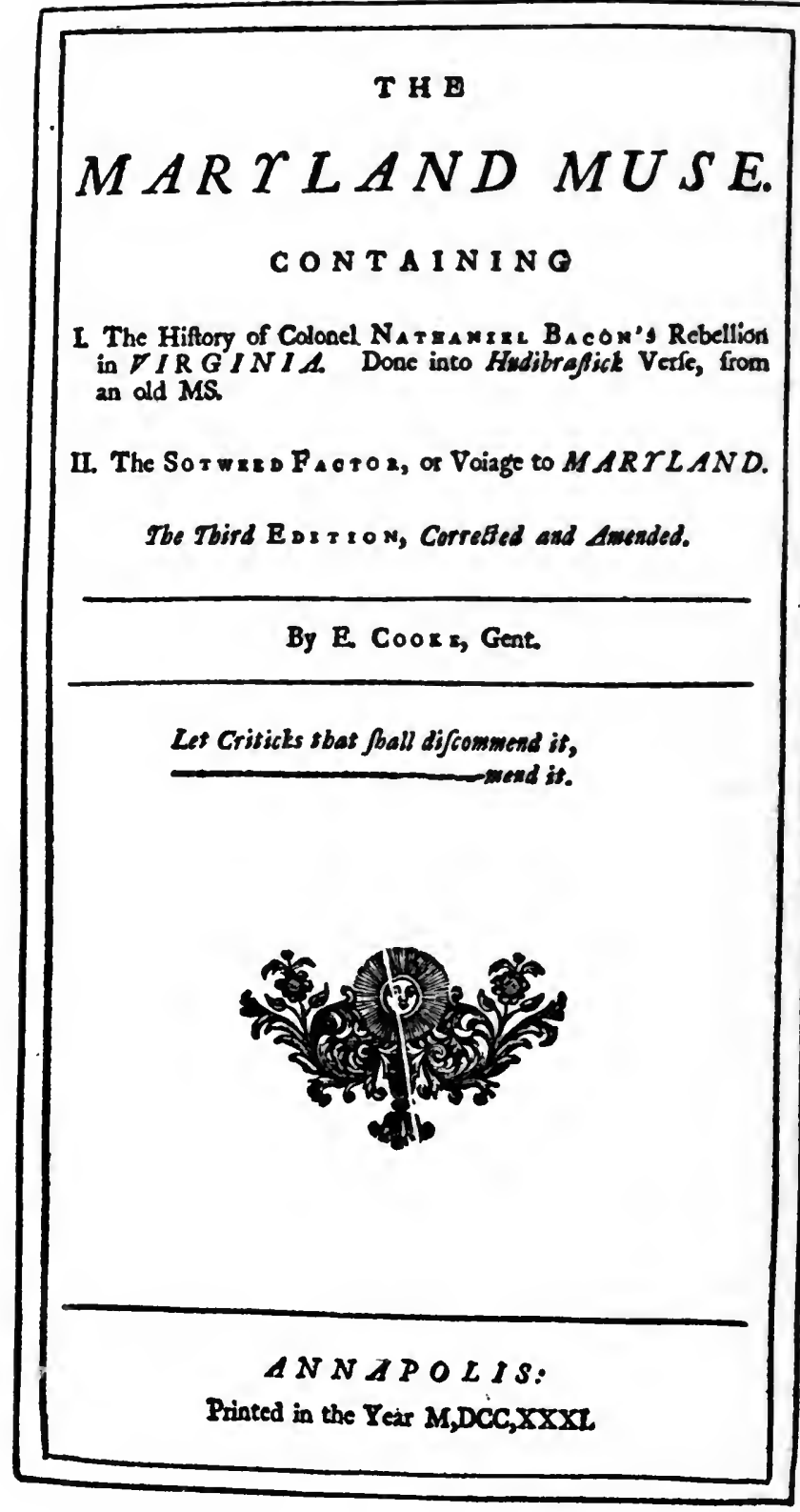

Plate V. See page xizi. 


\section{William Parks, Public Printer of SCaryland and Virginia}

School, Annapolis, was the first distinctly literary production of the Maryland press, and although it has thisinterest of priority in Maryland literary bibliography, yet its subject matter is of small concern to modern readers. It must have been indeed, even at the time of its translation, that its magniloquence was related only distantly to the interests of the Maryland people. ${ }^{1}$ After its publication Lewis remained in Maryland for some years, during which he continued, through the medium of the Parks press, to display his respectable talent for poetical expression. One of his most praiseworthy effusions was an ode, entitled "Carmen Seculare," in which, in well-turned lines, packed with a description of Maryland and an abstract of its history, ${ }^{2}$ he welcomed Charles Lord Baltimore on the occasion of that dignitary's visit to the Province in the year I732. A very minor poet indeed, Richard Lewis is yet not a figure to be despised as the founder of a literary tradition.

Of greater importance perhaps than the work of the elegant and conventional Lewis was the satirical verse of Ebenezer Cooke, Gent., who published in London in the year 1708 a poem entitled The Sot-Weed Factor; or a Voyage to Maryland. A Satyr.... In Burlesque Verse. ${ }^{3}$ No details remain by which may be identified this cruel satirist, who came out to Maryland, he tells us, as a tobacco, or "Sot-Weed" factor, and who, as distaste for the crude life of the country mingled with his grievances against its inhabitants, wrote in atrabiliar fluid a poem in which the wit was almost obscured by the bitterness and scurrility which appeared in every line. The picture of men and manners which he presented in The Sot-Weed Factor was colored by his mood, but so patently correct are its background and drawing that the student of Maryland social history must always turn to the contemplation of it as an important element in his studies.

With the passing of the years, Cooke's spleen subsided. In the year I730, there was written by "E. C. Gent.," and printed by William Parks, a satire, The Sotweed Redivivus, in which there was less wit than was apparent in the earlier work, and less scurrility, and in which bitterness was supplanted by a spirit of constructive criticism of local politics and trade. That at this time, however, Cooke was not in any sense repentant of his earlier and more vindictive criticism of the Province, appears from the fact that in I73I he republished The Sot-Weed Factor in a volume entitled The Mary-

\footnotetext{
${ }^{1}$ In referring to it in his Diary, Hearne noted under date of August 7, 1732, "'Twas printed at Annapolis that year and is one of the first things ever printed in that Country." In The Remains of Thomas Hearne, Bliss ed. London, 1869, 3: 90 .

2 A large portion of this ode was reprinted in American Museum for 1789, 6: 413, under title of "A Description of Maryland." For an account of the original edition, see bibliographical appendix of the present work.

${ }^{3}$ See Maryland Historical Society Fund Pub. No. 36, Early Maryland Poetry, edited by Bernard C. Steiner.
}

[67] 


\title{
A History of Printing in Colonial Taryland
}

land Muse, ${ }^{1}$ which Parks printed in his Annapolis establishment. In a note at the conclusion of this volume, described on its title-page as the third edition, the author thanked his friends and benefactors for the encouragement which they had given him and promised the publication of an annual collection under the same title. No traces remain, however, either of a second volume of the series, or of the two earlier editions of the first volume. A part of its contents was a poem entitled and described as "The History of Colonel Nathaniel Bacon's Rebellion in Virginia, Done into Hudibrastick Verse from an old Ms." One is fain to accept the pedigree for this poem which is provided in the pleasant, punning address indited by an unknown "H. J." to its author, E. Cooke, Gent. There are few who will not be amused by the lines which follow:

\author{
To The Author.2 \\ Old Poet, \\ As you may remember, \\ You told me sometime in September, \\ Your pleasant Muse was idly sitting, \\ Longing for some new Subject fitting \\ For this Meridian, and her Inditing, \\ Worth Praise and Pence, for Pains in Writing. \\ I therefore (thinking it great Pity \\ A Muse should pine, that is so witty) \\ Have sent an old, authentick Book, \\ For Her in Doggrel Verse to Cook; \\ For since it never was in Print, \\ ('Tho' wondrous Truths are written in't) \\ It may be worthy Clio's Rhimes, \\ To hand it down to future Times. \\ You know what never-fading Glory, \\ Old Salust got by Catlin's Story; \\ The Fame Hyde gain'd, I need not tell y'on, \\ By's Hist'ry of the Grand Rebellion: \\ You know how Butler's witty Lays \\ Procur'd for him immortal Praise: \\ I'll add no more-But if you please, Sir, \\ Attempt the same for Ebenezer, \\ Which you may gain, or I'm mistaken \\ If you can nicely Cook this Bacon.
}

H. J.

ISee Maryland Historical Society Fund Publication, No. 36, for reprints of the "Sotweed Factor" (London Edition of 1708 ), the "Sotweed Redivivus" and another poem of this Ebenezer Cooke or "E. C." who sometimes signed himself "Laureat," but by whose appointment is not known. Tyler, M. C., History of American Literature. N. Y., 1881, 2: 255, discusses Cooke and his satires. Nothing is known of Cooke besides his writings. He may

${ }^{2}$ The lines which follow were copied for this work from the unique British Museum copy of The Maryland
Muse. Muse. 


\section{William Parks, Public Printer of STaryland and Virginia}

One would like to know more of this "Old Poet" and his friends. Indeed the little group of essayists, versifiers and political writers who gathered around William Parks, the Annapolis publisher, has an interest for the student of American literary beginnings which on the personal side, at least, has never been satisfied.

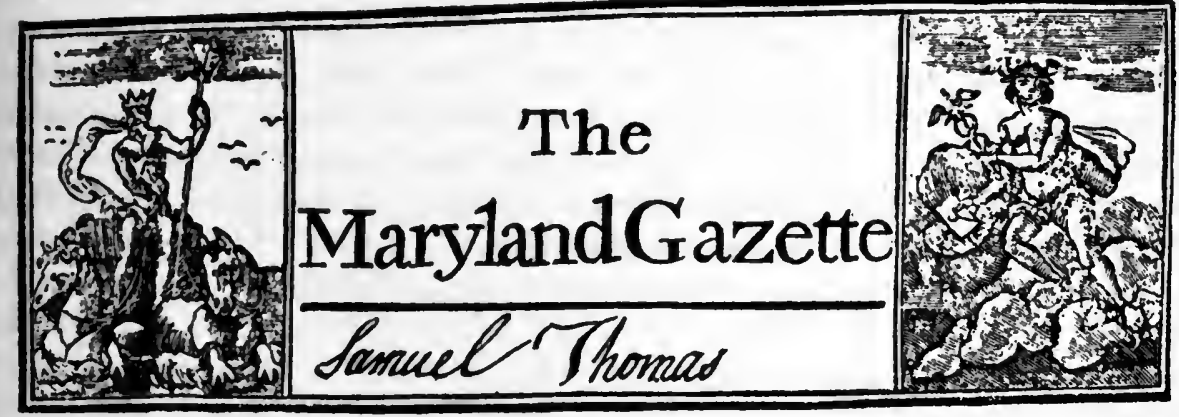

From Tuelday December 24 , to Tuefday December 31,1728 .

( Numb. LXVIII

He tibi erumt tres ; parifgee imponere morewt. Parcere Subjetis, Es dobillare foperbos. $\mathbf{S}$ I R,

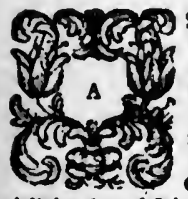

delightul, and fas, very far from Precarious. femhled tn fertle the Peace, and adjuft Meichants and the S.S. Compang, will be the only Affir; the Rights of all the contending Princes, to determine. Aftairs that are not of fuch Importance as to it miy not be thnught unfeafonable in of-. embroil us, or keep us long in Sufpence. "tis just that we fer fomo moled Conjedures on this Af- Mnold firt refur thefe to an amicable Mediation, and it fair: Pnfible it may influence a berter thai fnotild fail us, we map then recur to Arms : Bur the Enquiry: and the leaft Attention in this Crnwn of Spain is not in any Condition to with When we come to Blnwe, and will hardly eres hazard fuct a. dangerous liluc: it will coft them fo nuch Blood and

Fres to his Porrs in the sdriatizk Ser, and other Prnceeding of the like Kind. Shall we then, after all thic, he taugh tn fear the Comersss will hurt us in this Point, and eftablin a Commerce thus abindon'd by it: beft and moft fanguias Friends?

Plate Va. See page xiii.

\section{Parks's Maryland Gazette, the First Newspaper South of Pennsyluania}

Principally, however, was the Province indebted to Parks for his establishment of its first newspaper. In the month of September 1727, appeared the inaugural issue of the Maryland Gazette, the first newspaper to be published south of Pennsylvania, and the seven th to attain regular publication in English America. It was issued continuously until March $1730 / 31$, when it seems to have been discontinued to resume publication again nearly two years later, in December 1732 . At this time its proprietor formed a part- 


\section{$A$ History of Printing in Colonial Maryland}

nership with Edmund Hall ${ }^{1}$ which enabled him to extend his interests in Maryland without neglecting those newly established elsewhere. Afterwards, when in the summer or autumn of 1733 the partnership was dissolved, Parks alone carried on the paper until what was probably its last issue on November 29, $1734 .^{2}$

The first Maryland newspaper was by no means a contemptible journal. While in England in 1730, Parks arranged for regular foreign correspondence for its columns, ${ }^{3}$ and close at hand in Maryland he had some of the leading men in the colony, in whose contributions, usually in the form of letters, were discussed the local and colonial politics and questions of economics and trade. Furthermore, for his department of belles lettres he had always nearby Ebenezer Cooke, Richard Lewis and other regular contributors, whose weekly poems and essays gave an undeniable tone to the publication, howbeit that tone was frequently stilted and self-conscious, in the manner of an age when, abhorring to write naturally, men gave themselves up to an obsession for elegance and urbanity. It is unnecessary to remark on the value to the historian of the remaining copies of Parks's Maryland Gazette, for in that mirror is reflected the life of the Province during a period of years which were representative of the first half of the century. One resists with difficulty the temptation to philosophize the matter of its yellowed pages.

\section{Other Activities of Parks in Maryland, and his DEPARTURE FOR VIRGINIA}

To the activities of Parks as publisher and printer were added, as was customary in America at this period, those of bookseller and bookbinder.

\footnotetext{
${ }^{\mathrm{I}}$ Little is known of this Edmund $\mathrm{Hall}$ who appeared in the imprint of the Maryland Gazette and elsewhere in $173^{2}$ and 1733 as the partner of William Parks. On July 13,1732 (L. H. J.), "Mr. Edmund Hall a printer in Partnership with Mr. Parks is Allowed to print the Votes of this Session for the Usual Allowance," and again on March 14, 1732/33, a similar per:nission was granted Mr. Hall, "Conditionally that he print them Daily." The partnershi, must have been dissolved soon after this, for Hall's name disappeared from the imprints of the Parks establishment and, as before, Parks printed alone. He may have been retained as manager of the Annapolis establishm?nt, however, for on April 27, 1737 (L. H. J.), Mr. Hall again was authorized to print the Lower House proceedings. Nothing is heard of him after this, and his name only was known to Isaiah Thomas. Even less than this, however, is known of Mr. Webb, who in 1736, "agreed to print the Votes of the Lower House of Assembly this Session at the usual Allowance." This may have been Parks's foreman or the manager of the Annapolis branch of the establishment. When Parks went to Virginia to petition the Assembly in 1727, George Webb, Gent., was appointed to prepare the laws of that colony for the press. He was employed by the Virginia Assembly for similar tasks for several years afterwards. It is possible that he and Parks formed a connection. There was also a George Webb, journeyman printer, in Philadelphia in 1728 , but he is supposed to have returned to England before the date named above. John Webb, bookseller and publisher of Philadelphia a decade later, is the only other person of the name who seems in any way to have been connected with printing or the allied trades in this time and place.

${ }^{2}$ Evans, No. 2899; Brigham, C. S., Bibliography of American Newspapers, 1690-1820. (Part III.) In Proceedings of the American Antiquarian Society, April 1915 .

${ }^{3}$ Advertisement, Maryland Gazette, June 9, 1730. Evans, No. 2899.
} 


\section{William Parks, Public Printer of Scaryland and Virginia}

He advertised himself as one "Who binds old Books very well, and cheap," and in the same advertisement announced that he had for sale "A parcel of very curious Metzotinto Prints" at reasonable rates. ${ }^{1} \mathrm{He}$ imported books from London to sell to his Maryland customers, and in the case of certain religious works such as primers and catechisms, he seems to have imported the sheets, later to be folded and sewed in his own establishment. It is probable that as bookseller, he had for sale a variety of other articles, for the booksellers of the time traded busily in small stores of the unclassified sort; Bradford $^{2}$ of Philadelphia had in his stock such dissimilar articles as whalebone, live goose feathers, pickled sturgeon, chocolate and Spanish snuff, while a few years later, Hugh Gaine ${ }^{3}$ of New York dealt in everything from medicines to flutes and fiddle strings.

Until the year 1737, when he was brought to book by the House, the relations of Parks with the Assembly were such as to indicate that his merits were appreciated by that body, ${ }^{4}$ while on his part there seems to have been no dissatisfaction with his treatment by its members. Almost from his first coming to Maryland, however, Parks had recognized the possibilities of greatly increasing his business by uniting with it the printing of the colony of Virginia. He made tentative proposals to the Virginia Assembly for its printing work in the year 1727 , and so well were his proposals received that three years later he set up in Williamsburg a branch office of his Maryland establishment. Eventually, the new office overshadowed the old in importance, so that Parks began to neglect his Maryland business in favor of that of the colony to which later he was to transfer all of his interests. In an act of the Maryland Assembly of April 1737, wherein he was still described as "of the City of Annapolis," it was set forth against him that he had neglected to print the laws of the previous session, and that because of this neglect the Province had been put to the expense of having the laws of that session transcribed. As a consequence of this defection by the printer, it was enacted that thereafter the counties should not pay him unless he should have delivered the printed laws within four months after the conclusion of each session. This was the last incident in connection with the

${ }^{1}$ Maryland Gazette, July I 5, I729.

2 Thomas, Ist ed., 2: 31 .

${ }^{3}$ Ford, P. L. ed., Fournals of Hugh Gaine, Printer. 2 v. 1902, 1: 27 and 28.

1 In the first appendix to this narrative is to be found a copy of the Act of 1727 for the encouragement of William Parks, the first enactment on the Maryland statute book in which provision is made for printing. Following it is an abstract of later printing legislation in the Province. Isaiah Thomas, 1st ed., 2: 128, asserts that Parks was paid two hundred pounds a year by the Maryland Assembly. With tobacco at ten shillings a hundred in 1730 (Archives of Maryland, 37: 136) it is probable that Parks's allowance of twenty-four thousand pounds of tobacco from the counties for printing the laws, and his extra allowance from the Lower House for printing its votes and proceedings amounted to about the sum specified by Mr. Thomas. 


\section{A History of Printing in Colonial Maryland}

work of William Parks in Maryland, and very soon after the passage of the act of admonition, having in the meantime, however, rectified his negligence by printing the acts of April $1736,{ }^{1}$ he removed his entire establishment to Virginia, leaving the Province of Maryland without a printer. In November I737, at the close of a letter to a correspondent in Philadelphia, Governor Ogle wrote "as we have not a Press here at present, I have given Directions to the Bearer of this to get a good Number of Proclamations printed in Philadelphia."

\section{Parks Establishes Printing on a Firm Basis in Virginia}

Closely identified as Parks is with the Province of Maryland, his name is even more intimately associated with the literary history of Virginia than with that of the sister colony. Virginia had been without a printer since the failure of Nuthead's venture at Jamestown in the year $1683,{ }^{3}$ and when in February 1727 , Parks presented to the Virginia House of Burgesses his proposals for printing a collection of its laws, and its session laws of succeeding years, his tentatives met with immediate and intelligent approval by that body. A committee composed of some of the leading men of the colony was appointed to arrange the details of the publication with the printer, and when the work finally appeared in the year 1733, Parks had been for three years an important personage in the Virginia capital, between which and Annapolis he was then dividing his time and energies. In the year $173^{2}$ he was allowed by the Virginia burgesses an annual salary of one hundred and twenty pounds, a rate of payment at which he continued to serve the colony until the year 1738 , when, as the result of a petition which he presented to the Assembly, his emolument was increased to two hundred pounds. In 1742 he was allowed two hundred and thirty pounds, and again in 1744 his increasing importance in the colony was recognized by the addition of fifty pounds annually to this sum, so that in his last six years of life, his salary for public work was two hundred and eighty pounds a year. In his petition for a larger salary, addressed to the Virginia Assembly on December 5, 1738, he asserted that he had relieved the colony of the "Drawback of the Duty upon Paper." It is possible that he referred in this statement to the paper mill which he is known to have established at Williamsburg, the first paper mill, it should be said, to be built in English America south of Penn-

\footnotetext{
${ }^{1}$ See the bibliographical appendix under the year 1736 , where this set of session laws is recorded with date of March 19, 1735 .

${ }^{2}$ Minutes of the Provincial Council of Pennsyluania. Harrisburg, 1851, 4: 253.

3 Evans, No. 1057, records a pamphlet printed by Fr. Maggot of Williamsburg in 1702, but as nothing can be discovered concerning suct. a person or press, he concludes the name to be an ironym.
} 


\section{William Parks, Public Printer of STaryland and Virginia}

sylvania. It is generally believed, however, that Parks's paper mill was not established until the year $1744^{1}$

Although late in the field, the Virginia press soon obtained a position of importance among the typographical establishments of the colonies. Parks was a neat printer and an intelligent man of affairs. In Maryland he had been the first to establish a newspaper, and to print works of a literary nature; in Virginia also, he was the pioneer journalist, and to his publication of works of belles lettres, he added those of history and general literature. Copies of his Williamsburg edition of Stith's History of Virginia, published in 1747, are among the much sought after items of Americana; Typographia, an ode on printing by J. Markland, which he published in I730, would bring a great price as the first American contribution to its subject if the single known copy of it should ever emerge into the auction room from the shelves of the John Carter Brown Library. For his more important works he chose an excellent quality of paper, and in general his typographical execution was neat and dignified. His session laws of both colonies present a good appearance, and his edition of the Laws of Virginia, printed in the year 1733 , contends for first place in typographical excellence with two or three other well known works of the first half of the century.

Until his death in the year $175^{\circ}$, Parks continued to fill an important place in the public life of Virginia. In the course of a voyage to England undertaken in this year, he came down with a pleurisy and died after a short illness. His body was carried to England and there buried. That his labors after all had been unrewarded may be inferred from the fact that at his death his assets were found to be slightly more than six thousand pounds, while his liabilities were only a few pounds less than this amount. ${ }^{2}$ There was no printer of his day, however, Franklin alone excepted, whose service to typography and letters in America presents a greater claim on the interest and gratitude of posterity.

${ }^{1}$ See Weeks, L. H., History of Paper Manufacturing in the U. S., 169o-1916, N. Y. 1916, for an account of the first Virginia paper mill, particularly the verses from the Virginia Gazette quoted there, in which praise of the enterprise of Parks is united to a plea for rags to be used in the mill. Many will be amused at this jocular admonition to men and maidens to contribute their worn linen to Mr. Parks's mill. This mill probably continued in operation until Parks's death, for it was sold by his executors for $\mathfrak{f}_{96} 6,3 \mathrm{~s}$. $9 \mathrm{~d}$.

${ }^{2}$ For information as to Parks in Virginia, consult the fournals of the House of Burgesses of Virginia, [for the years 1727-1758]. Richmond, 1909-1910; Thomas, History of Printing in America; William and Mary College Quarterly, 7: 10-12; Weeks, L. H., History of Paper Manufacturing in the U. S., 1690-1916. N. Y. 1916. See also his will and inventory and accounts in the Court House, York Town, Va. Copies of these are in the Maryland Historical Society.

After this account of William Parks had been set and paged, and consequently when it was too late for an extensive investigation, the author came upon a clue which may lead to the discovery of the origin and early life of this interesting printer. In the Catalogue of an Exhibition of Books-Illustrative of the History E Progress of Printing and Bookselling in England, 1477-1800, Held at Stationer' Hall, 25-29 Fune 1912, by the International 


\section{A History of Printing in Colonial Scaryland}

Association of Antiquarian Booksellers, item No. 895 is an edition of Jones, S., The Most Important 2uestion, What is Truth, printed by William Parks at Ludlow in Shropshire, England, in 1719-20. The editor of the catalogue has appended this note: "The first book printed at Ludlow. The printer afterwards emigrated to America and started printing at Annapolis." Immediately after perusing this entry, the author began a search in available histories of Ludlow and Shropshire for verification of the statement as to the identity of William Parks of Ludlow and Annapolis, but in the short time at his disposal secured no definite information. He discovered, however, that at a short distance from the town of Oswestry in Shropshire there is a celebrated "half-timbered" mansion known as "Park Hall," and that there is another "Park Hall" in Bitterley near Ludlow. Recalling, as is stated in this narrative, that on April 19, 1731, a tract known as "Park Hall" was surveyed in Maryland for William Parks, and knowing the tendency of the colonial American to name his tract after some English estate dear or familiar to him, he felt that he was in the way of throwing light of an interesting nature on the early life of this emigrant printer. Through the kindness of the New England Historic Genealogical Society, examination was made of the parish registers of Oswestry in the Shropshire Porish Register Society (Diocese of St. Asaph series), but with negative results, except to show that Parks was a common name in that neighborhood, as it seems to have been also in the neighborhood of Bitterley.

This evidence is so slender in amount and character that the author hesitates to add to it more of the same nature, but the fact that among the slaves left by William Parks was a negro man named "Ludlow" seems to have sufficient significance to justify its inclusion among the other indications of the identity of William Parks, printer of Annapolis, Maryland, and William Parks, printer of Ludlow, England.

Through Messrs. B. F. Stevens \& Brown of London the following additional information has been received concerning William Parks, the first printer of Ludlow, England: The Rev. W. G. D. Fleteher, Honorary Secretary of the Shropshire Parish Register Society, writes that the Ludlow Parish Register records the baptism on March 20, 1719/20 of "William, son of William Parks and Elianor." This was doubtless the son of William Parks the Ludlow printer. The connection which this entry provides between William Parks of Ludlow and William Parks of Annapolis lies in the name of the wife, which is given as Eleanor in the will of the Maryland and Virginia printer (Wills and Inventories, 20: 183, 1746-1759 in Court House, Yorktown, Va., dated March 30, 1750.) No son was mentioned in this will. Mr. Fletcher communicated the matter of the inquiry to Henry T. Weyman, Esq. F. S. A. of Fishmore Hall, Ludlow, who transmitted to him in reply some interesting facts as to the activities of William Parks of Ludlow. Mr. Weyman writes in reference to this Parks that he was the publisher of the first newspaper of Ludlow, probably the first in Shropshire, entitled "The Ludlow Post-Man. Or the Weekly Journal." Some copies of this newspaper are in the British Museum and a reproduction of the first page of its first issue was printed in Cassell's Family Magazine in October 1896, p. 885. In this reproduction of No. 1, the date of publication is given as Friday, October 9, 1719 , and the introductory address of its publisher is signed "Typographer." One familiar with Park's Maryland Gazette, seeing this reproduction, will notice immediately the similarity in the arrangement of the two headings; that is, the title centered between two decorative and symbolical woodcuts, representing Neptune and Mercury in the Maryland Gazetse, a mounted postman and the arms of Ludlow in the Ludlow Post-Man. The imprint of this journal is "Ludlow published by William Parkes." Mr. Weyman refers to an announcement by W. Parkes in 1720 of the forthcoming publication by him of a "Prospect of the Demi Collegiate Church of Ludlow," price one shilling.

In an article on "English Provincial Presses" (part 3) in Bibliographica, vol. 2, pp. 301-303, W. H. Allnutt discussing Parks's Ludlow press adds the following note: "William Parks afterwards printed at Hereford and Reading, emigrated to America, died on his return voyage to England, and was buried at Gosport, April I, 1750 ." Under the heading "Hereford" and the date 1721, Mr. Allnutt gives the following title: Pascha, or Dr. Prideaux's vindication of the Rule and Table for finding Easter ... briefly examined. By a Well-Wisher to the Starry Science ... Hereford: Printed by Will. Parks. (1721). 8vo. [Bodl.]; and under the heading "Reading," date 1723, he records the title of Parks's second newspaper venture; namely, "Vol. I. Numb. I. The Reading Mercury, or Weekly Entertainer. Monday July 8, 1723. Reading: Printed by W. Parks, and D. Kinnier, next Door to the Saracen'shead, in High-street. 4 to. [Nos. $1-8$ in the Bodleian Library.]"

The author regrets the fragmentary form in which the information in the above paragraphs has been conveyed to his readers, but the exigencies of the situation permitted no other method. He is conscious that in this note there is to be found no legal proof of the identity of William Parks of Ludlow, Hereford and Reading with William Parks of Annapolis and Williamsburg, but he believes that taken together the several facts set forth above justify one in thinking of the Annapolis printer as "William Parks, printer and journalist of Ludlow, Hereford, Reading, Annapolis and Williamsburg." 


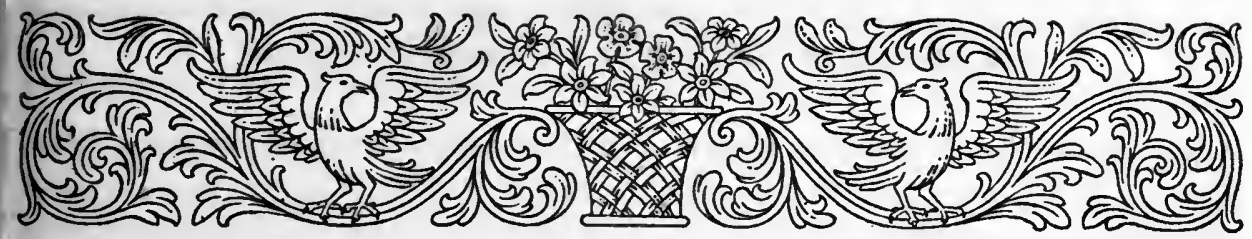

\section{CHAPTER SEVEN}

\section{Fonas Green, Printer to the Province-Green and Rind-Thomas Sparrow, the First SCaryland Engraver-Anne}

\section{Catharine Green and her Sons}

Franklin or in that of Bradford, a young journeyman
printer who had lately come to Pennsylvania from New onies. It is possible that through having been employed on the printing of these proclamations or of other Maryland papers, young Jonas Green had learned for the first time of the vacancy in the office of public printer of Maryland, caused by the recent removal of the Parks establishment from Annapolis to Williamsburg. Conjecture on this point, however, is unprofitable; what concerns us is not the manner in which Green heard of the vacancy, but the fact that within a few months after hearing of it, he had removed to Annapolis and set up an establishment in which for nearly thirty years thereafter he served the Province of Maryland with a fidelity and distinction that merit remembrance.

\section{Green's Ancestry and Early Life}

Jonas Green was the great grandson of Samuel Green, who, emigrating to Massachusetts with Governor Winthrop in the year 1630, settled in Cambridge and became in 1649 successor to the Dayes, father and son, the first printers in English America. ${ }^{2}$ For forty-three years Samuel Green continued as printer to the colony and government of Massachusetts, surrendering his press finally to one of his sons in the year 1692. During these years he carried out some amazingly ambitious works, among them the publication in $166 \mathrm{I}$ of Eliot's translation of the New Testament in the Indian dia-

\footnotetext{
${ }^{1}$ See preceding chapter. These proclamations had to do with the Maryland-Pennsylvania boundary dispute.

${ }^{2}$ Roden, R. F., The Cambridge Printers, $1638-1692$. N. Y. 1905.
}

[75] 


\section{A History of Printing in Colonial Maryland}

lect, followed in 1663 by an issue of the entire Bible in that tongue, a task tedious and honorable alike to the translator and to the printer. His sons and their sons continued to print in various towns of the New England colonies for several generations, and nearly two hundred years after he had taken over Daye's press in Cambridge, the sixth generation of his family was still engaged in printing and publishing in Maryland.

Jonas Green was the fifth son of Deacon Timothy Green, who was a grandson of Samuel Green the printer of Cambridge. His mother was Mary Flint. Jonas was baptized in Cotton Mather's Church in Boston on December 28, 1712. He served an apprenticeship with his father in New London, whither the Deacon had removed in $171_{4}$, and afterwards worked for a term of years with his brother, of the firm of Kneeland \& Green of Boston. Whether at the expiration of his articles the young journeyman attempted to establish himself independently in Boston is not clear, but one infers that this was his intention from the fact that in 1735 his name appeared alone on the imprint of a book intended for the use of the students at Cambridge. A Grammar of the Hebrew Tongue, Being an Essay to bring the Hebrew Grammar into English, ... by Judah Monis, was an excellently, and, it is said by authorities in that language, a correctly printed volume of one hundred pages. The imprint of this, the first Hebrew grammar to be printed in America, reads, "Boston, N. E. Printed by Jonas Green, and are to be sold by the Author at his House in Cambridge. MDCCXXXV." It must have been soon after the printing of this, his only recorded Boston publication, that Jonas Green proceeded to Philadelphia, where he found employment with both Franklin and Bradford. "Mr. Jonas Green of Philadelphia, Printer," was among the subscribers to Thomas Prince's Chronological History of New England, a work which issued from the press of Kneeland \& Green in Boston in 1736, from which circumstance it may be inferred that Jonas had been living in Philadelphia for two years at the least when he removed tience to Annapolis in 1738. He married, April 25, I738, in Christ Church, Philadelphia, Anne Catherine Hoof, who was born in Holland and was brought to America in her early childhood. Jonas and Anne Catharine Green had six sons and eight daughters ${ }^{1}$ but eight of their children died in

${ }^{1}$ Isaiah Thomas says that there were six sons and eight daughters, and the register of St. Anne's Parish records the baptism of the following fourteen children: John b. 18 October 1738, died infancy; Rebecca b. 22 September 1740 , married 2 December 1757 to Mr. John Clapham; Jonas b. 12 February 1741, died in infancy; Catherine b. 4 November 1743, died in infancy; her godfather was Samuel Soumaien, the silversmith; Marie b. 7 January $1744 / 5$, died in infancy; Mary b. 9 January 1745/6; William b. 21 December 1746 , "being named William after the Duke of Cumberland only;" Anne Catharine b. 19 January 1748, died October 5; Frederick b. 20 January 1750, "just as the Guns were Firing on account of the Birth of His Royal Highness the Prince of Wales;" one of his sponsors was the celebrated Dr. Alexander Hamilton of Annapolis, author of Hamilton's Itinerarium; Deborah b. 19 January 1752, died October 9; her godmother was Mrs. Susanna Soumaien; Elizabeth b. 10 No- 


\section{Fonas Green, his Family and his Associates}

infancy. The three sons who reached manhood continued in Maryland and passed on to another generation of their family the typographical tradition which they had inherited from their New England forefathers.

\section{The Date of Green's Coming to Maryland}

That the young journeyman from the north began his labors in Maryland sometime in the year $173^{8}$ seems to be true in spite of the fact that no Annapolis imprints of that year have been recorded. As early as May $173^{8}$ a bill was introduced into the Lower House providing for the repeal of the several laws which stood on the books in favor of William Parks, and five days later, on May 9 th, another bill was brought in for the encouragement of Jonas Green. The Assembly was prorogued in this year, as it was also in the following year, before any of its bills became laws, and it was not until the session of July I 740 that an act for the encouragement of thenew printer found place on the statute books. When Green died in 1767 his obituary affirmed that he had been for twenty-eight years printer to the Province, a term of service which, if exactly stated, would have had its beginning in the year I739, but on the other hand in a printed petition which he issued in $I 762,1$ Green himself spoke of having served the Province as public printer for twenty-four years, while additional evidence that he began his printing operations in Maryland in the year $173^{8}$ is found in an act of Assembly of ten years later ${ }^{2}$ in which provision was made for the payment of salaries owing him for his services in that year. Finally, there is to be considered the fact that in October $173^{8}$, the first-born child of Jonas and Anne Catharine Green was baptized in St. Anne's Church, Annapolis, an occurrence which indicates that the Greens were at that time residents of the Maryland capital. In the face of these several evidences of his association with Maryland in the year 1738 , it seems curious that the earliest recorded

vember 1753, died October 2; Jonas b. 29 August 1755, died of smallpox 26 December 1756; Samuel b. 27 April 1757; Augusta, b. 4 April I760.

For the foregoing facts relating to the ancestry and early life of Jonas Green, see "Flint Genealogy" by J. L. Bass; "Brief Memories and Notices of Prince's Subscribers," by Ashbel Woodward, the first in 14: 60 of New England Historical and Genealogical Magazine, the second in 16: 14 and 15 of the same magazine; Isaiah Thomas, both editions.

See also "Register of Births, Marriages and Deaths," St. Anne's Parish, Annapolis, copy in Maryland Historical Society, and "Marriages in Christ Church, Philadelphia," vol. 1 , in Record of Pennsylvania Marriages Prior to 1810 , being vol. 8, Pennsylvania Archives, Second Series. See also notice in Maryland Gazette for October 27,1763 , where is announced the death early in the month of Jonas Green's brother Timothy, who had given up his partnership with Kneeland of Boston and returned to New London at the time of his father's death in 1757.

1 See bibliographical appendix.

${ }^{2}$ Acts, 1748 . Printed copy in Maryland Historical Society. In an appendix to this narrative will be found references to all acts of Assembly concerning Green and Parks, and a concise statement of Green's financial relations with the Province. 


\section{CON SI DERATIONS}

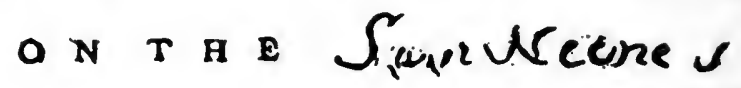

P R O P R I E. T $T$ Y $1>60$ ?

OFIMPOSING

T A X E S

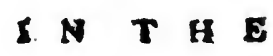

\section{Britifh GOLONIES,}

For the Purpore of raifing a REVBNUE; by ACT OP PARLIAMENT.

\section{2y. Danuct Dulary of moteram 191}

Haud Totum Verba-refgenent

Q2uod latet arcand, non enarrabile. fibod.

Boztb:ameticie.: Printed by a Doztbsamerican.

$$
\begin{gathered}
\text { moccexv. } \\
1765
\end{gathered}
$$

Plate VI. See page xiii. 


\section{Fonas Green, his Family and his Associates}

imprints from his press should be the Upper House "Address," the Votes and Proceedings and the Collection of the Governor's Several Speeches of the year 1739 .

\section{Jonas Green as Craftsman and Publisher}

Among the early specimens of Green's handiwork in the Province there are not many of such a character as to distinguish him from other colonial printers of his day. His Votes and Proceedings, as was the case usually with the Housejournals, were printed unimpressively in a crabbed letter on poor paper. On the other hand, his Collection of the Governor's Several Speeches showed a tendency toward that distinction of typographical manner which one learns to look for in examining his later work. How far he had been influenced by Franklin in his style is an interesting question which presents itself at the first view of the Collection, a work which he printed when the lessons of his service with or near the great Philadelphia printer were fresh in his memory. Early in his career he was able to procure better equipment than that in general use in America at this time, but if he had not used his new fonts and appliances with a serious and thoughtful craftsmanship, the mechanical aids alone would not have made for him the reputation, which ultimately he obtained, of being a printer as accomplished as any in the colonies. One remarks in his work a tendency toward studied simplicity, almost it might be said, toward austerity. He shortened and simplified the matter of his title-pages, and discontinued the use of ruled borders in their composition. He set his pages in broad measure without fussiness or mannerism, and imposed them with care for correct register. In the year 1764, having imported some months previously a rich assortment of Caslon for use in setting his edition of Bacon's Laws of Maryland, he advertised ${ }^{1}$ that thereafter the session laws would be printed in this letter and in the same style as the Bacon. The first use which he made of the new fonts may have been the printing of his petition to the Assembly of 1762 , mentioned earlier in this chapter. This broadside was a very handsome specimen of typography, and from the time of its publication until the fonts of Caslon had been worn out by continued use, Maryland public printing remained on a plane of dignified excellence to which, in spite of the great facility of modern methods, it has never attained since Jonas Green's day. Isaiah Thomas said of Green, whom he admired for other qualities also, that "His printing was correct, and few, if any, in the colonies exceeded him in the neatness of his work."'2

${ }^{1}$ Advertisement appended to Acts of 1763 .

2 Isaiah Thomas, Ist ed., 2: 129.

[79] 


\section{$A$ History of Printing in Colonial SCaryland}

Strangely enough Green seems to have been less versatile as a publisher than was his predecessor William Parks. In a great measure he confined his activities to governmental and political business, and although the greatly increased population of Maryland provided him a wider market than Parks had been able to count on, yet the breadth of his literary interests seems to have been less than that of the earlier publisher. An explanation of this may lie in the circumstance that with the passage of years and the consequent growth of population the governmental business unquestionably had increased in volume; moreover, it is certain that the editorship and publication of the second Maryland Gazette, which Green established in the year I745, consumed a great deal of the time and effort which might otherwise have gone into the conduct of a general publishing business. Green's journal was a much more elaborate publication than the newspaper which Parks had issued, and it is probable that he put into its maintenance so much effort and so much capital that he had little of either left for the continuance of the book trade so auspiciously begun by his predecessor.

\section{The Civic and Social Activities of Green}

Happily, it is not only as printer that Jonas Green engages our attention, for in his civic and social character one perceives a distinction as worthy of comment as are the qualities of intelligence which he devoted to the public service in the practice of his craft. During a part of his residence in Annapolis he was an alderman of the city, and more than once he was elected to serve as vestryman of St. Anne's Parish. At the time of his death he was registrar of the vestry, having held that office several times since his first election to it in 1746 . The vestry proceedings of St. Anne's are full of references to his activity in the work of the parish. Did the vestry need something in Philadelphia, Mr. Green would see that it was sent for; were some new pews to be put in, Mr. Green would arrange with the carpenter; were there printing to be done or a prayer book to be bound, Mr. Green, of course, would attend to that. Indeed both in the church and in the community at large Mr. Jonas Green was the cheerful and obliging servant of his neighbors.

For many years postmaster of Annapolis, ${ }^{1}$ acting sometimes as auctioneer at the country vendues, ${ }^{2}$ clerk of en tries for the Annapolis races, ${ }^{3}$ secretary of the local lodge of Masons, ${ }^{4}$ vestryman, alderman, journalist, printer, and

\footnotetext{
${ }^{1}$ See colophons to the Maryland Gazette, 1745 et seq.

${ }^{2}$ Chancery Depositions. I. R. No. 5, folio 730. Ms. in Land Office, Annapolis.

${ }^{3}$ Advertisements in Maryiand Gazetie.

${ }^{4}$ Verso of title-page of Brogden, William, Freedom and Love. Annapolis 1750 . See bibliographical appendix.
} 


\section{Fonas Green, his Family and his Associates}

good comrade, there seems to have been no local activity of any importance in which the "printer to the Province" was not concerned.

It is in the minutes of the Tuesday Club of Annapolis ${ }^{1}$ that Green as a social being may be seen at his best. Comprising in its membership some of the principal gentlemen and leading professional men of the Province, this typical eighteenth-century Club for many years held fortnightly meetings whereof its secretary, in spite of the prevailing high conviviality, succeeded in recording minutes as careful as those of a legislative assembly. In gaining other things, our more sophisticated age has lost something of the faculty for spontaneous enjoyment possessed by these breeched and powdered Annapolitans. Echoed through the pages of their treasured record are the guffaws and chuckles of honest gentlemen at their ease. In their company one breathes an atmosphere spiced, but not overladen, with the aroma of hot Jamaica rum and "Lisbon lemons," and peering through the soft tobacco haze one recognizes the mirthful faces of men seen before only in some starched and formal partin the Provincial drama. Jonas Green was a leading spirit in its "sederunts" or meetings. Mock trials, mock orations, fantastic ceremonies, serio-comic political and literary discussions-these and the punch formed the material of the fortnightly entertainment. Each member was known by a grandiloquent title, the significance of which in many cases does not appear, but "Poet Laureate" and "Master of Ceremonies" applied to our printer are terms that need no explanation. If the key were not supplied by the record, however, one might puzzleindefinitely over the meaning of that subsidiary title, which was represented by a string of five capital "P's" after his name, but there one discovers that in addition to the functions named above, Green exercised also in the club those of "Poet, Printer, Punster, Purveyor and Punchmaker general." Of his skill as punchmaker and purveyor we know nothing; of his poetry not much need be said, but with a full heart, we can return thanks that his printing was better than his punning, of which a few examples are represented in the minute book. He has been remembered, however, as a man of wit, and it does not become one century to judge the humor of its predecessors, lest in its turn it too be judged. With the knowledge that we gain of him in his hours of relaxation, he appears to us as a whimsical, good-natured man, quick of wit, kindly and obliging, the friend and comrade of all his little world. One may not doubt that the printing office and residence in Charles Street, the latter still occupied by his descendants, ${ }^{2}$ formed a rendezvous

1 One large volume and a few sheets of these minutes, in manuscript still, form one of the chief treasures of the Maryland Historical Society. A smaller volume is in the Ms. Division of the Library of Congress.

2 "The building occupied by Mrs. Anne Harwood, in Charles Street, is said to be the most ancient house now

[8I ] 


\section{$A$ History of Printing in Colonial SCaryland}

of the "Ancient City" where business and social interests were very pleasantly mingled. It is the business which was transacted there, however, which must again occupy our attention.

\section{Green's Maryland Gazette, I745-1777, I779-1839}

The fame of Green as a publisher and printer rests in the main upon his edition of Bacon's Laws of Maryland and upon his establishment and skillful conduct of the second Maryland Gazette. The latter was a weekly newspaper which he began to issue in April 1745, and which was continued by his wife, his sons and his grandson until December 12, 1839, a period of ninety-four years, during which this family established a record for long and useful service which few American newspaper concerns of that day or of this are able to boast having exceeded. ${ }^{1}$ Its early imprint read:

Annapolis: Printed by Jonas Green at his Printing Office in Charles Street; Where all Persons may be supplied with this Gazette, at $12 / 6$ a year; and Advertisements of a moderate length are inserted for 5 s. the First Week, and is. each Time after: and long ones in proportion.

In the following letter from Green to Benjamin Franklin, ${ }^{2}$ written not long after the establishment of the newspaper, are various matters of interest in connection with the Maryland Gazette and its printer's activities:

Dear Sir,

You will receive by this Mail two Packets from Barbadoes, which came inclosed to me from Mr. Ja. Bingham. One of them incloses the W. India Monthly Packet, which Mr. Bingham wrote me word he sent open that I might have a sight of it. They came by Capt. Seager.-Our Assembly added this Session 5 Pounds in each County to my Salary, but added to the Work likewise, which I am well content with; They give me now 260 Pounds our Currency a Year; And we are very busy in dispatching the Public Work. I wish I could get another Hand.-The Assembly has hinder'd me from Time to go to the Courts to collect my money, otherwise should have got you a Bill by this Time; But as soon as the Public Work is done, or sooner, will get you a good Bill. I wish I could get another parcel of Paper from

standing in the city. It was used as the printing office of the Maryland Gazetie, at its first establishment." (Ridgely, Annats of Annapolis. I84I, p. I20). The printing house was probably in a detached building. The following excerpt from Riley's Ancient City, p. I I9, seems to give support to this supposition. Riley has been discussing the smallpox ravages in Annapolis in 1756 and 1757 . "The family of Jonas Green," he writes, "was afflicted to such an extent that many of his customers were afraid to take the Gazette, lest they would catch the disease. Mr. Green, whilst he expressed a doubt as to paper carrying the disease, subsequently stated that people "need not fear to catch the small-pox from the paper, as it was kept all the time a good distance from the house, and beside the disease was now eradicated from his premises." The old house is now, 1920, occupied by Mrs. Nicholas Harwood Green.

${ }^{1}$ During the Revolutionary War, from December 25, 1777, to April 30, 1779, the Maryland Gazette suspended publication. After its resumption it continued without interruption until its final cessation sixty years later in
1839.

${ }^{2}$ Franklin Papers, I. 6, American Philosophical Society, Philadelphia. As far as is known, this letter has not been published previously in any collection. Permission to use it here courteously has been given by the authoritics of the American Philosophical Society. 


\section{Fonas Green, his Family and his Associates}

Philadelphia; a very favorable opportunity now offers; Mr. Daniel Rawlings is gone up the Bay in a Schooner, and brings down Goods from Philadelphia, and would bring some Paper or me. He went up yesterday. If you could send me such a parcel as before I'll get you a arge Bill of 40 or $45 £$ Sterling and send ... (one word missing) I likewise want some varnish, (a bottle by the post) and 4 or 5 Pound of Lampblack by Rawlings.-My Paper sinks fast; we now use 3 or 4 Reams a week. I have about 450 or 460 good Customers for Seal'd Papers, and about 80 unseal'd. The Virginian's speech made a deal of Laughter here; and was well approved of by some in that Colony; how the Baronet himself lik'd it, I have not heard.-We have had a Severe Hot Spell of Weather; and I have been a little troubled with Fevers; but they are, I hope, gone from me.-We are all well. I hope you are so too,Our hearty Respects to yourself and Mrs. Franklin, not forgetting Miss Sally.-I rejoice to see that our brave Countrymen are to be rewarded for their Expense in taking Cape Breton. I am, Dear Sir,

Annapolis, July 25, 1747 .

Your obliged Friend and humble Serv.

Jonas Green.

One has in this letter a glimpse of the Maryland journalist picking up some items of West Indian news for his Gazette; ${ }^{1}$ one learns of his relations with the Assembly, of his weekly circulation figures, of his need for another journeyman, for paper and more paper, and for the lampblack which he intended to mix with linseed oil for the manufacture of his printing ink. The letter presents a picture of conditions so typical that it might have been written by any colonial American printer.

Green's conduct of his journal was especially memorable during the troubled days when the Stamp Act was requiring the payment of a prohibitive tax on newspapers and pamphlets. Clearly he considered that then or never was the time for an exhibition of cheerfulness, and cheerful he succeeded in being, though with a rueful face. When the ill-judged legislation went in to effect, Green brought out his current number headed, "Maryland Gazette Expiring: In uncertain Hopes of a Resurrection to Life again." On successive days of issue for three weeks, he published a sheet which he called, in order of appearance, the first, second and third "Supplement" to the last regular issue of October Ioth. Then after a silence of a month or more, there appeared "The Apparition of the Maryland Gazette, which is not Dead but Sleepeth." On January 3oth another number was issued, bear-

${ }^{1}$ The colonial newspapers were in general dependant on "exchanges" for their news of the outside world. Green was constantly complaining in his columns of the tardiness of other publishers in sending him their papers, and his subscribers sometimes complained of the staleness of the news received by this method. In winter months with roads and navigation closed, the size of the Maryland Gazette frequently was reduced to a single leaf. On January 14, 1768, Mrs. Green wrote in a note to the public in this journal: "As the Northern Post is not yet arrived, and the Southern One brought no Mail; and our Rivers, at the same time being frozen up, by which we are prevented receiving any Articles of Intelligence from the different parts of the Province, we hope we shall stand excus'd for this Single Half Sheet." 


\section{A History of Printing in Colonial SCaryland}

ing the title, "The Maryland Gazette, Reviving," and finally on February 20th appeared, "The Maryland Gazette, Revived." On March 6th came "The Maryland Gazette" without further witty or indiscreet modification, and from that time until its ultimate extinction more than eighty years later, there was only one serious interruption to the issues of this celebrated newspaper. ${ }^{1}$ Thomas says of Green's journal: "The typographical features of this Gazette were equal to those of any paper then printed on the continent."2

\section{Green's Last Years and his Death in 1767}

'Throughout the period of his service in Maryland, Green continued to print the session laws of the Province and the Votes and Proceedings of the Lower House of Assembly ${ }^{3}$ together with such other governmental and political papers as circumstances rendered necessary. His great work, however, was the printing of that volume frequently referred to in this study, the edition of the laws compiled by Thomas Bacon. He began the composition of this book in 1762 , and worked at it steadily until its completion late in the year 1765 . In another chapter the printing of this work will be discussed at length, but there may be quoted at this time the dictum of a bibliographer who has been referred to several times earlier in this narrative: "This sumptuous volume," says Charles Evans, "is a monument to the reverend author, and to its printer, as one of the noblest monuments of printing produced in the American colonies." 4

On April 16, 1767, the following notice appeared in the Maryland Gazette:

On Saturday Evening last died, at his late Dwelling-House, Mr. Jonas Green, for twenty-eight years Printer to this Province, and Twenty-one years Printer and Publisher of the Maryland Gazette: He was one of the Aldermen of this City. It would be the highest Indiscretion in us, to attempt giving the character he justly deserved, only we have Reason to regret the Loss of him, in the various Stations of Husband, Parent, Master and Companion.

In the space beneath this modest notice of the passing of a good man and an honest and accomplished craftsman, Anne Catharine Green begged for the continued patronage by the people of Maryland of her press and newspaper. That this patronage was received the further history of this, the most famous of Maryland presses gives assurance.

\footnotetext{
${ }^{1}$ Brigham, C. S., Billiography of American Newspapers, 169o-1820. (Part III). In Proceedings of the American Antiquarian Society, April IgI 5.

${ }^{2}$ Thomas, Isaiah, under Newspapers, Maryland.

${ }^{3}$ Until the session of May 1747 , the printing of the Votes and Proceedings had been provided for by ordinance or resolution of each session. It became statutory at the session named.

4 Evans, Charles. American Bibliography, No. 10049 .
} 


\section{Fonas Green, his Family and his Associates}

\section{Green \& Rind, Publishers, I758-I 766}

It is proper that while speaking of Jonas Green notice should be taken of a printer, who was, as far as can be ascertained, the first native-born Marylander to practice the typographical art in the Province. Unfortunately little is known of the activities in Maryland of this William Rind, ${ }^{1}$ who for nearly eight years appears in the imprint of the Maryland Gazette as the partner of Jonas Green. Apprenticed at the usual age to Green, he had remained in his master's shop after the expiration of his articles, and eventually in October I $75^{8}$, he had become Green's partner in the publication of the Maryland Gazette. ${ }^{2}$ During these years he conducted a book store of no small pretension in the house on West Street, where, his advertisement informs us, "the late Mrs. M'Leod formerly kept Tavern." A long and interesting list of books imported by him appeared in the Maryland Gazette for August 26, 1762. In this house he established his circulating library, where the people of Annapolis, for one guinea a year might borrow under easy rules new and standard works of English writers. He had originally proposed a plan for "circulating a Library through the Province," but the uncertainty of the local system of transportation had discouraged him and his subscribers to such an extent that on January ${ }_{13}, 1763$, he advertised in the Gazette his restriction of the privilege to the people of Annapolis. His relations with his partner and former master seem to have been particularly close; his name appears more than once in the St. Anne's register as sponsor in baptism for the children of Jonas and Anne Catharine Green, and when their partnership was dissolved in 1766 , the several advertisements regarding the dissolution which appeared in the Maryland Gazette contained an interchange of the most amiable felicitations between the two associates.

It was in the year 1758 that the firm of "Green and Rind" was formed for the purpose of carrying on the newspaper. The junior partner, it seems, did not enter into the ordinary business of the establishment; his name appeared on none of its imprints except that of the Maryland Gazette. The relationship continued until the year 1766 , when at the solicitation of Thomas Jefferson and others in Virginia, Rind removed to the southern colony. "Until the beginning of our revolutionary disputes," wrote Thomas Jeffer-

\footnotetext{
1 The son of Alexander Rind and of Anne his second wife, he was born the 24th of December I733 and baptized soon afterwards in St. Anne's Church, Annapolis. His father was a member of St. Anne's Parish and was married by its rector for the first time to Abigail Green, alias Harvey, on the 24th of August 1725 . The maiden name of Anne his second wife does not appear in the "Register" of St. Anne's Parish from which these facts were abstracted.
}

${ }^{2}$ Advertisement in Maryland Gazette.

[85] 
A

SINGLE and DISTINCT

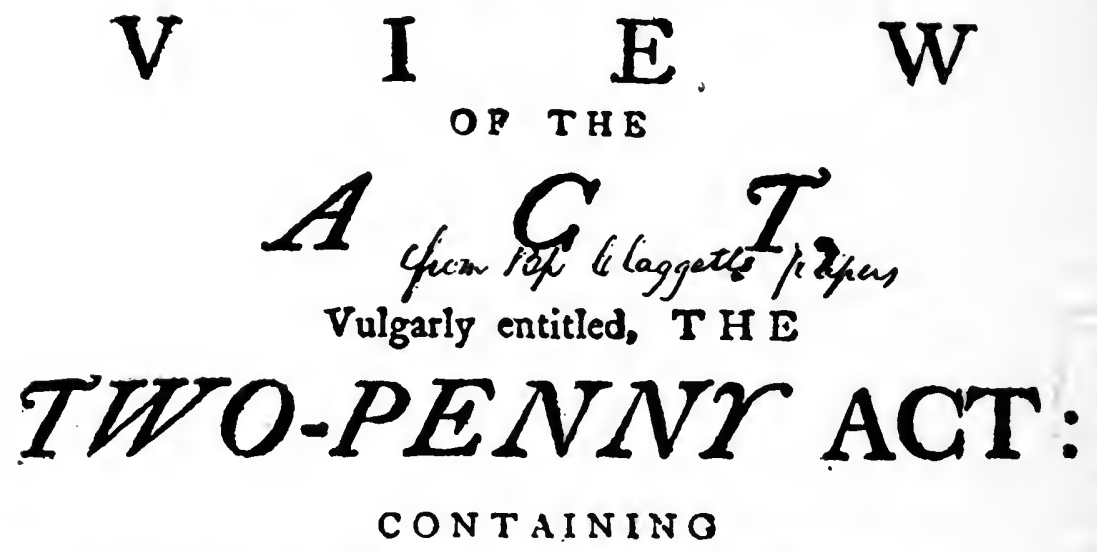

An Account of it's beneficial and. wholefome Effects in YORK-HAMPTON PARISH.

In which is exhibited

A SPECI M EN of Col. Landon Carter's Justicr and Charity; as well as of Col. Richard Bland's Salus Popuzs.

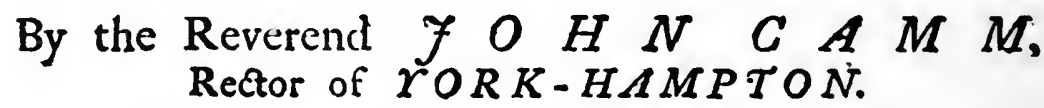

.Though I have the Gift of Prophecy, and underftand all Myftcries, "and all Knowledge, and have not Charity, I am Nothing.

Ne quid fals dicers audeat; ne quid veri non audean Bensd's Motta

Could notbing but thy chief Reproach ferve for a Motta Swirt.

Annapolis: Printed by Jonas 5reen, for the Authos, 1763 . 
son to Isaiah Thomas forty-three years later, "we had but one press, and that having the whole business of the government, and no competitor for public favor, nothing disagreeable to the governor could be got into it. We procured Rind to come from Maryland to publish a free paper."' That Jefferson had not forgotten the situation which existed in $\mathrm{I} 766$ when he wrote these words in 1809, one learns by reference to the Maryland Gazette at this period, wherein is to be found a bitter controversy, long extended, between Royle the Williamsburg printer and certain Virginians who were indignant with him for refusing to publish their attacks on the local government. In this connection, one may refer also to the Rev. John Camm's pamphlet on the Two-penny Act, ${ }^{2}$ printed by Green in 1763 , the appendix of which consists of an interchange of correspondence between Camm and Royle, the latter giving as his reason for refusing to print the pamphlet the fact that the gentlemen attacked in it were members of an Assembly which had not been dissolved at the time that the "copy was submitted."

In Virginia, Rind was soon appointed public printer. He established a newspaper called, as was the rival paper published also in Williamsburg, The Virginia Gazette. This journal was published regularly by Rind until his death on August 19, I 773, after which it was continued for a short time by Clementina Rind who died within two years of her husband. Thomas says that Clementina Rind was born in Maryland. If this be true, she is another woman with Maryland associations to be added to the list of those who have been referred to in this narrative as proprietors of printing establishments. One is inclined to wonder sometimes if women have been as rigorously excluded from opportunity in the past as theapostles of feminism would have us believe.

\section{Thomas Sparrow, the First Maryland Engraver}

It is to be wished that more could be learned of the life and training of one of the most interesting of the individuals connected with the Green establishment; ${ }^{3}$ namely, that Thomas Sparrow who is remembered as the first Maryland engraver. Very little, however, is known of his life, and because of its general artistic inferiority no careful study has been made of his work. From the antiquarian standpoint, however, both Sparrow and his work have their interest.

${ }^{1}$ Thomas, $2 \mathrm{~d}$ ed., $1: 336$.

${ }^{2}$ See bibliographical appendix. Copies in Maryland Diocesan Library and New York Historical Society.

${ }^{3}$ Of still another of Green's employees, William Poultney, who several times in May 1762 advertised in the Maryland Gazette that he bound books very neatly, only the name is known. His bindery was "at the Printing office." 


\section{$A$ History of Printing in Colonial SCaryland}

It is probable that of the several Thomas Sparrows who figure in Maryland records, that one with whom this narrative is concerned was born about the year $1746,{ }^{1}$ the son of Thomas Sparrow, Gent., of Annapolis, the codicil of whose will, ${ }^{2}$ probated in 1753, appointed Walter and Daniel Dulany, Jr., and Jonas Green as his executors, and more specifically named Daniel Dulany as the sole guardian of his son. The Dulanys declined to act as executors, a refusal which probably, on the part of Daniel, included also the declination of the post of guardian to the young Thomas. Green seems to have acted alone as executor of the will, ${ }^{3}$ and from the fact that the bonàs between Sparrow and the Greens remained close ever afterwards, one concludes that he assumed as well the guardianship of the orphan. One loses sight of the boy, however, during his adolescence, so that it may not be said with certainty where or how he was engaged, but he reappears on December 13, 1764, when in a land sale advertisement in the Maryland Gazette for that day, he informs those whom the fact concerns that he is to be found "at Mr. Green's in Annapolis." It was about this time, too, that he began the work in engraving, always in conjunction with the Green press, which is associated with his name.

There is reason to believe that Sparrow had spent the intervening years learning the art of gold and silver-smithing in the city of Philadelphia, for on March 2I, I765, an advertisement in the Maryland Gazette asserted that "Thomas Sparrow Goldsmith and Jeweller From Philadelphia Has Just open'd Shop near St. Ann's Church in South-East Street Annapolis Maryland," and that in this shop were to be made "all Sorts of Gold and Silver Work," a claim which was fully justified by the long list of specific articles which followed. The advertisement was headed by a woodcut of a coffee urn, which as the familiar signature attests, had been engraved by the smith himself, "T. Sparrow." Curiously enough, only one example of Sparrow's craftsmanship in the precious metals remains, although he continued to practise his trade certainly as late as August of the year $1767 .{ }^{4} \mathrm{He}$ is remembered chiefly because of a few specimens which have been preserved of his goldsmith's subsidiary art of engraving.

\footnotetext{
'In Chancery Record, $1774-1784$, v. 13 , folio 480 , Thomas Sparrow in February 1782 deposes that he is 36 years old or thereabouts. Ms. in Land Office, Annapolis.

${ }^{2}$ Maryland Wills, v. 28, Liber D. D. 7, p. 435, 175 I-54. Ms. in Land Office, Annapolis.

${ }^{3}$ On March 8, 1753, Jonas Green advertised in the Maryland Gazette that all claims against the estate of Thomas Sparrow, late of Annapolis, should be brought to him for settlement. No other executors were mentioned.

'The author's attention was called to Sparrow's establishment in Annapolis as a gold and silversmith by Mr. Howard Sill of Baltimore, the result of whose studies of the lives and work of the Maryland silversmiths is to be published in a notably beautiful and interesting book. Mr. Sill has in his collection of book-plates the Richard Sprigg and Gabriel Duvall plates, those very rare examples of Sparrow's work in this department of the engraver's art. Sparrow's last advertisement as a goldsmith appears in the Maryland Gazette for August 13,1767 .
} 


\section{Fonas Green, his Family and his Associates}

In the year 1774 Sparrow's name was signed to a petition of certain citizens of Annapolis protesting against that clause in the "non-importation agreement" which sought to prevent citizens of Great Britain from collecting debts in Maryland until the Boston "Port Act" should have been repealed in Parliament. ${ }^{1}$ The last glimpse that one has of him is in November I776, when he was on the Eastern Shore of Maryland acting as a confidential agent of the Committee of Safety. ${ }^{2}$

The following extracts from Charles Dexter Allen's American Book-Plates summarize Sparrow's position and activity in the world of art:

"T. Sparrow was an obscure engraver on wood, who worked at his trade in Annapolis from 1765 to about 1780 , and who did considerable work for "Anne Catherine Green \& Son, Printers," of that town, on title-pages, tail-pieces, etc. He engraved on copper the titlepage for the "Deputy Commissary's Guide of Maryland," published by the above firm in I774, and which is a creditable piece of work. All the book-plates known at present are on wood, and they are but two in number: the Richard Sprigg and the Gabriel Duvall, both of whom were men of prominence in the colonial times, in Maryland."

Elsewhere in the same work, Allen says in describing Sparrow's bookplates,

"Always using a border of floriated scrolls he never omitted an original contrivance which is the characteristic mark of his work-a group of thirteen stars surrounded often by a wreath. This is always found in a prominent place, and is an indication of his patriotism as well as that of the owner."

Sparrow's work was generally crude. The single exception to this description of it is that example on copper which served as title-page to Elie Vallette's Deputy Commissary's Guide, published by Anne Catharine Green $\&$ Son in 1774 . Poorly conceived, but delicately executed in the thin and flowing lines of the chaser of metals, this work has interest for us as the single engraved title-page to issue from a Maryland colonial press, but from an artistic standpoint it indicates only that with proper training its maker might have become an acceptable engraver on metal. The paper money which he engraved on wood for Anne Catharine Green from I 770 to I 774 is heavy and crowded in design, and the armorial seal of the Province on the title-page of Bacon's Laws of Maryland is incorrect from a heraldic standpoint and coarsely executed withal. Obviously wood was not Sparrow's medium, and when one learns that whether on wood or metal, engraving was a secondary pursuit with him, one is quick to condone the inexpertness of his burin.

${ }^{1}$ Riley, E., Ancient City, p. 167.

${ }^{2}$ Ms. letter of Maryland Committee of Safety to Thomas Sparrow, November 28, 1776. In Red Book, 16: 33, in Maryland Historical Society.

[89] 


\section{A History of Printing in Colonial SCaryland}

\section{Anne Catharine Green and her Sons, William, Frederick and SAMUEL}

Throughout the life of her husband, Mrs. Anne Catharine Green, the widow of Jonas, was heard of only incidentally, but after his death in 1767 , she showed the sturdy stuff that was in her by assuming the direction of the Green establishment and the responsibility for its completion of the government work then in hand. At this time she must have been about forty-five years of age; she had borne fourteen children and buried eight of them; she had nursed her household through a smallpox epidemic and through the infinitude of small ailments which must have beset so large a family. At a time when a less aggressive woman would have been content to seek the chimney corner, she undertook the support of her children and the accomplishment of important tasks in the public service.

After announcing the death of her husband, Mrs. Green's first concern was to solicit the continued patronage of his friends and customers for the press which she proposed to continue. "I Presume to address You," she wrote in an appeal to the public, ${ }^{1}$

"for your Countenance to Myself and numerous Family, left, without your Favour, almost destitute of Support, by the Decease of my Husband, who long, and, I have the Satisfaction to say, faithfully served You in the Business of Provincial Printer; and, I flatter myseli, that, with your kind Indulgence and Encouragement, Myself, and Son, will be enabled to continue it on the same Footing. . . . I am willing to hope, that the Pains taken by $\mathrm{my}$ late Husband, to oblige his very extensive Acquaintance, and the Character he deservedly bore, of an honest, benevolent Man, will recommend to your Regard,

Your grateful and faithful

humble Servant,

A. C. GREen.

The event will show that the confidence which she begged and received from the public was not misplaced. Under her management neither the Maryland Gazette nor the public printing suffered retrenchment or deterioration.

Assisted by her son, Mrs. Green completed the "Acts" and the "Votes" of the session of 1767 , which had been left unfinished by the death of her husband, maintaining throughout the ensuing year a sufficient number of hands to enable her to care for whatever public business came to her for executicin. In its act for her encouragement, the Assembly of 1768 recited these facts and declared that in all things she had performed the duty of Printer to the Province, ${ }^{2}$ and provided that for these services of the year

${ }^{1}$ Maryland Gazette, April 16, 1767 . The son referred to in this extract was William Green.

${ }^{2}$ If a statement in the Maryland Gazette for September 22, 1768, could be taken at full value it would seem 


\section{Fonas Green, his Family and his Associates}

1767 , she be allowed the sum of "Nine hundred and forty-eight dollars and one half a dollar," and further that for her future services as public printer she receive forty-eight thousand pounds of tobacco annually for those years in which there was a session of the Assembly, and thirty-six thousand one hundred and nine pounds of the current medium for the years in which no session was held, the same terms of payment as had been accorded to Jonas Green in the year 1765 .

Throughout her eight years of service to the Province as public printer, Mrs. Green's allowance remained unchanged. She attempted no enlargement of interest; her output consisted mainly of the government business and the Maryland Gazette, although in addition to work of this character she published an annual almanac, an occasional political pamphlet and one or two satirical pieces. Of literature and religion she published almost nothing except the frequent essays on thesesubjects which appeared in hernewspaper. The most ambitious work of her press, besides the government and newspaper publications, was the neatly printed octavo in which was comprised Elie Vallette's Deputy Commissary's Guide, a choice volume where appeared the engraved title-page by Thomas Sparrow of Annapolis, which has been referred to here as the best known example of that engraver's work. In speaking of individual examples of her press, there should not be overlooked her issue of The Charter and Bye-Laws of the City of Annapolis, a beautifully printed little volume of fifty-two pages, which for typographical nicety could hardly have been surpassed by the best of her contemporaries in the colonies.

During the years of her conduct of the press, after 1768, Mrs. Green worked in partnership with different ones of her sons. Various imprints,

that the recognition of Mrs. Green's merits was not the only motive which actuated the Assembly in appointing her to the office left vacant by her husband's death. Throughout the spring and summer of 1768 the columns of her journal had been given over week after week to the controversy between "C. D." (Walter Dulany) and "The Bystander" (the learned and unscrupulous Bennet Allen, rector of St. Anne's Parish, pluralist, rake and duellist). Finally, Mrs. Green and her son William refused to publish other letters of "The Bystander" unless he should indemnify them against suit and declare his identity. Allen declared that the Greens, as Jonas Green had been, were under the thumb of the Dulany family and complained strenuously of his exclusion from their newspaper while his enemies were permitted still to use its columns. Mrs. Green's son-in-law, John Clapham, came to the support of his wife's family in a long letter in the Gazette of September 22, 1768, in the course of which he wrote: "Mr. Allen's Treatment to Mrs. Green, left a widow, with large Family, he never can justify. On the 27 th of May, he called at the Printing-Office, and endeavoured to intimidate her, by threatening to knock up her press, if ever she published any more pieces against him: Accordingly, next Morning, a Manuscript .... was privately stuck up at the Door of the Stadt-House, the General Assembly then sitting, and the Office of Provincial Printer vacant, by which (tho' not intended) he did her real Service; for she was so happy, soon after, as to be unanimously chosen. It is generally supposed, had he acted a contrary Part, and given her a Recommendation to the Public, she wou'd not, for that very Reason, have received so general a Mark of Friendship and Approbation."

In the bibliographical appendix, under the year 1768 , are entered certain broadsides which relate to this quarrel between the Greens and Parson Allen. 


\section{T H E \\ B Y E - L A W S \\ O F T H E C I T Y O F \\ A N N A P O L I S \\ I $\mathrm{N}$ \\ M A R Y L A N D \\ TO WHICH IS PREFIXED THE \\ CHARTER of the faid CITY \\ Granted by her late MAJESTy \\ QUEEN A N N E \\ In the Year of our L ORD 1708}

A L S $O$

THREE ACTS OF ASSEMBLY

Paffed in 17081718 and 1725

Publifhed by Order of the Corporation

$\begin{array}{lllllllll}\text { A } & N & N & A & P & O & L & I & S\end{array}$

Printed by Anne Catharine Green.

Plate VIII. See page xiii. 


\section{Fonas Green, his Family and his Associates}

particularly those of the Maryland Gazette, supply the following list of names under which the business of the house was conducted:1

April 16, I767, to January 7, I768, Anne Catherine Green.

(In the colophon of the Maryland Gazette for January 28, 1768, and always thereafter, the name appeared "Anne Catharine Green.")

January 7, 1768, to August 23, 1770, Anne Catharine Green and William Green. (William Green died in August 1770.)

August 23, I770, to January 2, I772, Anne Catharine Green.

January 2, 1772, to March 30, 1775, Anne Catharine Green \& Son. (This was Frederick Green.)

March 30, 1775, to December 25, I777, Frederick Green. (Mrs. Green died March 23, I775.)

The Maryland Gazette suspended publication from December 25, I777, to April 30, 1779, but resumed on thelatter date and continued underFrederick \& Samuel Green to January 6, I8II. In this year the two brothers died and Jonas Green, the son of Samuel, assumed the publication and carried it on until its final issue in the year 1839 .

It is noteworthy that, whether from filial affection or from filial subjection it is not entirely clear, the several sons of the house always occupied second place in the firm name, and further that it was Anne Catharine Green and not "Anne Catharine Green and Son" who received the appointment of printer to the Province. The brief notice of Mrs. Green's death in the Maryland Gazette of March 30, I775, concluded with the assurance that "she was of a mild and benevolent Disposition, and for conjugal Affection, and parental Tenderness, an Example to her Sex," an encomium from which one may conclude that it was by the grace of her affectionate disposition that she maintained her ascendancy in the establishment. That she was able to do this speaks well for the character of those sons, two of whom were left to carry on the traditions of a family the history of which in its many branches is the history of the first two hundred years of American printing.

\section{The Last of the Greens in Maryland Printing History}

The activities of the sons, Frederick and Samuel, and of the grandson Jonas, of Jonas and Anne Catharine Green, are so largely concerned with periods into which this narrative does not enter that no attempt will be

${ }^{1}$ Brigham, C. S., Billiography of American Newspapers, 1690-1820. (Part III). In Proceedings of the American Antiquarian Society, April 1915. 


\section{A History of Printing in Colonial Saryland}

made here to chronicle them. When the last Jonas Green died in Annapolis in 1839, his family had been engaged in printing and publishing in that city for one hundred years and some odd months. He was the great-greatgreat grandson of that Samuel Green who had begun printing in Cambridge, Massachusetts, in the year 1649. With this brief remark must be concluded the account of certain members of that family of good citizens and hereditary practitioners of the typographical art, the Greens of New England and Maryland. 


\section{A History of Printing in Colonial SCaryland}

scribed as "a laborious and judicious Performance." ${ }_{1}$ It is probable that at this time he was in the civil service of Great Britain, and that he remained in that service until the year I744, when on September $23 \mathrm{~d}$ he was ordained deacon by the Rt. Rev. Thomas Wilson, Lord Bishop of Sodor and Man, who a few months later, on March IO, I $744 / 45$, ordained him to the priesthood for the specific purpose of service in the Plantations. ${ }^{2} \mathrm{He}$ arrived in Maryland between July and November 1745, settled at Oxford in Talbot County, and within a few months had become rector of St. Peter's Parish of that county. During the thirteen years of his rectorship he exercised his pastoral functions with notable success; he established a Charity Working School for poor children of all races, and preached ceaselessly to his parishioners their duty in the spiritual care of their negro slaves. Throughout his life in Maryland he was notable for his charitable enterprises; his kindness to the Acadians, when a shipload of these distressed neutrals was landed at Oxford, was of such a nature as to have been remembered until the present day. An accomplished musician, a hearty, sociable being of excellent parts, he was, as one of his parishioners wrote, "a very considerable man here $\&$ in great Esteem with every great Man from the Governor to the Parish Clerk;" and the same admirer wrote a few months later, "I think him the worthiest clergyman I ever knew, not Excepting the Bishop."3 His good deeds, his learning and his personal charm have caused Thomas Bacon to be remembered when men of greater piety and of more rigidly correct life have been forgotten. ${ }^{4}$

Evidently there was in his composition a strain of impetuosity which did him great disservice. On two occasions he was fined large sums of tobacco for his disregard of the law respecting the publication of the banns of matrimony. The first of these was when he united in marriage Miss Elizabeth Bozman to a reprobate brother clergyman, and the second was the occasion of his own marriage to this lady in the year 1757. Even before this, in the year 1755 , he had been indicted and compelled to stand trial on a charge

pose the Revenue of Ireland, etc. IV. The Method of Making Entries, etc. (An appendix containing forms of informations ... on the act of excise.) 5 pts. Dublin, 1737-36. 80. (In British Museum. Press Mark 517. e. 6).

${ }^{1}$ Bacon's obituary in Maryland Gazetie for June 9, 1768 . Given in full later in this chapter.

${ }^{2}$ See Appendix B of Bishop Wilson's Sacra Privata, ed. Oxford and London, 1853.

${ }^{3}$ Callister Letters. Ms. in Maryland Diocesan Library. In the second quotation, Callister, a Manxman, refers to Bishop Wilson, almost a divinity among his islanders. For a Manxman to compare any man favorably with Bishop Wilson was praise indeed.

'Even the rapacious parson, Bennett Allen, who having been promised the succession to Bacon's parish of All Saints, Frederick County, could not conceal the impatience with which he awaited his colleague's death, wrote to him in 1768 : "I have always loved your character for that Milkiness of Blood, (as Dryden expresses it) and Goodness of Heart, for which you are remarkable; and respected you as a Man of Letters, a Friend of the Lord Proprietary; and a Benefactor to the Public: . .." (Maryland Gazette, September 29, 1768). 


\section{Bacon's Laws the Typographical HConument of Colonial Baryland}

brought by a disreputable woman of his neighborhood. He was acquitted of this charge, and having been fined one hundred pounds sterling for her "false clamor," his accuser was committed to jail in default of payment. Between these two occurrences, he became seriously affected in his health, and his physical condition was not improved by the distress which ensued upon the loss at sea of his only son, his "dear Jacky." One is not astonished to find him in some respects a broken-spirited man in the later years of his residence in Talbot County.

Bacon's loyalty to the Proprietary interest shows him to have been a man of conservative tendencies. One must believe that his conscience was behind that loyalty, for he does not seem to have been the sort to have rendered service from unworthy motives. In the year 1754, the Proprietary recognized his devotion by appointing him one of his domestic chaplains in Maryland with the privilege of wearing his "scarf," the insignia pertaining to the holder of that office in a nobleman's household. When the rectorship of All Saints Parish in Frederick County fell vacant, Bacon in I759 was appointed to fill the vacancy as "reader," and finally was inducted as rector early in I 762 . In the year I 770 this parish was said to be worth one thousand pounds currency a year, but it is probable that during the greater part of Bacon's rectorship its value had been much less. In 1753 Sharpe had appraised its income at only three hundred and ninety-four pounds currency.

In the Maryland Gazette for June 9, I768, there appeared the following notice, with the quotation of which this short account of Thomas Bacon approaches its close:

On Tuesday, the 24th Ult. died at Frederick-Town, in Frederick County, the Rev'd Thomas Bacon, Rector of All Saints Parish, in that County, Author of a laborious and judicious Performance entitled, A Complete System of the revenue of Ireland, published in 1737, by Order of the Chief Commissioners and Governors of the Revenue, in that Kingdom. He also published several other valuable Pieces; and in the Decline of Life, by several years intense Labour, compiled a compleat Body of the Laws of this Province, as lately published. - His humane, benevolent Disposition and amiable Deportment, gained him the Love and Esteem of all his Parishioners. He was likewise an affectionate Husband, a tender Parent, a kind Master, and a most agreeable Companion; which renders his Death not only a Loss to his Acquaintances but to Society in general.

In spite of the emoluments which must have been his as the rector of All Saints, Bacon left an embarrassed estate. In advertisements published in several issues of the Maryland Gazette, beginning with that of July I4, 1768 , his widow and administratrix asked the "indulgence of the several creditors" until she could ascertain the whole amount of her late husband's 


\section{$A$ History of Printing in Colonial SCaryland}

indebtedness. It is probable that the expense of an assistant in his parochial work, of the maintenance of a family consisting of a wife and three daughters, and the inevitable expenses accruing to editorial and publishing work of the sort that he was engaged in seriously cut in upon the salary which he received as rector of the richest parish in Maryland.

One would prefer to bring this account of Thomas Bacon to a close in a happier strain, but from such knowledge as is at hand, the conclusion is inevitable that in spite of so much unselfish devotion to others, so many efforts in behalf of the poor and despised, so great labors on a work of public usefulness, this lovable and industrious man died poor and unregarded after years of bodily suffering and mental disquietude. Today those who would do honor to his memory have not even the satisfaction of reading his epitaph. It is supposed that he was buried inside his parish church of All Saints, but when that church was torn down in 1813 , all record of the bodies beneath its floor was lost. ${ }^{1}$

\section{The Beginning of the "Laws"}

In November 1753, Thomas Bacon, then resident in his first parish, on the Eastern Shore, petitioned ${ }^{2}$ the Justices of Talbot County for permission to make use of the printed copies of the laws in their possession, in the prosecution of a work which he affirmed to have been approved by the Governor, and which he described as intended to take the form of "a complete abridgement of all the Laws in force in this Province, digested alphabetically under proper heads." It is in this petition that there occurs the first intimation that Bacon had in mind either a compilation or an abridgement of the statutes. ${ }^{3}$

The early years of his labors on the "Abridgement" passed without incijent. Nothing more was heard of the progress of his work until March 1757, when, being then at the height of his troubles in court, suffering in spirit from these and from the loss of his son, and suffering in body from

\footnotetext{
${ }^{1}$ Admirable accounts of the life of Thomas Bacon are to be found in Harrison, S. A., History of Talbot County, Maryland, $1661-1861$, ed. by Oswald Tilghman, 2 v. Baltimore, 1915; and in the article by the Rev. Ethan Allen, D.D., in Sprague, Wm. B., Annals of the American Pulpit, 5: 117 -121. A discussion of his charitable projects was contributed to the Independent for August 14, 1899, by Bernard C. Steiner under the title, "A Pioneer in Negro Education;" and in "A Maryland Merchant and His Friends," in the Maryland Historical Magazine, v. 6, the present writer gave some facts bearing on his life and quoted at length from such of his letters as have been preserved in the Maryland Diocesan Library.

${ }^{2}$ Bacon's petition to the Justices of Talbot County is given in full in Tilghman's edition of Dr. Harrison's work, noted above.

${ }^{3} \mathrm{On} \mathrm{May} \mathrm{14,} \mathrm{1752,} \mathrm{Jonas} \mathrm{Green} \mathrm{had} \mathrm{issued} \mathrm{in} \mathrm{the} \mathrm{Maryland} \mathrm{Gazette} \mathrm{proposals} \mathrm{for} \mathrm{the} \mathrm{publication} \mathrm{by} \mathrm{himself} \mathrm{of}$ a body of laws. As nothing was heard of this work afterwards, it may be assumed that Green, willingly enough, had been induced to forego his own plans in view of Bacon's greater fitness for the task.
} 


\section{Bacon's Laws the Typographical SConument of Colonial SHaryland}

malaria and a vexatious internal derangement, he wrote these despondent words to his correspondent in Oxford: "I write to you," he says,

"with the Freedom of a Friend, as I shall always stile you though God knows few are the Friends I have now in the World. If you have any good News by your Ship, on whose Arrival I wish you Joy, please let me have a Sketch of it; if bad, keep it to your self, for I have had no other for some time past, and begin to be heartily tired of it. I would not write to you on such a scrap of Paper, if I had plenty as formerly; but the Man without Money or Credit must do as he can. Musick is departed \& gone into another World from me. The Laws are my only Employment and Amusement, yet they are a dry sort of stuff and sometimes apt to stick in the Throat." (Ms. in Maryland Diocesan Library.)

It seems to be true, as Mr. Augustine Birrell tells us in one of his essays, that commentators "learn in suffering what they observe in the margin."

Bacon completed his abridgement of the laws sometime in the year I $75^{8}$. On June $22 \mathrm{~d}$ of that year he advertised in the Maryland Gazette his proposals for its publication, announcing at the same time that he had petitioned unsuccessfully the Assembly at its last session for encouragement "to publish a Body of Laws . . . together with an Abridgement ... the Charter of the Province, and other useful matters." The work thus described was the great collection of laws which he issued seven years later. He received no authority for its publication from this Assembly, but not discouraged, he announced it as forthcoming and proceeded with its compilation. It is probable that this advertisement of a larger and more desirable work in preparation injured the prospects for the publication of his "Abridgement" by subscription. Nothing was heard of it afterwards as a separate publication, and when his body of laws was published in 1765 , it was made use of as the basis of the index to the greater work. ${ }^{1}$

\section{A Review of the Political Issue Involved}

The publication of the great body of laws now became a political issue in the Provincial Assembly, or rather it became the concrete expression of an old and wearisome issue on which there had been bickering in the two Houses for a generation. At the time of the Revolution of I689, the people had questioned the right of the Proprietary to certain duties granted him by an act of the year I66I, and an act of the first Assembly under the royal government had diverted the proceeds of this "tonnage" duty from his Lordship's purse to the treasury of the Province. Upon the advice of the Solicitor General, however, the Crown in 1692 had disallowed this act and had given direction that the proceeds of the tonnage duty should be paid as usual to the Proprietor for his private use. It was not until the year 1739

${ }^{2}$ Dulany Papers, Box I, No. 6, Bacon to W. D., Maryland Historical Society. 


\section{A History of Printing in Colonial Saryland}

that the question came up again, but from this time it had assumed an ugly form in thehands of a newly-arisen party that seemed determined in every possible way to defame the Proprietary and his government. The following sentences from the work of a Maryland historian summarize the situation as it existed at the time of which we are writing:

The pretence of that party with respect to the tonnage duty was that by a repealing act of the year 1704 the law imposing it had been repealed. It is true that the repealing act of 1704 did declare all laws that had ever been made in the province before that year to be repealed, save those mentioned in an excepting clause; and in that clause was no mention of the tonnage act. But there was also in that repealing act this saving clause, viz, 'Saving always to all and every person and persons whatever was his and their right and benefits which he or they had by the former acts of Assembly.' Therefore, on the same basis as that of the solicitor general's decision in the year 1692 , the proprietor was still entitled to his tonnage duty. Nevertheless, until the overthrow of the Proprietary government the lower house continued to deny his right to it. In $176 \mathrm{I}$, when the Board of 'Trade asked for copies of laws in force, that house would not agree to defray the expense of preparing them unless the editor would leave out, with one other act, the act for tonnage duty. But the fairminded Governor Sharpe and Daniel Dulany, Jr., with his distinguished legal talent, never gave a sign of doubting the Proprietor's right to that duty. ${ }^{1}$

\section{The Legislative Adventures of Bacon's Compilation}

With this outline of the political situation in mind, the failure of Bacon to secure encouragement from the Assembly for his proposed publication of the laws of the Province is easy of comprehension, for it was well understood by the Lower House that his Lordship's domestic chaplain could not be expected to omit from his collection laws which existed for his patron's advantage and emolument. On December I6, I $758,{ }^{2}$ however, the proposals of Bacon having been brought to the attention of the Lower House, a committee appointed for the purpose of considering the plan therein set forth asked him to propose to them the sum for which he would undertake to deliver eighteen printed bodies of laws to the Province, and also to set the price for the sale of copies to the public. Bacon named three hundred pounds currency as the price of the eighteen public copies, and forty shillings in the same medium as "the Price of each Copy to Subscribers (advancing one half as usual in such cases)." The committee reported that the proposed publication "would be of great utility," and recommended that another committee be appointed to consider what laws were in force, "or proper to be inserted or any Way to be taken Notice of in the said Body." It considered that the price named for the public copies was reasonable,

${ }^{1}$ Mereness, N. D., Maryland as a Proprietary Province. 190I. p. 9 I.

${ }^{2}$ V. \& P., December 16 and $20,1758$. 


\section{Bacon's Lares the Typographical MConument of Colonial SCaryland}

but that the price to subscribers should be adjusted when the work had been completed. Furthermore, it was recommended, that in any bill to be brought in for carrying on the design, it should be expressly declared that any laws now in dispute should be considered as in the same state "as if the said Body had not been collected, compiled and published; and that no Law whatever, or any Part thereof, shall be repealed, abrogated, or made null or void, or receive any additional Force or Strength, thereby." 'The Lower House had no desire that Bacon's or any other collection of laws should have the force of a code until the objectionable "Tonnage" act should have been expunged from the books. A week or so later, the House accepted the report of its committee and deferred full consideration of it to the next session of the Assembly. ${ }^{1}$

In the October session of the year 1760 a bill was introduced entitled "An Act for Encouraging a Collection and Publication of the Laws of this Province," by the terms of which a committee was to examine and compare the laws of Mr. Bacon's proposed collection with the originals and report their findings to the next session of Assembly. In case of the approval of that Assembly, Bacon was to have leave to proceed to print and publish the collection. It was provided, as had been suggested by the committee of the year $175^{8}$, that no additional force was to be lent to any disputed law by reason of its inclusion in that volume, and further carrying out the recommendations of that report, it was agreed that in the event of publication Bacon should be allowed three hundred pounds currency for eighteen copies "cast off upon good Paper, in large Folios, and with a fair Type," the public copies to be delivered, one to each house, the Provincial court and each county court. This bill was indorsed by the Lower House "will pass," but it was returned to that body from theUpper House with the uncompromising endorsement, "will not pass." 2 The struggle had begun, and had it not been for the interest of Governor Sharpe in the project, it is likely that the clashing of irreconcilable opinions would have prevented forever the publication of Bacon's collection.

In the session of April $176 \mathrm{I}^{3}$ this bill or another of the same tenor was reintroduced and passed by the Lower House after having been amended to read that "the Act by which the Lord Proprietary takes the I 2d. Sterling per Hogshead on all Tobacoes exported out of this Province, be not inserted in the Collection of Laws to be made by Mr. Thomas Bacon, but

${ }^{1}$ V. \& P., December $23,1758$.

${ }^{2}$ V. \& P., October 15, 1760; Maryland Gazette, October 30, 1760.

${ }^{3}$ V. \& P., April 25, 1761.

[IOI] 


\section{A History of Printing in Colonial SCaryland}

be put in an Appendix thereto" as a law in use but not in force. ${ }^{1}$ After several adventures, it was returned from the Upper to the Lower House on May 6, I76I, with the endorsement "Read the Second Time, and, with the Amendments, will Pass," but it is certain that Sharpe had no intention of signing a bill so at variance with the Proprietary's interests as this one had been shown to be. He permitted it to be endorsed affirmatively in the security of his knowledge that he intended to allow no bills of that session to pass the seal. He prorogued the Assembly almost immediately without affixing his mandate to the several bills which had been passed, and writing to Secretary Calvert several months later, ${ }^{2}$ he asserted that he was urged to this course by the gentlemen of the Council who alleged that the Assembly "had been sitting near a month without doing the Business for which alone they had been convened $\&$ had shown by the Bill they had framed entituled 'An Act for Encouraging a Collection \& publication of the Laws of this Province' ... that those Members of the Lower House who were left (for all the moderate men were gone off) had nothing in view but by offering such Laws as they knew would not pass to lay a foundation for popularity against the ensuing election."

After this occurrence Bacon's proposed book no longer was to serve as the shuttlecock of Provincial politics. ${ }^{3}$ Sharpe's peculiar personal interest in its publication was to give a turn to events which should remove it from the consideration of future Assemblies.

\section{The Publication of Bissett's “Abridgement" in I759}

In the year 1759 , when the contest over Bacon's publication was just beginning, a lawyer of Baltimore, one James Bissett, took advantage of the situation so far as to prepare a hasty abridgement of the Provincial laws, from which, as one of the "Patriot" party, he omitted the acts which were offensive to the opponents of the Proprietary. His Abridgement of the Laws of Maryland was printed in Philadelphia by William Bradford, the nephew of Andrew, and having been sold widely throughout the Province,

\footnotetext{
${ }^{1}$ Alarmed by this attempt of the Lower House to curtail his privileges, the Proprietary instructed Sharpe in October I76I that his subscription to Bacon's publication was to be paid only on the condition that "his Book or Books of our said Laws do strictly contain all acts of Assembly and all matter and things that has been at any time Enacted belonging to and for my Private Emolument and now stands Enacted." Proceeding, he ordered Sharpe as Governor to withhold his consent from any act of Assembly which provided for the publication of the book with these acts omitted or entered only in an appendix. (Calvert Papers, No. 654).

${ }^{2}$ Sharpe Correspondence, Archives of Maryland, I 4: 24.

${ }^{3}$ Schlesinger, A. M., Maryland's Share in the Last Intercolonial War, in Maryland Historical Magazine, vol. 7, and the wcrk of Mereness before cited, treat the larger aspects of the bickering between the Proprietary and the Lower House, of which the fate of Bacon's proposals in the Assembly presents in a concrete issue a plainly defined case. See note to No. 206 of the bibliographical appendix.
} 


\section{Bacon's Laws the Typographical SConument of Colonial SCaryland}

appreciably narrowed the market in which Bacon had expected to find an easy sale for his compilation. Bissett's "Abridgement," as it is known, left the press in the year $1759 .{ }^{1}$ It presents a mean appearance, and is a work which is usually spoken of with contempt as having been hastily compiled and poorly printed. In his Preface, Bacon did not dignify it by a mention in the enumeration of existing collections of Maryland laws.

\section{Sharpe Suggests a Plan for the Publication of "Bacon's Laws"}

Throughout the years that the two Houses of Assembly were disputing the publication of Bacon's collection, other influences had been at work which eventually were to cause that collection to be published when all hope had been given up by its editor of receiving aid and encouragement for it from the Provincial Legislature. It was while Bacon was still hoping for favorable action on the proposals which he had submitted to the Lower House in $175^{8}$ that Caecilius Calvert, secretary to Lord Baltimore, made a suggestion to Governor Sharpe, the relation of which, although it is not entirely germane to the subject of Bacon's book of laws, yet serves to advance somewhat the story of its publication. Calvert and Baltimore seem to have feared that Benjamin Franklin, now become a great leader in the colonies, was contemplating the publication of aspersions on the conduct of Maryland during the last French and Indian War, and in order that there should be at hand the material for a reply to any accusations that he might bring against the Proprietary government, they had suggested to Sharpe that Bacon be employed to write a historical summary of the Province. Their idea in proposing this work was that such a narrative would show the diffculties which the Lords Proprietary had contended with for many years in the task of keeping their refractory people in line. To this suggestion Sharpe replied with his unfailing good sense, that no scheme could have been so well devised to discredit the Proprietary government as this which had been proposed. After asserting that Bacon, already somewhat unfavorably known to many in the Province, would be under the necessity of leaving his parish in order to be near the records in Annapolis, he continued his protest in these words:

"A Clergyman taken from the Parishioners by whom he is supported \& who by Law are obliged to support him to Vindicate an ill Administration! would be one of the Exclamations I should expect to hear ecchoed thro the Province, $\&$ long would be the Catalogue of Vices whereof His Ldp as well as His Lieutt Governor might expect to be accused."

\footnotetext{
1 On January 4, 1759, Bissett advertised in the Maryland Gazette his thanks for the many subscriptions made to his work and announced its early publication. It was advertised on June 28,1759 , as "just published."

${ }^{2}$ Sharpe Correspondence, May 26, 1760, Archives of Maryland, 9: 417.
} 


\section{A History of Printing in Colonial Maryland}

Sharpe declined even to communicate the proposal to Mr. Bacon, and nearly a year passed before, moved by a demand from the Board of Trade for a printed edition of the Maryland laws, he took up in his correspondence with Secretary Calvert the project of publishing Bacon's compilation, then nearing completion. The plan for financing the volume which he proposed in his letter of January 28, 1761, was that which in the main was eventually followed.' ${ }^{1}$ Sharpe let it be understood that, having paid from his own pocket for a transcript of the laws demanded by the Council Office in 1755 , and having been refused reimbursement by the Assembly, he was very much in favor of encouraging the publication of Mr. Bacon's compilation by general subscription, instead of having another transcript made at his own expense. He did not believe that the Assembly would ever contribute a shilling toward this or any other edition of the laws unless the editor would leave out the "Tunnage Law \& the Act made in $170_{4}$ for the Support of Government," and as the expense would be large, perhaps four hundred pounds sterling, and as it would be a great pity both for Bacon's sake and on account of the Province that the result of so much labor and pains should remain unpublished, he proposed to head a list with a subscription of forty or fifty pounds toward the cost of its publication. Two or three years before this Bacon's published proposals for subscriptions had been coolly received, ${ }^{2}$ but Sharpe believed that once in print the book would have a good sale, and with about three hundred and thirty copies sold the expenses would be covered and the repayment of the subscriptions begun. He asked his Lordship's approval of this suggestion, and begged that in addition to giving his approval he would put his name down as one of the subscribers to the publication.

In reply to Sharpe's definite proposal, Secretary Calvert announced his I ordship's contribution of one hundred pounds to the expenses of the work, as well as his own subscription of a quarter of this sum. ${ }^{3}$ Having secured in all about twenty-one subscribers, or underwriters, from among the principal gentlemen and officials of the Province, Sharpe gave the word for the

\footnotetext{
1 Sharpe Correspondence, January 28, 176r, Archices of Maryland, 9: 489 .

${ }^{2}$ On January 25, 1759, and frequently throughout that winter, Bacon had published in the Maryland Gazetie proposals for the publication of his complete body of laws by subscription at forty shillings a copy. In this advertisement, he estimated the cost of new type and paper to be imported, of printing and binding at $£_{1200}$ currency. Sharpe's assertion as to the coolness with which his proposals were received is at variance with Bacon's statement in the Maryland Gazetse for June 7,1759 , in which he announced that because of the gratifying number of subscriptions received, his book of laws would "infallibly be printed." At this time he still expected to receive a subsidy of $£_{300}$ currency from the Assembly. The failure of that body to make an appropriation evidently made a very decided change in his plans for publishing the book by general subscription and governmental subsidy.

${ }^{3}$ Sharpe Correspondence, June 10, 1761, Archives of Maryland, 9: 519.
} 


\section{Bacon's Laws the Typographical SConument of Colonial Braryland}

publication of the book. ${ }^{1}$ All told, one thousand and fifty pounds currency were subscribed locally. ${ }^{2}$ The one hundred pounds sterling which stood in Lord Baltimore's name were later withdrawn as a subscription and given outright to Bacon in appreciation of the compiler's intention to dedicate the work to his noble patron. ${ }^{3}$ It was perfectly understood that the single condition upon which his Lordship insisted in the publication of the book was the inclusion of the acts which have been mentioned as forming the ground of the Assembly's refusal to support the work. ${ }^{4}$ It was in this fashion that the last Lord Baltimore and his people in Assembly confronted and affronted each other throughout their years of association.

\section{The Plan of the Book and its Completion}

The compilation of Maryland laws which Bacon had made differed from any that had been published before his day in the Province, and in many particulars it formed the most elaborate and laborious piece of editorial work until that time undertaken in America. Painstaking, scholarly fellow, he copied his versions of the laws whenever possible from the originals in the office of the Provincial Secretary, and with the most painful labor he rescued the titles of many laws not otherwiserecorded from the manuscript House journals and from the acts by which these laws had been repealed or continued. The industry and accuracy with which he addressed himself to his task are witnessed by the fact that with possibly one exception there is reported in his book, either at large or by title, every act passed by the Maryland Provincial Assembly during the century and a quarter of its existence. An idea of the magnitude of his task may be obtained from this

1 "The Conditions on which we all subscribed," wrote Sharpe at a later date, "are that the Subscribers shall be repaid out of the Money that the Books when printed may be sold for; It was represented to us that the Sum of about $£_{1000}$ [Sharpe means currency] would be wanted immediately to pay for Paper, Tipes, Printing \& Binding... a number of us agreed to advance the Money wanted on the Conditions above mentioned and thereupon the Paper \&c. was as I am told sent for by Mr. Jaques a merchant of this City whom Mr. Bacon impowered to receive the sums subscribed." (Sharpe Correspondence, February 1 5, 1762). ("Mr. Jaques," here referred to, was Mr. Lancelot Jacques, merchant of Annapolis, and one of the twenty-one underwriters of the book.)

${ }^{2}$ Preface, Bacon's Laros of Maryland, at the conclusion of which occurs the following list of those whose contributions made possible the publication of the book: contributor, the Rt. Hon'ble Frederick Ld Baltimore, $£ 100$ Sterling. Subscribers, His Excellency Horatio Sharpe, Esq. Gov. £10 Currency, and the following gentlemen at $£ 50$ currency each: Charles Carroll, Walter Dulany, Charles Carroll, Barrister, Daniel Wolstenholme, Upton Scott, Lancelot Jacques, Charles Wallace, Thomas Johnson, Samuel Galloway, Benj. Tasker, Sam. Chamberlaine, Edward Lloyd, Benedict Calvert, Daniel Dulany, Stephen Bordley, John Ridout, John Brice, George Steuart and John Ross.

${ }^{3}$ Sharpe Correspondence, April 24, 1762, Archives of Maryland, 14:45.

${ }^{4}$ Sharpe Correspondence, June 10, 1761, Archives of Maryland, 9: 519-520. That his Lordship was well satisfied with the publication as eventually issued appears in a letter from Bacon to Walter Dulany, July 30,1767 , in which the parson tells of the present of a small gold box from Lord Baltimore as a token of his appreciation of the Laws. He copied with great pride the letter which had accompanied the box. It is likely that this token and his Lordship's gratuity of $£$ roo were all that Bacon made by his great labor. (Dulany Papers, Box I, No. 8).

[105] 


\section{A History of Printing in Colonial Maryland}

short outline of the plan which appeared in his proposals to the Assembly of $176 \mathrm{I}$. To the Lower House in that year, he announced,

"That the several Sessions shall be distinguished by their proper Dates, Names of Governors, \&c. The Titles of all the Acts passed in each, inserted in their due Order, with Reference to the Records where they may be found; and an account of the several Continuations, and Time of Expiration or Repeal of such as are expired or abrogated. Each Session shall be divided in to Chapters, and the Chapters in to Sections with Numbers, for the easier Quotation of any Laws in Being.

"That ample marginal Notes shall be printed, with References to any subsequent Law, whereby a Paragraph may in any wise be affected or altered; and a compleat CommonPlace, or short Alphabetical Abridgement of the Laws, shall be added, whereby the Whole, relating to any one Article, may easily be seen, and turned to in the several Acts at large."

It is conceivable that to carry into effect this running commentary on the legislation of one hundred and twenty-six years was no small task. That its undertaker performed it worthily, his monumental work remains to attest.

In the winter of $I_{7} 62$ Bacon's work was so far advanced that he was compelled to go to Annapolis "in order to collate or examine his manuscript Acts of Assembly with the Records." 1 We may think of him as making that weary journey many times during this winter and spring, and we may share his rejoicing that the worst of his task was over, when on July 24,1762 , Reverdy Ghiselin, Gent., Clerk of the Provincial Court, and Thomas Bacon, Clerk, Rector of All Saints Parish in Frederick County, appeared before two of the justices of the Provincial Court and

“. . . produced Six Manuscript Books or Volumes in Folio, marked No. I, No. 2, No. 3, No. 4 , No. 5, and No. 6, containing a Transcript of the Acts of Assembly of this Province, now in Force or Use from the Year 1637 , to the Year $1762, \ldots$ as the same have been collected into one Body by the aforesaid Thomas Bacon; and made Oath on the Holy Evangels of Almighty God, That they had carefully and diligently Examined and Compared .ll the several Acts contained in the said Transcript, ... . with the Original Acts which Passed the Great Seal of this Province, where such Originals were extant, or to be found in the Secretary's Office of this Province; and, where the Originals of any of the said acts cou'd not be found, with the Records of the same, as they stand Recorded in the Secretary's Office aforesaid. And that the said several Acts contained in the said six Volumes or Transcript, and by them so Signed as aforesaid, are true Copies of the Original Acts, or Records respectively, with which the same have been by them Compared and Examined as aforesaid, to the best of their Knowledge, Skill and Belief."2

The above oath, which is to be found in the printed volume itself at the close of the session of March 1762, was signed by Reverdy Ghiselin and Thomas Bacon on the one part, John Brice and GeorgeSteuart on theother.

\footnotetext{
${ }^{1}$ Sharpe Correspondence, February 15, 1762, Archives of. Maryland, 14: 20.

2 Bacon's Laws of Maryland, at conclusion of acts of March 1762.
} 
In the same spirit of thankfulness in which the ancient printers appended "Laus Deo" to their colophons, it is headed by the words "Glory to God" in Greek, a doxology which, without doubt, Bacon uttered with a full heart when he had affixed his name to the attestation.

One likes to think of Parson Bacon with his six big books on a barrow in front of him proceeding from the office of the Provincial Court in the old Treasury Building, down the Duke of Gloucester Street to Jonas Green's residence and shop in Charles Street, and there plumping down his folios with that feeling of relief which comes to all editors when for the time being they have divested themselves of their burdens by laying them on the printer. It is safe to presume, while we are drawing pictures, that this particular printer on this hot day of July would not have permitted the Parson to leave his premises until he had exercised that skill in the concoction of refreshment which had gained him the title of "punchmaker-in-general" of the Annapolis Tuesday Club.

\section{The Printing of the Book}

The progress of Bacon's book through the press of Jonas Green was interrupted several times before its completion in 1765 and its belated publication in 1766. After the book had been in the press some months the Board of Trade renewed its demands for the Maryland laws, and from the reply which Sharpe returned to that body through the Proprietary, one learns that the slow importation of paper was delaying the work. ${ }^{1}$ For this contretemps, Sharpe blamed Mr. Anthony Bacon, the merchant brother of the compiler, through whose house in London the paper had been ordered by Mr. Lancelot Jacques of Annapolis. Nearly a year passed before, in March 1764, he sent to Secretary Calvert the first thirty-four sheets of the book to be drawn from the press. ${ }^{2}$ In the letter which accompanied them he preferred with some diffidence what seems to have been a modestrequest in behalf of the printer, when he wrote the following sentences:

"As Mr. Green the Printer takes great pains to perform his part well \& intimated to me that he wanted a Stamp or plate to sett off \& adorn the Frontispiece or Title Page with His Ldp's or the Province Arms, I could not help telling him that I would desire you to send One well engraved on Block Tin or Letter Metal for that purpose \& as it cannot I think cost much I hope you will put it in my power to gratify him. The Figure should I think be near twice as large as the Coat of Arms in the Frontispiece of the inclosed Book covered with blue paper \& I apprehend the Supporters \& also the Motto ought to be the same as on the Great Seal."

'Sharpe Correspondence, June 4, ${ }^{7} 763$, Archives of Maryland, 14: 97.

${ }^{2}$ Sharpe Correspondence, March 13, I764, Archioes of Maryland, I4: I 5 I.

[107] 


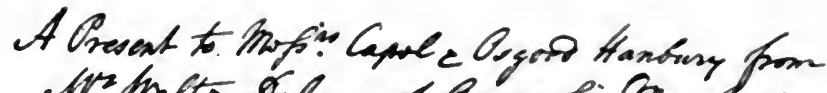

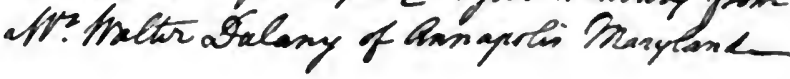 \\ L $\quad$ A $\quad$ W $\quad$ S Wattor $\mathrm{A}$. Dakiny- $M A R \quad r \quad L A A N$ \\ A T L A R G E,

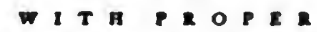

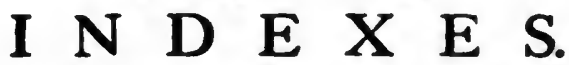

Now fint Colleted into One Coxplzat BODY, and Publimed from she Original ACTS and RECORDS, reminiog in the SECRETARY OPPICE of the fid

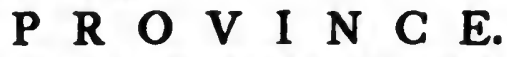

Together with NOTBS and other MATTERS, relative to the con. ifturtion thereof, extracted from the PROVINCIAL ateonges.

To which is prefixed, THE

\section{C $H A R$ T E R,}

With an Engliß TRANSLATION.

B) THOMAS BACON, ReAlor of All-Saines Parilh in Frederick County, and Domeftic Chaphain in Marland to the Righe Honourable FREDERICK Lond BALTImorz.

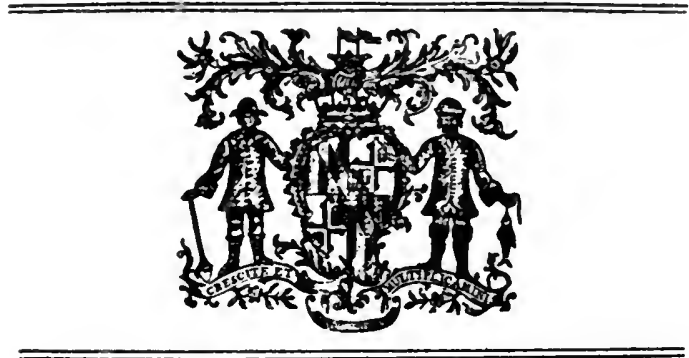

$A N N A P O L I S$ :

Printed yy JONAS GREen, Printra to the Provincz. MDCCLXV.

Plate IX. See page xiv. 


\section{Bacon's Lares the Typographical SConument of Colonial SCaryland}

It will be remembered in this connection, that the seal eventually used on Bacon's title-page was engraved on wood by Thomas Sparrow of Annapolis. On the title-page of the session laws of 1765 , however, Green used the seal of the Province, engraved by another hand. It is possible that here was the plate made in response to Sharpe's request, but the reason that Sparrow's woodcut was substituted for it in Bacon's book is not known.

In the meantime, on two occasions, November I3, 1764, and February 26, 1765 , to be exact, the Governor had transmitted additional sheets of the book as they issued from Green's press, announcing, in sending the second set of gatherings, that the work was now "printed down so low as the year I745." On the tenth of July I 765 , he announced the approaching completion of the task in the following words:

"The Acts are at length all printed \& I now send you copies of the last of them, \& as soon as some Copies of the Index \& Preface can be printed the Books will be bound \& exposed to Sale; as soon as they are I shall transmit you some of them with the Great Seal appendant to be lodged in the Council Office and delivered to the Board of Trade."1

Finally, on July 21 st, 1766 , a year after the announcement that the printing was practically completed, Sharpe wrote in the following terms to Hugh Hamersly, who had now taken the place of Caecilius Calvert as secretary to his Lordship:

"The Collection of the Maryland Laws which hath been printed here being at length published I shall by a Ship of Mr. John Buchanan (Capt Hanrick) which is ready to sail hence for London transmit you two bound Copies one of them for the Lords of Trade to be presented with the inclosed Letter \& the other for the use of the Council Office Their Lordships having long ago called on me for them, the next Ship Capt. Richardson in Groves's Employ will bring you another Copy or two."”2

When one recalls that nearly six years had passed since the Lords of Trade had given order that copies of the Maryland laws be sent them, one is inclined to admire the patience with which their Lordships had awaited their transmittal no less than the coolness of the note from Sharpe which accompanied the volume when it was finally put into their hands. "My Lds,"said the Governor,

"a compleat Collection of the Acts of Assembly which have been made in this Province $\&$ are now in force having been just printed here after many obstructions \& Delays I embrace the first opportunity to transmit Your Ldps a Copy in obedience to your Commands some time ago signified to Your Ldps most obedt. humb. servt."3

At last then, the great book was printed and published, evidently in the summer of 1766 . Although the title-page bears the date 1765 , yet from the

${ }^{1}$ Sharpe Correspondence, July 10, 1765, Archives of Maryland, 14: 202.
${ }^{2}$ Sharpe Correspondence, July 21, 1766, Archives of Maryland, 14: 322.
${ }^{3}$ Sharpe Correspondence, July 25, 1766, Archives of Maryland, 14:322.

[ I09] 


\section{A History of Printing in Colonial Saryland}

fact that Sharpe did not transmit copies to England until July 31, 1766, and from the further evidence that it was not until August 21, I766, that it was offered for sale in the Maryland Gazette by Mr. Lancelot Jacques of Annapolis, one concludes that the printing of the index and preface, and the binding of the book, referred to by Sharpe a year before, had held up its publication much longer than had been anticipated. Into its making had gone thirteen years of toil on the part of Bacon and four years of honest labor on the part of Green, not to speak of much concern and activity exercised by Sharpe and others prominent in the Provincial government. Green died about a year after its publication, while Bacon lived long enough to see his laborious compilation become a work of unquestioned public usefulness. In scholarly and systematic arrangement as well as in accuracy and completeness it excelled any of the former bodies of law which the Province had possessed. Since the Revolution and its constitutional changes, Bacon's compilation has been of little practical value in the courts, but until the publication of the Archives of Maryland was begun in the closing years of the nineteenth century, it remained to the historian and the antiquarian the most useful single source on the past of the Province of Maryland. As an easy and dependable guide to the store-house of Maryland history it remains still without a rival. To possess a collection of works on Maryland history from which a copy of Bacon has been omitted is to have a house built upon sand, while a collection of colonial laws or of works illustrative of American printing which does not include that work, by this omission confesses itself incomplete.

Green issued Bacon's great book in two distinct editions; that is, on an ordinary, thin but crisp and opaque paper, suitable for book work, and on a thick, creamy writing paper of the same make and watermark as that which the Province imported for many years for the volumes in which were written its acts of Assembly. ${ }^{1}$ In this "large paper" edition the Bacon presents a quiet splendor, a mellow and harmonious blending of paper and types which was not surpassed in any book printed in colonial America.

In Green's masterpiece of typography there is perceived a lapidarian dignity of intention, a determination, one seems justified in thinking, that these laws of a free people should be inscribed in a manner worthy of the spirit in which they had been enacted.

\footnotetext{
${ }^{1}$ From various evidences one concludes that this was a Dutch paper. The author sent a description of its watermarks to Mr. G. J. Honig of Laandijk, Holland, who asserted the probability in a courteous reply that this paper had been made by the house of L. van Gerrevink, at Egmond op de Hoef, near Alkmaar in Noord, Holland.
} 


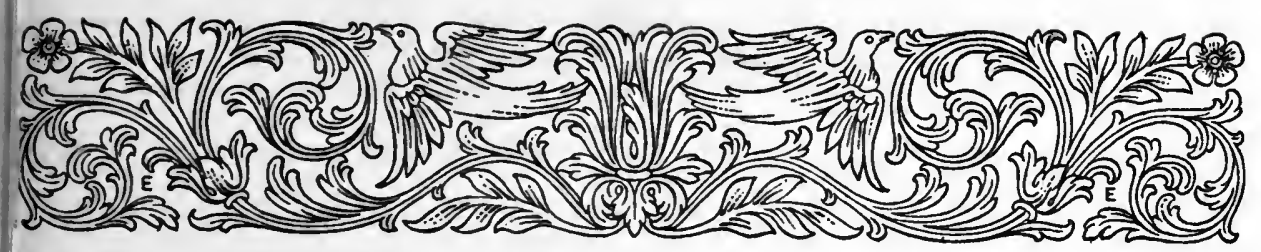

CHAPTER NINE

The Beginning of Printing in Baltimore Toren-Nicholas HasselbachEnoch Story the Younger-Hodge Eo Shober-Gohn Dunlap of Philadelphia and Baltimore-Fames Hayes, Fr.

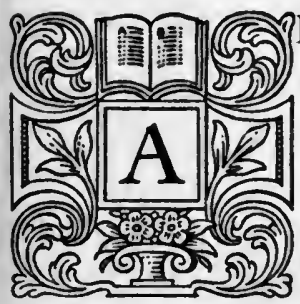

LTHOUGH it had been erected and laid out in the year 1729, the town of Baltimore began to assume prominence only in the decade preceding the Revolution. In 1764 , the year before the establishment of its first press, Sharpe wrote to Secretary Calvert concerning the town on the Patapsco in these words: "but as you seem to have been misinformed with respect to the Growth of Baltimore Town I must observe to you that altho there is more Business transacted there than at any other of our Maryland Towns, It is in point of both its Trade \& Buildings almost as much inferiour to Philada as Dover is to London, nor do I suppose that it contains at this time more than two hundred Families, it is however increasing \& will probably very soon get the Start of this City ${ }^{1}$ tho the number of Houses in this place also hath increased considerably with these few years." 2

The decade following the close of the Indian wars, indeed, proved to be a period of great increase of population in northern and western Maryland, an increase which brought Baltimore Town prominently forward as the natural port of the districts only then made safe for agricultural settlement. The decline of the Eastern Shore tobacco trade and the coincidental growth of the grain trade of the northern and western sections contributed further to increase the importance of the port of entry on the Patapsco, so that when the Revolutionary War began, Baltimore had become a town of about five thousand inhabitants and the most important port of Maryland. At the coming of its first printer, however, it was, as Governor Sharpe described it in the passage quoted above, still in its swaddling clothes, and it must have been with an eye for potentialities that its typographical pioneer set up his press within its bounds early in the year 1765 .

1 Annapolis.

${ }^{2}$ Sharpe Correspondence, August 22, 1764, Archives of Maryland, 14: 173.

[III] 


\section{A History of Printing in Colonial Maryland}

\section{Nicholas Hasselbach, I765-1770}

Nicholas Hasselbough or Hasselbach, ${ }^{1}$ a German who had emigrated to Philadelphia in August 1749, is known to have been employed in the year

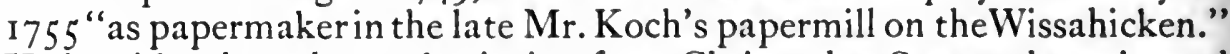
He is said to have learned printing from Christopher Sower, the universal genius of Germantown, and it is known that in the year 1762 he established a press in Philadelphia in conjunction with Anthony Armbruester, 2 a printer who was active for many years in the production of works in the German language. Of their activities only one imprint remains. ${ }^{3}$ Two other Philadelphia imprints of the years 1762 and 1763 have been recorded as bearing the name of Hasselbach alone. ${ }^{4} \mathrm{He}$ is known to have been in Philadelphia as late as April 1764 , but a little more than a year later, on July 6, 1765 , Thomas Harrison transferred to him the lot in Baltimore Town next to the Market House, which stood on what is now the northwest corner of Gay and Baltimore Streets.

It is probable that at this location Hasselbach set up his printing establishment. He made other purchases of real estate in succeeding years, and after his death his widow, Catherine Hasselbach, leased and purchased various properties in Baltimore and its vicinity. Late in the year 1769 or early in 1770 Nicholas Hasselbach was lost at sea while in passage for Europe to arrange there the details of a business venture, the nature of which is unknown. In the year 1775 his widow rendered the first account of her husband's estate which, less all debts, was valued at nearly two thousand pounds sterling. ${ }^{5}$ It does not appear that she continued his press, but she kept his equipment until the year I773, when she sold it to William Goddard, then newly come to Baltimore. ${ }^{6}$

It is said that the principal issues of Hasselbach's press, the first in Baltimore, were school books and other small works in the German and Eng-

\footnotetext{
${ }^{1}$ Isaiah Thomas spells the name as first given. On the only known Baltimore imprint of this printer bearing his name, it is spelled "Hasselbach."

2 Isaiah Thomas, $2 d$ ed., gives an interesting account of Anthony Armbruester.

${ }^{3}$ See Seidenstricker, O., First Century of German Printing in America, 1728-1830. Philadelphia, 1893.

${ }^{4}$ One of these, a German almanac for $176_{4}$, bore "Chestnut Hill" as its place of publication.

${ }^{5}$ Isaiah Thomas has a sketch of Hasselbach, but the greater part of the information given above was obtained from George W. McCreary's sketch of the printer in his reprint of Hasselbach's known Baltimore imprint, published in Baltimore in 1903 under the title of The First Book Printed in Baltimore-Town. Hasselbach's widow married a second time, George Aikenhead, a Scotch merchant of Baltimore, and after his death in 1781 , she took as her third husband, George Dowig, a Baltimore silversmith and jeweller who died in 1807 . The former Mrs. Hasselbach died in the same year in the eighty-second year of her age. The Hasselbachs were members of the First German Reformed Church of Baltimore, and their descendants intermarried with some of the leading families of that place.

${ }^{6}$ Isaiah Thomas records that Goddard afterwards sold part of this equipment to Francis Bailey of Lancaster, Pennsylvania.
} 
lish languages. Isaiah Thomas is responsible both for the statement that he had in contemplation at the time of his death the printing of a German Bible and for the preservation of the following anecdote which he says was at one time current in Maryland. The story is that a Maryland missionary, while addressing a congregation of Indians, held out his Bible and proclaimed that it was "the gospel-the truth-the work of God." "What!" said one of his audience, "did the great all-powerful spirit make this book?" "Yes," replied the missionary, "it is His work." The literal-minded Indian answered indignantly, "I believe it to be a great lie! I go to Baltimore last month where I see Dutchman make him. Great Spirit want no Dutchmen to help him." Whether this anecdote meant that Hasselbach actually began the printing of a Bible, or whether the Indian in his scornful rejoinder had reference to books in general as an article of German manufacture, Mr. Thomas was unable to say, nor have later investigators been more fortunate in determining the facts.

The single recorded Baltimore imprint bearing the name of Nicholas Hasselbach is entitled, A Detection of the Conduct and Proceedings of Messrs. Annan and Henderson ... at Oxford, $\left[\mathrm{Pa}_{\mathrm{a}}\right]$ Meeting-House, April 18 . . I 1764 . By John Redick. ${ }^{\mathrm{I}} \mathrm{It}$ is the labored relation of a quarrel between certain members of the Presbyterian Church of Marshes Creek, near Gettysburg, Pennsylvania, the matter of which does not concern this narrative. Its titlepage is without date, but the preface is dated from Tom's Creek, February 12, I 765. This little book of forty-seven pages is the earliest known example of printing done in Baltimore and the only certainly known specimen of Hasselbach's Baltimore press.

In the spring of 1768 , while Hasselbach was still alive and presumably active in the printing business in Baltimore, ${ }^{2}$ the inhabitants of that city and of the lower part of Baltimore County circulated a printed petition, addressed to the Governor and Assembly of Maryland, begging that the countyseat be transferred from Joppa to Baltimore Town on the Patapsco. The petition was printed in three distinct forms $s^{3}$ and in two languages, English and German. These sheets are without imprint and there are three possibilities to be taken account of in a consideration of their origin: they may have been from the Green press of Annapolis, but they are dissimilar to the work of that press in the Roman types employed, and it is not known that

1 See bibliographical appendix. Only known copy in the library of Robert Garrett, Esq., of Baltimore.

2See John Clapham's letter in the Maryland Gazette for September 22, 1768, and Bennet Allen's letter in the same place on September 29,1768 , in each of which are reprinted hand-bills issued by Allen in the summer of 1768 which, it is asserted in the letters, had been printed in Baltimore.

${ }^{3}$ For fall titles and descriptions of the three separate forms of this petition, see bibliographical appendix.

[II3] 


\section{A History of Printing in Colonial SCaryland}

the Greens had in their possession a font of German types; they may have been from a Philadelphia press, but there seems no good reason that the work should have been carried to Philadelphia when a printer capable of printing in both languages was living in Baltimore; they may have been and probably were from the Baltimore press of Nicholas Hasselbach. Unfortunately there remains only one known specimen of Hasselbach's Baltimore press for comparison with them, and this, printed three years earlier, evinces many typographical differences from the petitions. A prosperous printer, however, would have renovated his fonts with such frequency as to render this negative result of little importance in the investigation. On the positive side there is the fact that the petitions were printed in both Roman and German types, and that Hasselbach, a printer capable of printing in both types, was living in Baltimore at the time that the work was done, and further, that in a dispute where local pride was a large element it would have been natural that the literature of the dispute should be printed in the locality chiefly concerned. If these petitions, copies of which are now in the Maryland Historical Society, may be truly attributed to Nicholas Hasselbach's press, they are of particular interest in Baltimore printing history as very early examples of the press in that city and as the first recorded issues of the Maryland press in the German type and language.

It has been mentioned here that Hasselbach's widow sold his equipment to William Goddard, who set up an establishment in Baltimore in the year 1773. There is a tradition ${ }^{1}$ to the effect that Goddard believed himself at this sale to be purchasing an outfit of Caslon type, but that he discovered later a disparity in size between the bodies of his genuine Caslon and those of Hasselbach's letters. It was the discovery of his error which led Goddard to sell the Hasselbach fonts, which are said by Isaiah Thomas to have been cast by Sower of Germantown, to Francis Bailey, a printer of Lancaster, Pennsylvania, who at a later time, certainly, made conspicuous use of Sower's type faces. There seems to be no evidence, however, that Sower had commenced type-founding commercially before the year 1772 , so that one has difficulty in reconciling the tradition and the facts. The problem which is here presented is of interest to the student of American type-founding.

\section{Hodge ANd Shober}

After the death of Hasselbach, late in the year 1769 or early in 1770 , Baltimore was without a printer for nearly three years. It was not until

\footnotetext{
${ }^{1}$ Related to the writer by Mr. Preston Fiddis, of Baltimore. Mr. Fiddis is a repository of Baltimore printing traditions.
} 


\section{Typographical Beginnings in Baltimore}

November 5,1772 , that the following announcement appeared in the Maryland Gazette:

Baltimore, Oct. 31, 1772.

Printing, In all its Different Branches, Performed with the greatest neatness, accuracy and dispatch, by Hodge and Shober, At their new Printing-Office in Gay-Street a few doors below Market-Street, and opposite to Dr. Henry Stevenson's; who intend shortly to exhibit Proposals for publishing a News-Paper, which shall be justly entitled to the Attention and Encouragement of this Flourishing Town and Province, both for Entertainment and Elegance.

All kinds of Blanks, Hand-Bills, \&c. \&c. done in the neatest and most speedy Manner, at said office.

For some reason the expectations of these two printers came to nothing. They removed in this same year to New York, and no imprint remains to attest that their press was actually set up and operated in Baltimore.

Robert Hodge, of this firm, was born in Scotland, where he learned his trade. In I770 he came to America, settled in Philadelphia and worked for two years in the printing house of John Dunlap. His partner, Frederick Shober, was German born. Coming early to this country, he served his apprenticeship with Anthony Armbruester of Philadelphia. Both of these printers bore the reputation of being industrious, prudent men as well as good workmen. In 1775 Hodge sold to Shober his share of the establishment which they had set up in Maiden Lane, New York, on their removal to that city from Baltimore, and during the next few years found employment in a Boston printing house. At the close of the Revolution he returned to New York and established a book shop and publishing business in which, with varying success, he continued almost until his death, at his home in Brooklyn, in the year I8I3.

After the dissolution of his partnership with Hodge, Frederick Shober formed with Samuel Loudon, under the name of Shober \& Loudon, a firm which printed in New York for a few months, but becoming discouraged by the certainty of war, he sold out to Loudon and became a farmer. He died about the year I 806 near Shrewsbury, New Jersey. ${ }^{1}$

\section{ENoch Story, THe Younger, I774-I775}

Isaiah Thomas is authority for the statement that Enoch Story, the younger, came to Baltimore sometime in the year 1772 , immediately after the expiration of his apprenticeship to William Hall of Philadelphia, but as there exist no imprints from his Baltimore press before the year 1774, one must conclude that the earlier date is questionable. This printer was a rel-

${ }^{1}$ The above facts relative to Messrs. Hodge \& Shober after their departure from Baltimore are taken from Isaiah Thomas.

[II5] 


\section{A History of Printing in Colonial SCaryland}

ative of the elder Enoch Story of the Philadelphia firm, later established, of Story \& Humphreys. His Baltimore office was situated "in Gay Street, near the old Bridge", where he was to be found in the years 1774 and 1775 . It is recorded that he printed in the last-named year an edition of the New England Primmer, ${ }^{1}$ but no copy of this work has been located. It is probable that he could make no headway against the opposition of his rivals, Mary Goddard and John Dunlap. As publishers of newspapers these two would almost certainly have absorbed also the greater part of the local job work. In spite of the fact, therefore, that Story was a good printer with excellent equipment, he sold out his office to the Goddards in 1775 and returned to Philadelphia. In that city he opened an office in Strawberry Alley which Thomas says that he conducted for some years. No imprints of this office are on record, however, and it seems that again he failed to secure the needed patronage. He returned to Baltimore, we are informed, and died there after another vain attempt at success in the printing business.

\section{The Baltimore Branch of John Dunlap's Philadelphia House; James Hayes and "Dunlap's Maryland Gazette," \\ I775-I778; "The Maryland Gazette, AND ANNAPOlis Advertiser," I779}

The story of the printing and journalistic activity in Baltimore of William and Mary Katherine Goddard is of such a character as to require a separate chapter for its relation, and to them and their newspaper, The Maryland Fournal and Baltimore Advertiser, the concluding portion of this narrative has been devoted. The monopoly of the printing trade in Baltimore which they held for a short period was broken up by the intrusion, first, of Enoch Story, the Younger, and then more effectively, by the coming of John Dunlap, who in the spring of 1775 established there a branch of his Philadelphia house. This printer was born in the north of Ireland. Emigrating to America, he was trained in typography in the office of his uncle, William Dunlap of Philadelphia. When the elder Dunlap went to England in 1766 to secure ordination in the ministry of the established church, he resigned his printing house in Philadelphia to his nephew John, who soon purchased it outright and conducted it so creditably as to deserve the success that he met with in later years. He established and carried on from I77I to I794 a newspaper called the Pennsylvania Packet. He was appointed printer to Congress in 1778 and for five years thereafter the printed documents of that body, even when its sessions were held elsewhere than

\footnotetext{
${ }^{1}$ Evans, No. 14273.
} 
in Philadelphia, bore the imprint of John Dunlap. He is said to have retired from business in 1795 possessed not only of a handsome fortune, but of a reputation unique in journalism, "that whilst he conducted a newspaper, he never inserted a paragraph which wounded the feelings of an individual." $\mathrm{He}$ died in Philadelphia in the year $18 \mathrm{I} 2$.

Not satisfied with the extent of his Philadelphia printing and newspaper business, John Dunlap began the publication in Baltimore on May 2, 1775 , of Dunlap's Maryland Gazette; or the Baltimore General Advertiser, the imprint of which read, "Baltimore: Printed by John Dunlap, at his PrintingOffice in Market-Street, where Subscriptions at Ten Shillings per Annum, Advertisements \&c. are received for this paper, and all manner of Printing Work done with the utmost expedition." For more than three years Dunlap continued the proprietorship of this, the second Baltimore newspaper. It was excellently edited, well printed and distinctly literary in its tone. It is probable that in giving it up in 1778 , Dunlap yielded to the pressure of work which his position as printer to Congress entailed upon him.

\section{James Hayes, Jr., Takes Over Dunlap's Establishment}

Dunlap's office in Baltimore was conducted by James Hayes, Jr., who, becoming ambitious, bought the property from its founder in the year 1778 . On September 8 th of that year Hayes announced that he was about to remove his printing establishment to a house four doors above Mr. Grant's tavern on Market Street, where "having engaged the office of Mr. Dunlap, the original Proprietor," for whom, as he asserted, he had carried on the business "upwards of three years past," he now proposed to continue "in his own Name" the printing trade in all its branches. In the following week the newspaper appeared with the changed title,The Maryland Gazette, and Baltimore General Advertiser, volume 4, number 177, with Dunlap's name removed from the title and displaced in the imprint by that of James Hayes, Junior. It ceased publication in this form on January 5, 1779, and its proprietor went to Annapolis to enter a field which the temporary cessation of Green's Maryland Gazette had left open a year or more earlier.There, in April 1779, he began the publication of the Maryland Gazette, and Annapolis Advertiser, ${ }^{2}$ a newspaper whereof even the memory would have disappeared had it not been for the preservation in the Library of Congress of

\footnotetext{
${ }^{1}$ Isaiah Thomas records this and the other foregoing facts in regard to Dunlap. He seems to have been unaware, however, of Dunlap's Maryland connection.

2 See Brigham, C. S., Bibliography of American Nerospapers, 1690-1820. (Part III), in Proceedings of the American Antiquarian Society, April 191 5. The author's indebtedness to Mr. Brigham is such as must be acknowledged by all investigators of American literary history.
}

[II7] 


\section{$A$ History of Printing in Colonial SCaryland}

a single issue, that of July 9, I779. It is likely that Hayes's Maryland Gazette ceased to be published soon after this date.

The inauguration of a newspaper in Annapolis by Hayes seems to have aroused the Greens to a resumption of their Maryland Gazette, for on April 30,1779 , the last day of the month in which the intruding printer had begun his new publication, Frederick and Samuel Green resumed the printing of the journal which their father had begun in the year 1745, and which they and their descendants now proceeded to carry on for sixty uninterrupted years.

The foregoing sketch of Baltimore printing in the colonial period does not do justice to the early typographical history of that town, for the reason that in its pages William and Mary Katherine Goddard have been mentioned only incidentally. Their activities, to which the ensuing chapter is devoted, add importance and a touch of color to the story of disappointment and failure which is the burden of the tale here concluded. 


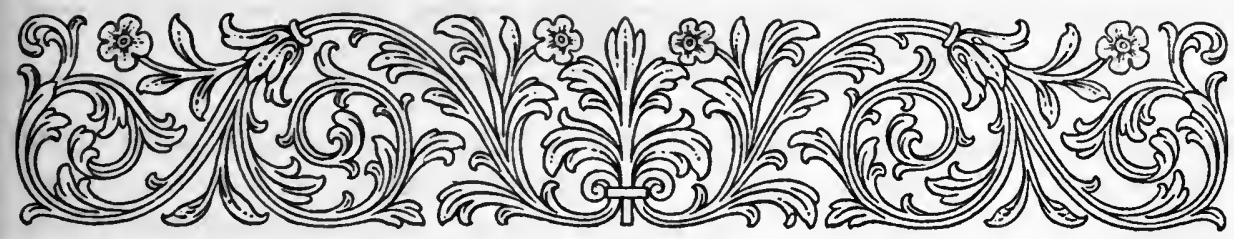

CHAPTER TEN

\section{William Goddard, Printer of Providence, New York, Philadelphia and Baltimore, Founder of the United States Post Office- Scary Katherine Goddard, Printer of Baltimore}

(he envisagement of the early history of typography in Baltimore, those practitioners of the craft whose activD 9) I $I[$ into a background against which stands relieved the high(c) colored figure of William Goddard, a printer and journalist of four American colonies and an individual who is known to posterity chiefly as the "Tory" founder of the postal system of the United States. Restless, ambitious, zealous, he plunged headlong into every project which he undertook, investing his least action unconsciously with that vividness of personality which sets an individual apart from his fellows even when, as in this instance, it does not exalt him above them.

Biographers have presented William Goddard to us in contrasted colors. ${ }^{1}$ Lorenzo Sabine, for example, has enrolled him in that questionable martyrology which we know as The American Loyalists; Isaiah Thomas, who knew him well, has lauded him as an unregarded patriot. The facts of his life, if studied superficially, might well be interpreted as they were by Sabine, but it will be shown here that although Goddard became the enemy of the popular party in Pennsylvania, yet was he to be found busily working in the service of the colonies at a time when many former leaders of that party were making terms with the British; that when the Baltimore mob hustled him from the city for a supposed act of disloyalty, the Maryland Assembly

\footnotetext{
${ }^{1}$ The limits of a single chapter permit only a skeleton outline of the activities in Baltimore and elsewhere of William Goddard, a many-sided and active man. Brief as it necessarily is, however, the author has attempted by the citation of numerous references and documents to make easy the path of any investigator who may be inspired with the worthy idea of giving William Goddard monographic treatment. For the general facts of Goddard's life, Isaiah Thomas is a reliable guide. Scharf's Chronicles of Baltimore provides much information as to his Baltimore enterprises. The present writer, however, is under a most particular obligation to Mr. Wm. J. M'Clellan of Baltimore, who on August 20, 1898, August 17, 1902, and August 27, 1905, contributed articles to the Baltimore American in which were displayed the fruits of an unremitting zeal in local antiquarianism and a life-long enthusiasm for William and Mary Goddard. Of Mr. M'Clellan's personal courtesy and helpfulness, the author here expresses his appreciation.
}

[IIg] 


\section{$A$ History of Printing in Colonial SCaryland}

gave him its protection and restored him to his home and occupation. A knowledge of the facts of his life shows that the misunderstanding of his political character which existed among many of his contemporaries may well be traced to his own tactlessness and to his lack of that higher form of humor whereby a man is enabled to see his own actions in just perspective; a characteristic which in positive terms may be described as the possession of that mental and spiritual defect known as obstinacy. It does not commend him to us any the less, however, when we learn that these characteristics of tactlessness and obstinacy were brought out chiefly in situations into which he had been drawn by loyalty to his friends, by refusal to pay homage to popular idols and by a willingness to fight and to suffer for the liberty of the press.

William Goddard was born in New London, Connecticut, in the year $1740,{ }^{1}$ the son of Giles Goddard, physician and postmaster in that town, and his wife, Sarah Updike, who was the daughter of Lodowick Updike and the representative of an old Rhode Island family. ${ }^{2}$ It was probably in 1755 , two years before the death of his father, that young William Goddard was apprenticed to James Parker, who in this year, in partnership with John Holt, had established at New Haven a newspaper known as the Connecticut Gazette. In this place, it is significant to notice, the two printers acted for some years as postmaster and deputy postmaster respectively. Parker soon returned to New York whither in 1760 Holt followed him. As James Parker and Company they established on July 31, 1760, the New-York Gazette and Weekly Post-Boy. ${ }^{3}$ It is probable that young William Goddard served with these eminent printers in both New Haven and New York. Their partnership was dissolved on May 2, 1762, and at about the same time Goddard's articles of apprenticeship expired. Not much more than a month after this date he appeared in Providence, Rhode Island, as the proprietor of the first printing office to be set up in that city.

In his venture as the inaugurator of printing in Providence in the month of July 1762 , as in all of his ventures while she lived, Goddard had the support of that excellent woman, his mother, who in this instance advanced from her own purse three hundred pounds for the establishment of his office. He began hisoperations in the usual humble fashion of the colonial printer; his earliest recorded publications were a broadside in which was proclaimed

\footnotetext{
${ }^{1}$ The Op Dyck Genealogy, by C. W. Opdyke. N. Y. 1889.

${ }^{2}$ Ibid.

3 Paltsits, V. H., “John Holt, Printer and Postmaster," in Bullet in of the New York Public Library, September 20, 1920, gives a concise statement of the relations of Parker and Holt and prints a number of interesting letters and documents relating to Holt and his public and private life.
} 
the fall of Moro Castle at Havana, ${ }^{1}$ and a play-bill announcing a performance at the local theatre. A few sermons followed, and on August 31,1762 , he published the prospectus of the Providence Gazette and Country Fournal, a newspaper which first appeared on October 2oth of the same year. For two and a half years, in spite of the fact that it was a well-edited sheet, Goddard's paper struggled so unsuccessfully against the indifference of the community that on May II, I765, it was forced to discontinue for lack of support. Goddard attempted to resume its publication by an issue dated August 24, I765, headed "Vox Populi, Vox Dei. A Providence Gazette Extraordinary ... Printed by S. and W. Goddard," but failing to receive the eight hundred subscriptions upon which its resumption had been made contingent, he allowed it once more to lapse. It was not until after the repeal of the Stamp Act, when Goddard had been resident in New York for many months, that on August 9, I766, his journal was resumed and conducted successfully for some time thereafter by "Sarah Goddard and Company.". After his appearance there, in August 1765, William Goddard never returned to Providence to take up his trade. It was probably during the years of his absence, and in her mother's service, that his sister, Mary Katherine Goddard, learned the practical side of typography and journalism, a knowledge which she put to distinguished use several years later in Baltimore.

It was during his period of discouragement in Providence ${ }^{3}$ that his friends, Messrs. Parker and Holt, urged Goddard to leave that unpromising field and to come to New York where his abilities would meet with greater appreciation and recompense. ${ }^{4}$ Urged by the restlessness which drove him ever

\footnotetext{
I For these and the other Rhode Island publications of Goddard, see Rhode Island Imprints, compiled by the John Carter Brown Library. Moro Castle fell on August 14, 1762. There could not have been a great many days intervening between the publication of Goddard's broadside announcement of the victory and that of his newspaper prospectus on August 31, 1762.

${ }^{2}$ Goddard's mother continued the printing and newspaper business actively in Providence until November 1768, when she sold the establishment and removed to Philadelphia, where she again invested in her son's business. (A list of her imprints during these years in Providence is to be found in Rhode Island Imprints, before mentioned). The purchaser of her Providence office was John Carter, whom Goddard had sent to her assistance from Philadelphia. He became a personage in Rhode Island. Among his descendants was John Carter Brown, the founder of the great library of that name in Providence. Mrs. Goddard died in Philadelphia on January 5, 1770. (Obituary in Providence Gazette for February 10, 1770). With her passing went the single restraining influence of his early life. Her exhortations to him (see The Partnership) to refrain from wasting his strength in petty controversies, her insistence that the ancient law of an eye for an eye and a tooth for a tooth had been repealed by the higher mandate of "Love one another," fill one with admiration for her maternal solicitude, her Christian gentlehood and her sound wordly sense.

${ }^{3}$ For excellent accounts of William Goddard and his activities in Providence, see Printers and Printing in Providence, 1762-1907, [by Hugh F. Carroll]; article in Providence Fournal for October 20, I91 2; Arnold, S. G., History of the State of Rhode Island. 2 vol. Providence $1894 ;$ Kimball, G. S., Providence in Colonial Times. Boston, 1912. In the last named and in the Collections of the Rhode Island Historical Society, v. 12, no. 2, April IgI9, are excellent portraits of Goddard, showing him in young manhood and old age, respectively.

4 The Partnership: or the history of the Rise and Progress of the Pennsylvania Chronicle, E ${ }^{c}$. Wherein the Conduct of Foseph Galloway, Esq; Speaker of the Honourable House of Representatives of the Province of Pennsylvania, Mr.
}

[I2I ] 
afterwards from one city to another, Goddard joined the staff of John Holt sometime in the late spring or early summer of 1765 . Since May 6, I762, when he had hired the New York business of the firm of James Parker and Company from the principal owner, John Holt had been conducting alone the New-York Gazette and Weekly Post-Boy, and Goddard doubtless had cherished good expectations in joining him in its publication. He asserted afterwards that his prospects in New York were ruined by the disagreement which arose between Parker and Holt some months after his arrival in that city. ${ }^{1}$ Parker had determined to resume his New York printing business and to takeinto his own hands the publication of the newspaper which he had leased to Holt some years before. Holt seems to have felt himself badly used in being compelled to turn over to his former partner the goodwill which had attached itself to the newspaper through his successful conduct of it during the preceding four years. ${ }^{2}$ Between these two, Goddard, the friend of both, found himself awkwardly placed, inasmuch as either would have been offended if he had associated himself permanently with the other. He has left it on record, however, that by his interposition, he was able to prevent his two friends from coming to an open break, ${ }^{3}$ and further, that Parkergave consent to his remaining with Holt until he should be able to form a permanent association elsewhere. He worked with Holt, therefore, until the late spring of 1766 . In June of that year he set up an establishment in Philadelphia, once more filled with that hope of success and distinction which never entirely left him until the approach of old age drove him to seek contentment in rural pursuits.

In the meantime, he had done more in New York than merely act as assistant to John Holt in the printing of the Gazette and Post-Boy. In the voluminous literature which opposition to the Stamp Act called forth, one finds a curious publication in newspaper form, the printing of which has been attributed by Isaiah Thomas, and others, to William Goddard. Thomas comments on this publication in the following words:

Thomas Wharton, Sen. and their Man Benjamin Towne, my Late Partners, With my Own is Properly Delineated, and their Calumnies Against me Fully Refuted. ... Philadelphia: Printed by William Goddard, in Arch Street, between Front and Second Streets, I770. 72 pp. 8 vo.

1 The Partnership.

2 Victor Hugo Paltsits in "John Holt, Printer and Postmaster," before referred to, gives the details of this disagreement in so far as it was externally apparent in the pages of the newspaper, which Parker took over finally in October 1766 . The advertisements which he quotes show that there was bitterness beneath the smooth surface which these two printers presented to the world, so that Goddard's brief account of their disagreement does not come as a surprise.

${ }^{3}$ The Partnership. Goddard's representation of himself in this instance as an angel of peace is not without its amusing elements in view of the tone of his attack upon his own partners which occupies the ensuing seventy pages of his pamphlet. 
"It was entitled The Constitutional Courant, Containing Matters interesting to Libertybut no wise repugnant to Loyalty. Imprint, Printed by Andrew Marvel, at the Sign of the Bribe refused, on Constitution-Hill, North America. In the center of the title was a device of a snake, cut into parts, to represent the colonies. Motto-Foin or die. After the title followed an address to the public from the fictitious publisher Andrew Marvel. This paper was without date but was printed in September 1765.1 . . A large edition was printed, . . . It excited some commotion in New York, and was taken notice of by government. A council was called, . . . but as no discovery was made of the author or printer, nothing was done. . . . Only one number of the Constitutional Courant was published; a continuance of it was never intended. It was printed by William Goddard."2

In his first edition Mr. Thomas asserted that the Constitutional Courant, or the Constitutional Gazette, as he incorrectly called it, had been printed by Goddard, with the connivance of Parker, in Parker's shop in Burlington, New Jersey. The editors of his second edition changed the word Burlington to Woodbridge, and later bibliographers have accepted the correction.

It does not seem as if, in these years of journalistic apprenticeship, William Goddard were training for Toryism.

\section{Goddard Goes to Philadelphia}

Goddard has related that he was moved to leave New York by hearing of the dissolution of the old partnership of Franklin and Hall, of Philadelphia. He persuaded himself that from this occurrence there should arise in that city an opportunity for a young printer of journalistic ambitions. ${ }^{3}$ Accordingly he went to the Pennsylvania city in June 1766 , bearing a letter, which he had obtained on the way, from William Franklin, then Governor of New Jersey, to Joseph Galloway, Esq., a Maryland Quaker who had been for many years resident in Philadelphia and active in its politics. In his turn, Galloway introduced him to Mr. Thomas Wharton, a prominent Quaker politician and merchant. If it were possible to accept unreservedly Goddard's account in The Partnership of the agreement which these three now entered into, one would be convinced that here had been reenacted the old nursery rhyme, wherein the Spider invited the Fly into her parlor with a

1 This is a mistake; the paper is dated September 21, 1765. See title as given by Evans, note No. 2, below.

2 Thomas, 2 d ed., 2: 130 . Evans, No. 9941 , gives the full title as follows: The Constitutional Courant. Containing Matters Interesting to Liberty-But No Wise Repugnant to Loyalty. Numb. I, Saturday, September $21,1765$. [Woodbridge, New-Jersey:] Printed by Andrew Marvel [William Goddard] at the Sign of the bribe refused, on Constitution-Hill, North America. [1765.] pp. (2). fol.

Buckingham, J. T., Specimens of Newspaper Literature, etc., 2 v., Boston $1850,1: 246$, describes the publication, and in $1: 236$, in speaking of an issue of the Massachusetts $S_{p y}$, which also bore a cut of the disjointed snake, states that the first use in the colonies of this celebrated symbol had been in the heading of The Constifutional Courant. Franklin, however, had used this emblem and motto on the Pennsylvania Gazetie of May 9, 1754 . See Hildeburn, No. 1378 .

${ }^{3}$ The Partnership.

[123] 


\section{A History of Printing in Colonial SCaryland}

cordiality beneath which lay a sinister intention. One turns from Goddard's ill-mannered and splenetic accounts of his Philadelphia experience, however, whenever possible; appreciation of the lack of mental balance which he exhibited in The Partnership and in other controversial writings of this period of his life destroys confidence in whatever testimony he offers in his own behalf. Governor William Franklin, writing to his father in London on November I 3 th, $1766,{ }^{1}$ gives a version of the formation of the partnership by Goddard, Galloway and Wharton, which differs only in temper from that later published in Goddard's pamphlet. It seems, according to His Excellency of New Jersey, that since the dissolution of the firm of Franklin and Hall, the anti-Proprietary party of Pennsylvania had been unable to reach the public through the press. Hall was not favorable to its members, and whatever they submitted either to him or to Bradford for publication in their newspapers was sure to be censored by some one in the Proprietary party before being printed. Reserving a place for Franklin should he desire it on his return, Messrs. Galloway and Wharton therefore had entered into partnership with Goddard, for the particular purpose of publishing an antiProprietary newspaper. Goddard had brought several good fonts of type with him, but having left his press in Providence with his mother, Governor Franklin and Mrs. Benjamin Franklin had hired to the partners one of Benjamin's old presses, and rented them the old printing shop in Market Street. The anti-Proprietary members of the Assembly were to see to it that Goddard should receive the public work and that his newspaper should be well patronized. In general, one learns from Governor Franklin, the prospects of the firm were promising, and much satisfactory service was expected from it by the party which was its patron. ${ }^{2}$

A little more than a month after this letter was written, on December 23, 1766 , Goddard issued from his own shop proposals ${ }^{3}$ for the publication of a newspaper to be known as The Pennsylvania Chronicle and Universal Advertiser, and on January 6, 1767, appeared the first issue of a journal which has been described as the best which was published in Pennsylvania prior to the Revolution. In a letter from one of the partners, Thomas Wharton, written to Benjamin Franklin a month later, it was asserted that the new journal had begun publication with seven hundred subscribers. ${ }^{4}$

\footnotetext{
${ }^{1}$ Franklin Papers, in American Philosophical Society, XIII : 3. Printed in Bigelow, John, The Complete Works of Benjamin Franklin, 3: 511 .

${ }^{2}$ For another contemporary reference to the new newspaper, see Pennsylvania Magazine of History, 10: 229232, letter of Wm. Strahan to David Hall.

${ }^{8}$ Evans, No. 10319.

${ }^{4}$ Franklin Papers in American Philosophical Society, II: 66, dated February 7, 1767.
} 


\section{William and STary Goddard, Printers and Public Servants}

The Pennsylvania Chronicle began its life as the chosen organ of the Junta, that anti-Proprietary organization which Franklin had brought in to being years before, and in which Galloway and Wharton were among his prominent associates. Thesegentlemen and their friends of the opposition wereits principal contributors; Franklin himself sent from England for its columns many of those essays which served to mould the political thought of the time. Some of the friends of the Chronicle, while sincere enough in their abhorrence of the Proprietary, yet were only lukewarm on the larger question of opposition to the measures of the Crown in its administration of the colonies. Among these, unfortunately for Goddard, who was a patriot of another stripe, were his partners, Messrs. Galloway and Wharton, the first of whom already had begun to lose standing with the more zealous by his perfunctory opposition to the Stamp Act in 1765 . He resented Goddard's action in beginning in the Chronicle, on December 3, I767, the publication of John Dickinson's "Letters from a Farmer," 1 a series of political essays wherein the broader question of American rights was discussed in a manner which influenced the increasing anti-British sentiment of the colonies. On his part Goddard resented no less bitterly the necessity which he was under of assailing on every occasion the Proprietary government of Pennsylvania, a policy for the prosecution of which his newspaper had been established, but of which he had wearied early in the campaign. It has been said, to put the result of the disagreement briefly, that "The obstinate Goddard refused to conduct the paper according to the wishes of the dictatorial Galloway, and the Chronicle, instead of supporting the Assembly party, became a bitter opponent of its former patron." 2 It is probable that this desertion of the cause of the Pennsylvania Assembly by Goddard provided the basis for the accusation of Toryism brought against him in later years, but it should be observed again that at the outbreak of the Revolution it was Galloway and Wharton who joined the British while Goddard remained in the American camp, and that it was this so-called "Tory," who after having labored with all of his strength in the service of the colonies in a civilian capacity, strove to secure an appointment from the Congress as a field officer in its army.

In the year 1769 Galloway and Wharton withdrew from partnership with the unmanageable Goddard, who affirmed afterwards that before the dissolution they had compelled him to take as a partner their "spy," Benjamin Towne, a journeyman printer of the establishment. Towne asserted

\footnotetext{
'This was the initial publication of Dickinson's "Letters." Newspapers throughout the colonies immediately began to reprint them as they appeared in Goddard's journal.

${ }^{2}$ See Foseph Galloway, the Loyalist Politician, by Ernest H. Baldwin, in the Pennsyloania Magazine of History, 26: 161-19I, 289-321, 417-442.
}

[125] 


\section{$A$ History of Printing in Colonial Saryland}

flatly that Goddard had taken him into the firm because he owed him journeyman's wages which he could not hope to pay otherwise than by giving him a share in the business. Whatever may have been the true reason for the new partnership, it turned out to be the unhappiest arrangement which any two men ever formed for the conduct of a business enterprise. Goddard hated Towne of all men second only to Galloway, and in the intervals between his attacks on the latter, he assailed his new partner in a manner the coarsest and most vindictive possible. ${ }^{1} \mathrm{His}$ great purpose in life after the separation from his earlier partners, however, left him relatively little time to devote to Towne's discomfiture, for his campaign to prevent Galloway's re-election to the Pennsylvania Assembly took precedence of all lesser contests. One of its first offensives, if the military figure may be carried out, was the publication in 1770 of The Partnership, a pamphlet in which he left unsaid nothing that could blacken the character of his former associates, except probably a few unimportant things which he forgot to record. In the seventy-two closely printed and frequently tedious pages of this pamphlet is to be found a mixture of mockery, "appeals of injured innocence," and downright blackguardism, the whole composed in a voluble, exaggerated style which at times is as shrill as a fish-wife's curse. How greatly he was in the wrong or how greatly he had been wronged becomes a matter of little importance in the face of the evidence which his defense presents of his lack of mental balance, a quality, which, had he possessed it, would have combined with his energy and talents to raise him to a high place in the life of the nation then in gestation. Of this or of a later literary assault on Galloway by the author of The Partnership, Franklin wrote to his son, "I cast my eye over Goddard's Piece against our friend Mr. Galloway, and then lit my fire with it. I think such feeble, malicious Attacks cannot hurt him."2 By leaving Philadelphia and standing for the Assembly from the county of

\footnotetext{
${ }^{1}$ Of the quarrel between Goddard and Towne, little need be said. It can be read in The Partnership; in the sheet issued by Towne on July 31, 1770, entitled "To the Public, and particularly the kind customers of the Pennsylvania Chronicle," in which Towne gives a sober account of his relations with one whom he considers to have been mentally unbalanced; and in a broadside "Advertisement" of August I, 1770, in which Goddard replied to 'Towne's dignified paper of the day before. These broadsides are in the Franklin Collection of the University of Pennsylvania, XII: $4^{\mathrm{I}}$ and X: 8, respectively. Goddard's language in the "Advertisement" was particularly rude. He seems to have been suffering under delusions of persecution at this time. Towne was a capable man whose politics changed during the Revolution in accordance with the distance of the British troops from Philadelphia. Isaiah Thomas gives an excellent sketch of him. The partnership lasted from May 19, 1769, until soon after the death of Goddard's mother on January 5, 1770, when Towne brought suit for its dissolution. In the meantime Goddard continued the Chronicle with his sister as silent partner. On the verso of the title-page of volume 3 of the paper (photostat copy in New York Public Library), he announced under date of February 12, 1770, the continuance and improvement of his journal, and asserted that he had purchased "an elegant Mahogany Press, made by an ingenious watchmaker, at New Haven," and that he was expecting by every ship fonts of "a beautiful new Elzivir Type, made by an inimitable Founder in England."

${ }^{2}$ Franklin to William Franklin, January 30, 1772. In Smyth, A. H., The Writings of Benjamin Franklin, 5:378.
} 
Bucks, Galloway succeeded in being re-elected in the years 1770 and 1772 , but Goddard's attacks seem so far to haveshaken him thathe contemplated retiring from public life. From this step he was dissuaded by Franklin, who retained esteem for his old friend of the Junta until the very eve of the Revolution. ${ }^{1}$

Even the small triumph which Goddard attained in harassing his enemy cost him more than it came to, for with the financial support of Galloway and Wharton withdrawn, and with constant dissension existing between Goddard and Towne, the affairs of The Pennsylvania Chronicle fell to such a depth that eventually creditors descended upon the property and took possession of it. In a letter from William Strahan, ${ }^{2}$ a London printer and publisher, is to be read the beginning of the catastrophe. Writing to Franklin on August 21, 1772, Strahan says:

"As you will probably write to Philadelphia by some of the Vessels now about to sail thither, may I request the favour of you to remind Mr. Galloway of the Money due to me for Types and Newspapers sent to Mr. Goddard by his order above four Years ago, and which, as stated in my Letter to him of the 6th Decr. I770. amounted to £172: 15: 2. I wrote him the 7 th of August last Year to which I have had no Answer.-It is surely high time this Money was repaid, which I beg your Interposition to procure me without farther Delay. It is hard I should suffer by the Madness and Ingratitude of Goddard whom I never had the least Concern with. It was Mr. Galloway's Order that I obeyed; and to him I look for my Reimbursement."”3

By just what steps the final ruin of the business was consummated, it is not clear, but it is certain that within two months after the date of Strahan's letter, the "mad" and "ungrateful" Goddard had begun to plan a retreat from his difficult position. Drawn always southward by his changing fortunes, he now made proposals for the establishment of a printing house in Baltimore, and in that city, less than a year later, he established himself in business, as he has recorded, on the capital of "a single solitary guinea.", The last issue of The Pennsylvania Chronicle bore the date of February 8, I774, and when it expired with its three hundred and sixty-eighth number, the Maryland Fournal and Baltimore Advertiser could boast already six months of vigorous life.

1 Foseph Galloway, the Loyalist Politician, before cited. In a letter to Abel James, December 2, 1772 (Smyth, A. H., The Writings of Benjamin Franklin, 5: 46I), Franklin says that he does not understand why James and Fox were slighted in the election, "while Goddard was voted for by so great a number." This is the only intimation which the author has seen that Goddard offered himself as a candidate for the Assembly or other office.

${ }^{2}$ William Strahan, printer and member of Parliament, b. 171 5, d. 1785 . He was the friend of Franklin and of Dr. Samuel Johnson and the London agent of many Pennsylvania printers. It was to him that Franklin wrote his celebrated letter at the outbreak of the Revolution, concluding with the words: "You are now my enemy, and I am, Yours, B. Franklin."

${ }^{3}$ Franklin Papers in American Philosophical Society, III : 117.

${ }^{4}$ Maryland Fournal, August 14, 1792.

[127] 


\section{A History of Printing in Colonial SCaryland}

\section{Goddard in BALTIMORE}

In the year 1773 Baltimore Town was a small city of about five thousand inhabitants. Its growth in size and importance had been notably rapid in the past decade, but it was not until after the conclusion of the Revolution that it became one of the great mercantile centers of America. At this time it had never had a newspaper, and since its foundation only three printers had been established within its limits. Its citizens therefore must have read with quickened interest an advertisement which was carried in the Maryland Gazette of Annapolis on October 20, 1772, in which William Goddard, already well known throughout the Province, writing from Baltimore Town, announced that on the invitation of many gentlemen of that city he had "engaged a suitable printing apparatus" with which he intended to prosecute the printing business there in all its branches in English and other languages, and particularly that he proposed "to publish by subscription, with all possible expedition, a weekly newspaper, under the title of the Maryland Journal and Baltimore Advertiser, at the moderate price of ten shillings current money per annum ... to be published regularly every Saturday morning."

Nearly seven months passed, however, before Goddard was ready for business. On May 12, 1773, he advertised again in the Maryland Gazette that printing was performed "in a neat, correct and expeditious manner, on the most reasonable terms, by William Goddard, at his printing office, at the corner of South and Market Streets, ${ }^{1}$ nearly opposite to Mrs. Chilton's in Baltimore-Town." He begged in the same advertisement that all subscriptions to the Maryland Fournal which had been received by his agents be sent to him, so that he might know how many papers to print, and in conclusion he promised that the paperwould be published as soon as proper posts or carriers had been established.

In the first number of the Maryland Fournal and Baltimore Advertiser, published August 20, 1773, Goddard apologized for the delay in the appearance of the paper, and asked consideration of the many disadvantages under which it had been brought out, notably his inability, because of illness, to establish a special post between Baltimore and Philadelphia. $\mathrm{He}$ proclaimed his intention of publishing any contributions received by him in favor of liberty and the rights of man, provided the language were decent and compatible with good government, but he affirmed resolutely that his paper was to be without party bias. Among the advertisements in the first

\footnotetext{
${ }^{1}$ The corner known to the present generation of Baltimoreans as the site of the Sun Iron Building, the printing and editorial office of the Baltimore $S u n$, until its destruction in the fire of February 1904.
} 


\section{William and STary Goddard, Printers and Public Servants}

issue of the paper was one in which George Washington of Mt. Vernon in Virginia offered for sale twenty thousand acres of western lands.

On November 2oth the publisher of the Maryland Fournal apologized once more for the irregular issue and delivery of his paper, but he pledged himself, now that he had returned from the north restored in health, henceforward to make its publication the primary object of his attention. It seemed for a few months that he had been sincere in making this promise to his public, but clearly he had made it without reckoning on the attraction of that other and more absorbing interest which was gradually taking possession of his thoughts. In February I 774, his sister, Mary Katherine Goddard, assumed control of the newspaper for what she doubtless thought would be the temporary absence of her brother. A year later, however, he had not returned to take up his responsibilities and his name was removed from the imprint of the journal, where it did not reappear until nearly a decade had passed. During the first two years of this period Goddard was busy at a task for the successful performance of which he has been given credit, but only scant praise, by historians; that is, the establishment of the postal system which was afterwards taken over by the Continental Congress, and which exists today as the United States Post Office.

\section{William Goddard and the Establishment of the "Constitutional Post Office"}

In seeking for the beginnings of Goddard's interest in American postal operations it is necessary to go very far back indeed in his life, for at one time, Dr. Giles Goddard had been postmaster of New London, and it is probable that throughout the receptive years of boyhood, the future founder of the United States Post Office had heard in his father's house much discussion of the British colonial postal system. While in Providence he was himself for a short time deputy postmaster of that place, and during his youth and early manhood his constant employment in and management of newspaper offices had kept him in intimate association with a system for which he seems to have acquired nothing but contempt and aversion. ${ }^{1} \mathrm{His}$ former associates, James Parker and John Holt, had been postmasters at New Haven, and John Holt became in later years a virile critic of the colonial post. ${ }^{2}$ The delivery of newspapers to their rural subscribers seems to

\footnotetext{
${ }^{1}$ There was in colonial days, as there is now, a close connection between the post office and the publisher. This condition is interestingly set forth in Mr. Paltsits's article on John Holt referred to earlier in this chapter; in American Archives, 4th series, 2: 537, and in "Letters from James Parker to Benjamin Franklin" in Proceedings of the Massachusetts Historical Society, 2d series, 16: 186-232, May 1902.

${ }^{2}$ See Mr. Paltsits's article before referred to. See also American Archives, 4 th Series, 2: 537.
}

[129] 


\section{A History of Printing in Colonial Maryland}

have been a frequent issue between the postal authorities and the printers. In a letter which will be quoted later, Goddard, in writing of himself, intimated that more than any other American printer he had been badly used by the ministerial Post Office, and from another source ${ }^{1}$ onelearns that having become unfavorably known to the government as the proprietor of "a very free press," he had suffered unusual oppression by the Post Office about the year 1770, when he had been charged one pound sterling a week for the delivery of three hundred and fifty papers to places outside of Philadelphia. From his first coming to Baltimore, Goddard, who had learned his lesson, seems to have had in mind a plan by the execution of which he might render himself independent of the established postal system, but it is doubtful if at this time he was thinking of any thing more ambitious than the establishment of a private line of riders between Philadelphia and his newlychosen abode.

In early issues of his journal in the summer and autumn of 1773 , one finds him advertising for reliable men to act as post riders. That he was successful in obtaining them and that his plan already had begun to be enlarged is made certain by the fact that on December 30, 1773, the news of the Boston Tea Party was brought from New York to his office in Baltimore by his own riders. About this time his idea seems to have advanced from the embryo, for on February 17, I774, Mary Katherine Goddard informed the readers of the Maryland Fournal that she would conduct the newspaper and printing business of her brother during his absence from Baltimore in the prosecution of a very important affair, "interesting to the common liberties of all America." This was, of course, the establishment of the "Constitutional Post Office," from which, and not from the British colonial post, the United States Post Office derives its origin.

Following the announcement made by Miss Goddard which has been referred to, Goddard spent the ensuing months in an eager questing of men and funds wherewith there might be inaugurated a post office system ${ }^{2}$ to supplant that one which had been conducted more or less satisfactorily since its establishment in the colonies by an Act of Parliament in I710. At this time, Benjamin Franklin, although he had been resident in England for about nine years, was holding under the British ministry the position of Postmaster General of the colonies. There was general dissatisfaction with the administration of the system, and although the great esteem in which

\footnotetext{
1 American Archives, 4 th Series, I: 500.

${ }^{2}$ See American Archives, $4^{\text {th }}$ Series, I: 500 et seq. where are given copious extracts from letters and newspapers of various colonies from Massachusetts to Virginia in which Goddard may be followed in his journeys and exertions in the cause of a Constitutional Post Office.
} 


\section{William and SCary Goddard, Printers and Public Servants}

Franklin was held throughout the colonies served in a measure to keep critical tongues silent, Goddard, either because he did not share in the general admiration of one who was the friend of his personal enemies, or because he was bolder than other disaffected publishers, cameout in an attack upon the system which caused some perturbation among the friends of the absentee Postmaster General. On March 31, 1774, a correspondent in Boston wrote to Franklin enclosing papers in which were contained one of these attacks on the Post Office, to which he added the following comment: "the attack ... by all I can learn orriginated with Mr. Goddard, and he says is adopted at the Southward. I can't yet learn what incouragement it meets here, he has proposed a subscription to pay Riders to go from hence to Hartford to receive the Mails and bring them to Boston, to be deliver'd to such Post Masters as shall be chosen by the subscribers. ..." ${ }^{1}$ From another source onelearns that the proposals had been kindly received in Boston, for a month after this, Governor Franklin wrote to his father, lately dismissed from his office of Postmaster General, ${ }^{2}$ in the following words:

"Your Friends in Boston, as I am told, before they heard of your running any Risk of a Dismission were encouraging Goddard in his new Post Office, which if successful must have deprived you of your Salary as Postmr. Genl. even if you had not been deprived of your office."

In view of these revelations there remains less cause for astonishment that Franklin should have passed over Goddard when, a year or so later, he was filling the higher offices of the American postal system. It should be said, however, that Goddard does not seem to have been instigated in his attacks on the Post Office by any personal feeling against Franklin. In an announcement, published in the Maryland Fournal on July I6, I774, he referred indignantly to the treatment which had been accorded the former Postmaster General, and asserted that the American people, "since the infamous Dismission of the worthy Dr. Franklin, and the hostile attack on the Town and Port of Boston, are unalterably determined to support a new constitutional Post Office on the ruins of one that hath for its Basis the slavery of America."

It is probable that the newspaper attack on the Post Office which has been referred to as having been transmitted to Franklin by a Boston correspondent on March $3 \mathrm{I}, \mathrm{I} 774$, was the same in essentials as that which appeared in the Maryland Fournal on July 2, 1774, wherein Goddard announced that,

${ }^{1}$ Franklin Papers, IV: 12, in American Philosophical Society: Tuthill Hubbart to B. F., March 31, $1774^{\circ}$

2 Franklin's transmission to Massachusetts of the contents of letters to the British Ministry from certain Boston loyalists had been visited upon him by his dismissal from the office of postmaster general early in this year.

${ }^{3}$ Franklin Papers, IV: 17, American Philosophical Society: William Franklin to B. F., May 3, I774.

[III] 


\section{A History of Printing in Colonial Saryland}

"The Printer of this Paper, with great Pleasure, acquaints the Public, that his Proposal for Establishing an American Post Office, on constitutional Principles, hath been warmly and generously patronized by the Friends of Freedom in all the great Commercial Towns in the Eastern Colonies, where ample Funds are already secured, Postmasters and Riders engaged, and, indeed, every necessary Arrangement made for the Reception of the Southern mails, which, it is expected, will soon be extended thither. As therefore the final success of the Undertaking now depends on the Public Spirit of the Inhabitants of Maryland and Virginia, it is not doubted, from the recent Evidence they have given of their Noble Zeal in the Cause of Liberty and their Country, but they will cheerfully join the rescuing the Channel of public and private Intelligence from the horrid Fangs of Ministerial Dependents; a Measure indispensably necessary in the present alarming Crisis of American Affairs.

The following Plan, \&c., hath been published and universally approved of at the Eastward."

The "Plan" which followed set forth briefly the history of the "present American PostOffice," ministerial in itscreation, direction and dependence, which not only was tampering with private correspondence, but as well, was interfering with the circulation of "our News-Papers, those necessary and important alarms in Times of public Danger." In view of the indictment of its management which he proceeded to unfold, Goddard proposed the establishment of a new, semi-public system, and laid down in eight paragraphs rules for its maintenance and government, therein establishing a set of principles by which his Constitutional Post Office was operated and which were adopted with certain essential changes when the Continental Congress at a later time took over the system. His method of securing support for his scheme seems to have been the publication of newspaper announcements such as that which has been quoted here from the pages of the Maryland Fournal, followed in each locality by the circulation of a subscription form, headed "The Plan for establishing a New American Post Office."' He seems to have worked at this task single-handed. His proposals vere entirely in his own name, and that he succeeded in his great undertaking may be accepted as an evidence of the esteem in which he was generally held. Little imagination is required to arrive at an understanding of the magnitude of his labors in carrying out an enterprise so great and complex as the establishment of a system of post offices and riders with routes and cross routes from Maine to Georgia.

On July I6, I774, ${ }^{2}$ he announced that a "New Post Office" would "shortly be opened in this and every Considerable Town, from Virginia to Casco

\footnotetext{
1 One such broadside, with the names of the subscribers torn off, has been preserved in the John Carter Brown Library. It is dated Boston, April 30, 1774, and in Goddard's own hand it is addressed as follows, "To the Gentn. of the Committee of Correspondence for the Town of Newbury, frum their most . . humble Servt.Wm. Goddard." The proposals and "plan" above described are printed in American Archives, 4 th Series, $1: 500$.

${ }^{2}$ Maryland Journal.
} 


\section{William and STary Goddard, Printers and Public Servants}

Bay," and affirmed the hope that the new system would be complete in all points "by the first of September next, that being the time appointed for the meeting of the Grand Congress at Philadelphia ..." On October 5, I 774, Goddard presented a petition to the Con tinental Congress, ${ }^{1}$ which doubtless had to do with his post office scheme, but as the text of it has not been preserved, one may not know what specific proposal he made to the delegates. Several mon ths later, in a broadside ${ }^{2}$ published in New York on May 2, I775, he pounced upon "a certain John Foxcroft," who, he asserted, had begun life as the servant of a Virginia gentleman of Williamsburg, and who, having been appointed recently to the position of Master of the Posts in North America, had "let loose the Reins of arbitrary Power" to such a length that the liberty of the press had been abridged and detestable publications inimical to the American cause had been circulated through the Philadelphia post office. He offered to give this "Mushroom Gentleman" an explanation on either a public or a private occasion, but he intimated that his offerwould not be taken up, as "the General of the Post-Office, like the renowned Gage, keeps himself encag'd."

The "Constitutional Post Office," known popularly as "Goddard's Post Offices," up to this time had received no official recognition. It was a private concern, operating from Massachusetts to Virginia as early as May $8,1775,{ }^{3}$ side by side with the British post. It had been set going by Goddard on subscribed capital, ${ }^{4}$ and that it had small chance of success as a private enterprise is clearly comprehended when one learns that in the year I 776 , even after it had become the official system of the colonies, the postmistress of Baltimore, Mary K. Goddard, received from postage only forty odd pounds, ${ }^{5}$ and that for several years thereafter she paid the riders with "hard money" out of her own purse. It must have been a devoutly hoped for consummation of Goddard's plans when on July 26, I775, the Constitutional Post Office was taken over by Congress as the official system of the United Colonies. ${ }^{6}$ After several months of attempted opposition to the new

${ }^{1}$ See Fournals of Continental Congress, October 5, 1774. (Ford ed.)

${ }^{2}$ Ms. Division Library of Congress has a copy of this broadside.

'See references to his activity at this time in American Archives, $4^{\text {th }}$ Series, 2: 537 , where is given a list of "Goddard's Post Offices" then established, and an interesting pronouncement on the subject of the "Constitutional" and "unconstitutional" post offices by John Holt.

"Memorial of William Goddard in Papers of the Continental Congress, 42: III, 178. Ms. Division Library of

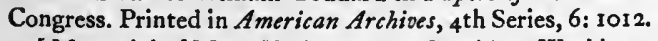

5 Memorial of Mary K. Goddard to President Washington, in Papers of the Continental Congress, Letters, 78 : X, 617-619. Ms. in Library of Congress. See also ms. vol. of Mary Goddard's Post Office Accounts, 1786-1789, in Maryland Historical Society.

- Fournals of Continental Congress. In a Congressional debate of October 7, 1775, it was said that a "Constitutional Post is now established from New Hampshire to Georgia." The debate discloses further the fact that the 
system, the British Post Office finally gave up the struggle and withdrew its riders from the roads on Christmas Day $1775 .^{1}$

If in the recognition of his plan by Congress he was made happy, however, there is no doubt that Goddard was disappointed when Franklin was immediately named as Postmaster General by the Congress, and Richard Bache, his son-in-law, was appointed Secretary and Comptroller of the system. For two years the great idea had obsessed him to the injury of his private business - two years during which he had kept the highways hot in his ceaseless journeyings in its interest. Now at the moment of success he was given as a reward for his great service his choice between nothing at all and the inferior position of Surveyor of the Post Office. However keen his disappointment, Goddard bore it with a high heart. In a memorial to Congress, dated June $2 \mathrm{I}, \mathrm{I} 776,{ }^{2}$ he recited his services in the establishment of the Constitutional Post Office, and reminded the delegates that they had given the Postmaster General no authority to reimburse him and his friends for their outlay of money in "establishing Postmasters, hiring Riders, and bringing the temporary Establishment, in all its Parts, to that State where your Officer found it, when it was resigned with all those Advantages;" and further, that the Comptrollership and the Secretaryship having been disposed of elsewhere, he had been compelled to content himself with the office of Surveyor, which at the time of writing, he had held for a year at a salary too small for decent maintenance; that the duties of this office having been completed, and scorning to hold a sinecure, he now asked recognition of another sort by the Congress. He apprised the delegates that he might repair his fortunes if he should ask for and receive the office of "Muster-Master-General," but he expressed disdain for that position as being,

British system was still in operation, although dying from lack of patronage. This seems sufficiently clear evidence that the present United States Post Office is not the descendant of the British colonial system, but of the Constitutional Post Office established by Goddard.

1 On December 5, 1775 (American Archives, 4 th Series, 4: 184), the Constitutional Post Office at Annapolis, William Whetcrofe, postmaster, announced itself as in operation, and on December IIth (American Archives, 4th Series, 4: 234 and 713), the Maryland Convention prohibited the riders of the Parliamentary Post "to travel

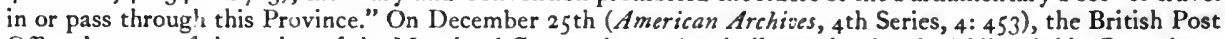
Office, because of the action of the Maryland Convention and a similar action by the Philadelphia Committee of Safety, announced the cessation of its service.

${ }^{2}$ Papers of the Continental Congress, 42 : III, 178. Ms. in Library of Congress. Printed, American Archives, $4^{\text {th }}$ Series, 6: 1012. In Smith, William, The History of the Post Office in British North America, 1639-1870, Cambridge, 1920, p. 64, occurs a statement which may explain three things in the life of the founder of the United States Post Office; namely, Goddard's especial animus towards Foxcroft, his failure to receive high office under Franklin when the Constitutional Post Office was adopted by Congress, and the fact that he owed Franklin a considerable sum of money, as the latter's will has left on record. Here is the statement, based upon a communication of Foxcroft, joint deputy postmaster general with Franklin, to Todd, (Public Record Office, C. O. 5. vol. I35): "Goddard had been postmaster of Providence, and when he relinquished the office, he was a defaulter for a considerable amount. As the loss from Goddard's defalcation fell partly upon Franklin, as joint deputy postmaster general, the latter would be reluctant to place him a second time in a position of responsibility." 
to use his own words, "less liable to those personal Dangers, which his natural Disposition impels him to encounter," and asked finally that he be given a commission as a field officer, more specifically as a lieutenant colonel, in either one of two regiments in which changes were about to be made. The Congress passed on his memorial to the Board of War, and to this body, on July 19, I776, Goddard addressed a letter showing exactly by what promotions and transfers of other officers his own appointment could be accomplished. ${ }^{2}$ The Board referred the matter to General Washington, who, on July 29,1776 , in a letter to Congress, ${ }^{2}$ expressed the belief that the induction of Mr. Goddard "in to the Army as Lieutt. Colo. would be attended with endless confusion." No more was heard of Goddard's military aspirations. His desire to serve his country had been genuine, and one must sympathize with him in the succession of disappointments which befell him in his efforts to be of use in the time of national trial.

\section{William Goddard in Baltimore Again. His Interpretation of "the Liberty of the Press"}

Following the collapse of his ambitions, his failure to receive from the Government either civil or military appointment commensurate with his services, Goddard took up his residence once morein Baltimore, ${ }^{3}$ and al though his name did not supplant that of Mary Katherine Goddard in the imprint of the Maryland Fournal, there is no doubt that he concerned himself very largely in its direction. It is possible that his financial condition rendered this sheltering of himself behind his sister's petticoats the more prudent part for him to play, but whatever the cause, he remained, if one may employ such a phrase, ostentatiously in the background. There can be no doubt that from 1776 until 1779 he had a voice in the affairs of a newspaper which had become one of the most vigorous of the colonial journals. By his occasional open participation in its affairs he brought on one of those conflicts of opinion upon the issue of which hangs the establishment of principles accepted unthinkingly by later ages as having been of eternal duration. Since the invention of printing, the phrase "the Liberty of the Press" had been construed as an assertion of the right of the publisher to express his convictions with immunity from ecclesiastical or governmentalinterference. Goddard gave the phrase a new construction, in Maryland certainly, when on two occasions he succeeded in extending it to include the publisher's

${ }_{1}$ Correspondence of George Washington with Continental Congress, 95: 145. In Ms. Division Library of Congress. Printed, American Archioes, 5 th Series, $1: 441$.

2 Ibid. M. III, 37. Printed, American Archives, 5 th Series, $1: 642$.

${ }^{3}$ Goddard was in New York acting as Surveyor of the Post Office as late as September 9, 1776. (American Archives, 5 th Series, 2: 256). The exact date of his resignation from the public service is uncertain. 


\section{A History of Printing in Colonial Maryland}

right to print what he would, regardless of the more powerful censorship exerted by public opinion. It is to an examination of the conflict between Goddard and the people of Baltimore that this narrative now leads.

\section{The “Tom-Tell Truth" Episode}

On the twenty-fifth of February 1777, there appeared in the Maryland Fournal two short contributions which related to the recent offer of the British Ministry to discuss what some persons considered to be advantageous terms of peace with the rebellious colonies. The first of these pieces, signed "Tom-Tell Truth," with obvious irony, advised the acceptance of these terms by the Americans. In the second article, signed "Caveto," the writer warned his fellow countrymen to distrust the British tenders and to continue the struggle with all their strength. "Caveto" was ignored; "TomTell Truth" became the talk of the town. ${ }^{1}$ A delegation of the "Whig Club" visited Mr. Goddard to require him to discover the author of the offensive piece, and were received, they averred, with the "grossest and most impolite" behavior. He refused to disclose the identity of "Tom-Tell Truth" for the reason that the gentleman whowas concealed behind that name was absent from town and unable to answer for himself. In this refusal Goddard displayed to his own hurt that quality of loyalty which was one of his admirablecharacteristics. The twice-offended and over-zealous patriots served him with a notice to attend the next evening a meeting of the Club. $\mathrm{He}$ ridiculed publicly the idea of obedience to the summons, and by so doing put the Club on trial before the people of the city. The issue became a personal one. Goddard was carried by force to the meeting, where, after more wrangling, he was ordered by the exasperated members of the Club to leave the town within twenty-four hours and the county within three days. With the edict of banishment he complied in a manner unlooked for by his opponents, for he went straightway to Annapolis and demanded protection from the Council of Safety. In his memorial, which this body referred to the Assembly on March 7, 1777, he said, after recounting the actions of the Whig Club, "that he, thinking himself bound in honour not to suffer the secrets of his press to be extorted from him in a tumultuous way," had "absolutely refused to comply with the demand of this self-created court;" that he had been "treated with circumstances of indignity and insult, not to be patiently endured by a freeman possessed with a spark of honor or

\footnotetext{
"Both "Tom-Tell Truth" and "Caveto" were Judge Samuel Chase. See annotations in Goddard's personal copy of his pamphlet The Prowess of the Whig Club, preserved in the American Antiquarian Society, wherein the fact is expressly affirmed. Isaiah Thomas asserted this to be the case, having learned it, probably, from Goddard himself.
} 


\section{William and SCary Goddard, Printers and Public Servants}

sensibility," and that he had been commanded by them "with the most ridiculous apery of a legal meeting or Congress," under pain of earning the resentment of "A Legion," "to depart the town and county within a short limited term. ..." Three days later the Committee of Grievances of the Lower House presented a report on his memorial in which the action of the Whig Club was condemned as being "a manifest violation of the Constitution" and "directly contrary to the Declaration of Rights."

Feeling that its position had been misunderstood, the Whig Club now issued a brief statement ${ }^{3}$ in which one may read a willingness to let the matter rest. Goddard, however, had tasted blood. In the latter part of March he brought out his pamphlet, The Prowess of the Whig Club, ${ }^{4}$ a publication in which he dusted the salt and pepper of derisive irony over the wounds of his opponents. Their exasperation was extreme. Goddard was roughly haled before the Whig Club and when his sentence of banishment had been reimposed by that body, he went once more to Annapolis and the Legislature. Taken in hand by Samuel Chase, his cause was so conducted that the Whig Club, summonsed from Baltimore, was forced to apologize to the Sovereign People at the bar of the House, ${ }^{5}$ and resolutions were passed in which the offending organization was castigated and the Governor was requested to afford Goddard protection against "all violence or injury to his person or property." 6

Rendered secure in his person and justified in his actions by the highest authority in the state, Goddard returned to Baltimore where he lived unmolested until his next and more serious offense against a sensitive public, when once again he vindicated the right of the press to a free expression of opinion.

\section{Goddard and the "Queries" of General Charles Lee}

On June 8, I779, there was published in the Maryland Fournal an announcement to the effect that William Goddard and Colonel Eleazer Oswald ${ }^{7}$ had formed a partnership for the prosecution of a printing, bookselling and

${ }^{1}$ V. \& P., Lower House, March 7, 1777.

${ }^{2}$ V. \& P., Lower House, March 10, 1777.

${ }^{3}$ Reprinted by Goddard in The Prowess of the Whig Club.

The Prowess of the Whig Club, and the Manoeuores of Legion. Baltimore: Printed for the Author, 1777, $24 \mathrm{pp}$.

${ }^{5}$ Letter of Benj. Galloway, Red Book, 3:45. (The Red Books are a series of volumes of $m s$. in the Maryland Historical Society which, with unclassified contents, have received this designation from the color of their bindings.).

' V. \& P., Lower House, April I1, I777. For other details of this affair, see letters and papers Nos. $3^{8}$ to 45 in Red Book No. 3, ms. in Maryland Historical Society; Goddard's Memorial to Continental Congress in Papers of the Continental Congress, 4I: III, 385, dated May 6, 1777, Ms. Division Library of Congress; Goddard's The Prowess of the Whig Club and his broadside dated March 25, 1777, addressed to David Rusk, Ms. Division Litrary of Congress; Scharf's Chronicles of Baltimore.

${ }^{7}$ Eleazer Oswald born in 1755 , had come to America in 1770 , gone into business with John Holt, married 


\section{A History of Printing in Colonial Scaryland}

stationery business in Baltimore, which was to be conducted neither in opposition to nor in conjunction with Mary $\mathrm{K}$. Goddard. It was not so stated in the advertisement, but one acquires the impression from reading it that Miss Goddard was to retain the newspaper, while the new firm should take over the job work and bookselling of the old establishment. It is certain that Goddard and Oswald took over the Elkridge paper mill, in which Mary Goddard had been interested for some time past. ${ }^{1}$

Goddard and Oswald had been brought together doubtless through their possession of a common friend in the person of John Holt, the former employer of the one and the father-in-law of the other. One understands also the tie between Oswald and his unfortunate militaryleader, General Charles Lee, but when and where had been formed an intimacy between Lee and Goddard has never been made clear. It is known, however, that when he had left the army in indignation at the result of Lee's court-martial, Oswald had come straightway to Baltimore and attached himself to one in whom he probably knew that he should find a doughty supporter of his old General. Cashiered for his conduct at Monmouth, Lee was now preparing to vindicate his reputation, and in the process, to blacken the character and attainments of Washington. In his need for a medium of publicity, he turned first of all to his friend Goddard, unaware it seems that assistance to his cause from that personage had been rendered doubly sure by the recently formed partnership between the Baltimore printer and his other friend and partisan Colonel Eleazer Oswald. On June 9, I779, he wrote to Goddard 2 asking him to publish an article entitled "Some Queries, Political and Military, Humbly Offered to the Consideration of the Public." Goddard was quick to consent. The ill-natured piece appeared in the Maryland Fournal on July 6, 1779, and once more, following its publication, Goddard had the

Holt's daughter, entered the Continental Army, and become one of the favorite officers of Gen. Charles Lee. He distinguished himself in several campaigns, and was promoted to Colonel. Indignantly he resigned from the army when Charles Lee was court-martialed and now at the age of twenty-four was in business in Baltimore with Goddard. Afterwards he became a printer of Philadelphia and still later led a romantic, soldier-of-fortune career. He fought several duels. Died in New York on September 30, 1795. For a very interesting account of his early life and army career sec a letter from John Holt to Samuel Adams in "John Holt, Printer and Postmaster," by V. H. Paltsits in Bulletin of New York Public Library, v. 24, No. 9, Pp. 483-499; also Scharf and Westcott, History of Philadelphia, note, I: 425 .

${ }^{1}$ On May 25, 1776, the Convention had granted James Dorsett four hundred pounds common money for the establishment of a mill at which was to be made paper "as cheap as the same can or shall be sold at any mill in the Province of Pennsylvania." It was probably this mill which Mary Goddard had been fostering in the columns of the Maryland Fournal for some years past, and the operation of which Goddard and Oswald now undertook. As early as November 8, 1775, Miss Goddard had advertised in the Maryland fournal that she would pay cash for linen rags for the paper mill now erecting near this town, that is, Baltimore.

${ }^{2}$ Contemporary copies of the letters from Lee to Goddard are in the Red Book, $3: 43$, in the Maryland Historical Society. Lee concludes one letter with these words: "You have and ought to have the first reputation for impartiality as a printer on the Continent." 


\section{William and SCary Goddard, Printers and Public Servants}

questionable honor of a visit from the mob. James Calhoun, Mayor of Baltimore, writing to Governor Johnson, ${ }^{1}$ said that Goddard's publication of the "Queries," a piece "evidently intended to injure the character of the Commander in Chief, ... determined the principal part of the Town to withdraw their names from the list of his subscribers, but theOfficersin general thought it more incumbent on them to resent so great an insult offered to their Genl. . .." by active measures. Accordingly, they visited Goddard, who as the result of their representations, agreed to meet them and other citizens the next morning. "Early in the morning," continued Calhoun,

"Goddard was seen parading the streets with a Gun \& his friend Coll. Oswald with a drawn Sword, venting his spleen in the most abusive language. . . . This naturally tended further to enrage $\&$ by the time appointed for the meeting a large number collected and seem'd determined to make him give up the Author which he found it most prudent to do $\&$ make the recantation published in his Supplement."

According to Goddard's account in his memorial ${ }^{3}$ to Governor Johnson, he and his friends were roughly used in this business which Calhoun described, without detail, in the letter here cited. An officer of militia interfered in his behalf and was in his turn attacked by the mob. Endeavoring to save her husband from their anger, this gentleman's wife had been "beaten and abused, with circumstances of barbarity that must have melted the flinty heart of a savage." In order to save his house from further pillage and himself from being carted through the streets with a rope around his neck by this "band of ruffians, composed of Continental recruits, mulattoes, or negroes, fifers and drummers," he had signed and printed as a supplement to the Maryland Fournal a paper "containing the most ridiculous and absurd concessions." He made clear his contention that he was being persecuted because of his stand for the liberty of the Press, exercised in pursuance of his conviction that it was his duty to help in the vindication of the character of General Lee, a gentleman and a patriot to whom he believed agreat injustice had been done by the recent court-martial proceedings.

This was parliamentary language, as became one addressing a Governor. In his published utterances ${ }^{4}$ during these days, his temper was violent and his words measured up to his feelings, but he expressed himself even more vividly to one whom he met on the Annapolis road when he said, ${ }^{5}$

${ }^{1}$ Red Book, 3: 4r.

${ }^{2}$ See Supplement Maryland fournal, No. 303, v. 6, Maryland Historical Society.

2 Ree Supplement Maryland fournal, No. 303, v. 6, Maryland Historical Society.
${ }^{2}$ Red Book, 3: 38. See also The Maryland Gazette, Ec. Extraordinary, No. 17, bound in v. 6 of Maryland Fournal, Maryland Historical Society copy.

"See v. 6 of the Maryland fournal, Maryland Historical Society; also The Maryland Gazetie, Ec. Extraordinary, No. 17 , in same volume.

${ }^{5}$ Red Book, 3: 42. In The Maryland Gazette, Ec. Extraordinary, No. 17, is printed the correspondence in which Oswald vainly invited Colonel Smith, referred to in this extract, to meet him on the field of honor.

[139] 


\section{A History of Printing in Colonial Scaryland}

"I had like to have been mobbed to death by a parcel of Poltroon Officers, Blackguard Continental Soldiers, \& Negroes, Headed by Coll. Smith, and the damn'd rascally Magistrates of Baltimore would not give me any redress, and am now going to Annapolis to the Governor if he does not give me some redress I will seek it to the farthest end of the world, yes I will take up the Tomahawk and Scalping knife and will be worse than any Hessian or Waldecker ...."

The issue of Goddard's appeal to the Governor is obscure. On July 17, 1779, the Council of Safety ordered the magistrates who had failed to give him protection to appear before them at a hearing on the twenty-sixth of the instant month, but the Council record for that day gives no indication that the hearing was held, nor did the Maryland Fournal thereafter refer to this phase of the affair. It is evident, however, that whatever was its legal conclusion, Goddard considered himself to have been vindicated a second time, for on July 27 th he published in his newspaper a retraction of the apology which he had printed under duress only a week earlier, nor does there seem to have been made by his enemies any protest against this emphatic disavowal of what Calhoun had termed his "recantation." Again the last word had been spoken by the publisher, and the "liberty of the press" once more had been upheld against an outraged populace.

\section{Goddard's Later Years}

During the fourteen years that Goddard remained in Baltimore after his second defiance of public opinion in that town, he gave his enemies and competitors many moments of uneasiness, touched them with his rapier point or hammered them with his bludgeon many times, but on the whole it was a well-ordered and fairly prosperous middle age that he entered into, a life laborious and useful but entirely devoid of the unusual. The story of his early career with its zealous exertion, its varied accomplishment, has been related in some detail; a concise statement of his activities throughcut his later years must suffice for these pages.

It is probable that Goddard and Oswald had employment for some years with Mary Katherine Goddard on the Maryland Fournal, for there is little evidence that their own business was sufficient to maintain them. On April IO, $178 \mathrm{I}$, the partners once more renounced all share in that good woman's business, ${ }^{1}$ and asked encouragement from the public in their designs for issuing a series of the British classics, publications which, they emphasized, were to be printed on American paper of their own manufacture. No traces of these works exist, however, to indicate that they were published. For how much longer the partnership between Goddard and Oswald continued

${ }^{1}$ Maryland Fournal. 
is uncertain, but on April I3, I782, Oswald issued in Philadelphia the first number of his Independent Gazetteer, ${ }^{1}$ so that one may think of him as having left Baltimore early in that year. Goddard seems to have con tinued alone his Baltimore printing establishment. On July I 5, I783, he advertised as from his press a circular letter from General Washington to the governors of the several States, and in December of this year Mary Goddard announced the publication of a "Pennsylvania, Delaware, and Virginia Almanac and Ephemeris for the Year of Our Lord I 784," edited by William Goddard.

Some months before this, General Charles Lee had died, and in dying had paid to Goddard and Oswald the debt of gra titude which he owed to them for their efforts to vindicate his fame. ${ }^{2}$ To these two faithful friends heleft onethird of his lands in Virginia, and by the generosity of his sister in England the legacy came to them free of debt. ${ }^{3} \mathrm{It}$ is to be hoped that they received a good price for these lands as a result of the sale advertised in the Maryland Fournal of November I $4, \mathrm{I}_{7} 83$.

One concludes that Goddard's reasons for refraining from taking over the newspaper from his sister years earlier had been financial, for on January 2, 1784 , very soon after his Virginia lands had been advertised as for sale, he announced in the Maryland Fournal that by a fortunate occurrence he had been enabled to purchase new printing equipment and that thereafter, as on this day, the paper would be published by "William and Mary Katherine Goddard." In the succeeding issue of January 6th Mary Goddard's name was dropped from the imprint and Goddard alone carried on the paper until the issue of January I I, 1785 , in which it was announced that he had taken Edward Langworthy into partnership. The Maryland fournal was published by these two until February 1786 , from which time

\footnotetext{
1 Evans, No. 17564 .

${ }^{2}$ General Lee to Mary Katherine Goddard, December 17, 1781: "it is inconceivable the desire I have to be acquainted with you-for upon my soul I love (and I ought to love) your Brother and Oswald more than any other two men on this Continent." (Addressed to "Mrs. K. Goddard, Printeress at Baltimore," in 4: 466, The Lee Papers, being vols. 4-7 of the Collections of the New York Historical Society, 1871-74. N. Y. I $872-75$, which see for many letters and documents relative to the affairs of General Lee in which Goddard was concerned).

${ }^{3}$ General Lee provided also that Goddard should become his literary executor, and having gained assurance of Washington's indifference to the publication, Goddard proceeded to issue proposals and prepare for the press a selection of the Lee papers. The project came to nothing. Goddard asserted that his partner Edward Langworthy clandestinely removed from his office that portion of the papers which he published in London in $179^{2}$ as Memoirs of the Life of the Late Charles Lee, Esquire. Isaiah Thomas gives an account of the incident. A letter from Goddard to Washington on the subject, dated May 30, 1785, is found in The Papers of George Washington, v. 233, 1785, May 20-October I, Ms. Division Library of Congress. Goddard enclosed his proposal and outline in manuscript. Isaiah Thomas gives Washington's reply. On December 16, 1793, soon after the appearance of the Memoirs, Goddard wrote to Washington from Johnston, R. I., disclaiming any connection with the publication as then issued. See The Papers of George Washington, v. 264, 1793-1794, November 30-January 20, Ms. Division Library of Congress. The ultimate fate of the mass of Lee papers left in Goddard's hands, and preserved by his descendants, was the use of them by the publication committee of the New York Historical Society in the production of The Lee Papers described in the preceding note.
}

[ I4I] 


\section{A History of Printing in Colonial SCaryland}

Goddard again conducted it alone until August 7, I789, when he formed a partnership with his brother-in-law, James Angell.' ${ }^{1}$ The last named publisher, who, it may be observed, was not a printer by trade, bought the newspaper from Goddard in the year I 792 .

Goddard's final appearance as the publisher of the newspaper which he had founded twenty years earlier was in connection with the issue of February I9, 1793. Six months before, on August I4, 1792, he had delivered through the columns of the Maryland Fournal a valedictory wherein appeared a great alteration in the state of his sentiments towards the people of a town which once, in his wrath, he had described as "a Theatre of Anarchy and Licentiousness." 2

The following portions of this farewell communication contain whatever it has of interest for this narrative:

"To retire from a Business not altogether unproductive, generally implies Success to the Prosecutor in the Accumulation of Wealth; but from a Despair of its Attainment, I have, at last, reconciled it to my feelings to retire without a Consolation of that pleasant Kind. Such a Consolation might, indeed, lessen the Emotion, and sensible Regret, that I now experience in offering this, probably my Last Address, . . . and in relinquishing a Business reared, under Favour of the Public, to its present Consequence and Respectability . . . on the small Capital of a single solitary Guinea, after the total Wreck of my fortune in another State. It is, however, an alleviating Circumstance, that, by this Measure, I am enabled to do Justice to a worthy Friend, who, from my too sanguine Anticipation of the Growth and importance of this really flourishing Town, spontaneously became my Security, in an unfortunate Speculation, for upwards of Twenty-Five Hundred Pounds. . . . From an anxious Desire to indemnify this disinterested Gentleman, ... I have .. . Disposed of my whole Printing-Concern (one of the most considerable in the United States) for a valuable Consideration, to my Partner and Brother-in-Law, Mr. James Angell, . . .

"Though there was a Moment when political Discussions produced a Degree of Animosity and Resentment repugnant to my Feelings and injurious to my Interest, yet I reflect with inexpressible satisfaction, that succeeding Liberality and Candour soon obliterated the Remembrance, and that I shall now leave this Town in perfect Friendship and Harmony with my Fellow-Citizens-ardently wishing them a Continuance of that prosperity I have for so many Years witnessed, in the rapid Rise of this opulent Town, with equal Admiration and Delight."

Goddard had determined to "cultivate his garden"; "contentment walks the unambitious plain," he wrote, ${ }^{3}$ and weary with his struggle he retired to his wife's farm in Rhode Island, where as "William Goddard of Johnston, yeoman," he lived peacefully another twenty-four years. Goddard served in the Rhode Island legislature for a short time, but in general his interests

\footnotetext{
${ }^{1}$ Goddard had married on the Thursday before May 27, 1786, Abigail, the daughter of General James Angell of Providence, R. I. (See Angell, Avery F., Genealogy of the Descendants of Thomas Angell. Providence, 1872.)

${ }^{2}$ Maryland Fournal, July 20, 1779.

${ }^{3}$ Maryland Fournal, August 14, 1792.
} 


\section{William and Kary Goddard, Printers and Public Servants}

were those of his farm and village. He died, aged seventy-seven years, in December I 817. Isaiah Thomas, who knew him in these later years, speaks of "his naïveté, and the pleasantness and facetiousness of his disposition," and asserts further that he was "a remarkably pleasant companion." One likes to think of him, after so much distress of mind and so many exertions of body, living unvexed and comfortable in his New England retreat.

In the various incidents which have been related here, particularly in connection with his career in Maryland, William Goddard is presented to us as a man who possessed the courage to stand up for his principles against that most subtle form of attack, the disapproval of one's neighbors. One cannot doubt the passion which underlay his pronouncements concerning the liberty of the press; one must admire the hardihood with which he gave himself to the vindication of General Lee's reputation; nor, when his utterances are read, the policy of his newspapers considered, his services in the establishment of the Post Office taken account of, may one doubt his devotion to the American cause in the Revolution. The Maryland Council of Safety, always ready to imprison or banish the enemies of that cause, twice took his side against those who had attacked him. The Maryland Assembly put his enemies to inglorious rout. In all of the official proceedings which exist there is no hint of an accusation of disloyalty against him, and his request of Congress that he be given a post of danger speaks for the quality of his devotion in a manner more audible than the loudest asseverations of loyalty.

In taking leave of Goddard, one comes back inevitably to a brief consideration of his position as the champion of the press. Of all the editors of his day, and Isaiah Thomas says that "Few could conduct a newspaper better than Goddard," there was none who held a view of the power, responsibility and privilege of the newspaper press nearer to the modern conception of these attributes than was maintained by William Goddard. The newspaper of today claims the right to present news and to discuss issues regardless of the opinion of its readers; in the ideal, it professes to arrive at truth by free discussion and by an examination of all the evidence. It is willing to suffer unpopularity that right shall prevail in the end. It was by the suffering of Goddard and others of his own and a later generation that this higher conception of the liberty of the press became an accepted tenet of modern civilization. Even though a certain class of newspapers consistently degrades this hard-won liberty, William Goddard must still be admitted to have interest for us as one of the proponents of a doctrine which on this account many deplore but the essential righteousness of which none is so bold as to question.

[ I43] 


\section{$A$ History of Printing in Colonial SCaryland}

\section{A Last Word on Mary Katherine Goddard}

It would be an ungracious act to conclude this chapter without a final word on Mary Katherine Goddard, the devoted woman who was ready always to take up the tasks of her erratic brother where he had pleased to drop them, and willing, without complaint, to assume the consequences of his indiscretions. Hers was no small accomplishment. In 1774 she assumed the management of an infant newspaper and conducted it successfully through all the years of a War in the course of which, for economic reasons, many vigorous journals ceased publication. In 1784 when she might have begun to reap where she had sown with such assiduity, she relinquished her journal, a prosperous concern, to the brother in whose interests she had been acting throughout that decade. In spite of the ill feeling which William Goddard's defense of General Lee had engendered in the summer of I779, she had found herself able to announce in November of that year that her journal circulated as extensively as any newspaper on the Continent. ${ }^{1}$ Compelled frequently during these ten years to issue her news sheet in reduced form, she had nevertheless contrived always to issue, approximately on time, a journal which was second to none in the colonies in interest. ${ }^{2}$ Isaiah Thomas asserts that she was herself "an expert and correct compositor of types." She must be thought of, therefore, not simply as a business executive whose part was to direct the labor of others, but as a craftsman whose manual labor was a considerable element in determining the success of her establishment.

During these years Mary Goddard's activities were not confined to the composing room and editorial office. Her advertisementsindicate the maintenance by her also of a well-stocked book and stationery store, her jobprinting office was a busy one where copper plate work and the finer kinds of printing were carried on, and where books of various sorts were creditably produced. It has been claimed for her, too, that she operated the local paper mill, but whether her appeals for rags and her advertisements of paper for sale indicate so close a connection with the enterprise as this is not certain. At any rate, she did much to foster the difficult infancy of paper manufacturing in Maryland.

To all of these activities which made Mary Goddard's Market Street office a very busy spot in old Baltimore must be added another important

\footnotetext{
${ }^{1}$ Maryland Fournal, November 16, 1779.

${ }^{2}$ That her task was sometimes a disagreeable one appears from her complaint to the Baltimore Committee of Safety in June 1776 that Mr. George Somerville had "abused her with threats and indecent language on account of a late publication in her paper," for which attack upon the freedom of the press, Mr. Somerville was severely censured by the committee. (American Archives, 4 th Series, 6: 1460 and $146 \mathrm{r}$.)
} 
William and SCary Goddard, Printers and Public Servants

one, namely, her conduct for fourteen years of the local post office. The first postmaster of Baltimore under the Constitutional PostOffice, afteritsadoption by Congress, was Mary K. Goddard, the sister of the founder of the system. Throughout the Revolution and until the year I789, she continued to serve in this capacity, and that her service was given at an actual sacrifice of her own interests appears from the words of the memorial ${ }^{1}$ which she addressed to His Excellency, President Washington, when in that year a new Postmaster General removed her from office because of his desire to appoint in her place one who should be able actively to visit and superintend the whole Southern Department of the postal system. Miss Goddard recited to his Excellency the tale of her services during the difficult years of the enterprise. She told of the small receipts of the office, and as has been referred to before, the necessity which she had been under of paying from her own purse "hard money" for the employment of riders. She contested the practicability of the plan whereby the office of local postmaster should be combined with that of superintendent of a department, and in words wherein one feels, rather than reads, a repressed resentment, she begged the President to overrule the decision of his Postmaster General. To her petition, a vain protest after all, she subjoined a schedule showing the great increase in the business of the Baltimore Post Office during the years of her incumbency.

After Mary Goddard's relinquishment of the printing and newspaper business to her brother in 1784 , and her removal from the post office in 1789 , there remained for her employment only the book store, the business of which she conducted until the year I 802 . It is doubtful if all of her enterprises together had sufficed to acquire for her more than a decent maintenance, but at the time of her death, in her eightieth year, on August I2, I 816 , she was able to leave a small property to a colored woman who had been the servant and companion of her later years.

One comes from a perusal of the facts of Mary Goddard's life with the feeling that, in spite of her activity in public affairs, she had worked, lived and died a lonely woman. An admirer lauded her as "a woman of extraordinary judgment, energy, nerve and strong good sense." Her service to Baltimore throughout the Revolution was of a high order, her patriotism unquestioned. History abounds with anecdotes of colonial ladies who paid fabulous sums to their hairdressers, of dames in silk and bombazine, of daughters of the cavaliers moving gracefully through the minuet. Their gra-

\footnotetext{
1 Papers of the Continental Congress, 78, v. 10, 617-619. In Ms. Division Library of Congress. Miss Goddard's first assumption of the Baltimore Post Office seems to have occurred on October II, I775, when under the heading "Constitutional Post-Office," she announced in the Maryland Fournal that two posts to the "eastward" and southward set out from and arrived at her office each week.
}

[ 145$]$ 


\section{A History of Printing in Colonial SCaryland}

cious manners, their brilliant plumage give such color to the picture of those olden days that the observer seldom looks beyond them into the shadows. He does not see Mary Goddard and her sisters in other cities laboring the hours through in their dingy shops. To see them there is to realize that the picture has depth and richness as well as color.

\section{In Conclusion}

The colonial period in Maryland printing history comes to an end with the work of William and Mary Katherine Goddard. After them, and indeed in their later years, came so many printers, such a flood of pamphlets, books and newspapers that the problem of keeping clear the record becomes one to be solved by catalogue making rather than by historical narrative. To the printing houses of Baltimore and Annapolis were added those of Frederick when Matthias Bartgis settled there in 1779, and of Easton and Hagerstown when James Cowan and Stewart Herbert set up their respective presses in these places in the year 1790. Within another decade or two every Maryland town had its press. To record their activities is a task so different in character from that which has been attempted in the foregoing pages that another hand must take it up. The author of this narrative has lived so happily with the Nutheads, with Reading and Zenger and Parks, and with the Greens and Goddards that he is inclined to regard with jealousy those who took their places in the years following the Revolution. Of many of these, there is not much to be said; for the best of them time and man's perennial interest in the printing craft will find a historian. 


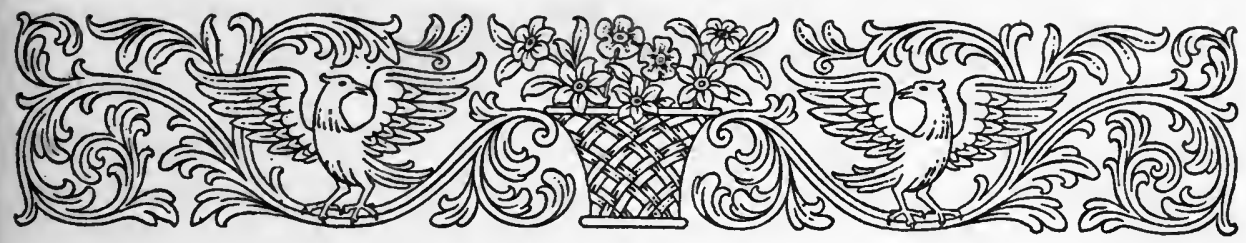

APPENDIX

\section{The Fabled Fesuit Press of St. OKary's City-Act of I 727 for the}

Encouragement of William Parks-A Summary of Fonas

Green's Relations with the Assembly

Ne regrets the inadvisability of beginning this study of (32) - D? (ce) Maryland printing history with the interesting account - of its origins invented and set afoot by Scharf (History of Q19 I Maryland, $\mathrm{I}: \mathrm{Ig0}$ ), wherein it is related that a catechism, - composed by Father AndrewWhite in the Indian dialects, was printed on a press controlled by the Jesuit missionaries 14 of St. Mary's sometime before the year 1655. Scharf'sstory was based solely upon his understanding or misunderstanding of Father William McSherry's report (probably an oral report) of his discoveries in the Professed House of the Jesuits in Rome, where in 1832 he had found the manuscript of Father White's Relatio Itineris in Marylandiam and a catechism in the Indian language by the same author. Of all authorities who mention these works, Scharf is the only one who believed, or to whom the thought seems to have occurred, that the catechism was a printed book. B.U.Campbell (Metropolitan Catholic Almanac, Baltimore I 84I, pp. 43-68) mentions Father McSherry's discovery, but says nothing as to the catechism having been printed. Richard H. Clarke (Metropolitan Magazine, Baltimore, 1856, p. 75) implies that the catechism was in manuscript. These two writers were contemporaries of Father McSherry; Scharf wrote a generation or more after his death. The late Rev. E. I. Devitt,S. J.,Professor of Colonial History in Georgetown University (Catholic Encyclopaedia, article "White, Andrew"), says "these works" (i.e. FatherWhite's Relatio, Grammar, Dictionary and Catechism) "were manuscript compositions." He repeats this statement with considerable elaboration in the Sun, Baltimore, June 2, 1907, and most emphatically in a letter to the author written a few days before his lamented death in I920. John Gilmary Shea (Catholic Church in Colonial Days, New York, I886, p. 4I) writes, "The manuscript of the Relatio with an Indian catechism was found in 1832 in the Archives of the Professed House at Rome, by an American Jesuit, Father William McSherry." Neither Father H. J.

[147] 


\section{A History of Printing in Colonial SCaryland}

Foley (Records of the English Province of the Society of Fesus, London, 1878, v.3) nor Father T. A. Hughes (History of the Society of Fesus in North America, London, 4 v., 1907-17) give the impression that Father White's catechism was printed. Indeed in a letter to the author, dated from Rome, August I 3, I920, Father Hughes, after commenting upon the dispersion of the archives of the Professed House among several Jesuit houses of Europe, goes on to say that, "There is not a jot or tittle in them (i.e. the European Jesuit Collections), as far as they concern America, which I did not take down ..." He says further that throughout the entire course of his research he "never lighted upon the catechism or McSherry's 'report' on it," and finally that he was unable to conceive of the existence of a printing press among the Maryland Jesuits in Father White's time. In Carlos Sommervogel's edition of De Backer's Bibliotheque de la Compagnie de Fesus, 8: 1092, is given a list of Father White's printed works followed by the entry of a "Grammar, Dictionary and Catechism, in the Indian language," to which is appended this note, "Mr. Shea dit que cette grammaire est restée en MS. à Rome."

Among writers contemporaneous with Father White whose evidence is of interest in this connection are the anonymous author of the Florus AngloBavaricus, Liége, 1685 ; the Bibliotheca Scriptorum Societatis Fesu, I643; and Nathaniel Southwell's edition of the same work, Rome, 1676 , in all of which the titles of Father White's Maryland writings are given, but no mention is made of any of them being in printed form. Certainly one of these writers, if the catechism had been a printed work, would have given such bibliographical details as place and date of publication, etc. In opposition to this strong negative evidence exists Scharf's statement alone, unsupported by any reference as to when or where Father McSherry had said that the catechism was in printed form. Finally, even if one accepts Scharf's statement to the extent of believing that Father McSherry saw a printed catechism in the tongue of the Maryland Indians, there is yetno evidence that it had been printed in Maryland. If printed at all, the probability is that it was printed on the continent of Europe.

The habit which Colonel Scharf had of jumping to his conclusions is well illustrated by his relation of the story of a later press (circa 1660), based upon an "act for the publication of all the laws within this Province," passed in the Assembly of 1660 . He assumes that the word "publication" as used here meant printed publication. Mr. James Walter Thomas has pointed out (Chronicles of Colonial Maryland, 2d ed.,p. 58) that if Scharf had read more than the title of this act, he would have seen immediately that publication by voice proclamation was specifically prescribed. 
Not the least particle of evidence exists to indicate the possession of a press by the Jesuits before I655, or by the Province in 1660 . Scharf's claims in this matter were dictated by his sentiment of intense local pride, or as has been said, by his misunderstanding of the nature of Father McSherry's discoveries in the Professed House. An uncritical person, such as he was, hearing of Father White's "Catechism" having been discovered in Rome, would be likely to assume that a printed catechism was meant. Even if such an assumption in this case had been correct, there would still exist no evidence that the "Catechism" had been printed at St. Mary's in Maryland. It would seem to be a futile exertion to attempt the refutation of a story which no responsible scholar has given credence to since Scharf's first relation of it in 1879 , but the frequent recurrence of the Jesuit press "legend" in newspaper articles, and elsewhere occasionally, makes it seem desirable in this narrative to present the case against its acceptance even as a legend containing the usual modicum of truth.

\section{The First Act on the Maryland Statute Book for the Encouragement of Printing}

An Act for the Speedy and Effrectual Publication of the Laws of this Province, and for the Encouragement of William Parks, of the City of Annapolis, Printer

(Passed in October Assembly 1727, printed at large in original printed acts of the Session, reprinted Archives of Maryland, 36: 89)

Whereas at a former Session of this present General Assembly, held in the Month of March, Seventeen Hundred and Twenty Six, it was Resolved, That the said William Parks should print the Publick Laws, Speeches, and Answers, at the Opening each Session, and that he should be allowed Two Thousand Pounds of Tobacco for each County, by the respective Counties, Yearly.

And whereas the said William Parks, did (pursuant to the said Resolution)print and de- liver to the Parties mention'd in the said Resolution, the several Publick Laws, enacted in the said Session of Assembly held in the said Month of March, and also in the Session of Assembly held in the Month of July, in the Year of Our Lord Seventeen Hundred and Twenty Six, for which there was due to the said William Parks, Two Thousand Pounds of Tobacco from each County respectively, according to the said Resolution.

And whereas the said William Parks, upon his Application to the Justices of the several Counties, for an Allowance of the Payment of the said Quantities of Tobacco so due to him as aforesaid, hath receiv'd the same from several Counties of this Province, but the Justices of some other Counties have (thro' a misapprehension of the said Resolution) refused to allow and pay the same to the said William Parks: For the Remedying whereof, and for the Prevention thereof for the Future, as also for the Encouragement of the said William Parks, in the Service of the Country, 


\section{A History of Printing in Colonial Maryland}

Be it Enacted by the Right Honourable the Lord Proprietary, by and with the Advice and Consent of his Lordship's Governour, and the Upper and Lower Houses of Assembly, and the Authority of the same, That the Commissioners of the several County-courts of this Province, are hereby impowered and directed to make an Allowance of Two Thousand Pounds of Tobacco in the Levy to be laid for each respective County, next after this present Session of Assembly; and that the said Two Thousand Pounds of Tobacco so to be allowed and assessed as aforesaid, shall be collected by the Sheriff of each respective County, and paid by him, free from all Charges of Collection, to the said William Parks, or his Order for the Printing and Stitching, and Delivering a Copy of the Publick Laws, Speeches, and answers made at this present Session of Assembly, to every Member of Assembly, and Commissioner of the Peace for the Time being, and a Copy of such Laws (bound in Leather) to the Publick, and each House of Assembly, and to each County-court of this Province.

And be it further Enacted, by the Authority aforesaid, That the commissioners of each County-court in this Province, during the Continuance of this Act, be and are hereby impowered and directed, at every Time of laying the Levy, in each respective County, after the End of this present Session of Assembly, to allow the Quantity of 'Two Thousand Pounds of Tobacco, Annually to the said William Parks, or his Order, for the Purposes aforesaid, which the said Justices are hereby impowered to levy upon the Inhabitants of the several Counties, with the Sheriffs Salary for Collection thereof.

And be it further Enacted, by the Authority aforesaid, That the Commissioners of each Court of the respective Counties, who have not already paid and allowed to the said William Parks, the said Quantity of Two Thousand Pounds of Tobacco, for Printing the Laws made at the Sessions of Assembly held in the Months of March and July as aforesaid, shall be and are hereby impowered and directed to allow the said Two Thousand Pounds of Tobacco to the said William Parks, in the Levy to be laid next after this present Session of Assembly, over and above the Two Thousand Pounds of Tobacco to be allowed him as aforesaid, for this present Session of Assembly.

This Act to continue in Force until the Twenty First Day of March which shall be in the Year of our Lord One Thousand Seven Hundred and Thirty Two.

This act expired five years later, and was continued by Chap. I, MarchApril I 732/33, Bacon's Laws of Maryland, for seven years, and a supplementary act was passed, Chap. I3, April-May, I737, Bacon's Laws of Maryland, by which as related in the foregoing narrative, Parks was taken to task for certain duties neglected, and provision made to protect the Province against loss by such neglect in the future. These acts are printed at large in the printed acts of the sessions named (see bibliographical appendix). At the time of passage of the "Supplementary Act" of 1737, the Upper House had proposed a more severe penalization of Parks for his tardiness in printing the acts than was later adopted, but the Lower House, because the existing act prescribed no date of completion, interposed with milder suggestions which were concurred in by the upper chamber and embodied in an act wherein dates of delivery were named and penalties prescribed for failure to observe them. 


\section{Report of the Committee on Jonas Green's Petition of 1762}

\section{$\left(\right.$ Votes and Proceedings, April 13,1762) ${ }^{1}$}

By the Committee appointed by the Honourable the Lower House of Assembly, to enquire into the Facts set forth in the Petition of Jonas Green.

Your Committee, upon Examination of the Facts contained in the said Petition, find, That no Act passed in the Year $173^{8}$ or 1739 , for the Levying or Payment of any Salary to the said Jonas Green; but that in the Year 1742 he was allowed 120 l. in the Journal of Accounts, the Payment of which was in 1743; and in the Year 1748, an Act passed, impowering and requiring Mrs. Hollyday, Executrix of James Hollyday, Esquire, to pay 180 l. to the said Jonas Green, for his Salaries in 1738 and 1739 . That an Act passed in the Year 1740, to continue till the Ist of December, 1742 , for the Yearly Allowance of $15 l$. in each County to the said Jonas Green, but no Session happening after the Expiration of that Act, till May 1744, the said Jonas Green had no Allowance for the Year 1743, till an Allowance was made to him on the Journal of Accounts of 144 l. in the Year 1744 , which was not paid till 1747: That in the Year 1744, an Act passed, to continue till the 25th of December, 1745 , which, in August 1745 , was continued till the 25 th of December, 1746 , giving the said Jonas Green the 15 l. yearly Allowance, in each County, as Printer; and in June 1746, an Act passed, impowering the Justices of Talbot and St. Mary's County to levy $15 l$. in each County in November 1746 , for the said Jonas Green's Use, omitted to be levied in Talbot in 1742 , and in St. Mary's in 1744: That in May 1747, the said Act of 1744 was revived and continued till the 25 th of December 1748 , and an additional Allowance of 5 l. each County given to the said Jonas Green for printing the Votes; but if no Session or Convention, the additional Allowance to cease: That in May 1749, an Act passed to continue till the 25th of December, 1750 , for 20 l. yearly Allowance to the said Jonas Green, in Each County, for his printing the Laws and Votes; but if no Session, 5 l. Part of the Allowance in Each County, to cease: By this Act $40 \%$. was to be levied in Kent County for Omissions in 1747 and 1748 , and 5 l. in Dorchester County, for an Omission in 1747 : In May 1750, the last mentioned Act was continued till the Ist. of December, 1752, and in June 1752, to the Ist. of December, 1753 .

That in October 1753, a new Act passed, to continue till the 20th. of December, 1755, giving the like Allowance to the said Jonas Green, subject to the like Abatement when no Session, as the Act of 1749 , and laying a further Duty on him to print the Inspection Law, passed that Session, for the Vestries and Inspectors, without giving any further Reward for that new Duty: That in February 1756, an Act passed to continue till the 2oth of December, 1757, apportioning the Said Jonas Green's Allowance by the Number of Taxables in the respective Counties, which was continued in September I 757, to the 20th of December $175^{8}$, and which expired on that Day, tho' the Session, begun in November 1758, ended but a few Days before the Expiration of that Law: That in March 1760, an Act passed, to continue to the 2d Day of April, I 76I, giving the like Allowance, and under the like Conditions, as the last mentioned Act, and also impowering the Justices of the respective Counties to levy in the whole, $210 \%$. for his Salary in 1759 , there not having been any Session in that year.

That the Said last mentioned Act Expired the 2d of April, I76I; since which there has not been any Session, and there hath been no Salary or Allowance to the said Jonas Green

${ }^{1}$ See bibliographical appendix for this volume.

[I5I] 


\section{A History of Printing in Colonial SCaryland}

for the Year 1761. That the said Jonas Green hath at several Times Printed long Bills, Records and Papers, inserted in the Journals and Proceedings of the Lower House of Assembly, too numerous to particularize, for which he has not received, as your Committee can find, any Reward, more than his yearly Allowance, tho' the Votes and Proceedings have been swelled to a great Size, by the Insertion of such Bills and Other Matters.

That since the Duties of Printing the Laws, andVotes and Proceedings, have been blended, including May Session, 1747 , and excluding the present Sessions, there have been Twentytwo Sessions, and Six Conventions of the Assembly, so that there have been Thirteen Meetings of the Assembly in and since 1747 , more than at the Rate of one for each Year.

\section{Later Legislation for the Encouragement of Jonas Green}

In 1762 , to expire April I 765 , an act was passed, as the result of the foregoing report, by the terms of which Green was to receive each year that there was held a session of Assembly two hundred and seventy-nine pounds currency, but only two hundred and ten pounds if there were no Assembly. To entitle him to the first mentioned allowance, he was obliged to produce a certificate from the Sheriff of AnneArundel County that he had delivered to him the printed laws of each Session within three months after its close, the $V$ otes and Proceedings within four months. By another section of this act five hundred pounds were to be paid him for public services for which he had received no allowances, this sum to be diverted from a fund which had been set aside in 1754 under the provisions of "An Act for his Majesty's Service."

In 1763 an act passed in November says that the limitations of time imposed in the act of 1762 being too short for printing the laws of this session on account of the approaching "bad Season," the time of printing the laws was extended to four and the Votes and Proceedings to five months (Bacon I 763 , ch. 33). At this session, although a short one, the Assembly had passed among others, "An Act for Amending the Staple of Tobacco, for preventing Frauds in his Majesty's customs, and for the Limitation of Officers Fees," a notable piece of legislation, embodied in one hundred and fifty-three sections, occupying fifty of Bacon's folio pages for its publication. With the short and dark days of the "bad Season" coming on, it is not remarkable that Green had asked for and obtained an extension of time on his printing of the acts and proceedings of this Assembly. In section I 8 of this long act of 1763 we find that hereafter Green was to be allowed by each County Court at the laying of its levy three hundred and twenty pounds of tobacco per annum for printing and delivering a sufficient number of books, notes and manifests for the use of the tobacco inspectors at their annual inspections. In Section I 20 of the same act it appears that three hundred and 


\section{The Fesuit Press . Documents Relating to Parks and Green}

twenty pounds of tobacco is almost equal to a moidore in money and quite a little more than an English guinea.

In 1765 an act of Assembly allowed him forty-eight thousand pounds of tobacco for session years, and thirty-six thousand one hundred and nine pounds for years in which there were no sessions, and at this rate of payment Green worked until his death two years later. In the session of I 768 his widow, Anne Catharine Green, was appointed public printer and an act passed for her encouragement at the above mentioned salary.

\section{The "Printing-House" Equipment of Jonas and Anne Catharine Green}

At the time of Jonas Green's death, intestate, his widow appeared as administratrix October I, I767 (Inventories, 94: I6I-I65, ms. in Land Office, Annapolis), and took oath as to the correctness of the subjoined inventory, in which appeared this item:

"To 2 old printing presses and a quantity of printing Materials consisting of Types \& Calculated to be of the Value of $£ 90$. 14. 5."

When Anne Catharine Green died, in 1775 , her inventory of goods and chattels (Inventories, I I 9: 344-349, ms. in Land Office, Annapolis) showed the following itemization of the contents of the Green "printing house":

About 360 wt. English letter $3 / 4$ worn at $3 d$

About 390 Small Pica do at $3 \mathrm{~d}$

$4^{-10-0}$

About 400 Long Primer $1 / 2$ worn at $6 \mathrm{~d}$

About 200 Burgeois do at $7 \mathrm{~d}$

$4-17-6$

About 600 do-Good for Little

$10-0-0$

About 300 different Sorts a great deal worn at $3 \mathrm{~d}$

5-I6-8

$3-0-0$

One Press and Furniture

$3-17-0$

One very old do

Five Friskets

Three pair Tympans one old

$10-0-0$

$2-0-0$

$I-\infty$

$I-\infty$

Four paire Pints [?] some Broke

$-\mathrm{I}-\mathrm{O}$

$-4-0$

Four pair old Ball Stocks

Nine paire Iron Chases

Twelve Composing Sticks

Twenty Gallies and some flies [?]

Fourteen Letter Boards
Two paire old Shears, one paste Brush, Tin fender, Board Stand

pair belows and a parcel quoins and Reglet

Seven old Frames

Two Imposing Stones on Frames

A pair Leather Buckets and Bag

$I-I 2-O$

I $-0-0$

I $-4-0$

$0-8-0$

$0-12-0$

$1-5-0$

$1-0-0$

[Total $\frac{1-73^{-2} \text { ] }}{53^{-}}$ 



\section{MARYLAND IMPRINTS OF THE COLONIAL PERIOD 1689-1776 \\ $\$$}


"... the publication of every book which has issued from printing house or Scriptorium is an event in the spiritual history of the human race, and more particularly in the spiritual history of the country and city in which it appears, and ... therefore a record of the publication of books ought to be kept."

-A.W. Pollard in The London Mercury for February 1921. 


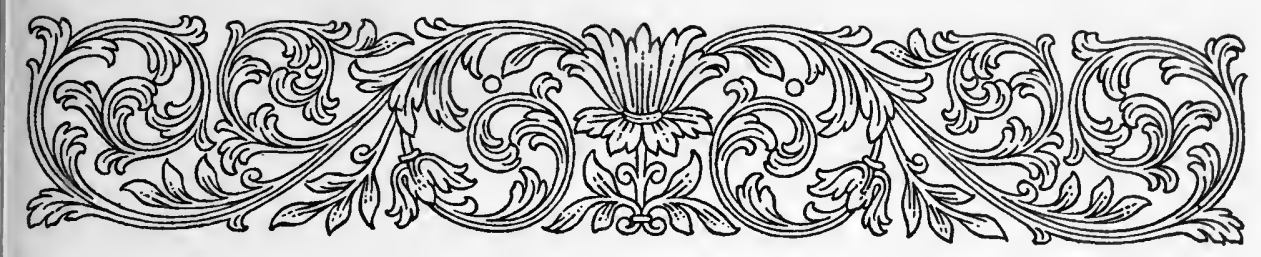

MARYLAND IMPRINTS

An Annotated Bibliography of Books, Broadsides and Newespapers Printed in SCaryland from I689 to 1776

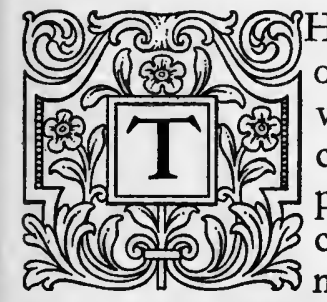
ject to show in regard to each book:

I. An exact transcript of its title-page with the line endings indicated.

2. Where title-page is lacking, an exact transcript of its main heading, and of its colophon, if present.

3. Where headings, imprints and dates are lacking to supply them in square brackets, giving, when possible, authorities for the matter supplied.

4. A moderately full collation, consisting of size (fold of the sheet); signature sequence (with a superior number indicating the number of leaves in each gathering of the copy examined); the total number of leaves; the pagination; the main heads and the pages occupied by each; typographical ornaments; linear size of the title-page in inches as being easy to visualize, and of the type page in millimeters as being exact for purposes of identification.

5. A note comprising facts in the life of the author; explanations of the matter of the book; such part of the history of the book as is known or seems of importance to record; cross references to works of a related character.

6. The library or libraries in which the book described is to be found.

The compiler has examined personally all of the items given with collations in this bibliography, except the following:

Nos. I, 20, 21, 70, I 22, I 40, I77, I86, 234, 244 and 245. Of these he has given title transcripts from photographic copies of all except Nos. I 77, 244 and 245 .

A number of additional titles not seen by the compiler are copied from Evans's American Bibliography where no location was given for them. In

[ 157 ] 


\section{A History of Printing in Colonial SCaryland}

these cases, the Evans reference is noted and the fact mentioned that no copies have been located.

Collations of the unique British Museum items have been supplied by Messrs. Edw. C. Allen and Son, Ltd. and Messrs. B. F. Stevens \& Brown, of London. The transcripts and collations of items in libraries outside of Maryland have been verified by the librarians of the institutions in which these items are found.

\section{Explanation of Symbols and Abbreviations}

Fol. 4to. 8 vo. The size notation employed, Fol., 4to, 8 vo, etc., indicates the fold of the sheet as determined by the Bodleian rules formulated for this purpose.

* Asterisk. Where the size notation is preceded by an asterisk, it means that the printer has used a paper without watermark and turned his paper in such a way as to render the format of the book difficult of determination. In these cases (almost invariably a volume of session laws or of "Votes and Proceedings"), the compiler has given the normal notation of the series to which the book was an annual addition.

( ) Round brackets have been used in the transcripts for interpolated or condensed information supplied by the book itself, as for example, dates of sessions of Assembly or inclusive annual newspaper dates.

[ ] Square brackets have been used to enclose titles not seen or not described as having been seen by competent authority; titles taken from newspaper advertisements; descriptive words or phrases introduced into the transcripts by the compiler; imprints or dates not actually present in the book.

Preliminary leaf $\}$ mean leaves at the beginning or end of the volume, forming part of Supplementary leaf $\}$ mean leaves at the beginning or end of the volume, forming part of usually found in copies of the "Acts" or of the "Votes and Proceedings" of the Assembly, and are not accounted for in the signature sequence of the series, which sometimes continues for several years.

\section{Signatures}

The alphabet employed by the colonial printer for signatures was that customarily used for this purpose by early printers; namely, one of twenty-three letters in which " $\mathrm{J}$ " and " $W$ " are never used, and either " $U$ " or " $V$ " is invariably omitted.

The description A-D" means A, B, C, D, with four leaves to each letter; in like manner $A-D^{8}$ would mean that each of the four gatherings had eight leaves, and in neither case would it mean necessarily that the work was in quarto or octavo. The size notation given first in the collation has been determined by the position of water marks and the direction of chain lines in accordance with the Bodleian rules.

A signature letter used with an inferior number, as for example $A_{2}, A_{3}$ or $A_{4}$, means the second, third or fourth leaf of the gathering A.

\section{General}

Except in instances where the result has seemed to be of importance, no attempt has been made to account for missing end leaves or fly leaves. Blank end leaves or fly leaves, however, have been noted when perfect copies have been found containing them. 
A page not mentioned specifically or inclusively in the collation by pages may be assumed to be a blank.

Capitals have been employed in the transcripts where the compiler believes that the printer or his contemporaries would have employed them if they had been writing the title for other purposes than display on a title-page. Unimportant words, even at the beginning of lines, have been put in lower case.

Because of the necessity of keeping the length of this bibliography within certain specified limits, the compiler has made no attempt to list the various issues of paper money engraved by Thomas Sparrow and printed by Anne Catharine Green and her sons, nor has he listed legal forms, land warrants, writs, etc., except when these have seemed to him to possess especial significance.

Abbreviations Used for Libraries in which Imprints Are to Be Found

AAS -American Antiquarian Society.

BA -Boston Athenaeum.

BBL - Library Company of the Baltimore Bar.

BM -British Museum.

HLS - Harvard Law School.

HSP - Historical Society of Pennsylvania.

HU - Harvard College Library.

JCB - John Carter Brown Library.

LC - Library of Congress.

Leiter Collection-The private collection of the late Levi Z. Leiter of Washington, See note to the Introduction of this volume.

MassHS-Massachusetts Historical Society.

MDioc-Maryland Diocesan Library.

MdHS-Maryland Historical Society.

MDSL-Maryland State Library.

NYBA-Association of the Bar of the City of New York.

NYHS-New York Historical Society.

NYPL-New York Public Library.

NYSL - New York State Library.

PI -Peabody Institute of Baltimore.

Pleasants-The private collection of Maryland "Acts of Assembly" and "Votes and Proceedings" of J. Hall Pleasants, M. D., of Baltimore.

PRO -Public Record Office, London.

SLM - State Library of Massachusetts.

VSL - Virginia State Library.

Authorities Frequently Referred to in the Notes and the Abbreviations by which They Are Indicated

Allen, St. Ann's Parish: Allen, Ethan, D. D., Historical Notices of St. Ann's Parish in Ann Arundel County, Maryland-1649 to 1857 . Baltimore. 1857.

[ I59] 


\section{$A$ History of Printing in Colonial Scaryland}

Brigham, American Newspapers: Brigham, Clarence, Bibliography of American Newspapers, I690-1820. Part III (Maryland) in Proceedings of the American Antiquarian Society for April I9I 5. (To be revised and issued in book form.)

Calvert Papers: The collection of papers of the Lords Baltimore and other members of the Calvert family relating to the government of Maryland, preserved in the Maryland Historical Society.

Charlemagne Tower: The Charlemagne Tower Collection of American Colonial Laws. Historical Society of Pennsylvania. 1890.

Clayton-Torrence: Clayton-Torrence, William, A Trial Bibliography of Colonial Virginia. 2 v. Richmond. Ig08-Io. (Being parts of the fifth and sixth annual reports of the Virginia State Library.)

Dulany Papers: Collection in Maryland Historical Society.

Evans, No. : Evans, Charles, American Bibliography. ... vols. I-8+, 1639-1792+. Chicago. 1903-1914.

Ford, Bibliographical Notes: In the Fournals of the Continental Congress, edited by Worthington C. Ford. 23 v. Washington. I 904-I9I 4. (Based on the work of the late Paul Leicester Ford and appended to the terminal volume of each year's journal.)

Fothergill: Fothergill, Gerald, A List of Emigrant Ministers to America, I690-I8II. London. I904.

Gilmor Papers: Collection in Maryland Historical Society.

Hildeburn: Hildeburn, C. S. R., A Century of Printing. The Issues of the Press in Pennsylvania, 1685-1784. 2 v. Philadelphia. I885.

Perry, Collections: Perry, William Stevens, Historical Collections of the American Colonial Church. v. 4, Maryland, v. 5, Delaware. 1878.

Sprague, Annals (Epis).: Sprague, Wm. B., Annals of the American Pulpit . . 9 v. New York. 1865-1877. (Vol. 5. Episcopal.)

U. H. J.: Upper House Journal of the Maryland Assembly.

L. H. J.: Lower House Journal of the Maryland Assembly.

Printed from the originals for the years 1637-1 740 in various volumes of the Archives of Maryland, vols. I-40+. Baltimore, $1883+$. In this same series are to be found also the "Acts of Assembly" printed from the originals. At the beginning of vol. 40 will be found the contents of the series.

V. \& P.: Votes and Proceedings of the Lower House of Assembly of Maryland. (For original printed editions of these, see under each year from $1727-1776$.

The compiler wishes to make an especial acknowledgment of the value to him of Charles Evans's American Bibliography in the preparation of the following list of Maryland imprints. Mr. Evans's contribution to American literary history has been of such a character as to entitle him to the gratitude of all students in that and related subjects. His diligence and courage and single-minded devotion have cleared a highroad through a wilderness in which, before his work was published, adventurers stumbled along uncertain trails. 


\section{Maryland Imprints of the Colonial Period, i689-i776}

I. Maryland, Province of. The | Address | of the Representatives of their Majestyes Protestant | Subjects, in the Provinnce [sic] of Mary-Land Assembled. | To the Kings most Excellent Majesty. | ... [Colophon:] Maryland printed by order of the Assembly at the Citty | of St. Maryes August: 26th. 1689.|

Broadside. $12 \times 8$ inches.

See Chapter One of the preceding narrative for a photographic reproduction and a discussion of this broadside, the earliest issue of the Maryland press of which a copy is known to be extant. As there remain no records or traditions of the existence of other printers in Maryland at this time, it seems reasonable to attribute the printing of this document to William Nuthead, the printer who was in the employment of the Province from 1686 to 1694. The single known copy of the broadside, that in the Public Record Office, London, (C. O. 5/718), bears the following written attestation: "This is a true coppy of the Originall Attested per John Llewellin Clk Assembly." It is endorsed "Maryland 26th August 1689. Address of the Representatives to the King. Recd. from my Lord Shrewsbury 7 th Feb: 89 . Copy recd: 31 . December." The copy referred to in the endorsement was in manuscript

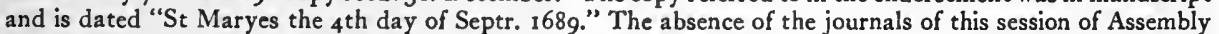
makes it difficult to explain the earlier date of the printed document, but its colophon and the attestation of the clerk of Assembly which it bears seem a guaranty of its Maryland origin and of its authenticity. The printed "Address" was reprinted in Archives of Maryland, 13: 232; the manuscript document was printed in the same volume, pages $239-240$.

PRO.

2. Protestant Association, The. The | Declaration | of the | Reasons and Motives | for the Present | Appearing in Arms | of | their Majesties / Protestant Subjects | in the Province of | Maryland.| Licens'd, November 28th I689. J. F.| [Colophon:] Maryland, Printed by William Nuthead at the city of St. | Maries. Re-printed in London, and Sold by Randal Tay-| lor near Stationers Hall, 1689.|

$\mathrm{Sm}$. fol. A-B"; 4 leaves; pages I-8: text, with heading as above; page 8: "Published by Authority", at conclusion of text, followed by colophon as above.

Leaf measures: II $\times 7 \frac{15}{16}$ inches. Type page, p. 3: $222 \times 135 \mathrm{~mm}$.

No copy of the original Maryland edition has been recorded. Evidence that it was published is found in the colophon cited above, in the known facts of William Nuthead's life (see Chapter One of the foregcing narrative), in the assertion regarding it in Chalmers, George, Political Annals (citation below), and in memorandum of the Lords of Trade of Jan. 7, 1689/90 (C. O. 5: 723, printed in Archives of Maryland, 8: 162) when their lordships requested their president to lay before the King, together with other Maryland documents, "a declaration in Print from the Inhabitants there." The last mentioned piece of evidence, however, is weakened by the fact that there is no printed copy of the "Declaration" among the Maryland papers preserved in the Public Record Office. A Ms. copy with signatures is in C. O. $5 / 718$.

In his Political Annals, Book I, Lond. 1780, p. 384, George Chalmers (lawyer, historian and typographical annalist, resident of Maryland, 1763 -circ. 1774) wrote: "The Declaration of the Associators was printed at St. Mary's by the printer of the Province." In his Ms. "Notes and Transcripts" in the New York Public Library, of which the transcripts are principally copies of papers in the Public Record Office, he has an abstract of the "Declaration" and in a parenthesis at the head of it the word "printed." It is possible, of course, that Chalmers had knowledge of the London reprint and accepted the statement of its colophon without question.

In the entry of the title as given above occurs the official imprimatur of the book: "Licens'd November 28th 1689. J. F." Under the impression that the person represented here by the initials "J. F." was the author of the "Declaration", Evans, No. 466, has entered it under these initials. This was setting up a difficulty where none existed; the "Declaration" was of joint authorship (see Chapter One of the foregoing narrative), and "J. F." was simply the licenser of the London edition. His initials, or full name "James Fraser," appear in precisely the same association in the entries of many works licensed in 1689 by the Stationers Company of London. (See $A$ Transcript of the Registers of the Worshipful Company of Stationers; from 1640-1708 A. D. 3v. Lond. 1913-1914, being the Roxburghe Club supplement to Arber, Edward. ed. A Transcript of the Registers of the Company of 


\section{$A$ History of Printing in Colonial Saryland}

Stationers of London; $1554-5640$ A. D. 5v. Lond. 1875-1894). By the Star Chamber decree of 1637 , continued in essentials by 13,14 Charles II, and by 1 James II, c. 17 and 18, and finally expired in 1694, the licensing power for books of law was vested in certain judges; of history, in the secretaries of state; of heraldry, in the earl marshall; of all other books, in the Archbishop of Canterbury and the Bishop of London. In this year the evidence of the Stationers' register indica tes that one James Fraser was acting as licenser for the secretaries of state. (For information as to the practises of the Stationers Company and the operation of the Licensing Act, see the several prefaces of the Arber "Transcript" and the Roxburghe Club supplement referred to above; for a brief and interesting discussion, see Birrell, Augustine. Secen Lectures on the Law and History of Copyright in Books. Lond. I89g. passim.)

The London reprint of the Maryland "Declaration" is analogous in many details to "The Declaration of the Gentlemen, Merchants and Inhabitants of Boston, and the Country Adjacent", which occupies pp. 7-19 of Byfield's "An Account of the Late Revolution in New England. Together with the Declaration ... [as above] April 18, 1689. Licensed June 27, 1689. J. Fraser.", printed in London in 1689 by Ric. Chiswell, who to his reprint of the "Declaration" appends a note asserting that it had been "Printed according to the copy Printed in New England by Samuel Green, 1689." Evans, No. 49I, locates one copy of the American edition of the Boston "Declaration" in the Massachusetts State Library and one in a private library. Another, according to Charles M. Andrews, Narratives of the Insurrections, p. 169, is in the Public Record Office.

The London reprint of the Maryland "Declaration" was reprinted in Magazine of American History, v. I, 1877, and in Charles M. Andrews, Narratives of the Insurrections, $1675-1600$, published in 1915 as one of the "Original Narratives of Early American History" series. The manuscript version, with the eight signatures of the leaders of the Association is in the Public Record Office (C. O. 5/718) whence it was copied in Archives of Maryland, 8: I01.

Copies of the London reprint described above are to be found in: JCB. LC. BM. BODLEIAN (three copies). Leiter Collection, which has the Brinley copy.

$$
1694
$$

3. [Coney, Peregrine. A Sermon preached before His Excellency and both Houses of Assembly of Maryland on Wednesday the 26th of September, 1694. By the Reverend Peregrine Coney. St. Mary's City: Printed by William Nuthead. 1694.]

No copy of this sermon has been recorded. On Sept. 27, 1694 (Archives of Maryland, 19: 40) the Upper House "Ordered that thankes be Returned to Mr. Coney and Mr. Hewet for their Sermons preached yesterday being the day appointed for the ffast. And that Mr. Coney be desired to print his Sermon". A brief account of this clergyman is found in Allen, St. Ann's Parish.

$$
1696
$$

4. [Coney, Peregrine. A Sermon preached before His Excellency and both Houses of Assembly on Thursday, the 7th of May 1696, being the Day set apart for a Solemn Thanksgiving for His Majesty's Success and Safe Arrival. By the Reverend Peregrine Coney. Annapolis: Printed by Dinah Nuthead. 1696.]

No copy recorded. See Archives of Maryland, 19: 313, $3^{16}$ and 362, where the suggestion "That Mr. Couey [sic] be desired to Print his Sermon preached yesterday" made by the Upper House on May 8th was answered next day by the delegates as follows: "Resolved that the thanks of this house be returned Mr. Peregrine Couey [sic] for his thanksgiving Sermon, preached on Thursday last being the Day sett apart for a Solemn thanksgiving for his Ma'tys Success and Safe Arrivall." Three days before the Upper House suggested that this sermon be printed, its mem'uers had read, approved and passed on to the Lower House Dinah Nuthead's petition to be allowed to establish her press in Annapolis. See Chapter One of the foregoing narrative.

\section{0}

5. Bray, 'Thomas. The / Necessity / of an Early | Religion | Being a / Sermon | Preach'd the 5 th. of May before the | Honourable |Assembly of | Maryland | By Thomas Bray D. D.| Annapolis Printed by Order of the | Assembly By Tho: Reading, for Evan Jones Book-| seller, Anno Domini 1700 .|

Sm. 4 to. $[\mathrm{A}]^{2}, \mathrm{~B}-\mathrm{C}^{4}, \mathrm{D}^{2}$; i I leaves; pages [i-ii], I-20; p. [i]: title, verso: "May the 9 th. 1700 . Ordered that Doctor Bray be Returned Thanks for his Excellent Sermon on that 'Text, Remember thy Creator in the days of thy yoath, [sic] \&c. And desire the same to be printed. Tho: Smithson Speaker."; pp. 1-20: text, with heading, A 1 


\section{SCaryland Imprints of the Colonial Period, $1680-1776$}

Sermon,| Preached before the | Honourable | Assembly, of | Maryland.| May the 5th. 1700.| Ecclesiiastes [sic] the XII. Verse the I.| [Verse quoted in three lines].

Leaf measures: $7 \frac{1}{2} \times 5 \frac{1}{16}$ inches. Type page, p. $2: 156 \times 130 \mathrm{~mm}$.

See Archives of Maryland, 24: 82. The edition here described is not to be confused with that which was entered by Watt in his Bibliotheca Britannica under the title: "Early Religion; a Sermon on Eccles. XII. I. I704. 8 vo.", for it must have been that in making this entry the indefatigable, but not always exact, Dr. Watt had in mind the following work: $A$ Pastoral Discourse to Young Persons, Reminding them of the Necessity and Advantage of an Early Religion ... By Thomas Bray, D. D. London. MDccIv. This publication in octavo, a copy of which is in the Maryland Historical Society, comprises a long preface and the same sermon which Dr. Bray had preached before the Assembly of Maryland and published in Annapolis in 1700, very much altered in parts for its more particular application to the needs of his younger auditors. It is likely that Watt had never heard of the Maryland edition.

The copy of The Necessity of an Early Religion in the Maryland Historical Society, Evans, No. 904, seems to be unique. It was bought at the Brinley Sale, $2: 3667$, for $\$ 72$, and it is in fair condition, although it has been cropped and the inner top margins of pages I-4 have been crudely repaired. It is the earliest example of Maryland printing extant in this country, as far as is known, and it is believed that this is the copy which was referred to in Stevens, Historical Nuggets, $1: 339$; Stevens, Auction Ca talogue, ' 61,381 ; Sabin, No. 7480. It was reprinted in Reo. Thomas Bray. His Life and Selecied Works Relating to Maryland, edited by Bernard C. Steiner as Maryland Historical Society Fund Publication No. 37. Balto. 1901, where it occupies pp. 99-122. In this publication also was printed $A$ Short Historical Account of the Life and Designs of Thomas Bray, D. D. late Vicar of St. Botolph's Without Aldgate, [by the Rev. Richard Rawlinson], the first publication in its entirety of the Rawlinson Ms. from which was chiefly taken the well known Public Spirit Illustrated in the Life and Designs of the Reverend Thomas Bray, D. D. London. 1746. Second ed. 1808. There should be consulted also as to Dr. Bray's American activities the following: "Rev. Thomas Bray and his American Libraries", by Bernard C. Steiner in the American Historical Review, 2: 59 et seq., and the History of the New York Society Library, by Austin Baxter Keep. N. Y. 1 go8. Other printed sources are available, notably Perry, William Stevens. History of the American Episcopal Church. 2v. Bost. 1885, and the same author's Historical Collections Relating to the American Colonial Church. v. 4 (Maryland).

See Plate II for a photographic reproduction of the title-page.

MdHS. NYPL. (Photostat copy).

6. [Maryland, Province of. An Act for the Service of Almighty God and Establishment of Religion in this Province According to the Church of England. Annapolis: Printed by Thomas Reading. 1700.]

No copy recorded. Ordered printed and distributed, one to each parish, by resolution of Lower House. See L. H. J. May 7, 1700 , Archioes of Maryland, 24:67.

7. - [A Complete Body of the Laws of Maryland. Annapolis: Printed by Thomas Reading. I700.]

Collation of unique and imperfect copy in Library of Congress is as follows:

Fol. 2 preliminary leaves, $A-Z^{2}, A a-B^{2}$ and fragments of $\mathrm{C}_{\mathrm{C}}-\mathrm{Ff}^{2}, \mathrm{Gg}^{1}$, making a total of $6 \mathrm{I}$ leaves and parts of leaves; pages [iii-vi], I-1 I8+; title-page lacking; p. [iii]: "To my Honoured and Ingenious Friend Mr. William Bladen at the [Port] of Annapolis"; pp. [v-vi]: "The Index"; pp. I-I 1 8: text of laws contained in "confirming" act of 1700 , together with laws, passed at session of Apr. 26-May 9, 1700 (Archives of Maryland, v. 24); p. I19 when present, as Index shows, contained text also; p. 120: contents unknown.

Leaf measures: $13 \frac{1}{\frac{1}{2}} \times 7^{\frac{3}{2}}$ inches. Type page, p. $5: 278 \times 145 \mathrm{~mm}$.

In the foregoing narrative (Chapter Two) there is an extended discussion of this book. The supposedly unique copy in the Library of Congress lacks its title-page, pages 49-62 are damaged and pages 101-1 20 exist only in small fragments. This copy belonged at one time to John Bozman Kerr and has his notes.

\section{702}

8. Great Britain. Anne by the Grace of God of Great Brittain [sic] France \& Ireland Queen Defender of the Faith \&c. To the Sheriff of County greeting. We com- $\mid$ maud [sic] you that you Summon that all Excuses set aside be and appear before the I Justices of our Court to be held at the day of next to testify the truth of knowledge in a certain / matter of Controversy in our said Court depending 


\section{A History of Printing in Colonial SCaryland}

between Plaintif and Defendant on / part of the hereof not to fail on pain of five pounds Sterling, and fail you not at your peril, and have you then and there his Writt. Witness | Chief Justice of our said Court this day of in the year of our Reign \&c. Anno Domini .| [Annapolis: Printed by Thomas Reading. 1702.]

Broadside. $1 \frac{1}{2} \times 14^{\frac{1}{2}}$ inches.

In the year 1700, William Bladen, Thomas Reading's associate in the press, petitioned the Assembly that only printed blank forms should be used by the Provincial officers in public business, and for his encouragement and recompense it was so ordered. See L. H. J. May 6, 1700, Archives of Maryland, 24: 60, where the following list of forms and the prices at which they could be purchased is given:
Writs
Citations
To be had at one penny or one
Summonses
Letters Testamentary
Letters of Administration pound of tobacco each.
Bail Bonds
To be had at two pence or two pounds of tobacco each.

The court summons above described is one of the printed official forms provided for in the ordinance of Assembly here referred to. This example is crudely printed in the worst style of Thomas Reading. It is entered here under the earliest year in which it could have been printed; that is, 1702, the first of Queen Anne. The copy described is addressed to the sheriff of Baltimore County requiring him to produce in court as a witness one "Patrick Murfy"; it is dated in script "April 20, 1714" and signed by John Stokes, clerk of the Court. The "Proceedings" of the Baltimore County Court show that John Stokes took oath as clerk of the court in Nov. 1710, was appointed or served as High Sheriff in March 1715 and took oath as clerk again in Aug. 1718. (Information from Mr. William B. Marye of Baltimore.)

MdHS.

9. Keith, George. The | Powe, $[$ [sic] | of the / Gospel, | in the | Conversion of Sinners | in a | Sermon | Preach'd at | Annapolis in Maryland, | By George Keith M. A.| July the $4^{\text {th }}$ [Annapolis:] Printed and are to be Sold by Thomas Reading, at the Sign of the George Anno Domini mDcciri.|

Sm. 4 to. B-C4, D3; II leaves; pages [i-ii], I-I9, [20]; p. [i]: title; pp. I-Ig: text, with heading, A|Sermon | Preach'd at Annapolis July the $4^{\text {th }}$ I 703.| By George Keith M. A.| I. Thess. I. 5.| [Two lines quoted].

Leaf measures: $8 \times 6 \frac{1}{8}$ inches. Type page, p. 2: $170 \times 121 \mathrm{~mm}$.

For the circumstances attending the delivery of this sermon and its publication in Annapolis see Keith, George, A Fournal of Travels from New Hampshire to Caratuck. . . , London, 1706, p. 66; reprinted New York, 1851, in "Collections of the Protestant Episcopal Historical Society," which see, p. 39. Quotation of the essential part of the passage is made in the foregoing narrative (Chapter Three). On page 52 of the New York reprint of t' ie Fournal, Keith gives the titles of the ten treatises which he "wrote and Published in Print, in North America, ... in the years 1702 , and 1703 , to 1704 ."

In the imprint of the above entry, the words "the George" are sometimes recorded as "tho [sic] George", but this is incorrect. The letter is not an "o," but a broken " $e$." The JCB. copy is evidently an earlier issue than that in the NYHS., for on the latter title-page the misplaced comma in the word "Powe, $r$ " has been caught by the printer and removed.

JCB. NYHS. Leiter Collection. MdHS. (Photostat copy).

$$
1704
$$

Io. An | Abridgement | of the | Laws | in Force and Use in | Her Majesty's Plantations; (Viz.) of

$$
\begin{aligned}
& \text { Virginia, } \\
& \text { Jamaica, } \\
& \text { Barbadoes, } \\
& \text { Maryland, }
\end{aligned}
$$

New England,

New-York,

Carolina, \&c. 
Digested under proper Heads in the Me-/ thod of Mr. Wingate, and Mr. Washington's | Abridgements. | London, | Printed for John Nicholson at the King's-Arms in | Little Britain, R. Parker, and R. Smith, under| the Royal-Exchange, and Benj. Tooke at the Middle-| Temple-Gate in Fleetstreet, $1704 . \mid$

8 vo. $\mathrm{A}^{2}, \mathrm{~B}-\mathrm{S}^{8}, \mathrm{~T}^{8}, \mathrm{~B}-\mathrm{N}^{8}, 2$ unsigned leaves, $\mathrm{U}^{8} ; 250$ leaves. In the second series of signatures, the sections B-F ${ }^{8}, G^{4}$, pages I-[87], [88], contain: An | Abridgement | of the | Laws | of | Maryland,| Now in Force.| Under Proper Heads.|; pp. [81-87] are wrongly numbered 65-7I, so that the Maryland laws while appearing to occupy only 71 pages, in reality occupy 87 pages. Full contents of the volume given in Charlemagne Tower, No. I, and in Clayton-Torrence, No. 91.

Leaf measures: $7^{\frac{3}{6}} \times 4^{\frac{5}{3}}$ inches. Type page, p. $2: 162 \times 82 \mathrm{~mm}$.

References in the Maryland section are to the statutes at large in the edition of collected laws printed at Annapolis in 1700 , see above, No. 7 . See foregoing narrative for reference to "An Abridgement" in connection with the discussion in Chapter Two of this edition of collected laws.

MdHS. LC. VSL. HSP. NYPL. NYBA. SLM. BA. JCB.

II. [Cоскsнuтt, Tномаs. A Sermon preached at the Opening of St. Anne's Church, Annapolis, on Sunday the $24^{\text {th }}$ of September, 1704, in the Afternoon. By the Reverend Thomas Cockshutt. Annapolis: Printed by Thomas Reading. 1704.]

No copy recorded. In the U. H. J. for Oct. 2, 1704 (Archives of Maryland, 26: 86) is found the following entry: "By the Council \&c. The Board resolve that the Sermon preached by Mr. Cockshutt at the opening of the Church at Annapolis on Sunday the 24th of September in the Afternoon be printed if the House shall think fitt. Signed per Order W. Bladen Cl Council. Which was returned by Major Greenberry with the Houses Concurrence."

12. [Maryland, Province of. The Laws of the Province of Maryland, made and passed at a Session of Assembly begun and held at the City of Annapolis on the fifth day of September, 1704. Annapolis: Printed by Thomas Reading. 1704.]

No copy recorded. See below, note to No. 19.

13. - [The Laws of the Province of Maryland, made and passed at a Session of Assembly begun and held at the City of Annapolis on the fifth day of December, I704. Annapolis: Printed by Thomas Reading. 1704.]

No copy recorded. See below, note to No. I9.

14. [Wooton (Wooten), James. A Sermon preached at the Opening of St. Anne's Church, Annapolis, on Sunday the 24 th of September, 1704 , in the Morning. By the Reverend James Wooton. Annapolis: Printed by Thomas Reading. 1704.]

No copy recorded. In the U. H. J. for Sept. 25, 1704 (Archives of Maryland, 26: 69-70) is found the following entry: "By the House of Deleg's... This House are very well Sa tisfied with the well composed Discourse preached by the Reverend Doctor Wooton at opening of the Annapolitan church and think it highly worthy of the press which if your Ex'cy does we pray your Ex'cy to give Order for ... which was assented to by the Council. W. Bladen $\mathrm{Cl}$ Coun."

The Rev. James Wooton received the royal bounty for his passage to America on Aug. I2, 1703. (Fothergill). A brief account of him is found in Allen, St. Ann's Parish.

\section{5}

I 5. [Maryland, Province of. The Laws of the Province of Maryland, made and passed at a Session of Assembly begun and held at the City of Annapolis on the fifteenth day of May, I705. Annapolis: Printed by Thomas Reading. 1705.]

No copy recorded. See below note to No. I9.

$$
1706
$$

16. Maryland, Province of. Maryland ss. | At a Sessions of Assembly begun and held at the Town and Port of | Annapolis April the Second and Ended the Nineteenth of the same 


\section{$A$ History of Printing in Colonial Saryland}

| Month Anno Domini I 706. In the Fifth Year of the Reign of Our Most | Gracious Sovereign Lady Queen Anne, \&c. His Excellency | John Seymour Esq؛ [sic] being Governour, were Enacted these | Laws following viz. | [Annapolis: Printed by Thomas Reading. 1706.]

Fol. B-C', $D^{1}$; 5 leaves; pages I-IO: text, with heading as above; p. IO: "Finis".

Leaf measures: $14 \frac{3}{\frac{3}{3}} \times 91^{\frac{1}{6}}$ inches. Type page, p. 2: $304 \times 151 \mathrm{~mm}$.

No copy of the separate issue of the session laws of April 1706 is known to exist, but the bibliographical evidence gives clear indication that a separate issue did exist at one time, and that when this separate issue was printed a number of extra sheets were run off and held for later inclusion in their proper chronological order in the volume of collected laws described below as All the Lawes of Maryland Now in Force, of which volume the sheets described in this entry form a part. This point is discussed below in the collation and note of No. 17.

1707

17. Maryland, Province of. [All the Laws of Maryland Now in Force. Published by Authority of the General Assembly. Annapolis: Printed by Thomas Reading. 1707.]

Fol. The single known copy is imperfect. The collation of the remaining leaves is as follows: $\mathrm{B}^{-\mathrm{U}^{2}}, \mathrm{X}^{1}, \mathrm{~B}-\mathrm{C}^{2}$, $\mathrm{D}^{1}, \mathrm{Aa}-\mathrm{Ee}^{2} ; 54$ leaves; pages I-77, [78]; 1-10; 95-1 14; pp. I-3: laws of April session 1704, with session heading; pp. 4-65: laws of September session 1704, with session heading; pp. 65-75: laws of December session 1704, with session heading; pp. 75-77: laws of May session 1705, with session heading; p. 77: "Errata"; p. [78]: blank; pp. I-10 (second series, signatures B-C $\mathrm{C}^{2}, \mathrm{D}^{1}$ ): laws of April session 1 706, with session heading; P. IO: "Finis"; pp. 95-106: laws of March session 1707, with session heading; pp. 106-1 I 3: "Several Acts of Assembly formerly made and declared to be in force"; p. I I 3 : note by the Printer in two paragraphs, the first of which is given below in note to this entry, and the second, containing evidence that Thomas Reading was the printer of the volume, is quoted here: "These are to give Notice to all Gentlemen \&c. that are any ways interested in private Acts of Assembly, that they may have them printed at lnrge [sic, for 'large']: And may likewise be furnished with blank Bills, Bonds, Writts Bills of Exchange, Bills of Lading, Administration Bonds, Testamentary Bonds, Letters of Administration, Letters Testamentary, Warrants for Appraisers \& c. with any other Matters printed at reasonable Rates by Thomas Reading living in the Town and Port of Annapolis."; p. I 4 : "The Index".

Leaf measures: $14 \frac{3}{8} \times 9$ inches. Type page, p. 2: $300 \times 151 \mathrm{~mm}$.

An explanation of the irregular pagination and signature sequence of this volume is found in the first paragraph of the note on p. 113, which reads as follows: "The Reader is hereby desired to take Notice that in the Assembly made Anno 1706 the Pages are Folio'd 123 \&c by reason the Laws made that Sessions were ordered to be first Printed so that they could not be truly ascertained, and instead thereof add 808182 \&c. otherwise the Index will be false." One assumes from this note that the printer had issued separately the session laws of April 1706 at some time previous to the publication of the present "collection," and that having, as the records show, the printing of the "collection" in view at this time he had planned to save himself a great deal of extra composition in the future by running off, without change of pagination or signatures, a number of extra sheets of these laws to be held and later to be bound in their proper chronological order in the "collection." If this assumption be correct, it follows that the signatures [ $\mathrm{X}_{2}$ ] and [ $\left.\mathrm{Y}-\mathrm{Z}^{2}\right]$ of the first series were never printed, and that the earlier printed sheets just described, B-C and $\mathrm{D}^{1}, \mathrm{Pp}$. I-IO, were substituted for them.

In spite of Reading's note, there exists an actual discrepancy in the pagination by which pp. 93-94 remain unaccounted for, a fact which does not necessarily mean that a leaf has been lost from the volume, but rather bears out certain other evidence that the printer was thoroughly confused by his own expedient for bringing his pagination into accord with his index. This is seen to be the case from an examination of the "Index", which, in spite of his pains, is "false", for therein p. I of the second series appears not as p. 81 but as p. 78 , and a similar discrepancy occurs for all pages in the second series $1-10$. Whoever made the Index considered that as $p$. I was the first page of type after p. 77 , it should accordingly be called p. 78 , even though it was a recto page.

The title under which this work is entered here is that given to it in the preface of Trott's Lawos of the Plantations, Londoil, 1721. See the foregoing narrative (Chapter Three) for a more extended historical and bibliographical discussion of this, the second collection of Maryland laws.

The presumably unique copy of the volume has been deposited for safe keeping in the Peabody Library of Baltimore by a descendant of Robert Goldsborough, its earliest owner. The first two leaves are torn away in the lower right hand corner destroying a portion of the text; corners and edges are gnawed throughout; last leaf is worm-eaten, making Index imperfect, but except for that portion of the first two leaves already referred to the text is complete. See Plate III for photographic reproduction of page $1_{13}$, containing the two notes quoted above. 


\section{Faryland Imprints of the Colonial Period, $1689-1776$}

18. - [Acts of the Province of Maryland made and passed at a Session of Assembly begun and held at the City of Annapolis on the twenty-sixth day of March, 1707. Annapolis: Printed by Thomas Reading. 1707.]

No copy recorded. See below, note to No. Ig.

I 708

19. [Maryland, Province of. Acts of the Province of Maryland made and passed at a Session of Assembly begun and held at the City of Annapolis on the twenty-ninth day of November, 1708. Annapolis: Printed by Thomas Reading. I708.]

No copy recorded. For authorization to print the laws of the sessions from Sept. 1704 to Nov. I708, omitting the Session of Sept. 1708 at which no laws were passed, see L. H. J. Sept. 12, I704, April 8, 1706, April 15, 1707. For evidence that the printing was done, see "Petition of Thomas Reading", L. H. J. Nov. I I, I 709. For full discussion and quotation of these references, see preceding narrative, Chapter Three.

20. - His Excellency's Speech to the General Assembly.| Mr. Speaker and you Gentlemen Delegates,| . . . [Annapolis: Printed by Thomas Reading. I708.]

Broadside. $12 \frac{1}{4} \times 6 \frac{3}{8}$ inches.

The address of his Excellency, John Seymour, delivered Nov. 29, 1708, at the session of Nov. 29-Dec. I5, I708. See below, note to No. 2I.

21. -The | Assembly's | Answer | to his | Excellency's | Speech.| December the 2d I708.| May it please your Excellency,| . . . Sign'd per Order Richard Dallam Clerk.| Annapolis, Printed by Thomas Reading Anno Domini mDccvin.|

Broadside. $10 \frac{1}{2} \times 5 \frac{3}{16}$ inches.

This is the reply delivered Dec. 2, I708, to the Governor's address noted above in No. 20. See Archives of Maryland, v. 27, where the two speeches are printed in connection with the Assembly Proceedings, Nov. 29-Dec. I5, I708, and where on p. 277, the following transaction is recorded: "By the House of Delegates 2nd December 1708. This House return your Excellency thanks for the Sa tisfaction you exprest to have received by our Answer to your Excellency's Speech and are desirous to have the Speech printed if your Excellency thinks fit".

On the same day the following reply to the foregoing message was received by the House: "Gentlemen, His Excellency will give Directions that both his Speech and your Answer thereto be forthwith printed for the better Satisfaction of the good People of this Province."

These two broadsides, Nos. 20 and 21 , appeared as item No. 452 in the catalogue of the Anderson Galleries, No. I 546. They were sold on Jan. I I, I921, to Dr. A. S. W. Rosenbach for $\$ 1,260$. Copies were at one time in the Maryland State Library, as appears from an incomplete list of governmental publications in that library, now in the compiler's possession, which was made about the year 1904 by Mr. L. H. Dielman of the Peabody Institute. Mr. Dielman was at that time cataloguer in the MDSL., and his list begins with the entry of these two broadsides. Nos. 244 and 245 of this bibliography were also on Mr. Dielman's list, but none of these items can now be found in the Maryland State Library.

1709

22. [Maryland, Province or. Acts of the Province of Maryland made and passed at a Session of Assembly begun and held at the City of Annapolis on the twenty-fifth day of October, I709. Annapolis: Printed by Thomas Reading. 1709.]

No copy recorded. For authorization to print, see L. H. J. Nov. I I, I 709. No evidence that the printing was done appears in succeeding Lower House Journals.

\section{8}

23. Maryland, Province of. The | Laws | of the | Province | of | Maryland, $\mid$ Collected into one | Volumn, [sic] | by Order of the Governour and Assembly of the said | Province,| at a General Assembly begun at St. Mary's the Ioth | Day of May, I692 and continued by several Assemblies | to the Year I718.| Philadelphia,| Printed by Andrew Bradford, and are to be Sold by Evan Jones at the / City of Annapolis in Maryland, I718.|

[167] 


\section{A History of Printing in Colonial SAaryland}

Fol. I" a-b², A-Z2 $A a-Z z^{2}, A a a-I i i^{2} ; 116$ leaves; pages [i-xii], 1-220; p. [i]: title; pp. [iii-iv]: "The Publisher to the Reader", signed, "Evan Jones"; pp. [v-xi]: "An Index to the following collection of Laws"; pp. I-218: text of laws of Maryland from 1692 to I71 8; Pp. 21 8-220: one law of May 1705; pp. 17, 20 and 125 wrongly numbered.

Leaf measures: $12 \frac{1}{2} \times 7 \frac{5}{8}$ inches. Type page, p. 2: $261 \times 140 \mathrm{~mm}$.

Hildeburn, No. 1 50. See foregoing narrative, Chapter Four.

PI. LC.

24. Maryland, Province of. His Excellency's | Speech, to | the Upper and LowerHouses of Assembly | of | Maryland.| [Philadelphia: Printed by Andrew Bradford. 1719.]

Fol. A-B ${ }^{2},[C]^{1}, 5$ leaves; pp. I-10: text, with heading as above and ornamental initial; contains also addresses of both houses to the Governor.

Leaf measures: $12 \frac{3}{8} \times 7 \frac{3}{6}$ inches. Type page, p. $2: 247 \times 155 \mathrm{~mm}$.

Address delivered at session of May 14-June 6, 17 I9. For authority to print see L. H. J. June 5, 1719. It was issued probably as part of the laws of this session, but its separate pagination and signa ture sequence entitle it to individual entry, especially as it is not accounted for in the contents of the volume of session laws with which it was issued. It is not recorded in Hildeburn. See below, No. 25.

PI. LC.

25. - The | Laws | of the | Province | of | Maryland, | at | a Sessions of | Assembly, | begun and held at the City of Annapolis the / Fourteenth Day of May, in the Fourth Year of the Dominion | of the Right Honourable Charles Lord Baron | of Baltemore, Absolute Lord and Proprietary of the | Province [sic] of Maryland and Avalon \&c. Annoq; | Domini One Thousand Seven Hundred | and Nineteen.| The following laws were enacted.| Philadelphia,| Printed by Andrew Bradford, and are to be Sold by Evan Jones at the City of | Annapolis in Maryland, I7I9.l

Fol. 1 preliminary leaf, Kkk-Q१q²; 5 leaves; preliminary leaf: title as above, verso: "The Contents"; pp. 221-248: text, with session heading; p. 228 wrongly numbered; p. 248: "Finis".

Leaf measures: $12 \frac{3}{8} \times 7 \frac{5}{8}$ inches. Type page, p. $222: 245 \times 156 \mathrm{~mm}$.

For authority to print, see L. H. J. June 5,1719 . In both this book and in the collected laws printed by Bradford in 1718 , there occurs on the second leaf of each gathering the signature symbol of that gathering followed by the figure " 3 ". Thus consecutive leaves read: $A, A_{3}, B, B_{3}$, etc. The signatures and pagination of this work are in continuation of the signatures and pagination of the collected laws of 1718 . The work is not mentioned in Hildeburn. See above, No. 23 .

The two known copies seem to have been issued with "His Excellency's Speech," delivered at this session, bound between the first and second leaves, but as the pagination and signature sequence of the "Speech" are separate and as the Contents does not take account of it, the "Speech" has been given individual entry above, No. 24 .

PI. LC.

\section{720}

26. [Maryland, Province of. The Laws of the Province of Maryland, made and passed at a Session of Assembly begun and held at the City of Annapolis, on the fifth day of April, Anno Domini 1720. Annapolis: Printed by John Peter Zenger. 1720.]

No copy known. For authorization to print, see L. H. J. April 12, 1720. For evidence that the printing was done, see L. H. J. Oct. 27. 1720: "Resolved that the Printer be Allowed five hundred pounds of tobacco for the Printing the Laws for the Counties \&c. ... as last Sessions, ...", [i. e. session of April, 1720.]

27. - - A Acts of a session of Assembly begun and held at the City of Annapolis, on the eleventh day of October, Anno Domini 1720. Annapolis: Printed by John Peter Zenger. 1720.]

No copy known. For authorization to print, see L. H. J. Oct. 27, 1720. For evidence that the printing was done, see L. H. J. Aug. 5, 1721: "Resolved that John Peter Zenger print the Body of Laws this Sessions as usual ..." 


\section{Faryland Imprints of the Colonial Period, $1689-1776$}

1721

28. [Maryland, Province of. Acts of a session of Assembly begun and held at the City of Annapolis, on the eighteenth day of July, Anno Domini I72I. Annapolis: Printed by John Peter Zenger. 1721.]

For authorization to print, see L. H. J. Aug. 6, 1721. No evidence has been discovered that the printing was done. For a discussion of Zenger's printing activity in Maryland, see foregoing narrative (Chapter Five).

29. - The | Speech | of His Excellency | Coll. Charles Calvert, | Governour of the Province of Maryland, to both Houses of Assembly, Febr. 20.| I72I.| Gentlemen of the Upper and Lower Houses of Assembly; . . . [Philadelphia: Printed by Andrew Bradford. I721.]?

Fol. $A^{2}, B^{1}$, only, in single known copy; pp. I-6: text, with head-piece and heading as above; p. 3 , wrongly numbered " 4 "; all after p. 6 , lacking.

Leaf measures: $12 \frac{9}{8} \times 7 \frac{7}{8}$ inches. Type page, p. 2: $220 \times 134 \mathrm{~mm}$.

Contains Governor Calvert's reasons for discharging Thomas Bordley from the Council, and Bordley's defence. In this Session, (see L.H. J., Feb. 28, $1721-22$, Archives of Maryland, 34: 328), the journal reads: "Mr. Jones has the liberty of printing the Tobacco Laws." This collection of speeches and papers, however, is the only recorded printed document of the session, and as it seems that Jones was acting as the Provincial printing agent again, it is likely that it was printed by Bradford, who customarily printed the papers which Jones undertook to publish for the Assembly.

MdHS. (in Miscellaneous State Papers.)

30. Trotr, Nicholas. The |Laws | of the | British Plantations | in | America, | Relating to the | Church and the Clergy,| Religion and Learning.| Collected in One Volume.| By Nicholas Trott, LL. D.| Chief Justice of the Province of South Carolina.| [Printer's mark, Rose and Crown]. London:| Printed for B. Cowse at the Rose and Crown in St. Paul's Church-yard.| MDccxxI.|

Fol. Full collation of this volume is found in the Benedict Catalogue, item No. 3. It contains thirty-one statutes at large of Maryland relating to the matters specified, as follows:

$\mathrm{Tt}-\mathrm{Zz}^{2}$, Aaa-Kkk${ }^{2}$; 30 leaves; pages [163-1 70], 17 I-221, [222]: text, with half-title, The | Laws | of the | Province | of | Maryland,| Relating to the | Church and the Clergy,| Religion and Learning.| [Printer's mark, Rose and Crownl.

This compilation contains in its preface much valuable information regarding the bibliography of American colonial statutes. Grateful reference has been made to it more than once in the narrative portion of this work, where is given also in Chapter Four a brief account of its learned compiler. The collection was reissued in 1725 with no changes except in the title-page, which bore the following imprint:

London:| Printed for John Clarke, at the Bible under the Royal-Exchange.| M.Dcc.xxv.|

A copy of this issue is in NYPL. The Benedict and the MDioc. copies are the only recorded copies of the edition of 1721 .

1723

31. Maryland, Province of. Acts | of | Assembly, | passed in the | Province of Maryland, from I692, to I 7 I 5.| [Royal Arms, surmounted by G. R.] London,| Printed by John Baskett, Printer to the King's most Ex-| cellent Majesty, mDccxxiIr.|

Fol. a-e ${ }^{2},{ }^{*} A-{ }^{*} Z^{2},{ }^{*} A a-{ }^{*} Z_{2}{ }^{2}, 102$ leaves; pp. [i-ii], iii-xi, [xii], [I-VIII], I-I 83, [184]; pp. 81, 82, 83, wrongly numbered; p. [i]: title; pp. iii-xi: His Majesty's Royal | Charter | to the |Lord Baron of Baltemore.l, with head and tail pieces; pp. [I-VII]: "Index to Maryland Laws", with head and tail pieces; pp. I-183: text, with head-piece and heading, The | Laws | of | Maryland.|, running heads.

Leaf measures: $14 \frac{1}{4} \times 9$ inches. Type page, p. 2: $265 \times 146 \mathrm{~mm}$.

Description and discussion of this work in foregoing narrative, Chapter Four.

MdHS. HSP. NYPL. NYBA. BA. LC.

[169] 


\section{$A$ History of Printing in Colonial Saryland}

\section{4}

32. [Maryland, Province of. Address and Resolves of the Lower House of Assembly at a Session begun and held at the City of Annapolis on the tenth day of October, 1722. Philadelphia: Printed by Andrew Bradford. 1724.]?

No copy recorded. See L. H. J. Oct. I3, I724: "Several printed Copys of the Address and the Resolves of the Lower House in October Assembly 1722 being produced to this house are well approved of in the manner as they are now printed." Not in Hildeburn. For discussion, see foregoing narrative, Chapter Five.

1725

33. Maryland, Province of. The | Charter | of | Maryland, $\mid$ Together with the | Debates and Proceedings $\mid$ of $\mid$ the Upper and Lower Houses of Assembly, in the Years I 722, I 723 and 1724. Relating to the | Government and Judicature of that Province.| [Royal arms, surmounted by $\mathrm{G} \mathrm{R}$; four lines of quotation from Wisdom, chap. 9. Verses 5, 6.] Collected from the Journals, and Published by Order of the Lower-House.| Philadelphia, Printed and Sold by Andrew Bradford, at the Bible in the / Second-Street. 1725.|

Sm. fol. I preliminary leaf, A-B ${ }^{2}, C^{1}, a^{2}, A-Q^{2}$, I supplementary leaf; 4 I leaves; pages [I-II], I-IO; [i-ii], iii-iv, 1-[65], [66]; p. [I]: title; pp. I-10: "The Charter of Maryland"; p. [i]: second title, as follows, with verso blank, The | Proceedings | and | Debates | of the | Upper and Lower | Houses of | Assembly | in | Maryland, in the Years 1722, 1723 and 1724. Relating to the | Government and Judicature of that Province.| |One line of Latin with translation beneath; Type devicel. Collected from the Journals, and Published by Order of the LowerHouse.| Philadelphia:| Printed and Sold by Andrew Bradford, at the Sign of the Bible in the | Second-Street. MDccxxv.| pp. iii-iv: An Epistolar Preface | to the | Maryland Readers.|; pp. 1-64: The | Proceedings and Debates | of / the Upper and Lower Houses of Assembly, in | Maryland.|; p. [65]: "Errata".

Leaf measures: $11 \frac{1}{4} \times 7$ inches. Type page, p. 2 of the Charter: $240 \times 120 \mathrm{~mm}$. Type page, p. 6 of the Proceedings: $240 \times 145 \mathrm{~mm}$.

General title from American Philosophical Society, Philadelphia. Collation from Maryland Historical Society copy, which lacks general title. See Archives of Maryland, 35: 149; also $35: 303$ where occurs the following entry: "Thomas Bordley Esqr pursuant to the request of the Lower House last Sessions of Assembly brings into the House Severall printed Copies of the proceedings of the Lower House in the years 1722-1723: 1724 relating to the Government and Judicature of this province, which were delivered to the severall members of this House.

Of which printed Copies Together with the printed Copy of the Charter of this Province and the Epistolary preface annext thereto all bound together this House approves...., And unanimously return their thanks to the said Thomas Bordley Esqr for his extraordinary care and pains in making a Collection of the said proceedings and Composing the preface thereto and getting them printed for the publick service. Thereupon the said Thomas Bordley Esqr expresses his Satisfaction in the House's kind acceptance of his Endeavour in the publick service." See foregoing narrative, Chapter Five.

$$
1726
$$

34. Maryland, Province of. Laws of Maryland, enacted | at a Session of Assembly, begun and held at the | City of Annapolis, March the $15^{\text {th, }}$ 1725.| [Annapolis: Printed by William Parks. I726.]

Sm. fol. Known copy lacks title-page. Has [A] $]^{1}, \mathrm{~B}-E^{2}$; 9 leaves; pages 3-20: Acts of Session of Mch. 15-Mch. $23,1725 / 26$, with heading as above; P. 20: "Advertisement" (of collected laws soon to be issued, see below, No. 38 , and other matters pertaining to Parks's duty as printer to the Province).

Leaf measures: $12 \times 7 \frac{1}{2}$ inches. Type page, p. $5: 253 \times 133 \mathrm{~mm}$.

The only known copy of this, the earliest recorded issue of the press of William Parks, is that in the Maryland Diocesan Library. See Chapter Six in the foregoing narrative.

35. - Acts of Assembly, | of the Province of | Maryland,| enacted | at a Session of Assembly, begun and held | at the City of Annapolis, in the said Province, | on Tuesday the 12th Day of July, in the Eleventh | Year of the Dominion of the Right Honourable | Charles Lord Baron of Baltemore, Abso-| lute Lord and Proprietary of the Provinces of | Mary- 
land and Avalon, 8c. Annoq; Dom' 1726.] [Baltimore arms] By Authority:] Annapolis: Printed by W. Parks.| [1726.]

Fol. [A]-B2; 4 leaves; pages [1]-8; p. [1] : title; pp. 3-8: Acts of session of July 12-25, I 726, with session heading. Leaf measures: $11 \frac{7}{6} \times 7 \frac{1}{2}$ inches. Type page, p. 7: $232 \times 131 \mathrm{~mm}$.

MDioc.

36. Proposals | for a | Tobacco-Law, in the Province of Maryland.| Humbly offered to the Consideration of | the Legislature, and all Lovers of their | Country. | In a Letter from a Gentleman to William Parks, Printer | in Annapolis.| [Type device] Annapolis: Printed in the Year, 1726.| (Price One Shilling.) |

Sm. 4 to. [A]-B ${ }^{4}, \mathrm{C}^{3}$; II leaves; pages [I]-2I, [22]; p. [I]: title; pp. 3-2I: text, with head-piece and heading, The Necessity of a Tobacco-Law consider'd.|, signed at end, "A Lover of his Country", and dated, "Nov. I9, 1726"; p. 21 : "Advertisement", (announcing the publication of the "Compleat Body of Laws" in the following March. See below, No. 38.)

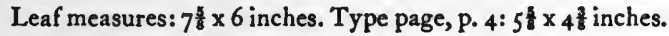

See below, Nos. 37 and 5 I.

NYHS. MdHS. (photostat copy).

36a. Advertisement to the Reader.| In the 237th Page of this Volume, there is I printed by Mistake, An Act Entituled,| An Act for Limitation of Trespass and E-| jectment. But the said Act is not in Force, | being dissented to by the Right Honourable | the Lord Proprietary: Therefore the Reader | is desired to cross it out with a Pen.| [Annapolis: Printed by William Parks. I727.]

Broadside. $3^{\frac{3}{4}} \times 3^{\frac{3}{4}}$ inches, with head and tail pieces.

Volume referred to is No. 38 , entered below, which in many copies, as for example MdHS. and MDioc. have this "Advertisement to the Reader" pasted on the inside back cover.

37. A | Letter | from | a Freeholder,| to | a Member of the Lower-House of | Assembly, of the Province of | Maryland.| [Type device] Annapolis:| Printed and Sold by William Parks: And to be sold in all | the Counties of the Province, 1727.| (Price One Shilling.) |

Sm. 4to. [A]-C ${ }^{2},[D]^{1} ; 7$ leaves; pages [1]-1 3 , [14]; p. [1]: title; pp. 3-1 3: text, with head-piece and heading, A Letter from a Freeholder, to a Member $\mid$ of the Lower House of Assembly.|

Leaf measures, p. $5: 7 \frac{8}{8} \times 5 \frac{18}{16}$ inches. Type page, p. $5: 154 \times 112 \mathrm{~mm}$.

"Sir," writes the Freeholder, "I am very glad that a Gentleman who is a Friend to his Country, (as I am firmly perswaded the Author of the late Letter to the Printer really is) has communicated his thoughts to the Publick, concerning a thing so much desired and so much wanted as a Tobacco-Law,..." It is probable that the "Letter to the Printer" on the subject of a "Tobacco-Law" which the Freeholder here refers to was Proposals for a Tobacco-Law, published late in I726. See above, No. 36; see also No. 5 I.

NYPL. MdHS. (photostat copy).

38. Maryland, Province of. A / Compleat Collection | of the / Laws of Maryland.| With | an Index, and Marginal Notes, directing | to the several Laws, and the chief Matters | contained in them.| Collected and Printed by Authority.| [Baltimore arms] Annapolis:] Printed by William Parks. MDccxxvir.|

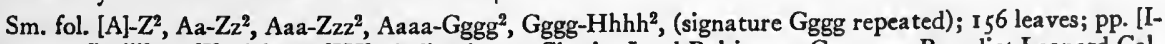
IV], I-300, [i-viii]; p. [I]: title; p. [III]: dedication to Charles Lord Baltimore, Governor Benedict Leonard Calvert and the two houses of Assembly, signed, "William Parks"; pp. 1-300: text, with heading, "Laws of Maryland", running heads; pp. 297-300: two private laws relating to the City of Annapolis; pp. [i-vi]: index; last leaf is blank but genuine. (Pasted on inside back cover of one copy in Maryland Historical Society is "Advertisement to the Reader" calling attention to act on p. 237 . See above, No. 36a.)

Leaf measures: $11 \frac{8}{16} \times 7 \frac{1}{1}$ inches. Type page, p. 2: $244 \times 130 \mathrm{~mm}$. 


\section{A History of Printing in Colonial Garyland}

Known in Bacon's day as the "Old Body of Laws." See foregoing narrative, Chapter Six.

Copies in many libraries, as for example:

MdHS. MDioc. MDSL. LC. HSP. NYPL. NYBA. MassHS. HU. AAS.

39. - Laws of Maryland, | enacted | at a Session of Assembly, begun and held | at the City of Annapolis, on Thursday, the | Tenth Day of October, in the Thirteenth Year | of the Dominion of the Right honourable | Charles, Lord Baron of Baltemore,| Absolute Lord and Proprietary of the Provin-| ces of Maryland and Avalon, \&c. Annoq;| Domini 1727.| To which are added,| Some Laws that were omitted to be Collected | in the bound Volume. As also the Speech | of his Excellency the Governour, and the | Addresses of both Houses, and the Answers | thereto, at the Opening this Session.| [Baltimore arms] By Authority.| Annapolis:| Printed and Sold by W. Parks. MDccxxviI. Price Two Shillings.|

Sm. fol. I preliminary leaf, A-G 2 ; 5 leaves; pages [i-ii], I-32 [28], pp. 17 to 28 wrongly numbered 21 to $32 ; \mathrm{p}$. [i]: title; pp. 1-4: "The Speech of His Excellency ... to both Houses ...", with tail-piece; pp. 5-29 [25]: text of Acts of Oct. 1727, with session heading and running heads; p. 29 [25]: resolution regarding prisoners for debt; pp. 30-32 [26-28]: "The following laws, made in October Assembly 1722, being omitted to be collected in the last Volume, are thought proper to be added hereto"; p. 32 [28]: "Advertisement".

Leaf measures: $11 \frac{9}{16} \times 7 \frac{1}{8}$ inches. Type page, p. $2: 240 \times 127 \mathrm{~mm}$.

Session lasted from Oct. 10-30, 1727. In the Addenda to this bibliography are given title-page transcript and description of a later issue of this book in which various errors were corrected.

MdHS. LC. NYBA. HU. BM.

40. - Proceedings of Assembly, | of the Province of | Maryland,| Containing | the Speeches of the Right Honourable the Lord | Proprietor, His Honour the Governour, \&c. With | the Addresses and Answers thereto. Also several | Messages, Debates, and other material Proceedings $\mid$ of the Three last Sessions of Assembly.| [Baltimore arms] Collected (by Order of the Honourable the Lower-House of Assembly) by John | Beale, and Vachel Denton, Esqrs. And Publish'd by Order of the same House.| Annapolis:| Printed by William Parks, Printer to the Right Honourable the Lord | Proprietor, and the Province. 1727.|

$\mathrm{Sm}$. fol. $[\mathrm{A}]^{1}, \mathrm{~B}-\mathrm{I}^{2},[\mathrm{~K}]^{1}$; ([A] is probably imposed as second leaf of $[\mathrm{K}]$ ); 18 leaves; pages [i-ii], $\mathrm{I}-33,[34] ; \mathrm{p}$ [i]: title; Pp. 1-33: text, with heading, The | Speech | of | the Right Honourable Charles, Absolute Lord | and Proprietor of the Provinces of Maryland and | Avalon, Lord Baron of Baltimore; and of His | Honour Charles Calvert, Esq; Governor | of Maryland; to the Members of the Upper | and Lower Houses of Assembly; with their Ad-| dresses, by way of Answer thereto. Together | with the Debates and Proceedings of the Upper | and Lower Houses of Assembly, in the Years | 1725 and 1726, relating to the Government,| Constitution and Judicature of that Province.|; (the several sections are headed as follows:) pp. 1-25: "In October Assembly, 1725"; pp. 26-30: "In March Assembly, I725 [1725/26]"; pp. 31-33: "In July Assembly, 1726"; p. 33: tail-piece.

Leaf measures: $11 \frac{3}{16} \times 7$ inches. Type page, p. 2: $243 \times 138 \mathrm{~mm}$.

Contains I ower House proceedings on the subjects named of sessions of Oct. 1725, March 1725/26 and July 1726, and is a continuation of the "Debates and Proceedings" on the English statutes published with the "Charter" in 1725 . I is history is discussed in Chapter Six of the foregoing narrative. See Nos. 33 and 42.

MdHS.

4I. [The Maryland Gazette. Sept. I2-Dec. 26, 1727, Nos. 1-16. Annapolis: Printed by William Parks.]

No copies recorded. The first issue of this newspaper which has been located is that of Dec. 10, 1728, No. 65, a datc and number which would make the date of No. $I$, assuming that there had been no interruptions, Sept. 12, 1727. Brigham, American Newspapers, calls attention to a news item in the American Weekly Mercury (Philadelphia) of Sept. 28, 1727, dated Annapolis, Sept. 16, 1727, and refers to occasional quotations from the Annapolis paper in 1727 and 1728 . Mr. Brigham's note on Parks's Maryland Gazette is an excellent summary of the history of this early newspaper, the seventh to attain regular publication in the colonies. The substance of it, with some additional matter, appears in this bibliography under the above title for the years 1728-1734. 


\section{Garyland Imprints of the Colonial Period, $1689-1776$}

\section{8}

42. Dulany, Daniel, the Elder. The | Right | of thf [sic] | Inhabitants of Maryland,| to thf [sic] | Benefit of the English Laws.| [Four lines of Cato, translated; type device.] Annapolis: Printed by W. Parks. MDccxxviri.|

Sm. 4to. [A]-I' ${ }^{2}$, B, repeated; C, omitted); 18 leaves; pages [I-2], 3-4, I-3I, [32]; p. [r]: title; pp. 3-4: To all true Patriots, and sincere | Lovers of Liberty.|, signed, "D. Dulany"; head-piece; pp. I- $3 \mathrm{I}$, second series: text, with head-piece and heading worded as in title, tail-piece.

Leaf measures: $8 \frac{3}{16} \times 6 \frac{3}{16}$ inches. Type page, p. 3 , second series: $162 \times 117 \mathrm{~mm}$.

Advertised as "lately published" in Maryland Gazette, Dec. 17, 1728. Price 2 s. Reprinted with a full discussion in Sioussat, St. G. L., The English Statutes in Maryland, (J. H. U. Studies in Historical and Political Science, Series XXI, Nos. I1-12, Balto. 1903). See also in same series and by the same author, Nos. 6-7, Economics and Politics in Maryland, 1720-1750, and the Public Services of Daniel Dulany, the Elder.)

MdHS. (Calvert Papers, 294).

43. Holdsworth, Edward. Muscipula,| sive | Kambpomyomaxia.| Authore E. Holdsworth,| E Coll. Magd. Oxon.| [Space left between rules for quotation is blank, except for words, "OMHPOY BATPAXOM", in Roman capitals in lower right hand corner.] Annapoli:| Impensis R. L. Typis W. P. M.Dcc.xxvir.| [Second title:] The | Mouse-Trap,| or the | Battle of the Cambrians | and Mice.| A Poem.| Translated into English,| By R. Lewis.| [Four lines translated from Homer's "Battle of the Frogs and Mice", and four lines from Roscommon, "Ess. Trans. Verse".] Annapolis:| Printed for the Author, by W. Parks. M.DCC.XXvirI.|

Sm. 8vo. [a] $]^{2}, b^{4}, c^{2},[A]^{4},\left(B\right.$, omitted) $C-G^{4}, H^{2} ; 34$ leaves; pages [i-iv], v-xvi, [1]-52; p. [i]: blank,-verso: first title as above; p. [iiil: second title as above,-verso blank; pp. v-ix: "To His Excellency Benedict Leonard Calvert,...", (poetical dedication, with head and tail pieces); pp. $x$-xiii: "The Preface", with head and tail pieces; pp. xiv-xvi: "A List of the Subscribers Names", with head-piece; p. [I]: blank; p. 2: Muscipula,| sive | Kambpomyomaxia.|, as heading of Latin text, with head-piece; p. 3: The Mouse-Trap,| or the / Battle (a) of the Cambrians | and Mice.|, as heading of English text, with head-piece; pp. 2-41: text of poem in Latin and English, Latin on verso, English on recto of pages throughout; pp. 40 and 41 : "Finis", and tail-piece, "The End", and tail-piece, respectively; pp. 42-52: "Notes to the foregoing Piece", with head and tail pieces; running heads to each section except "Notes."

Leaf measures, p. vii: $6 \frac{7}{8} \times 4 \frac{3}{16}$ inches. Type page, p. xi: $135 \times 80 \mathrm{~mm}$.

Reprinted by Bernard C. Steiner in Early Maryland Poetry, (Maryland Historical Society Fund Publications No. 36, Baltimore. 1900). For information concerning the poem and its translator and contemporary references to this edition see Chapter Six of the foregoing narrative. Copy in MdHS. lacks both title-pages which have been supplied by photostat from the copy in LC., which has pages 3-6 mutilated and supplied by photostat copies of these pages in the MdHS. copy. Both title-pages of this choice volume are printed in red and black, the only example known to the compiler of a rubricated title-page from a colonial Maryland press. See Plate IV for a photographic reproduction of these title-pages.

LEwis, RichaRd, translator, see above, No. 43.

44. Maryland, Province of. Laws of Maryland,| enacted | at a Session of Assembly, begun and held at the City of | Annapolis, on Thursday the Third | Day of October, in the Four-| teenth Year of the Dominion of | the Right Hon. Charles, Lord Baron of Baltemore, Abso-| lute Lord and Proprietary of the | Provinces of Maryland and Ava-| lon, \&c. Annoq; Domini I728, [ Baltimore arms] By Authority.| Annapolis:| Printed and Sold by William Parks, MDccxxviri. Price Two Shil-| lings, to those who bought the whole Body of Laws, and Two | Shillings Six Pence to others.|

$\mathrm{Sm}$. fol. [A] ${ }^{1}, \mathrm{~B}-\mathrm{G}^{2}, \mathrm{H}^{1}, \mathrm{H}^{2}$; $\mathrm{I} 6$ leaves; pages [i-ii], I-28 [30], wrongly numbered I-28; p. [i]: title; pp. I-28 [30]: text, with heading; p. 28 [30]: "Advertisement", (notice of acts repealed, list of useful blanks to be had of printer, etc.)

Leaf measures: $1 \mathrm{I} \frac{7}{16} \times 7 \frac{1}{2}$ inches. Type page, p. $2: 262 \times 137 \mathrm{~mm}$.

[173] 


\section{A History of Printing in Colonial Saryland}

A leaf with pagination 25 and 26 , with signature $H$, was inserted between signatures $\mathbf{G}$ and $H$ after the book had been made up, or possibly after the sheets had been printed, for the page numbers were not changed to take the insertion into account. The signatures and pagination of this portion run: $\mathrm{G}^{2}, \mathrm{H}^{1}, \mathrm{H}^{2} ; \mathrm{Pp} .21,22,23,24,25$, $26,25,26,27,28$.

MdHS. MDioc. BBL. (imp.) LC. NYBA. HU. HLS. BM.

45. - To his Excellency Benedict Leonard Calvert,| Governour and Commander in Chief, in and over the | the [sic] Province of Maryland,| The Humble Address | of the | Upper House of Assembly.| . . . To which His Excellency was pleas'd to make the following Answer.| . . . Benedict Leonard Calvert.| [Annapolis: Printed by William Parks. 1728.]

Single leaf, printed both sides; tail-piece.

Leaf measures: $12 \frac{1}{8} \times 7 \frac{3}{8}$ inches. Type page, $\mathrm{p}$. [r], including heading: $246 \times 140 \mathrm{~mm}$.

Contains addresses of session of Oct. 3-Nov. 2, 1728.

MDSL.

46. - Votes and Resolves, | of the | Lower House of Assembly, of the Province of | Maryland.| Maryland ss.| (Oct. 3-Nov. 2, 1728.) [Annapolis: Printed by William Parks. 1728.]

Fol. Issued separately in numbered parts, without signature; each part, except Nos. I and XIV, has at conclusion imprimatur as follows: "I Do (by order of the Lower House of Assembly, of the Province of Maryland) appoint William Parks, to Print the Votes and Resolves of the said House. John Mackall, Speaker." No. I: pp. I-4, with heading as above and session heading of five lines; No. II: pp. 1-7,-p. 8, blank; No. III: pp. I-2; No. IV: p. I,-p. 2, blank; No. V: pp. I-2; No. VI: pp. I+2; No. VII: pp. I-2; No. VIII: pp. I-2; No. IX: pp. I-2; No. X: pp. I-4; No. XI: pp. I-4; No. XII: pp. I-2, No. XIII : pp. 1-3,-p. 4 blank; No. XIV: pp. I-12.

Leaf measures: $12 \frac{3}{16} \times 7 \frac{3}{8}$ inches. Type page, p. 2, No. I: $249 \times 136 \mathrm{~mm}$.

The imprimatur of No. II has "by Order of the House of Delegates" instead of "Lower House of Assembly" as quoted above.

MDSL.

47. [Cut] The | Maryland Gazette | [Cut] (Jan. 2, I727/28-Dec. 31, I728; Nos. I7-68.)? [Colophon:] Annapolis: Printed by Will. Parks. By whom Advertisements, and Subscriptions | for this Paper, are taken in.|

II $\frac{3}{4} \times 7$ inches. In remaining issues, two leaves to each number, two columns to a page.

MdHS. has Dec. 10-Dec. 3I, I728, Nos. 65-68, the only known copies for this year and the earliest recorded copies of this newspaper. See Plate Va for title arrangement.

48. [Warner, John. An Almanack for the Year 1729. Calculated more exactly for these Parts, than any has been publish'd yet. By John Warner, Philom. living near Pattowmack. Printed and Sold by William Parks, in Annapolis. [1728.] Price 6 Pence a Piece, or shillings per Dozen to those who buy them to sell again.]

No copy recorded. Advertised as "Lately Published" in Parks's Maryland Gazette for Dec. 17, 1728.

1729

49. Beckett, William. The Duty both of Clergy and Laity | to each other. |A | Sermon | Preach'd before the Reverend the | Commissary, and the rest of the |Clergy | of | Pennsylvania.| In Christ Church,| Philadelphia.| On Wednesday, September 24, I $729 . \mid$ Being the First Visitation held there.| By William Beckett, Missionary at Lewes.| Annapolis:| Printed and Sold by W. Parks. M,Dcc, Xxix. [Price One Shilling.] |

Sm. 4 to. [A]-E2, $F^{1}$; I leaves; pages [i-iv], [I]-I8; p. [i]: title; p. [iii]: dedication to the Reverend Mr. Cummings, and five others of the Pennsylvania clergy; pp. [I]-18: text, with heading and tail-piece.

Leaf measures: $7 \frac{9}{4} \times 5 \frac{3}{16}$ inches. Type page, p. 2: $150 \times 117 \mathrm{~mm}$.

The Rev. William Beckett, a "pious, faithful and orthodox Pastor" received the King's Bounty on March 25, 1721. (Fothergill). Coning to Pennsylvania, he was given charge of the Church of England congregation at 


\section{Faryland Imprints of the Colonial Period, $1680-1776$}

Lewes, Delaware, about Sept. I, I721, and in this place he remained until his death on Aug. 20, I743. The facts of his life and ministry in America are found in the following sources: his letters to the Venerable Society are printed in Perry, Collections, vols. 2 (Pennsylvania) and 5 (Delaware); important letters and documents in Turner, C. H. B., Some Records of Sussex County, Delaware. Phila. Igog; there are references to him in the Classified Digest of the Records of the S.P.G. Lond. 1893; and there is an account of his ministry in Humphreys, David, An Historical Account of the Incorporated Society for the Propagation of the Gospel in Foreign Parts. Lond. I730. pp. 173-179. Various writers on Pennsylvania and Delaware Church history have sketches of him drawn in the main from the sources named. The sermon here described is entered in Hildeburn, No. 393 .

NYHS. (in Hawks-Niblo Collection).

50. Cummings, Archibald. An | Exhortation | to the | Clergy | of | Pennsylvania, at | Philadelphia.| September the 24th, 1729.| By the Reverend | Archibald Cummings, Commissary, and Rector | of Christs Church, in Philadelphia.| Annapolis:| Printed and Sold by W. Parks. M,DCc,xxix. [Price One Shilling.] |

Sm. 4to. [A]-D2 8 leaves only; pages [1]-16+; p. [1]: title; pp. [3]-16+: text, with heading, An | Exhortation | to the | Clergy | of | Pennsylvania.| Reverend Brethren, |, running heads.

Leaf measures: $7 \frac{3}{2} \times 5 \frac{6}{16}$ inches. Type page, p. 4: $157 \times 118 \mathrm{~mm}$.

The Rev. Archibald Cummings received the King's Bounty on Jan. 24, 1725/26, (Fothergill), and coming to Pennsylvania served as rector of Christ Church, Philadelphia from 1726-1741, and for the greater part of this time as the Bishop of London's Commissary in Pennsylvania. He was married on April 8, 1728 to Jane Elizabeth Assheton, and died in 1741. Perry, Wm. S. History of the American Episcopal Church, 1: 237-239, gives an account of this excellent incumbent of Christ Church; his letters to the Bishop of London and to the Venerable Society are printed in Perry, Collections, v. 2 (Pennsylvania) and Bishop Perry says that an account of him is to be found in Dorr's "History of Christ Church", and that his obituary is in "Coll. of the Pa. Hist. Soc'y.", I: 358. The sermon described above is entered in Hildeburn, No. 397.

NYHS. (in Hawks-Niblo Collection).

5I. Darnall, Henry. A | Just and Impartial Account | of the | Transactions | of the | Merchants in London,| for the | Advancement of the Price of | Tobacco.| About the latter End of the Year $1727, \mid$ and Beginning of 1728 .| By Henry Darnall. Who | was present at most of them.| In | a Letter | from him,| to the Inhabitants of Maryland.| Dated September 18, 1728.| Annapolis: Printed and Sold by W. Parks.| [1729.]

Sm. 8vo. A-C,$D^{3} ; 27$ leaves; pages [1]-54; p. [1]: title; pp. 3-53: text, with head-piece and heading, "A just Account of the Transactions of the Merchants, for the Advancement of the Tobacco-Trade, \&c.", tail-piece; p. 53: conclusion of text, signed, "Henry Darnall"; p. 54: "Postscript", with head-piece, and at end: "To all the Inhabitants in Maryland".

Leaf measures: $6 \times 3 \frac{5}{8}$ inches. Type page, p. 4: $129 \times 72 \mathrm{~mm}$.

It was announced in the Maryland Gazette for Jan. 14, 1728/29 that this pamphlet would be published on the following day. At this time, as at present, almost the only market for Maryland tobacco was in France, and as the French government maintained a monopoly in the tobacco trade, its agent in England had no competition in his dealings with the merchants who represented the Maryland planters. In his "Just and Impartial Account", Mr. Darnall relates the failure of the attempt on the part of these merchants to fix and adhere to a price below which none should sell to the French agent. The price was fixed easily enough, but the "combine" fell to pieces, and once more and for many years afterwards the French agent bought Maryland tobacco at his own price. A continuation of the discussion, including a defence of their action by the London merchants, is to be found in several issues of the Maryland Gazette for $1728 / 29$ and 1729, (copies in MdHS. only), in which Mr. Darnall, Mr. Nicholas Ridgely, an anonymous "P. P." and others took an active part. This pamphlet together with the Proposals for a Tobacco-Law of 1726 and $A$ Letter from a Freeholder of 1727 form valuable sources for the history of the Maryland tobacco trade. The Virginia planters too, had their troubles; see Clayton-Torrence, Nos. Iog, $109 B, 120,122$ and 123 .

JCB. MdHS. (photostat copy).

52. Maryland, Province of. Laws of Maryland, enacted | at a Session of Assembly, begun | and held at the City of Annapo-| lis, on Thursday the Tenth Day of | July, in the 


\section{$A$ History of Printing in Colonial Saryland}

Fifteenth Year of the | Dominion of the Right Honou-| rable Charles, Lord Baron | of Baltemore, Absolute Lord and | Proprietary of the Provinces of | Maryland and Avalon, \&c. Annoq; | Domini I729.| [Baltimore arms] By Authority.| Annapolis:| Printed and Sold by William Parks. M,DCc,xxix.| [Price Two Shillings to those who bought the whole Body of | Laws, and Two Shillings Six Pence to others.] |

Sm. fol. [A] $]^{1}, \mathrm{~B}-\mathrm{K}^{2}, \mathrm{~L}^{1} ; 20$ leaves; pages [i-ii], 1-[38]; p. [i]: title; pp. I-[38]: text, with session heading and tailpiece; page [38]: "Advertisement".

Leaf measures: $1 \mathrm{I} \frac{1}{2} \times 7 \frac{1}{4}$ inches. Type page, p. $2: 252 \times 137 \mathrm{~mm}$.

Advertised as "lately published" in the Maryland Gazette for Oct. 21-28, 1729.

MdHS. MDioc. (lacks t. p.) Pleasants (lacks t. p.) BBL. MDSL. LC. NYBA. HU. HLS. BM.

53. - To His Excellency | Benedict Leonard Calvert, Go-| vernor and Commander in Chief, in and over | the Province of Maryland,| The | Humble Address | of the | Upper House of Assembly.| [Address delivered July I I, 1729 on general matters, Court of Chancery, Act against Engrossing and Regrating, etc., and his Excellency's answer.] [Type device]. [Annapolis: Printed by William Parks. 1729.]

Single leaf, printed both sides, ornamental initial.

Leaf measures: $1 \frac{13}{16} \times 7 \frac{5}{8}$ inches. Type page, $p$. [r], including heading and rules: $260 \times 133 \mathrm{~mm}$.

NYPL.

54. - Votes and Resolves, | of the | Lower House of Assembly of the Province of | Maryland.| (July 10-Aug. 8, I729.) [Annapolis: Printed by William Parks. 1729.]

$\mathrm{Sm}$. fol. No signa tures. Issued in numbered parts, each part with separa te pagination, and each with imprimatur at end, as in V. \& P. of Oct. 1728; No. I: Pp. I-4, with heading as above and session heading of nine lines; No. II : pp. I-3,-p. [4]: blank; No. III: pp. I-4; No. IV: pp. I-4; No. V: pp. I-4; No. VI: pp. 1-4; No. VII: pp. I-4; No. VIII: pp. I-4; No. IX: pp. I-6; No. X: pp. I-4; No. XI: pp. I-5,-p. [6]: blank; No. XII: pp. 1-6; No. XIII: Pp. I-2; No. XIV: lacking in NYPL. copy, but present in BM. copy.

Leaf measures: $11 \frac{7}{8} \times 7 \frac{1}{2}$ inches. Type page, p. 2, No. I: $270 \times 135 \mathrm{~mm}$.

Each group of numbers as indicated above has a separate heading, and was published at its appropriate time in the course of the session. Also bound together and sold complete at close of session. See Maryland Gazetie, July $8-15,1729$.

NYPL. BM.

55. [Cut] The | Maryland Gazette | [Cut] (Jan. 7, 1728/29-Dec. 30, 1729, Nos. 69-1 20.) [Colophon, Nos. 69-93 as in 1728; beginning with No. 94, as follows:] Annapolis: Printed by William Parks; By whom Subscriptions are taken for this Paper, at Fifteen Shil- lings a Year; and Advertisements to be inserted in it, at Three Shillings for the first Week, and 'Two Shillings for | every Week after. N. B. Old Books are well bound by him.|

$1: \frac{3}{4} \times 7$ inches, two leaves each number except Nos. 69-7 I wich have one leaf each; two columns to a page.

MdHS. has Nos. 69-74, last leaf probably of 75, 77-86 (No. 80, wrongly numbered 79, which is used twice), 89,91 , last leaf of 92, 93-97. No. 97 probably had a supplement devoted to the conclusion of "A Modest Enquiry into the Nature and Necessity of a Paper-Currency", for end of second leaf stops in middle of a sentence in this article and has catch-word "who". NYPL. has Oct. 2 I-28, No. 11 I. See Plate Va for title arrangement.

56. [A Primer, containing a most Easy Way to attain to the True Reading of English. Instructing children in the Grounds of the Christian Religion. In a Catechism compiled by the Assembly of Divines. With Proper Lessons, Prayers and Graces. Annapolis: Printed by William Parks. I729.]?

No copy recorded of what seems to have been a Presbyterian catechism. Advertised as "just publish'd" in Maryland Gazeste, for July I, 1 ; 29 . See note to No. 59. "Primers" were advertised among Parks's importations in the Maryland Gazelle for Oct. 20, 1730. 


\section{Saryland Imprints of the Colonial Period, $1689-1776$}

57. [The Primer or Catechism, set forth agreeable to the Book of Common-Prayer: Authorized by the King, to be used throughout his Dominions. Containing Godly Prayers and Graces. Annapolis: Printed by William Parks. 1729.]?

No copy recorded. Advertised as "just publish'd" in Maryland Gazette, July I, 1729. See notes to Nos. 56 and 59 .

58. [Warner, John. The Virginia and Maryland Almanack. Shewing the Times of SunRising and Setting, Length of Days, New and Full Moon, Eclipses, Fixt and Moveable Feasts, Seven Stars Rising and Setting, Weather, Days of the several Courts, \&c. For the Year of our Lord Christ, I730. By J. Warner, Philomath. Annapolis: Printed by William Parks. I729. Price 6 d. or 4 s. per Dozen.]

No copy recorded. Advertised in Parks's Maryland Gazette for Oct. 2I-28, I729, as "Just Published."

59. [The Weeks Preparation, towards a worthy receiving of the Lord's Supper, after the warning of the Church for the celebration of the Holy Communion. . . . (Also) The Church of England-Man's Private Devotions ... (Also another book, entitled) an Explanation of the Feasts and Fasts as they are observed in the Church of England, . . . Printed on a good letter and Paper; and all Three bound up together, and Sold by W. Parks, Printer, in Annapolis, Price 2 s. 6 d. And considerable allowance to those that buy a Quantity.]?

Advertised in Maryland Gazette, May 6, 1729, as "This week will be published"; and afterwards as "Lately published", but the advertisement does not state specifically that Parks had reprinted these old favorites. It is probable that he imported them in sheets and bound them for local sale; indeed "The Weeks Preparation" and "Primers," see Nos. 56 and 57, are advertised in the Maryland Gazette for Oct. 20, 1730, as among his late importations.

$173^{\circ}$

6o. C., E., Gent. (Cooke, Ebenezer)? Sotweed Redivivus:| Or the Planters | LookingGlass.| In Burlesque Verse.| Calculated for the Meridian of | Maryland.| By E. C. Gent.| [One line from Juvenal.] Annapolis:| Printed by William Parks, for the Author.| M,Dcc, $\mathrm{xxx}$.

Sm. 4to. A-I'; 18 leaves; pages [i]-viii, [I]-28; p. [i]: title; p. [iii]: "The Preface to the Reader", with headpiece, and at end, "Vale."; pp. [iv]-viii: "To the Generous Subscribers, \&c.", with head and tail pieces and running head; pp. [r]-28: text, with head-piece and heading, "The Looking-Glass", in three cantos, tail-piece; p. 28: "Finis".

Leaf measures: $8 \times 6 \frac{1}{2}$ inches. Type page, p. 2 , height: $145 \mathrm{~mm}$.

Reprinted in Early Maryland Poetry, (Maryland Historical Society Fund Publication, No. 36, Baltimore. 1900) ed. by Bernard C. Steiner, with notes and photographic reproduction of the title-page.

JCB. NYPL.

61. Henderson, Jacob. The / Case / of the / Clergy of Maryland.| [Annapolis: Printed by William Parks. I730]?

4to. A, 4 leaves; pages I-8; pp. I-6: text of “Case"; pp. 6-8: “To the King's Most Excellent Majesty, The Petition of Jacob Henderson, Clerk, Rector of Queen Anne's Parish, in Prince George's County, in Maryland, in behalf of the Clergy of the said Province"; p. 8: "Finis".

Leaf measures: $9 \frac{1}{16} \times 7 \frac{1}{8}$ inches. Type page, p. 2: $191 \times 119 \mathrm{~mm}$.

"The Case of the Clergy of Maryland", was a protest against the "Act for Improving the Staple of 'Tobacco", (Act of Oct. 3, 1728, Archives of Maryland, 36: 275), by the terms of which a fourth of the "40 per poll" was taken away from the clergy. The Rev. Jacob Henderson was sent to England to present the "Case" to Lord Baltimore and the King, and while there he drew up the "Petition" attached to the printed case as noted above, or at least one assumes this to be so from the following assertion in a letter from him to the S. P. G. dated London, Sept. 18, 1729: "The case at large I have by the advice of our Rt Rev'd Diocesan drawn up in a petition to his most

$[177]$ 


\section{A History of Printing in Colonial Saryland}

Excellent Majesty, of which I am very desirous to have the Venerable Society's approbation ..." (Perry, Collections, v. 4). Whether he had the "Case" and the petition printed in England, or whether he had it printed in Annapolis on his return to Maryland in $173^{\circ}$ is not clear, but the general appearance of the pamphlet and the probabilities point to the Parks establishment as its place of origin. The political situation which brought it forth may be studied in Perry, Collections, v. 4, and in Hawks, Francis L. Contributions to the Ecclesiastical History of the United States of America. v. 2, (Maryland).

Another important source in the study of this controversy is:

The | Rev. Mr. Jacob Henderson's | fifth | Letter | to | Daniel Dulany, Esq; in Relation to the | Case and Petition | of the | Clergy of Maryland.| [Philadelphia]? Printed for the Author in the Year MDccxxxi1.| 4to. pp. [i-ii], 1-4 I, [42], in the New York Historical Society.

A part of this pamphlet, the Dr. Wildfire vs. Th. Extinguisher letters, first appeared in the American Weekly Mercury (Phila.) for April 6 and 13,1732. Additional material is to be found in this paper and in the Pennsylvania Gazetse during the spring of $1731 / 32$. An important source also of original documents concerning the "case"

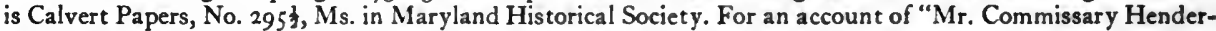
son", see article by Allen, Ethan, D. D. in Sprague, Annals (Epis.) Pp. 34-38. Jacob Henderson died Aug. 2 I, 175I, leaving his property, or a large part of it to the S. P. G. (Maryland Gazetie, Aug. 27, 1751.) The Classified Digest of the Records of the S.P.G. Lond. $1893, \mathrm{p}$. $85 \mathrm{I}$, says that the amount of the legacy was $£_{1}, \infty 00$.

A generation later the controversy over the "Two-penny Act" provided in Virginia a condition of affairs analogous to that which arose in Maryland at this time as the result of the "Tobacco Act" of 1728. See the Rev. John Camm's pamphlet, No. 243 of this bibliography.

JCB.

62. Maryland, Province of. Laws of Maryland,| enacted | at a Session of Assembly, begun and held at the City | of Annapolis, on Thursday, the | Twenty First day of May, in | the Sixteenth Year of the Do-| minion of the Right Honourable / Charles, Lord Baron of Bal-| temore, Absolute Lord and Pro-| prietary of the Provinces of Ma-| ryland and Avalon, \&c. Annoq;| Domini 1730.| [Baltimore arms] By Authority.| Annapolis:| Printed and Sold by William Parks. M,Dcc,xxx. Price | Two Shillings, to those who bought the whole Body of Laws, and | Two Shillings Six Pence to others.

Sm. fol. [A] ${ }^{1}, B^{2}, B_{-1}^{2}, M^{2}$, (Sign. B repeated); 24 leaves; pages [i-ii], I-[46]; p. [i]: title; Pp. 1-45: text, with heading; p. [46]: titles of private laws, etc.

Leaf measures: $11 \frac{7}{16} \times 7 \frac{1}{6}$ inches. Type page, p. 2: $252 \times 137 \mathrm{~mm}$.

Advertised as "la tely published" in Maryland Gazette for Oct. $20,1730$.

MdHS. MDioc (imp.) BBL. (imp.) MDSL. LC. NYBA. NYSL. HU. HLS. BM.

63. - [The New Tobacco Law, Made this Present Session of Assembly. Printed and sold by William Parks in Annapolis. 1730.]

No copy recorded. Evans, No. 3299, gives title and imprint as above, exactly as the work was advertised in the Maryland Gazette for June 16, 1730. The actual title of the act is long and begins: "An Act for Improving the "taple of Tobacco...", (Archives of Maryland, 37: 138-151). It is probable that Parks published it under its formal title and not as given in the ent:y above.

64. - The | Speech | of his Excellency | Benedict Leonard Calvert,| Governour and Commander in Chief, in and | over the Province of Maryland, to | both Houses of Assembly: at a Session of | Assembly, begun and held at the City | of Annapolis, on Thursday the Twenty | First Day of May, in the Sixteenth Year of $\mid$ the Dominion of the Right Hon. Charles,| Lord Baron of Baltemore, Absolute Lord and | Proprietary of the Provinces of Maryland and | Avalon \&c. Annoq; Domini 1730.| [Baltimore arms] By Authority.| Annapolis: Printed by William Parks, M.Dcc. xxx.|

Fol. 4 leaves, without signature; pages unnumbered; p. [r]: title; pp. [3-4]: "The Speech of His Excellency", etc., with head and tail pieces; pp. [5-6]: address of the Lower House to the Governor; pp. [7-8]: address of the Upper House to the Governor.

Leaf measures: $12 \frac{1}{4} \times 7 \frac{1}{3}$ inches. Type page, p. 3 , including head-piece: $243 \times 132 \mathrm{~mm}$.

MDSL. 


\section{SCaryland Imprints of the Colonial Period, $1689-1776$}

65. - To His Excellency | Benedict Leonard Calvert, Go-| vernour and Commander in Chief in and over | the Province of Maryland,| The | Humble Address | of the | Upper House of Assembly.| [Address delivered May 22, I 730 on "settling a Correspondency with the Government of Virginia" in the matter of tobacco legislation. The need of a new tobacco law, etc. His Excellency's Answer.] [Annapolis: Printed by William Parks. 1730.]

Single leaf, printed both sides, ornamental initial.

Leaf measures: $11 \frac{13}{16} \times 7 \frac{8}{8}$ inches. Type page, $\mathrm{p}$. [r], including heading and rules: $251 \times 134 \mathrm{~mm}$.

NYPL.

66. - To the Honourable | Benedict Leonard Calvert, Esq;| Governour of Maryland,| the | Humble Address | of | the House of Delegates.| [Address in regard to concerting an agreement with Virginia in relation to the common staple, tobacco.] Sign'd per Order of the House,| John Mackall, Speaker.| May 22, 1730.| [With the Governor's reply.] [Annapolis: Printed by William Parks. 1730.]

Single leaf, printed both sides, ornamental initial.

Leaf measures: $300 \times 195 \mathrm{~mm}$. Type page: $256 \times 134 \mathrm{~mm}$.

NYPL.

67. - Votes and Resolves, of the | Lower House of Assembly of the Province of | Maryland.| (May 21, prorogued from Aug. 8,-June 16, 1730) [Annapolis: Printed by William Parks. 1730.]

$\mathrm{Sm}$. fol. Issued separately in numbered parts, without signature; each number, except IX, has the following imprimatur at end: "By Order of the Lower House of Assembly, I do authorize and appoint William Parks to print the Votes and Proceedings of the said House, John Mackall, Speaker."; No. I: Pp. I-7, with heading as above and session heading of ten lines,-p. [8] blank; No. II: pp. I-2; No. III: pp. I-8; No. IV: pp. I-4; No. V: pp. I-4; No. VI: pp. I-4; No. VII : pP. I-[4],-p. [4], wrongly numbered “8”; No. VIII: pp. I-4; No. IX: Pp. I-8; No. X: Pp. I-4.

Leaf measures: $11 \frac{17}{16} \times 7 \frac{1}{2}$ inches. Type page, p. 2, No. I: $257 \times 135 \mathrm{~mm}$.

MDSL. MdHS. (Nos. I-VII only). NYPL.

68. [Cut] The / Maryland Gazette | [Cut] [Colophon as in issue No. 94 under year I729.]

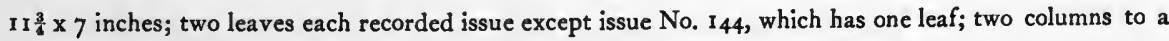
page.

NYPL. has issues as follows: Nos. I 29 (Feb. 24-Mch. 3, I729/30), I31 (Mch. 10-Mch. I7, 1729/30), I33 (Mch. 24-Mch. 31, 1730), I4I (May I9-May 26, 1730), I 43 (June 2-June 9, 1730), 144 (June 9-June 16, I 730 ), 162 (Oct. 13-Oct. 20, 1730), 68 (Nov. 24-Dec. 1, 1730 ), 170 (Dec. 8-Dec. 15, 1730), 171 (Dec. 15-Dec. 22, 1730), the only copies of this year located.

See Plate Va for title arrangement.

69. [WARner, Jонn. The Virginia and Maryland Almanack. Shewing the Time of SunRising and Setting, Length of Days, New and Full Moon, Eclipses, Fixt and movable Feasts, Seven Stars Rising and Setting, Weather, Days of the several Courts, \&c. For the Year of our Lord Christ, 1731. By J. Warner, Philomath. Annapolis: Printed by William Parks. 1730 . Price 6 d. or 4 s. per Dozen.]

No copy recorded. Advertised in Parks's Maryland Gazette for Oct. 13-20, 1730, as "Just Published."

$173^{1}$

70. Cooke, Ebenezer. The / Maryland Muse.| Containing | I. The History of Colonel Nathaniel Bacon's Rebellion | in Virginia. Done into Hudibrastick Verse, from | an old Ms.| II. The Sotweed Factor, or Voiage to Maryland.| The Third Edition, Corrected and

[179] 


\section{A History of Printing in Colonial Scaryland}

Amended.| By E. Cooke, Gent.| Let Criticks that shall discommend it,| . . . mend it.| [Type device] Annapolis:| Printed in the Year M,Dcc, XxxI.|

Fol. [A] ${ }^{1}, \mathrm{~B}-\mathrm{G}^{2},[\mathrm{H}]^{1} ; 14$ leaves; pages [i-ii], I-25, [26]; p. [i]: title, as above,-verso: "To the Author" (twentyfour lines of verse, three stanzas of 6, 8 and ro lines respectively, see note below); pp. 1-16: text of "Bacon's Rebellion", with head-piece and running heads; pp. 17-25: text of "The Sotweed Factor", with head and tail pieces, running heads; p. 25 , beneath type device: "N. B. The Author of these Poems intending to publish his Works annually, under the same Title, hopes The Second Part (when ready for the Press) will meet with the like Encouragement from his Friends and Benefactors."; type device at end same as on title page; text of poems in double column throughout.

Leaf measures: $12 \frac{1}{\mathrm{~g}} \times 7 \frac{5}{6}$ inches. Type page, p. 9: $260 \times 169 \mathrm{~mm}$.

No record remains of any copies of a first or second edition of The Maryland Muse, nor of any edition of "the second part" proposed by the author in his note on p. 25. "The Sotweed Factor" had been published first in London in 1708, but not in combination with "The History of ... Bacon's Rebellion." Mr. Wilberforce Eames thinks that the words "Third Edition" as used on the title-page refer only to the poem "The Sotweed Factor." If this be true, there is no need to look further for earlier editions of the collection, The Maryland Muse, but only for a second edition of "The Sotweed Factor," published sometime between 1708 and 1731 .

The twenty-four lines of verse on the verso of the title-page, initialed "H. J.", begin: Old Poet,| As you may remember,| You told me sometime in September / Your pleasant Muse was idly sitting,|, and continue with the information that "H. J." was sending to Cooke "an old, authentick Book", never before printed, for him to put into "Doggrel Verse". This, as appears later, was the "old Ms." of Bacon's Rebellion referred to in the title. Who was its author, and who was "H. J." who wrote this pleasant address, adjuring our poet to "Cook this Bacon"? For a description of "The Sotweed Factor", see foregoing narrative, Chapter Six. The London edition was reprinted in Shea's Early Southern Tracts, No. II, I 866, with introduction by Brantz Mayer, and in Early Maryland Poetry, (Maryland Historical Society Fund Publications No. 36, Baltimore. I900), edited by Bernard C. Steiner, with notes and photographic reproduction of the title-page.

See Plate V for a photographic reproduction of the title-page of The Maryland Muse.

BM. (press mark, 11686. 1).

7I. Maryland, Province of. Laws of Maryland,| enacted | at a Session of Assembly, | begun and held at the City of | Annapolis, on Tuesday the Thir-| teenth Day of July, in the Se-| venteenth Year of the Domi-| nion of the Right Honourable | Charles, Lord Baron of | Baltemore, Absolute Lord and | Proprietary of the Provinces | of Maryland and Avalon, \&c.| Annoq; Domini I 731.| [Baltimore arms] By Authority.| Annapolis:| Printed and Sold by William Parks, M,Dcc,xxxi. Price / Two Shillings, to those who bought the whole Body of Laws, and | Two Shillings and Six Pence to others.|

Sm. fol. [A]-B2; 4 leaves; pages [i-ii], I-6; p. [i]: title; pp. I-6: text, with session heading.

Leaf measures: $11 \frac{7}{16} \times 7 \frac{1}{1}$ inches. Type page, p. $2: 249 \times 137 \mathrm{~mm}$.

The dates of this session were July $13-29,1731$. The printing of the V. \& P. was not provided for by the customary resolution.

MdHS. MDioc. BBL. (dup.) MDSL. Pleasants. LC. NYBA. NYSL. HU. HLS. BM.

72. - Laws of Maryland,| enacted | at a Session of Assembly,| begun and held at the City of | Annapolis, on Thursday the Nine-| teenth Day of August, in the Se-| venteenth Year of the Domi-| nion of the Right Honourable | Charles, Lord Baron of | Baltemore, Absolute Lord and | Proprietary of the Provinces | of Maryland and Avalon, \&c.| Annoq; Domini I73I.| [Baltimore arms] By Authority.| Annapolis:| Printed by William Parks, M,DCC, XXXI.|

Sm. fol. [A]- $\mathrm{I}^{2}$, (omitting B and C); 14 leaves; pages [I-2], 3-27, [28]; p. [I]: title; pp. 3-27: text, with session heading; $\mathrm{P} .25$ is wrongly numbered $2 \mathrm{I}$, which is repeated.

Leaf measures: $I 1 \frac{1}{2} \times 7^{\frac{1}{4}}$ inches. Type page, p. $5: 252 \times 136 \mathrm{~mm}$.

MdHS. MDioc. BBL. (dup.) Pleasants. MDSL. LC. NYBA. HU. HLS. BM. 


\section{Taryland Imprints of the Colonial Period, $1680-1776$}

73. - Votes and Proceedings, | of the | Lower House of Assembly, of the Province of | Maryland.| (Aug. 19, prorogued from July 29,-Sept. 6, 1731) [Annapolis: Printed by William Parks. 1731.]

Fol. No signatures, 16 leaves; pp. I-32: text, with heading as above and session heading of eight lines; tailpiece. Numbered I-VIII, but is a compilation, not a collection of the separately issued parts.

Leaf measures: $12 \frac{1}{4} \times 7 \frac{8}{8}$ inches. Type page, p. $2: 288 \times 147 \mathrm{~mm}$.

MDSL. NYPL. (imp.)

74. [The Maryland Gazette (I730/3I-I 73I)].

No issues of the Maryland Gazette remain for the year I731, but from the sense of the following extracts from the Vestry Proceedings of St. Anne's Parish, Anne Arundel County, noted in Brigham, American Newspapers, it is clear that it was continued at least throughout March $1730 / 31$ :

"Tuesday March gth, 1730 . . . . Ordered that advertizement be Inserted and Continued in the Maryland Gazette relating to the parishioners Registring the births, Burialls \& Marriages, \&c: and that such advertizement be also sat up at the Mills Gate house, Court house and publick houses within this parish and that the printing such advertizements be paid for by this Vestry."

Again on Jan. 4, 1731/32:

"Mr. Parks produces to this Vestry the following account and prays allowance for the same (Viz)

I730 I [i. e. I730/3I] March. To an advertizement in the Gazette thrice

April 3d To Printing separate Advertizements about Registering

Errors Excepted per Wm. Parks

$$
\begin{aligned}
& \text { O.. } 7 . . \\
& 0 . .4 \ldots \\
& \hline 0 . .11 . .
\end{aligned}
$$

Which Acct being read is allowed off and ordered that the Regr draw an order for the same on Mr. John Beale payable to the said Parks." (Maryland Historical Magazine, 8: 158, 163).

The three issues here referred to would have been those of Mch. I6 and 23, I730/3I and Mch. 30, I731. It is generally believed that soon after this date Parks became so busily engaged with his Williamsburg press that he allowed his Maryland newspaper to lapse. He asserted in the (Phila.) American Weekly Mercury of July 15 , I73I, that he was at this time residing in the Virginia capital. It is possible that the "Gazette" lapsed soon after the issue of Mch. 30, 1731, and was resumed only with a changed title in Dec. 1732. (See under that year.)

$$
\text { I } 73^{2}
$$

75. [Grew, Theophilus. The Maryland Almanack, for the Year of our Lord God, I733. Being the First after Bessextile [sic]. Wherein is contained, the Lunations, Conjunctions, Eclipses; the Increase, Decrease, and Length of the Days and Nights, with the Rising, Southing, Setting, and Places of the Heavenly Bodies throughout the Year; the true System of the visible World explain'd; and many other Things both pleasant, useful, and necessary. Calculated according to Art, and referred to the Horizon of 39 Degrees North Latitude, and 75 Degrees West Longitude from the famous City of London, fitting the Province of Maryland, and without sensible Error, Virginia, New-Jersey, Pensylvania [sic], and New-York. By Theophilus Grew, Student in the Mathematicks. Printed and Sold by William Parks, and Edmund Hall, at their Printing Office in Maryland. 1732.]

No copy recorded. Advertised as "Just Publish'd" in Parks's Maryland Gazette for Jan. 26-Feb. 2, 1732/3.

76. Lewis, Richard. Carmen Seculare,| for the Year| M,Dcc,xxxir.| [Two lines, Hor. Ode vi. Lib. iv., Four lines from Bacon, Advanc. of Learn.; Baltimore arms] To the Right Honourable | Charles, | Absolute Lord and Proprietary of the | Provinces of Maryland, and Avalon,| Lord Baron of Baltimore, \&c.| [Annapolis: Printed by William Parks. 1732.]

Fol. 2 leaves; pages [I-4]: text, with heading as above; p. [4]: I am,| May it please your Lordship, / your most obedient, | Most devoted, Humble Servant, | Richard Lewis.| Annapolis,| Nov. 25, 1732 |.

Leaf measures: $14 \frac{5}{8} \times 9^{\frac{1}{2}}$ inches. Type page, p. [1], including heading: $262 \times 168 \mathrm{~mm}$.

Poetic address to Charles, Lord Baltimore, on the occasion of his visit to the Province to assume its government in person. Reprinted in American Museum for $1789,6: 413$, under title of "A Description of Maryland." See also note to No. 77 .

MdHS.

[I8I] 


\section{A History of Printing in Colonial Scaryland}

77. [Lewis, RichaRd.]? March I, I 73I-2 | A | Rhapsody.| [Four lines quoted, "Tacitus, vel ut aliis placet Quintil. in Dialogo de Oratoribus."] [Annapolis: Printed by William Parks. 1732.]

Fol. I leaf, printed both sides, with head-piece, tail-piece and heading as above.

Leaf measures: $14 \frac{8}{8} \times 9^{\frac{1}{2}}$ inches. Type page, p. [I], including head-piece: $277 \times 170 \mathrm{~mm}$.

Reflective poem, probably by Richard Lewis, see under 1728. The name of Parks does not appear either on this sheet or in Lewis's Carmen Seculare of this year, but circumstantial and typographical evidence render reasonably certain the attribution to Parks. A Rhapsody was reprinted in Parks's Maryland Gazeste for Feb. 9, 1732/ 33. See foregoing narrative, Chapter Six, for a brief account of Richard Lewis.

MdHS.

78. Maryland, Province of. Laws of Maryland, enacted | at a Session of Assembly, begun and held at the City of | Annapolis, on Tuesday, the Ele-|venth Day of July, in the | Eighteenth Year of the Domi-| nion of the Right Honourable| Charles, Lord Baron of | Baltemore, Absolute Lord and | Proprietary of the Provinces | of Maryland and Avalon, \&c.| Annoq; Domini 1732.| [Baltimore arms] By Authority.| Annapolis:] Printed and Sold by William Parks, and Edmund Hall, M,Dcc,xxxiI.| Price Two Shillings to those who bought the whole Body of Laws,| and Two Shillings and Six Pence to others.|

Sm. fol. [A]-Mi2; 24 leaves; pages [i-ii], I-43, [44], should be, I-l46], Pp. 37 and $3^{8}$ repeated; p. [i]: title; pp. 1-43 [45]: text, with session heading.

Leaf measures: $11 \frac{7}{16} \times 7 \frac{1}{4}$ inches. Type page, p. $2: 243 \times 137 \mathrm{~mm}$.

MdHS. BBL. MDSL. LC. BM.

79. - The | Speech | of His Excellency | Samuel Ogle,| Governor and Commander in Chief, in and | over the Province of Maryland, to / both Houses of Assembly: at a Session,| begun and held at the City of Annapolis, ou [sic] Tuesday, the Eleventh Day of July, in / the Eighteenth Year of the Dominion of | the Right Honourable Charles, Lord | Baron of Baltemore, Absolute Lord and I Proprietary of the Provinces of Maryland | and Avalon, \&c. Annoq; Dom' 1732.| [Baltimore arms] By Authority.| Annapolis:| Printed by William Parks and Edmund Hall. M,Dcc,xxxir.]

Fol. No signatures or pagination; 4 leaves; p. [1]: title; pp. [3-4]: head-piece and heading, "The Speech of His Excellency", etc; pp. [5-6]: address of Upper House; pp. [7-8]: address of Lower House.

Leaf measures: $12 \frac{1}{6} \times 7 \frac{1}{2}$ inches. Type page, p. A 2 recto, including head-piece: $246 \times 136 \mathrm{~mm}$.

MDioc.

8c. - Votes and Proceedings, | of the [ Lower House of Assembly of the Province of | Maryland.| (July II-Aug. 8, I732). [Annapolis: Printed by William Parks and Edmund Hall. I732.]

Fol. No signatures; pages 1-57, [58]: text, with heading as above and session heading of seven lines; Nos. I and 2: pp. 1-4; Nos. 3 and [4]: pp. 5-8; Nos. 5, 6 and 7: pp. 9-12, (p. 9, misprinted 5); Nos. 8 and 9: pp. 13-16; Nos. I0 and II: pp. 17-20; Nos. 12 and 13 : Pp. 21-24; No. 14: Pp. 25 and 26; No. 15: Pp. 27-30; Nos. 16 and 17 : Pp. $31-34$; No. 18: pp. 35-38; Nos. 19 and 20: pp. 39-42; Nos. 21, 22, 23, 24 and [25]: pp. 43-57.

Leaf measures: $12 \frac{3}{\frac{3}{3}} \times 7 \frac{1}{\frac{1}{3}}$ inches. Type page, p. 2: $265 \times 137 \mathrm{~mm}$.

MDioc. MDSL.

81. [The Maryland Gazette Reviv'd. Dec. 5-Dec. 26, 1732, Nos. I-4. Annapolis: Printed by William Parks and Edmund Hall.]

No issues of this year have been located, but the issue of Feb. 2, $1732 / 33$, has title and imprint as above and is No. 9. It is probable that with Edmund Hall as a partner, Parks found himself able to resume his Maryland newspaper. Sometime between Apr. 20 and Dec. 28, 1733 , Nos. 19 and 51, Parks again became sole publisher. See under 1733 . 
82. [Grew, Theophilus. Grew's Almanack; for the Year of our Lord God, I734. Being the Second after Bissextile. Wherein is contained, the Lunations, Conjunctions, Eclipses; the Increase, Decrease, and Length of the Days and Nights, with the Rising, Southing, Setting and Places of the Heavenly Bodies, throughout the Year; the true Reasons of Eclipses, and the Increase and Decrease of the Moon, explained and demonstrated, with many other Things pleasant, useful and necessary. Calculated according to Art, and referred to the Horizon of 39 Degrees North Latitude and 75 Degrees West Longitude from the famous City of London, fitting the Province of Maryland, and without Sensible Error, Virginia, New-Jersey, Pennsylvania, and New-York. By Theophilus Grew, Student in the Mathematicks.

God gave to Man an upright Heart, that $\mathrm{He}$

Might view the Stars and learn Astronomy.

Printed and Sold by William Parks, at his Printing-Office, in Maryland. 1733.]

No copy recorded. Advertised as "Lately Published" in Parks's Maryland Gazette for Dec. 28, 1733.

83. Maryland, Province of. Laws of Maryland,| enacted | at a Session of Assembly, begun and held | at the City of Annapolis, on Tuesday | the Thirteenth Day of March, in the | Eighteenth Year of the Dominion of | the Right Honourable Charles,| Lord Baron of Baltimore, Absolute | Lord and Proprietary of the Provin-| ces of Maryland and Avalon, \&c. An-f noque Domini, I732.) [Baltimore arms] By Authority.| Annapolis:| Printed and Sold by William Parrs. [sic] M,Dcc,xxxinI.| [Price Two Shillings to those who bought the whole Body of [ Laws, and Two Shillings Six Pence to others.]|

Sm. fol. [A]-L2; 22 leaves; pages [1-2], 3-44; p. [I]: title; Pp. 3-44: text, with session heading; p. 44: contents, tail-piece.

Leaf measures: $\mathrm{r} 1 \frac{1}{2} \times 7 \frac{1}{\frac{1}{2}}$ inches. Type page, p. 6: $255 \times 137 \mathrm{~mm}$.

MdHS. MDioc. BBL. (imp.) MDSL. LC. HLS. BM.

84. - Votes and Proceedings, | of the | Lower House of Assembly, of the Province | of Maryland. (March I3, I732/33-April I2, I733) [Annapolis: Printed by William Parks. I733.]

Sm. fol. A-I ${ }^{2}$; 18 leaves; pages I-36: text with heading as above, session heading of seven lines and tail-piece of three separate ornaments.

Leaf measures: $11 \frac{1}{2} \times 6 \frac{7}{8}$ inches. Type page, p. $2: 253 \times 135 \mathrm{~mm}$.

NYPL.

85. [Cut] The | Maryland Gazette | Reviv'd.| [Cut] [Colophon:] Annapolis: Printed by W. Parks, and E. Hall: By whom Subscriptions | are taken for this Paper, at I 5 s. a Year; and Advertisements at $3 \mathrm{~s}$. the first Week, and 2 s. every Week after.|

NYPL. has Nos. 9 (Jan. 26-Feb. 2, 1732/33), 10 (Feb. 2-Feb. 9, 1732/33), and I5 (Mch. 9-Mch. 16, 1732 [sicl.) Soon after No. 15 , the former style of the title was resumed as follows:

E. Hall.|

[Cut] The / Maryland Gazette [ [Cut]. [Colophon:] Annapolis: Printed by W. Parks, and

NYPL. has Nos. 19 (Apr. 6-13, 1733) and 51 (Dec. 21-28, 1733).

In No. 51 , the colophon reads as follows: Annapolis: Printed by William Parks: By whom Subscriptions are taken in for this Paper, at | Fifteen Shillings a Year; and Advertisements to be inserted in it, at Three Shillings for the first Week, and | Two Shillings for every Week after. N. B. Old Books are well bound by him.|

See Plate $\mathrm{V} a$ for title arrangement. When the word "Reviv'd" was added to the title, it was placed in the space immediately beneath the words "Maryland Gazette" in this reproduction. 


\section{A History of Printing in Colonial STaryland}

1734

86. [GREw, Theophilus. Grew's Almanack, for the Year of our Lord God, 1735. Being the third after Bissextile. Wherein are contained, The Lunations, Conjunctions, Eclipses; The Increase, Decrease, and Length of the Days and Nights, the Rising, Southing, and Setting of the Heavenly Bodies; with many other Things, both pleasant, useful and necessary. Calculated according to Art. And referred to the Horizon of 39 Degrees North Latitude, and 75 Degrees, West Longitude, from the famous City of London, fitting Virginia, Maryland, Pennsylvania, New-Jersey, and New-York. By Theophilus Grew, Student in the Mathematicks. Printed and Sold by William Parks, at his Printing-Offices in Virginia and Maryland. I734.]

No copy recorded. Advertised as "Just Published" in Parks's Maryland Gazette for Nov. 22, I734.

Maryland, Province of. (There were no acts passed at the convention of Assembly of March 19, I 733/34-March 25, 1734, nor was the printing of the V. \& P. provided for by the customary resolution.)

87. [Cut] The | Maryland Gazette | [Cut]. [Colophon as in issue No. 5 I under year 1733.]

NYPL. has Nos. 54 (Jan. 1 1-18, 1734), 64 (May 17-24, 1734), 71 (July 1 1-19, 1734), 73 (July 26-Aug. 2, 1734), 74 (Aug. 2-9, I734), 8 I (Sept. 20-27, I734), 86 (Oct. 25-Nov. I, 1 734), 89 (Nov. 15-22, 1734), 90 (Nov. 2229 , 1734), the only known copies of this year's issues. Evidently this newspaper ceased publication soon after this, for there are no traces of it in the year 1735 or later.

See $\mathrm{Plate} \mathrm{V} a$ for title arrangement.

\section{5}

88. Maryland, Province or. Laws of Maryland, enacted | at a Session of Assembly, begun and held | at the City of Annapolis, on Thursday,| the Twentieth Day of March, in the | Twentieth Year of the Dominion of the | Right Honourable Charles, Lord | Baron of Baltimore, Absolute Lord and | Proprietary of the Provinces of Mary-| land and Avalon, \&c. Annoq; Domini I734.| [Baltimore arms] By Authority.| Annapolis:| Printed and Sold by William Parks. M,Dcc, xxxiv. [sic] | (Price Two Shillings to those who bought the whole Body of | Laws, and Two Shillings and Six Pence to others.) |

La. 4 to. I preliminary leaf, A-F', $\mathrm{G}^{1} ; \mathrm{I}_{4}$ leaves; pages [I-2], 3-[28]; p. [I]: title; pp. 3-27: text, with session heading; p. [28]: contents.

Leaf measures: $12 \frac{3}{18} \times 8 \frac{1}{8}$ inches. Type page, p. $4: 256 \times 139 \mathrm{~mm}$.

The date of publication was printed as given above, but obviously should have been 1735 .

MdHS. MDioc. BBL. (imp.) MDSL. LC. HLS. BM.

89. - Votes anc Proceedings | of the [ Lower House of Assembly, of the Province / of Maryland.| (March 20, I734/35-April 24, 1735) [Annapolis: Printed by William Parks. 1735.]

$\mathrm{Sm}$. fol. A-I'; 18 leaves; pp. I-36: text, with heading as above, session heading of seven lines and tail-piece. Leaf measures: $11 \frac{1}{4} \times 7$ inches. Type page, p. 2: $247 \times 136 \mathrm{~mm}$.

This is a compiled edition, not a collection of the parts issued separately throughout the session.

MDSL.

\section{6}

90. Maryland, Province of. Laws of Maryland, enacted / at a Session of Assembly, begun | and held at the City of Annapo-| lis, on Friday, the Nineteenth Day | of March, in the Twenty First Year of | the Dominion of the Right Honourable | Charles, Lord Baron of Baltimore,| Absolute Lord and Proprietary of the | Provinces of Maryland and Avalon, 


\section{Karyland Imprints of the Colonial Period, $1689-1776$}

\&c.| Annoque Domini I735.] [Baltimore arms] By Authority.| Printed by William Parks, and Sold at his Printing-| Office in Annapolis. M,Dcc, Xxxvi.|

Fol. [A] ${ }^{1}, \mathrm{~B}-\mathrm{G}^{2}, \mathrm{H}^{1}$; 14 leaves; pages [i-iii], I-26; p. [i]: title; Pp. I-25: text, without heading; p. 25: titles of three private laws; pp. 25-26: contents, tail-piece.

Leaf measures: $12 \frac{3}{3} \times 8 \frac{1}{\frac{1}{3}}$ inches. Type page, p. 2: $253 \times 144 \mathrm{~mm}$.

The dates of this session were March 19, 1735/36-April 10, 1736. Although the printing of the V. \& P. was ordered, no copy for this Session has been recorded.

In Archives of Maryland, v. 40, is to be read the story of Parks's neglect to print on time the laws passed in the Session of April 20-May 6, 1736, and in the Acts for the Session of April 26-May 28, 1737 appears the Act by which it was attempted to render negligence on the part of the printer less likely to occur in the future. It appears from the proceedings of the Lower House, May 27, 1737, that although too late to avoid criticism, Parks had finally printed the laws of the previous session. Copies of this set of session laws (April 20-May 6, 1736) have often been regarded as non-existent, but the truth is that they were published with a misleading title-page; that is, although no laws received the governor's signature at the first convention of this Assembly (Mch. 19, 1735 /36-April 10, 1736), those which passed the houses at this convention were signed at the close of the session of April 20-May 6, 1736 and together with the laws properly belonging to the last named session were published by Parks with the title as given above, as being the laws of the session beginning March $19,1735 / 36$. As the session beginning April 20, I736 was by prorogation from the earlier convention, it is likely that technically this title was correct, but the procedure was unusual, and it has resulted in a general belief that the laws of the session of April 20-May 6, 1736 were not printed.

MdHS. MDioc. BBL. MDSL. BM.

(The printing of the V. \& P. for the Session of April 20-May 6, 1736 was ordered, but no copy of the volume has been recorded.)

\section{737}

9I. Maryland, Province of. Laws of Maryland, enacted | at a Session of Assembly, | begun and held at the City of Annapolis, | on Tuesday, the Twenty Sixth Day of April, in the | Twenty Second Year of the Dominion of the Right | Honourable Charles, Lord Baron of Balti-| more, Absolute Lord and Proprietary of the Provinces | of Maryland and Avalon, \&c. Annoq; Domini I737.| [Baltimore arms] By Authority.] Printed by William Parks, and Sold at his Printing-| Office in Annapolis. M,DCC,XXxviI.|

Fol. [A] ${ }^{1}$, B-E ${ }^{2}$; 9 leaves; pages [i-ii], I-I 5, [16]; p. [i]: title; pp. 1-15: text, without heading; p. [16]: contents. Leaf measures: $12 \frac{8}{16} \times 7 \frac{1}{2}$ inches. Type page, p. $3: 256 \times 144 \mathrm{~mm}$.

MdHS. MDioc. BBL. MDSL. NYBA.

92. - Laws of Maryland, enacted | at a Session of Assembly, begun and | holden at the City of Annapolis, | on Thursday, the Eleventh Day of August, in | the Twenty Second Year of the Dominion | of the Right Honourable Charles, | Lord Baron of Baltimore, Absolute Lord | and Proprietary of the Provinces of Ma-| ryland and Avalon, \&c. Annoque Domi-| ni 1737 .| [Type device] By Authority.| Annapolis:| Printed and Sold by William Parks. M,DCC, XXXvir.

Fol. [A] $]^{1}, \mathrm{~B}^{-C^{2}} ; 5$ leaves; pages [i-ii], I-8; p. [i]: title; pp. I-8: text, without heading; p. 8: contents.

Leaf measures: $12 \times 7 \frac{3}{4}$ inches. Type page, p. $2: 250 \times 145 \mathrm{~mm}$.

The dates of this session were Aug. I I-16, 1737. The printing of the V. \& P. was not provided for by the customary resolution.

MDioc. MdHS. BBL. NYBA.

93. - Votes and Proceedings | of the | Lower House of Assembly of the Province of | Maryland.1 (26 April, I737, prorogued from 6 May, 1736,-28 May, 1737.) [Annapolis: Printed by William Parks. 1737.]

$\mathrm{Sm}$. fol. A-C $\mathrm{C}^{2}, \mathrm{C}^{2}, \mathrm{E}-\mathrm{F}^{2}$, only ("C" repeated, " $\mathrm{D}$ " omitted); 12 leaves; pages I-24 + : text, with heading as above and session heading of eight lines; concludes with proceedings of May 26, 1737 .

Leaf measures: $11 \frac{3}{16} \times 7$ inches. Type page, p. 2: $237 \times 131 \mathrm{~mm}$.

MDSL. (imp.)

[185] 


\section{$A$ History of Printing in Colonial SCaryland}

\section{8}

Maryland, Province of. (There were no acts passed at the convention of Assembly of May $3-23,173^{8}$, nor was the printing of the V. \& P. provided for by the customary resolution. Although Jonas Green was in Annapolis in this year and employed by the Government (see Chapter Seven of the preceding narrative), no imprint of this year has been recorded bearing his name.)

\section{9}

94. Maryland, Province of. A | Collection | of the Governor's several | Speeches, and the | Addresses of each House;| Together with several | Messages and Answers thereto, which Passed between each House, at a Convention of an Assembly, begun the First of May, I739.| To which is added,| the Copy of an Order of Council, made | on Occasion of some Members being stiled, and Acting | after the Prorogation of the Assembly, as a Com-| mittee of the House of Delegates.| [Baltimore arms] Maryland:| Printed and Sold by Jonas Green. I $739 . \mid$

Sm. fol. [A] $]^{1}, \mathrm{~B}-\mathrm{K}^{2}, \mathrm{~L}^{4}, \mathrm{M}-\mathrm{X}^{2}$; 43 leaves; pages [i-ii], [r]-80, (should be 84 , pagination runs: 37 , xxxviii, xxxix, $\mathrm{xl}, \mathrm{xli}, 38,39,40,4 \mathrm{I})$; $\mathrm{p}$. [i]: title; pp. [r]-72 [76]: text of speeches and replies to and from Governor Ogle, with heading, head and tail pieces; pp. 73-80 [77-84]: text, with heading, At a Council,| Held in the Council Chamber,| On Wednesday the First Day of August, Anno Domini, 1739.|, with head and tail pieces.

Leaf measures: $11 \frac{3}{8} \times 7$ inches. Type page, p. $3: 236 \times 138 \mathrm{~mm}$.

"At a Council," etc. pp. 73-80 [77-84], was reprinted with other matters in the following year. See below, No. 10 . The "Collection" was not printed until after Aug. 1, 1739, the date of the Council record included in its contents.

MDSL. LC. (title-page defective).

95. - A | Journal | of the | Votes | and | Proceedings | of the | Lower House of Assembly | of the | Province of Maryland,! at their Session begun May I. I739.| (-1 2 June 1739.) [Baltimore arms] Annapolis: Printed and Sold by Jonas Green. 1739.1

Sm. 4to. Issued in unnumber:d parts with continuous paging and signatures; $\mathrm{p}$. [r]: title, serving as general title for series until new pagination was begun in Sept. 1742; pp. [3]- 197, [198]: text as follows:

[No. I]: $A^{3}, B^{4}, C^{1}, D^{2},-$ pp. [3]-22; [No. 2]: $E^{4}, F^{2}$, pp. 23-[34]; [No. 3]: $G^{4}, H^{2}, I^{1},-$ pp. 35-48; [No. 4]: $K^{4}, L^{4}$,

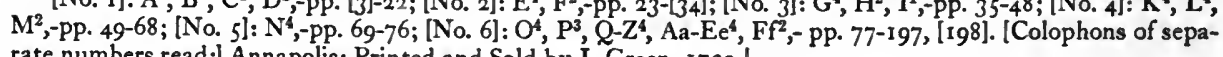
rate numbers read:] Annapolis: Printed and Sold by J. Green. 1739.|

Leaf measures: $8 \frac{1}{4} \times 6 \frac{1}{2}$ inches. Type page, p. $4: 189 \times 139 \mathrm{~mm}$.

On May 3, I739, the Lower House "Resolved, that the Votes and Proceedings of this House this Session be Printed: Mr. Jonas Green allowed to Print them; and Ordered, that he be Allowed Twelve Shillings per Day for sc doing, and that he have them finished every Monday and Thursday." The accumulated edition described above was late in attaining publication, as appears from the following note on p. 197 : "The foregoing Votes and Proceedings, \&c. would have been Published a considerable Time Since, had not Sickness, with which myself (and Family) have lately been afflicted, prevented it; which is the only Reason that has kept them so long from the Publick. Sept. 20. J. Green." This note may refer only to the last section [No. 6], Pp. 77-[198]. The earlier with the general title-page given above at the time of publication of the last section, [No. 6].

There were no Acts passed at this convention of Assembly.

MDSL. NYPL. MdUIS. (lacks title page).

96. - To his Excellency | Samuel Ogle, Esq; Governor and Commander in Chief in and over the Province of | Maryland: | The humble Address of the | Upper House of Assembly.| May it please your Excellency, . . . [Address and his Excellency's answer]. Annapolis: Printed aind Sold by J. Green. I 739.|

Single leaf, printed both sides, head-piece. 


\section{Scaryland Imprints of the Colonial Period, $1689-1776$}

Leaf measures: $11 \frac{1}{4} \times 7 \frac{1}{2}$ inches. Type page, p. 2 , including imprint: $226 \times 140 \mathrm{~mm}$.

This single leaf seems to be the earliest extant specimen of Jonas Green's Maryland Press, although unquestionably he had printed for the Assembly before this time. A Collection of the Governor's Several Speeches of this year was not printed until after Aug. I, 1739, (see note to No. 94, above); the earliest number of the V. \& P. of this session beginning May I, 1739 was not issued certainly until May roth, (see note to No. 95, above). This address "To his Excellency" on the contrary was doubtless printed and published as a current document during the early days of the May Session, at which Assembly it was delivered.

NYPL.

I 740

97. Maryland, Province of. An Act / made and passed at a Session of Assembly begun and held at the City of Annapolis, | on Wednesday the Twenty third Day of April, in the Twenty sixth Year of the / Dominion of the Right Honourable Charles, Lord Baron of Baltimore,| Absolute Lord and Proprietary of the Provinces of Maryland and Avalon, \&c.| Annoque Domini 1740.1

An Act for Issuing and Paying out of the Office of the Commissioners or Trustees | for Emitting Bills of Credit established by Act of Assembly the Sum of Two | Thousand Five Hundred and Sixty Two Pounds Ten Shillings Current Money | in Bills of Credit to be applied for the Encouragement of Persons voluntarily | Inlisting themselves in his Majesty's Service.|[ [Colophon:] Annapolis: Printed and Sold by Jonas Green. MDccxu.|

Fol. 2 leaves; pp. [I]-4: text, with heading as above; p. 4 : colophon.

Leaf measures: $13 \times 8 \frac{5}{6}$ inches. Type page, p. 2: $279 \times 169 \mathrm{~mm}$.

MdHS. BBL.

98-Acts of Assembly | of the | Province of Maryland:| made and passed | at a Session of Assembly, begun and held at the City / of Annapolis, on Monday the Seventh Day of July, in | the Twenty sixth Year of the Dominion of the Right | Honourable Charles, Lord Baron of Baltimore,| Absolute Lord and Proprietary of the Provinces of | Maryland and Avalon, \&c. Annoque Domini I 740.| [Baltimore arms] Published by Authority.| Annapolis: Printed by Jonas Green, Printer $\mid$ to the Province, and Sold at his Printing-Office.| M,DCc, XL.|

$\mathrm{Sm}$. fol. [A]-F², $\mathrm{G}^{\mathrm{I}}$; 13 leaves; pages [i-ii], I-24; p. [i]: title; Pp. I-23: text, without heading, running head; $\mathrm{p}$. 24: contents.

Leaf measures: $12 \times 8$ inches. Type page, p. 2: $233 \times 139 \mathrm{~mm}$.

MdHS. MDioc. BBL. (dup.) MDSL. LC. NYPL. (imp.) HLS.

99. - [Advertisement. In Pursuance of an Act of Assembly of this Province for Encouragement of his Majesty's Levies within the same . . . Annapolis: Printed by Jonas Green. 1740.]

No copy of this item, doubtless a broadside, has been located. It was a recruiting poster, setting forth the bounty and remission of taxes, etc. to those who should enlist in the West Indian Expedition, in accordance with the Act of Assembly of April 23, 1740. (See above.) By the terms of the act Jonas Green was ordered to print 600 copies of this "Advertisement", of which 50 copies were to be sent to each county. The "Advertisement" is printed in full in Archives of Maryland, 40: 573 and 574.

100. - At a Council.| Held in the Council Chamber, on Wednesday the First Day of August, Anno Domini, I 739.| Present,| His Excellency the Governor,| The Honourable [in a bracket the following names:] Col. Ward, | Benjamin Tasker, Esq;| Philip Lee, Esq; George Plater, Esq;| Edmund Jenings, Esq;| James Hollyday, Esq; Col. Hammond,| Col. Gale, James Harris, Esq;| [Colophon:] Annapolis: Printed and Sold by Jonas Green. I740.|

Fol. ${ }^{*},{ }^{* *},{ }^{*}{ }^{*}, *_{*}^{* *}$, two leaves each; 8 leaves; pages I-1 5, [16]; pp. I-8: text, with head-piece and heading as above, and at end "Copy", "J. Ross, Cl. Con.", tail-piece; pp. 9-1 5: text, with heading, Maryland, ss.| [Balti- 


\section{A History of Printing in Colonial SCaryland}

more arms] At a Council,| Held at the House of his Excellency Samuel Ogle, Esq;| in the City of Annapolis, on Tuesday the 22d Day | of January, in the Twenty-fifth Year of his Lord-| ship's Dominion. Annoque Domini, 1739.| Present,| His Excellency Samuel Ogle, Esq; Governor,|

$$
\text { The Honourable }\left\{\begin{array}{l}
\text { Benjamin Tasker, Esq; } \\
\text { Edmund Jenings, Esq; } \\
\text { Col. Levin Gale. }
\end{array}\right.
$$

Leaf measures: $12 \frac{1}{8} \times 7 \frac{5}{8}$ inches. Type page, p. 3: $234 \times 139 \mathrm{~mm}$.

The first eight pages, containing the Council minutes of Aug. 1, 1739, had been printed previously as part of "A Collection of the Governor's Several Speeches" in I739. See No. 94.

MdHS. (Portfolio No. I1). Henry E. Huntington Library (Church Cat. No. 935).

Ior. -The | Speech | of his Excellency | Samuel Ogle, Esq;| Governor and Commander in Chief in and over the | Province of Maryland;| to both Houses of Assembly:| at a Session of Assembly, begun and held at the City of | Annapolis, on Monday the Seventh Day of July, in the | Twenty sixth Year of the Dominion of the Right Honourable / Charles, Lord Baron of Baltimore, Absolute Lord 1 and Proprietary of the Provinces of Maryland and Avalon,| \&c. Annoque Domini 1740.| [Baltimore arms] Published by Authority.| Annapolis:| Printed and Sold by Jonas Green. 1740.|

Sm. fol. 2 leaves, without signature; pages unnumbered; p. [r]: title; pp. [3-4]: text, with head-piece and heading, "The Speech ... July 7, 1740".

Leaf measures: $12 \times 7 \frac{3}{3}$ inches. Type page, p. [3], including head-piece: $232 \times 13^{8} \mathrm{~mm}$.

HU.

102. - Votes and Proceedings | of the Lower House of Assembly of the Province of Maryland.| (23 April-5 June, 1740). [Colophons of separate parts read:] Annapolis: Printed and Sold by Jonas Green. 1740.1

Sm. 4to. Issued in unnumbered parts. Paging is continuous with V. \& P. of 1739 but signatures begin new series. [No. I]: $\mathrm{A}^{4}, \mathrm{~B}^{2}$,-pp. 199-[210] with heading as above and session heading of seven lines; [No. 2]: $\mathrm{C}^{4}, \mathrm{D}^{3}$,pp. 2 I I-[222]; [No. 3]: E-F $, G^{3},-$ pp. 223-[244]; [No. 4]: H-O4, P2,-pp. 245-304; [No. 5]: Q-R ,-pp. 305-320; [No. 6]: S-T $T^{4}, V^{3}$,-pp $32 \mathrm{I}-[342]$; p. $34 \mathrm{I}$ : three lines correcting error on p. 233.

Leaf measures: $8 \frac{2}{4} \times 6 \frac{7}{16}$ inches. Type page, p. $200: 193 \times 139 \mathrm{~mm}$.

MdHS.

103. - Votes and Proceedings | of the Lower House of Assembly of the Province of Maryland.| (7 July-29 July 1740) [Colophon:] Annapolis: Printed and Sold by J. Green, Printer to the Province.| [1740].

Sm. 4 to. A-H $\mathrm{H}^{4}, \mathrm{I}^{2} ; 34$ leaves; paged continuously with V. \& P. of former session; pp. 343-4IO: text, with heading as above and session heading of seven lines.

Leaf measures: $8 \frac{1}{6} \times 6 \frac{7}{16}$ inches. Type page, p. $344: 188 \times 139 \mathrm{~mm}$.

MdHS.

I 741

104. Maryland, Province of. Acts of Assembly | of the | Province of Maryland:| made and passed | at a Session of Assembly, begun and held at the / City of Annapolis, on Tuesday the Twenty sixth Day of | May, in the Twenty seventh Year of the Dominion / of the Right Honourable Charles, Lord Baron | of Baltimore, Absolute Lord and Proprietary of the | Provinces of Maryland and Avalon, \&c. Annoque | Domini, 1741.| [Baltimore arms] Published by Authority.| Annapolis: Printed by Jonas Green, Printer | to the Province, and Sold at his Printing-| Office in Charles-Street. 1741.|

Fol. [A]-D $D^{2}, E^{1} ; 9$ leaves; pages [i-ii], I-1 5, [16]; p. [i]: title; pp. I-1 4: text, with running heads; p. I5: contents.

Leaf measures: $12 \frac{7}{8} \times 8 \frac{1}{4}$ inches. Type page, p. 2: $228 \times 137 \mathrm{~mm}$.

MDSL. MDioc. BBL. Pleasants. MdHS. (Calvert papers.) 
105.- - Votes and Proceedings | of the Lower House of Assembly of the Province of Maryland.| (26 May-22 June, I74I) [Annapolis: Printed by Jonas Green. I74I.]

Sm. 4 to. A-G ${ }^{4}, \mathrm{H}^{2}, \mathrm{I}^{2}$ only, in single known copy; pp. $4 \mathrm{I} \mathrm{I}-474$ t: text, with head-piece, heading as above and session heading of seven lines.

Leaf measures: $8 \frac{1}{\frac{1}{4}} \times 6 \frac{7}{16}$ inches. Type page, p. $4^{12:} 189 \times 13^{8} \mathrm{~mm}$.

MdHS. (imp. ends, p. 474, with proceedings of June 20, 1741.)

1742

106. Georgia, Trustees of the Colony of. An | Account, Shewing the Progress of the | Colony of Georgia | in | America | from it's [sic] |First Establishment.| Published per Order of the Honourable the Trustees.| London: Printed in the Year M,Dcc,XLI.| Maryland: Reprinted and Sold by Jonas Green, at his Printing-Office in Annapolis. 1742.|

Sm. fol. a $a^{4}, B-R^{2}, S^{1} ; 37$ lea ves; (sign. "a" is two sheets "quired"); pages [I-II], [i]-iii, [iv], [1]-68; p. [I]: title; pp. [i]-iii: The | Preface.|, with head and tail pieces; pp. [1] $-36:$ text, with head-piece and heading in words of title, signed at end: By order of the Trustees,| Benj. Martyn, Secretary.|; Pp. 37-68: "Appendix", (Numbers I-1 I), with head and tail pieces; p. 68: "Finis".

Leaf measures: $11 \frac{1}{2} \times 7$ inches. Type page, p. $2: 221 \times 136 \mathrm{~mm}$.

It has been suggested that the New York Public Library copy of this work, because of its lack of a preface, is an earlier issue than that which is here described. This is possible. The collation of signature " $a$ ", which is two sheets "quired", making " $a$ ", is as follows: a I recto: title,-verso blank; a 2 recto-a 3 recto: "The Preface",verso blank; a 4 recto and verso: first two pages of text. "The Preface", therefore, occupies the inner sheet of the gathering " $\mathrm{a}$ "", and, without disturbing the signature sequence, could have been added to all later copies after there had been published an issue (see the NYPL. copy), which had [a] ${ }^{2}$ as its first gathering. Without further evidence, however, it seems more reasonable to assume that the inner sheet of the quire, containing the Preface, has been lost from the NYPL. copy. The two copies in the MdHS. and the one in LC. all have the Preface, and the copy from which Peter Force reprinted in 1835 had its preface, although it lacked, or Force omitted in his reprint, pp. 6I-68, containing appendices Nos. 9, ro and II. See Force's Tracts, 1: v.

The pamphlet was reprinted in Collections of the Georgia Historical Society, Savannah. 1842, 2: 265-325, in which reprint Nos. 3 and 8-1 I of the original Appendix were omitted, and no account taken of the omission of No. 3 in the enumeration of the appendices. A note by the editor of this Georgia Historical Society reprint asserts that the pamphlet was written by Benjamin Martyn, Esq., Secretary of the Trustees, and that the Preface to the American edition was composed by "a gentleman of Georgia, and defends Oglethorpe with much zeal and ability." It is declared in this American Preface that the "Account" is now reprinted here as an answer to that scandalous production, "A True and Historical Narrative of the Colony of Georgia in America," printed for the authors by Peter Timothy in Charleston, S. C., in 174I, reprinted in Force's Tracts, I: iv, and thence in Collections of the Georgia Historical Society, 2: $163-263$. The "Account" is a document of the greatest importance in the history of colonial Georgia, and in addition to the editions noted above, it was reprinted from the London edition with all appendices in The Colonial Records of the State of Georgia, 3:367-432, vol. 3, Atlanta. I905; and from Peter Force's edition as No. 5 of the American Colonial Tracts Monthly. Published by George P. Humphrey. Rochester. $1897-98$.

MdHS. (has one perfect copy and another in Portfolio No. 9, lacking appendices 4-1 I). LC. NYPL.

107. Maryland, Province of. Acts of Assembly | of the | Province of Maryland, made and passed / at a Session of Assembly, begun and held at the City | of Annapolis, on Tuesday the Twenty-first Day of Sep-| tember, in the Twenty-eighth Year of the Dominion of the | Right Honourable Charles, Lord Baron of Baltimore, | Absolute Lord and Proprietary of the Provinces of Mary-| land and Avalon, \&c. Annoque Domini, I 742.| [Baltimore arms] Publish'd by Authority.| Annapolis:| Printed by Jonas Green, Printer to the Province; and are to be Sold | at his Printing-Office in Charles-Street, 1742.|

Fol. [A] $]^{1}$, B-P ${ }^{2}$; 29 leaves; pages [i-ii], I-56; p. [i]: title; pp. I-55: text, without heading, running heads; pp. 55-56: contents.

Leaf measures: $13 \times 8 \frac{3}{8}$ inches. Type page, p. $2: 225 \times 133 \mathrm{~mm}$.

MdHS. BBL. MDSL. LC. HLS. 


\section{$A$ History of Printing in Colonial SCaryland}

108. -The | Report | of the | Committee | of the | Upper House | of | Assembly | Anno I 740, | Relating to the State of the Fund raised by Three | Pence per Hogshead on Tobacco Exported for Pur-| chasing Arms and Ammunition for Defence of the Pro-| vince.| [Baltimore arms] Maryland.| Annapolis: Printed and Sold by Jonas Green, Printer to | the Province. $M, D C C, X L I I . \mid$

Sm. fol. I preliminary leaf, a-o²; 29 leaves; pages [i-ii], [1]-55, [56]; p. [i]: title; pp. [1]-55: text, with headpiece and heading, "To the Honourable the Upper House of Assembly", tail-piece.

Leaf measures: $1014 \times 7 \frac{3}{16}^{3}$ inches. Type page, p. 2: $207 \times 135 \mathrm{~mm}$.

NYPL.

\section{3}

IO9. Hamilton, Alexander, M. D. Advertisement.| September 29, I743.| The Subscriber intending soon for Great-Britain, de-| sires all Persons indebted to him to discharge their | respective Debts; and likewise such as have Demands upon | him, to come and receive what is due.| [signed] Alexander Hamilton.| [Annapolis: Printed by Jonas Green. I 743.]

Broadside. $6 \frac{1}{3} \times 8 \frac{1}{6}$ inches.

For account of Dr. Alexander Hamilton, see the introduction and prefatory note of Hamilfon's Itinerarium, ed. by Albert Bushnell Hart and published for private distribution by William K. Bixby, Esq. in St. Louis, 1907.

MdHS. (Dulany Papers. Box 5.)

I 10. Maryland, Province of. A | Journal | of the | Votes | and | Proceedings | of the | Lower House of Assembly | of the | Province of Mary(land) | At a Session begun and h(eld September 21, 1742) | [-Oct. 29, 1742]. [Baltimore arms] (Annapolis:) | Printed and Sold by (Jonas Green, 1743.) |

Sm. 4 to. A-L ${ }^{4}$ only; 44 leaves; pages [1]-88+;p. [I]: title as above; Pp. 3-15, 17-88 +: text, with head-piece and heading; head-piece at the beginning of each week's proceedings; p. [16]: blank.

Leaf measures: $9 \times 7$ inches. Type page, p. 5: $183 \times 137 \mathrm{~mm}$.

This is the first copy of the V. \& P. since that of May 1739 which the compiler has found bearing a titlepage, although Mr. Evans gives title-pages to those for April and July $174^{\circ}$ and May 1741 , and locates copies in the Massachusetts Historical Society. No such copies exist in that Library, however, nor has the compiler met elsewhere with any that have title-pages. The four sets of V. \& P., May 1739, April and July 1740 and May 1741 have continuous pagination and were evidently issued to be bound together. This pagination came to an end with the issue of May 1741 when it had reached nearly five hundred pages, and the next collection of V. \& P., that described above, began a new pagination and bore a title-page. The title-page of the copy here described is defective, as is indicated in the entry above by the enclosure of several words in round brackets.

Pleasants. MdHS. (lacks title-page.)

(There was no session of Assembly held in the year 1743).

1744

III. Maryland, Province of. Acts of Assembly | of the | Province of Maryland, | made and passed | at a Session of Assembly, begun and held at the City | of Annapolis, on Tuesday the First Day of May, in the I Thirtieth Year of the Dominion of the Right Honourable | Charles, Lord Baron of Baltimore, Absolute Lord and | Proprietary of the Provinces of Maryland and Avalon, \&c.| Annoque Domini, 1744.l [Baltimore arms] Published by Authority.| Annapolis:| Printed by Jonas Green, Printer to the Province; and are to be Sold | at his Printing-Office in Charles-street.| [1 744 ].

Sm. fol. [A] $]^{1}, \mathrm{~B}-\mathrm{L}^{2},[\mathrm{M}]^{1} ; 22$ leaves; pages [1]-43, [44]; p. [1]: title; pp. 3-42: text, with running heads; pp. 42-43: contents, tail-piece.

Leaf measures: $12 \times 7 \frac{5}{8}$ inches. Type page, p. $4: 230 \times 137 \mathrm{~mm}$.

MDSL. MdHS. (lacks t. p.) BBL. Pleasants (lacks t. p.) 


\section{Saryland Imprints of the Colonial Period, $1689-1776$}

I 2. - Votes and Proceedings | of | the Lower House of Assembly | of the | Province of Maryland,| at a Session begun and held May I, I 744.| (-4 June, I 744). [Annapolis: Printed by Jonas Green. I744.]

Sm. fol. $A^{2}, B^{1}, C^{2}, D^{1}, E-F^{2}, G^{1}, H^{2}, I^{1}, K^{2},[L]^{2}, M^{1}, N-S^{2}, T^{1}, V-Z^{2}, A a-E e^{2}$, only; 48 leaves remaining in single known copy which lacks sign. $[\mathrm{L}]^{2}$, pages $33-36$, and whatever originally came after $E e^{2}$; pages $1-100+$ : text, with head-piece, heading as above and session heading of seven lines; pp. 12 and 58 blank; pp. 33-36 lacking; probably had originally $\mathrm{Ff}^{\mathrm{I}}$, $\mathrm{pP}$. 101 and 102 , of which $\mathrm{p}$. 102 was blank.

Leaf measures: $11 \frac{2}{8} \times 7 \frac{1}{6}$ inches. Type page, p. 2: $239 \times 137 \mathrm{~mm}$.

MDSL.

\section{I745}

II3. [Jones, Hugh. A Protest against Popery, shewing I. The Purity of the Church of England. 2. The Errors of the Church of Rome. And 3. The Invalidity of the most plausible Objections, Proofs, and Arguments of the Roman Catholics: Humbly addressed to the Inhabitants of Maryland. By Hugh Jones, Master of Arts, of the University of Oxford. Colos. ii.8. Beware lest any Man spoil you through Philosophy and vain Deceit, after the Tradition of Men, after the Rudiments of the World, and not after Christ. Annapolis: Printed by Jonas Green. 1745.]

No copy recorded. Advertised in the Maryland Gazette for Jan. 17, 1745, and frequently thereafter as "Just Published and to be Sold by the Printer hereof. [Price Three Shillings.l" Evans, No. 5615 records but does not locate a copy.

On Dec. 2, 1746 and thereafter in Maryland Gazette, Hugh Jones, under date of Sept. 1 5, 1746, writing from Bohemia (Manor) addresses a letter "To the Jesuits established in Maryland, and Pennsylvania: Learned Sirs," in which he asks that he be shown a copy of the "applauded answer to my Protest against Popery," which he has tried in vain to procure. In his History of the Society of fesus in North America, Text, 2: 514,515 and $53^{8}$, Father Thomas A. Hughes refers to Jones's work and the Jesuit reply to it as part of a long-continued controversy between the Rev. Hugh Jones and the Jesuits of Bohemia Manor, which lay in his Cecil County Parish. Father Hughes does not describe either book. He refers to Shea, I: 406 and to Records XXIII. IIO, III, E. I. Devitt, "Bohemia."

Hugh Jones was a man of attainments. One of the advertisements of Abraham Milton's Farmer's Companion, (see No. 234, contained an endorsement of the surveying methods described in that book signed "H. Jones, Philomath.", and in the same advertisement (Maryland Gazette Sept. 27 and Oct. 25, 1759) Milton congratulates himself on having secured a favorable testimonial from so distinguished a scholar. In Sprague, Annals (Epis.), the Rev. Ethan Allen, D. D. contributes an account of Mr. Jones in which it is asserted that he came to Maryland in 1696, was Rector of Christ Church Parish, Calvert County, until 1702 or 1703 when he went to Virginia and held charges in Williamsburg and Jamestown. He went back to England about 1722, and published in London in 1724 a book called The Present State of Virginia... From which is inferred a short view of Maryland and North Carolina (See Clayton-Torrence, No. 105). Returned to Virginia and became rector of St. Stephen's Parish in King and Queen County, which he left in Feb. 1726, returned to Maryland, was rector for five years of William and Mary Parish, Charles County, became rector in 1731 of North Sassafras Parish, Cecil County, and died there twenty-nine years later, Sept 8, 1760 , venerated throughout the Province, in the ninety-first year of his age. His obituary appeared in the Maryland Gazette for Sept. 18, 1760.

There is a possiblity that Dr. Allen's account of Mr. Jones is incorrect in some particulars. On the Ms. of his sketch of him, preserved in the Maryland Diocesan Library, there is written in an unknown hand words to the effect that there were three persons of the name of Hugh Jones mixed up in the sketch within.

1 14. Maryland, Province of. Acts of Assembly | of the [ Province of Maryland, made and passed | at a Session of Assembly, begun and held at the City | of Annapolis, on Monday the Fifth Day of August, in the | Thirty-First Year of the Dominion of the Right Honourable | Charles, Lord Baron of Baltimore, Absolute Lord and | Proprietary of the Provinces of Maryland and Avalon, \&c.| Annoque Domini, 1745.| [Baltimore arms] Published by Authority.| Annapolis:| Printed by Jonas Green, Printer to the Province; and are to be sold at | his Printing-Office in Charles-Street, I745.| 


\section{A History of Printing in Colonial Karyland}

Sm. fol. [A] $]^{1}, \mathrm{~B}-\mathrm{E}^{2}, \mathrm{~F}^{1}$; ro leaves; pages [i-ii], I-18; P. [i]: title; pp. 1-17: text, without heading, running head; p. 18: contents.

Leaf measures: $11 \frac{1}{6} \times 7 \frac{7}{6}$ inches. Type page, p. 3: $222 \times 139 \mathrm{~mm}$.

MdHS. BBL. MDSL. HLS.

I I 5. - Votes and Proceedings | of | the Lower House of Assembly | of the | Province of Maryland,| at a Session begun and held August 5, 1745.] (-Sept. 28, 1745) [Colophon:] Annapolis: Printed and Sold by Jonas Green, Printer to the Province, 1745.l

Fol. $A-B^{2}, C^{1}, D-Z^{2}, A^{2} ; 47$ leaves; pages [1]-93, [94]: text, with heading as above and session heading of seven lines; issued in unnumbered parts throughout session, as follows: [No. I] : A-B $\mathrm{B}^{2}, \mathrm{C}^{1},-\mathrm{pp}$. [I]-9, p. [10], blank;

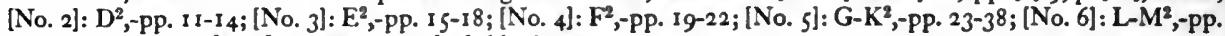
39-46; [No. 7]: N-Z2, $\mathrm{Aa}^{2},-$ pp. 47-93,-p. [94], blank.

Leaf measures: $12 \frac{1}{8} \times 7 \frac{1}{1}$ inches. Type page, p. $3: 251 \times 141 \mathrm{~mm}$.

Last number has colophon with date; all other numbers have same colophon lacking date.

MDioc. MDSL Pleasants.

116. The | Maryland Gazette.| Containing the freshest Advices Foreign and Domestic.| (Jan. 17, Apr. 26-Dec. 31, 1745, Nos. 1, I-36.)

Although the first issue of the Maryland Gazetse was published on Jan. 17, 1745, headed No. 1, there seems to have been a discontinuance of the paper until April 26, 1745 , on which day appeared an issue likewise headed No. 1. The Gazette continued with only one serious interruption (Dec. 25, 1777 to April 30, 1779) from this time until its final cessation with the issue of Dec. 12, 1839 .

In the year 1745 , the following three colophons were used:

Colophon No. I. On preliminary issue of Jan. 17, 1745, headed No. I: Annapolis: Printed by Jonas Green, Post-Master, at the Printing (-Office) $\mid$ in Charles-Street. |

Colophon No. 2. Beginning with issue of April 26, headed No. 1, and including No. 6: Annapolis: Printed by Jonas Green, Post-Master, at his [ Printing-Office in Charles-street, where Advertisements are taken in, and ] any Persons may be supplied with this Paper.|

Colophon No. 3. With the issue of No. 7, "any Persons" was changed to "all Persons", and with No. 8 a new type size and lining was adopted for the colophon, as follows: Annapolis: Printed by Jonas Green, Post-Master, at his Printing-Office in | Charles-Street; where Advertisements are taken in and all Persons may be supplied with this Paper.|

$9 \frac{1}{2} \times 7 \frac{1}{2}$ inches; 2 leaves each number; two columns.

MDSL (complete). MdHS. lacks No. I of Jan. I7th, the first leaf of No. I of April 26th, but has the remaining issues with Nos. 7, 8, 30 and 35 imperfect. Photographic reproduction of first page of No. 1 (Jan. 17, 1745) is in Scharf, J. T., History of Maryland, vol. 2, facing page 24.

\section{6}

117. [Gordon, John. A Thanksgiving Sermon, on Occasion of the Suppression of the Unnatural Rebellion, in Scotland, by his Royal Highness the Duke of Cumberland, preach'd at the City of Annapolis, before his Excellency Thomas Bladen, Esq; Governor of Maryland. By the Rev. Mr. Gordon. (Exodus XIV. 13.) Annapolis: Printed by Jonas Green. 1746.]

Sm. 4 to. Fragment in NYHS. has $\mathrm{A}^{2}, \mathrm{~B}-\mathrm{D}^{4}, \mathrm{E}^{3}$; pp. [v-viii], I-30 only; (lacks first two leaves of sign. A, containing probably half-title and title); pp. [v-viii]: dedication to Governor Bladen; pp. I-30 +: text, with headpiece and heading, A Thanksgiving | Sermon | on the | Defeat of the Rebels.|, tail-piece, running heads.

Leaf measures: $7 \frac{1}{\frac{1}{3}} \times 5^{\frac{1}{2}}$ inches. Type page, p. 2: $4 \frac{13}{16} \times 3^{\frac{1}{3}}$ inches.

The above work, only a single imperfect copy of which is known to exist, was advertised in the Maryland Gazetse for Oct. 14, 1746 as "Now in the Press, and speedily will be Published." On Oct. 28, it was advertised as "Just Published." The "Defeat of the Rebels" referred to was the Battle of Culloden, A pril 16, 1746.

The Rev. John Gordon was inducted as rector of St. Anne's Parish, Anne Arundel County, on May 7, 1745 and remained in this charge certainly until March 27, 1749. Soon after this he became rector of St. Michael's Parish, Taibot County. He was a stanch Whig in the Revolution and in 1785 he received the degree of D. D. from Washington College. He died April 12, 1790. (Allen, St. Ann's Parish.)

NYHS. 
II8. Maryland, Province of. Acts of Assembly | of the | Province of Maryland, made and passed | at a Session of Assembly, begun and held at the City | of Annapolis, on Tuesday the seventeenth Day of June, in | the thirty-second Year of the Dominion of the Right Ho-| nourable Charles, Lord Baron of Baltimore, Abso-| lute Lord and Proprietary of the Provinces of Maryland and | Avalon, \&c. Annoque Domini 1746.| [Baltimore arms] Published by Authority.| Annapolis:| Printed by Jonas Green, Printer to the Province; and are to be Sold at | his Printing-Office in Charles-Street; $1746 . \mid$

Sm. fol. [A]-E $E^{2}, F^{1}$; II leaves; pages [I]-22; p. [I]: title; pp. 3-22: text, without heading, running heads; p. 22: contents.

Leaf measures, last leaf: $11 \times 7 \frac{1}{1}$ inches. Type page, p. 4: $216 \times 137 \mathrm{~mm}$.

MdHS. BBL. MDSL. NYBA. (imp.) HLS.

II 9. - Votes and Proceedings | of | the Lower House of Assembly | of the | Province of Maryland, | at a Session begun and held March I2, 1745, 6.| (-29 March, 1746). [Colophon:] Annapolis: Printed and Sold by Jonas Green, Printer to this Province, 1746.|

$\mathrm{Sm}$. fol. A-F²; 12 leaves; pages [1]-23, [24]: text, with head-piece, heading as above and session heading of eight lines; p. 23: colophon.

Leaf measures: $11 \times 7 \frac{1}{8}$ inches. Type page, p. $2: 245 \times 140 \mathrm{~mm}$.

There were no acts passed at this convention of Assembly.

MDSL.

I20.- Votes and Proceedings | of | the Lower House of Assembly | of the | Province of Maryland.| (I7 June-8 July, 1746.) [Colophon:] Annapolis: Printed by Jonas Green, Printer to the Province.| [1746].

Sm. fol. A-K $\mathrm{K}^{2}, \mathrm{~L}^{1} ; 2 \mathrm{I}$ leaves; pages [I]-42: text, with head-piece, heading as above and session heading of seven lines, tail-piece; p. 42 : colophon.

Leaf measures: $11 \frac{1}{8} \times 7 \frac{1}{2}$ inches. Type page, p. $3: 241 \times 140 \mathrm{~mm}$.

MDSL.

12I. The | Maryland Gazette.| Containing the freshest Advices Foreign and Domestic.| (Jan. 7, 1746-Dec. 30, 1746, Nos. 37-88.) [Colophon, same as No. 3 under year 1745.]

$9 \frac{1}{2} \times 7 \frac{1}{2}$ inches, 2 leaves each number, double column.

No. 48 has an appendix of one leaf.

MdHS. has all numbers, Nos. 40 and 69 imperfect. MDSL. lacks Nos. $65,66,80$ and 88 . For location of scattered issues, see Brigham, American Newspapers.

1747

122. Cradock, Thomas. Two | Sermons, $\mid$ with a | Preface | shewing | the Author's Reasons for publish-| ing them.| By Thomas Cradock, A.M. Rector of St. Thomas's | in Baltimore County.| [Four lines from Horace.] Annapolis:| Printed and Sold by Jonas Green, MDCCXLVII.|

Sm. 8vo. A-B 4 , C2; ro leaves; pages [I-II], [i]-vi, [I]-II, [I 2]; p. [I]: title; pp. [i]-vi: The | Preface I, signed, "T. Cradock", and dated, "Baltimore, November 22, 1746", head and tail pieces, running heads; pp. [r]-6: text, with head-piece and heading, Innocent Mirth not inconsistent with Re-| ligion.| A | Sermon | Preach'd April the 23d, 1745, in St. Paul's | Church.| [Baltimore], (quotation from Proverbs XVII. 22), tail-piece, running heads; pp. [7]-11: text, with head-piece and heading, A | Sermon | Preach'd at St. Thomas's Church, on the Day set apart by his Ex-| cellency the Governor and his Council, to give God Thanks | for the Conquest of the Rebels by his Royal Highness the Duke | of Cumberland.| (three lines quoted from Psalm CXXII. 6, 7.), tail-piece, running heads.

Leaf measures: $6 \frac{8}{12} \times 4$ inches. Type page, p. $5: 133 \times 89 \mathrm{~mm}$. 


\section{A History of Printing in Colonial SAaryland}

Published on Monday, Feb. 9, 1747. See Maryland Gazette for Feb. 3d and 1oth. Sold at Is. 6d. The only known copy, the British Musuem copy, has the "A. M." after the author's name on the title-page inked out, and on page [I] the date on which the sermon was preached in St. Paul's Church has been changed from 1745 to 1746 ; that is, the " 6 " has been written in with a pen over what was doubtless a " 5 ". In the advertisement above referred to this date is given as 1745 .

The Rev. Thomas Cradock was born at Wolverham in Bedfordshire, England in 17 r 8; ordained deacon Sept. 20, 174 I, priest Sept. 25, 1743; received the King's Bounty Feb. 28, 1743/44 (Fothergill), and coming to Maryland became the first rector of St. Thomas's Parish, Garrison Forest, in which incumbency he remained until his death on May 7, 1770. For an account of this fine old parish priest see The Garrison Church. Sketches of the History of St. Thomas' Parish, Garrison Forest, Baltimore County, Maryland. 1742-1852. By the Rev. Ethan Allen D. D. Ed. by the Rev. Hobart Smith, M. A. with Additional Sketches. N. Y. I898. (Illus). There should be mentioned also the broadside, A | Friendly | Character | of the late | Revd. Thomas Cradock, | Rector of St. Thomas's Baltimore County, | Maryland.| Who departed this life, May 7, 1770, in the Fifty Second | year of his Age.| [Thirteen lines of encomium] [London:] Printed by Thomas Worrall, No. 99, Bishopsgate without.|, a copy of which is in the Maryland Diocesan Library. The only recorded copy of the "Two Sermons" described above is that in the British Museum. Dr. Allen, however, had by him a copy when he was writing "The Garrison Church" referred to in this note. See No. 189.

BM. (press mark, 4476 a 37 ).

123. Maryland, Province of. [Baltimore arms] An | Act of Assembly | of the Province of Maryland, | made and passed at a Session of Assembly, begun and held at the City of Annapolis, on Thursday the 6th | Day of November, in the Thirty-second Year of the Dominion of the Right Honourable Charles,| Lord Baron of Baltimore, Absolute Lord and Proprietary of the Provinces of Maryland and Avalon,| \&c. Annoque Domini 1746.| An Act for issuing . . . the Sum of Nine Hundred Pounds Current Money, in Bills of Credit: . . . [Annapolis: Printed by Jonas Green. 1747.]

Sm. fol. A, 2 leaves; pages [r]-4: text, with heading as above; p. 4: "Finis"; running head.

Leaf measures: $11 \frac{15}{16} \times 7 \frac{1}{2}$ inches. Type page, p. $2: 232 \times 137 \mathrm{~mm}$.

The dates of this Session were Nov. 6-1 2, 1746. The act described above was the only one passed. No copy of V. \& P. for the session has been recorded, none was advertised in the Maryland Gazette, and it is believed that none was printed.

MDSL. BBL.

124. - An Act to remedy some Defects in an Indenture of Bargain and Sale, / made and executed by Michael Curtis, and Sarah his Wife, late of $\mid$ St. Mary's County, deceas'd, to Charles Carroll, Esq; late of the | City of Annapolis, deceas'd.| [Annapolis: Printed by Jonas Green. 1747].

Broadside. $13 \times 8 \frac{1}{4}$ inches.

Private law bound in volume containing the Acts of Assembly of May 1747, Maryland Historical Society opy. Contains at end printed mandate: "On Behalf of the Rt. Hon. the Lord Proprietary of this Province, I Will this be a Law," signed, "Sam. Ogle."

MdHS.

I25. - Acts of Assembly | of the Province of |Maryland, | made and passed | at a Session of Assembly, begun and held at the City of | Annapolis, on Saturday the Sixteenth Day of May, in the | thirty-third Year of the Dominion of the Right Honourable / Charles, Lord Baron of Baltimore, Absolute Lord and / Proprietary of the Provinces of Maryland and Avalon, \&c. An- $\mid$ noque Domini 1747.| [Baltimore arms] Published by Authority.| Annapolis:| Printed by Jonas Green, Printer to the Province; and are to be Sold at his | Printing-Office in Charles-street, 1747.1

Fol. [A]-O⿰冫欠 $\mathrm{P}^{1}$; 29 leaves; pages [1-2], 3-57, [58]; p. [1]: title; pp. 3-57: text, without heading, running head; p. 57 : contents.

Leaf measures: $13 \times 8 \frac{1}{4}$ inches. Type page, p. $4: 278 \times 152 \mathrm{~mm}$.

MdHS. BEL. MDSL. LC. Pleasants. NYSL. HLS. 


\section{Karyland Imprints of the Colonial Period, $1689-1776$}

126. - Votes and Proceedings | of | the Lower House of Assembly | of the | Province of Maryland. | At a Session begun and held, May 16, r747.| (-July I I, I 747). [Colophon:] Annapolis: Printed and Sold by Jonas Green, Printer to the Province. 1747.l

$4^{\text {to. }} A-Q^{2}, R^{1} ; 33$ leaves; pages $[1]-65,[66]$ : text, with heading as above and session heading of seven lines. Leaf measures: $9 \frac{3}{4} \times 7^{\frac{1}{4}}$ inches. Type page, p. $2: 202 \times 152 \mathrm{~mm}$.

Advertised in Maryland Gazette for Jan. 6, 1748 , as "This Day is Published . . . at the usual Price of Three Pence for each Day's Proceedings."

MdHS. MDSL. NYPL. Pleasants.

127. The | Maryland Gazette.| Containing the freshest Advices, Foreign and Domestic.| (Jan. 6-Dec. 30, 1747, Nos. 89-140.) [Colophon, same as No. 3 under year 1745 .]

$12 \times 8 \frac{1}{6}$ inches, except No. 89 which is $9^{\frac{3}{4}} \times 7^{\frac{1}{2}}$ inches; 2 leaves each number; double column.

Green normally began his year with Jan. Ist, N. S. but sometimes an error crept in; No. g1 for example, is dated Jan. 20, 1746 instead of Jan. 20, 1747

No. 112 has a "Postscript" of one leaf.

MDSL. (complete) MdHS. lacks 89-92, II 5,117, I24-125, I30-133, I35-136, I 40 , and has II 9 and I22 imperfect.

1748

128. Maryland, Province of. Acts of Assembly | of the Province of | Maryland, | made and passed $\mid$ at a Session of Assembly, begun and held at the City of $\mid$ Annapolis, on Tuesday the Tenth Day of May, in the thirty-| fourth Year of the Dominion of the Right Honourable | Charles, Lord Baron of Baltimore, Absolute Lord and | Proprietary of the Provinces of Maryland and Avalon, \&c.| Annoque Domini, r748.| [Baltimore arms] Published by Authority.| Annapolis:| Printed by Jonas Green, Printer to the Province; and are to | be Sold at his Printing-Office in Charles-Street. 1748.]

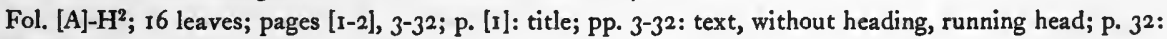
contents.

Leaf measures: $12 \frac{1}{16} \times 8$ inches. Type page, p. $4: 269 \times 143 \mathrm{~mm}$.

MdHS. BBL. MDSL. LC. HLS.

129. - Votes and Proceedings | of | the Lower House of Assembly | of the | Province of Maryland.| At a Convention begun and held, December 22, 1747.] (-23 December, 1747). [Colophon:] Annapolis: Printed and Sold by Jonas Green, Printer to the Provirice.| [1748].

$4_{\text {to. }} A^{2}, B^{1} ; 3$ leaves; pages [ 1$]-6$ : text, with head-piece, heading as above and session heading of seven lines; p. 6: colophon.

Leaf measures: $9 \frac{1}{16} \times 6 \frac{7}{8}$ inches. Type page, p. $2: 216 \times 150 \mathrm{~mm}$.

Advertised in Maryland Gazette for Jan. 27, 1748, as "Tomorrow will be published, Price 6d."

There were no acts passed at this convention of Assembly.

MDSL. NYPL.

130. - Votes and Proceedings | of the | Lower House of Assembly | of the | Province of Maryland.| At a Session begun and held, May 10. 1748.| (-I I June, 1748). [Colophon:] Annapolis: Printed and Sold by J. Green, Printer to the Province.| [r 748$]$.

Sm. 4to. A-V ${ }^{2}, \mathrm{X}^{1} ; 4^{\mathrm{I}}$ leaves; pages [I]-82: text, with head-piece, heading as above and session heading of eight lines; tail-piece; p. 82: colophon.

Leaf measures: $8 \frac{1}{4} \times 6$ inches. Type page, p. $2: 168 \times 124 \mathrm{~mm}$.

MDSL. NYPL.

131. - Maryland, the I748. Exchange for $£$ Sterling.| Pursuant to an Act of Assembly of this Province for Emitting and | making Current Ninety Thousand 


\section{A History of Printing in Colonial Scraryland}

Pounds Current Money of Maryland:] At Forty Days Sight of this our Fourth Bill of Exchange, (First, Second or Third, of the same Tenor / and Date, not Paid) Pay unto or order, the Sum of $\mid$ Sterling Money of Great Britain, and place the same to the Accompt of the Province of Maryland,| without further Advice from, Gentlemen, Your humble Servants, | | To Messieurs William Hunt,| Joseph Adams, and John | Hanbury, Merchants in | London.| Annapolis. Printed by Jonas Green.| [1748.]

$4 \frac{1}{2} \times 9^{\frac{5}{3}}$ inches.

Bill of exchange with imprint traversing the left end.

MdHS.

I32. The | Maryland Gazette,| Containing the freshest Advices, Foreign and Domestic.| (Jan. 6-Dec. 28, 1748, Nos. I 4 I-1 92.) [Colophon, same as No. 3, under 1745.]

$12 \frac{1}{2} \times 8 \frac{1}{1}$ inches, 2 leaves each number, double column.

No. 152 has "Supplement" of one leaf, as have also Nos. $156,158,159$. No. 160 has "Postcript" of one leaf. No. 162, June Ist, has the following extra number, containing two leaves with two columns to a page:

Saturday June 4, 1748.| The Maryland Gazette Extraordinary;| or,| An Appendix to No. 162.|

No. 175 has a supplementary leaf, printed on one side only, unheaded, with head and tail pieces.

MDSL. (complete). MDHS. lacks 149-1 52, 154-159, 162-163, 171, 173-174, 177-181, 183-186, 189-192, and has 187 imperfect. For location of scattered issues, see Brigham, American Newspapers.

I33. Prince George's County is so very large, that a Division of it is abso-l lutely necessary; . . . [Annapolis: Printed by Jonas Green. I748.]

Broadside. $13 \frac{1}{8} \times 8 \frac{1}{\frac{1}{2}}$ inches.

Relates to division of Prince George's County whereby Frederick County was formed, by Act of May 1748. Protests against establishment of county seat at Kennedy Farrell's instead of at Frederick-Town in case the division is made.

MdHS.

134. The Situation of Frederick-Town.] [Annapolis: Printed by Jonas Green. 1748.]

Broadside. $6 \frac{3}{6} \times 8 \frac{1}{3}$ inches.

Tells of advantages of Frederick-Town as county seat in case the division of Prince George's County is carried out, as it was finally by an Act of May 1748 .

MdHS.

135. [Royal Dublin Society.] Extracts | from the | Essays | of the |Dublin Society;|Relating to the |Culture and Manufacture of Flax.|[Annapolis: Printed by Jonas Green. 1748.]?

$8 v 0$. Imperfect copy in Boston Athenaeum contains signatures: $\mathrm{B}^{3}, \mathrm{C}^{-E^{4}}$ only; pages I- 30 : text, with headpiece, heading as above and cuts.

Leaf measures: $7 \frac{1}{2} \times 4 \frac{3}{4}$ inches. Type page: $81 \times 53 \mathrm{~mm}$.

These extracts were reprinted from the Maryland Gazette for July 5 and 26, 1745, Nos. I1 and 14 . In the year 1737, the Royal Dublin Society had devoted especial attention to flax culture and manufacture. Its papers on this subject were published in the "Dublin Society's Weekly Observations" in the Dublin News Letter in the year 1737. (Berry, Henry F. A History of the Royal Dublin Society. Lond. 1915.) It was probably from the "Weekly Observations" that Green reprinted his articles, which he headed in the issues of his paper above mentioned as "From the Essays of the Dublin Society," (Nos. XLIV and XLV, respectively). He had announced in the very first issue of his journal, Jan. 17, 1745, that in order to make his newspaper useful as well as entertaining, he would present his readers with the best directions for the culture of flax and hemp, especially of flax, instructions which he considered would prove to be of good public service because of the uncertainty of supplies and of the prevailing high prices. He kept his word, as has been seen, and three years later republished the articles in the book described above, which on March 2, 1748 was advertised in the Maryland Gazette as "Just Published," and in addition to the title as entered above, this further description was given of the work: "With Cuts, representing the principal Instruments used in Flax-Dressing." Some of these cuts are present in the Boston Athenaeum fragment. This is probably the first illustrated book printed in Maryland. It was issued at is. $6 \mathrm{~d}$. The typographical 


\section{Taryland Imprints of the Colonial Period, $1680-1776$}

features of the fragment also aid in its identification with the book which Green advertised as cited above. Evans, No. 6127, gives title and imprint as in entry above, but does not locate a copy. See also, Nos. 350 and 351 of this bibliography.

1749

136. Maryland, Province of. Acts of Assembly | of the Province of | Maryland, made and passed $\mid$ at a Session of Assembly, begun and held at the City of | Annapolis, on Wednesday the Twenty-fourth Day of May, in | the Thirty-fifth Year of the Dominion of the Right Honourable | Charles, Lord Baron of Baltimore, Absolute Lord and | Proprietary of the Provinces of Maryland and Avalon, \&c.| Annoque Domini, r749.| [Baltimore arms] Published by Authority.| Annapolis:| Printed by Jonas Green, Printer to the Province; and are to be Sold at his | Printing-Office in Charles-Street, I749.|

Sm. fol. [A]-E'; ro leaves; pages [1-2], 3-20; p. [I]: title; pp. 3-20: text, without heading, running head; p. 20: contents.

Leaf measures: $12 \times 7 \frac{1}{2}$ inches. Type page, p. $4: 257 \times 140 \mathrm{~mm}$.

MdHS. MDSL. Pleasants. LC.

137. - Votes and Proceedings | of | the Lower House of Assembly | of the | Province of Maryland.| (9 May-I I May, 1749.) [Colophon:] Annapolis: Printed by Jonas Green, Printer to the Province.| [1749].

Sm. fol. A-B ${ }^{2} ; 4$ leaves; pages [I]-8: text, with head-piece, heading as above and session heading of seven lines, tail-piece of two separate strips between which is the colophon.

Leaf measures: $11 \frac{1}{4} \times 7 \frac{3}{4}$ inches. Type page, p. $2: 231 \times 141 \mathrm{~mm}$.

There were no Acts passed at this convention of Assembly.

MDioc. MDSL. NYPL.

138. - Votes and Proceedings | of | the Lower House of Assembly | of the | Province of Maryland.| [24 May (by prorogation from II May)-24 June, 1749]. [Colophon:] Annapolis: Printed by Jonas Green, Printer to the Province, 1749.|

$\mathrm{Sm}$. fol. A-[O]2; 28 leaves; pages [1]-56: text, with head-piece, heading as above and session heading of four lines; p. 56: three lines of errata, and colophon.

Leaf measures: $11 \frac{1}{4} \times 7 \frac{3}{6}$ inches. Type page, p. 2: $239 \times 142 \mathrm{~mm}$.

MDioc. MDSL.

139. The | Maryland Gazette,| Containing the freshest Advices, Foreign and Domestic.| (Jan. 4-Dec. 27, I 749, Nos. 193-244.) [Colophon as No. 3, under 1745.]

II $\frac{1}{2} \times 7^{\frac{3}{4}}$ inches, 2 leaves each number, double column.

No. 193 dated Jan. 4, 1748 instead of Jan. 4, 1749. See note to this title under year 1747.

MDSL. (complete).

\section{0}

I40. Brogden, William. Freedom and Love.| A | Sermon | Preached before the | Ancient and Honourable Society | of | Free and Accepted | Masons, in the Parish Church of St. Anne, in the City of | Annapolis, on Wednesday the 27 th of December, 1749.| By the Rev. Mr. William Brogden,| Rector of Allhallows Parish.] Published at the Request of the Society.| [Three lines quoted from Cicero, Parad.; one from Cicero, de Leg.; two from Minut. Felix.] Annapolis: Printed, and Sold by Jonas Green, in Charles-Street, MDccL.|

Sm. 4to. I preliminary leaf, [A]-E' ${ }^{2}$ i I leaves; pages [i-vi], [r]-16; p. [i]: half-title, Mr. Brogden's $\mid$ Sermon | Preached before the / Ancient and Honourable Society / of | Free and Accepted Masons.|, head and tail pieces; p. [iii]: title as above,-verso: "In the Lodge, held at the Indian King, in Annapolis in Maryland, on Thursday the 28th of December, I 749. Agreed, that the Thanks of this Ancient and Honourable Society be given to our Brother, the Reverend Mr. William Brogden, for his Sermon preached yesterday, before the said Society; and 


\section{A History of Printing in Colonial SCaryland}

that he be requested to give a Copy of the same for the Press. J. Green, Secr.", head and tail pieces; p. [v]: dedication, "To the Right Worshipful Alexander Hamilton, M. D. Master; Mr. Samuel Middleton, and Mr. John Lomas, Wardens; and others the Worshipful Brothers and Fellows of the Ancient and Honourable Society of Free and Accepted Masons, in Annapolis; This Sermon, Preached and Published at their Request, is Dedicated by their faithful Brother, and most affectionate humble Servant, William Brogden."; pp. [1]-16: text, with headpiece and heading, Galat. V. 13.|...|...|..|; p. 16: at conclusion of text, "Amen".

Leaf measures: $7 \frac{1}{\frac{1}{3}} \times 5 \frac{1}{3}$ inches. Type page, p. $3: 159 \times 107 \mathrm{~mm}$.

The Rev. William Brogden, son of William Brogden of Calvert County, Md., went to England to obtain holy orders. He was ordained deacon on Aug. 6, 1735 and priest doubtless very soon afterwards, for he received the King's Bounty (Fothergill) for his passage to Virginia on Sept. 11, 1735. Soon after this date he is found in Maryland where he served successively as rector of All Hallows Parish, Anne Arundel County, and of Queen Anne's Parish, Prince George's County, retaining the incumbency of the latter until his death in 1770 . He was possessed of a comfortable estate and left a good memory and many descendants. A sketch of him by the Rev. Ethan Allen, D. D. appears in Sprague, Annals (Epis.) pp. 85-88. See below No. 177.

BM. (press mark, 4486 aa 77).

I4I. [Gordon, John. Brotherly Love Explain'd and enforc'd: A Sermon preached at the Parish Church of St. Anne, in the City of Annapolis, on Monday the 25th of June, 1750, before a Society of Free and Accepted Masons. By John Gordon, A.M. Rector of St. Michael's Parish, in Talbot County. Annapolis: Printed by Jonas Green. 1750.]

No copy recorded. Advertised as "Just Published" at 1s. 6d. in Maryland Gazette for Oct. 3, 1750. For brief notice of the author, see No. 117 .

142. Maryland, Province of. Acts of Assembly | of the Province of | Maryland, made and passed | at a Session of Assembly, begun and held at the City of | Annapolis, on Tuesday, the Eighth Day of May, in the Thir-| ty-Sixth Year of the Dominion of the Right Honourable | Charles, Lord Baron of Baltimore, Absolute Lord and | Proprietary of the Provinces of Maryland and Avalon, \&c.| Annoque Domini, 1750.| [Baltimore arms] Published hy Authority.| Annapolis:| Printed by Jonas Green, Printer to the Province; and are to be Sold at his | Printing-Office, in Charles-Street. 1750.|

${ }^{*}$ Fol. [A]-I' $\mathrm{I}^{2}$; 8 leaves; pages [I-2], 3-34, (should be 3-36, pp. 28 and 29 repeated); p. [I]: title; Pp. 3-33 [35]: text, without heading, running heads; pp. 33-34 [35-36]: contents.

Leaf measures: $12 \frac{1}{16} \times 8$ inches. Type page, p. $5: 253 \times 140 \mathrm{~mm}$.

In addition to its letter, each signature page has at foot in square brackets: [May, 1750.]

MdHS. BBL. MDSL. NYBA.

143. - Votes and Proceedings | of | the Lower House of Assembly | of the | Province of M.1aryland.| (8 May-2 June 1750). [Colophons of separate numbers read:] Annapolis: Printed, and Sold by Jonas Green, Printer to the Province, 1750.1

$\mathrm{Sm}$. fol. 28 leaves; pages [ $\mathrm{r}]-56$ : text, with general heading as above and session heading of eight lines; issued

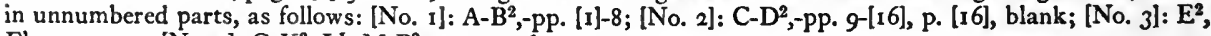
$F^{1}$,-pp. 17-22; [Nu. 4]: G-K ${ }^{2}, L^{1}, M-P^{2},-p p .23-56$.

Leaf measures: $10 \frac{3}{16} \times 7 \frac{1}{8}$ inches. Type page, p. $4: 238 \times 143 \mathrm{~mm}$.

Colophon of last number has date in Roman numbers.

MdHS. MDioc. MDSL. NYPL. Pleasants.

144. [The Maryland Almanack for the Year of our Lord 1751, containing the Motions of the Sur and Moon, true Places and Aspects of the Planets, Rising and Setting of the Sun and Moon, Lunations, Conjunctions, Eclipses, Judgment of the Weather, Rising and Setting of the Planets, Rising, Setting and Southing of the seven Stars: together with useful Tables, the Value of Coins in Philadelphia: of the Four Quarters of the Year; Negro Caesar's Cure for Poison, and the Bite of a Rattle Snake; Roads South-Eastward as far 


\section{Taryland Imprints of the Colonial Period, $1689-1776$}

as Boston; and South Westward, as far as Charles Town; the Courts in This Province, Virginia, and Pennsylvania; Quakers General Meetings, \&c. Annapolis: Printed by Jonas Green. I750.]

No copy recorded. Advertised in Maryland Gazette for Dec. 19, 1750 as "Just Published." Before this time Green had advertised various almanacs for sale, but never his own.

I45. The | Maryland Gazette, | Containing the freshest Advices, Foreign and Domestic.| (Jan. 3-Dec. 26, 1750, Nos. 245-296.) [Colophon as No. 3 under 1745.]

II $1 \frac{1}{2} 7 \frac{3}{4}$ inches; 2 leaves each number; double column.

MDSL. complete.

$$
175^{1}
$$

146. [Annapolis, (MD.) City of. The Bye-Laws of the City of Annapolis, in Maryland. To which is prefixed the Charter of the said City granted by her late Majesty Queen Anne, of glorious Memory, in the Year of our Lord 1708. Annapolis: Printed by Jonas Green. 1751.]

No copy recorded. Advertised in the Maryland Gazette for Feb. 13, 1751, as "Just Published" at 5 shillings.

I47. [Great Britain. The Act of Parliament, passed the last Session at Westminster, Entituled, An Act for the more effectual securing the Duties upon Tobacco. Annapolis: Printed by Jonas Green. 1751.]

No copy recorded. Advertised in Maryland Gazette for Nov. 6, 1751, as "Just Published (Containing 24 Pages in Folio, very necessary to be known by all Dealers in Tobacco) Price $2 s 6 \mathrm{~d} . "$

148. - [An Extract of a Law relating to Tobacco; which had passed the Honourable the House of Commons, and lay before the House of Lords in June last. Annapolis: Printed by Jonas Green. 1751.]

No copy recorded. Advertised in Maryland Gazette for Sept. 18, 1751, as "Just Published" at 6d.

I 49. Maryland, Province of. Acts of Assembly | of the Province of | Maryland, made and passed | at a Session of Assembly, begun and held at the / City of Annapolis, on Tuesday the fourteenth Day | of May, in the thirty-seventh Year of the Domi-| nion of the Right Honourable Charles,| Lord Baron of Baltimore, Absolute Lord and Pro-| prietary of the Provinces of Maryland and Avalon,| \&c. Annoque Domini 175I.| [Baltimore arms] Published by Authority.| Annapolis:| Printed by Jonas Green, Printer to the Province; and are to be Sold at his | Printing-Office in Charles-Street. 1751.|

Collation same as next entry, except that on p. 28 of this edition is: "Erratum. In the Title Page, for Tuesday the fourteenth, read Wednesday the fifteenth." The corrected title-page of the later issue is the only point of difference The MDioc. copy of above entry is perfect as issued. Instead of "I preliminary leaf, A-G'; I 5 leaves", it has: " 2 preliminary leaves, $A-G^{2}$; 16 leaves". The first preliminary leaf is blank and pasted down to the cover.

MDioc. MDSL. LC.

1 50. - Acts of Assembly | of the Province of | Maryland, | made and passed | at a Session of Assembly, begun and held at the / City of Annapolis, on Wednesday the fifteenth Day | of May, in the thirty-seventh Year of the Domi-| nion of the Right Honourable Charles, Lord Baron of Baltimore, Absolute Lord and Pro-| prietary of the Provinces of Maryland and Avalon,| \&c. Annoque Domini r75I.| [Baltimore arms] Published by Authority.| Annapolis:| Printed by Jonas Green, Printer to the Province; and are to be Sold at his | Printing-Office in Charles-Street. 1751.|

${ }^{*}$ Sm. fol. I preliminary leaf, $A-G^{2} ; 15$ leaves; pages [I-2], 3-[29], [30]; p. [1]: title; pp. 3-28: text, with running heads; p. [29]: contents.

[ 199] 


\section{$A$ History of Printing in Colonial SCaryland}

Leaf measures: II $7 \times 8$ inches. Type page, p. 4: $249 \times 144 \mathrm{~mm}$.

For variant title page, see preceding entry.

MdHS. BBL. HLS.

I51. - Acts of Assembly | of the Province of | Maryland, | made and passed | at a Session of Assembly, begun and held at the / City of Annapolis, on Saturday the seventh Day | of December, in the first Year of the Dominion of | the Right Honourable Frederick, Lord | Baron of Baltimore, Absolute Lord and Proprieta-| ry of the Provinces of Maryland and Avalon, \&c.| Annoque Domini 1751.| [Baltimore arms] Published by Authority.| Annapolis:| Printed by Jonas Green, Printer to the Province; and are to be Sold at his | PrintingOffice in Charles-Street. I75 I.|

*Sm. fol. No signatures; 4 leaves (first leaf is blank and pasted to front cover); pages [i-ii], [1-2], 3-6; p. [1]: title; pp. 3-6: text; p. 6: contents.

Leaf measures: $11 \frac{1}{2} \times 7 \frac{1}{1}$ inches. Type page, p. $5: 238 \times 14 \mathrm{Imm}$.

MDioc. (imp.) BBL. MdHS. MDSL. HLS.

1 52. - [The Charter of the Province of Maryland, granted by his late Majesty King Charles the First, to Caecilius, Lord Baron of Baltimore, in the Year 1632. Annapolis: Printed by Jonas Green. 1751.]

No copy recorded. Advertised in Maryland Gazette for May 15, 1751, as "Just Published" at 1s. 6d.

I 53. - [A Collection of all the Laws of this Province, relating to the Inspection of Tobacco, made and passed in the years $1747,1748,1749$ and 1750 . With a very accurate Index prefixed, for Direction to the Reader to turn readily to any Particular he may want to know. Printed by Order of the last Session of Assembly, for the particular Use of the several Inspectors and Vestries in the Province. Annapolis: Printed by Jonas Green. 175I.]

No copy recorded. Advertised in Maryland Gazette for Apr. 17, 1751, as "Just Published, (In large Quarto, containing 80 pages,)" and concluding: "Some few Copies more are Printed, and may be had of the Printer hereof. Price 5s."

154. - Votes and Proceedings | of | the Lower House of Assembly | of the | Province of Maryland.| (15 May-8 June 1751). [Colophons of separate numbers read:] Annapolis: Printed and Sold by Jonas Green, Printer to the Province. 175I.l

$\mathrm{Sm}$. fol. 26 leaves; pages [ $\mathrm{r}]-52$ : text, with general heading as above and session heading of seven lines; issued in unnumbered parts, as follows:

[No. I]: A-B ${ }^{2},-$ pp. [r]-8; [No. 2]: C-D2,- pp. 9-16; [No. 3]: E-N2,-pp. 17-52.

Leaf measures: $10 \frac{3}{16} \times 7 \frac{1}{1}$ inches. Type page, p. 2: $235 \times 143 \mathrm{~mm}$.

MDSL. MdHS. NYPL.

155. [The Maryland Almanack for the Year of our Lord, 1752, calculated according to the late Act of Parliament for altering the Stile, wherein is contained, the Motions of the Sun and Moon; the true Places and Aspects of the Planets; Rising and Setting of the Sun and Moon; Lunations; Conjunctions; Eclipses; Judgment of the Weather; Rising and Setting of the Planets; Rising, Setting and Southing of the seven Stars; a Table of Interest; a Table of Expences; Receipts, for curing a Flux, a Burn, a Pleurisy, an Ague, the Cholick, and Rheumatism or Pain in the Bones; a Description of the Roads; Courts in Maryland, Pennsylvania, and Virginia, \&c. \&c. Annapolis: Printed by Jonas Green. 1751.]

No copy recorded. Advertised as "Just Published" in the Maryland Gazetie for Nov. 27, 1751.

156. The | Maryland Gazette,| Containing the freshest Advices, Foreign and Domestic.| (Jan. 2-Dec. 25, I75 I, Nos. 297 to 348.) [Colophon as No. 3 under 1745.]

I $1 \frac{1}{2} \times 7^{\frac{3}{6}}$ inches; 2 leaves each number; double column.

MDSL (complete.) 


\section{Maryland Imprints of the Colonial Period, $1689-1776$}

\section{2}

I 57. Maryland, Province of. Acts of Assembly | of the Province of | Maryland,| made and passed | at a Session of Assembly, begun and held at the | City of Annapolis, on Wednesday the third Day | of June, in the Second Year of the Dominion of | the Right Honourable Frederick, Lord | Baron of Baltimore, Absolute Lord and Proprieta-| ry of the Provinces of Maryland and Avalon, \&c.| Annoque Domini 1752.| [Baltimore arms] Published by Authority.| Annapolis:| Printed by Jonas Green, Printer to the Province; and are to be Sold at his | Printing-Office in Charles-Street. I752.|

$\mathrm{Sm}$. fol. [A] $]^{\mathrm{I}}, \mathrm{B}-\mathrm{E}^{2}, \mathrm{~F}^{1} ;([\mathrm{A}]$ is imposed as the second leaf of $\mathrm{F})$; ro leaves; pages [I-2], $3^{-19}$, [20]; p. [r]: title; Pp. 3-19: text; p. [20]: contents.

Leaf measures: $12 \times 8$ inches. Type page, p. 4: $246 \times 144 \mathrm{~mm}$.

MDioc. MdHS. BBL. (imp.) MDSL. Pleasants. LC. HLS.

I58. - To the Honourable | Benjamin Tasker, Esq;| President and Commander in Chief of the Province | of Maryland;| The humble Address of the Upper House | of Assembly.| Sir, . . . [Address, signed "J. Ross, Cl. Up. Ho.", and dated "June 5, 1752". His Honour's answer, signed, "Benja. Tasker."] Annapolis: Printed by Jonas Green, Printer to the Province.| [1752.]

Broadside. 10:3 $\times 9 \frac{9}{16}$ inches.

NYPL.

159. - Votes and Proceedings | of | the Lower House of Assembly | of the | Province of Maryland.] (7 December-I4 December I75I). [Colophon:] Annapolis: Printed and Sold by Jonas Green, Printer to the Province. I752.|

4to. A-D ${ }^{2}, E^{1} ; g$ leaves; $p p$. [r]-18: text, with heading as above and session heading of seven lines.

Leaf measures: $10 \frac{1}{2} \times 7 \frac{1}{2}$ inches. Type page, p. 2: $229 \times 144 \mathrm{~mm}$.

MdHS. MDSL. Pleasants. NYPL.

I60. - Votes and Proceedings | of | the Lower House of Assembly | of the | Province of Maryland.| (3 June-23 June I752). [Colophon:] Annapolis: Printed and Sold by Jonas Green, Printer to the | Province. 1752.|

${ }^{*} \mathrm{Sm} .4^{\mathrm{t}} \mathrm{O} . \mathrm{A}-\mathrm{K}^{2}$; 20 leaves; pages [I]-40: text, with heading as above and session heading of seven lines.

Leaf measures: $8 \frac{12}{16} \times 6 \frac{3}{\frac{3}{6}}$ inches. Type page, p. 2: $190 \times 142 \mathrm{~mm}$.

MdHS. MDSL. NYPL.

161. [The Maryland Almanack, for the Year 1753. Annapolis: Printed by Jonas Green. I752.]

No copy recorded. Advertised in Green's Maryland Gazette for Dec. 14, 1752, as "Just Published."

I62. The | Maryland Gazette,| Containing the freshest Advices foreign and domestic.| (Jan. 2-Dec. 28, 1752, Nos. 349-399.) [Colophon:] Annapolis: Printed by Jonas Green, Post-Master, at his Office in Charles-Street;| by whom all Persons may be supplied with this Paper; and where Advertisements of a moderate / length are taken in and inserted for Five Shillings the first Week, and a Shilling per Week after for Con-l tinuance: And BookBinding is performed in the neatest Manner.|

137 99 inches, 2 leaves each number, except Nos. 354, 358 and 399 which have one leaf each; three columns. In the first issue of the year Green announces:

"The Printer of this Gazette, heartily wishes his Readers a happy New Year: The Size being now pretty much enlarged, he hopes his Number of Good Customers will be enlarged also; for one good Turn deserves another."

MdHS. (lacks 349 and 358 , Nos. 359 and 376 imperfect.) MDSL. (complete.) LC. (incomplete.)

[201] 


\section{A History of Printing in Colonial SCaryland}

\section{3}

163. [Bacon, Thomas. A Sermon, preached before the Ancient and Honourable Society of Free and Accepted Masons, in Annapolis, in June last. By the Rev. Mr. Thomas Bacon, of St. Peter's in Talbot County. Annapolis: Printed by Jonas Green. I 753.]

No copy recorded. Advertised in Maryland Gazette for Oct. I1, 1753, as "Just Published," to be sold at Is. 6d.

I64. Maryland, Province of. To His Excellency | Horatio Sharpe, Esq; Governor and Commander in Chief in and over the | Province of Maryland.| The humble Address of the Upper House of ] Assembly.|[ [Address, dated at conclusion, "October 3, 1753", and signed, "B. Tasker, President." Then follows the Governor's answer, signed, "Horo. Sharpe".] Annapolis: Printed by Jonas Green, Printer to the Province.| [1753].

Broadside. $11 \frac{13}{16} \times 6 \frac{8}{8}$ inches.

NYPL.

165.-An Act to Repeal an Act entituled, an Act for the / Confirmation of the Lands therein mentioned, to | Richard Bennett, Esquire.| Whereas, ... On Behalf of the Right Honourable the Lord | Proprietary of this Province, I will this | be a law.| [Signed,] Horo. Sharpe.| [Signed also by Clerks of Upper and Lower Houses, and dated Nov. 16, 1753]. [Annapolis: Printed by Jonas Green. 1753.]

Two sheets, printed on one side only, $12 \frac{5}{8} \times 7 \frac{3}{6}$ inches.

This was a private act and therefore not printed in the Session Laws of this Assembly. The copy here described is the official copy with the Provincial seal of Maryland attached, sent by the Governor to Lord Baltimore in England for his Lordship's approval. It was customary to sign and seal separately each Act passed at a Session, and the Calvert Papers contain many of these official copies in the form described.

MdHS. (Calvert Papers, No. 835).

I66. The | Maryland Gazette,| Containing the freshest Advices foreign and domestic.| (Jan. 4-Dec. 27, I753, Nos. 400-45I.) [Colophon as in 1752.]

14 x 9 inches; 2 leaves each number, except Nos. 400, 402-403,405-406, 408, 449, 450 and 451 which have one leaf each; three columns.

MdHS. (complete.) MDSL. (complete.) LC. (incomplete.)

I 754

167. Maryland, Province of. Acts,| of the Province of | Maryland, made and passed | at a Session of Assembly, begun and held | at the City of Annapolis, on Tuesday the Second | Day of October, in the Third Year of the Domi-| nion of the Right Honourable Frederick, | Lord Baron of Baltimore, Absolute Lord and | Proprietary of the Provinces of Maryland and | Avalon, \&c. Annoque Domini, 1753.| [Baltimore arms] Published by Authority.| Annapolis:| Printed by Jonas Green, Printer to the Province; and are to | be Sold at his Printing-Office in Charles-Street, 1754.l

Sm. fol. I preliminary leaf, $\mathrm{A}-\mathrm{X}^{2} ; 43$ leaves; pages [i-ii], 1-84; p. [i]: title; pp. I-84: text, with running heads; p. 84 : contents.

Leaf measures: $12 \times 7 \frac{3}{8}$ inches. Type page, p. $2: 258 \times 142 \mathrm{~mm}$.

Misprint occurs in "Act to prevent Masters of Ships and Vessels from clandestinely carrying Servants and Slaves, or Persons indebted, out of this Province," which is corrected on page 4 of "Acts" of February and May Sessions $\mathbf{7} 754$. See collation of next entry.

MdHS. MDioc. BBL. HSP. NYBA. LC. HLS.

168. - Acts | of the Province of |Maryland, | made and passed | at Two Sessions of Assembly, One begun and held at the City of Annapolis, on | Tuesday the 26th Day of February, in the Third | Year of the Dominion of the Right Honourable | Frederick, Lord Baron of Bal- 
Faryland Imprints of the Colonial Period, $1680-1776$

timore,| Absolute Lord and Proprietary of the Provinces | of Maryland and Avalon, \&c.| The Other, begun and held at the said City of An-| napolis, on Wednesday the 8th Day of May, in the Fourth Year of his said Lordship's Do-| minion, Annoque Domini I754.| [Baltimore arms] Published by Authority.| Annapolis:| Printed by Jonas Green, Printer to the Province; and are to | be Sold at his Printing-Office in Charles-Street, I 754.|

Sm. fol. $[\mathrm{A}]^{2}, \mathrm{~B}-\mathrm{C}^{2},[\mathrm{D}]^{2} ; 8$ leaves; (first and last leaves are blank and pasted to covers); pages [i-ii], [I-2], $3-\mathrm{I} \mathrm{I}$, [12-I4]; p. [I]: title; Pp. 3-I I: text, with running heads; p. 4: "Advertisement" (making a correction in an Act of October 1753 , see preceding entry); p. I I : contents.

Leaf measures: $11 \frac{1}{2} \times 7 \frac{1}{16}$ inches. Type page, p. $6: 233 \times 142 \mathrm{~mm}$.

MDioc. MdHS. BBL. LC. HLS.

I69. - Acts | of the Province of | Maryland,| made and passed | at a Session of Assembly, begun and held | at the City of Annapolis, on Wednesday the | Seventeenth Day of July, in the Fourth Year | of the Dominion of the Right Honourable | Frederick, Lord Baron of Baltimore,| Absolute Lord and Proprietary of the Provinces | of Maryland and Avalon, \&c. Annoque Domini | I754.| Published by Authority.| [Baltimore arms] Annapolis:| Printed by Jonas Green, Printer to the Province; and are to / be Sold at his PrintingOffice in Charles-Street, 1754.1

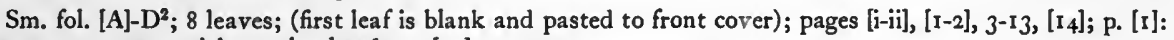
title; pp. 3-13: text, with running heads; $p$. [14]: contents.

Leaf measures: $11 \frac{8}{16} \times 7 \frac{13}{18}$ inches. Type page, p. 4:24I $\times 143 \mathrm{~mm}$.

MDioc. BBL. NYBA. HLS.

170. - Votes and Proceedings $\mid$ of $\mid$ the Lower House of Assembly | of the $\mid$ Province of Maryland.| (2 October-17 November 1753). [Annapolis: Printed by Jonas Green. 1754.] ${ }_{4} 4$ to. A-B ${ }^{4}, C-S^{2}, T^{1}$; 4 I leaves; pages [1]-82: text, with heading as above and session heading of seven lines. Leaf measures: $9 \frac{2}{8} \times 6 \frac{3}{\frac{3}{3}}$ inches. Type page, p. $2: 186 \times 143 \mathrm{~mm}$.

Copy in MdHS. has on inside front cover an unsigned affidavit dated September 1756 in which Green deposed that he had printed the "following Votes and Proceedings."

MdHS. (dup.) MDSL. NYPL. HU.

I7I. - Votes and Proceedings | of | the Lower House of Assembly | of the | Province of Maryland.| (26 February-9 March, 1754). [Colophon:] Annapolis: Printed and Sold by Jonas Green, Printer | to the Province, 1754.|

Sm. 4to. A-E $E^{2},[F]^{1}$; I I leaves; pages $[\mathrm{I}]-2 \mathrm{I},[22]$; text, with heading as above, session heading of seven lines and running heads.

Leaf measures: $8 \frac{13}{16} \times 6 \frac{3}{6}$ inches. Type page, p. 2: $190 \times 145 \mathrm{~mm}$.

MdHS. MDSL. LC. NYPL.

172. - Votes and Proceedings | of | the Lower House of Assembly | of the | Province of Maryland.| (8 May-30 May, I754). [Colophon:] Annapolis: Printed and Sold by Jonas Green, Printer | to the Province, I754.| heads.

Sm. 4 to. A-K ${ }^{2}$; 20 leaves; pp. [r]-4o: text, with heading as above, session heading of seven lines and running

Leaf measures: $8 \frac{7}{8} \times 6 \frac{8}{8}$ inches. Type page, p. 2: $185 \times 144 \mathrm{~mm}$.

MdHS. MDSL. NYPL. HU.

173. - Votes and Proceedings | of | the Lower House of Assembly | of the | Province of Maryland.| (I 7 July-25 July, I 754). [Colophon:] Annapolis: Printed and Sold by Jonas Green, Printer | to the Province.| [1754].

Sm. $4_{\text {to. A-C }}$, D $D^{1} ;$ leaves; pages [I]-I 4 : text, with head-piece, heading as above, session heading of seven lines and tail-piece; p. 14: colophon. 


\section{$A$ History of Printing in Colonial Saryland}

Leaf measures: $8 \frac{1}{4} \times 6 \frac{1}{2}$ inches. Type page, p. $2: 186 \times 144 \mathrm{~mm}$.

MDSL. MdHS. (Calvert Papers.) NYPL. HU.

174. [The Maryland Almanack, for the Year 1754. Annapolis: Printed by Jonas Green. 1754.]

No copy recorded. Advertised in Maryland Gazette for the first time on Jan. 17, 1754.

175. The | Maryland Gazette,| Containing the freshest Advices foreign and domestic.| (Jan. 3-Dec. 26, 1754, Nos. 452-503.) [Colophon as in 1752.]

$13^{\frac{7}{8}} \times 9$ inches; 2 leaves each number except Nos. $453^{-4} 456,45^{8}, 496-497$ and 498 , which have one leaf each; three columns.

MdHS. (one complete copy, and another copy lacking No. 452.) MDSL. (complete.) LC. (incomplete.) For location of scattered issues, see Brigham, American Newspapers.

\section{5}

I76. [Brice, John. The Case between Philip Hammond and the late Vachel Denton, stated: By John Brice. Annapolis: Printed by Jonas Green. 1755.]

No copy recorded. Advertised in Maryland Gazetse for Nov, 20, 1755 as "Lately Published, and [now] to be Sold by the Printer hereof, (Price 1s. 6d.)"

177. [Brogden, William. Popish Zeal inconvenient to Mankind, and unsuitable to the Laws of Christ. A Sermon preached in St. Barnabas Church, Queen Anne Parish, on the $5^{\text {th }}$ of November, 1754, by William Brogden, Rector of the said Parish, in Prince George's County. Annapolis: Printed by Jonas Green. 1755.]

Sm. 4 to. 47 pages.

No copy known. The above title and description are given by the Rev. Ethan Allen, D. D. in his sketch of the Rev. William Brogden in Sprague, Annals (Epis.) The place of publication is given in Dr. Allen's List of the Publications of the P. E. Clergymen of Maryland, in Ms. in the Maryland Diocesan Library. Dr. Allen says that the sermon was a "Gunpowder Plot" sermon. That he had a copy of the book by him when writing his biographical sketch for Sprague's "Annals" is sufficiently clear from the exactness with which he cites its title, and from the fact that he quotes a passage irom its dedicatory address "to the Vestry, and other inhabitants" of Queen Anne Parish. Dr. Allen concludes his account of the book with these words: "The Discourse shows Mr. Brogden to have been not only a man of piety, and an independent and unflinching spirit, but also to have been a well read historian, a fine classical scholar, and conversant with the French language." See No. $\mathbf{1}_{40}$.

178. Calvekt, Benedict. Advertisement.| July 23, 1755.| Ran away, Yesterday Morning, from the Plan-l tation of Benedict Calvert, Esq; at the Wood-l Yard in Prince-George's County,.... [Description, etc. of runaway servant, John Anderson, signed:] Benedict Calvert.| [Annapolis: Printed by Jonas Green. 1755.]

Broadside. $6 \frac{1}{2} \times 7 \frac{7}{8}$ inches.

Ridgway Branch of Library Co. of Philadelphia. Photostat copy in MdHS.

179. Maryland, Province of. Act of Assembly passed in December, 1754.| [Baltimore arms] At a Session of Assembly, begun and held at the / City of Annapolis, on Thursday the Twelfth Day / of December, in the Fourth Year of the Dominion / of the Right Honourable Frederick, I ord Baron | of Baltimore, Absolute Lord and Proprietary of the I Provinces of Maryland and Avalon, \&c. Annoque | Domini 1754, the following Act passed, viz.! An Act for taking and detaining able-bodied Men for | His Majesty's Service. [ [Colophon:] Annapolis: Printed by Jonas Green, Printer to the Province.| [1755]

Single leaf, printed both sides; pp. 1-2: text, with heading as above.

Leaf measures: $12 \frac{7}{3} \times 7$ inches.

MdHS. (dup.) MDioc. BBL. LC. NYSL. (imp.) HLS. SLM. 
180. - Acts | of the Province of | Maryland, | made and passed | at a Session of Assembly, begun and held | at the City of Annapolis, on Saturday the Twenty-| Second Day of February, in the Fourth Year of | the Dominion of the Right Honourable Fre-| derick, Lord Baron of Baltimore, Absolute | Lord and Proprietary of the Provinces of Mary- | land and Avalon, \&c. Annoque Domini I 755.| Published by Authority.| [Baltimore arms] Annapolis:| Printed by Jonas Green, Printer to the Province; and are to be / Sold at his PrintingOffice in Charles-Street, 1755.1

Fol. $[A]^{1}, B^{2}, C^{1} ;([A]$ is probably imposed as second leaf of signature $C) ; 4$ leaves; pages $[\mathrm{I}-2], 3-8 ; \mathrm{p} .[\mathrm{I}]$ : title; pp. 3-8: text; p. 8: contents.

Leaf measures: $12 \frac{3}{6} \times 7 \frac{3}{6}$ inches. Type page, p. 6: $254 \times 143 \mathrm{~mm}$.

MdHS. (dup.) MDioc. BBL. LC. NYPL. NYBA. NYSL. (imp.) HLS. SLM.

181. - Acts | of the Province of | Maryland,| made and passed | at a Session of Assembly, begun and held | at the City of Annapolis, on Monday the Twenty | Third Day of June, in the Fifth Year of the Do-| minion of the Right Honourable Frederick,| Lord Baron of Baltimore, Absolute Lord and | Proprietary of the Provinces of Maryland and | Avalon, \&c. Annoque Domini 1755.| [Baltimore arms] Published by Authority.| Annapolis:| Printed by Jonas Green, Printer to the Province; and are to be [ Sold at his Printing-Office in Charles-Street, 1755.1

Fol. [A] $]^{1}, \mathrm{~B}_{-} \mathrm{C}^{2}, \mathrm{D}^{1} ; 6$ leaves; pages [I]-12; p. [r]: title; pp. 3-12: text, with running head; p. 12: contents.

Leaf measures: $12 \frac{1}{2} \times 7 \frac{3}{4}$ inches. Type page, p. 7: $255 \times 144 \mathrm{~mm}$.

MDioc. MdHS. BBL. HLS.

182. - Votes and Proceedings | of | the Lower House of Assembly | of the | Province of Maryland.| (12 December-24 December, 1754). [Colophon:] Annapolis: Printed and Sold by Jonas Green,| Printer to the Province, 1755.|

Sm. 4to. A-E ${ }^{2}, F^{1}$; II leaves; pages [I]-22: text, with heading as above, session heading of seven lines and running heads.

Leaf measures: $8 \frac{3}{6} \times 6 \frac{3}{2}$ inches. Type page, p. $2: 185 \times 145 \mathrm{~mm}$.

MdHS. MDioc. MDSL. LC. NYPL. HU. Pleasants.

183. - Votes and Proceedings | of the | Lower House of Assembly | of the | Province of Maryland.| (22 February-26 March, 1755). [Colophon:] Annapolis: Printed and Sold by Jonas Green,| Printer to the Province, 1755 .|

Sm. 4 to. A- $\mathrm{L}^{2}, \mathrm{M}^{1} ; 23$ leaves; pages [I]-46: text, with heading as above, session heading of seven lines and running heads.

Leaf measures: $8 \frac{18}{18} \times 6 \frac{3}{4}$ inches. Type page, p. $2: 183 \times 144 \mathrm{~mm}$.

MdHS. (dup.) MDSL. LC. NYPL. HU. Pleasants.

184. - Votes and Proceedings | of the | Lower House of Assembly | of the | Province of Maryland.| (23 June-8 July 1755). [Colophon:] Annapolis: Printed and Sold by Jonas Green,| Printer to the Province, 1755.| heads.

Sm. 4 to. A-L $\mathrm{L}^{2} ; 22$ leaves; pages $[\mathrm{I}]-44$ : text, with heading as above, session heading of seven lines and running

Leaf measures: $8 \frac{13}{16} \times 67$ inches. Type page, p. $2: 183 \times 144 \mathrm{~mm}$.

MdHS. MDSL. Pleasants (lacks last leaf.) LC. NYPL. HU.

185. The | Maryland Gazette,| Containing the freshest Advices foreign and domestic.| (Jan. 2-Dec. 26, I755, Nos. 504-555.) [Colophon, Nos. 504-541, as in 1752; beginning with No. 542, as follows:] Annapolis: Printed by Jonas Green, Post-Master, at his Office in 


\section{$A$ History of Printing in Colonial SCaryland}

Charles-street; by whom all Persons may be supplied with this Gazette, at 12 s. 6 d. per Year. Advertise-| ments of a moderate Length are taken in and inserted for Five Shillings the first Week, and One Shilling | each Week after the First.|

I $4^{\frac{1}{4}} \times 9^{\frac{1}{6}}$ inches; 2 leaves each number, except Nos. 505-506, 508, 5 10, 550-55 I, 553 and 555 which have one each; three columns.

Note change in price this year from $\mathrm{I}_{4} \mathrm{~s}$. to $12 \mathrm{~s} .6 \mathrm{~d}$. per annum.

MdHS. has two copies, one lacks No. 555, and has Nos. 545 and 554 imperfect; the other lacks 553, 554 and 555. MDSL. (complete.) LC. (incomplete.) For location of scattered issues, see Brigham, American Newspapers.

186. Sterling, James. A | Sermon,| preached before | his Excellency the Govenor [sic] | of | Maryland,| and | both Houses of Assembly,| at | Annapolis,| December 13, 1754.| By James Sterling, A. M.| Rector of St. Paul's Parish, in Kent County.| Annapolis:| Printed by Jonas Green, Printer to the Province.| MDcclv.|

Sm. 4 to. [A]-F ${ }^{4} ; 24$ leaves; pages [i-v], vi-vii, [viii], 9-48; p. [i]: half-title, Mr. Sterling's | Sermon,| Preached before the Governor, and | both Houses of Assembly, De-l cember I3, I754.|, head and tail pieces; p. [iii]: title, as above,-verso: "By the Lower House of Assembly, December 13, 1754. P. M. Ordered, That Col. William Fitzhugh, Mr. Lloyd Buchanan, Col. John Henry, Mr. William Hicks, Mr. Henry Casson, and Capt. Alexander Williamson, do wait upon the Reverend Mr. James Sterling, and return him the Thanks of the House, for his Sermon preached this Day before his Excellency the Governor, and both Houses of Assembly, and request a copy thereof that it may be Printed. M. Macnemara, Cl. Lo. Ho."; head and tail pieces; pp. [v]-vii: text of "The Prayer", head and tail pieces; pp. 9-48: text, with head-piece and heading, consisting of quotation from Galatians, iv, 18; p. 48: "Finis".

Leaf measures: $7 \frac{2}{2} \times 5^{\frac{3}{6}}$ inches. Type page, p. $\mathrm{I}_{3}: \mathrm{I}_{5} \mathrm{I} \times 10_{4} \mathrm{~mm}$.

British Museum has also reprint of this same year, with the title "Zeal against the enemies of our country pathetically recommended ..." London. 1755. (Press mark, 225. h. 22. (18.)) (Evans, No. 7574). For order to print the Annapolis edition, see Votes and Proceedings Dec. 14, 1754, by which 300 copies were to be printed, 5 for the Governor, 4 to each member of the two houses, the remainder to Mr. Sterling. Advertised for sale by Jonas Green in Maryland Gazette of July 3, 1755 .

The Rev. Mr. Sterling received the King's Bounty on Sept. 16, 1737, (Fothergill), was inducted rector of St. Anne's Parish, Anne Arundel County on Aug. 5, 1739, and soon after May 7, 1740 became rector of St. Paul's, Kent County, a charge which he retained until his death in 1763 . (Allen, St. Ann's Parish.) His obituary notice and poetical epitaph were published in the Maryland Gazette for Nov. 17, 1763. He died Nov. 10, 1763. In addition to his parish, Mr. Sterling held office in Maryland as "Collector of his Majesty's Customs at Chester," a fact which the Rev. Bennet Allen used in extenuation of his own desire a few years later to employ himself in temporal occupations. (See B. Allen to Sharpe, Nov. 25, 1767. Gilmor Papers, MdHS.)

British Museum (press mark, 694. e. 3. (II.))

187. Tuesday Club of Annapolis. By Permission of his Honour the President, of the Tuesday Club | Sir, $\mid \ldots$. [Notice from Jonas Green that there would be no meeting of the Tuesday Club for that week. Signed, "Jonas Green, M.C.P.L. \& H.S.", and dated, "Annapolis, July 1 5, 1755."] [Annapolis: Printed by Jonas Green. 1755.]

Broadside. $6 \frac{3}{6}: 5 \frac{1}{8}$ inches.

Printed on green paper. In the heading, the words "of the Tuesday Club" are interspaced with printers" "flowers." A brief account of this celebrated club is given in the foregoing narrative, Chapter Seven; fuller accounts appear in Riley, E. S., The Ancient City, Annapolis. 1887 , and in an article entitled "Old Maryland Manners" in Scribner's Monthly, 17: 315 (Jan. 1879).

LC. (Ms. Div.)

188. - Sir,| I Hope is shall have the Honour of your Company,| at the Tuesday Club, to be held this | Evening in Charles-Street, at the Dwelling of,| Sir, Your very humble Servant,| Jonas Green, H S.| Annapolis,| December 2, 1755.| [Annapolis: Printed by Jonas Green. 1755.]

Broadside. $4 \mathrm{I} \times 69 \mathrm{~mm}$.

See note to No. 187

LC. (Ms. Div.) 


\section{Garyland Imprints of the Colonial Period, $1689-1776$}

\section{6}

189. Cradock, Thomas. A | New Version | of the | Psalms | of | David.| By the Reverend Thomas Cradock, Rector of | St. Thomas's, Baltimore County, Maryland.| Annapolis:| Printed by Jonas Green, MDcclvi.]

8vo. A-X ${ }^{4} ; 84$ leaves; pages [i-viii], [r]-16o; p. [i]: title; p. [iii]: dedication, to Governors Sharpe of Maryland and Hamilton of Pennsylvania; p. [iv]: advertisement, see note below; pp. [v-viii]: "Subscribers", with headpiece; pp. [I]-I60: text, with head-piece and heading. The |Psalms | of | David.|, tail-piece, running heads.

Leaf measures: $7 \frac{15}{16} \times 4 \frac{15}{16}$ inches. Type page, p. 4: $149 \mathrm{~mm}$. in height.

Mr. Cradock says in advertisement, p. [iv]: "He is sorry, that he could not comply with his Proposals as to the Time; but he was twice disappointed of his Paper, and then thought it most expedient to wait a little longer for the advantage of new Types." The a pology was not uncalled for. Proposals for the publication of the "New Version of the Psalms of David" by subscription at 6 shillings a copy had been advertised first by Mr. Cradock in the Maryland Gazette for July 23, 1752. In Maryland Gazette for Aug. 4, 1757, he announced that some of the original subscribers being dead, he had remaining a few copies for general sale. For personal particulars of the Rev. Thomas Cradock, see references in note under No. 122.

MdHS. MDioc. (imp.)

Igo. Maryland, Province of. Acts | of the Province of | Maryland,| made and passed | at a Session of Assembly, begun and held | at the City of Annapolis, on Monday the Twenty | Third Day of February, in the Fifth Year of the | Dominion of the Right Honourable Frede-| rick, Lord Baron of Baltimore, Absolute Lord | and Proprietary of the Provinces of Maryland and | Avalon, \&c. Annoque Domini 1756.| [Baltimore arms] Published by Authority.| Annapolis:| Printed by Jonas Green, Printer to the Province; and are | to be Sold at his Printing-Office in Charles-Street, 1756.

Fol. [A] $]^{1}$, B-I ${ }^{2}$; 17 leaves; pages [I-2], 3-33, [34]; p. [I]: title; pp. 3-33: text; p. [34]: contents, and one line of errata; running heads as follows: pp. 3-4: "March, 1756", all others: "May, 1756", while on last page printer notes that all are wrong and should be "February, 1756".

Leaf measures: $12 \frac{1}{2} \times 7^{\frac{3}{4}}$ inches. Type page, p. 6: $250 \times 144 \mathrm{~mm}$.

MdHS. MDioc. BBL. (dup.) LC. HLS.

191. - [At a Session of Assembly begun and held at the City of Annapolis, the 23d Day of February 1756, the following law was enacted: An Act Granting a Supply of Forty Thousand Pounds, for his Majesty's Service; and Striking Thirty-four Thousand and Fifteen Pounds Six Shillings thereof, in Bills of Credit; and raising a Fund for sinking the same. Annapolis: Printed by Jonas Green. 1756.]

No copy recorded. Advertised in Maryland Gazette for Aug. 12, 1756, as "Just Published (With all the other laws passed last session.)" It is not clear that separate publication is meant.

192. - The following Bill (which | did not Pass into a Law last | Session) is published, in Pur-| suance of an Order of the | Honourable Lower House of | Assembly, for the Perusal of | their Constitutents.| An Act for regulating the Militia of the Province of | Maryland.| [Colophon:] Annapolis: Printed and Sold by Jonas Green, Printer to the Province, 1756.|

Sm. fol. A-C ${ }^{2} ; 6$ leaves; pp. [I]-II, [12]: text, with head-piece, heading as above and tail-piece.

Leaf measures: $11 \frac{3}{16} \times 7$ inches. Type page, p. 2: $265 \times 143 \mathrm{~mm}$.

Advertised in the Maryland Gazette for June Io, 1756 as "Just Published."

MDSL.

193. [The Maryland Almanack for the Year 1756. Annapolis: Printed by Jonas Green. 1756.]

No copy recorded. Advertised as "Lately.Published" in the Maryland Gazette for Jan. I5, 1756.

194. [The Maryland Almanack for the Year of our Lord I757, containing the Lunations,

Conjunctions, Eclipses, \&c. \&c. Annapolis: Printed by Jonas Green. 1756.]

No copy recorded. Advertised as "Just Published" in Maryland Gazette for Dec. 30, 1756.

[207] 


\section{A History of Printing in Colonial Maryland}

195. The | Maryland Gazette,| Containing the freshest Advices foreign and domestic.| (Jan. I-Dec. 30, 1756, Nos. 556-608.) [Colophon, same as Nos. 542-555 in 1755.]

I 4 9 $9 \frac{1}{4}$ inches; 2 leaves each number, except Nos. 557, 606 and 608 which have one only; three columns.

MdHS. (lacks 606-608.) MDSL (complete.)

1757

196. Maryland, Province of. Acts | of the Province of | Maryland,| made and passed| at a Session of Assembly, begun and held | at the City of Annapolis, on Tuesday the Four- $\mid$ teenth Day of September, in the Sixth Year of the | Dominion of the Right Honourable Frede-| rick, Lord Baron of Baltimore, Absolute | Lord and Proprietary of the Provinces of Mary-| land and Avalon, \&c. Annoque Domini 1756.| [Baltimore arms] Published by Authority.| Annapolis:| Printed by Jonas Green, Printer to the Province; and are / to be Sold at his Printing-Office in Charles-Street, 1757.1

Sm. fol. I preliminary leaf, A-B ${ }^{2}$; 5 leaves; pages [i-ii], I-[8]; p. [i]: title; Pp. I-7: text, with running heads; p. 7: contents.

Leaf measures: $11 \frac{3}{4} \times 7$ inches. Type page, p. $3: 246 \times 144 \mathrm{~mm}$.

MDioc. MdHS. (dup.) BBL. LC. HLS.

197. - Acts | of the Province of | Maryland,| made and passed | at a Session of Assembly, begun and held at | Baltimore-Town, on Friday the Eighth Day | of April, in the Sixth Year of the Dominion of | the Right Honourable Frederick, Lord | Baron of Baltimore, Absolute Lord and Proprieta-| ry of the Provinces of Maryland and Avalon,| \&c. Annoque Domini I757.] [Baltimore arms] Published by Authority.| Annapolis:| Printed by Jonas Green, Printer to the Province; and are | to be Sold at his Printing-Office in CharlesStreet, 1757.1

Sm. fol. 1 preliminary leaf, A-C $C^{2},[D]^{1}$; 8 leaves; (preliminary leaf is imposed as second leaf of signature [D]); pages [i-ii], I-13, [14]; p. [i]: title; pp. I-1 3 : text, with running heads; $p$. I3: contents.

Leaf measures: $11 \frac{3}{7} \times 7$ inches. Type page, p. 2: $245 \times 143 \mathrm{~mm}$.

MdHS. (dup.) MDioc. BBL. Pleasants. LC. HLS.

198. - Votes and Proceedings | of the | Lower House of Assembly | of the | Province of Maryland.| (23 February-22 May, 1756). [Colophon:] Annapolis:] Printed and Sold by Jonas Green, Printer to the Province. MDCclvir.]

4to. $[\mathrm{A}]-\mathrm{Z}^{2}, \mathrm{Aa}^{2},[\mathrm{Bb}]^{1} ; 49$ leaves; pages [1]-97, [98]: text, with head-piece, heading as above, session heading of six lines, tail-piece and running heads.

Leaf measures: $9 \frac{8}{16} \times 7$ inches. Type page, p. 2: $186 \times 146 \mathrm{~mm}$.

MdHS. MDioc. MDSL. LC. NYPL. HU.

199. - Votes and Proceedings | of the | Lower House of Assembly | of the | Province of Maryland.| (14 September-9 October, 1756). [Colophon:] Annapolis: Printed and Sold by Jonas Green, Printer to the Province. MDcclvir.|

4to. A- ${ }^{2},[\mathrm{~K}]^{1} ;$ I 9 leaves; pp. [r]-37, [38]: text, with head-piece, heading as above, session heading of six lines and running heads.

Leaf measures: $9 \frac{3}{16} \times 7 \frac{1}{3}$ inches. Type page, p. $2: 181 \times 144 \mathrm{~mm}$.

MdHS. MDSL. NYPL. HU. Pleasants.

200. - Votes and Proceedings | of the | Lower House of Assembly | of the | Province of Maryland.| (8 April-9 May 1757). [Colophon:] Annapolis: Printed and Sold by Jonas Green, Printer to the Province, 1757.1

4to. A-N² 26 leaves; pp. [1]-52: text, with head-piece, heading as above, session heading of six lines and run-
heads. 
Leaf measures: $9 \frac{1}{16} \times 7^{\frac{1}{8}}$ inches. Type page, p. 4: $186 \times 145 \mathrm{~mm}$.

Session held at "Baltimore-Town."

MdHS. MDioc. (imp.) MDSL. LC. NYPL.

201. [The Maryland Almanack, for the Year 1758. Annapolis: Printed by Jonas Green. 1757.]

No copy recorded. Advertised in the Maryland Gazette for Dec. 8, 1757, as "Just Published."

202. The | Maryland Gazette,| Containing the freshest Advices foreign and domestic.| (Jan. 6-Dec. 29, 1757, Nos. 609-660.) [Colophon, same as Nos. 542-555 in 1755.]

$14 \times 9$ inches; 2 leaves each number except Nos. 611, 613 and 615 which have one each; three columns.

MDSL. (complete.) For location of scattered issues, see Brigham, American Newspapers.

$$
175^{8}
$$

203. Maryland, Province of. Acts | of the Province of | Maryland, made and passed | at a Session of Assembly, begun and | held at the City of Annapolis, on Wed-| nesday the Twenty-eighth of September, in | the Sixth Year of the Dominion of the Right | Honourable Frederick, Lord Ba-| ron of Baltimore, Absolute Lord and Pro-l prietary of the Provinces of Maryland and | Avalon, \&c. Annoque Domini 1757.| [Baltimore arms] Published by Authority.| Annapolis:| Printed by Jonas Green, Printer to the Province; land are to be Sold at his Printing-Office in | Charles-Street. 1758.|

Sm. fol. I preliminary leaf, A-B ${ }^{2}, C^{1}$, I supplementary leaf; 7 leaves; (preliminary leaf, containing title, and supplementary leaf, which is blank, are halves of the same sheet); pages [i-ii], I-IO, [I I-I 2]; p. [i]: title; pp. I-9: text, with running heads; $p$. Io: contents.

Leaf measures: I I $\frac{3}{4} \times 7$ inches. Type page, p. 2: $232 \times 127 \mathrm{~mm}$.

MDioc. MdHS. (imp.) BBL. NYBA. HLS.

204. - Acts | of the Province of | Maryland,| made and passed | at a Session of Assembly, begun and | held at the City of Annapolis, on Tuesday | the Twenty-eighth of March, in the Seventh | Year of the Dominion of the Right Honour-| able Frederick, Lord Baron of Bal-| timore, Absolute Lord and Proprietary of the | Provinces of Maryland and Avalon, \&c.| Annoque Domini 1758.| [Baltimore arms] Published by Authority.| Annapolis:| Printed by Jonas Green, Printer to the Province; and are to be Sold at his Printing-Office in | Charles-Street. $175^{8}$.|

Sm. fol. I preliminary leaf, A-B ${ }^{2}$ 5 leaves; pages [i-ii], I-8; p. [i]: title; pp. I-7: text, with running heads; $\mathrm{p}$. 8: contents.

Leaf measures: $11 \frac{3}{\frac{3}{4}} \times 7 \frac{1}{8}$ inches. Type page, p. $2: 233 \times 128 \mathrm{~mm}$.

MdHS. MDioc. HLS.

205. - Acts | of the Province of | Maryland, | made and passed | at a Session of Assembly, begun and held at | the City of Annapolis, on Wednesday the Twen-|ty-second Day of November, in the Eighth Year | of the Dominion of the Right Honourable | Frederick, Lord Baron of Baltimore, | Absolute Lord and Proprietary of the Provinces | of Maryland and Avalon, \&c. Annoque Domini | 1758.| [Baltimore arms] Published by Authority.| Annapolis:| Printed by Jonas Green, I758.|

Sm. fol. $[A]^{1}, B^{2}, C^{1} ;([A]$ is imposed as second leaf of signature $C) ; 4$ leaves; pages [I-2], 3-8; p. [I]: title; pp. 3-8: text, with running heads; p. 8: contents.

Leaf measures: $11 \frac{11}{16} \times 7$ inches. Type page, p. 4: $239 \times I_{4} \mathrm{I} \mathrm{mm}$.

MDioc. MdHS. LC. HLS.

206. - By the Lower House of Assembly,| December I, I757.| On Motion,| Ordered, That the Bill, entituled, An Act for / granting a Supply of Twenty Thousand Pounds for | his 


\section{$A$ History of Printing in Colonial SCaryland}

Majesty's Service, and the more immediate Defence and | Security of the Frontier Inhabitants of this Province; and | Emitting Ten Thousand Pounds thereof in Bills of Credit; | and Raising a Fund for Sinking and Replacing the Whole, by an equal Assessment on all Estates, Real and Personal,| and Lucrative offices and Employments, returned this | Day with a Negative from the Upper House, be Printed | by the I 4 th Day of January next, with the several In-| dorsements thereon, and such Part of the Proceedings as | relate thereto; and that Two Printed Copies be delivered | to each Member of the Upper and Lower Houses of Assem-| bly, and One to every Clerk of the several County Courts | of this Province, to be lodged in the respective County | Clerks Offices, for the Perusal of the Inhabitants of each | County; and forwarded in the same Manner, by the Prin-| ter, as the Laws, Votes and Proceedings, are directed to $\mid$ be. Signed per Order,| M. Macnemara, Cl. Lo. Ho.| [Colophon:] Annapolis:| Printed by Jonas Green, Printer to the Pro-| vince. I 758.1

Fol. A-O2, PI; 29 leaves; pages I-58; pp. I-49: text, with heading as above; Pp. 50-58: text, with this heading in square brackets: [Extract of the Votes and Proceed-| ings of the Lower House, relating to the | foregoing Bill]|; p. 58 : colophon.

Leaf measures: $12 \frac{3}{16} \times 7 \frac{3}{3}$ inches. Type page, p. 2: $232 \times 112 \mathrm{~mm}$.

Advertisement in Maryland Gazette Feb. 16, 1758: "Just Published, The (so-much talk'd of) Assessment Bill, which Passed the Lower House last Session, and was Rejected by the Upper House; with all the Proceedings relating thereto: Containing in the whole, Fifty-eight pages in Folio. A few Copies are to be Sold at the PrintingOffice. Price 3/6." The consequences of the lack of co-ordination between the two houses of the Maryland Assembly during this period are discussed in Schlesinger, A. M. Maryland's Share in the Last Intercolonial War, in Maryland Historical Magazine June and Sept. 1912, pp. 119 and 243, and in Mereness, N. D. Maryland as a Proprietary Province. N. Y. IgoI, Chapter 4, Military Affairs, in both of which the supply bill here described and others of a similar character are spoken of. The whole subject of the dispute between the Proprietary and the Assembly is fully treated in Maryland's Attitude in the Struggle for Canada, by J. W. Black (J. H. U. Studies in Historical and Political Science, Tenth Series, No. 7. Baltimore. 1892.)

MDSL. MdHS. MDioc. (imp.) LC. HLS.

207. - [Charter of Maryland, and Laws from 1754 to I758. Annapolis: Printed by Jonas Green. 1758.] fol.

Evans, No. 8168 , gives this title but does not locate a copy, nor has the compiler been able to find a copy. Is it possible that here are a copy of the charter and separate editions of session laws from 1754 to $175^{8}$ bound together, and that this is a binder's title or a bookseller's descriptive title? If this be true it is likely that the "Charter of Maryland" mentioned is that which Green printed in $175 \mathrm{I}$, but of which no copy has been located.

208. - Votes and Proceedings | of the | Lower House of Assembly | of the | Province of Maryland.| (28 Sept.-I6 December, I757.) [Colophon]: Annapolis:| Printed and Sold by Jonas Green, Printer to the Province. MDcclviII.|

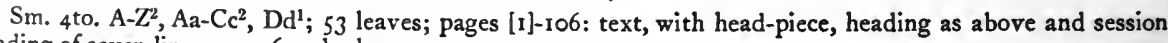
heading of seven lines; $p$. I06: colophon.

Leaf measures: $8 \frac{1}{2} \times 6 \frac{5}{8}$ inches. Type page, p. $2: 183 \times 144 \mathrm{~mm}$.

MDSL. MdHS. (dup.) HU.

209. - Votes and Proceedings | of the | Lower House of Assembly | of the | Province of Maryland.! (13 February-9 March, 1758). [Colophon:] Annapolis: Printed and Sold by Jonas Green.| [1758].

*4to. A-F"; 12 leaves; pp. [I]-24: text, with head-piece, heading as above, session heading of six lines and running heads.

Leaf masures: $9 \frac{1}{16} \times 7 \frac{1}{8}$ inches. Type page, p. $2: 185 \times 144 \mathrm{~mm}$.

There were no Acts passed at this convention of Assembly.

MdHS. MDSL. LC. HU. 


\section{SCaryland Imprints of the Colonial Period, $1680-1776$}

210. - Votes and Proceedings | of the / Lower House of Assembly | of the | Province of Maryland.| (28 March-13 May, 1758.) [Colophon:] Annapolis: Printed by Jonas Green, Printer to the Province.| [1758].

${ }^{*}$ Sm. 4 to. A-Z2, Aa-Cc ${ }^{2}$, [Dd] ${ }^{1}$; 53 leaves; pages [I]-105, [106]; pp. [I]-ro5: text, with head-piece, heading as above and session heading of six lines; p. I05: colophon; p. 65 has lower portion cancelled by a corrected printed version of the last three paragraphs.

Leaf measures: $8 \frac{1}{2} \times 6 \frac{8}{8}$ inches. Type page, p. 2: $183 \times 144 \mathrm{~mm}$.

MDSL. HU. MdHS. (Calvert Papers).

211. - Votes and Proceedings | of the | Lower House of Assembly | of the | Province of Maryland.| (23 October-4 November, 1758). [Colophon:] Annapolis:| Printed and Sold by Jonas Green, MDCCLVIII.|

*4to. A-D²; 8 leaves; pp. [1]-15, [16]: text with head-piece, heading as above, session heading of seven lines and running heads.

Leaf measures: $9 \frac{1}{16} \times 7 \frac{1}{1}$ inches. Type page, p. 2: $184 \times 143 \mathrm{~mm}$.

There were no Acts passed at this convention of Assembly.

MdHS. MDSL. Pleasants (lacks first leaf.) HU.

21 2. [The Maryland Almanack for . . . 1759. Annapolis: Jonas Green. 1759.]

I 2 mo. pp. 32.

No copy known. The above was recorded by Sabin, No. 45201 .

213. The | Maryland Gazette,| Containing the freshest Advices foreign and domestic.| (Jan. 5-Dec. 28, 1758, Nos. 661-71 2). [Colophon, Nos. 662-702 same as 542-555 in I 755 with exception as noted below. Colophon, Nos. 703-712, as follows:] Annapolis: Printed by Jonas Green, and William Rind, at the Printing-| Office, the Sign of the Bible, in Charles-street; where all Persons may be supplied with this Ga-l zette, at $12 \mathrm{~s} .6 \mathrm{~d}$. per Year. Advertisements of a moderate length are taken in and inserted | for Five Shillings the first Week, and one Shilling each Week after, and in Proportion for long Advertise-| ments.|

$I_{4} \times 9$ inches; 2 leaves each number, except Nos. 662-663,665, 667 and 71 2, which have one each; three columns.

No. 665 has colophon: Annapolis: Printed by Jonas Green.l

MDSL. (complete).

$$
\text { I } 759
$$

214. [An Almanack for the Year 1760, fitted to this Meridian, containing, beside what is common in an Almanack, a very famous Receipt, lately made public, and purchased of Mr. Joseph Howard of South-Carolina, by the Assembly of that Government, for which they gave him Three Thousand Pounds, for Curing the Lame-Distemper, Yaws or almost any corrupt Blood, \&c. Also a Receipt, by which Meat, ever so stinking, may be made as sweet and wholesome, in a few Minutes, as any Meat at all, \&c. \&c. Annapolis: Printed by Jonas Green. 1759.]

No copy recorded. Advertised in Maryland Gazette for Nov. 29, 1759 as "Just Published." Was this the publication advertised in the Maryland Gazette for Oct. II, 1759, and afterwards, as "Now in the Press, And will be published with all convenient speed, An Ephemeris for the Year of our Lord 1760 . Being Bissextile or Leap-Year. Or, An Almanack, containing, \&c. \&c. Fitted for the Province of Maryland. By Darius Marylander, Philomath."?

215. Bisset, James, ed. Abridgment and Collection / of the | Acts of Assembly | of the Province of | Maryland, | at present in Force.| With | a small choice | Collection of Precedents | in | Law and Conveyancing.| Calculated for the Use of the Gentlemen of the Province.| By James Bisset, Attorney at Law.| [One line from Virgil.] Ppiladelphia [sic]:|

[2II ] 


\section{A History of Printing in Colonial SCaryland}

Printed by William Bradford, Printer, in Market-| Street, for the Author, 1759.| [Price Bound, Twelve Shillings and Six Pence Currency.] |

8 vo. 4 preliminary leaves, $\mathrm{A}-\mathrm{Z}^{4}, \mathrm{Aa}^{-} \mathrm{Zz}^{4}$; (Qq2 incorrectly given as $\mathrm{Rr} 2$, which is repeated in its proper place); 188 leaves; pp. [i-viii], [1]-366, [368]; pp. 361-366 wrongly numbered 561-566, p. 343 wrongly numbered 344; p. [i]: title; p. [iii]: dedication to the Hon. Stephen Bordley, Esq; pp. [v-viii]: "Preface", with head and tail pieces, running heads; pp. [1]-10: The | Charter | of | Maryland.|, with head and tail pieces, running heads; Pp. 11-288: text, with running heads and heading, Abridgment | of the | Acts of Assembly | of the | Province of Maryland | at present in Force.|; p. 288: "Finis"; p. 289: half-title, Choice | and approved | Precedents | in | Law | and | Conveyancing:| alphabetically digested.| Calculated | for the Use of the Gentlemen of the Province | of | Maryland.|; pp. 291-338: text of Choice and Approved Precedents, etc. with heading; Pp. 339-[343] (printed 344): "Index."; p. [343] (printed 344): "Finis"; pp. 345-353: Index.| To | the Body of Laws. |; pp. 353-[362] (printed 562): "Table or list of the Acts of Assembly of the Province of Maryland inserted in this collection."; pp. [362-366] (printed 562-566): "Appendix. Of some material Laws, omitted to be inserted in the foregoing collection."; p. [366] (printed 566): "Finis" and tail-piece.

Leaf measures: $8 \times 5 \frac{1}{8}$ inches. Type page, p. 12: $166 \times 92 \mathrm{~mm}$.

For discussion of the work, see foregoing narrative.

Proposals for subscriptions published first in Maryland Gazette for June 1, 1758. On Jan. 4, 1759, in the same newspaper, Bissett thanks his subscribers for their generous response and announces early publication. It was advertised as "just published" in Maryland Gazette, June 28, 1759, "in large octavo."

MdHS. MDioc. HSP. NYPL. NYBA. and in many other law and reference libraries.

216. Maryland, Province of. Votes and Proceedings | of the / Lower House of Assembly | of the | Province of Maryland.| (22 November-23 December, 1758). Annapolis:| Printed and Sold by Jonas Green. MDcclix.|

${ }^{*}{ }_{4}$ to. $\mathrm{E}-\mathrm{N}^{2},[\mathrm{O}]^{1}$; 19 leaves; pp. [17]-53, [54]: text, with head-piece, heading as above, session heading of six lines and running heads; last leaf $\left(\mathrm{O}_{2}, \mathrm{pp} .55-56\right)$ lacking, but doubtless blank.

Leaf measures: $9 \frac{1}{16} \times 7 \frac{3}{16}$ inches. Type page, p. I $8: 184 \times 143 \mathrm{~mm}$.

Pagination and signatures continuous with those of the V. \& P. of Oct. $175^{8}$.

MdHS. MDSL. Pleasants. HU.

217. - Votes and Proceedings | of the | Lower House of Assembly | of the | Province of Maryland.| (4 April-17 April 1759.) [Colophon:] Annapolis: Printed by Jonas Green. MDCCLIX.|

*Sm. 4to. P-T2; 10 leaves; pages [57]-76: text, with head-piece, heading as above and session heading of six lines; p. 76: colophon.

Leaf measures: $8 \frac{1}{2} \times 6 \frac{3}{4}$ inches. Type page, p. $58: 181 \times 143 \mathrm{~mm}$.

There were no Acts passed at this convention of Assembly. Pagination and signatures of V. \& P. continuous since Oct. 1758.

MDSL. HU.

2I8. The | Maryland Gazette,| Containing the freshest Advices foreign and domestic.| (Jan. 4-Dec. 27, 1759, Nos. 71 3-764.) [Colophon, same as in Nos. 703-71 in 1758].

$14 \times 9$ inches; 2 leaves each number, except Nos. $714-715,717$ and 764 , which have one each; three columns. MDSL. (complete.) MdHS. (complete.)

219. Maryland, Province of. Acts | of the Province of | Maryland, | made and passed | at a Session of Assembly, begun and held at | the City of Annapolis, on Saturday the Twen-| ty-second Day of March, in the Ninth Year | of the Dominion of the Right Honourable | Frederick, Lord Baron of Baltimore,| Absolute Lord and Proprietary of the Provinces | of Maryland and Avalon, \&c. Annoque Domini | r760.| [Baltimore arms] Published by Authority.| Annapolis:| Printed by Jonas Green, Printer to the Province, 1760.|

Sm. fol. $[A]^{1}, B^{2} ; 3$ leaves; pages [1-2], $3^{-6} 6$; p. [1]: title; pp. $3^{-6}$ : text, with running heads; p. 6: contents.

Leaf mcasures: I $1 \frac{14}{16} \times 7 \frac{1}{\frac{1}{6}}$ inches. Type page, p. 4: $255 \times 124 \mathrm{~mm}$.

MdHS. MDioc. HLS. 


\section{Garyland Imprints of the Colonial Period, $1689-1776$}

220. - Acts | of the Province of | Maryland,| made and passed | at a Session of Assembly, begun and held | at the City of Annapolis, on Friday the Twenty / Sixth Day of September, in the Tenth Year of $\mid$ the Dominion of the Right Honourable Frede-| rick, Lord Baron of Baltimore, Absolute Lord | and Proprietary of the Provinces of Maryland | and Avalon, \&c. Annoque Domini 1760.| [Baltimore arms] Published by Authority.| Annapolis:| Printed by Jonas Green, Printer to the Province; and are to be | Sold at his PrintingOffice in Charles-Street. I760.|

Sm. fol. $[A]^{1}, B^{2}, C^{1} ; 4$ leaves; pages [I-2], $3^{-8} ;$ p. [I]: title; pp. 3-8: text, with running heads; p. 8: contents. Leaf measures: $\mathrm{I} 1 \frac{11}{16} \times 7 \frac{1}{8}$ inches. Type page, p. 4:253 $122 \mathrm{~mm}$.

MdHS. MDioc. HLS.

221. - At a Session of Assembly, began [sic] | at the City of Annapolis, on the 22d | Day of March, I760, which conti-| nued until the I I th Day of April, it | was Ordered by the Honourable the | Lower House, That the following | Three Bills which did not Pass in-| to Laws, with the Amendments pro-f posed to the first by the Lower House,| and Message sent with the second, | should be Printed, and sent to the se-f veral Counties in this Province.| [Colophon:] Annapolis:| Printed by Jonas Green, Printer to the Province.| M.Dcc.Lx.|

Sm. fol. A-O', P1; 29 leaves; pages I-58; pp. I-5: "An Act for Naturalization"; pp. 5-1 I: "An Act to continue the several Taxes ... for granting a Supply of Forty Thousand Pounds for his Majesty's Service, ..."; pp. I I-58: "An Act for granting a Supply of Sixty Thousand Pounds for his Majesty's Service,..."; p. 58: colophon.

Leaf measures: $11 \frac{2}{6} \times 7$ inches. Type page, p. 2: $227 \times 111 \mathrm{~mm}$.

MDSL.

222. -By his Excellency Horatio Sharpe, Esq; Governor | and Commander in Chief in and over the Province of | Maryland.| A Brief.| It having been represented to me, by his Majesty's Governor of the Massachusetts-| Bay in New-England, that on the 2oth of March last, a Fire broke out in | the Town of Boston, . . . Given at the City of Annapolis, the Sixth Day of May, in the Tenth Year of his|Lordship's Dominion, and in the Year of our Lord Christ, I760.| [Annapolis: Printed by Jonas Green. 1760.]

Broadside. $15 \times 12 \frac{1}{16}$ inches.

This broadside, testimony to close intercolonial relations, was distributed widely throughout the Province, and the collections for the homeless fire sufferers of Boston made the responsibility of the clergy of all denominations. The Maryland Historical Society has more than a hundred copies of the broadside, many of them bearing, either on separate sheets attached or on the backs, the names of the persons who contributed to the fund, in many cases with the amounts contributed by each person or the total subscription of the parish.

MdHS. MDioc.

223. - [Baltimore arms] By His Excellency | Horatio Sharpe, Esq;| Governor and Commander in Chief in and over the / Province of Maryland.| A Proclamation.| . . . Given at Annapolis, this Day of $\quad$ in the Year of his Lordship's Dominion, Annoque | Domini I76 | Signed per Order,| [Annapolis: Printed by Jonas Green. I 760-1768.]

Broadside. Approximately $10 \frac{1}{2} \times 7 \frac{1}{3}$ inches.

Form for prorogation of Maryland Assembly, with blank space for dates. The copy described here is dated Jan. $4,1768$.

MdHS.

224. - Votes and Proceedings | of the | Lower House of Assembly | of the | Province of Maryland.| (22 March-I I April, I760.) [Colophon:] Annapolis: Printed and Sold by Jonas Green, Printer to the Province, 1760.| 


\section{$A$ History of Printing in Colonial Scaryland}

*Sm. 4 to. V-Z2 ${ }^{2} \mathrm{Aa}-\mathrm{Cc}^{2} ; \mathrm{I}_{4}$ leaves; pages [77]-103, [104]; pp. [77]-103: text, with head-piece, heading as above and session heading of six lines; p. 103: colophon.

Leaf measures: $8 \frac{1}{2} \times 6 \frac{11}{16}$ inches. Type page, p. $78: 177 \times 142 \mathrm{~mm}$.

Page 103 has a notice beneath the colophon announcing that "The Three Bills" ordered printed by the House this Session were in the press. See No. 221. Pagination and signatures of V. \& P. continuous since Oct. 1758.

MDSL.

225. - Votes and Proceedings | of the | Lower House of Assembly | of the | Province of Maryland.| (26 September-I5 October, I 760.) [Colophon:] Annapolis:| Printed by Jonas Green, Printer to the Province. MDCcLx.|

4to. $\mathrm{Dd}-\mathrm{Hh}^{2}, \mathrm{Ii}^{1}$; II leaves; pages [105]-125, [126]: pp. [105]-125: text, with head-piece, heading as above, session heading of six lines and running heads; p. 125: colophon; leaf li2, doubtless blank, lacking in known copies, and not accounted for in pagination of the series. See collation of No. 231 .

Leaf measures: $10 \frac{1}{3} \times 7^{\frac{3}{4}}$ inches. Type page, p. 106: $187 \times 144 \mathrm{~mm}$.

Pagination and signatures of V. \& P. continuous since Oct. 1758.

MDSL. MdHS. (Calvert Papers, 808.)

226. [The Maryland Almanack, for the Year of our Lord, I76r. Being the First after Bissextile or Leap-Year. Wherein is contained The Motions of the Sun and Moon; the true Places and Aspects of the Planets, and Rising and Setting of the Sun and Moon. Likewise The Lunations, Conjunctions, Eclipses, Judgment of the Weather, Rising and Setting of the Planets; Rising, Setting, and Southing, of the Seven Stars: Together with the Courts of Maryland, Pennsylvania, and Virginia; Description of the Roads; an excellent Receipt for the Cure of the Dysentery or Bloody-Flux, taken from the Edinburgh Medical Essays; and several other useful and entertaining Particulars. Calculated for the Latitude of Thirty-nine Degrees, and a Meridian of Five Hours West from London; but will very well serve any of the neighboring Colonies. Annapolis: Printed by Jonas Green. I760.]

No copy recorded. Advertised in Maryland Gazetre for Dec. 24, 1760 as "Just Published."

227. The | Maryland Gazette,| Containing the freshest advices foreign and domestic.| (Jan. 3-Dec. 24, I760, Nos. 765-8I6.) [Beginning with Oct. 23d, No. 807, title changes from "freshest" to "latest advices." Colophon, 765-8 15 as follows:] Annapolis: Printed by Jonas Green, and William Rind, at the Printing-| Office, the Sign of the Bible, in Charles-street; where all Persons may be supplied with this /Gazette, at 12 s. 6 d. per Year. Advertisements of a moderate length are taken in and inserted | for Five Shillings the first Week, and One Shilling each Week after, and in Proportion for long Ones. | [Colophon to Numb. 816:] Annapolis: Printed by Jonas Green, and William Rind.|

I $4 \frac{1}{4} \times 9$ inches; 2 leaves each number, except Nos. 767 and 768 , which have one only; three columns.

Nos. 795 and 796 each have "Supplement" of one leaf.

MdHS. (one complete copy and an imperfect duplicate.) MDSL. (complete.) For location of scattered issues, see Brigham, American Newspapers.

$$
1761
$$

228. Maryland, Province of. By his Excellency | the Governor | and | Council, Ioth July, I76I.| [Colophon:] Annapolis: Printed by Jonas Green, Printer to the Province. I76I.| 4to. A-B2; 4 leaves; $\mathrm{FP}$. [I]-8: text, with head-piece and heading as above; p. 8: colophon.

Leaf measures: $10 \frac{1}{3} \times 7^{\frac{8}{8}}$ inches. Type page, p. 2: $187 \times 143 \mathrm{~mm}$.

The Lower House having neglected the Governor's request to include in their journal the record of proceedings undertaken to recover for the public the money due from Mr. Darnall, late Naval Officer of Patuxent, "It is therefore Ordered, that Mr. Green Print and Publish them, and that he deliver a Copy thereof, with every Copy that he shall deliver of the Journal of the Proceedings in the Lower House during the late Convention." See p. [r], above pamphlet. MdHS. 
229. - To his Excellency | Horatio Sharpe, Esq; Governor and Commander in Chief in and over | the Province of Maryland:| The humble Address of | the House of Delegates.| May it please your Excellency, . ...April 14, 1761. [Signed,] H. Hooper, Speaker.| His Excellency's Answer:| Gentlemen of the Lower House of Assembly,| . . . April 15, I761. [Signed,] Horo. Sharpe.| Annapolis: Printed by Jonas Green, Printer to the Province.| [176r.]

Broadside. $12 \frac{7}{16} \times 7 \frac{7}{16}$ inches; head and tail pieces; imprint beneath tail-piece.

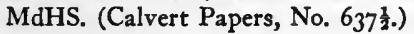

230. - To his Excellency / Horatio Sharpe, Esq;| Governor and Commander in Chief in and over / the Province of Maryland:| The humble Address of | the Upper House of Assembly.| May it please your Excellency,| . . A April 15, I761. [Signed,] B. Tasker, President.| His Excellency's Answer:| Gentlemen of the Upper House of Assembly,| . . . I6th of April, 1761. [Signed,] Horo. Sharpe.| Annapolis: Printed by Jonas Green, Printer to the Province.| [176r.]

Broadside. $12 \frac{3}{8} \times 7 \frac{7}{16}$ inches; head and tail pieces; imprint beneath tail-piece.

MdHS. (Calvert Papers, No. 637\%.)

231. - Votes and Proceedings | of the | Lower House of Assembly | of the | Province of Maryland.| (I3 April-6 May, I76r.) [Colophon:] Annapolis: Printed by Jonas Green, Printer to the Province, 176r.|

4to. Kk-Ss ${ }^{2}$, [Tt] ${ }^{1} ; 19$ leaves; pp. [127]-163, [164]: text with head-piece, heading as above, session heading of six lines and running heads.

Leaf measures: $10 \frac{1}{2} \times 7 \frac{8}{8}$ inches. Type page, p. 128: $197 \times 144 \mathrm{~mm}$.

See note to No. 228, a title which is sometimes found bound with the V. \& P. here described. With the above item is concluded the pagination and signature sequence begun with V. \& P. of Oct. 1758 . There were no Acts passed at this convention of Assembly.

MdHS. MDioc. (lacks last leaf) MDSL. Pleasants. (dup.)

232. The | Maryland | Almanack,| for the Year of our Lord,| I762,| Being the Second after | Bissextile or Leap-Year.| And from the Creation of the World, according to the / best of Profane History, 57 I I But by the East and Greek Christians, 7270 | By the Jews, Hebrews, and Rabbins, 5522 | And by the Account of Holy Scriptures, 5771 / Since the Discovery of America, 270 | Wherein is contained / the Motions of the Sun and Moon; the true Places and | Aspects of the Planets, and Rising and Setting of the | Sun and Moon.| Likewise | The Lunations, Conjunctions, Eclipses, Judgment | of the Weather, Rising and Setting of the Planets;| Rising, Setting, and Southing, of the Seven Stars:| Together with the Courts of Maryland, Pennsyl-| vania, and Virginia; Description of the Roads; and several other useful and entertaining Particulars.| Calculated for the Latitude of Thirtynine Degrees, | and a Meridian of Five Hours West from London; but | will very well serve any of the neighboring Colonies.| Annapolis:| Printed and Sold by Jonas Green.| [1761]. Price Eight Coppers, single.|

I 2 mo. $A^{4}, B^{2}, C^{4}$, apparently; actually is $A-B^{4}, C^{2}$, (see note below) Io leaves; pages unnumbered.

Leaf measures: $6 \frac{3}{8} \times 4 \frac{15}{16}$ inches. Type page, p. 2, including borders: $147 \times 8 \mathrm{I} \mathrm{mm}$.

Advertised in Maryland Gazette for Dec. 24, 176r as "Lately Published." The leaves in this copy are loose enough to render possible a careful examination of the gatherings which compose the book. These are seen to be as follows:

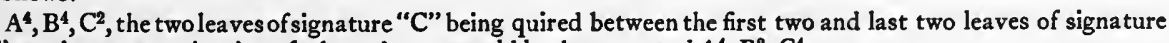
" $B$ ", so that an examination of a bound copy would lead one to read $A^{4}, B^{2}, C^{4}$.

LC.

[215] 


\section{A History of Printing in Colonial SCaryland}

233. The | Maryland Gazette,| Containing the latest Advices foreign and domestic.| (Jan. I-Dec. 31, 1761, Nos. 817-869.) [Colophon, as in Nos. 765-815 in the year 1760, except Nos. $817,818,820,822$ which are as No. 816 in that year.]

$14 \times 9$ inches; 2 leaves each number except $818,820,822,824,868$ and 869 which have one each; three columns.

MdHS. (two complete copies.) MDSL. (complete.)

234. Milton, Aвraham. The | Farmer's | Companion,| directing | how to Survey Land | after | a new and particular Method.| By Abraham Milton, Farmer,| of Kent County, in Maryland.| Annapolis: Printed for the Author.| mDcclxi.|

Half-title, pp. 34 , folding plate.

A copy of this work exists somewhere in private ownership. The compiler had a sight of it some years ago when its title-page as above given was photographed for the Maryland Historical Society. No description was taken of the book at that time, except the brief note given above. The photostat title-page in the Maryland Historical Society indicates $\mathrm{Sm} .4$ to in size.

On Sept. 27 and Oct. 25, 1759, "Abraham Milton, Inspector at Chestertown" published in the Maryland Gazette his proposals for issuing by subscription, provided 400 subscriptions at 20 shillings each were received, The Farmer's Companion, withdrawing his former proposals. His advertisment was accompanied by testimonials to his new method by well known farmers and gentlemen, among them the Rev. Hugh Jones of Cecil County, who signed himself "H. Jones, Philomath." In Maryland Gazetie for April 3, 1760, Milton announced a sliding scale for the price of the book, based upon the number of subscriptions which should be received. It was to cost $10 \mathrm{~s}$. down and Io s. at delivery, but if 500 subscribers were received, then only $7 \mathrm{s.} 6 \mathrm{~d}$. at delivery; if 600 , only $5 \mathrm{~s}$; if 700 , only $2 \mathrm{~s}$. $6 \mathrm{~d}$.; if 800 , nothing at delivery, the original 10 s. being sufficient. On Aug. 14, 1760 , in the same newspaper, Milton announced that although the prescribed number of subscriptions had not been received, he proposed to publish the book within two months. It was not, however, until April 23, 176r, that the book was advertised in the Maryland Gazette as "this day published," and to be Sold for "so s. Ready money only."

Evans, No. 8929 , gives this title from Hildeburn, No. 1747 :

235. Milton, Aвraham. The Farmer's Companion; instructing how to run land without a compass, and to plat the same in an easy manner. Also a supplement thereto, directing how any person may tell the time of day by a walking stick, or a piece of board, and thereby set off any course of the compass . . . Philadelphia: Printed by Andrew Steuart, I76r.

Hildeburn does not locate a copy of this edition nor give any description of it. It is possible that his entry may be a title made up from a newspaper advertisement of the Annapolis edition, and that Andrew Steuart was not the printer of a Philadelphia edition, but simply the agent employed by Milton to take subscriptions and sell copies in that city.

$$
1762
$$

$\therefore$ 36. [Green, Jonas. A Letter to his Excellency Horatio Sharpe, Esq; Governor and Commander in Chief, in and over the Province of Maryland; and to the Honourable the Upper and Lower Hcuses of Assembly of the said Province; From Jonas Green, Printer. Annapolis: Printed by Jonas Green. 1762.]

No copy recorded, but in his petition noted below, Jonas Green says: "That your Petitioner has, in a printed Letter addressed to your Excellency and your Honours, set forth with strict Truth, many Particulars, relating to his Situation with the Public,..."

237. - To his Exceilency Horatio Sharpe, Esq;| Governor and Commander in Chief, in and | over the Province of Maryland;| and | to the Honourable the Upper and Lower | Houses of Assembly of the said Province; The Petition of Jonas Green, Printer,| most humbly sheweth,| . . . [Annapolis: Printed by Jonas Green. 1762.]

Broadside. $18 \div \times 14 \frac{5}{4}$ inches.

Date determined by Cecilius Calvert's endorsement on back that it was noted in his letter of Mch. I, 1763. That letter was in reply to various ones from Sharpe written in 1762 . For the result of this petition see the report 
of committee on Jonas Green's petition in Votes and Proceedings of April 13, 1762, reprinted in Appendix to the foregoing narrative, and the Act passed in that Session, Chap. 24, 1762, Bacon's Laws of Maryland, also at large in Acts of Assembly, March-April 1762.

MdHS. (Calvert Papers, No. 672.)

238. Maryland, Province of. Acts | of the Province of | Maryland,| made and passed | at a Session of Assembly, begun and held at $\mid$ the City of Annapolis, on Wednesday the Seven-| teenth Day of March, in the Eleventh Year of the | Dominion of the Right Honourable Frede-| rick, Lord Baron of Baltimore, Absolute Lord I and Proprietary of the Provinces of Maryland I and Avalon, \&c. Annoque Domini 1762.| [Baltimore arms] Published by Authority.| Annapolis:| Printed by Jonas Green, Printer to the Province, $1762 . \mid$

Sm. fol. I preliminary leaf, A-D ${ }^{2}$; 9 leaves; pages [i-ii], 1-16; p. [i]: title, with running heads; pp. 1-I5: text; pp. I 5-16: contents.

Leaf measures: $11 \frac{9}{16} \times 7$ inches (cut down). Type page, p. I: $238 \times 142 \mathrm{~mm}$.

Page 16 has a "cancel" containing "Also the following private Laws" pasted over the list of private laws as originally printed on that page.

MdHS. Pleasants. HLS.

239. -A | Bill | for raising a | Supply | for | His Majesty's Service:| which was | Framed by the Lower House of Assembly of the Pro-| vince of Maryland, at a Session held at the City of Anna-I polis, in March I 762, and Rejected by the Up-l per House.| To which is prefixed,| All the Messages which passed between the Two Houses,| relating thereto.| Published by Authority, for the Perusal of the Inhabitants.| Annapolis:| Printed by Jonas Green, Printer to the Province.| MDCcLxII.|

4 to. $[A]^{2}, B-C^{2},{ }^{* 2}$ (inserted between $C_{1}$ and $C_{2}$ ) D-P2; 32 leaves; pages [I- 3 ], 4-10, 4 unnumbered pages of sign. *, [ [1 1 ]-59, [60]; p. [1]: title; pp. [3]-10: text of messages between the houses; head and tail pieces; pp. [**], ${ }^{*} *^{*}, *^{*}, *_{*}^{*}$ : text of address of Upper House, with head-piece and heading, To His Excellency / Horatio Sharpe, Esq;| ... signed on fourth page, "Benjamin Tasker, President", and dated "April 24, I762", tail-piece; pp. [I I]59: text, with head-piece and heading, An Act for granting a Supply of Forty Five Thou-l sand Pounds for his Majesty's Service, and for de-| fraying the Expences heretofore incurred for the | Defence and Security of the Frontier Inhabitants | of this Province, and for other Purposes therein | mentioned; and for raising the same by an equal | Assessment upon all Estates, real and personal, and | lucrative Offices and Employments.|, tail-piece.

Leaf measures: $9 \frac{5}{8} \times 7 \frac{1}{\frac{1}{4}}$ inches. Type page, p. 4: $193 \times 145 \mathrm{~mm}$.

In the Maryland Gazette for Oct. 21, 1762 the publication of this bill was announced, and further that a few copies in addition to those ordered by the Assembly were for sale at five shillings each.

See the letter of Gov. Sharpe to Secretary Calvert in Sharpe Correspondence, Archives of Maryland, I4: 51 . MdHS. MDSL.

240. - Votes | and | Proceedings | of the | Lower House of Assembly | of the | Province of Maryland.| March Session, I762.| (17 March-24 April, 1762). [Colophon:] Annapolis: Printed by Jonas Green, Printer to the Province.] MDcclXII.|

$\mathrm{Sm}$. fol. A-O $\mathrm{O}^{2} ; 28$ leaves; pp. [1]-55, [56]: text, with head-piece, heading as above, session heading of seven lines and running heads.

Leaf measures: $12 \times 7 \frac{11}{6}$ inches. Type page, p. $2: 241 \times 141 \mathrm{~mm}$.

MdHS. MDSL.

24I. The | Maryland | Almanack,| for the Year of our Lord,| $1763, \mid$ Being the Third after | Bissextile or Leap-Year.| And from the Creation of the World, according to the / best of Profane History, 571 2 | But by the East and Greek Christians, 727I | By the Jews, Hebrews, and Rabbins, 5523 | And by the Account of Holy Scriptures, 5772 | Since the Discovery of America, 27I | Wherein is contained | [etc. etc. exactly as in Maryland Almanack for 1762.] Annapolis:| Printed and Sold by Jonas Green.| [1762]. Price Eight Coppers, single.! 


\section{The MARYLAND GAZETTE.}

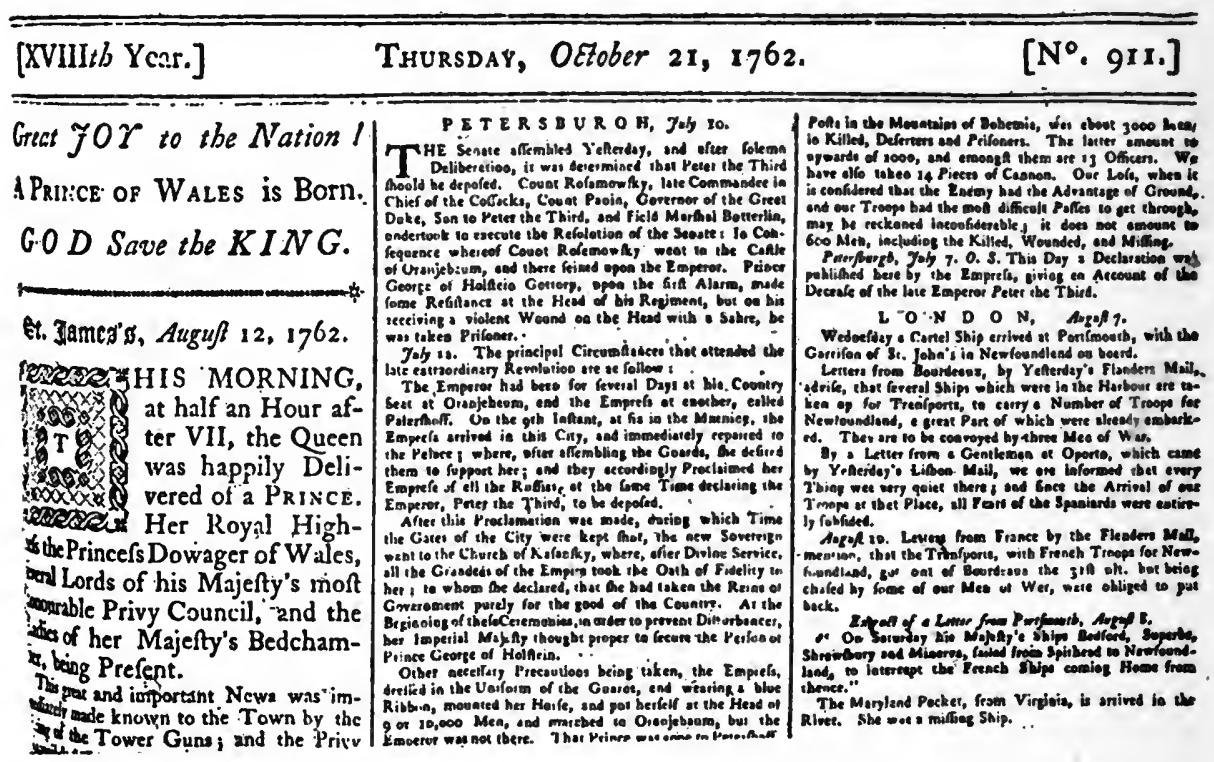

Plate Xa. See page xiv.

[XXIH, YrAR.] T E

[ $N^{\circ}$ :21840.]

$M A R Y L A N D$ G AZETTE. T H U R S D A Y, JULY 16, 1767.

I. $О$ N D O $\mathrm{N}_{3}^{\circ}$ Aprit a.

1 ESTER DAY Of the Jefuits at Barcelons on the isth ult. and add,

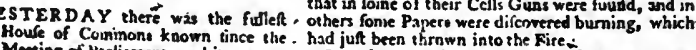
petted would fit later, and it was ex. petted would fit late.

of Trade, being the sre will be held a full Board - Trade, being the faft fince the Holidoys, amu, Ind uyon the Continent in North. Americt, to any of the por Sutiferers in the late War. - Number of Ships, to be paployed this Sevion in Several of the Foreign Natity and Gentry, lately arrived here, we are affed, have befpole very

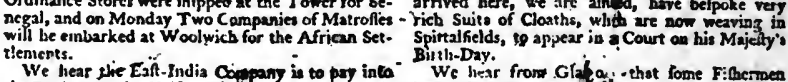

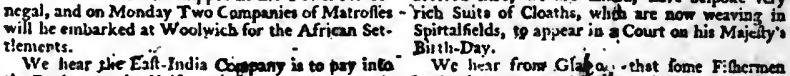

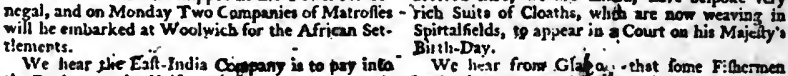

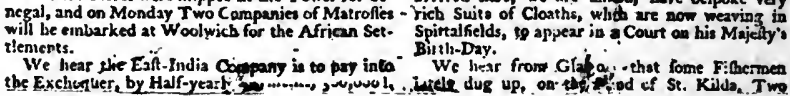

Plate Xb. See page xiv. 


\section{Maryland Imprints of the Colonial Period, $1689-1776$}

12 mo. $A^{4}, B^{2}, C^{4}$, apparently; actually is $A-B^{4}, C^{2}$; ro leaves; pages unnumbered.

Leaf measures: $6 \frac{3}{4} \times 4$ inches. Type page, p. [2], including borders: $151 \times 80 \mathrm{~mm}$.

See this title under year 1761 for explanation of collation.

MassHS. HU.

242. The | Maryland Gazette,| Containing the latest Advices foreign and domestic.| (Jan. 7-Oct. 14, 1762, Nos. 870-910.) [Title from 91 I to 921, Oct. 21-Dec. 30, 1762, reads:] The Maryland Gazette.| [XVIIIth Year.] (Date) (No.) | [Colophon, Nos. 870-910, as in Nos. 765-8I 5 of I760, changed with new title of No. 9II, and from gi I to gig reads as follows:] Annapolis: Printed by Jonas Green and William Rind, in Charles-Street. All Persons | may be supplied with this Gazette at I2s. and 6d. per Year. Advertisements of a moderate | length are inserted for $5 \mathrm{~s}$. the First Week, and Is. each Time after: And Long Ones in Proportion.) [Nos. 920 and 921 have as colophon:] Annapolis: Printed by Jonas Green and William Rind, in Charles-Street.|

$13^{\frac{3}{4}} \times 9$ inches; 2 leaves each number except Nos. 873,876 and 921 which have one each; three columns. each.

Nos. 899 and 902 have "Appendix" of one leaf each. Nos. 887, 904 and 908 have "Supplement" of one leaf

In issue of July 29, I762, Green prints first column in a "Specimen of New English"; second column, "new small-pica"; third column, "new Long-primer."

For arrangement of new title beginning with No. $9^{\text {I } ~}$, see Plate Xa.

MdHS. (two complete copies.) MDSL. (complete.)

$$
1763
$$

243. Самm, John. A| Single and Distinct | View | of the | Act,| Vulgarly entitled, the | Two-Penny Act:| containing | an Account of it's [sic] beneficial and wholesome Effects in | York-Hampton Parish. In which is exhibited | a Specimen of Col. Landon Carter's Justice and Charity; as well | as of Col. Richard Bland's Salus Populi.| By the Reverend John Camm,| Rector of York-Hampton.| ["Carter's Text", two lines; "Bland's Motto", one line; quotation from Swift, one line.] Annapolis: Printed by Jonas Green, for the Author. 1763.1

Sm. 4to. [A]-G4; 28 leaves; pages [I-3], 4-55, [56]; p. [I]: title; pp. [3]-44: text with heading, head and tail pieces; pp. 45-55: "The Appendix"; p. 52: text of Two-Penny Act; pp. 53-55: "Advertisement. To every serious Reader in Lunenburg Parish.", signed, "Landon Carter", and prefaced by a satirical paragraph, doubtless by Camm.

Leaf measures: p. 3: $7 \frac{6}{8} \times 6 \frac{1}{16}$ inches. Type page, p. 6: $147 \times 112 \mathrm{~mm}$.

For a photographic reproduction of the title page, see Plate VII.

The first part of the Appendix, pages 45-5I, contains a correspondence wherein Camm seeks to persuade Joseph Royle of Williamsburg, public printer of Virginia, to print his pamphlet. Royle declines because of its "Satyrical Touches upon the Late Assembly." For an account of the literature of the controversy between the Virginia clergy and the Assembly, arising from the passage of the Act of 1758 whereby the clergy might be paid either in currency or tobacco, see Clayton-Torrence, Nos. 268, 278, 304, 310, 311 , 31 1 . Clayton-Torrence records also above item, but says that no copy of it has been found. See also Griffin, A. P. C. A Catalogue of the Washington Collection in the Boston Athenaeum, in which the compiler refers to "a reply to the works of Carter and Bland" which Camm "brought out in Maryland ... called "The Colonels dismounted." " Clayton-Torrence gives this title as follows: The / Colonel Dismounted:| or the Rector Vindicated.| In a Letter Addressed to His Reverence:| Containing | A Dissertation upon the Constitution | of the Colony.|... [Williamsburg: Printed by Joseph Royle. MDcclxIv.] (Title page. Text, $30 \mathrm{pp}$. Appendixes, XVII pp.) Quoting H. J. Eckenrode, he says that the author was not Camm but Colonel Bland, and describes the work as "Richard Bland's sardonic rejoinder to John Camm's 'Observations on Colonel Bland's Letter to the Reverend John Camm',... published in Virginia Gazette October 28, 1763." In the only known copy (Library of Congress) the lower half of the title page has been torn away. Clayton-Torrence attributes it, in square brackets, to the Williamsburg press, and the internal evidence of the book sustains the attribution. In attributing it to the Maryland press, Mr. Griffin probably had in mind Camm's "Single and Distinct View" described above. 


\section{A History of Printing in Colonial Karyland}

For a brief note on the Rev John Camm (171 8-1 779) containing essential details, see The William and Mary College Quarterly 4: 61. See also Bishop Meade's Old Churches, Ministers and Families of Virginia, 1: 21 6-226.

An analogous controversy was carried on in Maryland a generation earlier when the Rev. Jacob Henderson fought for the privileges of the Church of England establishment in that Province. See No. 6I and note to No. 3II.

MDioc. NYHS.

244. Great Britain. By the King,| A Proclamation,| Declaring the cessation of Arms, as well by | Sea as Land, agreed upon between His Majesty, the Most Christian King, and the Catholic King,| and enjoining the Observance thereof.| George R.| Whereas Preliminaries, for restoring Peace, were signed at Fontainebleau | . . . [Colophon:] London: Printed by Mark Baskett, Printer to the King's most ex-| cellent Majesty; and by the Assigns of Robert Baskett. 1762.| Annapolis:| Re-printed by Jonas Green, Printer to the Province of Maryland. 1763.1

Broadside. $10^{\frac{3}{4}} \times 5^{\frac{3}{4}}$ inches.

See concluding paragraph of note to No. 2I.

245. Maryland, Province of. [Baltimore arms] By His Excellency | Horatio Sharpe, Esq; Governor and Commander in Chief in and over the | Province of Maryland:| A Proclamation.| Whereas His Majesty's Royal Commands, have been signi-| fied to me by the Right Honourable the Earl of Egremont | . . Given at the City of Annapolis, this eleventh Day / of February, in the Twelfth Year of his Lordship's Do-| minion, and in the Third Year of his Majesty's Reign,| Annoque Domini 1763.| Signed per Order . . . [ [Annapolis: Printed by Jonas Green. I 763.]

Broadside. $9^{\frac{3}{4}} \times 5^{\frac{3}{4}}$ inches.

See concluding paragraph of note to No. 21 .

246. The | Maryland | Almanack,| for the Year of our Lord,| 1764, | Being | Bissextile or Leap-Year.| And from the Creation of the World, according to the $\mid$ best of Profane History, 5713 | But by the East and Greek Christians, 7272 | By the Jews, Hebrews, and Rabbins, $5524 \mid$ And by the Account of Holy Scriptures, 5773 | Since the Discovery of America, 272 Wherein is contained | [etc. etc. exactly as in The Maryland Almanack for 1762.] Annapolis:| Printed and Sold by Jonas Green.| [ $\left.{ }_{17} 6_{3}\right]$. Price Eight Coppers, single.|

12 mo. $\mathrm{A}^{4}, \mathrm{~B}^{2}, \mathrm{C}^{4}$, apparently; actually is $\mathrm{A}-\mathrm{B}^{4}, \mathrm{C}^{2}$; 10 leaves; pages unnumbered.

Leaf measures: $6 \frac{9}{16} \times 4 \frac{1}{8}$ inches. Type page, p. [2], including borders: $150 \times 82 \mathrm{~mm}$.

Not advertised for sale in Maryland Gazetie until Jan. 5, 1764. See note to this title under 1761 for explana$t$ on of collation.

MdHS.

247. The Maryland Gazette.| (January 6-Dec. 29, 1763, Nos. 922-973; beginning with April 21st, change in heading from XVIIIth to XIXth Year.) [Colophon, as in Nos. 911919 in 1762 , except Nos. 924 and 973 which are as in Nos. 920 and $921,1762$.

$13^{\frac{3}{6}} \times 9$ inches; three columns; two leaves each number except Nos. 924 and 973 which have one each.

No. 968 wrongly numbered 969 . Nos. 941 and 953 have each a "Supplement" of one leaf; No. 949 has a "Postscript" of one leaf.

For title arrangement see Plate $\mathrm{X}_{\mathbf{a}}$.

MdHS. (two complete copies in one of which No. 973 is imperfect.) MDSL. (complete.)

$$
1764
$$

248. An Answer to the Queries on the Proprietary Government of Maryland, inserted in the Public Ledger. Also, an Answer to the Remarks upon a Message sent by the Upper to 


\section{Saryland Imprints of the Colonial Period, $1689-1776$}

the Lower House of Assembly of Maryland, i762. . . . By a Friend to Maryland. Printed in the Year 1764 .

8vo. pp. (2), 160.

Evans, No. 9582, prefixes Annapolis, in square brackets, to the title as given above in short entry, but there are reasons for questioning this attribution. Its typographical features are not those of Green's work, and its author, if one may assume his opening sentences to have been written without attempt at deception, was resident in England at the time of its composition. He writes as follows: "The Pamphlet you were pleased to send me some time ago, entituled, 'Remarks upon a Message sent by the Upper to the Lower House of Assembly of Maryland, 1762 , by a friend to Maryland', I have not only perused with attention, but by my avocation lately from London to the country, have had leisure and time enough to draw up the following remarks upon it. The Letter you refer me to, printed in the Public Ledger here, November 17 th, I $76_{3}$, I have also read..."

There exists further negative evidence that the work was printed elsewhere than in Maryland. From the first appearance of the "Queries" in the Public Ledger, throughout the discussion which arose when the "Remarks upon a Message" (see below) was published, Governor Sharpe had been opposed to having anyone "enter the Lists \& combat about it with an Anonymous Scribler who being unknown may throw Dirt in the Dark without any Risk of losing his Reputation." (See Archives of Maryland, $14: 150$ and 159 .) Then writing on 10 July 1765 , obviously some months after the publication of "An Answer to the Queries" in 1764, Sharpe implied that nothing had been published in reply to the "Remarks upon a Message" in Maryland, and he is surprised that Secretary Calvert is still harping on it. He writes, (Archives of Maryland, 14: 201) "From the Pamphlets being taken no Notice of here by the Upper House or any one on their behalf It soon fell in to Oblivion, nor did the Author think it would be for his honour or Reputation to acknowledge his Offspring (for he is not yet known;) \& in my Opinion the Publishing an Answer to it here would answer no other end but to revive useless Disputes $\&$ to furnish some Lover of Mischief among us with an Occasion \& Pretence for throwing Dirt on those who are concerned in the Government or who might be suspected of writing such answer,..." These words were written after the "Answer" had been published, but Sharpe seems not yet to have learned of its appearance, although his last letter from Calvert had been April 2, 1765. If the work had been of American publication, he would surely have known of it when writing his letter of July 10, 1765. At one time, however, the Governor seems to have been considering the advisability of sending a champion into the lists against the 'anonymous dirt thrower', for six months after his first contemptuous reference to the publication, Daniel Dulany, Jr. wrote to Lord Baltimore:

"It was said that an Answer was preparing to the Remarks with the Assistance of Mr. Bacon. He is an ingenious Man, \& well acquainted with the springs of our political Disputes,..." (Calvert Papers, No. 1288, Sept. Io, 1764 ). Sharpe's disclaimer of July 10, 1765 , quoted above, and his refusal to employ Bacon on a similar task in 1760 (See foregoing narrative, Chapter Eight) seem sufficient evidence that this intention was not carried out to the point of publishing a reply. In the Maryland Historical Society Portfolios there is a draft of an "Answer" in Ms. which indicates that some person, an official probably, had made an attempt at preparing a reply to the animadversions in the Public Ledger article.

The work referred to here in reply to which the "Answer" had been in part composed, was entitled:

"Remarks upon a Message, sent by the Upper to the Lower House of Assembly of Maryland. 1762. . . By a Friend to Maryland. Printed in the year MDCcLxiv."

There are reasons for believing that this work was printed by Franklin \& Hall of Philadelphia, and that Franklin himself had something to do with its authorship. A letter in the Calvert Papers, No. 1288, from Daniel Dulany, Jr. to Lord Baltimore, dated Sept. 10, 1764, makes the following statement in regard to the pamphlet: "From whose Quiver this shaft came, is not at present known. Something of the kind was long expected, \&, I suspect was sent, when I was in England, to Mr. Anderson under a direction to Mr. Franklin, who, I believe, from many Circumstances hath been concerned in the Composition-the Diction or Style of it is very much like his-it was printed at his Press. [Italics not in original]. In a late Publication, wch He is known to be the Author of, there appears a great Resemblance of The Remarks."

Some months before this on May 8, 1764, Gov. Sharpe (Archives of Maryland, 14: 160) had written to Secretary Calvert, asserting that most people were of the belief that the "Remarks" had been written by Mr. James Tilghman, formerly a burgess from Talbot County, Md. but at that time a resident of Philadelphia. Sharpe further intimated that Daniel Dulany, Jr. had lent a hand to the revision of the pamphlet, but a perusal of the whole of the Dulany letter above mentioned convinces one that this suggestion on the part of the Governor had its origin in the state of dislike which existed between these two. The question of the authorship of this pamphlet and the reply to it present an interesting literary problem. The Dulany letter here cited should be read in connection with letters from Secretary Calvert to Sharpe, (Archives of Maryland, 31: 540.); Sharpe to Calvert (Archives of Maryland, 14: 149, 150, 157-160, 201.)

[221] 


\section{A History of Printing in Colonial STaryland}

Copies of the "Answer to the Queries" are to be found in LC. and in JCB. Copies of the "Remarks" in MDioc. MdHS. HSP.

249. Maryland, Province of. Acts | of | Assembly, of the | Province of Maryland,| made and passed | at a Session of Assembly, begun and held at the City of (Annapolis), | on Tuesday the Fourth Day of October, in the Thirteenth (Year of) the | Dominion of the Right Honourable Frederick, (Lord Baron) of | Baltimore, Absolute Lord and Proprietary of the Provin(ces of Mar)yland | and Avalon, \&c. Annoque Domini 1763.| (Published by Authority) [Baltimore arms] Annapolis:| Printed by Jonas Green, Printer to the Province.| [1 764.]

"Fol. I preliminary leaf, A-S2; 37 leaves; pages unnumbered; preliminary leaf: title,-verso blank; $\mathrm{A}_{1}$ recto$S_{2}$ recto: text, with session heading and running heads; $S_{2}$ recto and verso: contents; $S_{2}$ verso: "Advertisement" of the forthcoming Bacon's Laws of Maryland. (See No. 254).

Leaf measures: $13^{\frac{8}{8}} \times 9^{\frac{1}{4}}$ inches. Type page, p. A2 recto: $269 \times 148 \mathrm{~mm}$.

Imperfections in the MDioc. title-page are indicated in the above transcript by round brackets. The MdHS. copy is the official copy sent to Lord Baltimore, each act printed separately, signed and sealed; in brief, the Acts of the session and not a book containing the acts. Hence no title-page.

MDioc. MDHS. (Calvert Papers).

250. Maryland, Province of. I 3 Frederick Lord Baltimore.| At a Session of Assembly, begun and held at the / City of Annapolis, on Tuesday the Fourth Day of | October, in the Thirteenth Year of the Dominion of | the Right Honourable Frederick, Lord Baron of | Baltimore, Absolute Lord and Proprietary of the | Provinces of Maryland and Avalon, \&c. Annoque | Domini 1763 , and ended the 26 th November, the | following Laws were Enacted. | Horatio Sharpe, Esq; Governor.| Chap. I.| An Act for amending the Staple of Tobacco, for preventing | Frauds in his Majesty's Customs, and for the Limitation of Of-| ficers Fees.| [Colophon:] Annapolis:| Printed and Sold by Jonas Green, Printer to the Province.| [I $\left.176_{4}\right]$.

${ }^{*}$ Fol. $\mathrm{A}-\mathrm{M}^{2}, \mathrm{~N}^{1}$; 25 leaves; pages unnumbered; $\mathrm{A}_{1}$ recto- $\mathrm{N}_{1}$ verso: text, with heading as above; $\mathrm{N}_{1}$ verso: colophon.

Leaf measures: $13 \frac{\frac{1}{8}}{8} \times 8 \frac{1}{2}$ inches. Type page, p. A1 verso: $275 \times 148 \mathrm{~mm}$.

The above is a separate issue, with colophon, of Chapter I of the Acts of October 1763 .

MdHS.

25I. - Votes and Proceedings | of the | Lower House of Assembly | of the | Province of Maryland.| October Session, 1763 , | being the second Session of this Assembly.| (4 October26 November, I763.) [Colophon:] Annapolis: Printed by Jonas Green, Printer to the Province.| MDCCLXIV.|

Sm. fol. P-Z2 $\mathrm{Z}^{2}$ Aa-Ii ${ }^{2}$; 36 leaves; Pp. [57]-1 27, [1 28]: text, with head-piece, heading as above, session heading of six lines and running heads.

Leaf measures: $11 \frac{11}{16} \times 7 \frac{1}{2}$ inches. Type page, p. $58: 241 \times 145 \mathrm{~mm}$.

Continues the pagination and signature sequence of the V. \& P. for March Session, 1762 .

MdHS. MDioc. MDSL. Pleasants (lacks pp. 57-68.)

252. The | Maryland | Almanack, for the Year of our Lord, $|1765$,$| Being the First after |$ Bissextile or Leap-Year.| And from the Creation of the World, according to the / best of Profane History, 5714 | But by the East and Greek Christians, 7273 | By the Jews, Hebrews, and Rabbins, 5525 | And by the Account of Holy Scriptures, 5774 | Since the Discovery of America, 273 | Wherein is contained | [etc. etc., exactly as in 1762 , except that in last paragraph before imprint, "from" is misprinted "fron", and "Colonies", "Colones", and in next to last paragraph, "Virginia" is followed by a colon instead of a semi-colon.] Annapolis:| Printed and Sold by Jonas Green.| [1 764.] Price Eight Coppers, single.] 


\section{Saryland Imprints of the Colonial Period, $1689-1776$}

8vo. $A^{4}, B^{2}, C^{4}$, apparently; actually is $A-B^{4}, C^{2}$; ro leaves, pages unnumbered.

Leaf measures: $7 \frac{3}{\frac{3}{3}} \times 5^{\frac{1}{2}}$ inches. Type page, p. [2], including borders: $152 \times 80 \mathrm{~mm}$.

For explanation of collation, see note to this title under $176 \mathrm{r}$.

LC.

253. The Maryland Gazette.| (Jan. 5-Dec. 27, 1764, Nos. 974-1025; beginning with April 19th, change in heading from XIXth to XXth Year.) [Colophon, as in Nos. 911-9r9 in 1762 , except No. 1025, which is as in 920 and 921, 1762.]

$14 \times 9 \frac{1}{3}$ inches; three columns; two leaves each number except No. 1025, which has one leaf.

Nos. 991, 994, 1001, 1003, 1007, and roro have "Supplement" of one leaf each.

For title arrangment, see Plate Xa.

MdHS. (one copy complete except that it lacks "Supplement" to 1001, and another copy which lacks this "Supplement" as well as No. ro25 and second leaf of No. 1024.) MDSL. (complete.)

\section{5}

254. Bacon, Thomas. Laws | of | Maryland | at Large,| with proper | Indexes.| Now first Collected into One Compleat Body, and Published from the |Original Acts and Records, remaining in the Secretary's-| Office of the said | Province.| Together with Notes and other Matters, relative to the Con-| stitution thereof, extracted from the Provincial Records.| To which is prefixed, The | Charter,| With an English Translation.| By Thomas Bacon, Rector of All-Saints Parish in | Frederick County, and Domestic Chaplain in Maryland to | the Right Honourable Frederick Lord Baltimore.| [Provincial Arms, Signed, T. Sparrow, sculp.] Annapolis:| Printed by Jonas Green, Printer to the Province.| MDcclxv.|

Fol. [a]- $\mathrm{f}^{2}, \mathrm{~g}^{1}, \mathrm{~A}-\mathrm{Z}^{4}, \mathrm{Aa}-\mathrm{Zz}^{4}, \mathrm{Aaa}-\mathrm{ZzZ} \mathrm{z}^{4}, \mathrm{Aaaa}-\mathrm{Hhhh}^{4}, \mathrm{Iiii}^{2}, \mathrm{~A}-\mathrm{Y}^{2}, \mathrm{z}^{1} ; 368$ leaves; pages unnumbered; [al] recto: title; [a2 recto]: dedication, "To the Right Honourable Frederick, ... Lord Baron of Baltimore, \&c. ... [signed] Thomas Bacon"; b1 recto-[ $b_{2}$ verso]: "Preface", with list of subscribers at end; [c1 recto]: half-title, The | Charter | of the | Province | of | Maryland.|; [c1 verso]-g1 recto: text of Charter, Latin on each verso, English translation on each recto; $A_{1}$ recto-[Iiii氵 ] verso: text of laws, $1637-1763$, each session with session heading, running heads; A1 recto-U1 recto: "Index: or, an Alphabetical Abridgment of the Laws of Maryland: With References to the Acts at Large, as contained in the foregoing Collection"; [u2 recto]-[Y2 verso]: "Index to Private, Parochial, and Town Laws"; [z1 recto]: "Advertisement", consisting of one page of errata.

Leaf measures: $15^{\frac{3}{4}} \times 9 \frac{3}{\frac{3}{6}}$ inches. Leaf measures, large paper edition: $16 \frac{1}{6} \times 10 \frac{1}{4}$ inches. Type page, $\mathrm{d}$ I recto: $272 \times 148 \mathrm{~mm}$.

For full history of this work, see Chapter Eight in foregoing narrative. For photographic reproduction of the title-page, see Plate IX. Although the printing was completed in 1765 , it was not published probably until Aug. 1766. Announcement that purchases were now to be made through Mr. Lancelot Jacques was published in Maryland Gazette for Aug. 21, 1766.

MDHS. MDSL. MDioc. PI. LC. HSP. NYPL. NYHS. NYBA. and in many public and private libraries.

255. [Dulany, Daniel, Jr.] Considerations / on the /Propriety / of imposing/Taxes / in the | British Colonies,| for the Purpose of raising a Revenue, by | Act of Parliament.| - Haud Totum Verba resignent | Quod latet arcanâ, non enarrabile, fibrâ.| North=America: Printed by a North=American.| MDcclxv.| [Annapolis: Printed by Jonas Green. I765.]

Sm. 4to. [A]-G"; 28 leaves; pages [r]-55, [56]; p. [r]: title; pp. 3-4: "Preface", with head-piece, and "Virginia, August 12, 1765", at end; pp. 5-48: text, with head-piece and heading, "Considerations \&c."; pp. 49-55: "Appendix", with head-piece; p. 55: "The End".

Leaf measures: $7 \frac{7}{8} \times 6 \frac{1}{16}$ inches. Type page, p. 6: $147 \times 112 \mathrm{~mm}$.

For photographic reproduction of title-page, see Plate VI.

In the Maryland Gazette for Thursday, Oct. 10, 1765, Jonas Green announced that a pamphlet bearing this title would be published, and gave at the same time a description of the forthcoming publication which aids considerably in identifying the copy above described as being one of the edition which he advertised in these words, the earliest known reference to Dulany's celebra ted work: "Next Monday, will be Sold, at this Printing-Office, a 


\section{A History of Printing in Colonial SCaryland}

pamphlet (of Seven sheets Quarto, in Small-Pica,) entitled, Considerations on the Propriety of Imposing Taxes in the British Colonies, for the Purpose of raising a Revenue, by Act of Parliament. Haud Totum Verba resignent Quod latet arcana, non enarrabile, fibra. Printed by a North-American, 1765. [Price Two Shillings and Sixpence.]"

On Oct. 17th and 24th he advertised this same pamphlet as "To be Sold, at this Printing Office." Five days after the advertised date of publication, on Oct. 19, 1765, Gov. Sharpe wrote to Secretary Calvert (Archives of Maryland, $\mathrm{x}_{4}: 233$ ): “... I shall not fail writing as often as Opportunities offer, tho I should have nothing worthy notice to communicate, which would be the Case at present if the Pamphlet \& Paper that I inclose for his Ldp's \& your perusal had not lately made their Appearance. ... As to the Pamphlet it is said to have been printed in Maryland, but the Author it seems chooses to remain unknown. It would be unnecessary to tell you that whatever Opinion might be Entertained of it in England it meets with general Approbation here \& you may from its Contents form a true Judgment of the Sentiments of the People throughout this \& the Neighboring Tobacco Colony."

Again, on Nov. 11 , 1765, writing to Baltimore (Ibid. p. 238) Gov. Sharpe said: "That your Ldp. might see what the Colonies have to offer against the Stamp Act \& particularly those who reside in Virginia \& Maryland I lately transmitted in a Letter to Mr. Calvert a Pamphlet which had been published here \& is I think by far the best that has appeared in favour of the Colonists Pretensions."

Secretary Hamersly to Sharpe, Feb. 20, 1766 , describing the Stamp Act debate in the House of Lords, ( $A r$ chives of Maryland, I 4: 267) wrote: "he [Lord Camden] Laboured a distinction in the case of Internal Taxation upon the Doctrine Laid down in that able performance you transmitted wch has since found its way to the Press with the name of Mr. Dulany Prefixed."

For an exhaustive description and discussion of the Dulany pamphlet in all except its bibliographical aspects, see Tyler, M. C. The Literary History of the American Revolution, 1763-1783, 2 v. N. Y. I897, I: 101-1 I 3, wherein the author, in speaking of the effect of the "Considerations" at home and abroad, says: "On the fourteenth of October, I765, while the members of the Stamp Act Congress were in the midst of their labors upon the great problem of the hour, there came from a printing office in Annapolis, a pamphlet ... dealing with the same problem, and doing so with a degree of legal learning, of acumen, and of literary power, which gave to it, both in America and in England, the highest celebrity among the political writings of this period. It was entitled "Considerations, etc.' ... on the fourteenth of January, 1766, just three months after the publication of Dulany's pamphlet, Pitt appeared in the House of Commons . . . and spoke with tremendous power in favor both of an immediate repeal of the Stamp Act, and of the final abandonment of all measures looking towards the taxation of the colonies by Parliament. In one of the speeches which he made in the course of that debate, he held up Dulany's pamphlet to the approval and the admiration of the imperial legislature; and though but a meagre outline of his speech is now in existence, even from such outline it is made clear that in all but one of the great features of his argument as to the constitutional relations of Great Britain to her colonies, he followed the very line of reasoning set forth by Daniel Dulany, an old Eton boy like himself." In a note Professor Tyler gives parallel passages from Pitt's speech and Dulany's pamphlet.

The following passage occurs in a letter from the Earl of Shelburne to Pitt dated Feb. 6, 1767 (see Taylor and Pringle's Correspondence of William Pilt, Earl of Chatham, 4 v. Lond. I839, 3: 192): "But all that I have to say on this head [i.e. "The New York Petition"] is so much better expressed in a letter from Mr. Delaney, the author of the American pamphlet to which your Lordship did so much honour last session, than in any words of my own, that I beg to refer you to that, and enclose it with the other papers, with that view."

MDioc. JCB.

In the Maryland Gazette for Oct. 3I, I765, is printed a letter, the writer of which orders a dozen copies of the "Considerations." The publisher, Jonas Green, adds this note: "The first impression of, Considerations on the Propriety of imposing Taxes on the British Colonies, for the Purpose of Raising a Revenue, by Act of Parliament, being nearly all Sold, a Second is now in the Press, and will be published in a few Days." This announcement must refer to the following title:

256. [Dulany, Danzel, JR.] Considerations / on the /Propriety / of imposing / Taxes / in the | British Colonies,| for the Purpose of raising a Revenue, by | Act of Parliament.|-Haud Totum Verba resignent | Quod latet arcanâ, non enarrabile, fibrâ.| The Second Edition.| Annapolis: Printed and Sold by Jonas Green. 1765 | [Price Two Shillings and Sixpence.]|

The collation of the Second Edition here entered is the same as that of the anonymously published edition noted above, with the exception that the title-page has been reset, the ornamental initial of the Preface has been changed and the head-piece and ornamental initial of page 5 have been changed. The similarity of these two 


\section{Saryland Imprints of the Colonial Period, $1680-1776$}

editions "of Seven sheets Quarto, in Small-Pica", and the circumstances attending their announcement and publication are such that there can be no reasonable doubt that as Jonas Green was the confessed publisher of the second, so was he the pseudonymous "North-American" who printed the first.

NYPL. HSP. LC. BA.

There are two other editions of Daniel Dulany's "Considerations" which give as their place of publication simply "North America", and each of these at various times has been confused with the first edition described above. The most common of these is as follows:

257. [Dulany, Daniel, Jr.] Considerations / on the | Propriety | of imposing | Taxes | in the | British Colonies,| For the Purpose of raising a Revenue, by Act of Parliament | [Between single rules the following Latin couplet and its translation:] Haud totum verba resignent |Quod latet arcanà non enarrabile, fibrà.| (Let not my words shew all;| The hidden mischief cannot be express'd.) | North America:|

8vo. [A]-F4; 24 leaves; pages [I-II], [i]-ii, [5]-47, [48]; pp. [I]: title; pp. [i]-ii: The / Preface./ with head-piece and at end the one word "Virginia" without date; Pp. [5]-4I: text with head-piece and heading: Considerations, \&c.|; pp. 42-47: Appendix.|; p. 47: "Finis"; p. [48]: blank but in most copies has a slip pasted on it commending the book.

Leaf measures: $8 \frac{1}{8} \times 5$ inches. Type page, p. 6: $175 \times 91 \mathrm{~mm}$.

The printer and place of publication of this edition are unknown. It is the least rare of all the secretly printed editions of the pamphlet, and it has been assumed to be the first edition by persons who must have been ignorant of the existence of the small quarto edition ascribed above to the Annapolis press of Jonas Green. Good internal evidence that this was one of the later editions, however, is found in the circumstance that throughout wherever a Latin sentence or phrase is quoted, as on the title-page, it has been rendered into English. The punctuation too is more profuse than in the Green editions. In general, of course, a copy containing additions to the text not in another copy is presumably of later date and has been edited. One makes a suggestion as to printer and place of publication of this edition with some hesitation, but such a suggestion may help to a solution. In the Pennsylvania Gazette for Dec. 5 and 12, 1765, appeared advertisements of an edition of the "Considerations" for sale by the printers in which the Latin couplet of the title was translated exactly as on the title-page given above. This of course is not conclusive evidence that Franklin and Hall were the printers of this Edition, as they may simply have been advertising the edition of another printer. Apparently not knowing of this advertisement, Hildeburn leaves the question of a Philadelphia edition open, and in his Collection of Franklin Imprints in the Museum of the Curtis Publishing Company. Phila. 1918, William J. Campbell follows Hildeburn.

Most copies of this edition seen by the compiler have a printed slip pasted on the blank page [48] which has been identified by the Library of Congress as "containing extracts from the Newport Mercury of Feb. 17 and March 3, I 766, relating to this pamphlet." (See printed Library of Congress card, 7-1 8396 Revised.)

A possible clue to identification which the compiler has not been able to follow to his satisfaction is typographical in its character, and is to be found in the peculiar form of the lower case " $b$ ", which has a flat serif extending entirely across the ascending stroke. This unusual letter is used throughout the pamphlet.

EPFL. LC. HSP. BA.

A second unidentified "North America" edition is described as follows:

258. [Dulany, Daniel, Jr.] Considerations $\mid$ on the $\mid$ Propriety $\mid$ of imposing $\mid$ Taxes $\mid$ in the | British Colonies,|For the Purpose of raising a Revenue, by Act of Parliament.|-Haud Totum Verba resignent | Quod latet arcanâ, non enarrabile, fibrâ.| North=America: Printed by a North=American.| MDCcLxv.|

8 vo. [A]-L ${ }^{4}, \mathbf{M}^{1}$; 45 leaves; pages [I]-9o; p. [I]: title,-verso blank; pp. 3-5: "Preface", with head-piece, and "Virginia, August I 2, I 765 " at end; p. 6: blank; pp. 7-78: text, with head-piece and heading, "Considerations, \&c."; pp. 79-90: "Appendix.", with head-piece; p. 90: "The End"; tail-piece; remaining leaves cut away by original binder.

The compiler knows of only one copy of this edition; namely, that which was purchased by a descendant of the Dulany family, Mrs. W. Howard White, of Baltimore, at the sale of the late Dr. Ridgely B. Warfield's library, Baltimore 1920. This edition also bears internal evidence of being a later edition than that which has been described here as the first, inasmuch as on page 32 , appended to the note which begins "It is asserted in the pamphlet, entitled, The Claim of the Colonies, \&c.", there is an "N. B." in which an unknown editor comments at 


\section{$A$ History of Printing in Colonial Karyländ}

some length on a feature of the case as regards Maryland which had been left unnoticed by "the Excellent author of this pamphlet." (Italics not in original.)

In addition to the four editions described above there exist also the New York edition of 1765 (Evans, No. 9958), the Boston edition of [1765] (Evans, No. 9959), and the two London editions of 1766 , printed by J. Almon, the second of which was in a collection of pamphlets, and in the general table of contents was ascribed to "Mr. Dulaney of Maryland." The Maryland Historical Magazine, 6: 374-406 and 7: 26-59 reprinted the "Considerations," using the edition described in No. 257 under the impression that it was the first edition.

259. Great Britain. Anno Regni | Georgii III.| Regis | Magnae Britanniae, Franciae \& Hiberniae,| Quinto.| At the Parliament begun and holden at Westminster, the Nine-l teenth Day of May, Anno Dom. I76I, in the First Year of | the Reign of Our Sovereign Lord George the Third,| by the Grace of God, of Great Britain, France, and Ireland,| King, Defender of the Faith, \&c.l and from thence continued by several Prorogations to the Tenth Day of | January, I765, being the Fourth Session of the Twelfth Parliament of | Great Britain.| London:| Printed by Mark Baskett, Printer to the King's Most Excellent Majesty;| and by the Assigns of Robert Baskett, I 765.| Maryland:| Re-printed by Jonas Green, Printer to the Province;| and to be Sold at his Printing-Ofeice, [sic] in Annapolis.| [1765.]

Fol. I preliminary leaf, A-D²; 9 leaves; pages [i-ii], [1]-15, [16]; p. [i]: title; pp. [I]-15: text, with heading, "Anno Quinto Georgii III. Regis".

Leaf measures: $12 \frac{1}{2} \times 7 \frac{5}{8}$ inches. Type page, p. 2: $246 \times 121 \mathrm{~mm}$.

Aug. I, 1765, in the Maryland Gazette, Green announces that he has "Just Reprinted The.....Stamp Act ....", and further advertises them as to be had at his own office or of Mr. John Clapham at Oxford.

MDioc. MdHS.

260. The Maryland Gazette.| (Jan. 3-Oct. I0, 1765, Nos. I026-1066 and supplements; XXih-XXIst year.) [Colophon, Nos. 1026-1066 as in 9II-9I9 of I762; exceptions noted below.] 1762 .

$14 \times 9$ inches; 2 leaves each number except No. 1029 which has one leaf, and colophon as in 920 and 921 of

Nos. I04I, 1052, 1056, 1064, I065 have "Supplement" of one leaf each. No. I066, Oct. Ioth, has the following title: uncertain

The Maryland Gazette,| Expiring:| In $\wedge$ Hopes of a Resurrection to Life again.| page.

Bore a skull and cross bones surmounted by legend "The fatal Stamp" in lower right hand corner of first

No. 1066 had also the following "Supplements":

\section{(Ist Supplement)}

A Supplement to the | Maryland Gazette, of last Week.| Annapolis, October 17, 1765.| [Colophon:] Annapolis: Printed by Jor as Green, at his Printing-Office in Charles-Street.|

I $3^{\frac{7}{8}} \times 9$ inches; 2 leaves; 3 columns; date line and colophon enclosed in heavy black rules.

(2d Supplement.)

Second Supplement to the Maryland | Gazette, of the Week before last.| Annapolis, October 24, I765.| [Colophon as in ist "Supplement"].

I $3 \frac{7}{8} \times 9$ inches; 2 leaves; 3 columns.

(3d Supplement.)

Third and Last Supplement | to the ( Maryland Gazette, of the Tenth Instant.|Annapolis, October 31, 1765.| [Colophon as in Ist "Supplement"].

$13 \frac{7}{8} \times 9$ inches; one leaf; 3 columns; heavy black rules throughout.

On [Dec. 10, 1765] appeared this issue: late

An Apparition | of | the $\wedge$ Maryland Gazette, | which is not Dead, but only Sleepeth.| [Colophon:] Annapolis: Printed by Jonas Green by whom Subscriptions are taken in at $12 / 6$ per Year.| 


\section{SCaryland Imprints of the Colonial Period, 1689-1776}

$13 \frac{3}{4} \times 8 \frac{3}{4}$ inches; 2 leaves; 3 columns.

For additional information as to this crisis in the life of the Maryland Gazette, see Isaiah Thomas, Evans, Brigham, Chapter Seven of the foregoing narrative, and Scharf, J. T. History of Maryland, I: 541.

MDSL. LC. (incomplete). For location of scattered issues, see Brigham, American Newspapers.

262. Redick, John. A | Detection | of the / Conduct and Proceedings of | Messrs. Annan and Henderson, Mem-| bers of the Associate Presbytary's | whole Sitting at Oxford Meeting-| House April the 18 th. Anno Domini $1766_{4}$. Together with their Abet-|tors; wherein is contained some | Remarks.| By John Redick-Le-Man.| [Two lines from Prov. 25:18. Five lines from Eccles. 8:14.] Baltimore-Town:| (Pri)nted by N. Hasselbac(h.) [1765.]

Sm. 8vo. [A]-F4; 24 leaves; pages [1-4], 5-46, [47-48]; p. [r]: title; pp. [3-4]: The | Preface.|, dated at end, "Tom's-Creek, February 12. 1765 ", tail-piece; pp. 5-46: text with head and tail-pieces, ornamental initial; p. 46: "Finis"; pp. [47-48]: "Erratta" [sic].

Leaf measures: $6 \frac{1}{16} \times 4$ inches. Type page, p. $6: 138 \times 88 \mathrm{~mm}$.

Unique copy now in possession of Robert Garrett, Esq., of Baltimore. Reprinted in The First Book Printed in Baltimore Town, Nicholas Hasselbach, Printer. By George W. McCreary, Baltimore 1903. See a further discussion of this book and its printer in Chapter Nine of the foregoing narrative.

$$
\text { I } 766
$$

263. Chase, Samuel. July I8th, I766.| To the Publick.| I waited upon Mr. Jonas Green the Printer of this Province, with the following Vindication of myself, from the Aspersions of Messrs. Walter|Dulany, M. Macnemara, Geo. Steuart, John Brice and U. Scot; published against me in the Maryland Gazette Extraordinary of June Igth I766,| but he refused to give it a Place in his Paper; . . . [Baltimore: Printed by N. Hasselbach. 1 766.]?

Broadside. Size uncertain. Only known copy cut in pieces and pasted in vol. 1766-67 of the Maryland Gazette in MDSL. Is in columns and crudely printed.

Refers to quarrel about local Annapolis affairs and is signed "Samuel Chase", Annapolis, July 16, 1766. Underneath in long hand is statement "This was not printed by J. Green," probably in the hand-writing of one of Green's family, as this volume was part of the office file of the Maryland Gazette. If not printed by Green, then it is likely to have come from a Baltimore or Philadelphia press. It is subscribed July 16, 1766 and dated at the head July 18, 1766. If the first date be that of its writing (see Maryland Gazette for July 17, 1766, in which under date of July 16,1766 , Chase announces that he will soon have his hand-bills ready), and the second date be that of its publication, there would hardly have been time for the Ms. to have been sent to Philadelphia and put into type. Hasselbach was, it is believed, operating a press in Baltimore at this time. Evans, No. 10253, suggests William Rind of Williamsburg as the printer, but the conflict between time and distance is even more difficult to reconcile in the case of Williamsburg than of Philadelphia.

MDSL.

264. County, ss. March 1766. Whereas the shutting up all the Public Offices of this Province, since the first day of November last, is an Obstruction to Justice, injurious to | . . . [Annapolis: Printed by Jonas Green. 1766.]

Broadside. $4 \frac{7}{\frac{7}{8}} \times 13^{\frac{6}{8}}$ inches.

Calls on the principal gentlemen of each county to repair to Annapolis to compel the officials to open their offices and proceed to conduct their business without stamped paper.

NYHS.

265. [Dulany, Daniel, Jr.] The | Right | to the | Tonnage,| the Duty of | Twelve Pence per Hogshead on all exported Tobacco, | and the | Fines and Forfeitures | in the | Province of Maryland, Stated;| In a Letter from a Gentleman in Annapolis | to his Friend in the Country.| [Type Device] Annapolis:| Printed and Sold by Jonas Green. MDcclxvi.|

Fol. [A]-K $\mathrm{K}^{2}$; 20 leaves; pages [1-3], 4-40; p. [r] : title; pp. [3]-40: text with head-piece and heading, same wording as title, and salutation "Dear Sir"; p. 40: at conclusion of text, "Yours, \&c." and "Annapolis, Dec. 30, 176 5", note and one line of errata. 


\section{A History of Printing in Colonial STaryland}

Leaf measures: $12 \frac{1}{6} \times 7 \frac{8}{8}$ inches. Type page, p. 4: $242 \times 144 \mathrm{~mm}$.

Advertised in Maryland Gazetse May I, 1766, as "just published." Dulany, champion of the colonists in his Stamp Act pamphlet, see 1765 , here takes the Proprietary's side in the contention between him and the Lower House of Maryland. Attacked bitterly by the "Patriot" party for this and other unpopular, but conscientious utterances, he was driven into a position of opposition to the popular cause, and his services lost to the Americans in the Revolution a few years later. The following reference to the pamphlet determines its authorship: Gov. Sharpe to Lord Baltimore, 15 May 1766, Archices of Maryland, 14: 304, writes: "In order to shew the unreasonableness of the Lower House in making such a Point \& to satisfy the minds of such as questioned your Ldp's Right Mr. Dulany \& Mr. Ridout after an end was put to the Session resolved to examine into \& communicate to the publick whatever Discoveries they could make relative to the Shilling pr. Hhd payable on Tobo exported, the Tonnage Duty \& Fines \& Forfeitures \& the same hath been since done in a Pamphlet that Mr. Dulany with my Approbation sent to the Press of which I shall now transmit your Ldp a Copy. Whether it will entirely answer the end of printing it I cannot yet tell as it was not published till about three Weeks ago ...."

MDSL. LC. MDioc. MdHS.

266. Maryland, Province of. Council Proceedings,| from Ioth of May 1756, to the 12th Nov. 1764.| [Colophon:] Annapolis: Printed by Jonas Green, Printer to the Province. 1766.1

Sm. fol. a-b ${ }^{2} ;$ leaves; pages $[\mathrm{r}], 2-6,[7],[8] ; \mathrm{pp}$. [1]-6: text, with heading as above; p. [7]: text, with second heading, Council Proceedings,| From I 5 th December 1764, to 3 1st October 1765.|; p. [8]: text, with heading, The Public Debtor to the Clerk of the Council.|, colophon.

Leaf measures: $11 \frac{13}{16} \times 7 \frac{3}{6}$ inches. Type page, p. $2: 228 \times 145 \mathrm{~mm}$.

On May 14, 1766, Green was brought to the bar of the Lower House and there admonished for his failure to print the above financial statement of the Clerk of the Council with the V. \& P. for Nov. 1765, and ordered to print them with the V. \& P. of the present session. Publication advertised in Maryland Gazeste for Sept. 11,1766 .

MdHS. LC.

267. - Laws | of | Maryland, | made and passed | at | Two Sessions of Assembly,| begun and held at the City of Annapolis, on Monday the 23d Day | of September: and | on Friday the First Day of November; in the Fifteenth Year of | the Dominion of the Right Honourable Frederick, Lord | Baron of Baltimore, Absolute Lord and Proprietary of the Pro-l vinces of Maryland and Avalon, \&c. Annoque Domini, I765.| Published by Authority.|[ [Provincial Arms] Annapolis:| Printed by Jonas Green, Printer to the Province.| [1766.]

Fol. I preliminary leaf, Kkkk-Tttt², Uuuu'; 22 leaves; pages unnumbered; preliminary leaf: title,-verso blank; Kkkk1 recto: text of single act of September session, with session heading; Kkkk 1 recto-Uuuu1 recto: text of acts of November session, with session heading, first act numbered "Chap. II", running heads; Uuuu1 verso: contents.

Leaf measures: $14 \frac{1}{2} \times 9 \frac{1}{2}$ inches. Type page, p. Kkkk1 verso: $270 \times 147 \mathrm{~mm}$.

Green continues here the signature sequence of Bacon's Laws of Maryland, published this year probably, though dated 1765. The cut of the Provincial Arms on this title-page, was not the one engraved for the Bacon by T. Sparrow and' used for several ensuing years on editions of session laws.

MDioc. MDSL. BBL. LC. NYPL.

268. - Laws | of | Maryland, | enacted | at a Session of Assembly, begun and held at the | City of Annapolis, on Friday the 9 th Day of May, in the I6th Year of the Dominion of the Right | Honourable Frederick, Absolute Lord and Pro-| prietary of the Provinces of Maryland and Avalon, | Lord Baron of Baltimore, \&c. and ended the 27th | Day of May, Anno Domini r 766.) Published by Authority.| [Provincial arms, T. Sparrow, sculp.] Annapolis:| Printed by Jonas Green, Printer to the Province.| MDcclxvi.|

Fol. 1 preliminary leaf, $\mathrm{Xxxx}-\mathrm{Zzzz}^{2}, \mathrm{Aaaaa}^{1}$; 8 leaves; pages unnumbered; preliminary leaf: title,-verso blank;

Xxxxi recto-Aaaaa recto: text, with session heading, running heads; Aaaaal verso: contents.

Leaf measures: ${ }^{1} 4 \frac{3}{8} \times 9^{\frac{3}{8}}$ inches. Type page, p. Xxxx/ verso: $274 \times 148 \mathrm{~mm}$.

Signature sequence in continuation of Acts of preceding session.

MDioc. MDSL. LC. NYPL. HLS. SLM. 
269. - Votes and Proceedings | of the | Lower House of Assembly | of the | Province of Maryland.| September Session, 1765.| Being the First Session of this Assembly.| (23 September-28 September, 1765.) [Colophon:] Annapolis: Printed by Jonas Green, Printer to the Province.| [ 1766$]$.

${ }^{*}$ Sm. fol. A-C ${ }^{2} ; 6$ leaves; pp. [1]-1 2: text, with head-piece, heading as above, session heading of seven lines and running heads.

Leaf measures: $11 \frac{3}{2} \times 7 \frac{3}{3}$ inches. Type page, p. 2: $237 \times 143 \mathrm{~mm}$.

MdHS. MDioc. MDSL. LC. NYPL.

270. - Votes and Proceedings | of the | Lower House of Assembly | of the | Province of Maryland.| November Session, 1765.| Being the Second Session of this Assembly.| (1 November-20 December, 1765). [Colophon:] Annapolis: Printed by Jonas Green, Printer to the Province.| [ 1766.$]$

*Sm. fol. Pagination and signatures continuous with V. \& P. of September session $1765 ;$ D-X ${ }^{2}, Y^{1}$; 37 leaves; pp. [I3]-86: text, with head-piece, heading as above, session heading of six lines and running heads. [Second title, coming after colophon, with separate pagination and signatures but without imprint:] Pursuant to an Order of the Honourable House | of Representatives, of the 7 th of December,| the following Bill, which was then brought | in to the House, and referred to the Con-| sideration of next Session of Assembly, is | here annexed, for the Perusal of the Inha-| habitants [sic] of this Province, viz.| An Act to enable the Proprietors of inspected Tobacco, to remove the same from the inspecting Houses, to | other Warehouses, convenient for the lading thereof $\mid$ on board Vessels for Exportation.| $a^{2}, b^{1}, 3$ leaves; Pp. [r]-6: text, with heading as above.

Leaf measures, $E_{1}: 11 \frac{5}{8} \times 7 \frac{14}{16}$ inches. Type page, p. 14:236 $\times 145 \mathrm{~mm}$.

MdHS. MDioc. MDSL. NYPL. LC. (lacks second title).

271. - Votes and Proceedings | of the | Lower House of Assembly | of the | Province of Maryland.| May Session, 1766.| Being the Third Session of this Assembly.| (9 May-27 May, 1766). [Colophon:] Annapolis: Printed by Jonas Green, Printer to the Province.| [1766.]

*Sm. fol. Pagination and signatures continuous with V. \& P. of November session 1765 , excluding second title attached to that edition; $\mathrm{Z}^{2}, \mathrm{Aa}_{-} \mathrm{Dd}^{2}$; 10 leaves; Pp. [87]-106: text, with head-piece, heading as above, session heading of seven lines and running heads.

Leaf measures: $11 \frac{1}{16} \times 7 \frac{5}{8}$ inches. Type page, p. 88: $236 \times 145 \mathrm{~mm}$.

MdHS. LC.

272. The Maryland Gazette,| Reviving.| (Jan. 30, 1766, Feb. 20, 1766-Dec. 26, 1766, [XXIst-XXIId Year.] Nos. I067-I I I I.) [Colophon:] Annapolis: Printed by Jonas Green, at his Printing-Office, in Charles-Street: where all | Persons may be supplied with this Gazette, at I2/6 a Year; and Advertisements of a moderate / Length are inserted for $5 \mathrm{~s}$. the First Week, and Is. each Time after: And long Ones in Proportion.|

$14 \times 9 \frac{1}{4}$ inches; 2 leaves each, except No. 111 I which has one leaf. Issues discontinued from Jan. 30, 1766, No. 1067 , until Feb. 20th which appeared with this title and heading:

The Maryland Gazette,| Revived.| [XXIst Year.] Thursday, February 20, 1766. [No. 1068.] |

Then on March 6th appeared: The Maryland Gazette.|, without modification.

On May 8th was issued in two leaves: The Maryland Gazette,| Extraordinary.| Annapolis, May 8, 1766.|

On June 19th was issued in one leaf: The Maryland Gazette Extraordinary.| Annapolis, June 19, 1766.| [Colophon:] Annapolis: Printed by Jonas Green, at his Old Printing-Office in Charles-Street.|

Nos. 1077 and 1080 have "Supplement" of one leaf each.

MDSL. (complete). LC. (incomplete). For location of scattered issues, see Brigham, American Newspapers.

273. Proceedings | of the | Congress | at | New-York.| [Colophon:] Annapolis:| Printed by Jonas Green, Printer to the Province. MDcclxvi.|

$\mathrm{Sm}$. fol. A-G ${ }^{2}$; 4 leaves; pages [r]-28: text, with head-piece and heading as above, running heads. 


\section{A History of Printing in Colonial Maryland}

Leaf measures: $11 \frac{11}{16} \times 7 \frac{3}{6}$ inches. Type page, p. 2: $230 \times 144 \mathrm{~mm}$.

This was the Maryland edition of the proceedings of the Stamp Act Congress, Oct. 7-25, 1765. Its publication was advertised in Maryland Gazelle for Sept. I , 1766.

MdHS. LC.

274. The Proceedings of the Sons | of Liberty, March I, 1766.| The Sons of Liberty of Baltimore County and Anne-Arundel / County, met at the Court-House of the City of Annapolis, the | first Day of March I766.| . . . [Annapolis: Printed by Jonas Green. 1766.]

Broadside. $13 \frac{5}{8} \times 8 \frac{3}{4}$ inches.

Relates to the forming of "Sons of Liberty" organizations in other counties to oppose the Stamp Act, and calls a general meeting for March 31,1766 .

NYHS.

\section{7}

275. Maryland, Province of. Laws | of | Maryland, | made and passed | at a | Session of Assembly, begun and held at the City of Annapolis, on Saturday the / First Day of November, in the Sixteenth Year of the Do-l minion of the Right Honourable Frederick, Absolute | Lord and Proprietary of the Provinces of Maryland and | Avalon, Lord Baron of Baltimore, 8c. and ended the I Sixth Day of December, Anno Domini, I766.| Published by Authority.| [Provincial arms, T. Sparrow, sculp.] Annapolis:| Printed by Jonas Green, Printer to the Province.| [ 1767 .

Fol. I preliminary leaf, Bbbbb-LIll12, I supplementary leaf; 22 leaves; pages unnumbered; preliminary leaf: title,-verso blank; Bbbbb1 recto-Lllll 2 verso: text, with session heading, running heads; supplementary leaf recto: contents,-verso blank.

Leaf measures: $14 \frac{9}{16} \times 9 \frac{1}{2}$ inches. Type page, p. Ccecc recto: $272 \times 143 \mathrm{~mm}$.

Signature sequence in continuation of No. 268.

No copy of the V. \& P. for this Session has been recorded.

MDioc. MdHS. MDSL. NYPL. LC. SLM.

275a. [The Maryland Almanack, for the year 1767. Annapolis: Printed by Jonas Green. I767.]

In the Maryland Gazette for Feb. 5, 1767, appears this notice: "To-morrow morning will be Published; Another Edition of the Maryland Almanack. Price Eight Coppers single, or 5s. a Dozen."

276. [The Maryland Almanack, for the Year 1768. Annapolis: Printed by Anne Catherine Green. 1767.$]$

No copy recorded. Advertised in Maryland Gazetie for Dec. 24, 1767, as "Lately Published."

277. The Maryland Gazette.) (Jan. I-Dec. 3I, I767, Nos. I I I2-I I64; beginning with Aug. 2oth, change in heading from XXIId to XXIIId Year.) [Colophon, Nos. I I I2-I I 26; same as in year 1766.$]$

$I_{4} \times 9$ inches; 2 leaves each number except Nos. III $3, I_{1} I_{4}$ and $I_{1} 6_{3}$ which have one each; three columns.

Nos. I12 I, I I 35, II 37, II39, 1145 have "Supplement" of one leaf each.

The following changes occurred in colophons:

Nos. I I 3 and I I 4 had: Annapolis. Printed by Jonas Green, at his Printing-Office, in Charles-Street.|

After the death of Jonas Green on April 11 th, beginning with issue of April 16th, the colophon read: Annapolis: Printed by Anne Catherine Green, at the Printing-Office: where all !, [etc. as in 1766.] With the issue of Nov. 5, 1767 . Nos. 1156 to I 164 : Annapolis: Printed by Anne Catherine Green, at the Printing-Office: where all Per-1 sons may be supplied with this Gazette, at 12s. 6d. a Year; Advertisements, of a modera te Length,| are inserted the First 'Time, for 5s. and 1s. for each Week's Continuance. Long Ones in Proportion to their | Number of Lines. At same Place may be had, ready Printed, most kinds of Blanks, viz. Common and / Bail Bonds; Testamentary Letters of several sorts, with their proper Bonds annexed; Bills of | Exchange; Shipping-Bills, \&c. \&c. All Manner of Printing-Work performed in the neatest and / most expeditious Manner, on applying as above.|

See Plate Xb for new title arrangement, adopted July 9, 1767.

MDSL. (complete). LC. (incomplete). 
278. [Allen, Bennet. Advertisement.] Baltimore: Printed by Nicholas Hasselbach. (?) I768.]

No copy known. Reprinted in Maryland Gazette for Sept. 22, 1768, where, as also on Sept. 29, 1768, it is specifically stated that it was printed in Baltimore. There is no evidence that any other printer was living in Baltimore in 1768 except Hasselbach, and indeed the evidence herein contained that printing was being done in Baltimore in 1768 is the only existing indication that Hasselbach or any other printer was active there at that time, although it is known traditionally that Hasselbach lived until 1769 .

This broadside, a reply to that issued by William Green on May 28, (below, No. 280) was an attack on the Greens, Anne Catharine and William, for their refusal to print more of Allen's letters under the pseudonym "The Bystander," unless he should disclose his identity. This Allen refused to do, although he was willing to indemnify them against suit for libel. He alleged that the Greens were under such obligations to the Dulanys that they feared to incur the displeasure of that family by publishing matter which was distasteful to them. The Greens were ably defended by Mrs. Green's son-in-law, John Clapham, in Maryland Gazette for Sept. 22, 1768. Allen was abusive, the Greens conducted their cause with reticence and dignity.

279. Allen, Bennet. To the | Public.| November 9, I768.| Mr. Wolstenholme having, in his Hand-Bill of this Day, vindicated his Conduct I . . . [signed, Bennet Allen, and has below a note asserting that two hand-bills by him on this subject had preceded this one.] [Annapolis: Printed by Anne Catharine and William Green. 1768.]

Broadside. $17 \frac{1}{2} \times 10 \frac{3}{2}$ inches.

Among those who were forward in contesting Mr. Allen's attempt at ecclesiastical pluralism was Mr. Walter Dulany, between whom and Allen a newspaper controversy was carried on in the columns of the Maryland Gazette in the spring of $\mathrm{x} 768, \mathrm{Mr}$. Dulany signing his articles "C. D.", Parson Allen pretending to conceal his identity behind "The Bystander." The controversy was carried on at first with common sense and righteous indignation by Dulany and with remarkable learning and impudence by Allen. Degenerating into invective, especially on Allen's part, the Greens eventually had refused to print more of it except under conditions noted below, entry No. 280. Feeling became so warm between Dulany and Allen that on Sunday, Nov. 6, 1768, these two met in Annapolis and after high words proceeded to cudgel play. Dulany wrested Allen's cane from him and gave it into the keeping of Mr. Daniel Wolstenholme. Immediately after the encounter, Allen published two handbills, as he says in a footnote to the above broadside, reflecting on Wolstenholme's part in the affair, and these were replied to by Wolstenholme in the broadside noted below, No. 288. The item here described is Allen's reply to Wolstenholme's broadside and contains his own version of the altercation.

The story of this brilliant clerical profligate has never been fully written. Ample material exists for it in the Sharpe Correspondence; in the Maryland Gazette for the spring and fall of 1768 ; in the "Gilmor Papers" and the "Dulany Papers" in the Maryland Historical Society; in Allen, St. Ann's Parish; in the "Letters of Jonathan Boucher" in vols. 7-9 of the Maryland Historical Magazine; and in Allen's own pamphlet, printed by William Goddard of Philadelphia in 1768, entitled An Address to the Vestrymen, Church-Wardens, and Parishoners of AllSaints, in Frederick County, Maryland, a copy of which is in the Gilmor Papers.

It should be said that the Dulanys later had cause to regret whatever victories they had obtained over Allen. In London in 1782, Allen avowed himself the author of an attack on Daniel Dulany, Jr. which had appeared some time before in an English journal. Lloyd Dulany, the younger brother of Walter and Daniel, challenged the detractor of his brother to a meeting on the field of honor. Dulany was killed; Allen plead his "clergy" and was acquitted of the charge of manslaughter which was brought against him.

MdHS. (in Gilmor Papers).

280. Green, William. To the Public.| Annapolis, May 28, 1768.| Whereas a Controversy has been published in the Gazette, for | a considerable Time, betwixt a certain Gentleman, who calls | himself a Bystander, and his Opponents, ... . [Annapolis: Printed by Anne Catharine and William Green. I768.]

Broadside. 11 政 $\times 7 \frac{7}{8}$ inches.

First paragraph signed "The Printers"; second, unsigned; third and last signed "William Green." Refers to the demand made by the Greens upon the Rev. Bennet Allen (The Bystander) either to disclose his identity or to indemnify them against suit for libel by Walter Dulany (C. D.), the other principal in the controversy, whom Allen had begun to attack on personal grounds. See Nos. 278 and 279.

MdHS. (Gilmor Papers).

[23I] 


\section{A History of Printing in Colonial Scaryland}

28I. [Maryland, Province of. Acts of Assembly, to compleat Bacon's Laws to this time. Annapolis: Printed by Anne Catharine Green, I 768.]

Evans, No. 10953, gives this title but does not locate a copy. On Dec. 8, 1768, the following advertisement appeared in the Maryland Gazetse: "A few Acts of Assembly, to compleat Bacon's Laws, to this Time, may be had at the Printing-Office, if applied for soon." The above title must have been taken from this advertisement, which doubtless did not refer to a single book, a compilation of the laws since 1763 , but to sets of annual session laws remaining in the printer's stock and now offered for sale. The signatures and pagination of these issues ran in continuation of those of Bacon's Laws, so that they might well have been said to bring that compilation up to date, but there is no evidence that they were issued as compiled laws with a title-page as given above.

282. - Laws | of | Maryland,| made and passed | at a | Session of Assembly, | begun and held at the City of Annapolis, on Tuesday the | Twenty-fourth Day of May, in the Eighteenth Year of the Do- minion of the Right Honourable Frederick, Absolute | Lord and Proprietary of the Provinces of Maryland and | Avalon, Lord Baron of Baltimore, \&c. and ended the | Twenty-second Day of June, Anno Domini, 1768.| Published by Authority.| [Provincial arms, T. Sparrow, sculp.] Annapolis:| Printed by Anne Catharine Green, Printer to the Province.| [1 768$]$.

Fol. x preliminary leaf, Mmmmm-Zzzzz², 6A'; 26 leaves; pages unnumbered; preliminary leaf: title,-verso blank; $\mathrm{Mmmmm} 1$ recto- $6 \mathrm{~A}_{1}$ verso: text, with session heading and running heads; $6 \mathrm{Al}_{1}$ verso: contents.

Leaf measures: $13 \frac{1}{\frac{1}{2}} \times 8 \frac{1}{8}$ inches. Type page, p. Mmmmm I verso: $270 \times 143 \mathrm{~mm}$.

No copy of the V. \& P. for this Session has been recorded.

MdHS. MDioc. MDSL. NYPL. LC. (imp.) SLM.

283. [The Maryland Almanack, For the Year 1769, Containing many instructive and entertaining Pieces, both in Prose and Verse; together with Receipts for the Cure of different Disorders incident to this climate, \&c. Annapolis: Printed by Anne Catharine and William Green. 1768.]

No copy recorded. Advertised in the Maryland Gazetie for Oct. 13, 1768, as "Now in the Press," and in the "Supplement to the Maryland Gazette" for October 20, 1768, as "Just Published." The advertisement as given above has the following addition: "We have added a Sheet extraordinary this Year, for the Benefit of our Customers only, as we shall dispose of them at the usual Price of 5 s. per Dozen, or 8 Coppers single."

284. The | Maryland Gazette.| (Jan. 7-Dec. 29, 1768, Nos. 1165-1216; beginning with Aug. $25^{\text {th }}$, change in heading from XXIIId to XXIVth Year.) [Colophon as in numbers 1156 to I 64 of 1767 , except that beginning Jan. 7, 1768, the printers were Anne Catherine and William Green, and beginning Jan. 28, Mrs. Green altered the spelling of her middle name "Catherine" to "Catharine."]

$14 \frac{3}{4} \times 9 \frac{1}{2}$ inches; three columns; two leaves each number except Nos. I 166 and I 215 which have one each.

Nos. 1184 and 1186 have "Supplement" of one leaf each. No. 1206 has a "Supplement" of two leaves.

See Plate $\mathrm{Xb}$ fr arrangement of title.

MDSL. (complete). MdHS. (scattered issues).

285. To His Excellency | Horatio Sharpe, Esq; Governor and Commander in Chief in and over the Province of Maryland, and, | to the Honourable the | Upper and Lower Houses of Assembly | of the said Province:| The Petition of the Subscribers, Inhabitants of Baltimore County,| Humbly Sheweth,| . . . [Baltimore: Printed by Nicholas Hasselbach. 1768.]?

Fol. 2 leaves; p. [r]: petition, with heading as above; pp. [2, 3 and 4 ]: blank, for signatures; ornamental initial. Leaf measures: $17 \frac{1}{6} \times 11 \frac{1}{8}$ inches.

Concerns the removal of county seat from Joppa to Baltimore Town. A ms. affidavit attached to one of the several copies with signatures in the Maryland Historical Society asserts that these petitions had been posted at certain piaces named between Jan. II and Jan. 25, 1768. For a discussion of the possibilities of this, and the two following broadsides, having been printed by Hasselbach, see foregoing narrative, Chapter Nine.

MdHS. 


\section{Faryland Imprints of the Colonial Period, $1689-1776$}

286. To His Excellency | Horatio Sharpe, Esquire,| Governor and Commander in Chief in and over the Province of Maryland: and,| to the Honourable the / Upper and Lower Houses of Assembly of the said Province:| The Petition of the Subscribers, Inhabitants of Baltimore County,| Humbly Sheweth,| . . . [Baltimore: Printed by Nicholas Hasselbach. I768]?

Broadside. $20 \frac{1}{2} \times 15^{\frac{1}{2}}$ inches.

Another form of the petition relating to the removal of the Court house from Joppa to Baltimore Town. See foregoing narrative, Chapter Nine.

MdHS.

287. To His Excellency / Horatio Sharpe, Esquire,/ Governor and Commander in Chief in and over the Province of Maryland,| and,| to the Honorable the | Upper and Lower Houses of Assembly | of the said Province:| The Petition of the Subscribers, Inhabitants of Baltimore County,| Humbly Sheweth,| . . [Second heading in German, as follows:] An Seine Excellenz | Horatio Scharpe, Esqueir,| Guvernoer und Oberst-Befehlshaber in und ueber die Provinz Maryland,| und | an die Groszachtbaren | Obere und Untere Haeuser der Assembly | der besagten Provinz:| Die Bittschrift der Unterschriebenen, Einwohner von Baltimore County,| Welche demuethig anzeiget,| . . . [Baltimore: Printed by Nicholas Hasselbach. 1768]?

Fol. 2 leaves; p. [1-2]: petition with headings as above and text in English and German; part of p. [2] and all of pp. [3 and 4$]$ : blank, for signatures.

Leaf measures: $17 \frac{1}{x} \mathrm{I} 1$ inches.

If this petition was printed in Baltimore, it was the first piece of printing done in Maryland in the German language and type. Thomas says that Hasselbach was equipped to print in German. It is the third form of the petition for the removal of the court house from Joppa to Baltimore Town. See foregoing narrative, Chapter Nine.

MdHS.

288. Wolstenholme, Daniel. To the | Public.| As Mr. Allen, in two Hand-Bills, which he has caused to be distributed about the Town, has en-| deavoured to bring me in as a Principal, in the Affair of a little Skirmish, which happened betwixt | Mr. Walter Dulany, and himself, on Sunday last, ... . [Concludes with affidavit dated Nov. 9, 1768, sworn to by Daniel Wolstenholme before Reverdy Ghiselin.] [Annapolis: Printed by Anne Catharine and William Green. 1768.]

Broadside. $17 \frac{1}{x}$ 10 $\frac{5}{8}$ inches.

See Allen's reply above, No. 279.

MdHS. (Gilmor Papers).

\section{9}

289. Annapolis, (Maryland) Ciry or. Annapolis, (in Maryland) June 22, I769.| We, the Subscribers, his Majesty's loyal | and dutiful Subjects, the Merchants,| Traders, Freeholders, Mechanics, and other Inhabitants of the Pro-f vince of Maryland, seriously considering the present State and Condition of $\mid$ the Province, ... [Annapolis: Printed by Anne Catharine and William Green. 1769.]

Fol. 2 leaves; pages [1], 2-3, [4]; p. [4]: blank.

Leaf measures: $14 \frac{13}{16} \times 8$ inches. Type page, p. [1]: $294 \times 163 \mathrm{~mm}$.

Non-importation agreement, signed by Robert Lloyd, and forty-two others.

MdHS.

290. - Annapolis, May 23, I769.| Sir,| Yesterday there was a Meeting of a considerable Num-| ber of the principal Inhabitants of this County, when the / Plan of an Association

[233] 


\section{A History of Printing in Colonial SCaryland}

was formed, a Copy whereof we inclose you,| which is expected to be signed very generally by every Degree of the / People here. ... [Annapolis: Printed by Anne Catharine and William Green. I769.]

Broadside. $12 \frac{3}{5} \times 7 \frac{9}{8}$ inches.

Relates to the adoption of the Non-importation agreement.

MdHS.

291. - The | Bye-Laws | of the City of | Annapolis | in | Maryland | To which is prefixed the | Charter of the said City | Granted by her late Majesty | Queen Anne | in the Year of our Lord I708 | Also | three Acts of Assembly | Passed in 1708 171 8 and 1725 | Published by Order of the Corporation | Annapolis | Printed by Anne Catharine Green.| [1769.]

8vo. [A]-F $\mathrm{F}^{2}$; 26 leaves; pages [1-3], 4-12, [1]-40; p. [1]: title; pp. [3]-1 2: The / Charter | Granted by her late Majesty |Queen Anne | to the City of | Annapolis | Anno 1708.]; pp. [1]-7, in second pagination: text of the three Acts of Assembly relating to Annapolis in 1708, 1718 and 1725, each with title of act as heading; pp. [8]-40: text of twenty-one bye-laws of the Corporation of Annapolis.

Leaf measures, title-page: $8 \frac{8}{8} \times 5 \frac{1}{16}$ inches (Irregularity in width of leaves throughout.) Type page, p. $4: 165$ $\times 92 \mathrm{~mm}$.

In Maryland Gazetie for Jan. 12, 1769, appeared "[This Day is Published,] Price 3 s. 9 d. And to be sold by Mr. Edward Ford, Clerk of the Mayor's Court, "The Bye-Laws'...", (as in next entry). The press work and composition of this book is particularly neat, but the great irregularity in the sizes of the leaves takes away somewhat from the beauty of the production as a whole. See Plate VIII for a photographic reproduction of the titlepage.

MDHS. (An imperfect copy is owned by Ruxton M. Ridgely, Esq. of Baltimore.)

292. [The Bye-Laws of the Corporation of the City of Annapolis:-to which is prefixed the Charter and Acts of Assembly, relative to said City. Annapolis: Printed by Anne Catharine and William Green at the Printing-Office. I769.]

Evans, No. 1 1 156 , gives this title but does not locate a copy. It is likely that this is simply the advertisement of the book described in No. 291, for it was in exactly these words that its publication was announced in the Maryland Gazetie for Jan. 12, 1769.

293. [The Maryland Almanack, For the Year 1770. Containing many instructive and entertaining Pieces, both in Prose and Verse; together with Receipts for the Cure of different Disorders incident to this climate, \&c. Annapolis: Printed by Anne Catharine and William Green. 1769.]

No copy recorded. Advertised in Maryland Gazette for Oct. 26, 1769, as "Just Published," and the "Price, as usual, 5s. per Dozen, or Eight Coppers single."

294. The | Maryland Gazette.| (Jan. 5-Dec. 28, I769, Nos. I 217 to 1268 ; beginning with Aug. $3 \mathrm{I}$, change in heading from XXIV th to XXVth Year.) [Colophon, as in year 1768.$]$ $15 \frac{3}{4} \times 9 \frac{3}{4}$ inches; 2 leaves each number except Nos. 1220 and 1268 which have one each; three columns. Nos. 1235 and 1236 have "Supplement" of one leaf each.

No. 1268 has colophon: Annapolis: Printed by Anne Catharine and William Green.l

See Plate $\mathrm{Xb}$ for arrangement of title.

MDSL. (complete). For location of scattered issues, see Brigham, American Nerospapers.

1770

295. [Allen, Bennet.] A | Reply | to the | Church of England Planter's | First Letter | Respecting the Clergy.| [Type device] Annapolis:| Printed by Anne Catharine Green. MDCCLXX.|

Sm. 4to. [A]-C4; I2 lenves; pages [I-3], 4-22, [23-24]; p. [I]: title; pp. [3]-16: text, with heading, To the I 
Church of England Planter.|; p. 16, at end: "A Constitutionalist."; pp. 17-22: "Postscript"; p. 22: "Finis."; last leaf pp. $[23-24]$ is blank but genuine.

Leaf measures: $8 \frac{7}{16} \times 6 \frac{1}{4}$ inches. Type page, p. $4: 161 \times 125 \mathrm{~mm}$.

MDioc. MdHS. (Gilmor Papers.)

296. [The Contract; being a concise and impartial Account of a late Dispute between a Captain of a Ship, and a certain exotick Planter: also several curious interesting and entertaining Anecdotes, with a Frontispiece ... By a Buckskin. [Ten lines of verse.] Annapolis: Printed by Anne Catharine and William Green. 1770.]

No copy located. Evans, No. 1161 . Advertised as above in Maryland Gazette for May 31, 1770, as "Speedily will be Published," with the following note: "N. B. Subscriptions are taken in by Solomon Mackery Barrot, Esq; at Talbot County Court-House."

297. [Maryland, Province of. An Act for emitting Bills of Credit, and other Purposes therein mentioned. Annapolis: Printed by Anne Catharine Green. 1770.]

No copy located. Evans, No. 11717. Advertised in Maryland Gazette for Mch. 15, 1770. This act is Chapter XIV of session laws described below in No. 298.

298. - Laws | of | Maryland,| made and passed | at a | Session of Assembly,| begun and held at the City of Annapolis, on Friday the Se-l venteenth Day of November, in the Nineteenth Year of the | Dominion of the Right Honourable Frederick, absolute | Lord and Proprietary of the Provinces of Maryland and | Avalon, Lord Baron of Baltimore, \&c. and ended the / Twentieth Day of December, Anno Domini, I769.| Published by Authority. | [Provincial arms, T. Sparrow, sculp.] Annapolis:| Printed by Anne Catharine Green, Printer to the Province.| [1770.]

Fol. I preliminary leaf, $6 \mathrm{~B}-\mathrm{K} 6^{2}$; ig leaves; pages unnumbered; preliminary leaf: title,-verso blank; 6 B 1 recto- $K 6_{1}$ verso: text, with session heading, running heads; $K 6_{2}$ recto: blank; $K 6_{2}$ verso: contents.

Leaf measures: ${ }^{3} \frac{1}{7} \times 8 \frac{7}{8}$ inches. Type page, p. $6 \mathrm{C}_{1}$ recto: $273 \times 144 \mathrm{~mm}$.

MdHS. MDioc. MDSL. LC. NYPL. HLS. SLM. BM.

299. - The [ Proceedings | of the | Committee | Appointed to examine into the Importation of Goods by | the Brigantine Good Intent, Capt. Errington,| from London, in February 1770.| [Type device.] Annapolis:| Printed by Anne Catharine Green.| mDcclxx.|

Sm. 4to. A-E4, F'; 22 leaves; pages [I-IV], i-xii, I-[28]; p. [I]: title; p. [III]: "To the Inhabitants," etc;; pp. i-xii: preliminary matter relating to Non-importation agreement; pp. I-21: text of the inquiry; pp. 22-27: "The Queries".

Leaf measures: $7 \frac{8}{8} \times 6$ inches. Type page, p. ii: $153 \times 130 \mathrm{~mm}$.

Under the impression that the copy of this pamphlet in the Public Record Office was unique, Mr. Richard D. Fisher had a transcript made of it and reprinted the entire work in three succeeding issues of the Maryland Historical Magazine, vol. 3 , beginning on pages $14 \mathrm{I}, 240$ and 342 . In the same volume $\mathrm{P} .386$, is a note by Mr. Fisher on the "Proceedings," and in vol. 16, No. I, Mch. 1921, pp. 60-62, has been reprinted from the Maryland Gazetse a protest in which certain members of the committee disclaim the pamphlet "as being the Proceedings of the Committee".

HU. PRO.

300. - Votes and Proceedings | of the | Lower House of Assembly | of the | Province of Maryland.| November Session, I769.| Being the second Session of this Assembly.| (17 November-20 December, 1769.) [Colophon:] Annapolis: Printed by Anne Catharine Green, Printer to the Province.| [1770].

Fol. Tt ${ }^{2}$, Iii-LII', LIl-Sss ${ }^{2}$; 24 leaves; pages [207]-253, [254]; pp. [207]-253: text, with head-piece, heading as above and session heading of six lines; p. 253 : colophon; P. 237 wrongly numbered 273 .

Leaf measures: $13 \times 7 \frac{7}{8}$ inches. Type page, p. $208: 23^{8} \times 143 \mathrm{~mm}$.

MDioc. 


\section{A History of Printing in Colonial SCaryland}

301. [The Maryland Almanack, (for the Year I771.) Containing Several instructive and entertaining Pieces, both in Prose and Verse. Annapolis: Printed by Anne Catharine Green. I770.]

No copy recorded. Advertised in Maryland Gazette Nov. 8, 1770, as "Just Published," at "Eight Coppers Single, or Five Shillings per Dozen."

302. The | Maryland Gazette.| (Jan. 4-Dec. 27, 1770, Nos. I269 to I 320; beginning with Aug. 23 , change in heading from XXVth to XXVIth Year.) [Colophon as in year 1768 , except that in Nos. I 302-1 320, issued after death of William Green in August, his name was dropped from the colophon.]

$15^{\frac{3}{4}} \times 9^{\frac{3}{6}}$ inches; Nos. 1279-1 286 measure $14 \frac{1}{4} \times 9^{\frac{1}{8}}$ inches; Nos. $1287-1290$ measure $12 \times 7 \frac{1}{\text { inches; } 2 \text { leaves }}$ each number, except Nos. 1271-1272, 1274, 1276, 1278 and 1320 which have one each; three columns.

No. 1316 has "Supplement" of 4 leaves of Assembly Proceedings. No. 1278 has colophon: Annapolis: Printed by Anne Catharine and William Green. | Each of the numbers I287-1 290 has two columns only, and "Supplement" of one leaf; their colophon reads: Annapolis: Printed by Anne Catharine and W. Green.|

See Plate $\mathrm{Xb}$ for title arrangement.

MDSL. (complete). For location of scattered issues, see Brigham, American Newspapers.

I 771

303. [Cockburn, Robert. Poor Robert Improved: Being an Almanack and Ephemeris For the Year of our Lord 1772. By Robert Cockburn, Teacher of the Mathematicks. Annapolis: Printed by Anne Catharine Green. 1771.]

No copy recorded. Advertised in the Maryland Gazetie for Nov. 7, 1771, as "Just Published."

304. Maryland, Province of. A | Bill, entitled,| An Act to redress the Evils arising from the Variation of the / Compass in surveying Lands.| [Annapolis: Printed by Anne Catharine Green. I771.]

Fol. 2 leaves without pagination; pages $[\mathrm{I}-4]$; pp. [I-3]: text, with heading as above.

Leaf measures: $12 \frac{13}{16} \times 8 \frac{3}{16}$ inches. Type page, p. [2]: $270 \times 141 \mathrm{~mm}$.

On Oct. 31, 1770, (V. \& P. Third Session p. 30I) a bill (title as above) was read a second time and referred for consideration on the second Tuesday of the next session. It was ordered also "That the Said Bill be immediately published in the Maryland Gazette, and that it be likewise printed in Hand Bills, and Four Copies thereof delivered to each Member of the Upper and Lower Houses of Assembly." The V. \& P. of the Third Session were not published until after the conclusion of the Fourth Session, which followed it immediately, when the V. \& P. of both Sessions were issued together with four copies of the bill above described stitched to the book. The copy in possession of J. Hall Pleasants, M. D. of Baltimore, is complete as issued, containing the V. \& P. of both Sessions with the four copies of the bill at tached, the only examples of the bill known to the compiler. This bill did not become law. It had been introduced in an earlier session, (see Maryland Gazette for Jan. 4, 1770, where it is published for the irst time). It was printed in the Maryland Gazette also for Dec. $13,1770$.

Pleasants.

305. - By the Lower House of Assembly, Nov. 30, $1771 . \mid$ Ordered, that the Proceedings upon the Conference, the Address to / the Governor upon the Subject of his Proclamation, the Resolves there-| with sent, and the Governor's Answer thereto, be immediately printed | separate from the Journal, and Four distinct Copies sent, in the same / Manner as publick Letters are sent, to each Person who is entitled to | receive the Votes and Proceedings of this House.| Signed by Order,| John Duckett, Cl. Lo. Ho.| [Annapolis: Printed by Anne Catharine Green. I77I.]

Fol. A-G,$H^{1} ; 15$ leaves; pages [I]-30: text of documents as named in title, with heading as above.

Leaf measures: $12 \frac{7}{8} \times 8 \frac{1}{4}$ inches. Type page, p. 3:258 $\times 141 \mathrm{~mm}$.

MDioc. LC. 


\section{Saryland Imprints of the Colonial Period, $1689-1776$}

306. - Laws | of | Maryland,| made and passed | at two | Sessions of Assembly, | begun and held at the City of Annapolis, on Tuesday the / Twenty-fifth Day of September: And | on Tuesday the Sixth Day of November; in the Twentieth | Year of the Dominion of the Right Honourable Frede-| rick, absolute Lord and Proprietary of the Provinces of | Maryland and Avalon, Lord Baron of Baltimore, \&c.| Annoque Domini 1770.| Published by Authority.| [Provincial arms, T. Sparrow, sculp.] Annapolis:| Printed by Anne Catharine Green, Printer to the Province.| [I77I.]

Fol. I preliminary leaf, 6L-6R², I supplementary leaf; I 6 leaves; pages unnumbered; preliminary leaf: title,verso blank; $6 \mathrm{~L}_{1}$ recto to $6 \mathrm{P}_{1}$ recto: text of September session, with session heading, running heads; $6 \mathrm{P}_{1}$ verso: blank; $6 \mathrm{P}_{2}$ recto to recto of supplementary leaf: text of November session, with session heading, running heads; verso of supplementary leaf: contents.

Leaf measures: $12 \frac{3}{6} \times 7 \frac{7}{7}$ inches. Type page, p. $6 \mathrm{~L}_{1}$ recto: $265 \times 143 \mathrm{~mm}$.

Signature sequence is continuation of acts of preceding session.

MdHS. MDioc. MDSL. LC. NYPL. HLS. SLM. BM.

307. - Maryland ss. By his excellency Robert Eden, esq. lieutenant general and chief governor in and over the Province of Maryland. A Proclamation. [Regarding four several Acts of Parliament to become operative within the Province. Dated, Annapolis, 26th August, 1771.] [Annapolis: Printed by Anne Catharine Green.1771.]

Broadside. fol.

Evans, No. 12110. (no copy located.)

308. - Votes and Proceedings | of the | Lower House of Assembly | of the | Province of Maryland.| September Session, 1770.| Being the Third Session of this Assembly.| (Sept. 25-Nov. 2, 1770.) [Colophon:] Annapolis:| Printed by Anne Catharine Green, Printer to the Province.| [1 77 I.]

Fol. Ttt-Zzz'; Aaaa-Hhhh'; 26 leaves; pp. [255]-305, [306]; pp. [255]-305: text with head-piece, heading as above, session heading of six lines and running heads; $p .305$ : colophon.

Leaf measures: I $3 \times 8 \frac{1}{2}$ inches. Type page, p. 256:261 $\times 143 \mathrm{~mm}$.

See above, note to No. 304 .

MDioc. MdHS. Pleasants.

309. - Votes and Proceedings | of the | Lower House of Assembly | of the | Province of Maryland.| November Session, 1770.| Being the Fourth Session of this Assembly.| (Nov. 5-Nov. 21, 1770.) [Colophon:] Annapolis:| Printed by Anne Catharine Green, Printer to the Province.| [1771.]

Fol. Iiii-Qqqq ${ }^{2}$, Rrrr $^{1}$; 17 leaves; pp. [307]-340: text, with head-piece, heading as above, session heading of six lines and running heads; p. 340: colophon.

Leaf measures: $12 \frac{3}{\frac{3}{4}} \times 8 \frac{1}{3}$ inches. Type page, p. $308: 257 \times 142 \mathrm{~mm}$.

See above, note to No. 304 .

MDioc. MdHS. (imp.) Pleasants.

310. The | Maryland Gazette.| (Jan 3-Dec 26, 1771, Nos. 1321-I372; beginning with Aug. 22, change in heading from XXVIth to XXVIIth Year.) [Colophon as in Nos. 1302-1 320 in year 1770, except Nos. 1360-1369, which have:] Annapolis: Printed by Anne Catharine Green.|

$15 \frac{3}{3} \times \frac{3}{4}$ inches; 2 leaves each number; 3 columns.

No. 1360 has "Supplement" of one leaf.

See Plate $\mathrm{Xb}$ for title arrangement.

MDSL. (complete). For location of scattered issues, see Brigham, American Newspapers.

[237] 


\section{A History of Printing in Colonial SKaryland}

311. Maury, James. To | Christians of every Denomination among us, espe- $\mid$ cially those of the Established Church,| an | Address:| Enforcing | an Inquiry into the Grounds of the Pretensions | of the Preachers, called Anabaptists, to an extraor-| dinary Mission from Heaven to preach the Gospel;| Recommending / a Method, by which even the unlearned may engage in and prosecute | that Inquiry, so as to satisfy themselves whether their Pretensions be | admissible or not, on Scripture Principles;| and shewing,| that there is but one Case, wherein the Members of the Established Church | can innocently separate from her Communion; together with the Sin and | Danger of separating in any other Case.| By the Reverend James Maury, A.M. late Rector of | Fredericksville, in the County of Albemarle.| I Thess. v. 20, 21.| Despise not Prophecyings-prove all Things-hold fast that which is good.| Annapolis:| Printed by Anne Catharine Green,| MDcclxxI.|

Sm. 4to. [A]-L', [M]'; 23 leaves; pages [1-3], 4-45, [46]; p. [r]: title,-verso: "Advertisement to the Reader"; pp. [3]-45: text, with heading, To | Christians of Every Denomination | among us, \&c.|; p. 45: "Finis".

Leaf measures: $8 \frac{1}{4} \times 6 \frac{3}{8}$ inches. Type page, p. 4:147 $\times 112 \mathrm{~mm}$.

In the "Advertisement to the Reader" the anonymous editor remarks upon the recent death of Mr. Maury, and asserts that this "Address" had been composed during the last illness of that active and faithful parish priest.

The Rev. James Maury, rector of Fredericksville Parish, Louisa and Albemarle Counties, Virginia, was born April 8, 1718, the son of Mathew and Anne Fontaine Maury. He was ordained in England in 1742, and died in his Virginia parish on June 9, 1769 . He was the father of thirteen children and through them the progenitor of a line distinguished among the Hugenot families of America. One of his grandsons was Matthew Fontaine Maury whose book, The Physical Geography of the Seas was said by Humboldt to have founded a new science, and which gained for its writer the popular title the "Philosopher of the Seas." (William EJ Mary Coll. 2uart. 10: 122; Collections of Va. Hist. Soc., 5: 128 ; Maury, Ann. Memoirs of a Hugenot Family, N. Y. 1853).

One of the most celebrated trials of the validity of the Two-Penny Act, see No. 243, was that which resulted when the Rev. James Maury sued his vestry for salary withheld under its provisions. Patrick Henry, then a young man, rode into fame as attorney for the defendants in this case, and so successful was his conduct of it that Mr. Maury was awarded damages of only one penny. An account of this trial may be read in Wirt, Life of Patrick Henry; Meade, Old Churches, etc. 1: 219-220; Hawks, Contributions to the Ecc. Hist. of the U. S. A. 1: 122125, but above all in the letter which Mr. Maury wrote to the Rev. John Camm, Dec. 12, 1763, published in the Memoirs of a Hugenot Family cited above.

The only recorded copy of Maury's work described above is that in MdHS., purchased in I920 at the sale of the library of the late Ridgely B. Warfield, M. D. of Baltimore.

\section{2}

312. Maryland, Province of. Laws | of | Maryland, | made and passed | at a | Session of Assembly, / begun and held at the City of Annapolis, on Wednesday the / Second Day of October, in the Twenty-first Year of the | Dominion of the Right Honourable Frederick, abso-| lute Lord and Proprietary of the Provinces of Maryland | and Avalon, Lord Baron of Baltimore, \&c. Annoque | Domini I 77r.| Published by Authority.| [Provincial arms, T. Sparrow, sculp.] Annapolis:| Printed by Anne Catharine Green, Printer to the Province.| [1772.]

Fol. I preliminary leaf, $6 \mathrm{~S}-6 \mathrm{Z}^{2}, 7 \mathrm{~A}-7 \mathrm{E}^{2} ; 23$ leaves; pages unnumbered; preliminary leaf: title,-verso blank; $6 \mathrm{~S}_{1}$ recto- $7 \mathrm{E}_{2}$ recto: text with session heading and running heads; $7 \mathrm{E}_{2}$ verso: contents.

Leaf measures: $13 \frac{3}{16} \times 8 \frac{1}{2}$ inches. Type page, p. $6 S_{1}$ verso: $267 \times 139 \mathrm{~mm}$.

MdHS. MDioc. BBL. MDSL. LC. NYPL. SLM.

313. - Votes and Proceedings | of the | Lower House of Assembly | of the | Province of Maryland.| October Session, 1771.| Being the first Session of this Assembly.| (October 2November 30, 177I.) [Colophon:] Annapolis:| Printed by Anne Catharine Green, Printer to the Province.| [1772] 


\section{SCaryland Imprints of the Colonial Period, $1689-1776$}

Fol. A-Y $Y^{2},[Z]^{1} ; 45$ leaves; pages $1-89$, [go]: text, with heading as above, session heading of six lines and running heads; p. 89: colophon.

Leaf measures: $13 \frac{1}{8} \times 8 \frac{1}{4}$ inches. Type page, p. 2: $260 \times 139 \mathrm{~mm}$.

MdHS. BM.

314. [The Maryland Almanack and Ephemeris For the Year of our Lord 1773. Annapolis: Printed by Anne Catharine Green and Son. 1772.]

No copy recorded. Advertised in Maryland Gazette for Dec. 3, 1772, as "Just Published."

315. The | Maryland Gazette.| (Jan. 2-Dec. 31, 1772, Nos. 1373-1425; beginning with Aug. 27, change in heading from XXVIIth to XXVIIIth Year.) [Colophon as in Nos. I $302-1320$ in 1770, except that at the beginning of this year Mrs. Green admitted her son Frederick to partnership and the colophon read:] Annapolis: Printed by Anne Catharine Green and Son, ... . . . . . . . . . . . . .

$15^{\frac{3}{4}} \times 9^{\frac{3}{4}}$ inches; 2 leaves each number except No. 1379 which has one only; 3 columns.

Nos. 1405, 1414-1 425 have colophon: Annapolis: Printed by Anne Catharine Green and Son.| Nos. 1412 and $14 \mathrm{I} 3$ have no colophons; each may have had a "Supplement" bearing colophon but these are not in MDSL. copies.

See Plate $\mathrm{Xb}$ for title arrangement.

MDSL. (lacks No. 1373, Jan. 2, 1772.) For location of scattered issues, see Brigham, American Newspapers.

1773

316. Baltimore County, (Maryland). Baltimore County, to wit. The Right Honourable Henry Harford, Esquire, Absolute Lord and Proprietary of the | Province of Maryland. To | Greeting: Whereas by Petition | to our Justices of Baltimore County Court ha set forth, that [Annapolis: Printed by Anne Catharine Green. I773.]

Broadside. $11 \frac{3}{8} \times 7 \frac{8}{8}$ inches.

Form used in appointment of commissions to prove and perpetuate the boundaries of land.

MdHS.

317. [Maryland, Province of. An Act for the Relief of the Poor of Baltimore. November Session, 1773. Annapolis: Printed by Anne Catharine Green. 1773.] ?

Evans, No. $1284 \mathrm{I}$, gives this title and imprint as above, but does not locate a copy. The title was probably taken from the Boston Athenaeum Catalogue, p. 1882, where it occurs precisely as given as a short title entry of a pamphlet of 24 pages which was issued without title-page. The first heading in this pamphlet accounts for only pages I-IO, and is as follows:

November 1773.| Chap. XXX.| An Act for the relief of the Poor within the County of Baltimore.|

The remainder of the pamphlet contains other poor laws of Baltimore City and County from 1773 to 1820 . Its typographical features also are of a much later date than that suggested for it by Mr. Evans. Copies of this pamphlet are in the Boston Athenaeum and the Maryland Historical Society.

318. - Laws | of | Maryland,| made and passed | at a | Session of Assembly, begun and held at the City of Annapolis, on Tuesday the / Fifteenth Day of June, in the Second Year of the Dominion | of the Right Honourable Henry Harford, Esq; absolute Lord and Proprietary of the Province of Maryland,| Annoque Domini 1773.| Published by Authority.| [Provincial arms, T. Sparrow, sculp.] Annapolis:| Printed by Anne Catharine Green, Printer to the Province.| [1773.]

Fol. I preliminary leaf, $7 \mathrm{~F}-7 \mathrm{~K}^{2}$, I supplementary leaf; 2 leaves; pages unnumbered; preliminary leaf: title,verso blank; $7 \mathrm{~F}_{1}$ recto- $7 \mathrm{~K}_{2}$ verso: text, with session heading and running heads; supplementary leaf, recto: contents,-verso blank.

Leaf measures: $14 \frac{3}{16} \times 9 \frac{1}{1}$ inches. Type page, p. $7 F_{1}$ verso: $270 \times 140 \mathrm{~mm}$.

Signature sequence is in continuation of No. 312 .

MDioc. MDSL. LC. NYPL. HLS. SLM. BM.

[239] 


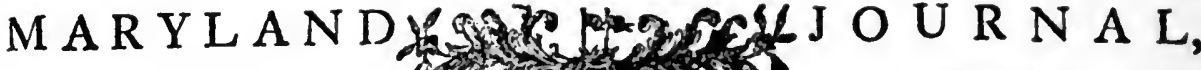 A N D \\ T H E}

B A L T I M O R E

Containing the Freshret Advices,

Omae culit pastum, gal mifanit wrile dolei,

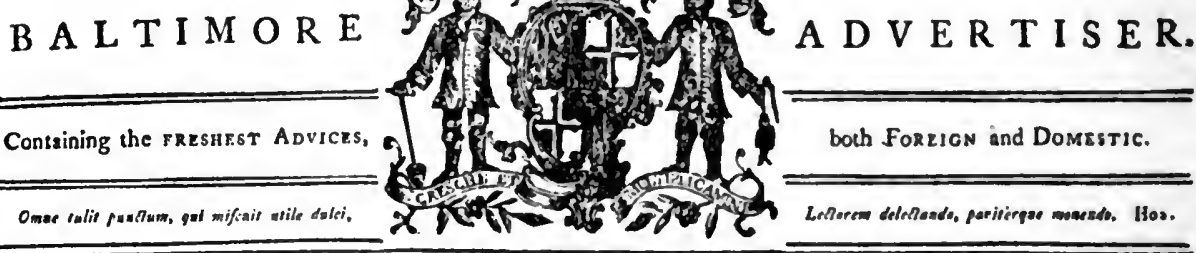

F R I D A , August 20, 1773.

[ Vol. I.]

To the P U B L I C.

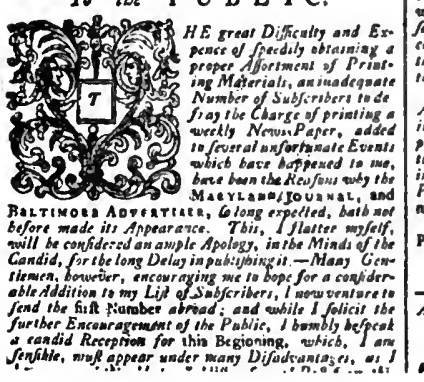

I Bope ith will dikenfe with a perfoed Appliearion. wbicb ourr if prasticable, mould to oery painfal, and

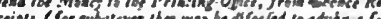
cipers

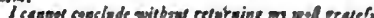

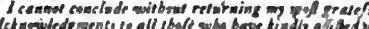

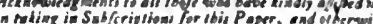

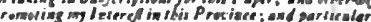

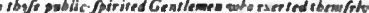

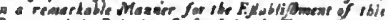
Paper and lbe Pristing. Bufineff in the Tow of Balo more.

Paiarino Orisa, Daroted bemble Servant, Palatima.Oryica, Bal. W. GODDARD. TIMORz, Augah 20 ,

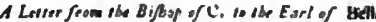
moot, on bis lale dwal wish Lord Towndeod. MY LOR D porchaf the good opiajion of the world, Beogh at the

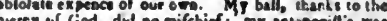
noercy of God, ded no mifchief, ony antegenilti wu

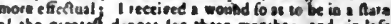
of the piesuell darger lor three monits; and, in lefis than we.e. tawe poesece of what sian al of my cure. Of wy Lord, the lcorn of a sheufand werlee would hase been el finm io whar I lelt on inas dieadful oceation! How olien did I with it at matere tad formed me witk' difpofition the moft dallardly that eter fell to the lot of hes meseef. fons I II I Hew to reslos lor comiont, the rold me thas I had defvifed her bett advice ; if i torned so religion, he bid me remem. ber bow bad trampled os hat srapelt admontinea.

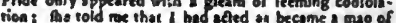
ron al and for as

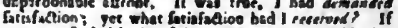
I wat goof y inicliod at firts, I was oow urepurably ip. joest. and clestls faw, that, tincigh I might tere be

Plate XIa. See page xiv.

V O L. I.

D U N L A P's

\section{MARYLAN D GAZETTE;}

- R $T H E$

\section{BALTIMORE GENER AL ADVERTISER.}

\section{$\begin{array}{llllllllllll}T & \text { U } & \text { E } & \text { S } & \text { D } & \text { A } & \text { Y, } & \text { M } & \text { A } & \text { Y } & \text { 2, } & 1775 .\end{array}$}

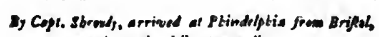
- we beve the following atslligeme.

FLOREN C E, FIRA OANY 18.

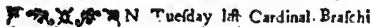
6. 3 wa unanimoitly elected Pore. Col 0 He was born a' Cefena, near Rs. fox $O$ venns in the Romagna is 58 X 3 years of axe: wat created Cardi.

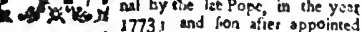
Treafurer rotbe A ponfolic Chenber. He has now reafuret ro the A prosios VI.

I. O N D O N, trantaer s.

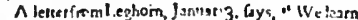
from the life of Cyprys, that a loft terrible earth. bas been injured by the operations of Pasliament...Second, foliciting redrefs from thern as the heredicary guardians of the nariwa....And laflly, peayinz the peticioners may be licard by counsel at the bar of the Houfe, prevsous to their Lord hips havina, any fubjet."

This petition, after bxing read three sintes, was unasimoufty approved of A motion was then made that is thould lie for fizning from fout o'cloct thet

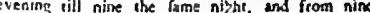
o'clock this morning till steven in tho forenom Afte which follolved another " ulas thould be prefented to day as foon as the Houf of Lords pould fit" Both thefe motions were likewife tranigouny a provid of.

Fia. 10. An eminent Ooster at the metilas of

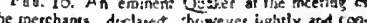

Plate XIb. See page xiv.
Fos. 14. An allumsntation of 250 men ro each of the trateallions of foos upon the Eaglith wablib. ment is 10 be forthwith made.

There are at this time, between J.ondon-bridat ard Lime-houre, more than 300 velf. is with braoms to heir mathesds, as a tokes they are for fale. Housa op CONMON', Hon. I6. Sir Chmples and Means for nifing itse fopply 10 ie ermeted to his Majethy, and reppred the foliowine refol-ition. That the closting and pay of the millin be do frayed out of the lasd us for ilve year 1775 . Lord Berringron theo moved, that i firs not ex. sceding 67.7061. 9\%. Id. be lianted for the your 1775, to enable his Majefly th wurmex $x$ his land foe crs with 4383 men, officets and nonseromeifioned

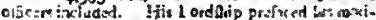
On with fiewing the neceficy of the prefent poppolo 


\section{SCaryland Imprints of the Colonial Period, $1689-1776$}

319. - Votes and Proceedings | of the | Lower House of Assembly | of the | Province of Maryland.| June Session, I 773.| Being the First Session of this Assembly.| (June I5-July 3, I773.) [Colophon:] Annapolis:| Printed by Anne Catharine Green, Printer to the Province.| [1773].

Fol. $\mathrm{A}-\mathrm{G}^{2} ; \mathrm{I}_{4}$ leaves; pages [ $\mathrm{I}-28$ : text with heading as above, session heading of six lines and running heads; p. 28: colophon.

Leaf measures: $13 \frac{f}{6} \times 8 \frac{2}{3}$ inches. Type page, first full page: $10 \frac{8}{5} \times 5 \frac{5}{8}$ inches.

BM.

320. The | Maryland Gazette.| (Jan. 7-Dec. 30, I773, Nos. I426-I477; XXVIII-XXIXth Year) [Colophon as in $1414-1425$ of year 1772 .]

1 $5^{\frac{3}{2}} \mathrm{x}$ 10 inches; 2 leaves each number, except Nos. 1447, 145 I, 1455 and 146I which have four leaves each; three columns.

Nos. 1432, 1435, 1436, 1439, 1443, I446 and 1450 have "Supplement" of one leaf each.

See Plate Xb for title arrangement.

MDSL. (complete). For location of scattered issues, see Brigham, American Newspapers.

32I. The | Maryland Journal,| and the | Baltimore Advertiser.| Containing the Freshest Advices, both Foreign and Domestic.| (Aug 20-Dec 30, I773, being Nos. I-I 8 of vol. I, pages I-72.) [Two lines from Horace, printed as one line; Provincial arms in center of title, dividing it throughout.] [Colophon:] Baltimore: Printed by William Goddard, at the Printing-Office in Market-Street, op-| posite the Coffee-House, where Subscriptions, at Ten Shillings per Annum, Advertisements and Letters of Intelligence, are / gratefully received for this Paper, and where all Manner of Printing-Work is performed whith [sic] Care, Fidelity and Expedition. Blanks and Hand-| Bills, in particular, are done on the shortest Notice, in a neat and correct Manner.]

$15 \frac{1}{16} \times 9 \frac{3}{4}$ inches; two leaves each number; three columns; pages numbered continuously; running title; after No. 2, the dates are inclusive, as "From Friday, August 20, to Saturday, August 28, 1773 ".

No. 6 has a "Postscript" of one leaf. Colophon as given above used throughout until Dec. 30,1773 , when because of change of location it was altered in part to read as follows: Baltimore: Printed by William Goddard, at the Printing-Office in Market-Street, | next Door above Dr. John Stevenson's, and two doors below the FountainInn, where Subscriptions, ... $|\ldots| \ldots \mid$ (wording exactly as in first colophon).

See foregoing narrative Chapter Ten, for an account of the origin of this newspaper.

See Plate XIa for title arrangement.

MdHS.

322. Proposals | for Establishing | a Circulating | Library,| in Baltimore-Town.| [Baltimore: Printed by William Goddard, I773.]

Broadside. $14 \times 8 \frac{5}{8}$ inches.

Maryland Fournal for Oct. 16, 1773, advertises the above for publication "on Tuesday next."

MdHS.

1774

323. Annapolis, (Maryland) Oct. 20.| The brig Peggy Stewart, Captain Jackson, from | London, having on board seventeen packages, con- $\mid$ taining $2320 \mathrm{lb}$. of that detestable weed tea, arrived | here on Friday last. ... [Signed] By Order,| John Ducket, [sic] Clk. Com.| [Annapolis: Printed by Anne Catharine Green and Son. 1774.]

Broadside. $16 \times 4 \frac{1}{4}$ inches.

Contains an account of the burning of the "Peggy Stewart" on Oct. 19, 1774, by her part owner, Mr. Anthony Stewart, acting under mob compulsion. Reprinted from Maryland Gazette for Oct. 20, 1774. This incident has been discussed by Mr. Richard D. Fisher in a series of letters to the Baltimore Neevs beginning with the issue of April 8, 1905, and extending to Nov. 2, 1907. See scrap book of clippings, "The Arson of the Peggy Stewart," in Maryland Historical Society. Mr. Fisher regarded the incident as by no means creditable to the zealous Annapolitans.

MdHS. (bound with Maryland Gazette for Nov. 17, 1774.) LC.

[24I] 


\section{A History of Printing in Colonial Scaryland}

324. At a General Meeting of the Freeholders, Gen-| tlemen, Merchants, Tradesmen and other | Inhabitants of Baltimore County, held at the Court-house of | the said county on Tuesday the $3^{\text {Ist }}$ of May, 1774.| Capt. Charles Ridgley, Chairman.| . . . Baltimore: Printed by Enoch Story, at his Printing-Office.| [1774]

Broadside. $16 \frac{1}{2} \times 10 \frac{1}{2}$ inches.

Contains resolutions in regard to the Boston Port Bill and the Non-importation Agreement, signed "William Lux, Clk."

NYPL.

325. At a meeting of the inhabitants of the City of Annapolis, on Wednesday | the 25th day of May, 1774, after notice given of the time, place, | and occasion of this meeting;| ... [Annapolis: Printed by Anne Catharine Green and Son. 1774.]

Broadside. $16 \frac{1}{8} \times 6 \frac{7}{8}$ inches.

Contains resolutions of Non-importation until the Boston Port Act should be repealed, adopted in Annapolis on May 25, 1774, (see heading); a protest against general approval of these resolutions until further investigation, and a note of a meeting called on May 27 th, at which was confirmed the action of the meeting of May 25 th, signed "John Duckett, Clk."

MdHS. (in Gilmor Papers). NYHS. HSP.

326. By command of the King of Kings (and at the desire of all who love His appearing) at the theatre of the universe on the eve of time, will be performed The Great Assize, or the day of judgment; tickets for the pit at the easy purchase of following the vain pomps and vanities of the fashionable world, ... Bath (England), Printed. Baltimore, Reprinted by William Goddard. [1774.]

Broadside. fol.

Evans, No. 13182 . No copy located.

327. Extracts of private Letters from London, dated April 7 and 8, to Persons in | NewYork and Philadelphia.| [Annapolis: Printed by Anne Catharine Green and Son. 1774.]

Broadside. $16 \frac{1}{2} \times 10 \frac{3}{\frac{3}{3}}$ inches, (three columns.)

Refers to the Boston Port Act and other matters of interest to the colonists. Issued in connection with the Maryland Gazette of May 19, 1774. See volume for that year in MdHS.

MdHS. HSP.

328. Maryland, Province of. At a Meeting of the Committees appointed by the Several Counties of the Pro-l vince of Maryland, at the City of Annapolis, the 22d Day of June, I 774, and continued by Adjournment from Day to Day, till the 25th Day of the same | Month;| Were Present,| [Names of 92 delegates]. [Annapolis: Printed by Anne Catharine Green. I774.]

Single sheet, printed both sides, $13 \frac{9}{16} \times 8 \frac{15}{16}$ inches. Type page, p. [1]: $270 \times 161 \mathrm{~mm}$.

Contains resolutions of the Convention regarding non-importation in case of passage into law of the Boston Port Bill. Contains at the conclusion of the Resolutions, an order of the Convention that "these resolutions be transmitted to the Committees of correspondence for the several Colonies, and be also published in the Maryland Gazette."

MdHS. HSP.

329. - At a Meeting of the Deputies appointed by the several Counties of the / Province of Maryland, at the city of Annapolis, by Adjournment, on the 8th / day of December, I774, and continued till the I2th Day of the same Month.| Were Present | [Names of 85 delegates.] [Annapolis: Printed by Anne Catharine Green. 1774.]

Single sheet, printed both sides, $13 \frac{5}{8} \times 8 \frac{15}{16}$ inches. Type page, p. [1]: $326 \times 178 \mathrm{~mm}$.

Contains various proceedings for raising a militia force, internal regulations, etc., but notably the following 


\section{Maryland Imprints of the Colonial Period, $1680-1776$}

resolution: "The proceedings of the Continental Congress were read, considered, and unanimously approved. Resolved, That Every member of this Convention will, and every person in the province ought, strictly and inviolably to observe and carry into Execution the Association agreed on by the said Continental Congress." Concludes with same order to publish as in preceding item.

MdHS. LC.

330. - Laws | of | Maryland,| made and passed | at a | Session of Assembly, begun and held at the City of Annapolis, on Tuesday the / Sixteenth Day of November, in the Third Year of the | Dominion of the Right Honourable Henry Harford,| Esq; absolute Lord and Proprietary of the Province of Ma-| ryland, and ended the Twenty-third Day of December,| Anno Domini 1773.| Published by Authority.| [Provincial arms, T. Sparrow, sculp.] Annapolis:| Printed by Anne Catharine Green, Printer to the Province.| [1774].

Fol. I preliminary leaf, $7 \mathrm{~L}-7 \mathrm{Z}^{2}, 8 \mathrm{~A}-8 \mathrm{~K}^{2}$, I supplementary leaf; $4^{8}$ leaves; pages unnumbered; preliminary leaf: title,-verso blank; $7 \mathrm{~L}_{1}$ recto- $8 \mathrm{~K}_{2}$ verso: text, with session heading and running heads; supplementary leaf, recto: contents.

Leaf measures: $13 \frac{1}{2} \times 8 \frac{1}{16}$ inches. Type page, p. $7 \mathrm{~L}_{1}$ verso: $268 \times 141 \mathrm{~mm}$.

No copy has been recorded of the V. \& P. of this Session.

MdHS. MDioc. MDSL. LC. NYPL. NYBA. SLM. BM.

331. -Laws | of | Maryland,| made and passed | at a | Session of Assembly,| begun and held at the City of Annapolis, on Wednesday the / Twenty-third Day of March, in the Third Year of the | Dominion of the Right Honourable Henry Harford,| Esq; absolute Lord and Proprietary of the Province of | Maryland, and ended the Nineteenth Day of April, Anno | Domini 1774.| Published by Authority.| [Provincial Arms, T. Sparrow, sculp.] Annapolis:| Printed by Anne Catharine Green, Printer to the Province.| [1774].

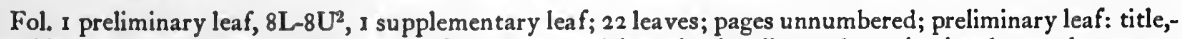
verso blank; $8 \mathrm{~L} 1$ recto to supplementary leaf, recto: text, with session heading and running heads; supplementary leaf, verso: contents.

Leaf measures: $14 \frac{\frac{1}{8}}{8} \times 9 \frac{3}{\frac{3}{4}}$ inches. Type page, p. $8 \mathrm{~L}_{1}$ verso: $267 \times 140 \mathrm{~mm}$.

Signature sequence continued from Acts of preceding session, concluding a continuous sequence since Bacon's Lawes of Maryland, 1765 . These were the last laws passed in Maryland under the Charter granted to the first Lord Baltimore in 1632 . At the next session of Assembly in 1777, the acts passed were signed by Thomas Johnson as governor, representing the people of the State of Maryland.

MDioc. MdHS. (imp.) MDSL. LC. NYPL.

332.- Votes and Proceedings | of the | Lower House of Assembly | of the | Province of Maryland.| March Session, 1774.| Being the third Session of this Assembly.| (March 23April 19, 1774.) [Colophon:] Annapolis:- Printed by Anne Catharine Green, Printer to the Province.| [1774].

Sm. fol. Y-Z ${ }^{2}, \mathrm{Aa}^{-\mathrm{Ee}^{2}}, \mathrm{Ff}^{1}$; I $_{5}$ leaves; pages [83]-1 1 2: text, with heading as above, session heading of six lines and running heads; p. II2: colophon.

Leaf measures: $11 \frac{7}{16} \times 7 \frac{7}{16}$ inches. Type page, p. $84: 253 \times 144 \mathrm{~mm}$.

This was the last session of the Provincial Assembly of Maryland. It was prorogued to July 11, 1774, but from its close on April 19th until its final dissolution on June 13,1776 , by Governor Eden's proclamation and order for a new election, it was prorogued twenty times without a single meeting having been held. During this interval the Convention of the Province held its Sessions, and at one of these, July 25, 1776, "The Convention being informed, that writs of Election have been issued in the name of the proprietary, for the election of delegates in Assembly, Resolved, That the said writs be not obeyed, and that no Election be made in consequence thereof." On June 24, 1776, Governor Eden set sail for England, leaving the Province in the hands of the Convention and the Council of Safety. The first session of Assembly under the new conditions, "convened by the Council of Safety" was held in Annapolis from February 5 to April 20, 1777.

MdHS. 


\section{A History of Printing in Colonial SCaryland}

333. The | Maryland Gazette.| (Jan. 6-Dec. 29, I774, Nos. I478-1 529; XXIXth-XXXth Year.) [Colophon as in $1414-1425$ of year 1772.$]$

$15 \frac{3}{2} x$ Io inches; 2 leaves each number; 3 columns.

No. 1514 has "Supplement" of one leaf printed one side only.

See Plate $\mathrm{Xb}$ for title arrangement.

MDSL. (complete). For location of scattered issues, see Brigham, American Newspapers.

334. The | Maryland Journal,| and the | Baltimore Advertiser.| (Jan. 8-Dec. 26, 1774; Nos. 19-52, being remaining Nos. of vol. I, Nos. 53-54 being the first two numbers of vol. 2; pages 73-204.) [Colophon:] Baltimore: Printed by William Goddard, at the Printing-Office in Market-Street, | next Door above Dr. John Stevenson's, and two Doors below the Fountain-Inn, where ...1... . . . .

$15 \frac{7}{3} \times 9 \frac{3}{4}$ inches; two leaves each known number except Nos. 19 and 24 which have one each; three columns.

See Plate XIa for title arrangement.

Mary Katherine Goddard took over the management of the newspaper with the issue of Feb. 17, 1774, but her name did not find a place in the imprint until May 10, 1775. Colophons of Nos. 19, 24, 39, 41 and 43 are shortened forms of the above.

MdHS. has a fairly complete file, but lacks Nos. 25, 27, 28, 36-39, 42, 44-46 and 52; No. 23 is imperfect.

335. [Thомas, David. The Virginian Baptist: a View and Defence of the Christian Religion as it is Professed by the Baptists of Virginia. In three parts. Baltimore: Printed by Enoch Story. [774.] pp. 68. 8vo.

Evans, No. 1365 I. No copy located.

336. United Colonies of North America. Extracts | from the | Votes and Proceedings | of the American Continental | Congress,| held at Philadelphia on the / 5 th of September, 1774. Containing | the Bill of Rights, a List of Grievances, Occasi-| onal Resolves, the Association, an Address to the People | of Great Britain, and a Memorial to the Inhabit-| ants of the British American Colonies.|Annapolis:| Printed by Anne Catharine Green, and Son. $\mid \mathrm{M}, \mathrm{DCC}, \mathrm{LXXIV}$.

8vo. [A]-F $\mathrm{F}^{4} ; 2$ leaves; pages [i-iv], [1]-44; p. [i]: half-title, Extracts | from the | Votes and Proceedings ] of the | American Continental | Congress.|; p. [iii]: title; pp. [1]-8: (Bill of Rights) (Grievances, Letter to Gen'l Gage etc.); pp. 9-1 I5: "The Association, \&c."; pp. 16-24: "To the People of Great Britain from the Delegates"; pp. 25-36: "To the Inhabitants of the Colonies of ..."; pp. 37-44: "To the Inhabitants of the Province of Quebec".

Leaf measures: $7 \frac{1}{2}$ inches in height. Type page, p. $2: 152 \times 85 \mathrm{~mm}$.

See below, note to No. 337 .

NYPL.

337. - Extracts from the Votes and Proceedings of the American Constitutional Congress, held at Philacielphia, on the 5 th of September, 1774 . Containing the Bill of Rights, a List of Grievances, Occasional Resolves, a Letter to General Gage, the Association, an Address to the people of Great Britain, a Memorial to the Inhabitants of the British American Colonies, and a Letter to the Inhabitants of the Province of Quebec. Annapolis: Printed by Anne Catharine Green and Son. I774.

I 2 mo. 44 pages.

Evans, No. 13727 gives this title, but does not locate a copy. The entry preceding this one, as the collation shows, contains in its text all that is mentioned in this fuller title. The "Extracts" were advertised as "in the press" in the Maryland Gazette of Nov. 3, 1774, and as "Just Published" on Nov. Ioth. In the advertisement the contents are given as in this entry, but no copy of a Maryland edition has been located in which " $A$ Letter to General Gage" and "A Letter to the Inhabitants of the Province of Quebec" are mentioned on the title-page. It is possible that Mr. Evans's title was taken from the advertisement above referred to. Neither of these editions is given in Worthington C. Ford's "Bibliographical Notes", (see Nos. 19-42) appended to vol. 1, Fournals of the Continental Congress, $1774-1789$. 
338. Vallette, Elie. [Cut] The | Deputy Commissary's | Guide | within the Province | of | Maryland,| together | with plain and sufficient directions for Testators to form, and Executors | to perform their Wills and Testaments; for administrators to | compleat their Administrations, and for every Person any / way concerned in deceased Person's Estates, to proceed therein | with Safety to themselves and others.| [Cut] By Elie Vallette.| Register of the Prerogative Office of the said Province.| Annapolis,| Printed by Ann [sic] Catharine Green and Son.| MDcclxxiv. T. Sparrow Sculpt |

8vo. 3 preliminary leaves, A-[Q] ${ }^{8}, \mathrm{R}^{2}$; 133 leaves; pages [I-II], [i]-iv, [I]-248, [249-260], p. [I]: title, (engraved on metal by Thomas Sparrow, having at head a scroll with blank space for owner's name); p. [i]: dedication to his Excellency, Robert Eden, Esq; pp. iii-iv: "Preface."; pp. [I]-I60: text, with heading, The | Deputy Commissary's | Guide.|, running heads; facing p. I06: "Table of Descent", (engraved on metal by Thomas Sparrow); pp. I6I-248: appendix, (containing precedents, forms, tables for reduction of sterling to currency, etc.) p. [I62]: (Note to the printer); p. 248: "The End"; pp. [249-257]: "Alphabetical Index of the principal Matters"; p. [258-259]: "Contents of the Appendix", with tail-piece; some copies have six blank and genuine leaves at end, so that in these the collation by signatures reads: 3 preliminary leaves, A-R ${ }^{8}$; 139 leaves.

Leaf measures: $7 \frac{3}{\frac{3}{2}} \times 4 \frac{7}{6}$ inches. Type page, p. 4: $141 \times 71 \mathrm{~mm}$.

The book was advertised in the Maryland Gazette of May 5, 1774, as "Just Published," and in Maryland Gazette June 29, 1775, Vallette begs the subscribers to pay their money and take away their books, otherwise he must lose money. The book was well advertised in the Maryland Gazetie both before and after publication, as well as by prospectus and subscription paper, (see Nos. 339 and 340 ). It was an exceedingly useful compilation, and its engraved title-page, the only one issued from a colonial Maryland press, was Sparrow's best work.

MdHS. MDSL. (many duplicates, probably the "remainder"), and in many public and private collections.

339. - Now ready for the Press, and to be printed by Subscription, in One large Octavo I Volume, containing about Three Hundred Folios |(price Ten Shillings, [Space surrounded by border with words "For", "Mr.", "County" for purchaser's name and address.] The | Deputy Commissary's Guide | Within the Province of | Maryland.| . . . By Elie Vallette, | Register of the Prerogative Office of the said Province.| [Annapolis: Printed by Anne Catharine Green and Son. 1774.]

Broadside. $7 \frac{8}{16} \times 6 \frac{1}{16}$ inches.

Prospectus of Vallette's "Deputy Commissary's Guide." In Scharf Papers, MdHS.

340. - Subscription Paper for the Deputy Commissary's Guide.] [Annapolis: Printed by Anne Catharine Green and Son. 1774.]

Broadside, with ruled columns for names, addresses, etc. Leaf measures: $14 \frac{5}{16} \times 12 \frac{1}{4}$ inches.

In Scharf Papers, MdHS.

341. Where are ye All now?| A very curious and Modest Address, lately | sent to Mr. Charles Ridgely, by some of the | Great Men of Baltimore-Town, versified.| . . . [signed,] Captain Bob-Ad-Ill.| [Baltimore: Printed by Mary K. Goddard. 1774.]

Broadside. $10^{\frac{1}{4}} \times 7^{\frac{3}{3}}$ inches.

This poetical address to Mr. Charles Ridgely calls on that gentleman to withdraw from his candidacy for the Assembly in favor of Mr. Robert Alexander. It refers to the con templated trip of the Governor to Great Britain, doubtless Eden's hurried visit to England in 1774. Mr. Ridgely was elected to the Assembly, however, in spite of the opposition of this element of his constituency.

MdHS.

1775

342. January 7, I775.| To the Inhabitants of Anne-Arundel county.| Gentlemen,| You are requested to meet at the city of Annapolis, on Monday the I6th instant, to | nominate deputies to attend, on behalf of this county, at the next provincial con-l vention, and to 


\section{A History of Printing in Colonial Scaryland}

chuse a committee of observation; ... . [signed,] an American.] [Annapolis: Printed by Anne Catharine Green and Son. 1775.]

Single sheet, printed both sides; $13^{\frac{1}{2}} \times 7^{\frac{3}{6}}$ inches. Type page, $\mathrm{p}$. [r]: $297 \times 178 \mathrm{~mm}$.

MdHS.

343. At a full Meeting of the Inhabitants of Anne-Arundel / county, including the Citizens of Annapolis, on Monday | the I6th Day of January, 1775.| Charles Carroll, Esq; Barrister, Chairman.| Mr. Isaac M'Hard, Clerk.| The association agreed on by the American continental congress, and the / proceedings of the deputies of the several counties of this province, at their | late provincial convention, were read and approved: . . . [signed,] Isaac M'Hard, Clerk.| [Annapolis: Printed by Anne Catharine Green and Son. I775.]

Broadside. $14 \times 9 \frac{1}{8}$ inches.

Resolutions on part of citizens of Anne Arundel County to observe and maintain the Association proposed by the Continental Congress; naming a Committee of Observation for the County, and other matters connected with the execution of the resolves of the Provincial Convention.

MdHS.

344. Articles | of | Capitulation, | made and entered into between Richard | Montgomery, Esquire, Brigadier Ge-| neral of the Continental Army, and the Citi-| zens and Inhabitants of Montreal, . . . duly elected for that purpose. ... [Signed on the one part by the twelve citizens named in the heading, on the other by Richard Montgomery, BrigadierGeneral of the Continental Army, dated Nov. 12, 1775.] [Baltimore:] Printed by John Dunlap.| [I775.]

Broadside. $12 \frac{7}{16} \times 7 \frac{1}{3}$ inches.

Ford, "Bibliographical Notes," No. 67, attributes this to Dunlap's Philadelphia office.

MdHS. (in v. I, Dunlap's Maryland Gazette.) LC.

345. Baltimore: April 26.| We have just received the following import-| ant Intelligence. viz.| Watertown, (Massachusetts-Bay) April 19.| Wednesday morning, 10 o'clock.| To all Friends of American | Liberty.| Be it known that this Morning, before Break / of Day, a Brigade, consisting of about I000 or | 1200 men, landed at Phip's Farm, at Cambridge, | and marched to Lexington, where they found a Com-| pany of our Colony Militia in Arms, upon whom they | fired, without any Provocation, and killed 6 men, and | wounded 4 others.| ... [Baltimore: Printed by Mary K. Goddard, 1775.]

Broadside. $10 \frac{1}{\frac{1}{4}} \times 5 \frac{1}{\frac{1}{8}}$ inches.

LC.

346. Baltimore, May 1st, 1775.| Intelligence by Express Last Night.| The inclosed came by Express about an hour ago, we have thought it | adviseable to forward the letter to you ... Baltimore: Printed by John Dunlap, at his Printing-Office in Market-Street.| [1775.]

Broadside. $17 \frac{7}{16} \times 9^{\frac{3}{4}}$ inches.

Refers to the necessity of stopping ships sailing for Boston with provisions which might fall into the hands of General Gage; contains a letter from New York, signed, Isaac Sears, Hugh Hughes, John H. Kip and John Lamb, describing the self-imposed embargo and announcing the probability that Gage would occupy the town. Has at conclusion of postscript these words: "Let this be forwarded from Town to Town, with the utmost expedition, to the remotest of the Colonies, especially to Virginia."

MdHS. (in v. 2, Dunlap's Maryland Gazette.)

347. Christie, James, JR. Baltimore, July I8.| At a special Meeting of the Committee of

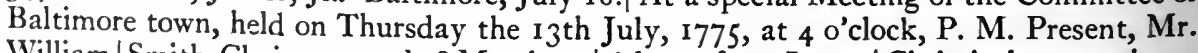
William /Smith, Chairman, and 28 Members.|A letter from James |Christie, jun. merchant, 


\section{SCaryland Imprints of the Colonial Period, $1680-1776$}

of | this town, directed to Lieut.| Col. Gabriel Christie . . . [Baltimore: Printed by Mary Katherine Goddard. I775.]

Broadside. $16 \frac{3}{4} \times 10 \frac{1}{4}$ inches.

In this broadside, James Christie lays before the public the action taken by the Committee of Safety on his intercepted letter to his kinsman Col. Christie, stationed in Antigua, also a copy of that letter, in which the political references, he claimed, were not of such a character as to call for drastic action by the Committee.

MdHS.

348. - The | Case | of | James Christie, jun.| Late of the Province of Maryland, Merchant.| [Annapolis: Printed by Frederick Green]? 1775.

pp. 24. 8vo. Evans, No. 13868.

Regarding the sale by auction of goods imported against the resolution of the American Continental Congress and forfeited under its provisions. Mr. Evans wisely questioned his attribution of the book to the Annapolis press, for it was printed after Christie's banishment, ordered by the Convention on Aug. 7, 1775 to take place on the Ist of September. His receipt for money paid through Robert Milligan, published in this book, is Sept. 4, 1775. In conclusion he says "I have been expelled and banished for ever," and at beginning "The public and my friends, being desirous to know the particulars of my conduct, in Maryland," ... In the title, moreover, he describes himself as "Late of the Province of Maryland." These two items, Nos. 347 and 348, the Maryland Gazette for the period, Eddis's Letters from America (pp. 218, 228-229) and Archives of Maryland (I I: 9, I1-13, 44-48, 51-52) contain Christie's case in detail.

JCB. LC.

349. Dunlap's | Maryland Gazette; or the | Baltimore General Advertiser.| (May 2-Dec. 26, 1775, being Nos. I-XXXV of vol. I). [Colophon:] Baltimore: Printed by John Dunlap, at his Printing-Office in Market-Street, where Subscriptions at Ten Shillings per Annum, Advertisements, \&c. are received for this Paper, and all Manner of | Printing Work done with the utmost expedition.|

$16 \frac{3}{16} \times 9 \frac{7}{8}$ inches; three columns; two leaves each number.

Nos. 8, 9, 12, 14, 19, 20, 22, 27, 33, 34 have one "Postscript" each. No. I6 has two postscripts. Nos. II and 17 have three postscripts each. No. II has title: Dunlap's | Maryland Gazette;| Baltimore General Advertiser.| No. 12 has title as given in the first instance with a comma after the "or", and this style was continued.

See Plate XIb for title arrangement.

MdHS. (lacks No. Ig.)

350. An Essay on the Culture and Management of Hemp, more particularly for the purpose of making coarse linens. By a Farmer. [Annapolis: Printed by Frederick Green. 1775.]

No copy located. In Maryland Gazette July 13, 1775, advertised as "Just Published, and to be sold at the Printing-Office, and at the Loan-Office, price $2 s .6 \mathrm{~d} . "$

351. Same. [with 3 lines from Virgil on title as advertised.] [Printed by Mary Katharine Goddard. I776.]

No copy recorded. In Maryland fournal, Jan. 10, 1776, advertised as "Published and sold at the PrintingOffice." It is probable that this was a reprint of Green's pamphlet announced six months earlier, or it may be that neither of the Maryland offices actually printed these, but that their proprietors imported them from a common source.

352. Fresh Intelligence.| Baltimore, August 10.| Extract of a Letter from a Gentleman in New York, of undoubted veracity, to his Friend in Bal-| timore, dated August 4, I 775.| By express just arrived from Boston, we are informed, That the Lieut. Governor of Canada is taken Prisoner.- That Gen. Gage is at the Point of Death-That the People and Soldiers in | Boston die from 50 to 100 in a Day-The Soldiers had a Mutiny, . . . [Colophon:] [Baltimore:] Published by M. K. Goddard.| [1775.]

Broadside. $13 \frac{1}{2} \times 7^{\frac{3}{8}}$ inches.

MdHS.

[247] 
353. General Gage's | Account of the late Battle at Boston.| Baltimore, April 15 [sic for May 15.] | Annapolis, May 12, 1775.| The following was this Day received by the Post, inclosed in a Letter from General Gage, dated,| Boston, April 29, I775, which we give to the | Public by Authority.| A Circumstantial Account of an | Attack, that happened on the 19th of | April, I775, on His Majesty's Troops, | by a Number of the People of the Pro-| vince of Massachusetts-Bay.| [Baltimore: Printed by Mary K. Goddard. 1775.]

Broadside. $10 \frac{1}{8} \times 6 \frac{7}{8}$ inches.

MdHS.

354. [Great Britain. An authentic copy of Lord Chatham's proposed bill, entitled, A Provisional Act, for settling the troubles in America, and for asserting the supreme legislative authority and superintending power of Great Britain over the Colonies. Annapolis: Printed by Frederick Green. 1775.]

Evans, No. 14076 . No copy located.

355. [Harvey, Edward. The Manual Exercise, as Ordered by his Majesty, in 1764 . Together with Plans and Explanations of the Method Generally Practiced at Reviews and Field-days, \&c. Baltimore: Printed and Sold by M. K. Goddard. I775.]

Evans, No. I4101, gives the above title; no copy has been located. This work was printed widely throughout the colonies in 1774 and 1775 . On July 5, 1775, Mary Goddard advertised an edition of it in her Maryland Fournal as "Just Published, and Sold at the Printing-Office."

356. Henderson, Richard. Bladensburgh, 2 August, 1775.| Sir,| The letters which Mr. Johnson the adjutant brought, were read at the / head of the company on Monday, according to your orders; and the | question being put on Tuesday, for every man who would risk his life, in / defence of American liberty, to repair to the colours, every man present made | up to them.| ... [Annapolis: Printed by Frederick Green. 1775.]

4to. No signatures; pages [r]-4; pp. [r]-2: letter to Col. Joshua Beall; pp. 2-4: letter to Mr. Cunningham Corbett, merchant in Glasgow; both letters signed "Richard Henderson." For other references to Richard Henderson at this period, see Archives of Maryland, II: II, 39, 49 and 5 I.

Leaf measure: $8 \times 7 \frac{1}{8}$ inches. Type page, p. 2: $185 \times 147 \mathrm{~mm}$.

LC. (Ms. Div.)

357. Important Intelligence from St. John's.| Philadelphia, November I 5.| By Yesterday's Post from New-York we have the | following important Intelligence, viz.| Extract of a lett'r.r. from an officer of the New-York | forces, dated at St. John's, 3d Nov. I 775.| Baltimore: Printed by J. Dunlap.| [1775.]

Broadside. $16 \% \mathrm{x}$ 10 inches.

Contains an account of the capture of St. John's, articles of capitulation, stores captured, etc., and other current news items.

MdHS. (in v. I, Dunlap's Maryland Gazette.)

358. Maryland, Province of. Proceedings | of the | Conventions | of the | Province of Maryland, held at the City of Annapolis, on the twenty-second | day of June, 1774; on the twenty-first day of No-| vember, I774; on the eighth day of December,| I774; on the twenty-fourth day of April, 1775; and on the twenty-sixth day of July, I775.| Annapolis:| Printed by Frederick Green.] [I775.]

Sm. 4to. A-C4, $\mathrm{D}^{1}$; I 3 leaves; pages [r]-26; p. [r]: title; Pp. [3]-4: convention, June I774; p. [5] : convention, Nov. I 774; p. [6]-8: convention, Dec. I774; pp. [9]-12: convention, April I775; pp. [13]-26: convention, July I775; running heads throughout. 


\section{Saryland Imprints of the Colonial Period, $1680-1776$}

Leaf measures: $8 \frac{7}{8} \times 6 \frac{3}{6}$ inches. Type page, p. $4: 180 \times 130 \mathrm{~mm}$.

MdHS. MDSL. LC. JCB. and in other public and private collections.

This collection of the Proceedings of the Revolutionary "Conventions" of Maryland, and those of Dec. 1775, May 1776, June 1776 and August 1776, were reprinted with the following title and imprint:

Proceedings | of | the Conventions | of the | Province of Maryland, | held at | the City of Annapolis, in | 1774, 1775, \& 1776.| Baltimore:| James Lucas \& E. K. Deaver.| Annapolis-Jonas Green.| 1836.|

8vo. pp. [i-ii], [r]-378. For the history of this reprint, see the Fournal of the Proceedings of the House of Delegates of the State of Maryland for Jan. I Ith and Feb. 18 th, 1834.

359. - Association | of the Freemen of | Maryland | July 26, I775.| The long premeditated, and now, avowed design of the British government, to raise a revenue from the property of the colonists without their consent,| . . . [Annapolis: Printed by Frederick Green. 1775.]

Broadside. With signatures of 112 Associators appended.

MdHS. (photographic copy.) Photographic reproduction in Scharf, J. T. History of Maryland, vol. 2, facing p. 184 .

360. - At a meeting of the delegates ... of the Province of Maryland, at the City of Annapolis, . . . twenty-sixth of July, I775, and continued till the fourteenth day of August in the same year ... [Resolution for the enrollment of minute-men.] [Annapolis: Printed by Frederick Green, 1775.]

pp. 4 , fol.

Evans, No. 14178. No copy located.

361. [The Maryland Almanack and Ephemeris for the Year of our Lord 1776. Annapolis: Printed by Frederick Green. 1775.]

No copy recorded. Advertised in Maryland Gazette for Nov. 30, 1775 as "Just Published."

362. The | Maryland Gazette.| (Jan. 5-Dec. 28, 1775, Nos. 1530-1 581; XXXth-XXXIst Year.) [Colophon as in 1414-1425 of year 1772 until March 30, 1775, No. 1 542, when Mrs. Green died, (Mch 23d) and the colophon beginning with this number was:] Annapolis: Printed by Frederick Green.|

Sizes vary, Nos. I $53^{0-1} 533$ measure $15^{\frac{1}{2}} \times 9^{\frac{1}{2}}$ inches, thereafter, $15^{\frac{3}{2}} \times 9^{\frac{3}{4}}$ inches; 2 leaves each number; 3 columns.

See Plate $\mathrm{Xb}$ for title arrangement.

MDSL. (complete). For location of scattered issues, see Brigham, American Newspapers.

362a. The | Maryland Journal, and the | Baltimore Advertiser.| (Jan. 2-Dec. 27, 1775, Nos. 55-106, pages 205-424; Nos. 55-104 being the remaining numbers of vol. 2, and 105-106 being the first two numbers of vol. 3.) [Colophons vary, but remain in substance as in 1774 until No. 73 when Mary Katherine Goddard's name appeared in the imprint, as follows:] Baltimore: Published by M. K. Goddard, at the Printing-Office in Market-Street,| next Door above Dr. John Stevenson's ... ... . . . [ [From 88-106, additional advertising matter was included in imprint, but no material change occurred.]

Size varies. Nos. 55-56: $12 \frac{1}{2} \times 9^{\frac{1}{2}}$ inches; Nos. 58-59: $12 \frac{1}{\frac{1}{4}} \times 7^{\frac{1}{2}}$ inches; normal size: $15^{\frac{1}{3}} \times 9^{\frac{3}{4}}$ inches. Three columns; two leaves each number except No. 61, which seems to have only one leaf.

See Plate XIa for title arrangement.

Nos. $5^{8}$ and 59 have a "Supplement" of one leaf each. Nos. 74, 76, 83, 85,89 and 98 have a "Postscript" of

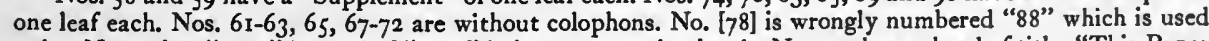
twice. No. 55 has "1774" instead of "1775" in last two running heads. No. 104 has at head of title: "This Paper Compleats the Second Year." Pagination is frequently incorrect.

MdHS. has all issues except Nos. 57, 60, 64, 66, 80 and roo. Brigham, American Newspapers records scattered issues in other libraries. 


\section{$A$ History of Printing in Colonial SCaryland}

363. [The New-England Primmer. Baltimore: Printed and sold at Enoch Story's PrintingOffice in Gay-Street, near the old-Bridge. I775.]

Evans, No. 14273. Heartman copied title from Evans but could not locate a copy of the book. Paul Leicester Ford does not mention it.

364. To the Citizens of Annapolis.| January I I, I775.| A Hand-Bill for the most infernal and dastardly purpose, of glutting pri-| vate revenge with the sacrifice of a few individuals, is now industriously cir- / culating in a particular part of this county. . . . [signed,] A Citizen.) [Annapolis: Printed by Anne Catharine Green and Son. 1775.]

Broadside. $6 \frac{5}{16} \times 7 \frac{\frac{1}{2}}{4}$ inches.

Principally of local interest. See below, No. 365 .

LC. MdHS.

365. To the Citizens of Annapolis.| Jan. 13, I 775.| Gentlemen,| You have been particularly addressed, by a writer, under the signature of "A Citizen", on the subject of my hand bill to the inhabitants of this | county,... . [signed,] An American.| [Annapolis: Printed by Anne Catharine Green and Son. 1775.]

Single leaf, printed both sides. $13 \frac{13}{16} \times 9 \frac{1}{6}$ inches. Type page, $\mathrm{p}$. [r], including heading: $294 \times 164 \mathrm{~mm}$.

A reply to "A Citizen." See preceding entry. Deals with local affairs and the appointment of suitable Revolutionary Committees.

LC. (Ms. Div.)

366. To Walter Tolley, Benjamin Nicholson, John Moale, Robert | Alexander, and Jeremiah Townley Chase, Esqrs.| Gentlemen, | Waving [sic] all useless apology for this Address, we think it incumbent on | us, as freemen of Baltimore county, freely to give you our sentiments $\mid$ on the conduct which we wish you to pursue at the ensuing Conventi-| on, of Maryland. . . . [Baltimore: Printed by Mary K. Goddard. 1775.]

Broadside. $12 \frac{13}{16} \times 13 \frac{13}{16}$ inches; two columns.

MdHS.

367. United Colonies of North America. Rules and Articles, for the better Government of the 'Troops raised, or to be raised, and kept in pay / by and at the joint Expence of the Twelve United English Colonies of North-America.| . . . [signed,] By Order of the Congress, | John Hancock, President.| Philadelphia, June 30, I775.| A true copy from the Minutes,| Charles Thompson, Secretary.| [Baltimore: Printed by John Dunlap. 1775.]

Single sheet, printed both sides. $17 \times$ 10 $10 \frac{1}{4}$ inches.

A copy of this sheet is bound between the issues of Nov. 7 and 14, 1775 of Dunlap's Maryland Gazetle, vol. I in the MdHS., wl ich has a loose copy also. See Ford, "Bibliographical Notes," Nos. 50, 68-70, 127-130.

MdHS.

368. Williamsburg, October 26.| Whereas Lord Dunmore, not contented | with having involved the affairs of this Colony $\mid$ in extreme confusion . . . Baltimore, Printed by John Dunlap.| [1775.]

Broadside. $10^{\frac{3}{4}} \times 7^{\frac{3}{4}}$ 1nches.

An order of the Committee of Safety of Virginia, signed "John Pendleton, junior, Clerk," forbidding persons to pass to or from Norfolk during Dunmore's operations against it in 1775. Contains also an account headed, "To the Printer," of a small action at Hampton against the besieging ships by troops on shore. It was during this attack by Dunmore that the printing office of John Holt was dismantled by his Lordship's orders. See Isaiah Thomas, History of Printing in America, and "John Holt, Printer and Postmaster" by Victor H. Paltsits in the Bulletin of the New York Public Library for Sept. 20, 1920.

MdHS. (in v. 1, Dunlap's Maryland Gazette.) 


\section{Saryland Imprints of the Colonial Period, $1680-1776$}

369. Williamsburg, (Virginia) Sept. 9.| The shocking accounts of damage done by the rains last week are numerous; . . . [Baltimore:] Printed by John Dunlap.| [I 775.]

Broadside. $10 \frac{1}{2} \times 8 \frac{1}{2}$ inches.

Contains also news item of Congress in Philadelphia.

MdHS. (bound in v. I Dunlap's Maryland Gazette.)

\section{6}

370. Dunlap's | Maryland Gazette; or, the | Baltimore General Advertiser.| (Jan. 2-April 23, I776, being Nos. XXXVI-LII of vol. I; April 30-Dec. 31, 1776, being Nos. LIIILXXXVIII of vol. II.) [Colophon, Nos. XXXVI-LX as in year I775; Nos. LXI-LXXXVII (probably to LXXXVIII) as follows:] Baltimore: Printed by John Dunlap, at his PrintingOffice in Market-Street, where / Subscriptions at Ten Shillings per Annum, Advertisements, \&c. are received for this Paper; also for the Pennsyl-|vania Packet, and all manner of Printing Work done with the utmost expedition.|

$16 \frac{2}{2} \times 9 \frac{7}{8}$ inches; three columns; two leaves each number except No. 87 , which has one leaf.

See Plate XIb for title arrangement.

Nos. 40, 41, 57, 61, 67, 82 have one "Postscript" each. No. 63 has three postscripts, one of which, dated "July 12,1776 ", is on blue paper.

On April 16, No. 51, Dunlap announced that because of the increased cost of paper and of other things, he would be compelled to raise the subscription price to $15 s$. per annum, but on May 6 th, he withdrew this statement without explanation and announced that the old price of ros. would be continued. See foregoing narrative, Chapter Nine, for the later history of this newspaper.

MdHS. (lacks Nos. $38,44,55,58,59,76,78,79,81,83$ and 88 .)

370a. See No. 35 I.

371. Extract of a letter from New York, dated Aug. 28, I776.| Yesterday morning the enemy stole through the $\mid$ wood I mentioned in my last, ... . [Annapolis: Printed by Frederick Green. 1776.]

Broadside. $10 \frac{3}{8} \times 8 \frac{3}{3}$ inches.

Contains also extract from a letter from Philadelphia Aug. 3I, 1776. Both of these letters give an account of the Battle of Long Island and the conduct of Smallwood's Maryland Battalion in that engagement.

In collection of Howard Sill, Esq. Baltimore.

372. Great Britain. His Majesty's most gracious Speech to both Houses of | Parliament, on Friday, October 27, I775.| [Annapolis: Printed by Frederick Green. 1776.]

Broadside. I0 $\frac{1}{2} \times 8 \frac{1}{4}$ inches.

Evans, No. 14786, attributes this in square brackets to Mary K. Goddard's press, but a comparison of it with the report in Green's Maryland Gazette shows conclusively that it was a reprint of the speech as published in that paper on Jan. 18,1776 .

MdHS.

372a. Maryland, Province of. By the Convention of Maryland, June 25, $1776 . \mid$ You are empowered to enroll effective Freemen, to | act as Militia of this Province in the Middle Department,| . . . Matthew Tilghman, President.| To of County.| [Annapolis: Printed by Frederick Green. I776.]

Broadside. $4 \frac{5}{8} \times 6 \frac{7}{8}$ inches.

Copy described is addressed to John Reynolds of Caroline County, and the form promises that when twenty men are enrolled by him and passed, he shall receive commission as second lieutenant. MdHS.

$[25 \mathrm{I}]$ 


\section{A History of Printing in Colonial SCaryland}

373. - The Constitution and Form of Go-| vernment proposed for the Considera-l tion of the Delegates of Maryland.| [Annapolis: Printed by Frederick Green. 1776.]

8 vo. No signatures; 5 leaves; pages [ 1 ]-10: text, with heading as above.

Leaf measures: $8 \frac{7}{16} \times 4 \frac{13}{16}$ inches. Type page, p. 2: $148 \times 83 \mathrm{~mm}$.

HSP.

374. -The Declaration and Charter of Rights.| [Annapolis: Printed by Frederick Green. 1776.]

Single sheet, printed both sides, with "Printed for the consideration of the members", at end.

Leaf measures: $15 \frac{5}{10} \times 8 \frac{7}{16}$ inches. Type page, p. [r]: $382 \times 159 \mathrm{~mm}$.

HSP.

375. - A | Declaration | of | Rights,| and the | Constitution | and | Form of Government, | Agreed to by the Delegates of Maryland, in | free and full Convention assembled.| [Type device.] Annapolis:| Printed by Frederick Green.| [ 1776.$]$

Sm. 8vo. $A^{7}, B^{8}, C^{4}, D^{2} ; 21$ leaves; pages [3-5], 6-43, [44]; pp. [1-2]: probably half-title, lacking; p. [3]: title; pp. [5]-15: A | Declaration of Rights, | Agreed to by the Delegates of Maryland,| in free and full Convention assembled.!, with head-piece; p. I5, at conclusion of text: "This declaration of rights was assented to and passed in convention of the delegates of the freemen of Maryland, begun and held at Annapolis the 14th day of August, anno domini 1776. By order of the Convention, Matthew Tilghman, President."; p. 16: blank; pp. [17]-43: The Constitution and | Form of Government,| agreed to by the Delegates of Maryland,| in free and full Convention assembled.|, with head-piece; p. 43, at conclusion of text: "This form of government was assented to and passed ... the $1_{4}$ th day of August, anno domini 1776. By order of the Convention, Matthew Tilghman, President."

Leaf measures: $6 \frac{1}{8} \times 3^{\frac{3}{4}}$ inches. Type page, p. $6: 4 \frac{8}{16} \times 3^{\frac{12}{16}}$ inches.

LC.

376. - The | Declaration | of | Rights,| and the | Constitution | and | Form of Government, | Established by the | Convention of Maryland,| Held at the City of Annapolis, on Wednesday the I4th o[f] | August, anno domini I776.|[Type device.] Annapolis:| Printed by Frederick Green.| [ 1776.$]$

8vo. [A] $]^{1}, \mathrm{~B}-\mathrm{D}^{4},[\mathrm{E}]^{1}$; 14 leaves; pages [i-ii], [1]-26; p. [i]: title; pp. [1]-7: The Declaration of Rights.|, with conclusion as given in collation of No. 375; pp. [9]-26: The Constitution and Form of Go-/ vernment agreed to by the Delegates | of Maryland in free and full Convention | Assembled.|, with conclusion as given in collation of No. 375 .

Leaf measures: $8 \frac{1}{2} \times 5$ inches. Type page, p. $2: 144 \times 85 \mathrm{~mm}$.

Advertised as "Just Published" in Maryland Gazette for Nov. 21, 1776. See title above, "A Declaration of Rights, etc."

LC. HSP.

377. - The Delegates of the Freemen of Maryland in Convention,| To We, reposing especial trust and confidence in your / fidelity, courage, good conduct, and attachment to the liberties of America, Do, by these presents, constitute and ap-/ point you to be ... [Annapolis: Printed by Frederick Green. 1776.]

Broadside. $81 \times 13 \frac{3}{16}$ inches.

Blank form for commissions issued by the Convention and Council of Safety.

MdHS.

378. - Proceedings | of the | Convention | of the | Province of Maryland,| held at the City of Annapolis, on Thursday the seventh | of December, 1775.| Annapolis:| Printed by Frederick Green.| [1776.]

Sm. 4to. $[\mathrm{A}]^{2}, \mathrm{~B}-\mathrm{H}^{4}, \mathrm{I}^{1}$; $3 \mathrm{I}$ leaves; pages [I-5], 6-62; p. [I]: half-title, Proceedings $\mid$ of the | Convention | of the | Province of Maryland.|; p. [3]: title; PP. [5]-62: text, with heading and running heads. 


\section{Garyland Imprints of the Colonial Period, $1689-1776$}

Leaf measures, $B_{1}: 8 \frac{11}{16} \times 6 \frac{11}{16}$ inches. Type page, p. $6: 182 \times 131 \mathrm{~mm}$.

See note to No. $35^{8}$.

MdHS. MDSL. LC. HSP. JCB.

379. - Proceedings | of the | Convention | of the | Province of Maryland, / held at the City of Annapolis, on Wednesday the | eighth of May, 1776.| Annapolis:| Printed by Frederick Green.| [1776.]

Sm. 4to. [A] $]^{1}, B-D^{4}, E^{3} ; 16$ leaves; pages [i-ii], [I]-29, [3o]; p. [i]: title; pp. [r]-29: text, with heading and running heads.

Leaf measures: $7 \frac{3}{2} \times 6$ inches. Type page, p. 2: $164 \times 131 \mathrm{~mm}$.

See note to No. 358 .

MdHS. MDSL. LC. HSP. JCB.

380. - Proceedings | of the | Convention | of the | Province of Maryland,| held at the City of Annapolis, on Friday the | twenty-first of June, I776.| Annapolis:| Printed by Frederick Green.| [1776.]

Sm. 4to. $[A]^{1}, \mathrm{~B}-\mathrm{E}^{4},[\mathrm{~F}]^{\mathrm{I}} ; 18$ leaves; pages [i-iil],[I]-33, [34]; p. [i]: title; pp. [I]-33: text, with heading and running heads.

Leaf measures, $\mathrm{C}_{2}: 8 \frac{1}{16} \times 6 \frac{7}{16}$ inches. Type page, p. 2:162 $\times 131 \mathrm{~mm}$.

See note to No. $35^{8}$.

MdHS. MDSL. HSP. JCB.

381. - Proceedings | of the | Convention | of the | Province of Maryland, / held at the City of Annapolis, on Wednesday the Fourteenth | of August, 1776.| Annapolis:| Printed by Frederick Green.| [1776.]

4to. [A] ${ }^{1}, \mathrm{~B}-\mathrm{Z}^{2}, \mathrm{Aa}^{2} ; 47$ leaves; pages [i-ii], [r]-9I, [92]; p. [i]: title; pp. [I]-9I: text, with heading and running heads.

Leaf measures: $10 \frac{1}{4} \times 8 \frac{2}{4}$ inches. Type page, p. 2: $200 \times 184 \mathrm{~mm}$.

See note to No. 358 .

MdHS. MDSL. LC. HSP. JCB.

382. The | Maryland Gazette.| (Jan. 4-Dec. 26, 1776, Nos. 1582-1633; XXXIst-XXXIId Year.) [Colophon as in Nos. 1 542-1 581 of year 1775.]

$15^{\frac{3}{2}} \times 9^{\frac{1}{2}}$ inches; 2 leaves each number; 3 columns.

See Plate $\mathrm{Xb}$ for title arrangement.

MDSL. (lacks I 609 containing July 4, 1776.) For location of scattered issues, see Brigham, American Newspapers.

382a. The | Maryland Journal,| and the | Baltimore Advertiser.| (Jan. 3-Dec. 30, 1776, Nos. 107-1 59. Nos. 107-1 56 being remaining numbers of vol. 3; Nos. I $57^{-1} 59$ being first three numbers of vol. 4.) [Colophon varies but without material change until No. 159, which reads as follows:] Baltimore: Printed by M. K. Goddard,/ at the Post-Office in Marketstreet.l

Size and number of columns vary; two leaves each number, except Nos. 137, 138, 139, 145 and I 59, which have one each.

See Plate XIa for title arrangement of early numbers of this year. With No. 137 , July 31 , 1776, the Provincial Arms were dropped from the title; with No. 140, "the" was omitted from title before "Baltimore Advertiser".

Nos. 122, [125], 127 and [129] have a "Supplement" of one leaf each; No. 132 has two supplements; Nos. 138, 144 and 148 have a "Postscript" of one leaf each; No. [ $\left.{ }_{3} 3\right]$ is wrongly numbered " 134 " which is repeated; Nos. I08 and 109 are both dated Jan. 10, 1776; No. 156 has at head of title: "This Paper Compleats the Third Year";

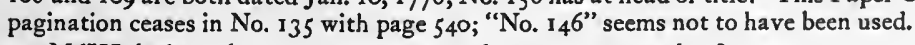

MdHS. lacks I 16, 120, 125, 128, 129, 136, 149, 151-1 55 and 158.

\section{[253]}




\section{A History of Printing in Colonial SCaryland}

383. To the People of Maryland,| Gentlemen,| You have from the beginning of our | struggles for Liberty, with unconsti-| tutional ministerial power, seen that | our success depended almost, or alto-| gether, upon the strength of the pro-| vinces united together, as each dis| tinctly must become an easy prey to | our enemies. . . . [signed,] A Countryman.| Baltimore County, May 28, I776.| [Baltimore: Printed by Mary K. Goddard. 1776.]

Broadside. $16 \frac{1}{16} \times 6 \frac{1}{2}$ inches.

MdHS.

384. United Colonies of North America. General Post-Office, Philadelphia, May i, I 776 .

A broadside containing an admonition from William Goddard, surveyor of Post Office, directed to deputy postmasters, and other post office business. Evans, No. 15127 , suggests that it was printed in Baltimore by Mary K. Goddard, but it is more likely to have been printed in Philadelphia. During his post office surveyorship, Goddard was everywhere, and the fact that the communications contained in this broadside are dated at Philadelphia leads one to believe that the sheet was printed there. No copy of it has been located.

385. United States of America. Baltimore, Dec. 3I, I776.| This Morning Congress received the | following Letter from General | Washington.| Head-Quarters, Newtown, 27th Dec. I776.| Sir, I have the Pleasure of congratulating | you upon the Success of an Enterprize,| which I had formed against a Detachment | of the Enemy lying in Trenton, and which | was executed Yesterday Morning.| . . . Published by Order of Congress,| Charles Thomson, Sec.| Baltimore: Printed by M. K. Goddard.| [1776.]

Broadside. $16 \frac{7}{8} \times 7$ inches.

Contains an account of the Battle of Trenton, prisoners, arms and stores captured, etc. Congress was now in session in Baltimore and Mary Goddard was doing some of its printing.

NYPL. In collection of Howard Sill, Esq., Baltimore.

386. - In Congress.| December II, I776.| Whereas, the just War into which the United | States of America have been forced by Great Britain, is | likely to be still continued by the same Violence and Injus-| tice which have hitherto animated the Enemies of American Freedom:| ... Extracts from the Minutes,| Charles Thomson, Secretary.| Baltimore: Printed by John Dunlap.| [1776.]

Broadside $13 \frac{1}{4} \times 8 \frac{1}{8}$ inches.

Recommending a day of solemn fasting and humiliation, the date of which each State was to fix as "most proper for their several bounds."

Congress adjourned at Philadelphia on Dec. I I th to meet in Baltimore on the 2oth, when it is likely that this ! roadside was published. See Ford, "Bibliographical Notes," No. ${ }_{3} 6$.

MDioc. NYPL.

387 - In Congress.| December 23, I776.| Resolved, That the Assemblies, Conventions, Com-| mittees or Councils of Safety, and other Persons that are or | may be entrusted with Money for the Militia reinforcing the Armies . . . Baltimore: Printed by John Dunlap.| [I776.]

Broadside. $9^{\frac{1}{4}} \times 7^{\frac{1}{4}}$ inches.

Directs those named to transmit to the paymaster-general the receipts of officers to whom payment has been made. See Ford, "Bibliographical Notes," No. 138.

MdHS. NYPL.

388. - In Congress.| December 30, 1776.| It appearing to Congress that it will be extremely difficult, if not / impracticable, to supply the army of the United States with | Bacon, Salted Beef and Pork, Soap, Tallow and Candles, unless the / Exportation thereof be Pro- 


\section{Faryland Imprints of the Colonial Period, $1689-1776$}

hibited. Therefore | . . . By Order of Congress.| John Hancock, President.| Baltimore: Printed by John Dunlap.| [1776.]

Broadside. $12 \frac{7}{8} \times 7 \frac{15}{16}$ inches.

Resolution prohibiting exportation of the articles named until November, 1777. See Ford, "Bibliographical Notes," No. 139.

MdHS. LC. (Ms. Div.)

389. - In Congress. | December 31, 1776.| Resolved,| That any Restrictions heretofore imposed upon | the Exportation of Staves, or other lumber, except to Great-Britain, Ireland and the British Islands, or any Place under the Dominion of Great-Britain, cease.| By order of Congress,| John Hancock, President.| Baltimore: Printed by John Dunlap.| [1776].

Broadside. $5^{\frac{3}{3}} \times 6 \frac{1}{2}$ inches.

MdHS.

390. Winchester, Elhanan. Thirteen hymns suited to the present times: containing the past, present and future state of America. Baltimore: Printed by Mary K. Goddard. I776.

Evans, No. 15222, gives this title, but does not locate a copy. See below, No. 39 r.

39I. - Thirteen Hymns,| suited to the present Times:| Cotainging [sic]; the past, present, and future State of America; with Advice to Soldiers and Christians.| Dedicated to the Inhabitants of the United | Colonies.] By Elhanan Winchester.| [Three lines from Psalm cxviii. xxv.] The Second Edition.| Baltimore:| Printed by M. K. Goddard, in Market-| Street, M,DCC, LXXVI.|

Sm. 8vo. A-B ${ }^{4}, C^{2}$; 10 leaves; pages [r]-20; p. [r]: title; pp. [3]-20: text, with heading, Thirteen Hymns, suited to the present Times:| Containing, the past, present, and future State of | America: Dedicated to the Thirteen United | Colonies.|

Leaf measures: $6 \frac{9}{16} \times 4$ inches. Type page, p. 4:125 mm. in height.

The Rev. Elhanan Winchester was born in Brookline, Mass., in 1751 . He became the first minister of the Baptist Church in Newtown, Mass., and in 1778 was to be found teaching Calvinistic doctrines on the Pedee River, S. C. In $178 \mathrm{I}$ he became a preacher of the Universal Restoration in Philadelphia. Died in Hartford, Conn., in April 1797. Author of various collections of sermons and hymns, and of works of theology. Allibone refers to a sketch of his life and a review of his writings by William Vidler. 1797. 8vo.

BA. (in Washington Collection.)

\section{7}

392. United States of America. In Congress, July 4, 1776.| The Unanimous | Declaration | of the | Thirteen United States of America.| [Signed, John Hancock and all except one of the signers.] In Congress, January 18, I777.| Ordered,| That an authenticated Copy of the Declaration of Independency, with the Names of the Members of Congress, subscribing the same, be sent to Each / of the United States, and that they be desired to have the same put on Record.| By Order of Congress,| John Hancock, President.| Baltimore, in Maryland: Printed by Mary Katharine Goddard.| [1777.]

Broadside. $20 \frac{3}{6} \times 16 \frac{3}{4}$ inches.

The first issue of the Declaration of Independence printed with the names of the signers. Library of Congress copy is attested in long hand by Charles Thomson, Sec'y, and John Hancock, President. Signatures of signers do not include Thomas McKean of Delaware who was in the field with the army and signed the document only in 1781. This session of Congress was held in Baltimore, and Mary Goddard acted as its printer. There is a copy of the broadside in the Ms. Div. of the Library of Congress, and another in the State House, Annapolis. (Ford, Bibliographical Notes, No. 117 ).

The entry above of a Maryland printed copy of the "Declaration of Independence" is the crown of the task which the compiler set himself in attempting to record through the production of its press the development in social and political ideals of one of the oldest of the American commonwealths.

$[255]$ 


\section{A History of Printing in Colonial SCaryland}

\section{ADDENDA}

\section{7}

After the foregoing bibliography was in page form, the compiler found in the Benedict Catalogue (item No. 80) a description and title-page reproduction of a variant edition of the Laws of Maryland of October 1727, the earlier edition of which is entered in this bibliography as No. 39. The variant is given below as No. 39 a.

39a. Laws of Maryland.| Enacted | at a Session of Assembly, begun and held | at the City of Annapolis, on Tuesday the | Tenth Day of October, in the Thirteenth Year | of the Dominion of the Right Honourable | Charles Lord Baron of Baltemore,| Absolute Lord and Proprietary of the Pro-f vinces of Maryland and Avalon, \&c. Annoq; Domini 1727.| To which are added,| Some Laws that were omitted to be Collected | in the bound Volume [.] As also the Speech | of His Excellency the Governour, and the | Addresses of both Houses, and the Answers | thereto, at the opening this Session.| [Baltimore Arms.] By Authority.| Annapolis:| Printed and Sold by William Parks. MDccxxvir. Price Two Shillings.|

Sm. fol. I preliminary leaf, A-F², G1; $1_{4}$ leaves; pages [i-ii], I-26; p. [i]: title; pp. I-4: the speech of his Excellency with addresses of both Houses and replies; pp. 5-23: Acts of Oct. 1727, with session heading and running heads; p. 23, list of 16 private acts, and two resolutions of Lower House; pp. 24-26: "The following Laws made in October Assernbly 1722," etc; p. 26: "Advertisement."

Leaf measures: $1 \mathrm{I} \frac{1}{6} \times 7$ inches.

The correct date of the beginning of this Session was, as given above, "Tuesday the Tenth Day of October," and not "Thursday the Tenth Day of October" as given on the title-page of the Maryland Historical Society copy, recorded as No. 39 of this bibliography. The corrected title-page and the corrected pagination establish the Benedict copy clearly enough as a later issue than that recorded here as No. 39 . In the later issue, the titlepage, many headings of acts and in some cases whole pages have been reset, and the book has been reimposed with correct pagination. Copies of this corrected issue are in the following libraries:

BBL. (imp.) NYSL. (imp.) MassHS. HLS. MDioc. (imp.) 
I N D E X

$\&$ 


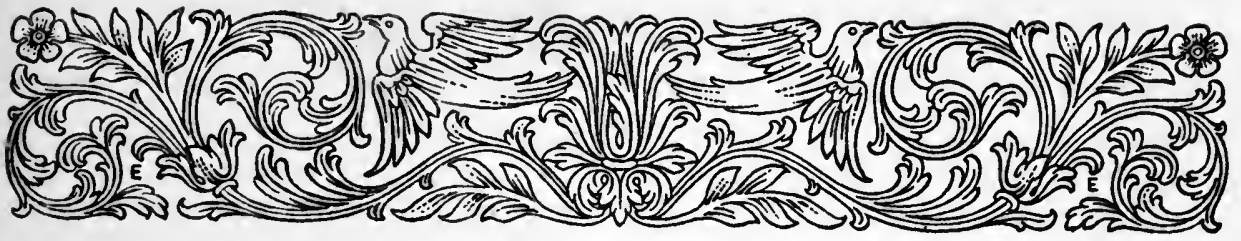

\section{$I N \mathcal{D} E X$}

References in this Index preceded by "No." are to the entries in the bibliographical portion of the work. All other references are to pages in the narrative portion. The letter " $n$ " after a number indicates that the reference is to a footnote on the page in question.

Abridgement and Collection of the Acts of Assembly of the Province of Maryland, by James Bisset, 102, 103, 103n; No. 215.

Abridgement of the Laws in Force and Use in Her Majesty's Plantations (1704), 25, 26; No. Io.

Acadians in Maryland, 96.

An Account Shewing the Progress of the Colony of Georgia, No. 106.

"Act Ascertaining the Laws of this Province" (1699), see "Ascertaining Act" (I699).

"Act for Repealing certaine Laws in this Province and Confirmeing others," see "Confirming Act" ( 1700 ).

Acts of Assembly of the Province of Maryland, see Maryland, Session Laws of.

Adams, Samuel, 138n.

Address and Resolves of the Lower House of Assembly of Maryland (1722), 56, 57n; No. 32.

Address of the Representatives (1689), 6-8; No. I.

Advertisement, Nos. 36a, 99, 109, 178, 278.

Aikenhead, Catherine (Hasselbach), I I2n.

Aikenhead, George, I12n.

All Saints Parish, Frederick County, Maryland, $96 \mathrm{n}, 97$.

All the Laws of Maryland Now in Force (1707), 28-33; No. 17.

Allen, Bennet (the Rev.), 91n, 96n, I I3n; Nos. 278, 279, 295.

Allen, C. D., American Book-plates, cited 89. Allen, Ethan (the Rev.), Historical Notices of St. Ann's Parish, cited, $4 \mathrm{In}$; List of Works by Maryland Clergymen (ms.) cited, 14n; article in Sprague's Annals (Epis.), cited, 98n.
Almanacs, Warner, John (1729), No. 48; (1730), No. 58; (1731), No. 69; Grew, Theophilus (1733), No. 75; (1734), No. 82; (1735), No. 86; Maryland Almanack 1751, No. 144; (1752), No. 155; (1753), No. 161; (1754), No. 174; (1756), No. 193; (1757), No. 194; (I758), No. 20I; (I 759), No. 214; (1761), No. 226; (I762), No. 232 ; $(1763)$, No. 241 ; ( 1764$)$, No. 246; ( 1765$)$, No. 252; (1767), No. 275a; (1768), No. 276; (1769), No. 283; (1770), No. 292; (I771), No. 301; Cockburn, Poor Robert Improved (1772), No. 303; Maryland Almanack (1773), No. 314; (1776), No. 36r.

An Seine Excellenz Horatio Scharpe, Esqueir, No. 287.

Anderson Galleries, New York, 35n.

Angell, Abigail, see Goddard, Abigail (Angell).

Angell, Avery F., Genealogy of the Descendants of Thomas Angell, cited, $142 \mathrm{n}$.

Angell, James, I42, $142 \mathrm{n}$.

Annapolis, Maryland, 60, 75, 1 1 8; Bye-Laws and Charter of, Nos. 146, 291 and 292; Post Office in, I $34 \mathrm{n}$; Printing in, probable establishment of, by Dinah Nuthead (1696), I2-1 5; Bladen-Reading press, 1726; Reading press, 27-37; Zenger's press, 49-53; Michael Piper's abortive press, 5354; the Parks press, 59-74; the Green press, 75-94; James Hayes's press, II 7 , 118.

Anne by the Grace of God, etc., (court summons), No. 8.

Anne, Queen of Great Britain, orders revision of laws (1703), 29; orders second revision (1715), 42, 45 . 
Anno RegniGeorgiiIII (StampAct), No. 259 . "Answer" of the Assembly to Governor's "Speech" of 1708 , printed, 35; No. 21.

Answer to the 2ueries on the Proprietary Government of Maryland, No. 248.

Archives of Maryland, IIO; cited in footnotes passim.

Armbruester, Anthony, I I 2, I 5 .

Arms of Maryland, Cut of, for Bacon's Laws, asked for by Sharpe, 107; engraved by Thomas Sparrow, I09; another cut of, on title-page of Session Laws of 1765 , 109.

Arnold, S. G., History of the State of Rhode Island, cited, I2In.

Articles of Capitulation (Montreal 1775), No. 344.

"Ascertaining Act" (1699), 23, 29.

"Ashby," Talbot County, Maryland, 3in. Assembly of Maryland, passim; publications of, see Maryland, Assembly Documents; Maryland, Compiled Laws of; Maryland, Session Laws of; Maryland, Votes and Proceedings of.

The Assembly's Answer to his Excellency's Speech (1708), 35; No. 21.

Association of the Freemen of Maryland (1775), No. 359.

At a full Meeting of the Inhabitants of AnneArundel County (1775), No. 343.

At a General Meeting of the Freeholders (1774), No. 324.

At a Meeting of the inhabitants of the City of Annapolis (1774), No. 325 .

Bache, Richard, 134 .

Bacon, Sir Anthony, 107.

Bacon, Elizabeth (Bozman), 96, 97.

Bacon, (John?), son of Thomas Bacon, 97.

Bacon, Nathaniel, Rebellion of, versified by E. Cooke, 68; see also The Maryland Muse, No. 70.

Bacon, Thomas (the Rev.), 25n, 30, 3I, 3I n, 43,63 ; birth (1700), 95; work on the Revenue of Ireland, 95, 95n, 97; ordination and emigration to Talbot County, Maryland, 96; character and characteristics, $96,96 \mathrm{n}$; second marriage and its unfortu- nate circumstances, 96 ; other troubles, 97 receives honorary office from Lord Baltimore, 97; becomes rector of All Saints Parish,Frederick County, 97; death (1768) and obituary, 97 ; beginning of work on the Laws of Maryland, 98; despondency, 99; progress and completion of his work, 99-110; Nos. 163, 254.

Bacon's Laws of Maryland at Large, 25, 30, $45,46,50$, $63,79,82,84,89 ; 95$-I IO; sketch of compiler, 95-98; beginning of the work as an abridgement, 98-99; determination to make a complete body of laws, 99; political objections to its publication, 99IOO; its legislative adventures, 100-102; Gov. Horatio Sharpe's plan for its publication, 103-105; terms of subscription, cost, etc., 104, 105n; the plan of the work, 105-106; its completion, 106; its printing by Jonas Green, 107-110; transmittal to the Board of Trade, I09; a description of the finished work, Iog-I Io; title-page reproduced, 108; date of publication questioned, IO9-IIO; its value from various standpoints, IIO; a typographical monument of the colonial American press, 110.

Bailey, Francis, of Lancaster, Pennsylvania, II $\mathrm{n}, \mathrm{II} 4$.

Baldwin, E. H., Foseph Galloway, the Loyalist Politician, 125n, I27n.

Baltimore, Charles Calvert, 3rd Lord, 8.

Baltimore, Charles Calvert, 5th Lord, 45, 46, 67.

Baltimore, Frederick Calvert, 6th Lord, 102n, 103-105, 105n.

Baltimore, Maryland, Description of ( 1764 ) I I ; first press in (I 765), I I I-I I 4; first imprint, No. 262; other presses, I1 4-I I 8; William Goddard (1773) establishes press and first newspaper, 128-1 29; Post Office in, 133; press riots in, during Revolution, 135-1 40.

Bartgis, Matthias, printer of Frederick, Maryland, 146.

Baskett, John, London printer, 46.

Bass, J. L., "Flint Genealogy," cited, $77 n$.

Beale, John, 41, 62. 
Becker, Elizabeth, see Curzon, Elizabeth (Becker).

Beckett, William (the Rev.), No. 49.

Bennett, Richard, No. I65.

Berkeley,SirWilliam, Governor of Virginia, I.

Bibliotheca Scriptorum Societatis Fesu, cited, I 48.

Birrell, Augustine, cited, 99.

Bissett, James, Abridgement of the Laws of Maryland, 102, 103, 103n; No. 215.

Bladen family, $19 n$.

Bladen, Anne, 19.

Bladen, Anne (Van Swearingen), 19.

Bladen, Thomas, Governor of Maryland, 19.

Bladen, William, I I 1 7-27; services to Province, 18-19, 23 ; proposes to establish press, I 8; brings in a printer, Thomas Reading, 19; begins to operate press, 21; Assembly encourages him by ordinance, 21 ; the early work of his press, 21, 22; authorized to print compiled laws, 22, 23; ordered to correct mistakes in printing laws, 24 ; dedication of, to, 24 ; retires from publishing business, 26 ; mentioned, 29, 36, $54 \mathrm{n}$; possibility that session laws were printed by, 36; death and inventory of estate, 37 .

Bladen-Reading press, see Bladen, William, and also Reading, Thomas.

Board of Trade and Plantations, I, 2, 7, 8, 19, 29n, 45, 104, 107, 109.

Bohemia Manor, Maryland, 55 .

Bonnet, Captain Stede, $47 n$.

Bookbinding in Maryland, 71, 87n.

Bookselling in Maryland, Evan Jones, 22, 40; William Parks, 71; William Rind, 85; William Goddard and Eleazer Oswald, 138; Mary K. Goddard, I44, 145.

Bordley, John, 25n.

Bordley, Stephen, ro5n.

Bordley, Thomas, 29n, 4I, 44, 56, 57, 57n, 58,59 .

Bozman, Elizabeth, see Bacon, Elizabeth (Bozman).

Bradford, Andrew, 33, 39, 42, 43n, 44, 45, $49,55,56,57,59,63,71,75,102$.

Bradford, Major John, 40.

Bradford, Mary, see Jones, Mary (Bradford).
Bradford, William, printer of Philadelphia and New York, 28, 49, 52, 52n.

Bradford, William, printer of Philadelphia (grandson of preceding), 102, 124.

Bradley, Robert, 34 .

Bray, Thomas (the Rev.), Necessity of an Early Religion, 20, 21, 22; No. 5 .

Brice, John, 105n, 106; No. 176.

The Brig Peggy Stewart, Captain Jackson, from London (1774), No. 323.

Brigham, C. S., Bibliography of American Newspapers, I600-1820, cited, 70n; 84n; 93n, II7n.

Brogden, William (the Rev.), Freedom and Love, 8on; No. 140; Popish Zeal Inconvenient to Mankind, No. 177.

Brotherly Love explain'd and enforc'd, by the Rev. John Gordon, No. I4I.

Brown, John Carter, I 2 In.

Bruce, P. A., Institutional History of Virginia in the I7th Century, cited, 3n.

Buchanan, John, Iog.

Buckingham, J. T., Specimens of Nerwspaper Literature, cited, 123 n.

Buckner, John, I-3.

Burlington, N. J., I23.

By Command of the King of Kings, No. 326.

By his Excellency. Proclamation, (1760), No. 222; (1760-1768), No. 223; (1763), No. 245; (1771), No. 307.

By the King. A Proclamation Declaring the Cessation of Arms, No. 244.

Bye-Laws of the City of Annapolis, Nos. 146, 291 and 292.

"The Bystander" see Allen, Bennet.

“C. D." see Dulany, Walter.

Calhoun,James, Mayor of Baltimore,139,140.

"Callister Letters," cited, 96n.

Calvert, Benedict, I05n; No. 178.

Calvert, Benedict Leonard, Governor of Maryland, 62, 65, 65n.

Calvert, Cecilius, secretary to Lord Baltimore, 102, 103, 104, 107, 109.

Calvert, Charles, Governor of Maryland, 44, 62; The Speech of His Excellency Coll. Charles Calvert, No. 29. 
Calvert, Charles, Lord Baltimore, see Baltimore, Charles Calvert, 3rd and 5th Lords.

Calvert, Frederick, Lord Baltimore, see Baltimore, Frederick Calvert, 6th Lord.

Calvert Papers, cited, IO2n.

Camm, John (the Rev.), $A$ Single and Distinct View of the Act, Vulgarly Entitled, the Two-Penny Act, title-page of, reproduced, 86; referred to, 87 ; No. 243 .

Campbell, B. U., cited, 147 .

Carmen Seculare, by Richard Lewis, 67; No. 76.

Carroll, Charles, of Annapolis, 105n.

Carroll, Charles, barrister, 105n.

Carroll, Hugh F., Printers and Printing in Providence, 1762-1907, cited, I21n.

Carroll, James, 6 on.

Carter, John, I2In.

Carvile, Robert, 13.

The Case between Philip Hammond and the late Vachel Denton, Stated, by John Brice, No. 176.

The Case of the Clergy of Maryland, by the Rev. Jacob Henderson, No. 6I.

Catechism, Church of England, No. 57.

Catechism in the Indian dialect, by Father Andrew White, I47-I 49 .

"Caveto," see Chase, Samuel.

Chamberlaine, Samuel, $105 \mathrm{n}$.

Charity Working School, Talbot County, Maryland, established by ThomasBacon, 96.

The Charter of Maryland, together with the Debates and Proceedings, (1725) 59; No. 33; Charter (1751), No. I 52; Charter and Laws (1754-1758), No. 207; Charter (1765), No. 254.

Chase, Samuel, 136n, 137; To the Public, No. 263.

Chestertown, Maryland, 50-53.

Chestnut Hill, Pennsylvania, I I $2 n$.

Chilton, Mrs., I 28.

Christie, James, Jr., Nos. 347 and 348 .

Church of England-Man's Private Devotions, No. 59.

Church of England in Maryland, 39; Nos. 6, 30, 61, 6In, 295.
Clapham, John, 76n, 9In, I I3n.

Clapham, Rebecca (Green), 76n.

Clarke, Richard H., cited, 147.

Cockburn, Robert, No. 303 .

Cockshutt, Thomas (the Rev.), 28n; Sermon, No. II.

Collection of all the Laws of this Province, relating to the Inspection of Tobacco, 1747 1750, No. 153.

A Collection of the Governor's Several Speeches, 79; No. 94.

Compass, variation of, Bill concerning the, No. 304 .

A Compleat Collection of the Laws of Mary. land (1727), No. $3^{8 .}$

A Compleat System of the Revenue of Ireland, by the Rev. Thomas Bacon, 95, 95n, 96n.

Coney, Peregrine (the Rev.), 10, 14; Sermons, Nos. 3 and 4.

"Confirming Act" (170), 23, 24, 29.

Connecticut Gazette, 120.

Considerations on the Propriety of Imposing Taxes in the British Colonies, by Daniel Dulany, Jr., Nos. 255-258.

Constitution and Form of Government Proposed for Maryland (1776), No. 373.

The Constitutional Courant, I23, $123 \mathrm{n}$.

Constitutional Post Office, see Post Office, Constitutional.

Continental Congress, Extracts from the Votes and Proceedings of (1774), Nos.336 and 337 .

The Contract, by a Buckskin, No. 296.

Coode, John, 4, 7, 8, 10.

Cooke, Ebenezer, 65, 67-68, 70; History of Colonel Nathaniel Bacon's Rebellion in Virginia, 68; No. 70; The Sot-weed Factor; or, a Voyage to Maryland, 67, 68n; No. 70; Sotweed Redivivus, No. 60.

Copley, Sir Lionel, Governor of Maryland, I 8 n.

Cowan, James, printer, 146 .

Cradock, Thomas (the Rev.), Nos. 122, 189.

Culpeper, Thomas, Lord, I.

Cummings, Archibald (the Rev.), No. 50.

Curson, see Curzon.

Curtis, Michael, No. 124. 
Curzon, Elizabeth (Becker), 52.

Curzon, Richard, 52 .

"D., C." see Dulany, Walter.

Darnall, Henry, 8, 9; No. 51 .

Daye, Matthew, 75, 76 .

Daye, Stephen, 75 .

"Debates and Proceedings" (1725), see The Charter of Maryland, together with the Debates and Proceedings (1725).

The Declaration and Charter of Rights (Maryland, 1776), No. 374 .

Declaration of Independence, No. 392.

A Declaration of Rights and Constitution Agreed to by the Delegates of Maryland (1776), No. 375.

The Declaration of Rights and Constitution Established by the Convention of Maryland (I 776 ), No. 376.

The Declaration of the Reasons and Motives for the Present Appearing in Arms, 4, 5, 7, 8; No. 2.

Denton, Vachel, 62 ; No. 176.

The Deputy Commissary's Guide, by Elie Vallette, No. 338.

"A Description of Maryland," by Richard Lewis, $67 \mathrm{n}$; No. 76n.

$A$ Detection of the Conduct and Proceedings of Messrs. Annan and Henderson, by John Redick, No. 262.

Devitt, E. I. (the Rev.), cited, 147.

Devoran, Catherine, I4.

Devoran, Dinah (Nuthead), 14, I $5,15 n$.

Devoran, Manus, 14.

Dickinson, John, Letters from a Farmer, 125, 125n.

Dorsett, James, 138n.

Dowig,Catherine (Hasselbach)(Aikenhead), II $2 n$.

Dowig, George, I1 2 .

Dulany, Daniel, the elder, $57 \mathrm{n}, 63,65$; No. 6In; The Right of the Inhabitants of Maryland to the Benefit of the English Laws, No. 42.

Dulany, Daniel, Jr., 87, 100, I05n; Considerations on the Propriety of ImposingTaxes in the British Colonies, title-page of, re- produced, 78; Nos. 255-258; The Right to the Tonnage, No. 265.

Dulany, Walter, 88, 9I, 99n, 105n.

Dulany Papers, cited, 99, ro5n.

Dunlap, John, printer, of Philadelphia and Baltimore, II6-117.

Dunlap, William, printer, of Philadelphia, I 6.

Dunlap's Maryland Gazette: or the Baltimore General Advertiser, I I 7; Nos. 349, 370.

The Duty both of Clergy and Laity to each other, by the Rev. William Beckett, No. 49.

Duvall, Gabriel, $88 \mathrm{n}, 89$.

Easton, Maryland, Printing in, 146.

Effingham, see Howard of Effingham, Lord Francis.

Eliot, John (the Rev.), 75, 76.

Elkridge Paper Mill, I38, I38n.

Engraving in Maryland, 87-88.

An Essay on the Culture and Management of Hemp, Nos. 350 and $35 \mathrm{I}$.

Evans, Charles, American Bibliography, 2n, $70 \mathrm{n}, 72 \mathrm{n}, 84,84 \mathrm{n}, 116 \mathrm{n}, \mathrm{I} 23 \mathrm{n}, \mathrm{I} 24 \mathrm{n}, \mathrm{I} 4 \mathrm{In}$.

An Exhortation to the Clergy of Pennsylvania, by the Rev. Archibald Cummings, No.50.

An Explanation of the Feasts and Fasts, No. 59 .

Extract of a letter from New York, dated Aug. 28 , 1776, No. 37 I.

Extracts from the Essays of the Dublin Society Relating to the Culture and Manufacture of Flax, No. 135 .

Extracts of private Letters from London (1774)

No. 327.

The Farmer's Companion, by Abraham Milton, Nos. 234 and 235.

Fiddis, Preston, Anecdote related by, 1 I 4 .

Fisher, Edward, 4.

Flax, Culture of, No. 135 .

Fletcher, W. G. D. (the Rev.), cited, 74n.

Flint, Mary, mother of Jonas Green, 76.

Florus Anglo-Bavaricus, cited, 148.

Foley, H. J. (the Rev.), ed., Records of the English Province of the Society of Fesus, cited, 148. 
Ford, Paul Leicester, ed., Fournals of Hugh Gaine, Printer, cited, 7 In.

Forms, Official, Nos. 8, 131, 223, 264, 316, $372 a, 377$.

Fox, 127 n.

Foxcroft, John, deputy postmaster general, $133,134 \mathrm{n}$.

Franklin, Benjamin, 52n, 54n, 73, 75, 79, 82, $83,103,123 \mathrm{n}, 124,125,126,126 \mathrm{n}, 127 \mathrm{n}$, I 29n, I30, I3 I, I34, I34n.

Franklin, Mrs. Benjamin, I24.

Franklin, Gov. William, of New Jersey, I 23; letters to Benjamin Franklin, I24, I3I.

Franklin and Hall, printers, of Philadelphia, 123, 124 .

"Franklin Papers," cited, 124n, 127n, I31, I3In.

Frederick, Maryland, 97, Printing in, 146; Nos. 133, I34.

Freedom and Love, by the Rev. William Brogden, No. 140.

Freeholder, Letter from a, No. 37 .

Fresh Intelligence. Baltimore, August 10 (1775), No. $35^{2}$.

Gaine, Hugh, printer, 7I.

Galloway, Benjamin, cited, $137 n$.

Galloway, Joseph, I23; partnership with Goddard and Wharton, 124-127; Goddard's attacks on, 126-1 27.

Galloway, Samuel, I05n.

General Gage's Account of the late Battle at Boston (1775), No. 353.

Georgia, Trustees of, No. 106.

German printing in Maryland, I I3, II4.

Gerrevink, L. Van, papermaker in Holland, I IO.

Ghiselin, Reverdy, 106.

Gittings-"the Widow Gittins," married to Thomas Reading (1705), 28.

Goddard, Abigail (Angell), I 42n.

Goddard, Giles, I20, I29.

Goddard, Mary Katherine, I5, I16, 118 , I I $\mathrm{n}, \mathrm{I} 2 \mathrm{I}, 126 \mathrm{n}, 129, \mathrm{I} 30,133,133 \mathrm{n}, 135$, I 38,140, I 4 I, I 4 I n; summary of her work as printer and publisher, and as postmistress of Baltimore, 144-I 46 .
Goddard, Sarah (Updike), 15, 120, 121, 121 n. Goddard, Sarah and Company, I2I.

Goddard, William, printer and journalist, I I 2, I I 2n, I I4, I I6, I 18, I I 9 -1 46; sources of information concerning, 119n, 12 In; patriot or loyalist in Revolution, I19-120, 125, 143; birth and ancestry, 120; apprenticed to James Parker and John Holt, New Haven, I20; establishes first press and newspaper in Providence, R. I., I20I2I; removes to New York, 122; prints the Constitutional Courant, 123; removes to Philadelphia and establishes the Pennsylvania Chronicle, 124 ; falls out with his partners, 125-126; financial troubles and failure of the Chronicle, 127; removes to Baltimore (1773) and establishes Maryland Fournal, 128-129; establishes Constitutional Post Office, 129-134; becomes Surveyor of the U.S. Post Office, 134; defalcation as postmaster of Providence, I $34 \mathrm{n}$; petitions Congress for commission in army, 134-135; returns to Baltimore, 135; defends the freedom of the Press, 135-136; the "Tom-Tell Truth" episode, and the "Queries" of General Charles Lee, I 36-I 40; conflicts with the Whig Club and the Baltimore mob, 136-140; partnership with Eleazer Oswald, $137-14$ I ; legacy from General Charles Lee, I4I; literary executor of General Lee, I 4 In; resumes publication of Maryland Fournal, I4I ; partnership with Edward Langworthy, I4I; with James Angell, 142; marriage, 142n; farewell to Baltimore (1792), I42; retirement to Johnston, R. I., 142; death there (I817), I43; summary of character and achievements, 143 .

"Goddard's Post Offices," I33, I33n; see also Post Office, Constitutional.

Goldsborough, Robert, 3 In.

"Good Intent," Proceedings of committee on, No. 299.

Gordon, John, Nos. 11 7, I 41.

Gould, John, 5 I.

Gover, Samuel, 54. 
"Government and Judicature"of Maryland, Debates on, 57 ; No. 33 .

Governors' Speeches, see Maryland, Assembly Documents.

Great Britain, Nos. 8, $147,148,244,259$, 354, 372.

Green family, Long connection of, with American printing, 75-76, 94; Maryland branch of, 76; children of Jonas and Anne Catharine Green, 76; Anne Catharine (2d), Augusta, Catherine, Deborah, Elizabeth, Frederick, John, Jonas (two of the name), Marie, Mary Rebecca, Samuel, William, $76 \mathrm{n}, 77 \mathrm{n}$.

Green, Abigail, see Rind, Abigail (Green).

Green, Anne Catharine (Hoof), 15 ; marries Jonas Green, 76; their children, 76n; continues press after husband's death, 84 ; employment of Thomas Sparrow, engraver, 89; address to the public, 90; appointment as public printer, 90-9I; some issues of her press, $9 \mathrm{I}$; controversy with Parson Allen, 91n; various firm names of Anne Catharine Green and sons, 93; death and obituary, 93; character, 93 .

Green, Frederick, 76n, 93, I 18.

Green, Jonas, 46, 75-94; ancestry; 75-76; early life, 76; prints alone in Boston, 76; prints in Philadelphia, 76; marries and removes to Annapolis, 76; children, 76, $77 \mathrm{n}$; date of coming to Maryland, 77; becomes public printer, 77; earliest Maryland imprints, 78-79; skill as printer, 79; civic and social activities, $80-8 \mathrm{I}$; membership in Tuesday Club, 8I; establishes second Maryland Gazette ( 1745 ), 82; letter from, to Franklin, 82; his printing house, $8 \mathrm{In}$; conduct during the Stamp Act controversy, 83; edition of Bacon's Laws of Maryland, 84; partnership with William Rind, 85 ; association with Thomas Sparrow, engraver, 87-89; death, 84; widow and sons, 90-94; proposes to issue body of laws, $98 \mathrm{n}$; printing equipment, 153 ; acts for his encouragement and other official relations with the Assembly, I 5 I-1 53; mentioned, in connection with printing of
Bacon's Laws of Maryland, 95, 107, 109, I IO; Nos. 236, 237.

Green, Jonas, grandson of Jonas Green(Ist), 93, 94.

Green, Mary (Flint), 76.

Green, Mrs. Nicholas Harwood, $82 \mathrm{n}$.

Green, Samuel, printer, of Cambridge, Massachusetts, 75, 76, 94 .

Green, Samuel, son of Jonas, 77n, 93, I 8.

Green, "Deacon" Timothy, father of Jonas, 76.

Green, Timothy, brother of Jonas, 76, 77n.

Green, William, 76n, 90, 91 n, 93; No. 280.

Green and Rind, Publishers (1758-1766), 85 .

Grove,-(shipowner), Iog.

\section{“H. J.," see J., H.}

Hagerstown, Maryland, Printing in, I46.

Hall, David, printer, of Philadelphia, I24n.

Hall, Edmund, partner of William Parks, 70, 7 on.

Hall, William, printer, of Philadelphia, 115. Hamersly, Hugh, secretary to Lord Baltimore, Iog.

Hamilton, Dr. Alexander, of Annapolis, 76n; No. Iog.

Hamilton, Andrew, 42n, $52 \mathrm{n}$.

Hamilton's Itinerarium, $76 \mathrm{n}$.

Hammond, Philip, No. 176.

Hanrick-(ship captain), Iog.

Harrison, S. A., History of Talbot Co., Maryland, cited, $98 \mathrm{n}$.

Harrison, Thomas, I 12.

Hart, John, Governor of Maryland, 42.

Hartford, Connecticut, Postal Service with Boston, I3I.

Harvey, Abigail, see Rind, Abigail (Green).

Harvey, Edward, No. 355 .

Harwood, Mrs. Anne, 8 In.

Hasselbach, Catherine, wife of Nicholas Hasselbach, I I2, I I 2n, I I 4 .

Hasselbach, Nicholas, printer, of Philadelphia, Chestnut Hill and prototypographer of Baltimore, 112; activities of his press, I 2 2-I I 4 ; single known Baltimore imprint, I 3 ; questionableimprints, I I 3-I I 4 ; dea th II 2 . 
Hasselbaugh, see Hasselbach.

Hayes, James, Jr., manages John Dunlap's Baltimore office, I17; buys Dunlap's Maryland Gazette and conducts it (1778-1779), 117 ; removes to Annapolis and starts newspaper, I17-118.

Hearne, Thomas (the Antiquary), 65; Collections, cited, $65 \mathrm{n}$; Diary, cited, $67 \mathrm{n}$.

Hemp, Culture of, Nos, 350 and 351 .

Henderson, Jacob (the Rev.), Nos. 6r, 6in.

Henry, Patrick, 60.

Henry, Sarah (Shelton), 60.

Herbert, Stewart, printer, ${ }_{4} 6$.

Herman, Ephraim, Copies of some Records and Depositions Relating to Great Bohemia Mannor lying on Bohemia River in Maryland, cited 55 .

Hildeburn, C. S. R., A Century of Printing, the Issues of the Press in Pennsyluania, 1685-1784, cited, 12n; Sketches of Printers and Printing in Colonial New York, cited, I2n, 52n.

His Excellency's Speech (1708), 35; No. 20; (I719), No. 24.

His Majesty's Most gracious Speech (1775), No. 372.

The History of Colonel Nathaniel Bacon's Rebellion, by Ebenezer Cooke, No. 70.

Hodge, Robert, printer, of Baltimore and New York, i 15.

Hodge and Shober, I I4-I I 5; advertise printing office in Baltimore, 115 ; failure and removal to New York, II 5.

Holdsworth, Edward, 65 ; No. 43.

Holt, John, printer, I 20, I21, 122, I 29, I33, I $37 \mathrm{n}, 138,138 \mathrm{n}$.

Honig, G. J., cited, I Ion.

Hoof, Anne Catharine, see Green, Anne Catharine (Hoof).

Howard of Effingham, Lord Francis, 2, 3, I $8 \mathrm{n}$.

Hubbart, Tuthill, cited, I 3 In.

Hughes, T. A. (the Rev.), History of the Society of Fesus in North America, cited, $55 \mathrm{n}$, 148.
Important Intelligence from St. Fohn's (1775), No. 357 .

In Congress (Dec. 11, 1776), No. 386; (Dec. 23, 1776), No. 387; (Dec. 30, 1776), No. 388; (Dec.31 , 1776), No.389; (July 4,1776), No. 392.

Independence, Declaration of, No. 392.

Independent Gazetteer, published by Eleazer Oswald (1782), 140.

Intelligence by Express Last Night (1775), No. 346.

International Association of Antiquarian Booksellers, Catalogue issued by (I912), $73^{n}$.

It appearing to Congress (1776), No. 388 .

"J., H." addresses verses to Ebenezer Cooke, 68.

Jacques, Lancelot, 105n, 107, 110.

James, Abel, $127 \mathrm{n}$.

Jamestown, Virginia, Printing in, 1, 2.

Jefferson, Thomas, 85,87 .

Jesuit Press of St. Mary's City, Maryland, $147,148,149$.

Johnson, Thomas, Governor of Maryland, $105 \mathrm{n}, 139,140$.

Johnston, Christopher, cited, Ign.

"Join or die," motto used by Franklin, Goddard and Isaiah Thomas, 123, 123 n.

Jones, Evan, publishes Bray Sermon( 1700 ), 22; services to the Province, 40-41; petition to print compiled laws granted(1718), 41 ; printed by Andrew Bradford, 42; importance of this compilation, 42; Jones's "Preface," 42; publishes session laws (1719), 43; authorized to print tobacco laws $(1721 / 22), 44$; acts as provincial publication agent, 44; death (1722), 4I, 44; mentioned 51,63 .

Jones, Evan, Fr., 4on.

Jones, John, 4on.

Jones, Hugh (the Rev.), No. 1 I 3.

Jones, Mary (Bradford), 4on.

Jones, S., The Most Important Question, What is Truth, cited, $74 \mathrm{n}$.

Joppa, Maryland, Petition to remove court 
house from, to Baltimore, II3-II4; Nos. 285-287.

Fournal of the Votes and Proceedings of the Lower House of Assembly of Maryland, see Maryland, Votes and Proceedings of.

Fournals of the Continental Congress (Ford, ed.), cited, 133n.

Junta, (political organization), 125.

A Fust and Impartial Account, by Henry Darnall, No. $5 \mathrm{I}$.

Keimer, Samuel, 54n.

Keith, George, mission in Maryland; 27, 28; Fournal, 27n; Power of the Gospel in the Conversion of Sinners, 27; No. 9.

Kent County, Maryland, 50, 51 .

Kimball, S. G., Providence in Colonial Times, cited, I 2 In.

King William's School, Annapolis, Maryland, 54 .

Kneeland \& Green, printers, of Boston, 76.

Koch, Mr., papermaker in Pennsylvania, II 2 .

Langworthy, Edward, I4I, I4In; Memoirs of the Life of the Late Charles Lee, Esquire, cited, I4In.

Lawrence, Sir Thomas, 9 .

Laws of Maryland, see Maryland, Compiled Laws of, also Maryland, Session Laws of.

Laws of Maryland at Large, by the Rev. Thomas Bacon, No. 254 .

Laws of the British Plantations, by Nicholas Trott, No. 30.

Lee, Major General Charles, 137, 138, 138n, 139, I 40, I4I, I I I n.

Lee, J. W. M., Hand List of Maryland Laws, cited, 30 .

The Lee Papers, cited I4In.

A Letter from a Freeholder, No. 37.

$A$ Letter to his Excellency, by Jonas Green, No. 236.

Lewis, Richard, 65, 65n, 67, 70; translator of Muscipula, No. 43; author of Carmen Seculare, No. 76; Rhapsody attributed to, No. 77.

Liberty of the Press in Maryland, 135-137.
Library, Circulating, established by William Rind in Annapolis, 85; proposed in Baltimore, No. 322.

Library of Congress, 24, 26.

Literary beginnings in Maryland, 63-69.

Llewellin, John, 7 .

Lloyd, Edward, I05n.

Lords Commissioners of Trade and Foreign Plantations, see Board of Trade and Plantations; also Lords of Trade.

Lords of Trade, 1, 2, 7, 8; see also Board of Trade and Plantations.

Loudon, Samuel, printer, of New York, I 5.

Ludlow, England, 74 n.

Ludlow Post-Man, 74n.

M'Clellan, William J., cited, I I gn.

McCrady, Edward, History of South Carolina, cited, $47 \mathrm{n}$.

McCreary, G. W., The First Book Printed in Baltimore-Town, cited, I12n.

McMahon, J. V. L., An Historical View of the Government of Maryland, cited, 42, 42n, 43 .

Macnemara, Mr., 60.

McSherry, Father William, 147, 148, 149.

Maggot, Fr., 2n, $72 n$.

The Manual Exercise, by Edward Harvey, No.355.

Markland, J., Typographia, 73.

Marvel, Andrew, pseudonym of William Goddard, 123, $123 n$.

Marye, William B., Old Indian Road, cited, 6 on.

Maryland, Assembly Documents, Address of the Representatives (1689), No. I; His Excellency's Speech (1708), No. 20; The Assembly's Answer (1708), No. 21; His Excellency's Speech (1719), No. 24; The Speech of Coll. Charles Calvert (1721), No. 29; Address and Resolves (1722), No. 32; Charter and Debates and Proceedings (1725), No. 33; Governor's Speech and Assembly's Answer (1728), No. 45; UpperHouse Address and Governor's Answer (1729), No. 53; Governor's Speech (1730), No.64; Upper House Address and Governor's 
Answer (1730), No. 65; Lower House Address and Governor's Answer (1 730), No. 66; Governor's Speech (1732), No. 79; $A$ Collection of the Governor's Several Speeches (1739), No. 94; Upper House Address and Governor's Answer, No. 96; Council Proceedings (1739), No. I00; Governor's Speech (1740), No. IOI ; Report of Committee on the Fund Raised by Three Pence per Hogshead (1742), No. 108; Charter, No. 152 ; Upper House Address and Governor's Answer (1752), No. I 58; Same (1752), No. 164; Militia Bill (1756), No. 192; Supply Bill (1757), No. 206; "Three Bills" (Naturalization and two Supply Bills, I 760), No. 221; Governor's Proclamation regarding Boston fire sufferers (1760), No. 222; Form for prorogation of Assembly, No. 223; Council Proceedings (1761), No. 228; Lower House Address and Governor's Answer (176I), No. 229; Upper House Address and Governor's Answer (1761), No. 230; Supply Bill (1 762 ), No. 239; Proclamation (I 763 ), No. 245; Council Proceedings (I 756-1 764), No. 266; Proceedings of Committee on the "Good Intent" (1770), No. 299; Bill for redressing Evils Arising from Variation of Compass (1771), No. 304 ; Proceedings on Conference (177I), No. 305; Governor's Proclamation (1771), No. 307; Constitution and Declaration of Rights (1776), Nos. 373-376.

Maryland, Compiled Laws of, first compilation proposed ( 1696$)$, I 7 ; printed ( 1700 ), 23; corrections in, printed, 24; unique copy of, discussed, 24-27, and described, No. 7; second compilation printed ( 1707$)$, 28-29; discussed, 29-33; unique copy described 3 In, and No. I 7; third compilation printed (Philadelphia, I 7 I8), 4I-43; described, 42,43 , and No. 23; fourth compilation printed (London, I 723), 45-46; described, No.3I; fifth compilation printed (1727), 63; described, No. 38 ; sixth compilation printed (1765), 95-110; described, No. 254; Collection of all Laws Relating to
Inspection of Tobacco (1747-1750), No. 153; Bisset's Abridgement (1759), 102, 103, IO3n; described, No. 215.

Maryland, Council of, Proceedings (1740), No. 100.

Maryland Diocesan Library, Baltimore, 63 . Maryland Gazette (Ist), 63; heading reproduced, 69; established by Parks (1727), 69; description, 70; heading compared to that of the Ludlow Post-Man, 74n; entered in bibliography, Nos. $4 \mathrm{I}, 47,55,68,74$, $81,85,87$; second Maryland Gazette, established by Jonas Green (1745), 80; 82 85; published by Green \& Rind, $85-87$; continued by Anne Catharine Green, 90; continued by her sons and grandson until 1839, 91, 93; lapses and resumes, I1 7-118; in bibliography see entries under every year from 1745 to 1776 .

Maryland Gazette and Annapolis Advertiser, published by James Hayes, Jr., 117.

The Maryland Gazette and Baltimore General Advertiser, published by James Hayes, Jr., 117.

Maryland Historical Society, 22, 6on, 73n.

Maryland Fournal and Baltimore Advertiser, I16, I27; announcement and first issue of (1773), I28; Mary K. Goddard assumes control of, (1774), 129; William Goddard resumes control ( 1784$), I_{4} \mathrm{I}$; published by Goddard and Langworthy, 141 ; by Goddard and Angell, 142; Nos. 321,334, 362a, $382 a$.

The Maryland Muse, by Ebenezer Cooke, title-page of, reproduced, $66 ; 67,68,68 n$; No. 70.

Maryland, Printing in, fabled Jesuit press, I 47-I 49; establishment of first press, 3 ; regulation of, by Council, 8-9; extent and character of, in I 7 th century, II ; second press and its probable activities, 12-14; evidence for press in Maryland, in 17 th century, I 5-16; third press, the Bladen-Reading press proposed and established, 18, 19, $2 \mathrm{I}$; its imprints, 2I-26; fourth press, the Reading press conducted alone by Thomas Reading, 27-37; printing of Province 


\section{$I N \mathcal{D} E X$}

done by Andrew Bradford of Philadelphia through Evan Jones, 39-45; fifth press established by John Peter Zenger, 49-53; question of Michael Piper's press, 53-55; AndrewBradford again, 56-57; first period ends (1725), 58; sixth press established by William Parks, 59; greater dignity and permanency of press in Maryland from this time, 60; act of 1727 the first for encouragement of printing in Maryland, 60 , 149-I 50; literary and journalistic aspect, 63-70; seventh press established in Annapolis by Jonas Green, conducted by him and by his widow and sons and grandson until I 839, 75-94; the printing of Bacon's Laws of Maryland, the typographical monument of the Province, 95-1 IO; early printing in Baltimore, I I I-I I8; the Goddards in Baltimore and the struggle for the freedom of the press, $128-146$; the conclusion of the history of Maryland printing in the colonial period, 146 ; the printing equipment of a colonial Maryland establishment, I 53 .

Maryland, Session Laws of, beginning of printed series (1704), 33-36; edition of Philadelphia (1719), 33, 43-44; editions probably printed by John Peter Zenger (1720-1721), 50-51; beginning of uninterrupted series by Parks (1726), 63; for descriptions of printed laws of separate sessions, see Nos. 6, 12, 13, 15, 16, 18, 19, $22,25,26,27,28,34,35,39,44,52,62,7 \mathrm{I}$, $72,78,83,88,90,91,92,97,98,104,107$, I I I, I I 4 , I I $8, I_{2} 3, I_{24}, I_{2} 5$, I $28, I_{36}, I_{4} 2$, $149-151$; I $57,165,167,168,169,179-181$, 190, 191, 196, 197, 203-205, 219-221, 238, $249,250,267,268,275,282,297,298,306$, $3^{12}, 3^{17} 7,3^{18}, 330,33^{1}$.

Maryland, Votes and Proceedings of, beginning of series found in certain constitutional documents, 55 ; regular printing of, provided for, 61-62; for description of printed copies of individual sessions, see Nos. 32, 33, 40, 46, 54, 67, 73, 80, 84, 89, 93, 95, 102, 103, 105, I10, I12, I15, II9, I 20, I 26, I 29, I 30, I 37, I 38, I 43 , I 54, I 59 ,
I60, $170-173,182-184,198-200,208-21 \mathrm{I}$, $216,217,224,225,231,240,251,270,271$, $300,308,309,313,319,332$; for proceedings of Revolutionary conventions, see Nos. 328, 329, 358, 360, 378-381.

Massachusetts, Printing in, 12.

Massachusetts Spy, Motto of, I23n.

Mather, Cotton, 28.

Maul, Anna Catherina, 52.

Maury, James (the Rev.), No. 3 II.

Mereness, N. D., Maryland as a Proprietary Province, cited, Ioon, Io2n.

Metropolitan Catholic Almanac, cited, I47.

Metropolitan Magazine, cited, 147.

Milton, Abraham, Nos 234 and 235.

Monis, Judah, A Grammar of the Hebrew Tongue, 76 .

The Mouse-Trap, by E. Holdsworth, trans. by R. Lewis, No. 43 .

Muscipula, by E. Holdsworth, title-page of, reproduced, $64 ; 65$; No. 43 .

The Necessity of an Early Religion, by the Rev. Thomas Bray, 20, 21 ; No. 5 .

Negroes in Maryland, Bacon's interest in, 96. The New England Primmer, Edition of, attributed to Enoch Story, the younger (1775), i16; No. 363 .

New Tobacco Law, No. 63.

A New Version of the Psalms of David, by the Rev. Thomas Cradock, No. 189.

New-York Gazette and Weekly Post-Boy, 120, I 22.

New York, Printing in, 12, 39.

Newspapers in Maryland, first Maryland Gazette established by William Parks, (1727), 69; second Maryland Gazette established by Jonas Green (1745), 82-93; Maryland Fournal, established by William Goddard in Baltimore (1773), 116, 128129; Dunlap's Maryland Gazette, established in Baltimore (1775) by John Dunlap, I 17; carried on (1778-1779) by James Hayes, Jr., as The Maryland Gazette, and Baltimore General Advertiser, 117.

Nicholson, Francis, Governor of Maryland, $17,18 n, 23,28,29,53$. 
Non-importation agreement, Nos. 289, 290, $324,325,328$.

Nothead see Nuthead.

Now ready for the Press, No. 339.

Nulhead, see Nuthead.

Nuthead, Dinah, possession of press, 9; administratrix of William, Io; probable establishment of press at Annapolis, I 2; petition for license to print and her bond for good behavior as printer, 13; possible imprints, I4; second marriage, I 4 ; third marriage, 15 ; character and services of, 15 ; mentioned, 18.

Nuthead, Susan, or Susannah, I4, I $5 \mathrm{n}$.

Nuthead, William, 2-16; first employment as printer in Maryland, 3-4; land surveyed for, 4 ; spelling of name, $4 \mathrm{n}$; first imprint recorded, 4; first imprint extant, (Plate I), 6-8; deposition concerning illegal printing of warrants and action of Council, 8-9; signing of St. Mary's "Remonstrance," 9; death and inventory of estate, IO-I I ; equipment, I I ; summary of services, I 5-16; mentioned 58, 72 .

Nuthead, William, Jr., I4.

"Nutheads Choice," 4.

Nutthead, see Nuthead.

Oely see Oley.

Ogle, Samuel, Governor of Maryland, 72.

Oley, Dinah (Nuthead) (Devoran), i 5 .

Oley, Margaret, $15 \mathrm{n}$.

Oley, Sebastian, I $5,15 \mathrm{n}$.

Opdike, C.W., The Op Dyck Genealogy, cited, izon.

Oswald, Col. Eleazar, 137, I37n, 138, 139, I 39n, I 40, 14 I.

Paltsits, V.H., "John Holt, Printer and Postmaster," cited, I 20, I22n, I 29n, I 38 n.

Papermaking in Maryland, 138 .

Paper Mill, established by William Parks, at Williamsburg, 72-73; sale of, 73n.

Papers of George Washington, cited, I $4 \mathrm{In}$.

Papers of the Continental Congress, cited, I33n, I 34n, I 45n.

"Park Fiall," Carroll County, Maryland, 6on; in Prince George's County, Mary- land, 6on, 74n; at Oswestry, England, $74^{n}$; at Bitterley, England, 74n.

Parker, James, printer, 120, 121, 122, 129; "Letters of, to Benjamin Franklin,"cited, I2gn.

Parks, Eleanor, wife of William Parks, 60, $74 \mathrm{n}$.

Parks, Eleanor, daughter of William Parks, 60.

Parks, William, 2, 16, 33, 55, 58; 59-74; brought to Maryland by Thomas Bordley, 59; origin, 59,73-74n; descendants, 60; will and inventory, 6on, 73; "Park Hall," Maryland, 60; law of 1727 for his encouragement, 60, 149-1 50; proposals to Assembly, 60-6I ; discord between the Houses as to his title and as to what he should print, $61-62$; prints compiled laws of 1727 , known as "the old Body of Laws," 63; inaugurates a literary tradition in Maryland, 63-69; founds the Maryland Gazette, first newspaper South of Pennsylvania, 69-70; his partner and assistants, 7on; neglects part of duties and is admonished by act of Assembly (1737), 7I; removes to Virginia, 71 ; long and honorable service in Williamsburg, 72-73; builds in Williamsburg first paper mill south of Pennsylvania, 72; salary in Maryland and Virginia, 71n, 72; death (1750), 73; discussion of identity with William Parks, printer of Ludlow, Hereford and Reading, England, 73-74n; mentioned, 75, 76, 80 .

The Partnership, by William Goddard,cited, I In, I22n, I23, 123n, 124, I26, 126n.

Peabody Library of Baltimore, 3 In.

"Peggy Stewart" (brig), No. 323.

Penn, William, Printing disapproved by, $2 n$.

The Pennsylvania Chronicle and Universal Advertiser, Philadelphia, first issue of, 124 ; sketch of, 125-127; failure of, 127.

Pennsylvania, Delaware and Virginia Almanac and Ephemeris, edited by William Goddard (I784), I4I.

Pennsylvania Gazette, motto used on, 123n.

Pennsylvania Packet, I 6 .

Pennsylvania, Printing in, 2n, 12, 39. 
Piper, Michael, master of the Free School, Annapolis, proposes to print the session laws (1722), 54; fails to carry out proposals, 54-55; mentioned, 46n, 56, 65.

Pitt, William (Lord Chatham) Bill of, for setthing the troubles in America, No. 354.

"The Plan for Establishing a New American Post Office," I 32.

Pleasants, J. Hall, The Curzon Family of New York and Baltimore and their English Descent, cited, 52n.

Poor Robert Improved, by Robert Cockburn, No.303.

Popish Zeal inconvenient to Mankind, by the Rev. William Brogden, No. 177.

Post Office, British, in North America, 128 134; supplanted by Goddard's Constitutional Post Office, 134n.

Post Office, Constitutional, establishment of, by William Goddard, 129-135.

Post Office, United States, established as Constitutional Post Office by William Goddard, 129-135; No. $3^{84}$.

Poultney, William, bookbinder, $87 \mathrm{n}$.

The Power of the Gospel, in the Conversion of Sinners, by the Rev. George Keith, place of publication determined, 27 ; No. 9 .

Primers, Nos. 56, 57, 363.

Prince, Thomas, Chronological History of New England, 76.

Prince George's County is so very large, No. 133.

"Printer to the Province," origin and use of title, 6r, 6in.

Printing equipment in Maryland, Nuthead's I ; Bladen's 18, 21 , 22; Reading's, 21, 37; question of disposition of Bladen's press, $54,54 \mathrm{n}$; list of equipment owned by Anne Catharine Green, 153.

Printing in Colonies, chronology of, 12; royal instructions to governors concerning, I $8 \mathrm{n}$; scarcity of printers, 40; freedom of the press established by Zenger's trial, 49, and by Goddard's contests with the Baltimore populace, I36-1 40 : see also under names of individual colonies.

Privy Council, Office of, rog.
Proceedings of the Committee on the Brigantine Good Intent, No. 299; of the Congress at New York (Stamp Act), No. 273; of the Convention of the Province of Maryland, Nos. 328, 329, 358, 360, 378-381; of the Sons of Liberty, No. 274.

Proposals for a Tobacco-Law, No. 36; for Establishing a Circulating Library in Baltimore-Town, No. 322.

$A$ Protest against Popery, by the Rev.Hugh Jones, No. II 3 .

Protestant Association, No. 2.

"Protestant Declaration" 1689, see The Declaration of the Reasons and Motives for the Present Appearing in Arms.

Protestant Revolution in Maryland (1689), $3,4,7,8,99$.

Providence, R. I., first printing office established by William Goddard, 120 ; continued by Sarah Goddard and John Carter, I21, I2In.

Providence Gazette and Country Fournal, 121.

Providence Fournal, cited, $12 \mathrm{In}$.

Prowess of the Whig Club, cited, 137, 137 n.

Public Record Office, London, 7; documents in, cited, in, 2n, 5n, $7 n$.

Randall, J. W., Endowment Guild of St. Anne's Parish, cited, 4In.

Reading, Thomas, I I, I9-37; as Bladen's associate prints first compilation of Maryland Laws (1700), 24; the Bray and Keith Sermons (1700 and 1703), 21-22, 27; constituted public printer (1704), 28; marriage, 28; petition to print compiled laws (1707), 28; petition granted, 29; payment determined 29; editions of session laws discussed, 33-36; petition of, (1709), 34; death (1713), 36; services to the Province, 36-37; inventory of estate, 37 ; mentioned, 55,58 ; for imprints, see bibliographical appendix, Nos. 5-22.

Redding, Thomas, see Reading, Thomas.

Redick, John, $A$ Detection of the Conduct and Proceedings of Messrs. Annan and Henderson (1764), I I3; No. 262.

Redick-Le-Man, see Redick. 
Religion, Act for Establishment of (1700), 22, 23; No. 6.

Remarks upon a Message, No. $248 \mathrm{n}$.

Reply to the Church of England Planter's First Letter, by the Rev. Bennet Allen, No. 295.

Resolved, that any Restrictions (1776), No. 389; that the Assemblies (1776), No. 387.

The Rev. Mr. Facob Henderson's fifth Letter to Daniel Dulany, Esq., No.6in.

A Rhapsody, by [Richard Lewis], No. 77 .

Richardson (ship captain), Iog.

Richardson, Hester Dorsey, Maryland Gleanings, cited, Ign.

Ridgely, Charles, No. 34I.

Ridgely, David, Annals of Annapolis, cited, $82 n$.

Ridout, John, 105n; No. $265 \mathrm{n}$.

The Right of the Inhabitants of Maryland to the Benefit of the English Laws, by Daniel Dulany, the Elder, No. 42.

The Right to the Tonnage, by Daniel Dulany, Jr., No. 265 .

Riley, E. S., Ancient City, cited, 4In, 82n, $89 n$.

Rind, Abigail (Green), $85 \mathrm{n}$.

Rind, Alexander, 85 n.

Rind, Anne, $85 \mathrm{n}$.

Rind, Clementina, 15,87 .

Rind, William, parentage, $85 \mathrm{n}$; apprenticeshipto, and partnership with Jonas Green, 85 ; opens book store and establishes circulating library in Annapolis, 85; the newspaper firm of Green \& Rind, 85 ; solicited to come to Virginia by Thomas Jefferson, 85 ; removes to Williamsburg and establishes Virginia Gazette, 87; public printer of Virginia, 87; death (I773), 87.

Roden, R. F., The Cambridge Printers, cited, I 2n, 75n.

Rosenbach, A. S. W., $35 \mathrm{n}$.

Ross, John, 105n.

"Roughead, William," 4n.

Royal Dublin Society, No. I35.

Royle, Joseph, printer, 87 .

Rules and Articles for the better Government of the Troops, No.367.

Rusk, David, I37n.
Rutherford, Livingston, Fohn Peter Zenger, Second New York Printer, his Press, his Trial, cited, 52n.

Sabine, Lorenzo, The American Loyalists, cited, IIg.

St. Anne's Parish, Anne Arundel County, 28n, 40n, 4 In, 80 .

St. John's College, Annapolis, Maryland,54.

St. Mary's City, Maryland, 3-15; first press in, 3 ; imprints, $5-8$; removal of capital from, 9; legend of a Jesuit press in, 147I 49.

St. Peter's Parish, Talbot County, Maryland, 96.

Scharf, J. T., Chronicles of Baltimore, cited, I I gn, I37n; History of Maryland, cited, I 47, I 48, I49; Scharf and Westcott, History of Philadelphia, cited, I38n.

Schlesinger, A. M., Maryland's Share in the Last Intercolonial War, cited, I02n.

Scott, Upton, 105n.

Seidenstricker, O., First Century of German Printing in America, cited, I $12 \mathrm{n}$.

A Sermon preached before his Excellency and both Houses of Assembly, Dec. 13, 1754, by the Rev. James Sterling, No. I 86.

A Sermon preached before the Society of Free and Accepted Masons, by the Rev. Thomas Bacon, No. 163.

Sharpe, Horatio, Governor of Maryland, 97, $100,101,102,102 n$; proposes plan for publication of Bacon's Laws of Maryland, 103I05, 105n, mentioned 107, 109, III.

Sharpe Correspondence, cited, 102n, 103n, I04n, I06n, 107n, I09n, I I In.

Shea, J. G., Catholic Church in Colonial Days, cited, 147 .

Shelton, Eleanor (Parks), 60.

Shelton, John, 60.

Shelton, Sarah, 60.

Shober, Frederick, printer, of Baltimore and New York, 115.

Shober and Loudon, printers, of New York, II 5 .

The Shocking accounts of damage (Williamsburg, Virginia, 1775), No. 369. 
Shrewsbury, Charles Talbot, 1 2th Earl of, 7 , $7 \mathrm{n}, 8$.

Sill, Howard, 88n.

$A$ Single and Distinct View of the Two-Penny $A c t$, by the Rev. John Camm, No. 243 .

Sioussat, St. George L., English Statutes in Maryland, cited, $57 \mathrm{n}$.

Sir, the letters which Mr. Fohnson the adjutant brought (I775), No. 356.

Sir, Yesterday there was a Meeting (1769), No. 290.

Situation of Frederick-Town, No. 134.

Smith, Richard, 8, 9 .

Smith, Samuel, I39n, I 40.

Smith, William, History of the Post Office in British North America, cited, I34n.

Smithson, Thomas, 22n.

Smyth, A. H. ed., Writings of Benjamin Franklin, cited, 126n.

"Some Queries, Political and Military," by General Charles Lee, I37-I40.

Somerville, George, 144 n.

Sommervogel, Carlos, ed. Bibliotheque de la Compagnie de Fesus, cited, 148.

Sotweed Factor, by Ebenezer Cooke, No. 70 . Sotweed Redivivus, by E[benezer] C[ooke], Gent., 65, 68n; No. 60.

Soumaien, Samuel, $76 \mathrm{n}$.

Soumaien, Mrs. Susanna, $77 \mathrm{n}$.

Southwell, Nathaniel, ed. Bibliotheca Scriptorum Societatis Fesu, cited, $\mathrm{I} 48$.

Sower, Christopher, of Germantown, II 2.

Sower, Christopher, Jr., II 4 .

Sparrow, Thomas, Sr., 88.

Sparrow, Thomas, first Maryland engraver, $87-89,91$; probable parentage, 88 ; guardianship by Jonas Green, 88 ; training as goldsmith, 88; his work as an engraver, 89; engraves Provincial Arms for titlepage of Bacon's Laws, Iog.

Speech of his Excellency (I 708), No. 20; (1721) No. 29 ; (1730), No. 64 ; (1732), No. 79; (1740), No. IOI.

Spencer, Nicholas, Sec'y of Virginia Council, 2.

Sprague, Wm. B., cited, $98 \mathrm{n}$.

Sprigg, Richard, 88n, 89.
Stamp Act, broadside concerning, No. 264; Proceedings of the Congress at New York (1765), No. 273; broadside (1766), No. 274; Maryland Gazette during operation of, 83; Daniel Dulany's Considerations, Nos. 255-258; title-page reproduced, 78 ; Goddard's publication against, I22-123.

Stamp Act, Maryland edition of, No. 259.

Statutes, English in Maryland, 55; No. 42.

Steiner, Bernard C., "Andrew Hamilton and John Peter Zenger," cited, 42n, 52n; Early Maryland Poetry, cited, 67n; "A Pioneer in Negro Education," cited, $98 \mathrm{n}$.

Sterling, James (the Rev.), No. 186.

Steuart, George, 105n, 106.

Stevens, Henry, "Calendar of Maryland Papers," cited, 7 n.

Stevenson, Dr. Henry, II 5 .

Stith's History of Virginia, printed by William Parks, 73.

Story, Enoch, the elder, I 6 .

Story, Enoch, the younger, sets up press in Baltimore about 1774 , II 5 ; sells equipment and removes to Philadelphia(1775), iI 6.

Story and Humphreys, printers, of Philadelphia, II6.

Strahan, William, English publisher and politician, I24n, I27, I27n.

Subscription Paper for the Deputy Commissary's Guide, No. 340.

"Sun Iron Building," I 28n.

Swearingen, see Van Swearingen.

Talbot, Charles, 12th Earl of Shrewsbury, see Shrewsbury, Charles Talbot, I2th Earl of.

Talbot, John, 28.

Tasker, Anne (Bladen), 19.

Tasker, Benjamin, 19, 5 1.

Tasker, Benjamin (2d), Io5n.

Taylard, William, $13,15,15 \mathrm{n}$.

Taylor, John, 25 n.

Taylor, Randal, 5 .

Taylor, Randolph, see Taylor, Randal.

Tea, Destruction of, No. 323 .

$A$ Thanksgiving Sermon on the Supression of 


\section{$I N \mathcal{D} E X$}

the Unnatural Rebellion in Scotland, by the Rev. John Gordon, No. II 7.

Thirteen Hymns, by Elhanan Winchester, Nos. 390, 391.

This Morning Congress received the following Letter from General Washington (I 776), No. 385 .

Thomas, David, No. 335 .

Thomas, Isaiah, History of Printing in America, cited 12, 12n, 43n, 52n, 58, 59n, 7In, $73 \mathrm{n}, 76 \mathrm{n}, 79 \mathrm{n}, 87$, II $2 \mathrm{n}, \mathrm{II}_{3}, \mathrm{II}_{4}, \mathrm{II}_{5}$, II $\mathrm{n}$, II $\mathrm{n}, \mathrm{II} 9$, IIgn, I22, $123,123 \mathrm{n}$, I $26 \mathrm{n}, 136 \mathrm{n}, \mathrm{I} 4 \mathrm{In}, 143,144$.

Thomas, J. W., Chronicles of Colonial Maryland, cited, 148.

Tilghman, Oswald, cited, $98 \mathrm{n}$.

Timothy, Lewis, printer, $47 \mathrm{n}$.

To Christians of Every Denomination among us, by the Rev. James Maury, No. 3II.

To his Excellency (Address of Assembly) (I 708$)$, No. 20; ( 1728 ) No. 45 ; ( 1729 ), No. 53; (1730), No.65; (1739), No. 96; (1761), Nos. 229 and 230; (Petition of certain inhabitants of Baltimore County), Nos. 285-287; (Petition of Jonas Green), No. 237.

To the Citizens of Annapolis (signed A. Citizen, I 775), No.364; (Signed An American, I 775), No. 365 .

To the Honourable Benedict Leonard Calvert, Esq. (1730), No. 66.

To the Honourable Benjamin Tasker, Esq. (1752), No. I 58 .

To the Inhabitants of Anne Arundel County (1775), No. 342.

To the People of Maryland (signed, A Countryman, 1776), No. 383 .

To the Public (signed, Samuel Chase, 1766), No. 263; (signed, Bennet Allen, I768), No. 279; (signed, William Green, I 768), No. 280; (signed, Daniel Wolstenholme, I768), No. 288.

To Walier Tolley, Benjamin Nicholson, Fohn Moale, Robert Alexander, and Feremiah Townley Chase, Esqrs. (1775), No. 366.

Tobacco, Nos. $36,37,51,63,108,147,148$, $153,243,265$.
Tobacco, equivalent in currency, Ion, 26, $26 n$.

"Tobacco Laws," 44.

"Tom-Tell Truth" episode, 136, 136n, I37.

Tonnage duty, 99-100, 101, 104; No. 265.

Towne, Benjamin, Philadelphia, partner of Goddard, 125-126; quarrel and dissolution of partnerhisp, $\mathrm{r} 26 \mathrm{n}$; mentioned 127.

Trott, Nicholas, Laws of the British Plantations, 25, 26, 30, 30n, 46, 47; its editor, $47 \mathrm{n}$; described, No. 30 .

Tuesday Club of Annapolis, 81, 107; printed notices of meetings, Nos. 187,188 .

Two Sermons, by the Rev.Thomas Cradock, No. 122.

Type-founding in America, I 14.

The Unanimous Declaration of the Thirteen United States of America (July 4, 1776), No. 392.

United Colonies of North America, Nos.336, $337,367,3^{8} 4$.

United States of America, Nos. 385-389, $39^{2}$. Updike, Lodowick, 120.

Updike,Sarah, see Goddard,Sarah (Updike)

Vallette, Elie, Deputy Commissary's Guide, 89 , 91; No. $33^{8}$; subscription papers for, Nos. 339, 340.

Van Swearingen, Anne, see Bladen, Anne (Van Swearingen).

Van Swearingen, Garrett, I9.

Vinegar Bible, 46.

Virginia Gazette, established by William Parks, 73, 73n; Rind's Virginia Gazette, 87.

Virginia Laws (compiled), printed by Parks (1733), 72.

Virginia Laws (session), Parks proposes to print (1727), 72 .

Vriginia, Printing in, I, 2, 2n, 3, I2, 7I-73, 85,87 .

Virginia Baptist, by David Thomas, No. 335 .

Votes and Proceedings of the Lower House of Assembly of the Province of Maryland, see Maryland, Votes and Proceedings of. 
Votes and Resolves of the Lower House of Assembly of the Province of Maryland, see Maryland, Votes and Proceedings of.

"Vox Populi, Vox Dei. A Providence Gazette Extraordinary," I2I.

Wallace, Charles, rogn.

Wapping Wharf, Annapolis, 29.

Warner, John, Nos. 48, 58, 69 .

Washington, George, 129, 135, 138, 139, I4 I, I4In, I 45 .

We have just received the following important Intelligence (1775), No. 345 .

We, the Subscribers, his Majesty's loyal and dutiful Subjects, (1769), No. 289.

"Webb, Mr." George (?), John (?), 7on.

Weeks, L. H., History of Paper Manufacturing in the U. S., I690-1916, cited, 73n.

The Weeks Preparation, No. 59.

Weyman, Henry T., cited, $74 \mathrm{n}$.

Wharton, Thomas, 123; partnership with Goddard and Galloway, 124-127.

Where are ye All now? (1774), No. 341.

Whereas Lord Dunmore (1775), No. 368.

Whereas, the just War (1776), No. 386.

Whetcroft, William, 134 n.

Whig Club of Baltimore, attack upon William Goddard, 136, 137.

White, Father Andrew, Catechism, 147,148, I49.
Williamsburg, Virginia, existence of press there in 1702 questioned, 2; press established there in 1730 by William Parks, 71 ; Nos. 368 and 369 .

Wilson, Thomas (the Rt. Rev.), 96, $96 \mathrm{n}$.

Winchester, Elhanan, Nos. 390, 391.

Wolstenholme, Daniel, 105n; No. 288.

Women printers in America, 15.

Woodbridge, N. J., I23, I23n.

Woodward, Ashbel, "Brief Memories and Notices of Prince's Subscribers," cited, $77 \mathrm{n}$.

Wooten, see Wooton.

Wooton, James (the Rev.), 28n; No. 14.

Wroth, L. C., "A Maryland Merchant and his Friends," cited, $98 \mathrm{n}$.

Zenger, Anna Catherina (Maul), 52.

Zenger, John, 52.

Zenger, John Peter, 42n, 44; 49-58; sketch of his life, 49-50; arrival in Maryland, 50; petition to print Session Laws (1720), 50; his naturalization in Maryland, 50; location of residence and printing house, Chestertown or Annapolis, 50-53; evidence of his printing Maryland Session Laws ( 720 I 72I), 50-5I; removal from Maryland and later life, $5^{1-52}$; discussion of his Maryland activities, 52,53 . 
$133 ! 2$

w 


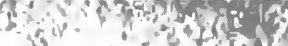

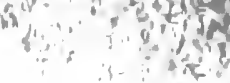

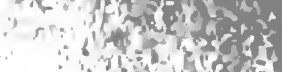

- tofsis

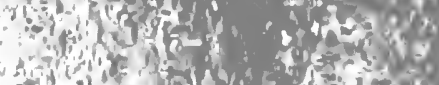

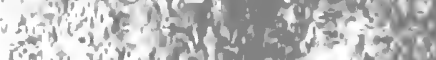

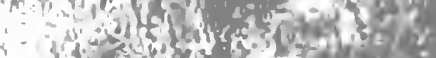

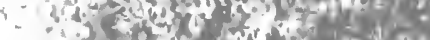

a de who 04

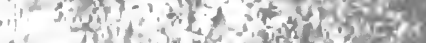

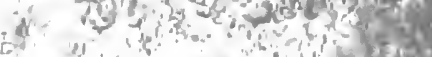

$\rightarrow+1$

$4: 340$

$\therefore$ is...

$\therefore \therefore$.

thes

4. 3. $4 \times K^{\prime \prime}$

. . 13 now

.

4

ity

$\therefore 6,18$

$\because \quad ; \quad \therefore$ ate

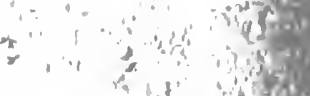

$\therefore+1$

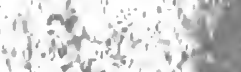

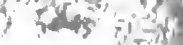

i 1... क ज

vifo

$\therefore,-36$

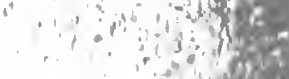

.r.

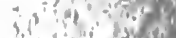

rnits

$\therefore$ oning

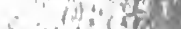

$\because 2$ -

$7 w^{2}, 20$

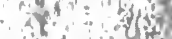

"ivity

at

$1, y+x^{3}$

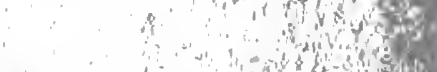

i

A $14 x^{2}$

- 1.

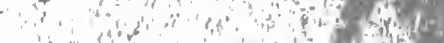

$\therefore$ ded

ad 


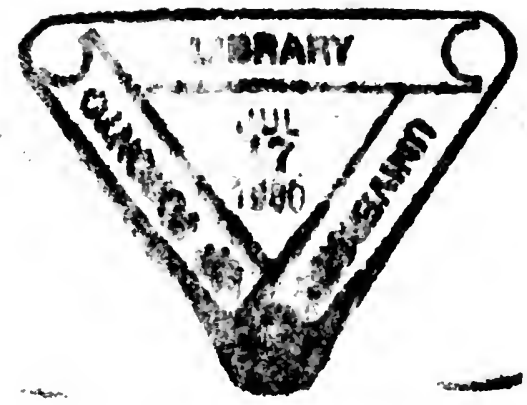




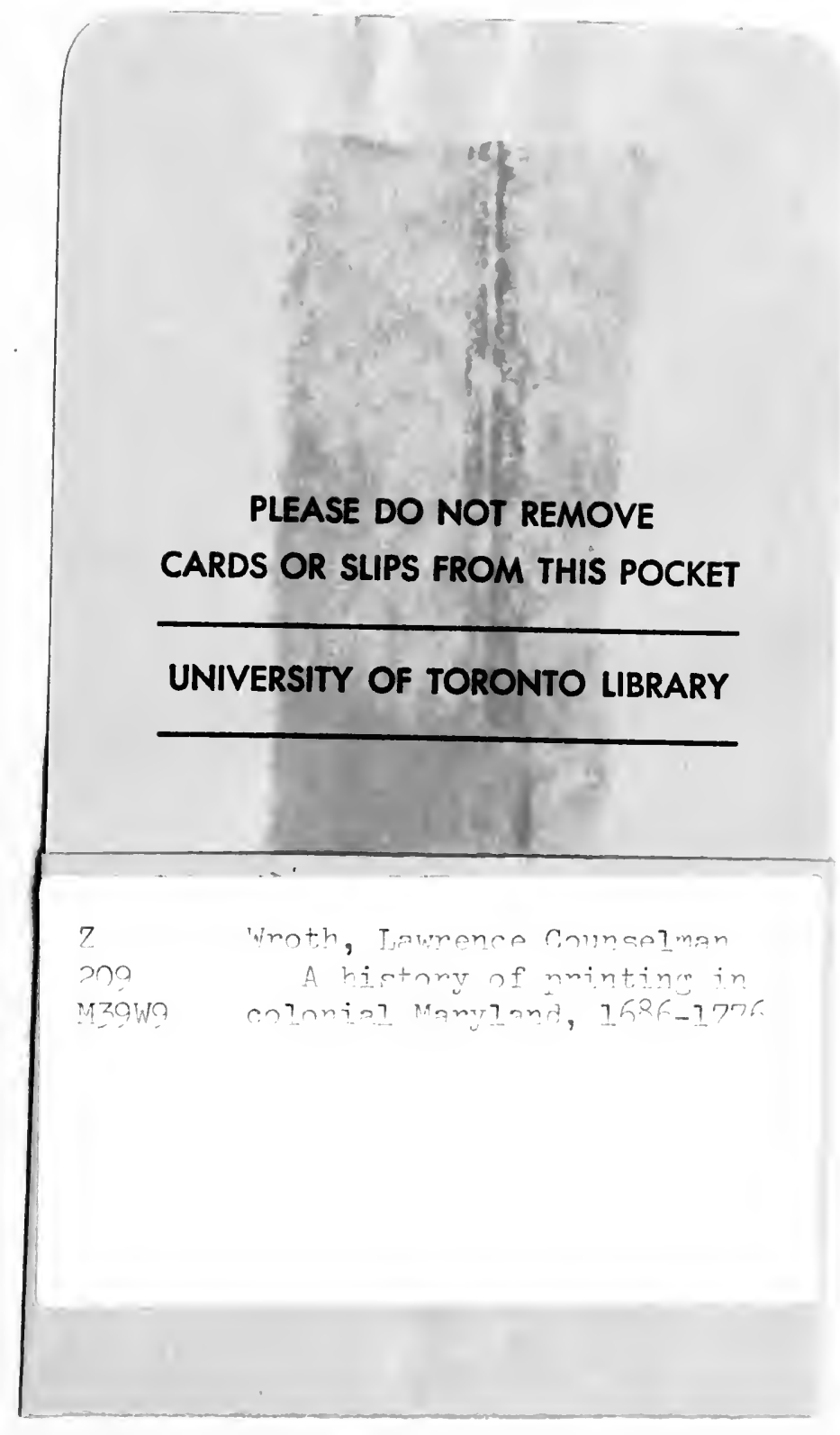


